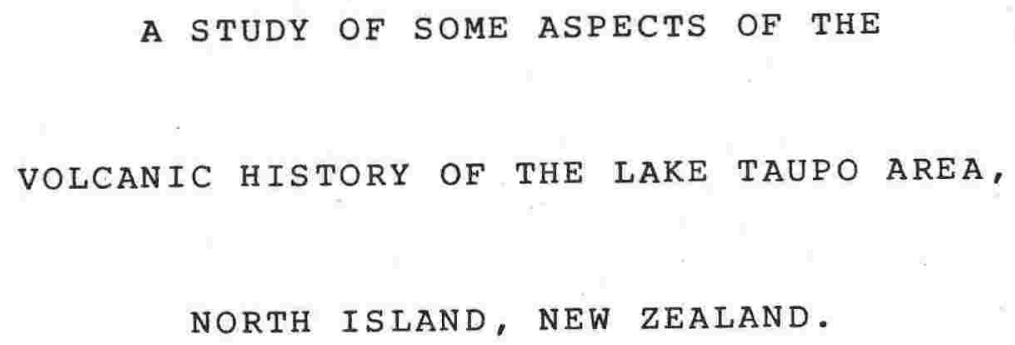


Rhyolitic pyroclastic eruptives from the Taupo area, New Zealand have been mapped as nine tephra formations of Holocene (0-10 kyr B.P.), and six of late Pleistocene age (20-c.50 kyr B.P.). Only the 10 younger tephras are dated by radiocarbon. All formations contain PLINIAN type airfall units but three, KAWAKAWA, WAIMIHIA and TAUPO also contain a major pyroclastic flow deposit (IGNIMBRITE) unit. Dome extrusion can only be demonstrated for KARAPITI eruptive episode, but is inferred for the other Holocene episodes.

TAUPO IGNIMBRITE is the product of the most recent eruption and is a particularly well preserved and extensive, unwelded pyroclastic flow deposit, up to $50 \mathrm{~m}$ thick. Its variety of appearance is described in terms of three lithofacies; valley facies, fines depleted facies and veneer facies, each being formed by particular mechanisms within a pyroclastic flow. Abundant charred logs, lying prone within Taupo Ignimbrite, are radial about the source and attest to a radially outward moving mass dominated by laminar flow.

Lake Taupo today covers most of the volcanic source area, preventing close examination and the identification of individual source vents. A vent for each Holocene tephra is inferred from isopachs, grainsize and lake bathymétry, but the vents so inferred show no spatial distribution with time. Nevertheless they are evenly spaced along a northeast trending line and lie on intersections with a northwest trending set of lineations, indicating deep, crustal, structural control on volcanism.

Cumulative volume of airfall and ignimbrite material erupted in the Taupo area in the last $50 \mathrm{kyr}$ has amounted to about $175 \mathrm{~km}^{3}$ of magma. Eruptions have proceeded in a step-wise manner, indicating the period to the next eruption is about 8 kyr. By the same approach, the next eruption from the Okataina area, $50 \mathrm{~km}$ to the north of Taupo is expected in less than 400 years.

Whole rock and mineral chemistry clearly distinguishes between the Holocene and the late Pleistocene tephras, but within each group variations are subtle and no trends with time are apparent. None of the formations exhibit evidence for a chemically zoned magma body, but some data, especially pyroxene phenocryst chemistry, suggests magma inhomogeneities 
of mafic elements. The Holocene tephras were probably all erupted from the same magma chamber in which crystallisation was the dominant process but convection, crystal fractionation, element diffusion and chamber replenishment were all probably operative.

Results obtained by electron microprobe analysis of glass shards are critically dependent on the beam diameter and current used. By standardising these at 10 microns and 8 nanoamps respectively, comparable major element analyses on glass shards from numerous tephras ranging in age from $20 \mathrm{kyr}$ to $600 \mathrm{kyr}$ were obtained. The stratigraphic relationships between sets of samples (located mainly distal from source) and the close chemical similarity of some samples enabled a comprehensive tephrostratigraphy to be established. In particular, MT. CURL TEPHRA has a glass chemistry quite different from other stratigraphically separate tephras, establishing correlation of Mt. Curl Tephra to Whakamaru Ignimbrite. Likewise, other ignimbrite formations can be correlated to widespread airfall tephras, so establishing an absolute ignimbrite stratigraphy .

Microprobe analysis of glass shards provides a method for indirectly determining the amount of hydration. For dated samples from a known weathering environment, the parameters controlling hydration can be quantified. For glass of uniform chemistry, shard size and porosity, ground temperature and groundwater movements are the most important parameters. No shards in the 63-250 micron size range have been found with more than $9 \%$ water, suggesting once this maximum is reached, glass rapidly alters to secondary products.

Detailed knowledge of the volcanic history of the Taupo area, particularly since 50 kyrs B.P. allows the volcanic hazards of the region to be assessed. Fifteen major eruptions in 50 kyr gives a frequency of 1 in 3300 years, but the timing of individual events is not evenly spread throughout that time. Monitoring for volcanic precursory events (not being undertaken at present) is essential to gauge the present and shortterm future volcanic activity of the Taupo Volcanic Zone. 


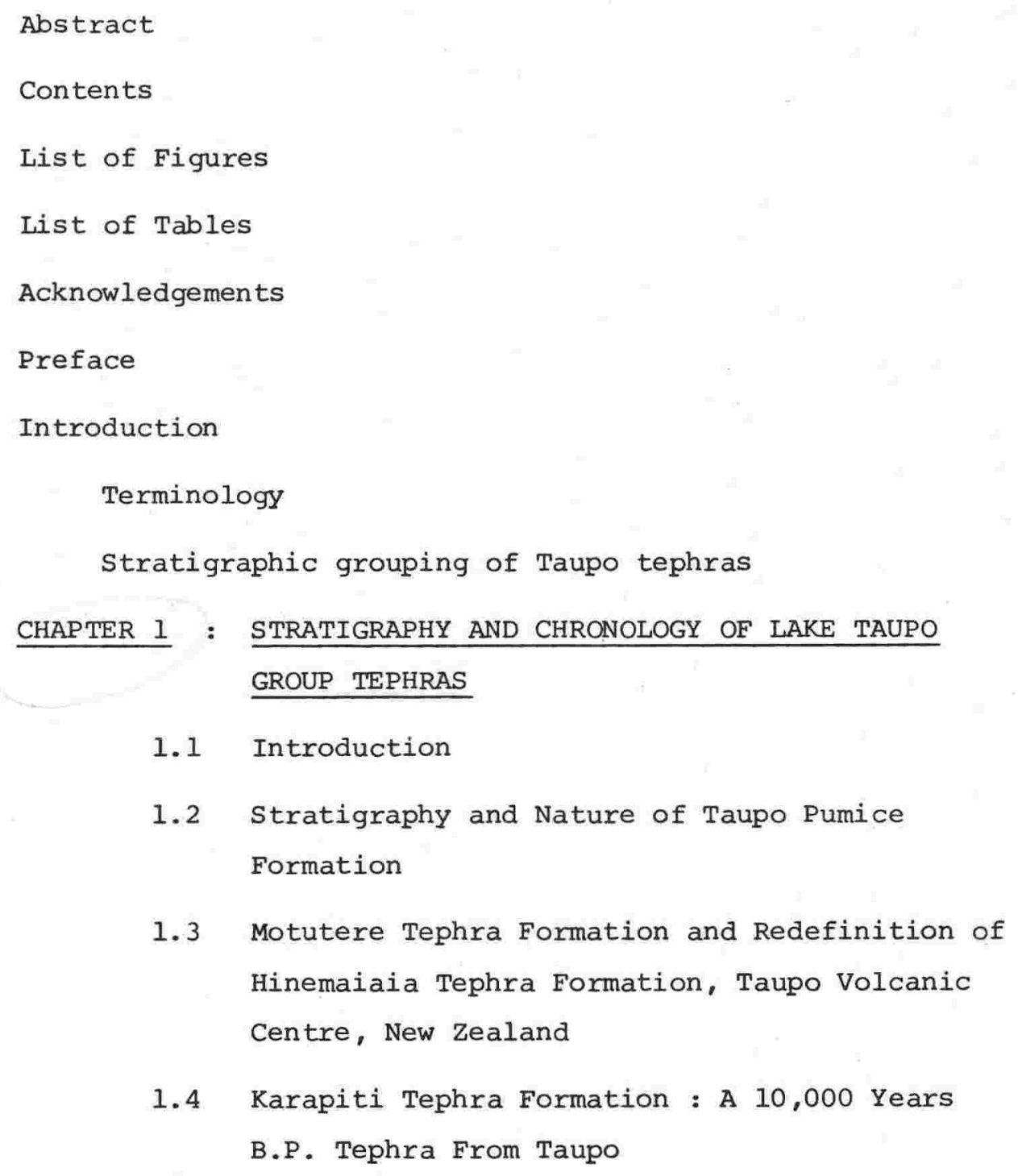

1.2 Stratigraphy and Nature of Taupo Pumice Formation

1.3 Motutere Tephra Formation and Redefinition of Hinemaiaia Tephra Formation, Taupo Volcanic Centre, New Zealand

1.4 Karapiti Tephra Formation : A 10,000 Years B.P. Tephra From Taupo

CHAPTER 2 : VOLCANIC PROCESSES AND ERUPTIVE MECHANISMS OF TAUPO PUMICE FORMATION

2.0 Introduction

2.1 Source of Taupo Pumice Formation

2.1.1 Lake Taupo - Probable Source of Taupo Pumice Formation

2.2 Eruptive Phases in Taupo Pumice Formation and a Note on the Origin of Grey Pumiceous Blocks About Northeast Lake Taupo 
2.3 Density and Porosity of Pumice from Taupo Pumice Formation

2.3.0 Introduction

2.3.1 Sampling

2.3.2 Density Measurements

2.3.3 Results of Density-Porosity Measurements

2.4 Taupo Ignimbrite Facies : Description and Origin

2.4.0 Introduction

2.4.1 Ignimbrite Veneer Facies : The Trail Marker of a Pyroclastic Flow

2.4.2 Fines - Depleted Facies of Taupo Ignimbrite - The Product of a Turbulent Pyroclastic Flow

2.4.3 The "Lithic Lag Layer" of Taupo Ignimbrite : A Striking Example of Sedimentation from a Pyroclastic Flow

2.5 A Model for the Eruption and Emplacement of the Members of Taupo Pumice Formation

3.1 Inferred vent positions 50

3.2 Time-space relationship of source vents 53

CHAPTER 4 : VOLUME OF MAGMA ERUPTED FROM TAUPO VOLCANIC CENTRE

4.0 Introduction $\quad 55$

4.1 Review of Methods of Estimating Rhyolitic Tephra Volumes; Applications to the Taupo Volcanic Zone, New Zealand 
CHAPTER 5 : TOPOGRAPHY AS AN INDICATOR OF CALDERA SUBSIDENCE AND STRUCTURAL CONTROL OF VOLCANISM AT TAUPO

5.0 Introduction

5.1 The Drainage Pattern About Northeast Lake Taupo

5.2 Evolution of the Present Topography About the Northeast Margin of Lake Taupo

5.2.1 Taupo Pumice Caldera Subsidence

5.2.2 Kawakawa Tephra Caldera Subsidence

CHAPTER 6 : TAUPO GROUP ERUPTIVES

6.0 Introduction

6.1 Analytical Techniques

6.1.1 Whole Rock Chemistry : What Constitutes a "Whole Rock" Analysis?

6.1.2. Glass Major Element Chemistry

6.1.3 Phenocrysts

6.2 Between Sample Variations in "Whole Rock" Major Elements

6.2.1 Random Errors

6.2.2 Hydration of Glass and Normalising of Analyses

6.2.3 Analysis of Size Graded Pumice

6.2.4 Analysis of Pumice Sampled Vertically Through Waimihia Lapilli

6.2.5 Taupo Ignimbrite Sampled Areally

6.2.6 Conclusions 
6.3 Comparison of the Mineralogy and Chemistry Between the Lake Taupo Group Tephras

6.4 Changes in the Chemistry Between the Taupo Subgroup Tephras

6.5 Conclusions

CHAPTER 7 CORRELATION OF UPPER QUATERNARY TEPHRAS AND IGNIMBRITES : FINGERPRINTING USING THE ELECTRON PROBE MICROANALYSER

7.0 Introduction

7.1 Establishment of an Analytical Technique for Electron Microprobe Analysis of Rhyolitic Glass

7.1.1 Effect of the Probe Beam on Alkali Metals 132 in Glass

7.1.2 Detection Limits of the Microprobe

7.1.3 Establishing Mean Values

7.1.4 Analysis of Glass Standards

7.1.5 Comparing Analyses

7.2 Towards a Comprehensive Upper Quaternary Tephra and Ignimbrite Stratigraphy in New Zealand Using Electron Microprobe Analysis of Glass Shards

7.3 Identification and Correlation of Mt. Curl Tephra and Whakamaru Ignimbrite Using Electron Microprobe Analysis of Glass

CHAPTER 8 : DISCUSSION OF RELATED TOPICS

8.1 Did Taupo's Eruption Enhance European Sunsets?

8.2 Evaluation of the Hazards Caused by Volcanic Activity in the Taupo Region (Taupo Volcanic Centre) North Island, New Zealand 
8.3 Hydration of Glass and Implications for the Weathering of Rhyolitic Tephras

8.4 Future Fingerprinting Possibilities

CHAPTER 9 : SUMMARY OF CONCLUSIONS

Appendices

APPENDIX A1 Techniques for the Preparation of Tephra Samples for Minerological and Chemical Analysis and Radiometric Dating

APPENDIX A2 Supporting Published Papers

A2.1 Orientation of Logs in the Taupo Ignimbrite as an Indicator of Flow Direction and Vent Position

A2.2 An Ignimbrite Veneer Deposit : The Trail Marker of a Pyroclastic Flow

A2.3 Fines Depleted Ignimbrite in New Zealand the Product of a Turbulent Pyroclastic Flow 294

A2.4 The Ground Layer of the Taupo Ignimbrite : a Striking Example of Sedimentation from a Pyroclastic Flow

A2.5 Late Quaternary Volcanic Ash Stratigraphy of the Poukawa Area, Central Hawke's Bay, New zealand

A2.6 Uniformity of Vertical Faulting for the Last 7000 Years at Lake Poukawa, Hawke's Bay, New Zealand.

A2.7 Uniformity of Late Quaternary Tectonic Tilting, Lake Poukawa, New Zealand 


\section{LIST OF FIGURES}

1.2.1 Stratigraphy and nomenclature used in this paper compared to that of previous workers.

1.2.2 Type section for Taupo Pumice Formation beside Hatepe River.

1.2.3 Schematic cross-sections through Taupo Pumice Formation to show the relationship and distribution of each unit and facies.

1.2.4 Ignimbrite thins rapidly up slopes to maintain a near-level upper surface.

1.2.5 A valley eroded into Taupo Ignimbrite at Maroa accentuating the flat upper surface and the typical "box canyon" type of valley cut into this deposit.

1.2.6 Section 5 on Rotokui Road with thin ignimbrite veneer facies.

1.2.7 Ripped up clasts of Rotongaio Ash within the Basal part of Taupo Ignimbrite.

1.2.8 Fines depleted facies at section 10.

1.2.9 Lower part of section 3, reference section for the upper part of Taupo Ignimbrite.

1.2.10 A collapse feature interpreted as a gas vent.

1.2.11 Section 6, a road cutting through the upper part of Taupo Ignimbrite.

1.2.12 A road cut on Hingapo Road with Taupo Ignimbrite Middle unit overlain by the Upper unit

1.2.13 Slightly weathered section of Rotongaio Ash mantling the regularly undulating, eroded top of Hatepe Tephra.

1.3.1 Map of Lake Taupo area showing the sections and correlation lines.

1.3.2 Section through Hinemaiaia and Motutere Tephras with probable bed correlation shown.

1.3.3 Isopach map of thickness and maximum pumice size on Motutere Tephra. 
1.3.4 Stratigraphy and relevant radiocarbon dates on Hinemaiaia Tephra and enclosing beds.

1.4.1 Stratigraphy and relevant radiocarbon dates for Karapiti Tephra.

2.1.1 Average orientation of charred logs within Taupo Pumice flow tephra at each site.

2.2.1 Locations of known outcrops of "protopumice" about northeast Lake Taupo.

2.3.1 Variation of pumice clast density with grainsize, for published data.

2.3.2 Comparison of sample volumes calculated by measuring side lengths and from immersion in water of saturated blocks.

2.3.3 Variation of clast bulk density with grainsize for Taupo Pumice and other TSG tephra.

2.3.4 Separation of pumice types by comparison of bulk density and porosity.

2.3.5 Variation of porosity and density with distance from source for clasts from Taupo Ignimbrite.

2.3.6 Variation of standard deviation on porosity and dry density with distance from source.

3.2.1 Location of known and inferred eruptive vents for Taupo Subgroup Tephras.

4.1.1 Taupo Volcanic Zone New Zealand, showing the location of Taupo and Okataina Volcanic Centres.

4.1.2 Plot of isopach thickness against distance from isopach centre.

4.1.3 Log-log plot of area enclosed by each isopach against thickness.

4.1.4 Log volume plotted against thickness used to calculate the total erupted volume.

4.1.5 Cumulative volume plotted against age for tephras from Okataina and Taupo. 
5.1.1 Drainage and topography of the area northeast Lake Taupo.

5.2.1 Areas of caldera subsidence approximated to a cone and rectangle.

6.3.1 Proportions of orthopyroxene, clinopyroxene and amphibole in Lake Taupo Group Tephras.

6.3.2 Summary of glass chemistry of LTG tephras; element concentrations plotted against the glass differentiation index.

6.3.3 FeO and $\mathrm{TiO}_{2}$ contents of titanomagnetites from LTG tephras plotted against glass differentiation index.

6.4.1 Whole rock analyses plotted as individual elements against whole rock differentiation index.

6.4.2 Sr and $\mathrm{Zr}$ for TSG tephras with data for Maroa and Okataina tephras for comparison.

6.4.3 Change of whole rock differentiation index with time.

6.4.4 Change of glass differentiation index on LTG tephras with time.

6.4.5 $\mathrm{FeO}, \mathrm{TiO}_{2}$ and $\mathrm{MgO}$ contents of titanomagnetites compared to glass for TSG tephras.

6.4.6 $\mathrm{FeO}, \mathrm{TiO}_{2}$ and $\mathrm{MgO}$ contents of ilmenite and coexisting glass.

6.4.7 Variation of mole $\&$ ulvospinel and $\mathrm{R}_{2} \mathrm{O}_{3}$ with coexisting glass differentiation index.

6.4.8 Changes in $\mathrm{Fe}-\mathrm{Ti}$ oxide equilibration temperatures with time.

6.4.9 Molecular proportions of $\mathrm{Mg}, \mathrm{Fe}$ and $\mathrm{Ca}$ in orthopyroxenes plotted for each TSG tephra.

7.1.1 Changes in the measured concentrations of 4 elements with different beam diameters and the count rate for $\mathrm{Na}$ in glass for 8 and 12 $\mathrm{nA}$ beam currents and various beam sizes.

7.2.1 Location of sections and cores in the New Zealand region. 
7.2.2 Plots of Feo against differentiation index calculated from individual glass shard analyses.

7.2.3 Correlation of tephras in the sections studied, as developed from the glass analyses.

7.3.1 Location of sections sampled for tephras of similar age to Mt. Curl Tephra.

7.3.2 Molecular proportions of $\mathrm{Mg}, \mathrm{Fe}$ and $\mathrm{Ca}$ for pyroxenes and amphiboles.

8.2.1 Generalised volcanic geology map of Taupo Volcanic Centre.

8.2.2 Time-volume relationships of rhyolitic tephras erupted in the last 50,000 years from Taupo.

8.2.3 Generalised isopach maps for rhyolitic tephras with the thickness interval between lines halving ( $a$ and $b$ ) and a base map on the same scale (c).

8.3.1 Increase in water content with time for tephras from core RC12-215.

8.3.2 Dependence of hydration on porosity and time for Holocene tephras at Taupo.

8.3.3 Stages in the dissolution of hypersthene in Mt. Curl Tephra.

8.3.4 Variation of the hypersthene/hornblende ratio and glass hydration for Whakamaru Tephra Formation. 


\section{LIST OF TABLES}

1.1.1 Stratigraphy of Taupo tephras together with relevant Cl4 dates.

1.2.1 Relevant C14 dates on Taupo Pumice Formation.

1.3.1 Description of the type section for Motutere Tephra and Hinemaiaia Tephra Formations on Opawa Road.

1.3.2 Ferromagnesian mineral proportions based on 600 grain counts for each bed of Hinemaiaia and Motutere Tephras.

1.4.1 Modal analyses of Karapiti Tephra and obsidian from the dome at Acacia Bay.

1.4.2 Ferromagnesian mineral proportions'based on 500 counts for Karapiti Tephra samples.

1.4.3 Major element analyses on glass and whole rock samples of Karapiti Tephra and the associated dome.

2.3.1 Comparison of pumice particle densities using saturated block and powdered pumice techniques.

4.1.1 Stratigraphy and chronology of tephras erupted from Taupo and Okataina volcanic centres post-50,000 years B.P.

4.1.2 Examples of volume calculations based on an exponential decay of thickness along the major and minor axes of the isopach ellipses.

4.1.3 Data for representative tephras as used in the volume calculations.

4.1.4 Tephra volumes calculated by the various techniques described in the text.

4.1.5 The estimated volumes of ignimbrites erupted from Taupo Volcanic Zone.

6.1.1 Probe analyses on 7 samples of Taupo Ignimbrite. 
6.2.1 Duplicate analyses on Waitahanui "protopumice" as a measure of intra-sample variations in XRF major elements.

6.2.2 Whole rock analyses on samples of Taupo Pumice Formation, sieved in size fractions.

6.2.3 Whole rock analyses on samples collected vertically through Waimihia Lapilli.

6.2.4 Whole rock analyses on samples of Taupo Ignimbrite.

6.3.1 Ferromagnesian mineralogy of Lake Taupo Group Tephras.

7.1.1 Typical detection limits on standard glass $\mathrm{KN}-18$ and mineral phases from Whakamaru Ignimbrite.

7.1.2 Statistics on 120 probe analyses of Mt. Curl Tephra.

7.1.3 Mean and standard deviation on 18 analyses of a tephra from Cape Kidnappers, with the analyses regrouped into 2 populations.

7.1.4 Means and standard deviations on 2 glass standards as determined by microprobe.

7.1.5 Coefficient of variation values comparing 7 analyses of Taupo Ignimbrite and Mt. Curl Tephra.

7.2.1 Analyses on glass standards and detection limits determined on the JEOL 733 microprobe.

7.2.2 Comparison of probe analysis deficiency from $100 \%$ with loss on ignition data.

7.2.3 Representative glass analyses of New Zealand tephras.

7.2.4 Coefficient of variation values for 6 sets of analyses on Taupo Ignimbrite.

7.2.5 Location data for the 3 cores.

7.2.6 Coefficient of variation values comparing analyses on deep sea core tephras to the 5 "type" tephras.

7.2.7 Coefficient of variation values produced by comparing "type" analyses. 
7.2.8 Coefficient of variation values that confirm the correlations.

7.3.1 Ferromagnesian mineral proportions.

7.3.2 Chemistry of bulk glass separates from 4 samples.

7.3.3 Microprobe analyses on glass shards from airfall and ignimbrite samples.

7.3.4 Microprobe data for $\mathrm{Fe}-\mathrm{Ti}$ oxides.

8.2.1 Stratigraphy, chronology, erupted volume and type of eruption for pyroclastic deposits from Taupo Volcanic Centre.

8.2.2 Calculated return periods for various eruption types. 


\section{ACKNOWLEDGEMENTS}

In addition to the acknowledgements contained in each published paper, many people have assisted with this work.

Continual enthusiasm, discussion and support in the field and laboratory by Mr. C.G. Vucetich was fundamental to this thesis and is especially acknowledged. Dr. R. Howorth also assisted with field-work and provided many useful discussions. Fellow staff and research students stimulated ideas and discussion, especially Prof. P. Vella, Dr. J. Cole and Dr. R. Grapes.

Analytical Facility provided the $x$-ray fluorescence and electron microprobe equipment and $\mathrm{Mr}$. K. Palmer instructed in their use and discussed problems of analysis. Probe mounts were polished by Keith Calder and Jenny Brown.

Dr. G.P.L. Walker provided the stimulation and incentive to develop and publish ideas on Taupo Pumice Formation. The individuals who were critical of the application of the electron microprobe to the analysis and discrimination of New zealand tephras encouraged a more rigorous approach and the analysis of many more samples than originally planned. This resulted in a more comprehensive and widespread stratigraphy being developed.

Access to forests was provided by New Zealand Forest Products Ltd., Tokoroa; New Zealand Forest Service at Taupo, Iwitahi, Kaingaroa and Turangi. Permission to enter Lake Taupo Forest and examine many invaluable sections was given by the Tuwharetoa Trust Board. Field-work was financially supported by the Internal Research Committee and Geology Department, Victoria University.

I am especially grateful for the help and encouragement provided by my wife, my father and my mother who looked forward to the completion of this thesis. 


\section{PREFACE}

This study divides into four parts:

(i) stratigraphy and chronology;

(ii) whole rock major and trace element chemistry and phenocryst microprobe chemistry of Taupo tephras;

(iii) correlation of widespread upper Quaternary tephras using electron microprobe analyses of glass shards;

(iv) discussion of related topics.

Many aspects of the thesis are presented as published papers or as manuscripts submitted for publication. In the appendices are several additional, jointly authored papers that arose out of this study. Summaries of three such published papers are incorporated into the main text to elaborate on aspects of the physical volcanology of Taupo Pumice Formation. The remaining published papers are offered to illustrate the value of tephras and tephra studies to a range of Quaternary research. 


\section{INTRODUCTION}

From the time of the earliest explorers in New Zealand, the region about Lake Taupo has been regarded as a unique volcanic area, covered in a thick mantle of pumice, containing numerous thermal areas and lying in sight of the impressive volcanoes of Ruapehu, Ngauruhoe and Tongariro. To the early New Zealand colonists, geologists included, volcanoes were manifested by mountains, generally conical or irregular in shape. Even today, it is difficult to accept that a volcano which has produced some of the most voluminous and explosive eruptions ever studied in the world is represented by an attractive lake filled depression. Consequently, until recently little attention has been paid to Lake Taupo as a volcano, because it cannot easily be seen, examined, sampled or measured. Its craters or eruptive vents cannot be visited, nor roads cut into their flanks, but a study of the voluminous material erupted by this volcano has lead to an intimate knowledge of its eruptive history. A thick pile of volcanic ejecta (here termed "TEPHRA") is well preserved about Lake Taupo and numerous road cuttings and engineering works, such as hydro dam sites, provide excellent exposures that have allowed a detailed stratigraphy and distribution of these tephras to be established. The youngest tephra is Taupo Pumice Formation, which afforded an excellent opportunity to study in detail one particularly complex event and to develop a model for its eruption. In this way knowledge abcut the eruptive history of Taupo would be gained, bearing in mind that the central volcanic complex cannot be approached closer than 5-15 kilometres.

The questions asked about Taupo Pumice were:- 
1. Stratigraphy: how many mappable layers, their extent and distribution?

2. The nature of each layer, what type of eruption produced it?

3. Where was the source vent(s) for each tephra?

4. How big was the eruption and what volume of material was erupted?

5. Chronology, when did the eruption occur and for how long did it last?

6. What affect did the eruption have on the land and topography of the volcano?

7. Is there any detectable chemical or mineralogical variations through the deposits?

8. Can a model for the eruption be used to interpret older eruptive deposits?

Assuming that the answer to Question 8 is YES, the older Holocene and Late Pleistocene tephras are interpreted. The knowledge gained, especially about the larger eruptions could then be applied to the even older and much more voluminous and widespread tephras, the welded ignimbrites and their distal airfall components. A study of the chemistry of the deposits, obtained principally by electron microprobe analysis of glass shards and minerals, is shown to be of great assistance in identifying and correlating the widespread products of each major eruption, regardless of where they were preserved and the degree of subsequent weathering.

Knowing the answers to questions of how many eruptions, where, when and how big, the hazards posed by Taupo volcano were assessed for Civil Defence purposes. Determination of the volume of magma produced and the date of each eruption leads to the rate of magma eruption and the 
periodicity of volcanic events. This in turn indicates the possible future activity of Taupo.

Combining this new data on Taupo Volcano with that for other New Zealand volcanoes is considered critical to all Quaternary studies. Being able to identify tephras of known age, today preserved in a variety of environments, provides a chronology for other geological events such as loess accumulation, fault movements, tectonic deformation, erosion, sedimentation and climatic change. Without the tephras, geological knowledge would be much impoverished. 


\section{TERMINOLOGY}

ASH, LAPILLI \& BLOCKS are size terms for pyroclastic ejecta after Fisher (1971): blocks > 64mm; lapilli, 64-2mm; coarse ash, 2.0-0.25mm; fine ash, $<0.25 \mathrm{~mm}$.

These terms are not incorporated in formation names, unless by historical precedent and the tephra is exclusively of this size grade (e.g. Rotongaio Ash).

CENTRAL VOLCANIC REGION (CVR): is a triangular area with southern apex south of Ruapehu and boundaries running north-west to Tauranga and east to Whakatane. It includes several centres of volcanism: Okataina, Maroa, Taupo and Tongariro are the currently active centres.

ERUPTIVE EPISODE: is a sequence of eruptive events with no significant time separation and includes all successive phases of an eruption such as plinian, pyroclastic flow and dome extrusion. All the pyroclastic products of an eruptive episode are grouped in a Tephra Formation.

IGNIMBRITE: originally used in New Zealand by Marshall (1934) as a genetic term for deposits of pyroclastic flow origin. The term was subsequently used in New Zealand in a lithogic sense, applying only to massive, welded deposits. As welding is a post-depositional process it should not be implied by genetic usage of "ignimbrite". The term is used here for a deposit of pyroclastic flow origin whether welded in part or not. An ignimbrite may be made up of 1 or more individual flow units and constitutes a member of a tephra formation. 
PLINIAN ERUPTION: is a continuous-blast eruption that produces airfall tephra.

PYROCLASTIC FLOW: is a fluidised body of erupted material flowing horizontally outwards from a source vent. The material deposited by this flow is a "pyroclastic flow deposit" or ignimbrite.

TAUPO VOLCANIC CENTRE (TVC): is loosely defined as the area about Lake Taupo incorporating known volcanic vents, but excludes the andesites south of Turangi and rhyolite domes north of Wairakei.

TAUPO VOLCANIC ZONE: is the presently active part of CVR and includes Tongariro, Taupo, Maroa, Rotorua and Okataina volcanic centres.

TEPHRA: defined by Thorarinsson $(1954,1974)$ as all the primary, pyroclastic material ejected from a volcano, including deposits of both airfall and pyroclastic flow origin.

TEPHRA FORMATION: a tephra formation is strictly neither a lithostratigraphic nor chronostratigraphic unit but incorporates elements of both. It is defined here as all the primary pyroclastic material produced during one eruptive episode and may include several members. The formation usually covers a range of lithologies including pumice, (ash to blocks) and unwelded or welded ignimbrite. The base of a Tephra Formation defines a virtually instantaneous time-plane but the top of the formation is often eroded and represented by disconformities, or has developed a soil. 
TYPE SECTION \& TYPE AREA: are defined by the criteria established by Vucetich \& Pullar (1973). Type area is preferred to type locality due to the usually short lifetime of individual sections exposing unconsolidated pyroclastics. Road cuts are susceptible to future engineering works but within 5 years or less are generally covered by luxuriant vegetation anyway.

VOLCANIC CENTRE: is loosely defined as a region in which eruptive vents are clustered and is here used more or less synonymously with volcanic complex and volcano.

VOLCANIC COMPLEX: is a cluster of eruptive vents, or domes marking the sites and is used in more or less the same sense as VOLCANO.

VOLCANO: is the site of one or more eruptive vents and in the Taupo area more or less coincides with the volcanic centre. The term does not necessarily imply a positive physiographic feature, as Taupo Volcano is today represented by a lake filled depression. 
STRATIGRAPHIC GROUPING OF TAUPO TEPHRAS

As established by Healy et al (1964), Vucetich \& Pullar (1969, 1973) and Vucetich \& Howorth (1976), tephras erupted from the Taupo area broadly fall into 3 groups: The Holocene 0-10 kyr group, The Late Pleistocene 20-50 kyr group and the tephras older than $50 \mathrm{kyr}$. Healy et al (1964) proposed the nomenclature of Taupo Sub-Group for the Holocene tephras which together with the Holocene tephras from Okataina (Rotorua Sub-Group) would constitute the Arawa Group. Further detailed stratigraphic mapping of Okataina (Howorth 1975; Nairn 1980) and Taupo (Vucetich \& Pullar 1973; Vucetich \& Howorth 1976; Froggatt 1981) has shown this scheme to be too simplistic to be useful. Subsequently, Howorth et al (1981) proposed an alternative stratigraphy in an attempt to rationalise the proliferation of names in the interest of the "tephra user". This grouping, adopted here, is shown in the following figure:

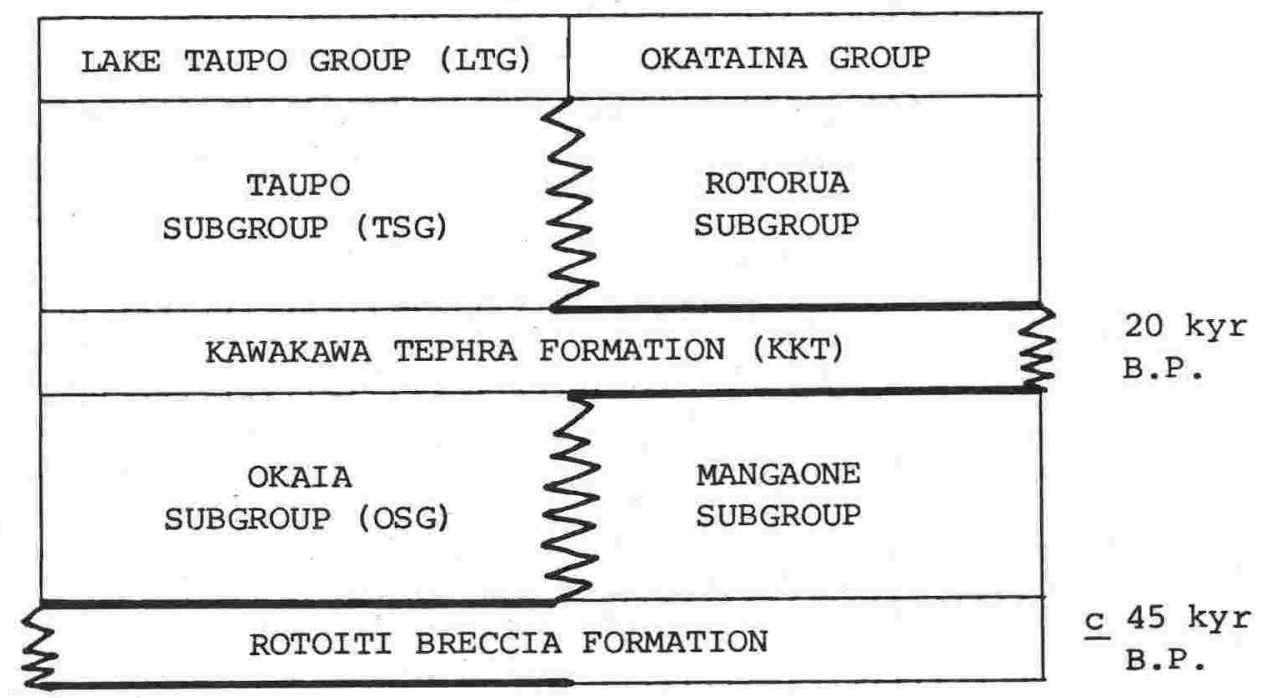

The Taupo Holocene tephras constitute Taupo Sub-group (TSG), Kawakawa Tephra Formation (KKT) retains formation status within Lake Taupo Group (LTG) and the late Pleistocene tephras form Okaia Sub-group (OSG). This nomenclature, often abbreviated as above, will be used throughout the thesis. Tephras older than OSG are at present poorly defined. 
CHAPTER 1.

STRATIGRAPHY AND CHRONOLOGY OF THE

LAKE TAUPO GROUP TEPHRAS. 


\section{CHAPTER 1}

\section{STRATIGRAPHY AND CHRONOLOGY OF THE LAKE TAUPO GROUP TEPHRAS}

\section{$1.1 \quad$ Introduction}

Early soil survey work by Grange $(1927,1929,1931,1937)$

showed that the tephra deposits around Taupo could be divided stratigraphically into what Grange calls the Taupo "sands" overlying the older Taupo "showers" which are underlain by Waitahanui Breccia. Waitahanui Breccia was a "hold-all" term for thick, massive and undifferentiated tephra deposits that outcrop throughout the Rotorua-Taupo region. Further soil mapping led Baumgart (1954) to examine in more detail the tephra stratigraphy about Taupo. A pumice pit near the Napier-Taupo road exposed a dipping sequence of beds overlying Waitahanui Breccia that Baumgart numbered 1 to 26 from the top down. Some of the numbered beds were part of one eruptive episode and others were paleosols. Baumgart also published isopach maps for four of the more widespread, younger tephras which he named Taupo Lapilli, Rotongaio Ash, Hatepe Lapilli and Waimihia Lapilli; names taken from localities near the isopach centres. Baumgart \& Healy (1956) named a further bed, the Rhyolite Block.

Tephras in a major new road deviation opposite De Bretts hotel were described using Baumgart's nomenclature by Healy et al (1964) and Healy (1966). The De Brett's section was subsequently redescribed by Vucetich and Pullar (1973) when they used this and many other sections to divide the Taupo sequence into named tephra formations, each representing one eruptive episode and each separated by a paleosol. It is this stratigraphy and nomenclature that is extended here.

Vucetich and Pullar (1973) established the De Brett's section as the type for all the Taupo Holocene tephras including Taupo Pumice Formation, but were unable to attempt further mapping of the youngest, most complex 
volcanic event.

Kawakawa Tephra Formation was defined by Vucetich and Howorth (1976a) to consist of an upper Oruanui Breccia Member, a middle Scinde Island Ash Member and a lower Aokautere Ash Member, replacing the Oruanui Formation of Vucetich and Pullar (1969).

Vucetich and Howorth (1976b) examined late Pleistocene tephras in the Taupo area and established 5 new tephra formations with type sections north of Lake Taupo. All have limited exposure and restricted distribution.

Extensive field-work by the author during 1978-1980 developed a stratigraphic framework and a volcanological rationale for Taupo Subgroup Tephras and in particular Taupo Pumice Formation. The results of the stratigraphic study are contained in 3 published papers and the major points are summarised below.

1. Stratigraphy of Taupo Pumice Formation is redefined to include Taupo Ignimbrite; A widespread, unwelded, pyroclastic flow deposit that can be subdivided into 3 stratigraphic units (Chapter 1.2).

2. Taupo Ignimbrite is described in terms of 3 lithofacies termed Valley Facies, Fines-depleted facies and Ignimbrite veneer facies (Chapter 1.2). Each facies is formed by particular characteristics of a pyroclastic flow.

3. Hinemaiaia Ash of Vucetich \& Pullar (1973) is redefined as two tephra formations; Hinemaiaia and Motutere (Chapter 1.3).

4. The general term 'Waitahanui Breccia', used by Grange (1937), for deposits about Taupo, consists in different outcrops of either Taupo Ignimbrite, Waimihia Ignimbrite, or Oruanui Breccia. Consequently the term should lapse (Chapter 1.2). 
5. Recognition of a rhyolite dome, extruded as a part of the Karapiti. Tephra event (Chapter 1.4) confirms that Taupo eruptive episodes generally conform to the global pattern of rhyolitic eruptions. This pattern consists of an explosive plinian phase, often progressing to eruptive column collapse to produce an ignimbrite that is followed by quiet extrusion of a dome (Sparks et al 1973).

6. Stratigraphic mapping of all tephras down to Kawakawa Tephra Formation confirms that there are no Taupo source tephras preserved between Kawakawa and Karapiti. Widespread erosion during the last stadial (Ohakean) glacial episode is represented by a marked unconformity over Oruanui Breccia. Much of the erosion products formed extensive aeolian deposits (Mokai Sand) in which are recognised 2 Okataina source tephras.

7. Two new radiocarbon dates establish a chronology for Hinemaiaia and Motutere Tephras and a third date confirms the estimated age of Karapiti Tephra (Table 1.1.1).

8. Two samples of organic material (U19/fl and U19/f2) from within 8,300
Oruanui Breccia at Te Karetu produced duplicate dates of $42,100+4,050$ 54,700

(NZ 4575A) and 45,600 $\pm 5,650$ (NZ 4576A). A similar date was previously

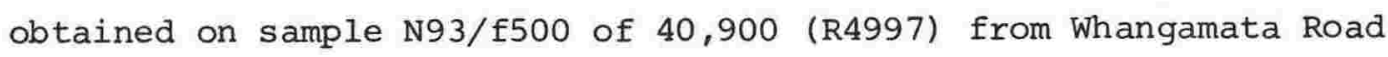
(S. Self pers. comm.). All samples are clearly from xenolithic clasts, probably peat.

9. The revised stratigraphy and chronology of the Lake Taupo Group Tephras is contained in Table 1.1.1. 


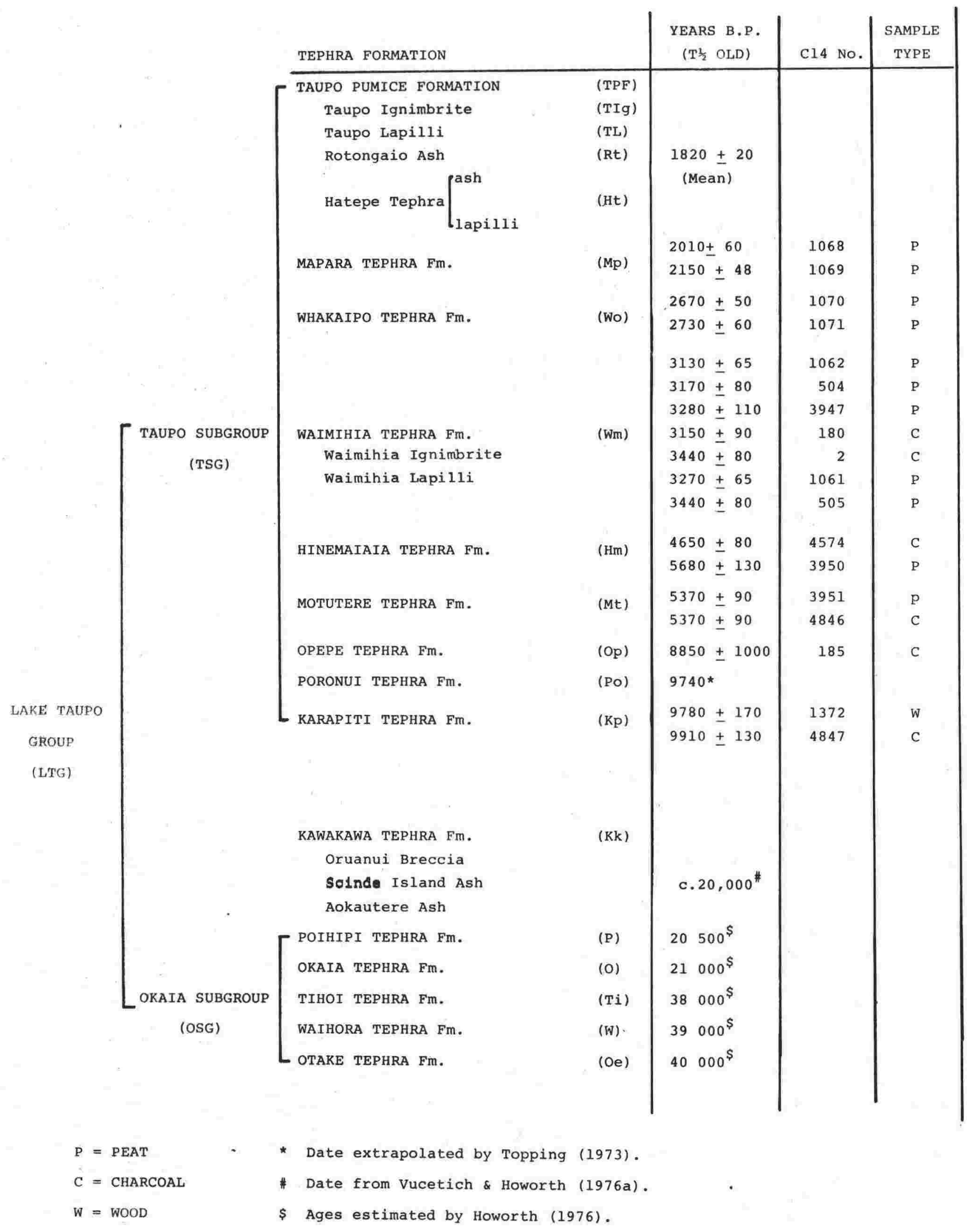

TABLE 1.1.1: Stratigraphy of Taupo tephras, together with relevant radiocarbon dates and ages estimated for the older tephras. 
1.2 STRATIGRAPHY AND NATURE OF TAUPO PUMICE FORMATION.

Reprinted from: New Zealand Journal of Geology and Geophysics; Vol 24 (2) pp231-248.1981. 
1.3 MOTUTERE TEPHRA FORMATION AND REDEFINITION OF HINEMAIAIA TEPHRA FORMATION, TAUPO VOLCANIC CENTRE.

Reprinted from: New Zealand Journal of Geology and Geophysics; Vol 24 (1) pp99-105. 1981. 
1.4 KARAPITI TEPHRA FORMATION: A 10000 YEARS B.P. RHYOLITIC TEPHRA FROM TAUPO.

Reprinted from: New Zealand Journal of Geology and Geophysics: Vol 24 (1) pp95-98. 1981. 


\section{Karapiti Tephra Formation: \\ a 10000 years B.P. rhyolitic tephra from Taupo}

\section{P. C. FROGGATT}

Geology Department

Victoria University of Wellington

Private Bag

Wellington, New Zealand

\begin{abstract}
Karapiti Tephra is a widespread Holocene rhyolitic tephra found throughout the central Taupo Volcanic Zone, North Island, New Zealand. A new radiocarbon date (NZ4847A) on charcoal from within the tephra establishes an optimum age for the eruption of $9910 \pm 130$ years B.P. Stratigraphy indicates a small rhyolite dome at Acacia Bay, northeast Lake Taupo, was extruded from the eruptive vent during the later stages of the Karapiti Tephra eruption and is therefore also about 10000 years old. Mineral and chemical data generally support this association. This is the first tephra-dome correlation established within Taupo Volcanic Centre.
\end{abstract}

Keywords Karapiti Tephra; Taupo Volcanic Zone; rhyolite dome; absolute ages; C-14; Holocene; tephrochronology

\section{INTRODUCTION}

In conformity with recent nomenclature (e.g., Howorth 1975), the formal stratigraphic name Karapiti Lapilli, of Vucetich \& Pullar (1973) is here broadened and re-defined as Karapiti Tephra Formation. Karapiti Tephra is a widespread marker bed throughout the central part of Taupo Volcanic Zone, North Island, New Zealand. It was erupted from Taupo Volcanic Centre (Healy 1964b) after about 10000 years of quiescence which followed eruption of the extraordinarily widespread Kawakawa Tephra about 20000 years ago (Vucetich \& Howorth 1976). Vucetich \& Pullar (1973) defined Karapiti Lapilli Formation as "...rhyolitic lapilli and ash layers conformably overlying the Waiohau Ash Formation and commonly identified from its upper contact with Te Rato Lapilli...", and described the type section from near De Bretts

Received 18 July 1980, revised 13 October 1980
Hotel, Taupo (N94/573353*). They tentatively correlated Taupo Sub-group (Tsg) members 24 and 25 (Healy 1964) to Karapiti Tephra. Their published isopach map shows a distinctly elliptical NNE-SSW distribution centred on eastern Lake Taupo, and their estimated volume was $5 \mathrm{~km}^{3}$. No source was identified by them, nor were any radiocarbon dates available on Karapiti Lapilli, though other dated tephras indicated the age was about 10000 years.

Examination of new road sections around Taupo has clearly indicated the eruptive source of Karapiti Tephra, and charcoal found in a new road cutting in Lake Taupo Forest (see Fig. 2) has provided a radiocarbon date on this tephra.

\section{STRATIGRAPHY AND CHRONOLOGY}

Karapiti Tephra lies immediately beneath Te Rato and Papanetu Tephras south of Taupo (Topping \& Kohn 1973) and overlies Waiohau Ash to the north (Vucetich \& Pullar 1973; Fig. 1). These tephras are considered to be reliably dated (Fig. 1), establishing an age range for Karapiti Tephra between 9780 and 11250 years B.P.

In a road section within Lake Taupo State Forest at N103/481082 Karapiti Tephra appears as:

$$
2 \mathrm{~cm} \quad \text { Te Rato Lapilli }
$$

$15 \mathrm{~cm}$ medium ash (paleosol) pale yellow

$35 \mathrm{~cm}$ lapilli and coarse ash weakly shower bedded

\section{tephric loess}

Abundant small charcoal fragments of twigs and small branches up to $2 \mathrm{~cm}$ diameter lay immediately above the basal lapilli bed, and were overlain by the medium ash. A sample of this charcoal (U19/: $3^{\dagger}$ ) has been dated (NZ4847A) at $9910 \pm 130$ years B.P. (old half life), thus directly dating eruption of Karapiti Tephra.

"Grid references are based on national thousand-yard grid of 1:63 360 topographical map series (NZMS1); sheet N94-Taupo, and sheet N103-Rangitaiki.

†New Zealand Fossil Record File number. 


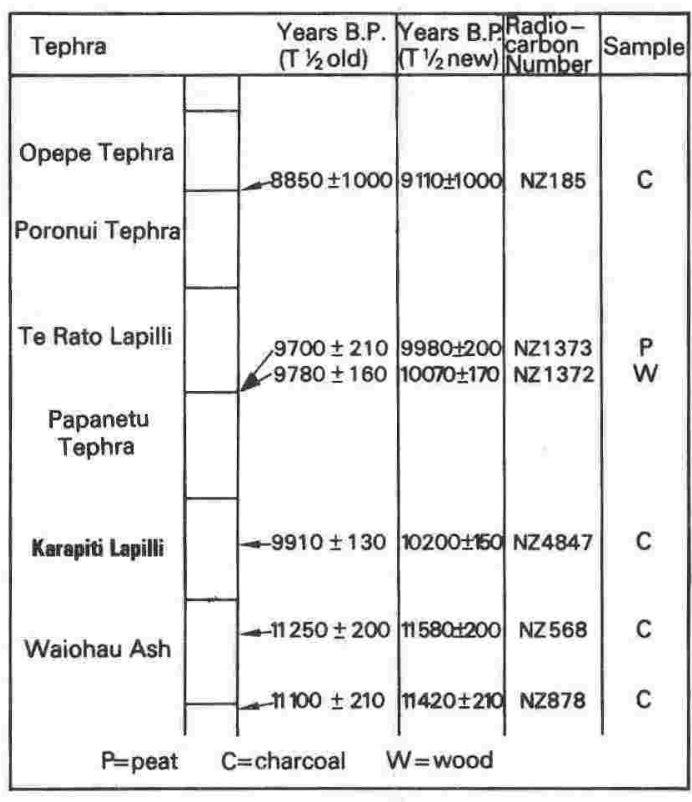

Fig. 1 Stratigraphy and relevant radiocarbon dates for Karapiti Tephra and adjacent tephras. All tephras are rhyolitic except the andesitic Te Rato Lapilli (Topping 1973).

\section{SOURCE}

Despite the common observation in many parts of the world that magma extrusion follows plinian and ignimbrite type eruptions (Sparks et al. 1973), to date none of the rhyolite tephras from Taupo Volcanic Centre has been correlated with rhyolite domes. Generally this results from a lack of outcrops, or poor preservation of the tephras, and has led to an overestimation of the age of many of these domes. A new road cutting on Mapara Road, Taupo (N94/495352), immediately west of Acacia Bay (Fig. 2), and described in Appendix 1, lacks Karapiti Tephra where the isopachs indicate maximal thickness. Instead, Opepe Tephra and a weak paleosol (incorporating Poronui Tephra) rest directly on coarse obsidian blocks and ash suggesting the underlying dome lies between Opepe and Karapiti Tephras in age. In another section 100 $\mathrm{m}$ to the east, Opepe Tephra immediately overlies at least $15 \mathrm{~m}$ of coarse poorly sorted ash consisting almost entirely of essential lithics of pale grey obsidian with frequent angular obsidian blocks up to $0.5 \mathrm{~m}$ diameter. The bottom of this bed is not seen. Bedding, where developed, is deformed beneath the larger blocks, but regular and conformable immediately above them, characteristic of a ballistic trajectory and indicating a nearby eruptive vent. Lack of weathering of the obsidian and weak soil

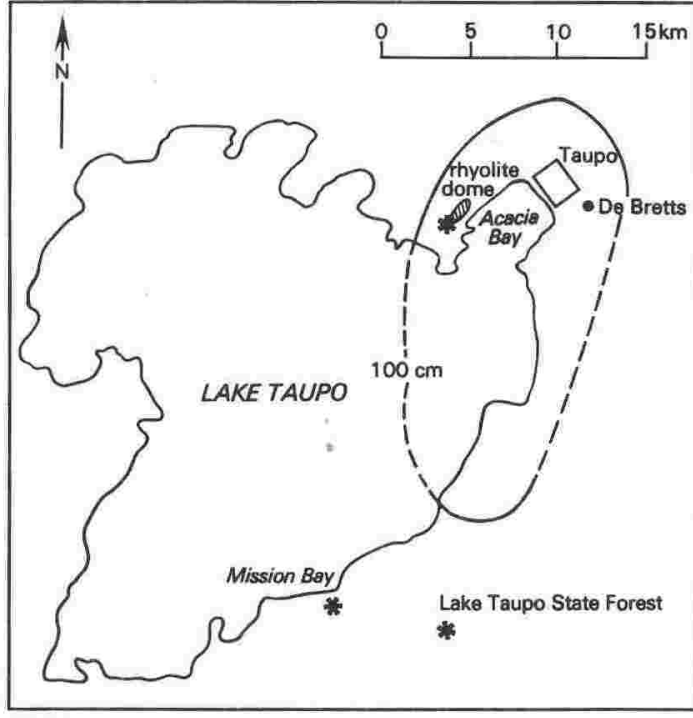

Fig. 2 Lake Taupo area, with locations of type and reference sections of Karapiti Tephra Formation marked by asterisks $\left({ }^{*}\right)$. The $100 \mathrm{~cm}$ isopach is from Vucetich \& Pullar (1973).

development beneath Opepe Tephra indicate an age little older than that of Opepe Tephra for this material. This road section lies on the southern end of a small elongate rhyolite dome about $1.5 \mathrm{~km} \times$ $1.0 \mathrm{~km}$ in area and rising $146 \mathrm{~m}$ above lake level. Acacia Bay township is on the eastern flank. No other tephra sections are exposed on this dome. In the field and from air photographs the dome appears youthful and undissected compared with Maroa Volcanic Centre domes, but all were mapped by Grindley (1960) as older Haparangi Rhyolite $\left(\mathrm{ha}_{1}\right)$. Stratigraphy of the mantling tephras and isopach thickness suggest the extrusion of this dome was almost certainly associated with the Karapiti Tephra eruption, and lava extrusion immediately followed the main pumiceous tephra eruption. Thus the dome is only c. 10000 years old, and is to date the only positively dated dome in the Taupo Volcanic Centre.

\section{VOLUME OF ERUPTED MATERIAL}

Based on isopach geometry, Vucetich \& Pullar (1973) calculated the erupted tephra volume as 5 $\mathrm{km}^{3}$. Dense rock equivalent volume is $1.6 \mathrm{~km}^{3}$, assuming a pumice density of $0.8 \mathrm{Mg} / \mathrm{m}^{3}$ and solid rock of $2.5 \mathrm{Mg} / \mathrm{m}^{3}$. From dome geometry the volume extruded is about $0.1-0.2 \mathrm{~km}^{3}$, giving a total erupted volume of less than $2 \mathrm{~km}^{3}$ of dense rock. 


\section{MINERALOGY AND CHEMISTRY}

Mineral composition of Karapiti Tephra is typical of Taupo Holocene tephras: plagioclase, hypersthene, and magnetite with small amounts of hornblende and clinopyroxene (Ewart 1963). Modal analyses of the tephra and dome obsidian (Ewart 1963; 1968) are reproduced in Table 1 . Relative abundance of ferromagnesian minerals within samples from De Bretts type section and a reference section at Mission Bay (N103/429102) are included in Table 2. Clinopyroxene observed as traces in the tephra has not been observed in the dome material, consistent with the tephra forming first from hotter, more volatile-rich magma, with later extrusion of the dome.

Whole rock chemical analyses of Karapiti Tephra pumice and associated dome obsidian are listed in

Table 1 Modal analyses of Karapiti Tephra and obsidian from the dome at Acacia Bay (P29203) (after Ewart 1963, 1968). Tsg 24 and 25 (Taupo sub-group, Healy 1964b) correlated to Karapiti Lapilli. Each analysis recalculated to $100 \%$ solid (vesicle-free) basis.

\begin{tabular}{|c|c|c|c|c|c|c|}
\hline & \multicolumn{2}{|c|}{ Tsg 25} & \multicolumn{2}{|c|}{ Tsg 24} & \multicolumn{2}{|c|}{ P29203 } \\
\hline & (a) & (b) & (a) & (b) & (a) & (b) \\
\hline Matrix & 46.5 & 95.3 & 37.0 & 94.8 & 85.5 & 90.7 \\
\hline Vesicles & 51.05 & - & 61.0 & - & 5.8 & - \\
\hline Plagioclase & 2.2 & 4.5 & 1.7 & 4.4 & 7.4 & 7.9 \\
\hline Hypersthene & 0.1 & 0.2 & 0.2 & 0.5 & 1.0 & 1.1 \\
\hline Magnetite & 0.1 & 0.1 & 0.1 & 0.3 & 0.3 & 0.3 \\
\hline
\end{tabular}

Table 3, and compared with 2 tephra glass analyses by Ewart (1963). Small differences between analyses are not considered to be significant. However, small variations in $\mathrm{MgO}$ and $\mathrm{CaO}$ between tephra and obsidian are here attributed to the presence of traces of augite in the tephra (Table 2). Lower values of $\mathrm{TiO}_{2}, \mathrm{Fe}_{2} \mathrm{O}_{3}, \mathrm{MnO}$, and $\mathrm{CaO}$ in Ewart's glass analyses (1 and 2) compared to the whole rock figures (3, 4, and 5) are caused mainly by phenocrysts of orthopyroxene, hornblende, and magnetite in the whole rock. Such close similarities between the tephra and dome material are consistent with the stratigraphic evidence of dome extrusion immediately following eruption of the tephra from the same volcanic vent.

Analysis of the phenocryst phases is currently being undertaken by the author.

Table 2 Ferromagnesian mineral proportions based on 500 counts for Karapiti Tephra samples from De Bretts type section (N94/573353) and a reference section at Mission Bay (N103/481082).

\begin{tabular}{lccccc}
\hline & \multicolumn{2}{c}{ De Bretts } & & \multicolumn{2}{c}{ Mission Bay } \\
\cline { 2 - 2 } \cline { 5 - 5 } \cline { 5 - 5 } & basal lapilli & & upper ash & basal lapilli \\
\hline Hypersthene & 96.7 & & 95.6 & 98.6 \\
Hornblende & 2.6 & & 2.4 & 1.1 \\
Clinopyroxene & 0.7 & & 2.0 & 0.3 \\
\hline
\end{tabular}

Table 3 Major element analyses on glass and whole rock samples of Karapiti Tephra and the associated dome. Analyses $3 \mathrm{a}, 4 \mathrm{a}$ and $5 \mathrm{a}$ are recalculated to $100 \%$ loss-free basis, for comparison.

\begin{tabular}{lcrrrrrrr}
\hline & 1 & 2 & 3 & $3 a$ & 4 & $4 a$ & 5 \\
\hline $\mathrm{SiO}_{2}$ & 71.3 & 71.3 & 71.23 & 74.49 & 70.57 & 74.00 & 74.55 & 74.71 \\
$\mathrm{Al}_{2} \mathrm{O}_{3}$ & 12.6 & 12.9 & 13.04 & 13.63 & 13.53 & 14.18 & 13.18 & 13.21 \\
$\mathrm{TiO}_{2}$ & 0.10 & 0.15 & 0.26 & 0.27 & 0.26 & 0.27 & 0.24 & 0.24 \\
$\mathrm{Fe}_{2} \mathrm{O}_{3}{ }^{*}$ & 1.90 & 1.90 & 2.32 & 2.43 & 2.37 & 2.49 & 2.30 & 2.30 \\
$\mathrm{MnO}_{\mathrm{MgO}}$ & 0.10 & 0.15 & 0.06 & 0.06 & 0.05 & 0.05 & 0.08 & 0.08 \\
$\mathrm{CaO}$ & 0.20 & 0.15 & 0.40 & 0.42 & 0.42 & 0.44 & 0.26 & 0.26 \\
$\mathrm{Na}_{2} \mathrm{O}$ & 1.35 & 1.25 & 1.83 & 1.91 & 1.77 & 1.86 & 1.55 & 1.55 \\
$\mathrm{~K}_{2} \mathrm{O}$ & 4.35 & 4.30 & 3.61 & 3.77 & 3.62 & 3.80 & 4.64 & 4.65 \\
$\mathrm{PO}_{2}$ & 3.10 & 3.10 & 2.84 & 2.97 & 2.69 & 2.82 & 2.99 & 3.00 \\
$\mathrm{LOI}$ & 0.02 & 0.05 & 0.05 & 0.05 & 0.09 & 0.09 & nd \\
Total & 4.80 & 4.40 & 3.58 & - & 4.26 & - & 0.86 & - \\
& 99.82 & 99.65 & 99.22 & 100.00 & 99.63 & 100.00 & 100.65 & 100.00 \\
\hline
\end{tabular}

* total $\mathrm{Fe}$ expressed as $\mathrm{Fe}_{2} \mathrm{O}_{3}$

+ LOI $=$ Loss on Ignition

n.d. = not detected

All elements analysed by X-ray fluorescence after the method of Norrish \&.Hutton (1969)

1. Tsg 24 glass analysis (Ewart 1963)
2. Tsg 25 glass analysis (Ewart 1963)

3. De Bretts (Basal Lapilli) whole rock (15751)

4. Mission Bay (Basal Lapilli) whole rock (15752)

5. Obsidian, Acacia Bay dome (15753)

(Sample numbers refer to Geology Department, VUW, petrology collection) 


\section{SUMMARY}

1. A new radiocarbon date on charcoal from within Karapiti Tephra dates the eruption of Karapiti Tephra from Taupo Volcanic Centre at $9910 \pm 130$ years B.P. (NZ4847A).

2. Isopach thicknesses indicate the source for Karapiti was in an area northeast of Lake Taupo and west of Taupo Borough. Tephrostratigraphy in this area suggests the small rhyolite dome at Acacia Bay as almost certainly being the contemporary of the tephra eruption. Karapiti Tephra is thus the first Holocene tephra from Taupo Volcanic Centre to have a proven association with dome-building.

3. Mineralogy of Karapiti Tephra consists of phenocrysts of plagioclase, hypersthene, and magnetite with minor hornblende and clinopyroxene. Clinopyroxene appears to be absent from the dome obsidian, reflected by small differences in the major elements, expecially $\mathrm{CaO}$ and $\mathrm{MgO}$. The whole-rock analyses are consistent with the stratigraphic association.

\section{ACKNOWLEDGMENTS}

I wish to thank Mr C. G. Vucetich and Dr R. Howorth for useful discussions in the field as well as Mr I. Nairn for valuable comments on the manuscript; the Analytical Facility, V.U.W. for use of the XRF; the Internal Research Committee of Victoria University for funding fieldwork (Grants 118/78 and 62/79); and the Conservator of Forests and Trustees of the Lake Taupo Forest Trust, for access to Lake Taupo State Forest.

\section{REFERENCES}

Ewart, A. 1963: Petrology and petrogenesis of the Quaternary pumice ash in the Taupo Area, New Zealand. Journal of petrology 4(3): 392-431. 1968: The petrology of the Central North Island Lavas. (Part 2). New Zealand journal of geology and geophysics 11: 478-545.

Grindley, G. W. 1960: Sheet 8-Taupo. Geological map of New Zealand 1:250 000. Wellingon, Department of Scientific and Industrial Research.

Healy, J. 1964a: Volcanic mechanisms in the Taupo Volcanic Zone, New Zealand. New Zealand journal of geology and geophysics 7: 6-23.

1964b: Dating of the younger volcanic eruptions of the Taupo region. Part 1 in: Healy, J.; Vucetich, C. G.; Pullar, W. A.: Stratigraphy and chronology of Late Quaternary volcanic ash in Taupo, Rotorua, and Gisborne districts. New Zealand Geological Survey bulletin 73.

Howorth, R. 1975: New formations of Late Pleistocene tephras from the Okataina Volcanic Centre, New Zealand. New Zealand journal of geology and geophysics 19: 683-712.
Norrish, K.; Hutton, J. T. 1969: An accurate X-ray spectrographic method for analysis of a wide range of geological samples. Geochemica et cosmochemica acta $33: 431-453$.

Sparks, R. S. J.; Self, S.; Walker, G. P. L. 1973: products of ignimbrite eruptions. Geology 1:115-118.

Topping, W. W. 1973: Tephrostratigraphy and chronology of late Quaternary eruptives from the Tongariro Volcanic Centre, New Zealand. New Zealand journal of geology and geophysics 16: 397-423.

Topping, W. W.; Kohn, B. P. 1973: Rhyolitic tephra marker beds in the Tongariro area, North Island, New Zealand. New Zealand journal of geology and geophysics 16 : $375-395$.

Vucetich, C. G.; Howorth, R, 1976: Proposed definition of the Kawakawa Tephra, the c. 20000 years B.P. marker horizon in the New Zealand region. New Zealand joumal of geology and geophysics 19: $43-50$.

Vucetich, C. G.; Pullar, W. A. 1973: Holocene tephra formations erupted in the Taupo area, and interbedded tephras from other volcanic sources. New Zealand journal of geology and geophysics $16: 745-780$.

\section{APPENDIX 1}

Description of the section exposed in a road cutting at Mapara Road, Acacia Bay, Taupo (N94/495352), by the entrance to the deer park, on the extreme southern end of small rhyolite dome.

Deposit Thickness Description
$(\mathrm{cm})$

Taupo c.450 unsorted pumice ash, lapilli and Ignimbrite

Taupo

Lapilli

20 coarse pumice lapilli and blocks up to

Rotongaio

$11 \mathrm{~cm}$, eroded top.

Ash

Hatepe

Tephra

Mapara

Tephra

27

uniform dark grey coarse ash.

Whakaipo

Tephra

Waimihia

Formation

5 pumice lapilli with thin layer of fine ash at top.

Hinemaiaia

Tephra

Opepe

Tephra

20 coarse pumice ash, shower bedded, prominent lithics, faint paleosol upper $5 \mathrm{~cm}$.

77 pumice lapilli and ash, prominent shower bedding and lithics.

30 pumice lapilli and coarse ash, medium ash top. Scattered grey pumice lapilli.

70 coarse ash and fine lapilli, faint bedding, lapilli at base to $3 \mathrm{~cm}$.

145 uniform coarse lapilli up to $5 \mathrm{~cm}$ overlain by $33 \mathrm{~cm}$ fine to medium ash.

5 weak paleosol incorporating Poronui Tephra on grey obsidian blocks and ash. 


\section{CHAPTER 2.}

VOLCANIC PROCESSES AND ERUPTIVE MECHANISMS

OF

TAUPO PUMICE FORMATION. 


\section{CHAPTER 2}

VOLCANIC PROCESSES AND ERUPTIVE MECHANISMS OF TAUPO PUMICE FORMATION

2.0

\section{Introduction}

As rhyolitic volcanoes only erupt infrequently, few rhyolitic eruptions have been directly observed. Consequently the eruptive processes and mechanisms are poorly known. Detailed studies of rhyolitic tephras are an important contribution to understanding this type of volcano so that extensive preservation and widespread exposure of Taupo Pumice Formation (TPF) in comparison to other deposits on a worldwide basis make it an ideal subject for detailed study. Prior to 1978, only limited stratigraphic work was published on Taupo Pumice Formation (Healy et al 1964) and none on volcanic processes.

Self \& Sparks (1978) included Rotongaio Ash as a type example of the product of a new class of eruption which they termed "phreatoplinian" to indicate the role of water on an erupting plinian column. They also suggested Lake Rotongaio as the eruptive vent for Rotongaio Ash. Soon after the present author's study was initiated, parallel work was begun by G.P.L. Walker and C.J.N. Wilson both from Imperial College, London, who concentrated on processes involved in the eruption and emplacement of Taupo Pumice Formation. The author had intended to first complete a detailed stratigraphy of Taupo Pumice Formation as a framework for developing eruptive models. Whilst fieldwork was mostly independent, similar eruptive models and concepts were evolved, some of which were amalgamated and published jointly before the stratigraphy was completed.

Four main questions were approached by the author in the volcanic processes study of Taupo Pumice Formation: 
1.

location of the source vent or vents for TPF;

2 . how many phases to the eruptive sequence, including dome extrusion and the number of pyroclastic flows;

3. explanations for the wide diversity in field appearance of TPF, including evidence for mechanisms of pyroclastic flow transport and laminar or turbulent flow;

4. the nature of pumice clasts in Taupo Lapilli and Ignimbrite.

2.1 Source of Taupo Pumice Formation

Location of the source vent for rhyolitic eruptives in the CVR is confounded by a lack of positive topographic features indicative of a volcano and the extensive area covered by lakes, especially Lake Taupo. Despite its youth, Taupo Pumice Formation is no exception to this problem. Early writers assumed Tongariro as the source for Taupo Pumice Formation but Grange (1931) was the first to place the source in the northeast part of Lake Taupo. Isopach maps compiled by Baumgart (1954) led Baumgart and Healy (1956) to postulate source vents that are now buried lying east of the lake. Later writers have added further possible sources north and south of Lake Taupo. These are summarised by Froggatt (1979): Chapter 2.1.1.

The establishment of the radial orientation of numerous charred logs in Taupo Pumice Formation, together with the distribution of pumice and lithic clasts, the absence of ballistic lithics, heat flow under Lake Taupo and the bathymetry of the lake all indicate a single source vent for Taupo Pumice Formation at Horomatangi Reefs.

Further work on the distribution of the charred logs in Taupo Pumice Formation was published by Froggatt et al (1981; Appendix A2) where implications for flow mechanics are examined. In particular, the logs lie sub-horizontally at all levels in the ignimbrite, not just at 
the base, indicating their incorporation and transport by the pyroclastic flow. Although small branches are missing, most logs are intact, including bark, and it is doubtful whether they could have been so well preserved in a turbulent flow. Intact logs thus indicate laminar flow over nearly all the distance travelled by the flow. 
2.1.1 LAKE TAUPO - PROBABLE SOURCE OF TAUPO PUMICE FORMATION.

Reprinted from: New Zealand Journal of Geology and Geophysics; Vol $22(6)$ pp763-4. 1979. 


\title{
Lake Taupo-probable source of Taupo Pumice Formation (Note)
}

\author{
P. C. Froggatt
}

\author{
Geology Department, Victoria University of Wellington, Wellington, New Zealand
}

\section{Abstract}

New evidence for the source of Taupo Pumice Formation includes orientation of charred logs, distribution of pumice and lithic material, absence of ballstic lithics, and bathymetry of Lake Taupo. All these clearly suggest an origin within eastern Lake Taupo, most probably at Horomatangi Reefs. No new evidence was found to substantiate sources beyond Lake Taupo.

Keywords Taupo Pumice Formation, Lake Taupo, pumice, charcoal, pyroclastic rocks, volcanism, heat sources

\section{INTRODUCTION}

Considerable speculation has been revived recently concerning the source or sources of Taupo Pumice Formation (Healy 1964). Baumgart (1954) and Baumgart \& Healy (1956) published isopach maps indicating the now "traditional" Waitahanui sources for Taupo Lapilli, Rotongaio Ash, and Hatepe Lapilli members. Baumgart also suggested additional sources for Taupo Lapilli to the west and south of Taupo township. Topping \& Kohn (1973) were convinced of multiple sources for the pyroclastic flows (Upper Taupo Pumice members) to the south of Lake Taupo, inferred these to explain local thickness and pumice size at Rotoaira. Cole \& Nairn (1975, p. 74) postulated in their summary of volcanic centres further vents "submerged in Lake Taupo". Recently, Rijkse (1977) inferred a southern source to explain the thickness and extent of flow tephra and pumice alluvium in the King Country. $\mathrm{He}$ further suggested the rhyolite domes around Tokaanu as possible sources, views generally supported by Birrell (1978) and Pullar (1978). However, these domes were examined by Topping (1974) who, using tephrostratigraphy, concluded that they were not associated with the Taupo Pumice eruption.

While mapping the soils of the Waiotapu region, Vucetich \& Wells (1978) were impressed with the thickness and coarseness of parts of Upper Taupo Pumice members. They named this "Ngaufuku Block and Ash" and believed a major source vent lay within or close to Maroa Basin.

\section{Probable Source Location of Taupo Pumice}

Evidence for a probable source location is given as follows:

1. One of the prominent features of Taupo Pumice flow tephra (upper Taupo Pumice members) is the abundance of charcoal, often as whole branches or logs. These are always found lying prone within the deposit and may be aligned with the direction of flow. At sites in open areas the flow would be unconfined so logs should be aligned radially from source. Orientation of these logs was measured, and the values of each site averaged (Fig. 1). Where flow direction was controlled by valleys in the pre-eruptive topography, the orientation

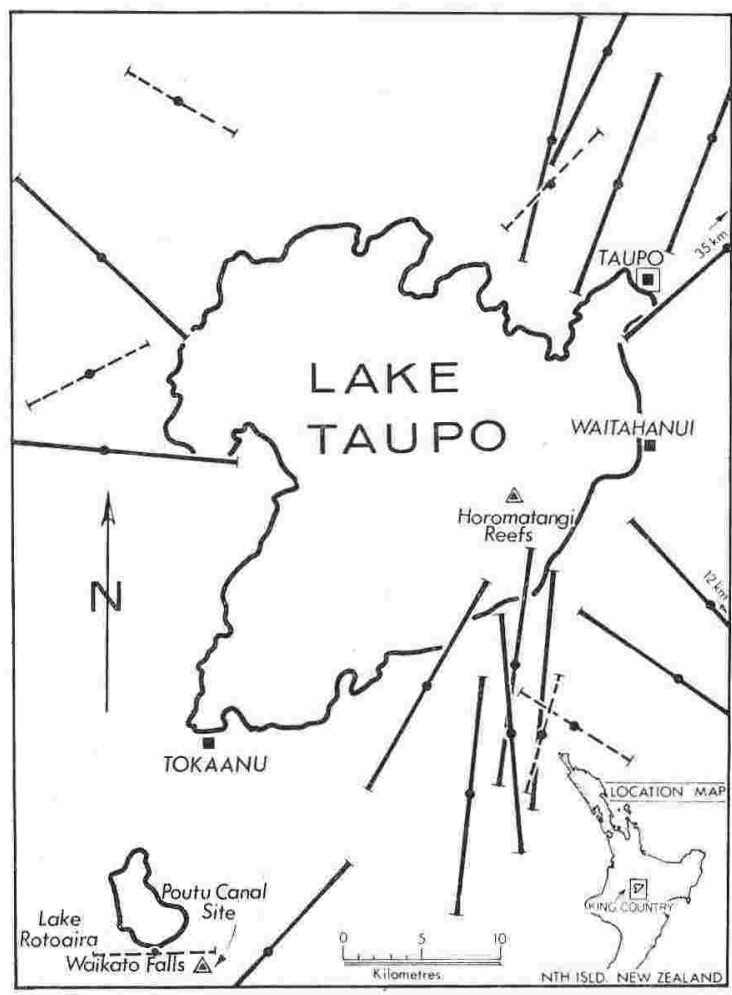

Fig. 1-Average orientation of charred logs within Taupo Pumice flow tephra at each site. Range of orientations for logs at each site is $\pm 15^{\circ}$ about the mean. Dashed lines are for less reliable valley sites.

of logs is considered an unreliable indicator of direction to source. A few examples of this type of site were sampled to demonstrate the unreliability of this data.

2. Thickness of the Taupo Pumice flow tephra will not necessarily be greatest at source because it resulted from a flow of very high mobility. Maximum thickness will be in valley situations where this flow "ponded". Hence exceptional flow thicknesses at Maroa, Waikato Falls, Poutu Canal (Pullar 1978), or King Country (Rijkse 1977) do not imply a nearby source. 
3. Distribution of lithics, especially ballistic sized material, is regarded as a reliable indcator of source. Ballistic lithics in plinian type eruptions usually extend $3-6 \mathrm{~km}$ from the vent (Booth et al. 1978). No ballistic lithics have been found within Taupo Lapilli or Hatepe Lapilli, strongly suggesting the source of these plinian phases is within Lake Taupo. At distal sites of the flow tephra, such as Waikato Falls, the content of lithic material (rhyolite, obsidian, rare mudstone, and ignimbrite) is negligible, but lithics increase steadly in size and abundance towards the north.

4. Heat flow measurements in Lake Taupo (Christoffel \& Calhaem 1979) revealed a hot spot centred over Horomatangi Reefs, where heat output through the lake floor exceeded $100 \mathrm{MW}$. They attributed the heat source to conductive heat from a recent intrusive body.

All available field evidence strongly indicates the source area for several Taupo Pumice members is within eastern Lake Taupo, possibly near Horomatangi Reefs. Examination of the detailed bathymetric map of this area in Lake Taupo (Irwin 1972) shows three roughly circular depressions. One depression of $500 \mathrm{~m}$ diameter, lying between the major reefs, drops steeply to $164.6 \mathrm{~m}$ depth or $44.6 \mathrm{~m}$ below the average lake floor depth. This depression is the deepest point in the lake and the surrounding reefs suggest a "volcano-like" form. It may be the source for most members of the Taupo Pumice.

\section{ACKNOWLEDGMENTS}

I wish to thank Mr C. G. Vucetich for helpful discussions and critically reading drafts of this paper. Dr W. A. Pullar, Mr I. A. Nairn, and Dr K. S. Birrell provided helpful comments and reviewed the manuscript. Fieldwork was financially supported by the Internal Research Committee of Victoria University of Wellington (Grants 21/78 and 118/78).

\section{References}

BAUMGarT, I. L. 1954: Some ash showers of central North Island. N.Z. Journal of Science and Technology $B 35: 456-7$.
Baumgart, I. L.; Healy, J. 1956: Recent volcanicity at Taupo, New Zealand. Proceedings, $8 t h$ Pacific Science Congress 2: 113-25.

BIRRELl, K. S. 1978: More about sources of Taupo Pumice. N.Z. Soil News 26 (1): 32-3.

Booth, B.; Croasdale, R.; Walker, G. P. L. 1978: A quantitative study of five thousand years of volcanism on Sao Miguel, Azores. Pbilosopbical Transactions of Royal Society A 288: 271-319.

Christoffel, D. A.; Calhaem, I. M. 1979: Geothermal measurements over a hot spot in Lake Taupo (Abstract). 49th ANZAAS Congress, Auckland, January 1979. Abstracts Vol. 1 Section 3, p. 158.

Cole, J. W.; NatrN, I. A. 1975: "Catalogue of the active volcanoes of the World including solfatara fields. Part XXII New Zealand". International Association of Volcanology and Chemistry of the Earth's Interior. Rome. 156 p.

HEALY, J. 1964: Stratigraphy and chronology of late Quaternary volcanic ash in Taupo, Rotorua, and Gisborne districts. Part 1. N.Z. Geological Survey Bulletin 73. 88 p.

IRWIN, J. 1972: Lake Taupo, provisional bathymetry, 1: 50000 . N.Z. Oceanograpbic Institute Chart, Lake series.

Pullar, W. A. 1978 : Sources of Taupo Pumice-a discussion. N.Z. Soil News 26 (1): 33-4.

RiJkse, W. C. 1977: Additional sources of Taupo Pumice. N.Z. Soil News 25 (6): 219-21.

TopPING, W. W. 1974: Some aspects of Quaternary history of Tongariro volcanic centre. (Unpublished Ph.D. thesis lodged in Victoria University of Wellington library.)

ToppING, W. W.; KoHN, B. P. 1973: Rhyolitic tephra marker beds in the Tongariro area, North Island, New Zealand. N.Z. Journal of Geology and Geopbysics $16(3)$ : 375-95.

Vucetich, G. G.; Wells, N. 1978: Soils, agriculture, and forestry of Waiotapu region, Central North Island, New Zealand. N.Z. Soil Bureau Bulletin 31. $100 \mathrm{p}$. 
2.2 Eruptive Phases in Taupo Pumice Formation and a Note on the Origin of Grey Pumiceous Blocks about Northeast Lake Taupo

Stratigraphic mapping (Chapter 1.2) established 4 major pyroclastic eruptive phases in Taupo Pumice Formation: Hatepe Tephra, Rotongaio Ash, Taupo Lapilli and Taupo Ignimbrite. Hatepe Tephra is divided on field evidence into 2 units, a lower coarse plinian pumice (Hatepe Lapilli) and an upper fine pumiceous ash (Hatepe Ash). The upper ash is regarded as being of phreatoplinian origin (Walker 1981). The 2 units are conformable and no evidence for a time break between them has been found. The top of Hatepe Tephra is deeply eroded to form a regularly rilled surface, paraconformably mantled by Rotongaio Ash, also of phreatoplinian origin. Minor erosion and internal, deformed bedding of Rotongaio Ash suggest a short time break before the eruption of the plinian Taupo Lapilli. Taupo Lapilli was followed by a series of pyroclastic flows that formed Taupo Ignimbrite, but a number of sections close to source expose lenses of plinian pumice within the Lower unit of the ignimbrite. For the plinian pumice to be preserved, a number of separate flows must have occurred. The Upper unit of Taupo Ignimbrite also consists of an interbedded sequence indicating several flows. Some of these beds show cross-bedding and dune forms typical of base surge deposits. The airfall beds contain chalazoidites (accretionary lapilli) and possibly represent co-ignimbrite airfall ashes. 
Sparks et al (1973) observed that rhyolitic eruptions commonly followed the same sequence of events from initial explosive plinian and pyroclastic flow phases to the relatively quiet extrusion of a lava dome. If the Taupo Pumice eruptive episode followed this pattern, then a dome is predicted at the site of the eruptive vent. Evidence cited above leads to the conclusion that the Horomatangi Reefs area was almost certainly the eruptive vent for Taupo Pumice Formation, so that if any dome extrusion occurred following the ignimbrite eruptions this was the most probable site. The reefs are completely covered by Lake Taupo and lie in up to $264 \mathrm{~m}$ of water (Irwin 1972) prohibiting direct observation. At times of low lake level the reefs are within $1-2 \mathrm{~m}$ of the surface and can be seen to be composed of grey, low porosity material broken by a network of regular polygonal joints. Similar grey rhyolite has been noted as a selvedge to rhyolite domes at Motutaiko Island and the Maroa area indicating that Horomatangi Reefs is probably a dome of Taupo Pumice age.

The eruptive sequence of Taupo Pumice can be summarised as:-

1. plinian pumice

2. phreatoplinian ash

3. short time break with erosion

4. phreatoplinian ash

5. plinian pumice

6. interbedded plinian/ignimbrite

7. ignimbrite - Middle unit

8. interbedded ignimbrite/plinian pumice

9. co-ignimbrite airfall ash

10. dome 
GREY PUMICEOUS BLOCKS ABOUT NORTHEAST LAKE TAUPO

The origin of prominent blocks of grey, poorly vesicular rhyolite, outcropping near the northeast margin of Lake Taupo has long been the subject of controversy, but nothing is published on them. Further outcrops of this material, named "protopumice" by H.W. Wellman were discovered by D. Northey and H.W. Wellman (pers. comm. 1980) who considered the possibility of the outcrops being in situ extrusives along a Taupo Pumice Formation-aged ring fracture. All outcrops but one sampled by Northey have normal magnetic polarity. These outcrops (Fig. 2.2.1, nos. 3-7, 11, 12) do lie on an arc centred near Horomatangi Reefs but further outcrops, discovered by the author (Fig. 2.2.1) are not all on this arc. The protopumice occurs as large coherent blocks up to $150 \mathrm{~m}^{3}$, with near-vertical polygonal jointing forming 3,5 and 6 sided columns up to $200 \mathrm{~mm}$ across. Sets of columns are separated by horizontal joints 2-3m apart. At 3 outcrops (numbers 1, 2, 13 on Fig. 2.2.1) the blocks could clearly be seen overlying postTaupo Pumice pumiceous lacustrine sediments and are thus "rootless". All outcrops lie on clearly defined post-Taupo Pumice lake benches cut into Taupo Ignimbrite and all are in the sector north to southeast of Horomatangi Reefs. Bulk density of the protopumice is $0.97 \mathrm{gm}^{\mathrm{cm}} \mathrm{cm}^{-3}$ and small blocks rapidly saturate and sink in water, but larger $(0.3 \mathrm{~m}$ diameter) blocks remain afloat. The blocks are identical in appearance and chemistry to Horomatangi Reefs and Taupo Pumice. It is here considered that these blocks have all been emplaced after the Taupo Pumice eruptions by being detached from the top of the dome at Horomatangi Reefs and then driven shorewards by storm winds. The prominent horizontal and polygonal jointing assisted the formation of tabular blocks which retained their attitude of formation after becoming grounded on the then lake shoreline. 


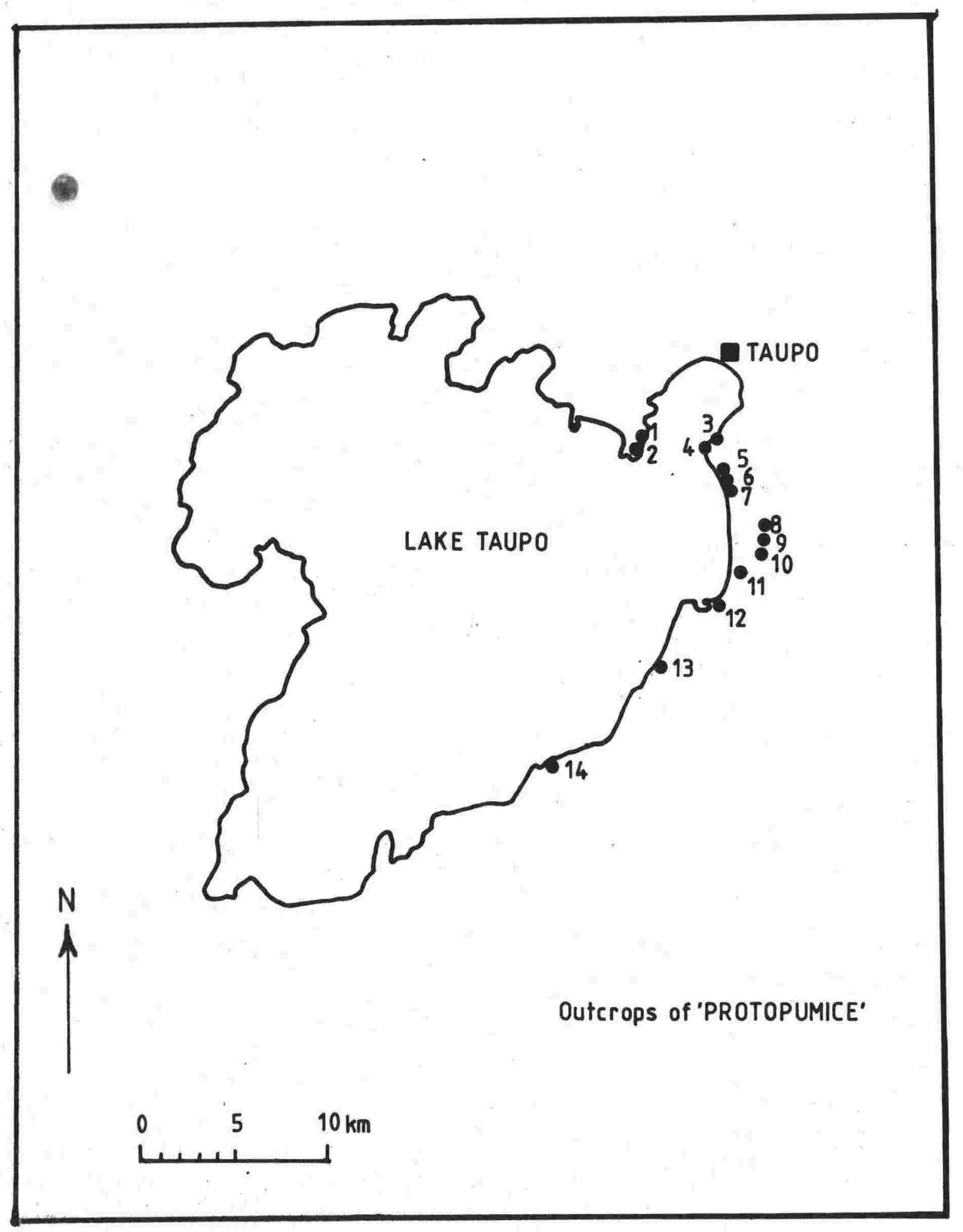

F'IGURE 2.2.1: Locations of known outcrops of grey,poorly vesicular pumice ("protopumice") about Lake Taupo. Outcrops 8-10 13,14 are newly discovered. Outcrops 1,3 and 13 are rootless and 14 sits directly on Rangitaiki Ignimbrite. 
Some blocks are rectangular with long axis vertical and so could not have floated in their present attitude. If the lower portion of these blocks had become saturated by the rising lake, the increased density of the lower part would have kept the blocks floating upright until they grounded on the shoreline and were partly buried by alluvium.

\subsection{Density and Porosity of Pumice from Taupo Pumice Formation}

\subsubsection{Introduction}

Differences in pumice density and porosity are clearly visible in the field. In particular, some clasts within Taupo Ignimbrite appear to have an extremely high porosity and distinctive, elongated vesicles. Pumice clasts can be visually divided on vesicle shape into two types: linear and non-linear. Linear vesicles are straight and tube-like, quite different from the randomly shaped vesicles in "frothy" pumice. The linear vesicles are only found in Taupo Ignimbrite so measurements of pumice density and porosity were undertaken in an attempt to quantify the linear pumice group and to distinguish pumice from plinian and ignimbrite phases. As porosity is a measure of the intensity of magma vesiculation at the time of eruption it may provide information on the mechanisms of plinian and ignimbrite eruptions.

Few systematic studies of these parameters have been published. Ewart (1963) measured bulk density and modal vesicles and vesicle size range from thin sections for some of the Taupo Holocene tephras but no account was taken of the clast size. A study on the density of sizegraded pumice from the 1947 eruption of Hekla, Iceland (Henson 1952), showed an almost log-normal variation of density with grain size. While examining the rate of fall of pyroclasts, Walker et al (1971) measured the density of various size grades of pumice from Fogo A (Azores) and 
Askja 1874 (Iceland) eruptions. Lirer et al (1973) give three size classes of pumice from Somma-Vesuvius, and Walker (1980) gives several size-density measurements, including one for Taupo Lapilli. These data are plotted on Fig. 2.3.1. All show a strong log-normal relationship.

A pumice bulk density of 0.5 or $1.0 \mathrm{Mgm}^{-3}$ has commonly been assumed for the purpose of calculations (Kittleman 1973; Sparks et al 1978). Murai (1961) gave the average dry bulk density of pumices larger than lapilli size for many Japanese pyroclastic flows and associated airfall tephra. Values of $0.211-0.777 \mathrm{Mgm}^{-3}$ are cited by Kuno et al (1964) for pumice from the Towada pyroclastic flow and Katsui et al (1979) give a range of 0.35 to $1.4 \mathrm{Mgm}^{-3}$ for pumice from Usu Volcano. In a catalogue of physical properties of New Zealand rocks, Whiteford and Lumb (1975) list density measurements for samples of pumice ranging from 0.37 to $1.90 \mathrm{Mgm}^{-3}$. Nairn (1971) gives densities on rhyolitic pumice between 0.77 and $1.04 \mathrm{Mgm}^{-3}$ and porosity between 56.6 and $68.8 \%$. Thus pumice shows a wide range of density. The relationships in Fig. 2.3.1 suggested that 2 approaches to measuring pumice density be adopted; the first to investigate the dependence of density on grain size and the second to examine the variation in density and porosity of large blocks from plinian and ignimbrite deposits. Each technique needs different types of samples so two collections were made.

\subsubsection{Sampling}

Bulk samples of Taupo Lapilli and Taupo Ignimbrite were collected for sieving and the determination of density on each size class. For comparison, similar samples were taken from the type section of other TSG tephras. 


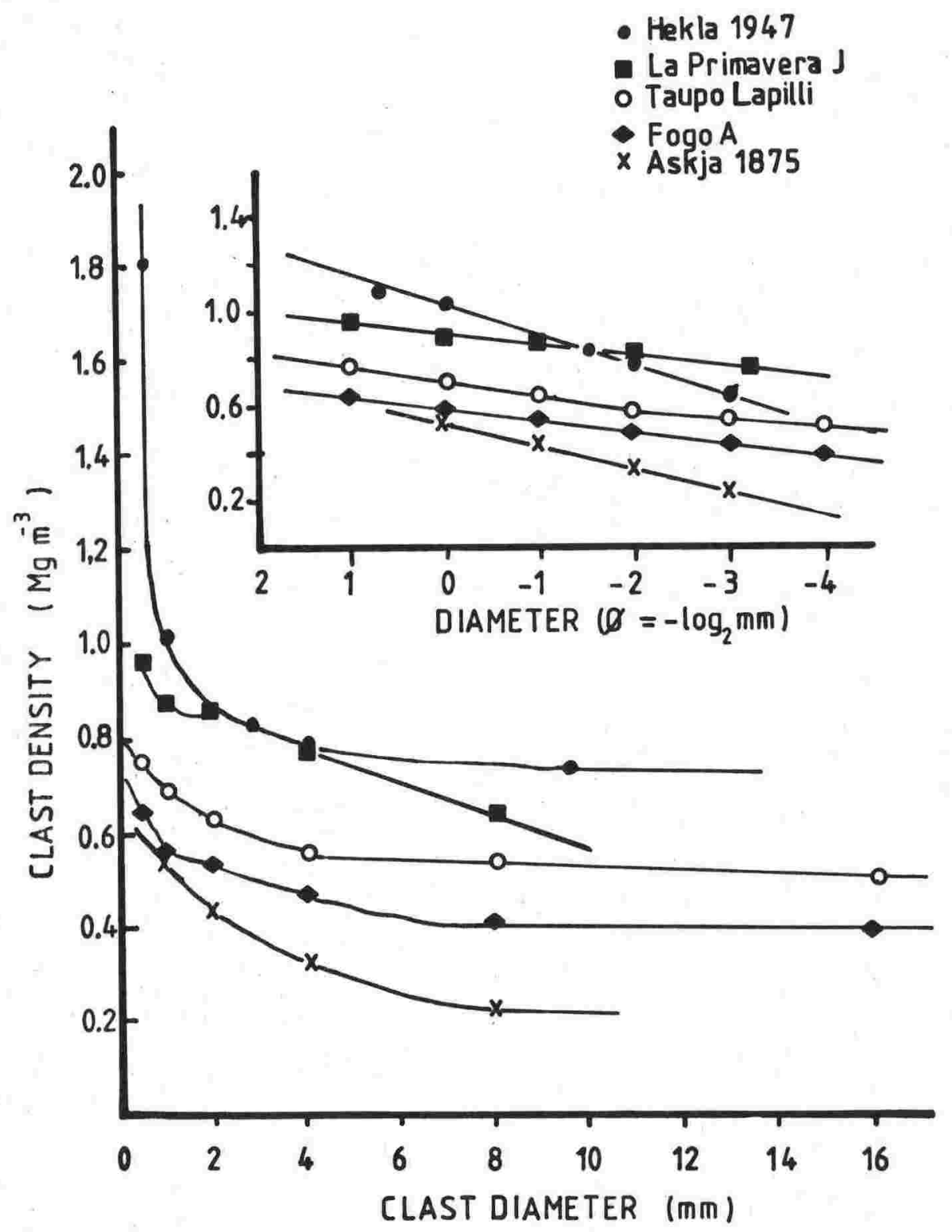

FIGURE 2.3.1: Variation of pumice clast density with grainsize for published data, plotted on linear and log scales. 


\section{6}

To examine the variations of density and porosity, plinian deposits were sampled by selecting large pumice clasts from outcrops near to source where the clasts are largest. Taupo Ignimbrite has a wide range of clast size even at great distances from source, with some blocks more than 1 metre across. About 10 individual clasts were chosen from each site to sample the range of clast size, density and porosity. Large clasts were subsampled on site by splitting with a spade and some were later further split to provide duplicate samples.

\subsubsection{Density Measurements}

Determining the density of natural pumice clasts presents several problems. When dry, pumice generally floats in all liquids making immersion methods for determining volume difficult. Also open pores and an irregular surface texture may lead to large volume errors using immersion methods. Walker (1972) estimated the inter-grain voids in a known volume of pumice clasts by assuming a particle shape and packing, but this method is not considered reliable for clasts with an irregular shape.

(a) Sieved Samples

For this study bulk samples of airfall tephras were hand sieved at $\frac{1}{2} \varnothing$ intervals down to $2 \mathrm{~mm}(-1 \varnothing)$ and visible lithics or free crystals removed by hand or settling in water. Pumice clasts in each size grade were packed into a beaker of known volume with inter-grain voids filled by glass beads of $0.3 \mathrm{~mm}$ mean diameter and known bulk density. By weighing, the average clast density for each size grade was calculated. All determinations were triplicated and meaned.

\section{Large Pumice Blocks}

The major problem in density measurement of large pumice clasts 
from Taupo Lapilli and Ignimbrite was determining the volume. Standard methods of density determinations use regular shaped cylinders or blocks, so allowing the volume to be directly measured and also to minimise surface effects. Sample volume in this study was measured by two methods; direct measurement of cut cuboid blocks and by weighing the blocks in water after saturation. The former is considered to give a better total volume by eliminating surface effects, and has been used in all further calculations.

Steps followed for determining density (after Hatherton and Leopard 1964) on blocks cut with orthogonal faces were:

(a) Blocks were oven dried at $105^{\circ} \mathrm{C}$ for at least 48 hours, cooled to room temperature $\left(15^{\circ} \mathrm{C}\right)$ in a dessicator then weighed to $0.001 \mathrm{gm}$.

(b) Side lengths were measured to $0.1 \mathrm{~mm}$ from which volume and then Dry Bulk Density were calculated.

(c) Blocks were saturated in water at reduced pressure for 8-10 weeks or until no further air was expelled.

(d) Saturated mass and mass in water were determined.

(e) Saturated volume, then saturated density and "particle" density were calculated.

From the values of dry density and particle density the percentage porosity was calculated from:

$$
\text { Porosity }(\%)=100\left(1-\frac{\text { dry density }}{\text { particle density }}\right)
$$

A total of 189 samples were measured: 30 from airfall tephras and 159 from Taupo Ignimbrite. Errors involved in each determination are small and measurement errors are estimated at less than $1 \%$. Twentyone sets of duplicate samples (sub-samples) were cut to test for sample 
homogeneity and reproducibility. Maximum differences between duplicates were $0.04 \mathrm{mgm}^{-3}$ for dry density and $5.1 \%$ for porosity, with the average figures for these parameters being $0.01 \mathrm{Mgm}^{-3}$ and $1.0 \%$ respectively. Thus the average errors were about $3.5 \%$ for density and $1.3 \%$ for porosity.

Particle density was directly determined on 10 powdered samples as a check on the saturation measurements.

The procedure was:

(a) Powder sample in "Tema" mill for 10 seconds

(b) Weigh dry 100ml volumetric flasks

(c) Weigh bottle with deaired water only

(d) Weigh flask with powdered sample (between 2-15gm used)

(e) add distilled, deaired water to $3 / 4$ fill flask

(f) apply vacuum and heat flask to remove air

(g) fill flask to volumetric level and let stand for at least 48 hours

(h) weigh sample + bottle + water

Particle density is calculated from

$$
D p=\frac{W s}{W b w+W s-W b w s} \times \frac{\gamma_{w}}{\gamma_{0}}
$$

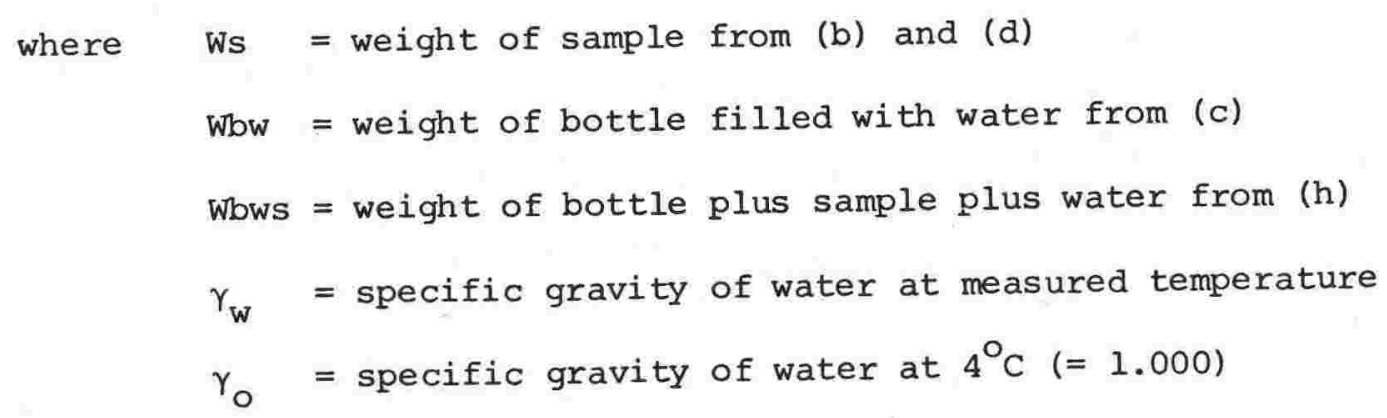

The ratio $\gamma_{w} / \gamma_{0}$ compensates for the change of water density with temperature, being the maximum density of $1.000 \mathrm{gm} \mathrm{cm}^{-3}$ at $4^{\circ} \mathrm{C}$. The above 
measurements were made at a constant room temperature of $14^{\circ} \mathrm{C}$ when the ratio $\gamma_{W} / \gamma_{0}=0.99927$. Considering the accuracy of the density measurements, undertaken without precise temperature control, this factor was omitted when Dp was calculated.

\subsubsection{Results of Density-Porosity Measurements}

\section{(i) Degree of Saturation}

Pumiceous material has an inherently high porosity, but many of these pores or vesicles are considered closed and normal saturation techniques were thought not to fill them. For instance, 4 measurements on a "Iight grey pumice obsidian" by Nasedkin et al (1967) gave an averaged true porosity of $74 \%$ and apparent porosity of only $5.5 \%$ with closed pores constituting $93 \%$ of the total. Because of this, porosity has seldom been measured, dry density being used instead (Murai 1961; Aramaki \& Yamasaki 1963). Ewart (1963) and Heiken (1978) measured modal vesicles in thin sections of pumice clasts. This method is potentially unsatisfactory as pumice vesicles are not regularly distributed and the vesicles are often extremely nonspherical. The method suffers a similar problem to grain-size analyses of thin sections (Adams 1977). Nonetheless, saturation under vacuum was attempted and maximum saturation appeared to have been reached in 8-10 weeks when no further air was expelled and a constant saturated mass was achieved. Blocks were then weighed and volumes calculated. As a test of the degree of saturation, saturated volume is compared to total volume (Fig. 2.3.2). A good linear correlation exists $(R=0.993)$ and the relationship is nearly one to one, suggesting almost total saturation was achieved. If the degree of saturation was volume dependent, the relationship on Fig. 2.3.2 would not be linear. 


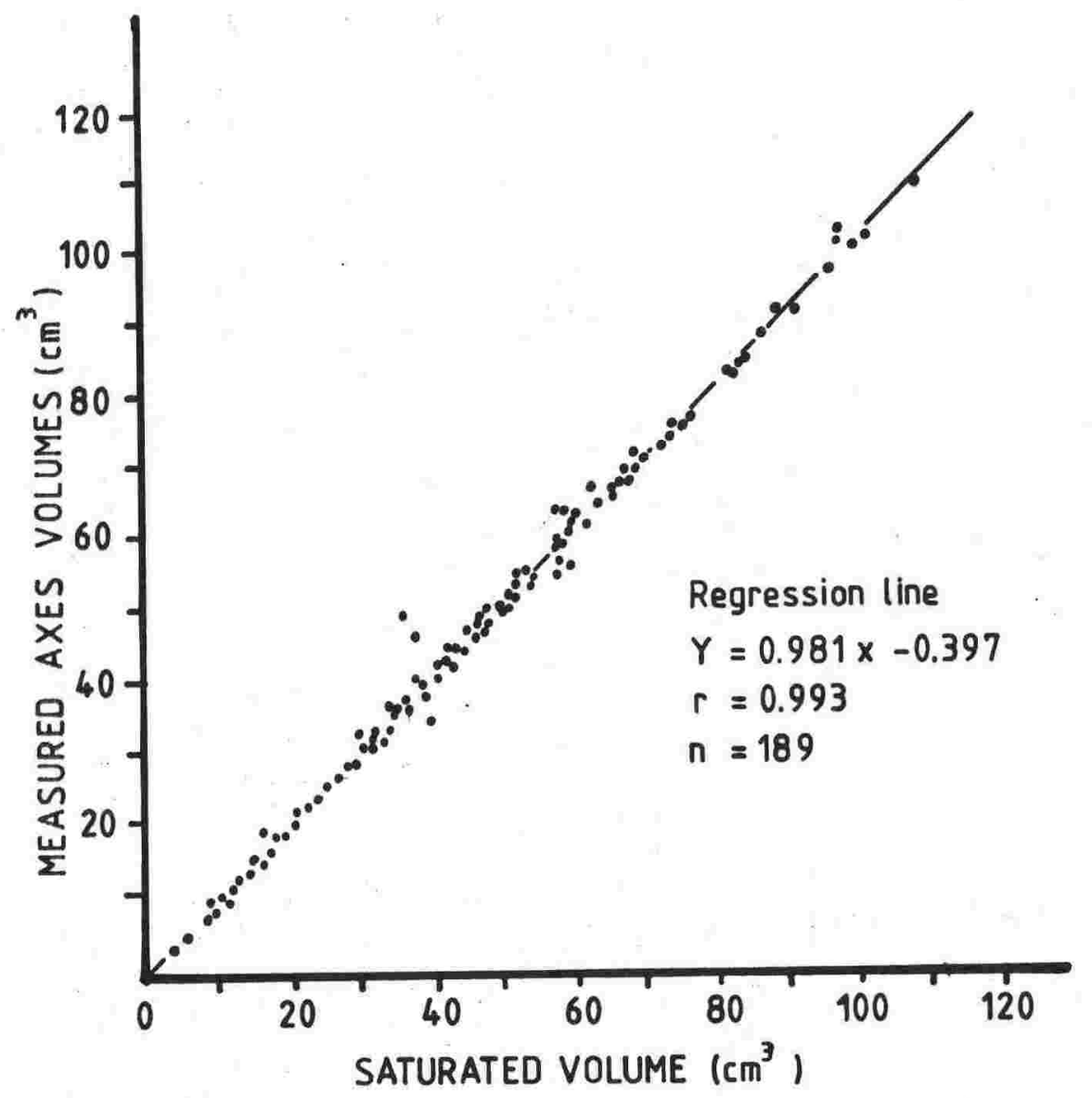

FIGURE 2.3.2: Comparison of sample volumes calculated by measuring side lengths of rectangular blocks and from immersion in water after saturation. 
(ii) Comparison of Particle Density Measurements

Calculation of porosity is dependent on particle density, the reliability of which is governed by the efficiency of pumice saturation. Although saturation appears to have been successful, calculated particle densities range from 1.6 to $2.2 \mathrm{gm} \mathrm{cm}^{-3}$. Rhyolite glass has a density of about 2.37 and granite glass $2.45 \mathrm{gm} \mathrm{cm}^{-3}$ (Clark 1960) suggesting the measured particle densities are significantly low. This would result in low calculated porosities.

The particle density of 10 powdered samples is greater than for equivalent saturated blocks (Table 2.3.1) but is also significantly lower than the density of rhyolite glass. The mean value of 2.13 suggests a porosity of $10 \%$ and as the pumice was powdered to less than 50 microns the vesicles must be smaller than this. To grind the sample finer and remove smaller vesicles would be difficult and density measurement of fine powder is complicated by surface tension effects. Particle density values of around $2.0 \mathrm{gm} \mathrm{cm}^{-3}$ were also obtained on pumice by Terry Mumme of Geophysics division DSIR (pers. comm. 1980) and Hodder (1974). The glass was significantly hydrated (about 5\% water) and this may be responsible for lower densities.

\section{(iii) Density Variations of Size Graded Pumice}

Published data on the variation of density with pumice clast size show a strong log-normal relationship (Fig. 2.3.1) with density increasing as the size decreases. Taupo Lapilli and other TSG tephras also follow this trend (Fig. 2.3.3a) including the ignimbrites (Fig. $2.3 .3 b)$. 
TABLE 2.3.1

\begin{tabular}{|l|c|c|}
\hline \multicolumn{1}{|c|}{ Sample } & $\begin{array}{c}\rho \text { gm. } \mathrm{cm}^{-3} \\
\text { Powdered }\end{array}$ & $\begin{array}{c}\rho \mathrm{gm} . \mathrm{cm}^{-3} \\
\text { Saturated }\end{array}$ \\
\hline TAUPO IGNIMBRITE & & \\
Boat Harbour & 2.15 & $1.83 \pm 0.02$ \\
Straight Line Road & 2.15 & $1.77 \pm 0.32$ \\
Chasm Bog & 2.14 & $1.78 \pm 0.15$ \\
Kinloch & 2.19 & $1.63 \pm 0.36$ \\
Maroa & 2.40 & $1.75 \pm 0.32$ \\
Mangatete Road & 2.07 & $2.07 \pm 0.26$ \\
Marotiri School & 2.23 & $1.68 \pm 0.12$ \\
Waikato Falls & 1.75 & $1.93 \pm 0.33$ \\
Tarawera & 1.98 & $1.68 \pm 0.36$ \\
WAIMIHIA LAPILLI & 2.27 & $1.81 \pm 0.14$ \\
\hline
\end{tabular}



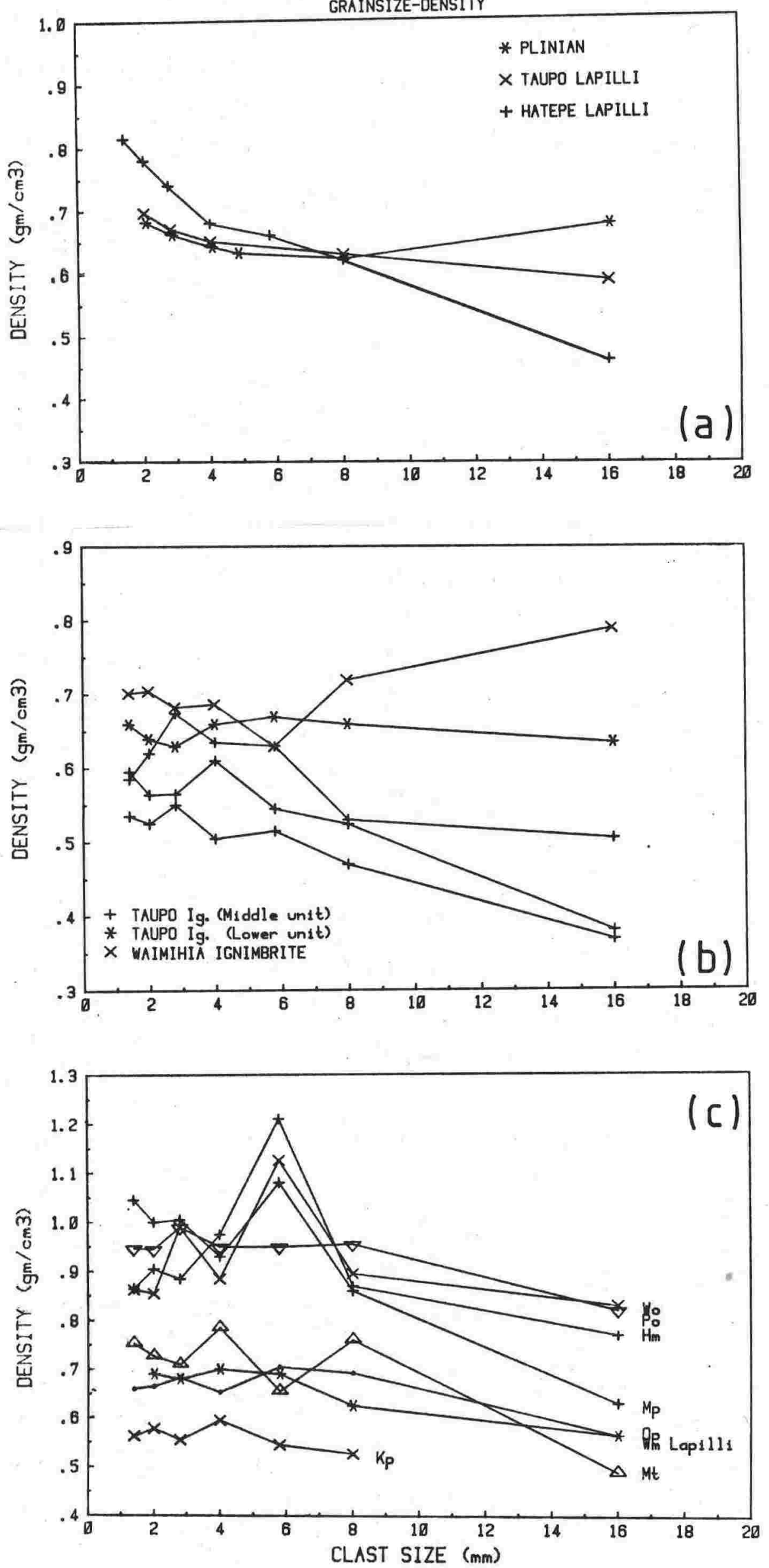

FIGURE 2.3.3: Variation of clast density with grainsize for Taupo Pumice and other Taupo Subgroup tephras. Data for the "plinian" tephra from Walker (1980). 
The tephras plotted on Fig. 2.3.3 fall into two groups; a low density group of Karapiti, upper Motutere, Waimihia Lapilli and Taupo Pumice and a higher density group of Poronui, lower Motutere, Whakaipo and Mapara Tephras. All the curves plotted are nearly parallel, indicating a uniform increase in density although individual curves plot between 0.5 and $1.0 \mathrm{gm} . \mathrm{cm}^{-3}$. All but Poronui of the higher density group have a marked peak at $5.8 \mathrm{~mm}(-2.5 \varnothing)$. This could be a result of the measuring technique but the plotted values were reproducible for each tephra. Mapara, Whakaipo and Motutere Tephras are prominently shower bedded or graded bedded, in contrast to the other tephras plotted so bulk sampling will have mixed material from several beds.

\section{(iv) Variation of Density with Porosity}

For a given particle density, bulk density decreases linearly as porosity increases. As a means of visually comparing data for plinian tephras and ignimbrites, these parameters are plotted on Fig. 2.3.4. Slope of a line on this plot is determined by the particle density and lines with particle densities ranging from 1.0 to $2.5 \mathrm{Mgm}^{-3}$ are shown. Plinian tephras plot over wide range of Fig. 2.3 .4 but have dry densities greater than about $0.4 \mathrm{Mgm}^{-3}$ and less than $80 \%$ porosity. Pumices from Taupo Ignimbrite also plot over a wide range that overlaps the airfall tephras but with typically lower densities and higher porosities. Within these pumices is the group of linear pumices with markedly elongated vesicles. These pumices were easily identified visually and plot (Fig. 2.3.4) as a separate cluster with low densities and extremely high porosities (83-91\%). Similar linear pumice was described by Murai (1961) from several Japanese flows and these also had consistently lower densities. 


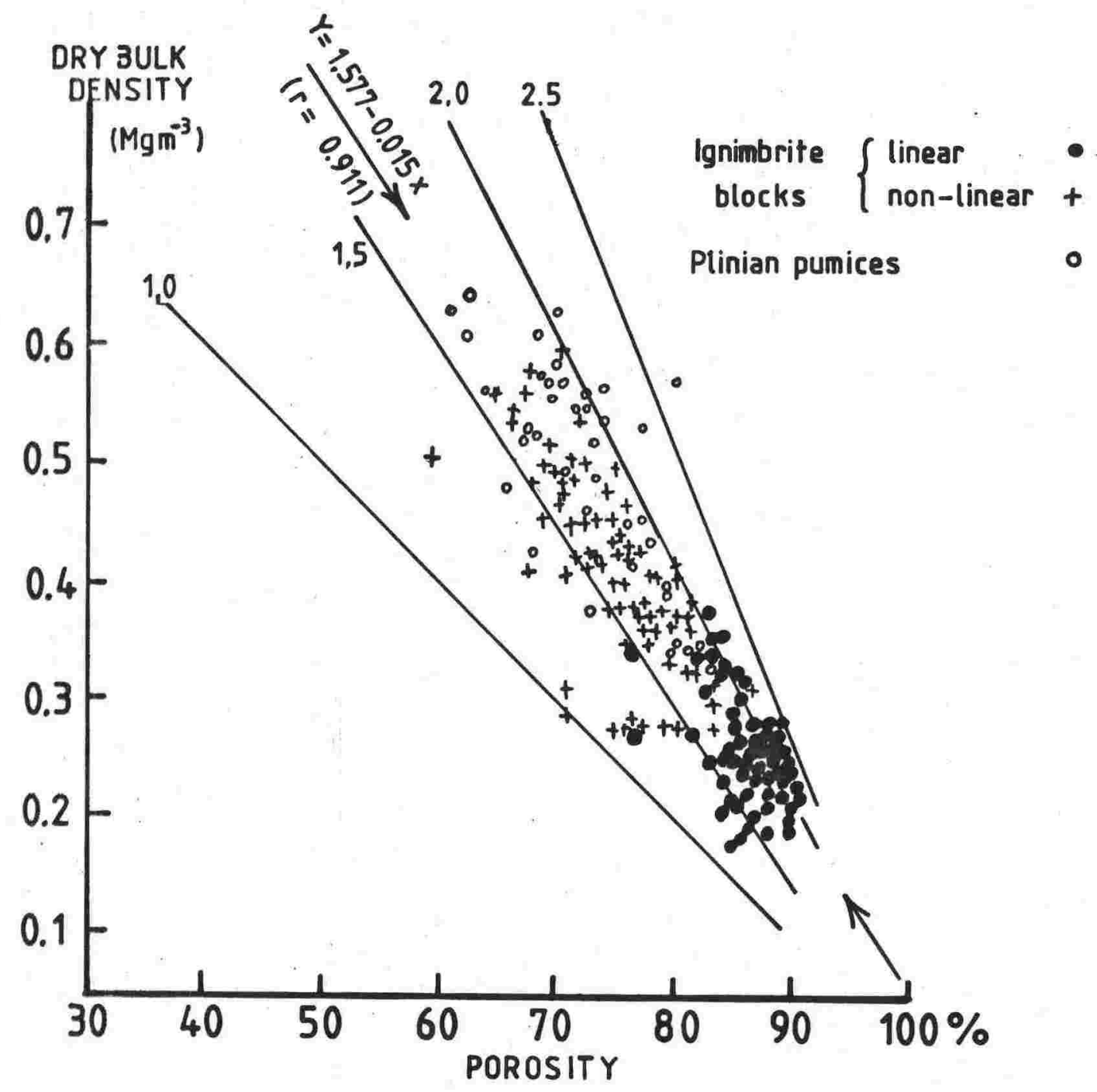

FIGURE 2.3.4: Separation of pumice types according to bulk density and porosity. 
Pumices from Taupo Lapilli have overall higher densities and lower porosities than those from the immediately succeeding ignimbrite. This finding is at variance with the conclusions of Murai (1961, p. 228-9) and Walker (1971). However Aramaki and Yamasami (1968) suggest density decreases and hence porosity increases with increasing erupted volume (mis-quoted by Sparks et al 1978), a conclusion supported here.

\section{(v) Density Variations with Distance in Taupo Ignimbrite}

A total of 18 widespread sites (159 samples) located on several radii, at distances of 11 to $54 \mathrm{~km}$ radially from source were sampled in Taupo Ignimbrite. Previous studies of variations within ignimbrites have concentrated on grain-size parameters and lithic-crystal distribution (e.g. Walker 1972, Sparks 1976). A study of roundness of pumice clasts (Murai 1961) concluded that no significant increase in roundness occurs with distance travelled, however clasts from ignimbrites are significantly more rounded than airfall clasts. These conclusions are supported by field observations at Taupo.

Within Taupo Ignimbrite, average pumice density significantly decreases with distance from source as shown on Fig. 2.3.5. The form of this decrease may be linear $(R=-0.637)$ but could also be fitted to an exponential. Either function would seem equally plausible but the critical, near source sites needed to resolve this are buried beneath Lake Taupo. As expected, saturated density decreases slightly while porosity shows a sympathetic increase with distance.

From Fig. 2.3.5 the $95 \%$ confidence limits, and hence standard deviation for both dry bulk density and porosity, appear to improve with distance (Fig. 2.3.6). This change and the trend on Fig. 2.3.5 is reflecting the better density-sorting with distance as the lower density linear pumice variety increases in visual abundance from less than $10 \%$ 


\section{7}

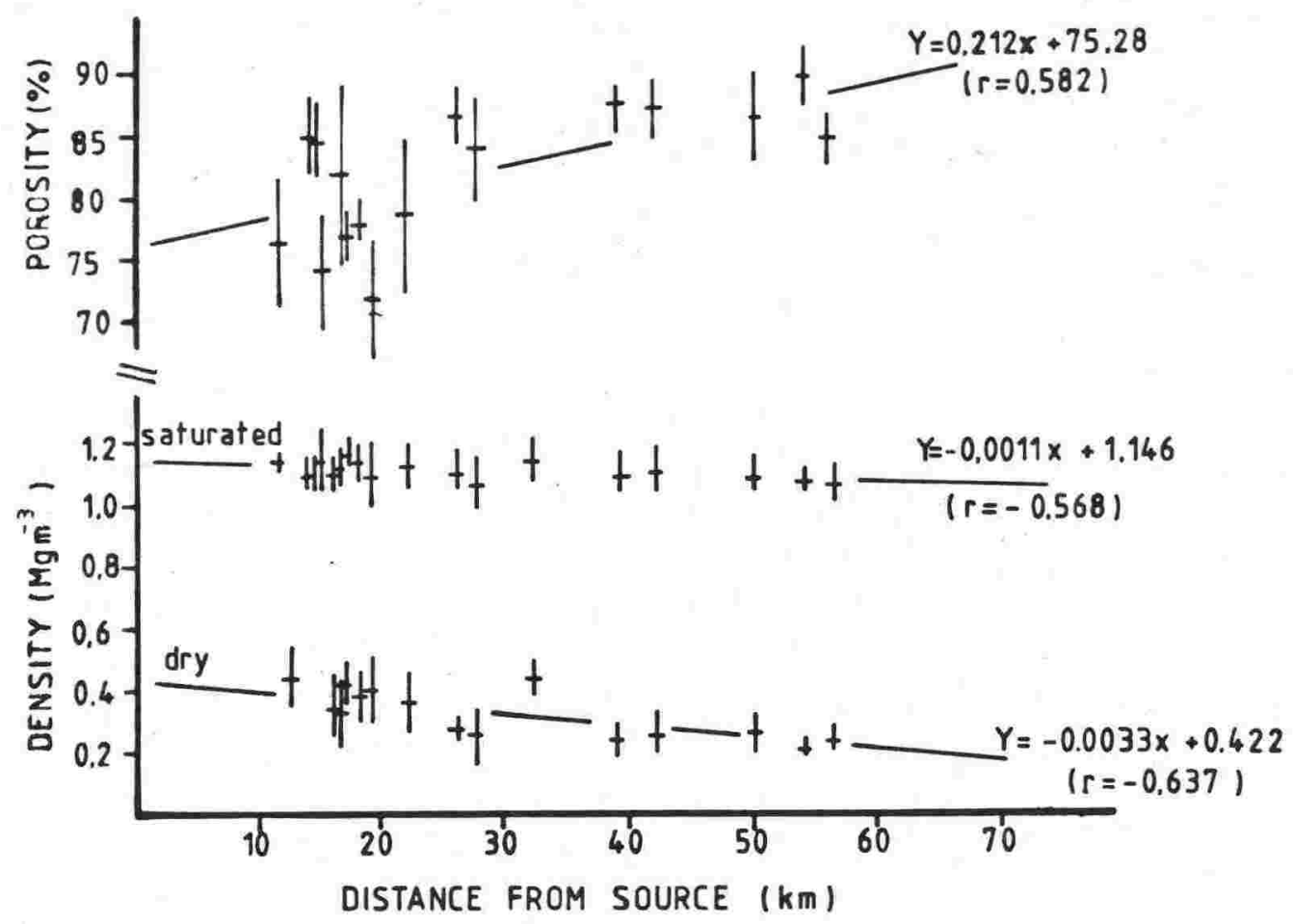

FIGURE 2.3.5: Variation of mean density (dry and saturated) and porosity with distance from source for clasts from Taupo Ignimbrite. Regression lines through data as shown. Vertical lines represent 95\% confidence limits on means.

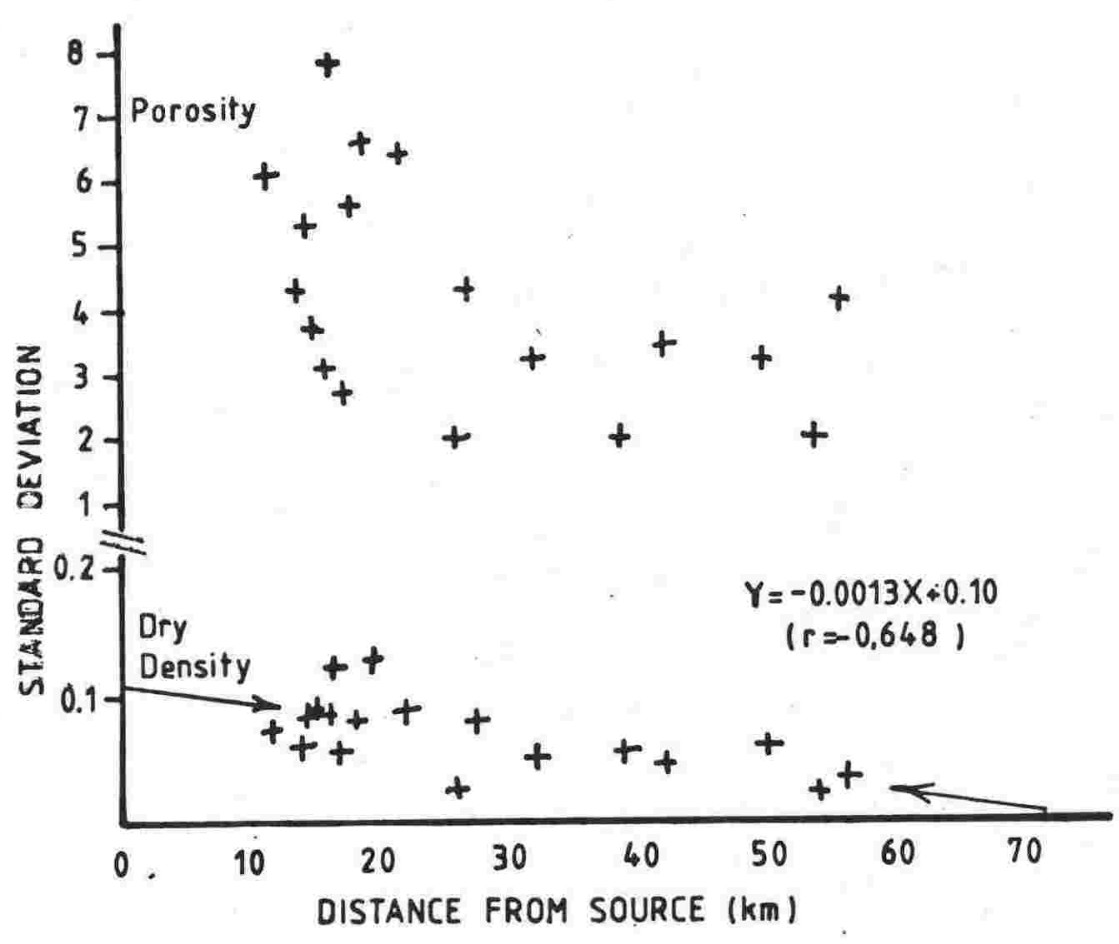

FIGURE 2.3.6: Variation of standard deviation on porosity and dry density with distance from source for Taupo Ignimbrite samples. 


\section{8}

near source to over $90 \%$ of the larger clasts beyond $60 \mathrm{~km}$. In near source deposits, linear pumice occurs mostly in the Upper unit suggesting ejection in the latter part of the eruption. Thus as the eruption proceeded, denser pumice and lithic material was erupted and deposited first, while the lighter, more buoyant pumice, erupted later was also carried further from source. 


\section{4 \\ Taupo Ignimbrite Facies : Description and Origin}

\subsubsection{Introduction}

Taupo Ignimbrite shows considerable lithological variation, from being typically poorly sorted and matrix supported to fine grained without pumice blocks or coarse-grained without fines. In Chapter 1.2, these three "endmembers" of a continuous lithological variation were described in terms of three facies: valley facies (VF), ignimbrite veneer facies (IVF) and fines depleted facies (FDF). Also described was the "Lithic Lag Layer" (LLL), being a thin discontinuous layer, rich in crystals and accessory lithics and found at the base of the Middle unit. The three facies and Lithic Lag Layer are described in detail by this author and others in three joint papers, published before the stratigraphy and facies terminology were published. A summary of each paper is given in this section and the full papers in Appendix A2.

\subsubsection{Ignimbrite Veneer Facies : The Trail-Marker of a Pyroclastic Flow} The term "ignimbrite veneer facies" (IVF) is proposed for a new kind of pyroclastic deposit which is found associated with, and passes laterally into, Taupo Ignimbrite of valley facies type, in New zealand. It forms a thin layer mantling the landscape over $15,000 \mathrm{~km}^{2}$, and is regarded as the deposit from the trailing "tail" of a pyroclastic flow, where 
a relaxation of shear stress favoured the deposition of the basal part of the flow. The IVF differs little in grain-size from the associated ignimbrite, but it shows a crude internal stratification attributed to the deposition of a succession of layers, possibly after the passage of each pulse of the pyroclastic flow. It locally contains laterallydiscontinuous lenses of coarse pumice ("lee-side lenses") on the farvent side of topographic obstacles and shows lensoid and cross-stratified bed-forms even where it stands on a planar surface, attributed to deposition from a flow travelling at an exceedingly high velocity.

An IVF can be distinguished from a poorly sorted pyroclastic fall deposit because the beds in it show more rapid lateral variations in thickness, it may show a low-angle cross-stratification, and it contains carbonised wood from trees not in the position of growth. It differs from the deposit of a wet base surge because it lacks vesicles and strong antidune-like structures and contains carbonised vegetation, and from a hot and dry pyroclastic surge deposit because it possesses a high content of pumice and "fines".

The significance of an IVF is that it records the passage of a pyroclastic flow, where the flow itself has moved farther on.

\subsubsection{Fines-Depleted Facies of Taupo Ignimbrite - The Product of a}

\section{Turbulent Pyroclastic Flow}

A new type of ignimbrite facies, a "fines-depleted facies" is largely depleted in the finer constituents and is clast-supported for all clasts exceeding about $2 \mathrm{~mm}$ in size. Its formation is attributed to the loss of fine (mostly submillilitre-sized) vitric material from the pyroclastic flow, by an amount equal to about half of the original mass of the flow. This loss, the large size and high content of lithic clasts, and the thorough intermixing of carbonised vegetation are believed 
to indicate that the pyroclastic flow, at least in part, travelled turbulently. Turbulent flow was partly a consequence of a high flow velocity, for which there is independent evidence (the same flow climbed $1,500 \mathrm{~m}$ up a mountain $46 \mathrm{~km}$ from source), and was partly caused by the ingestion of forest and the resulting high throughput of gas in the flow head. The implication is that normal ignimbrite is generated by laminar flow, whereas turbulent flows generate the significantly different, fines-depleted variant.

\subsubsection{The "Lithic Lag Layer" of Taupo Ignimbrite : A Striking Example} of Sedimentation from a Pyroclastic Flow

A "lithic lag layer" or "ground layer" rich in lithic fragments and crystals which underlies a young and widely-spread non-welded ignimbrite from Taupo, New Zealand, has formed by the sedimentation of heavy constituents from the pyroclastic flow. This origin is revealed by the progressive impoverishment of these constituents in the ignimbrite, and by the progressive decrease of lithic size in both the lag layer and ignimbrite towards the distal end. The lag layer is separated from the ignimbrite by a sharp and near-planar erosive contact, suggesting that sedimentation of "heavies" took place in the more strongly fluidised head of the pyroclastic flow, and that the layer was then over-ridden by the remainder of the flow. It is thus distinct from the lithic-rich layer often present immediately above the basal layer of ignimbrites and which form an integral part of the flow unit. Near source, the Taupo lag layer contains metre-sized blocks and is akin to a co-ignimbrite lag-fall deposit. 
2.5 A Model for the Eruption and Emplacement of the Members of Taupo Pumice Formation

Taupo Pumice Formation has several distinctive phases to the eruptive episode and all the phases are well exposed and little modified by weathering or erosion. The deposits offer an exceptional opportunity to develop models for the eruption and emplacement of rhyolitic pyroclastic deposits. Some aspects have been discussed in preceeding chapters, especially in relation to Taupo Ignimbrite.

Several models for particular explosive pyroclastic eruptions have been published. Wilson (1976), Sparks \& Wilson (1976) and Sparks et al (1978) examined the theoretical aspects of eruptive columns and their collapse to produce pyroclastic flows. Heiken (1978) discussed pumice formation and the growth of vesicles. Ewart et al (1975) speculated on the physical conditions in a pre-eruption magma chamber based on the chemistry of lavas and pyroclastics.

\section{AN ERUPTIVE MODEL}

Lake Taupo existed prior to the eruptions of Taupo Pumice, but evidence for the level and extent of the lake is sparse. The Waikato River almost certainly flowed along a similar course to the present and Huka Falls would have controlled the level of the lake at a position similar to or higher than the present day. Prior to the Taupo Pumice eruptions, the lake may have extended further east, in which case the vent for the eruption was almost certainly within Lake Taupo.

The eruptive episode began with the eruption of a small amount of pumiceous ash from a vent position now occupied by Horomatangi Reefs, but rapidly developed into a full plinian eruption with the widespread dispersal of coarse vesicular pumice. The coarse nature of Hatepe Lapilli indicates that the vent was clear of Lake Taupo so was presumably 


\section{3}

either in an island or the lake floor was updomed above lake level by pre-eruption tumescence.

Hatepe Lapilli is conformably overlain by fine ash from a phreatoplinian type of eruption, showing many characteristics of the interaction of water on the eruption, when the vent was breached by the lake. A large volume of lake water could have been expelled in this eruption, mostly as steam, and subsequent condensation and rainfall would have produced the distinctive rilled erosion surface on Hatepe Tephra (see Fig. 1.2.13). The length of time represented by this erosion is probably very short; from a few hours to a few days. Only one rainstorm need have occurred as the erosion is not very deep or extensive, and further rain would have caused more widespread erosion. The products of the erosion are seldom identified.

Following the hiatus, Rotongaio Ash was erupted. Rotongaio is composed predominantly of non-vesicular glass (obsidian). Obsidian is often formed by the extrusion of volatile-depleted magma to form a rhyolite dome. If extrusion of a dome occurred beneath Lake Taupo, interaction of the magma with lake water could create a phreatomagmatic style eruption with the extruded material shattered into fine ash by thermal shock. Shower bedding within Rotongaio Ash often shows internal deformation but no major erosional unconformities have been noted. As with the preceeding phreatoplinian eruption, a large volume of lake water could have been incorporated into the eruption column and the lake almost emptied. The phreatoplinian origin of Hatepe and Rotongaio is discussed by Walker (1981), but his deduction that pure water was erupted for part of the Hatepe event is speculative.

Rhyolitic eruption sequences typically consist of a plinian

phase followed by extrusion of degassed magma to form a dome (e.g. Sparks et al 1973). As noted in earlier chapters, most Taupo eruptive 
episodes conform to this pattern but Taupo Pumice has additional events. Hatepe Tephra (plinian phase) and Rotongaio Ash (dome phase) follow the "normal" sequence and the eruptive episode would be expected to cease after Rotongaio Ash. The additional phases of plinian, pyroclastic flow and dome (Taupo Lapilli, Taupo Ignimbrite and dome) would not have been predicted.

The additional beds could be the result of injection of new, volatile-rich magma into the partially emptied magma chamber and thus represent a separate, distinct eruption following on almost without a break from Rotongaio Ash. If this "new" magma rapidly moved up through several kilometres of crust $(\geqslant 5 \mathrm{~km})$ the drop in confining pressure on a volatile rich magma could lead to supersaturation of volatiles and a potentially unstable magma. An event that triggers nucleation of volatiles to form vesicles would probably initiate earlier than normal eruption of the magma as the magma chamber had previously been weakened by the preceeding eruptions. Once nucleation of the volatiles began, upper parts of the magma would rapidly expand and rise. Rapid vesiculation to form a frothing foam probably began at $1-2 \mathrm{~km}$ depth (McBirney \& Murase 1970), depending on the rate of ascent of the magma. From theoretical considerations, Sparks (1978) determined the maximum growth size for single bubbles in rhyolitic magma as 200 microns, the limiting factor ultimately being magma viscosity. Larger bubbles must, therefore, form by coalescence.

Taupo Lapilli pumice clasts have a "swirling knotty texture" (Ewart 1963) with large irregular shaped vesicles, very rough, irregular clast surfaces and relatively low porosity. This indicates that most of the exsolved gases had been released into the eruptive column by magma fragmentation, bubble coalescence and glass flowage before "chilling". Chilling is used here as the temperature drop needed to convert material 


\section{5}

from a plastic to a brittle solid. Fragmentation and solidification of the magma, initiated within the vent, was probably completed above the vent in the ballistic part of the column. Loss of volatiles before chilling would provide most of the gas needed to fuel the "continuous jet blast" of "gas streaming" part of the column and also the thermal convection plume as modelled by Sparks et al (1978). Very poor rounding of the clasts indicates the magma fragmented, or at least solidified in the eruptive column itself where abrasive forces would be less than in the conduit and vent. No lithics have been found with fresh magma attached, so their probable point of addition into the column must always be at or above the level of magma fragmentation. Lithic material is found throughout the plinian deposits, indicating continual vent widening and deepenina.

As the vent widened, the rate of eruption of magma increased until the volume became too great for the jet blast and convection cells to cope with all of the ejecta. The excess erupted material would have fallen en masse as a partial column collapse, forming small pyroclastic flows. A paucity of fluidising gas in the material appears to have restricted the mobility of the flows. They were emplaced almost hot enough to weld, as today they are characteristically coloured red near to source. The volume of this material is small and known occurrence is assymetrical, found mostly east of the vent.

Total and irreversible collapse of the plinian eruption column, above the jet thrust part, generated a continuous supply of highly gas rich pyroclastic material that fell from perhaps $3-5 \mathrm{~km}$ height and had attained terminal velocity before reaching the ground. Momentum was converted from a vertical to horizontal direction and a continuous, radially outmoving pyroclastic flow was generated. Walker (1980), walker et al (1980) and Wilson (1980) infer the horizontal velocity 
of Taupo Ignimbrite was exceptionally high due to collapse of an unusually high column, greater than $50 \mathrm{~km}$ height. The initial horizontal momentum of the flow is not dependent on collapse height, but on the density and terminal velocity of the material. Once terminal velocity was reached momentum could not increase. Walker et al (1971) showed terminal velocity of pumice clasts was reached after about 100 metres of fall.

Fragmented pumice, solidified whilst still within the vent or conduit, would be subjected to tremendous abrasion during ascent, with the consequent generation of voluminous fine material, rupturing of some vesicles and release of gas. In contrast, the plinian phase produced less fine ash and more free gas as the pumice solidified above the vent. A high content of fine ash and minimal free gas in the eruption column could enhance column collapse and the generation of pyroclastic flows. Of significance is the pumice roundness study by Murai (1961) showing no change of roundness with distance from source, within an unwelded ignimbrite in Japan.

Pumice is easily rounded (Adams 1978) and maximum attainable roundness must have been achieved in the conduit and vent, before the pumice clasts entered the pyroclastic flow. This does not preclude further abrasion or attrition within the flow, generating further fines and the continual release of gases that are essential for continuing fluidisation.

Soon after column collapse occurred, pumice with long tubular vesicles was produced. As these tubes are straight and not collapsed or deformed, chilling of the magma must have rapidly followed their formation. The most plausible method of formation of the tubes is the drawing out of spherical vesicles (Heiken 1978) by laminar flow of magma foam within the conduit. Once drawn, these tubes were rapidly solidified 
then fragmented. Heiken (1978) further suggested that fragmentation of this type of pumice was by a downward expansion wave as all the clasts he examined had surfaces parallel and normal to the vesicles. This type of pumice in Taupo Ignimbrite, although well rounded, was found to preferentially split in these directions regardless of the angle of shear. Linear pumice was observed to increase in abundance with distance from source. Being lighter, this material was transported further, but it only occurs in the upper part of near source deposits, suggesting its formation later in the eruption.

Pumice porosity and erupted volume indicate the erupting magma was unusually rich in volatiles (mostly water) and column collapse would have retained most of the free gas with the solid material (Sparks et al 1978) to produce an exceptionally highly fluidised pyroclastic flow. This flow moved radially outward from source at high velocity, rapidly converting from turbulent to laminar flow. The radius of the collapsing column was less than $3 \mathrm{~km}$ as Taupo Ignimbrite today outcrops within ? $\mathrm{km}$ of the vent. An example of planar and antidune bedding $5 \frac{1}{2} \mathrm{~km}$ from the vent (N103/515173) indicates laminar flow was achieved within this distance.

Topography was the major factor influencing the passage of the pyroclastic flows and the nature of the ignimbrite deposited. East of source, low topography was covered with at least 50m of ignimbrite. Once the flow rose over the top of the scarp of Rangitaiki Ignimbrite only a thin "veneer facies" $(0.5 \mathrm{~m})$ was left covering a massive erosion surface on topographic highs (see Fig. 1.2.6) with thicker deposits in the valleys. East and north-east across the mostly flat top of Kaingaroa plateau only relatively thin $(2-5 \mathrm{~m})$ ignimbrite is found. In other directions, where rugged topography was encountered, the thin, fine grained veneer facies mantles ridges, whereas valleys are filled with 
typically coarser "valley facies".

Vegetation affected the pyroclastic flow especially in valleys where dense, moist forest was encountered. Consumption of this forest by the nose of the flow would have greatly increased the gas content and hence fluidity of the nose resulting in loss of buoyancy for coarser material and the "flushing" out of fines. As a result, the "fines depleted facies" was produced.

The Upper unit of Taupo Ignimbrite incompletely preserves the waning phases of the eruptive episode, being composed of interbedded airfall and pyroclastic flows deposits. The airfall beds are predominantly fine, vitric ash and some outcrops contain abundant accretionary lapilli. The lapilli have resulted from rain flushing co-ignimbrite ash out of the atmosphere. Rare outcrops record erosion and water sorting in these beds. Cross-bedding and dune forms in some of the pyroclastic flow deposits are similar to those described from pyroclastic surge deposits (e.g. Crowe \& Fisher 1973) but are not as extensive. They were possibly produced by small, highly fluidised flows that may have been turbulent or were flowing at a very high velocity. Fisher (1979) describes a similar sequence of deposits in the upper part of the Bandelier Tuff.

Following the surge and airfall beds, a rhyolite dome was probably extruded at the site of the vent to form Horomatangi Reefs. The bathymetry of the reefs area (Irwin 1972) suggests two domes partly infilling the vent. No pyroclastic material has been recognised with this phase.

The depression occupied by Lake Taupo prior to the Taupo Pumice eruptions is floored by at least $100 \mathrm{~m}$ of Taupo Ignimbrite (Northey pers. comm. 1980) but was not completely filled in. After the eruptive episode, 
the depression again filled with water to a level about $30 \mathrm{~m}$ higher than the present level. During the period of filling and high lake level, widespread erosion of Taupo Ignimbrite occurred, mostly forming vertical sided, flat floored valleys. Major valleys east of Lake Taupo were initially filled with extensive shallow lakes in which large quantities of pumice alluvium formed. The extent of these lakes is today marked by a strand line of large pumice blocks. The level of Lake Taupo dropped to the present day level in two steps and benches cut at each stage are preserved at many places around the lake. The density and depth of incision of drainage channels cut into the benches decreases down the flight, with the youngest terrace totally undisected. The first drop in lake level coincided with the incision of all major drainage into the present river channels, after an initial period of widespread rill erosion. Major river channels today appear to occupy the same courses as rivers prior to the eruption, even in areas where the pre-existing topography was completely buried.

Vegetation must have rapidly returned to stabilise the landsurface. A widespread cover would have existed by the time the lake dropped to the present level as the lowest lake bench shows little sign of erosion. Observations following the 1886 eruption of Tarawera indicate a minimum time of 5 years for re-establishment of vegetation, and this accords with estimates on the time of refilling of Lake Taupo (Northey pers. comm. 1980). 


\section{CHAPTER 3.}

ERUPTIVE VENTS FOR THE LAKE TAUPO GROUP TEPHRAS. 


\section{CHAPTER 3 \\ ERUPTIVE VENTS FOR LAKE TAUPO GROUP TEPHRAS}

\subsection{Inferred Vent Positions}

of the 15 tephras erupted from the Taupo area in the last 50 kyr only Taupo Pumice and Karapiti Lapilli have the vent position reasonably well established. Isopach maps of Taupo Pumice members (Healy et al 1964; Walker 1980) show that isopachs do not always centre over the eruptive vent and other data such as ballistic blocks or charred logs are required to substantiate the source. Lake Taupo covers much of the potential vent area and the immediate surroundings have a thick blanket of Taupo Ignimbrite, so data from the critical, near vent area are limited. Bathymetry of Lake Taupo (Irwin 1972) reveals a near flat bottom at $100 \mathrm{~m}$ depth over most of the lake, disturbed only by prominent projections of Horomatangi Reefs, Waitahanui Bank,

Motutaiko Island and Te Rangiita. Horomatangi Reefs is the most probable site for eruption of Taupo Pumice. Isopach maps for Mapara (Vucetich \& Pullar 1973) and Waimihia Tephra (Baumgart 1954), and lack of ballistic lithics in near source exposures suggest the Horomatangi Reefs-Waitahanui bank area as the most probable source for these two tephras. The large amount of fresh rhyolite lithics in Taupo Pumice indicates destruction of a rhyolite dome, possibly of Mapara or Waimihia age. Which of these two tephras corresponds to Waitahanui Bank is unknown.

Whakaipo Tephra, mapped with maximum thickness of $0.66 \mathrm{~m}$ by Vucetich \& Pullar (1973) has nearly circular isopachs centred on Hatepe Hill. Whakaipo is a distinctively shower-bedded tephra with alternating lapilli 
and ash layers containing abundant $(<40 \%)$ fresh glassy lithics especially in the upper part. A single outcrop on the Taupo-Turangi Highway at Hatepe Hill (N103/542213) exposed:

\section{Hatepe Lapilli}

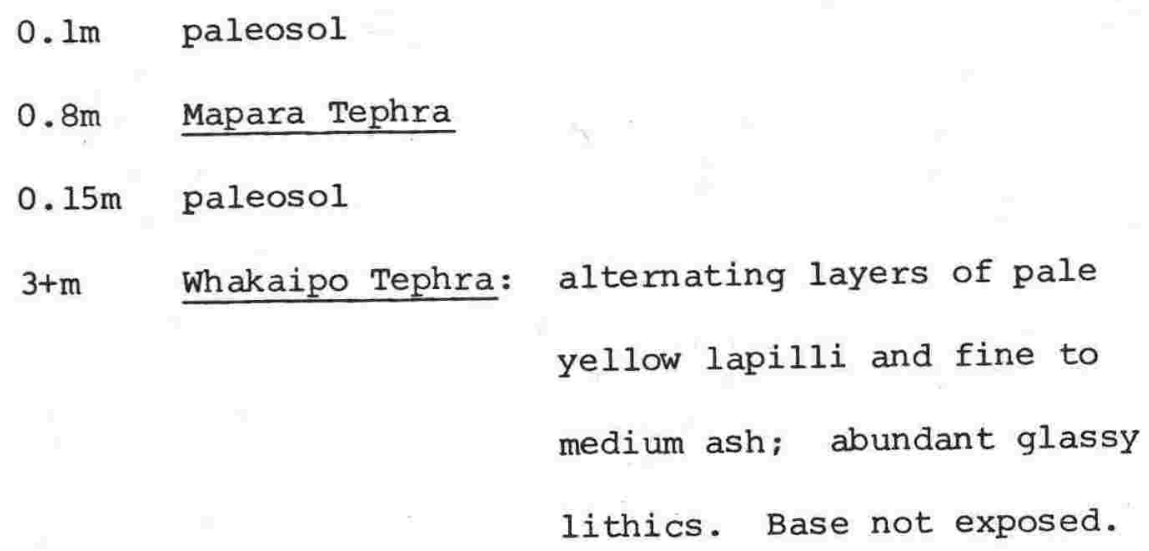

No ballistic blocks or large lithics were found, suggesting the outcrop was at least $2-3 \mathrm{~km}$ from source. The small elongate dome at Hatepe called Ouaha $\left(\mathrm{N}_{103 / 516197)}\right.$ is a possible source for Whakaipo Tephra.

Hinemaiaia and Motutere Tephras were probably erupted from near Te Rangiita (Froggatt 1981 b; Chapter 1.3).

Opepe Tephra is thickest about Taupo Borough (Vucetich \& Pullar 1973) and to the west of Acacia Bay. No ballistic lithics have been found in the few outcrops in this area but the rhyolite dome at Tuhingamata (N94/471350) is a possible source. The dome has a thick blanket of Taupo Ignimbrite and the age can be substantiated only if a major new outcrop such as a road cutting is formed.

Poronui Tephra is seldom seen at optimum thickness, with $0.8 \mathrm{~m}$ being the maximum observed. The tephra is dominated by fresh, glassy, grey lithic material similar to Rotongaio Ash indicating the tephra was almost certainly erupted during extrusion of a rhyolite dome. The isopach map of 


\section{2}

Vucetich and Pullar (1973) clearly shows the source to be within the central to eastern part of Lake Taupo where the rhyolite dome of Motutaiko Island is situated. The island is undissected and the dome still retains a fresh vesicular, glassy selvedge in many places. It appears very youthful relative to domes in the Maroa area (some of which are mantled by Rotoehu Ash) and may be of an age comparable to the Acacia Bay dome associated with Karapiti Tephra. The island is covered by up to $30 \mathrm{~m}$ of Taupo Ignimbrite but Waimihia Ignimbrite and Lapilli were also identified. There is no exposure beneath Waimihia and no evidence for Kawakawa Tephra was found, leaving the strong probability that the eruption of Poronui Tephra and extrusion of the rhyolite dome of Motutaiko Island are closely related.

Kawakawa Tephra Formation: isopach maps for "Oruanui Formation", now called Kawakawa Tephra Formation (Vucetich and Howorth 1976a) show this eruptive episode to be extremely widespread from a vent close to the northern edge of Lake Taupo (Vucetich and Pullar 1969; Pullar 1973). Scinde Island Ash, the middle layer of Kawakawa Tephra, is characterised by abundant accretionary lapilli (chalazoidites), some containing freshwater diatoms (Berry 1928). This, together with the overall extremely fine grained nature of Kawakawa indicates an eruptive vent beneath an existing Lake Taupo. Rare exposures of Oruanui Breccia immediately north of Lake Taupo contain lithics up to $10-15 \mathrm{~cm}$ across, as do exposures in the northern part of Lake Taupo Forest, east of the lake. An eruptive vent within north eastern Lake Taupo is inferred. A prominent circular feature is noted on the bathymetric map (Irwin 1972) north of Horomatangi Reefs. Seismic reflection profiles of this area (Northey, pers. comm. 1980) reveal a large, circular, steep-sided hole, now infilled. Only the upper two of three layers of the "low velocity material" that floor Lake 
Taupo dip into and fill this "hole". They are here regarded as Taupo and Waimihia Ignimbrites with the third layer being Oruanui Breccia. Consequently the "hole" is possibly the source vent for Kawakawa Tephra. No dome is known to be associated with Kawakawa Tephra but thick deposits of Taupo and Waimihia Ignimbrites beneath Lake Taupo may have completely obscured it.

Okaia Sub-Group Tephras: These tephras are presently only exposed over a small area north of Lake Taupo and isopachs based on few data points suggest a source area about northeast Lake Taupo. The fine-grained nature and mixed chemistry of Poihipi Tephra (Roxburgh 1976) indicates a source under Lake Taupo, probably the same as for Kawakawa Tephra. The source of each of the older tephras remains unknown but could possibly be associated with the large rhyolite domes that form promontories along the north shore of Lake Taupo.

\subsection{Time-Space Relationship of Source Vents}

Known or inferred vents for LTG tephras are shown on Fig. 3.2.1 labelled in order of age. No regular progression of site with age is identified other than a general trend of widely separated sites of the older tephras, Kawakawa to Hinemaiaia, narrowing into the central area of Horomatangi Reefs for the younger tephras. Spatially, the vents mostly lie on a NE trending arc and are remarkably evenly spaced along this arc. Inferred structural control for these sites is discussed in Chapter 5. Kohn \& Topping (1978) proposed a chemically-based mechanistic relationship between Tongariro andesites and Karapiti to Hinemaiaia Tephras. The location of the Karapiti Tephra vent at the extreme north of the arc makes an intimate chemical relationship less certain. of the three older tephras, only Hinemaiaia has a source towards the south. 


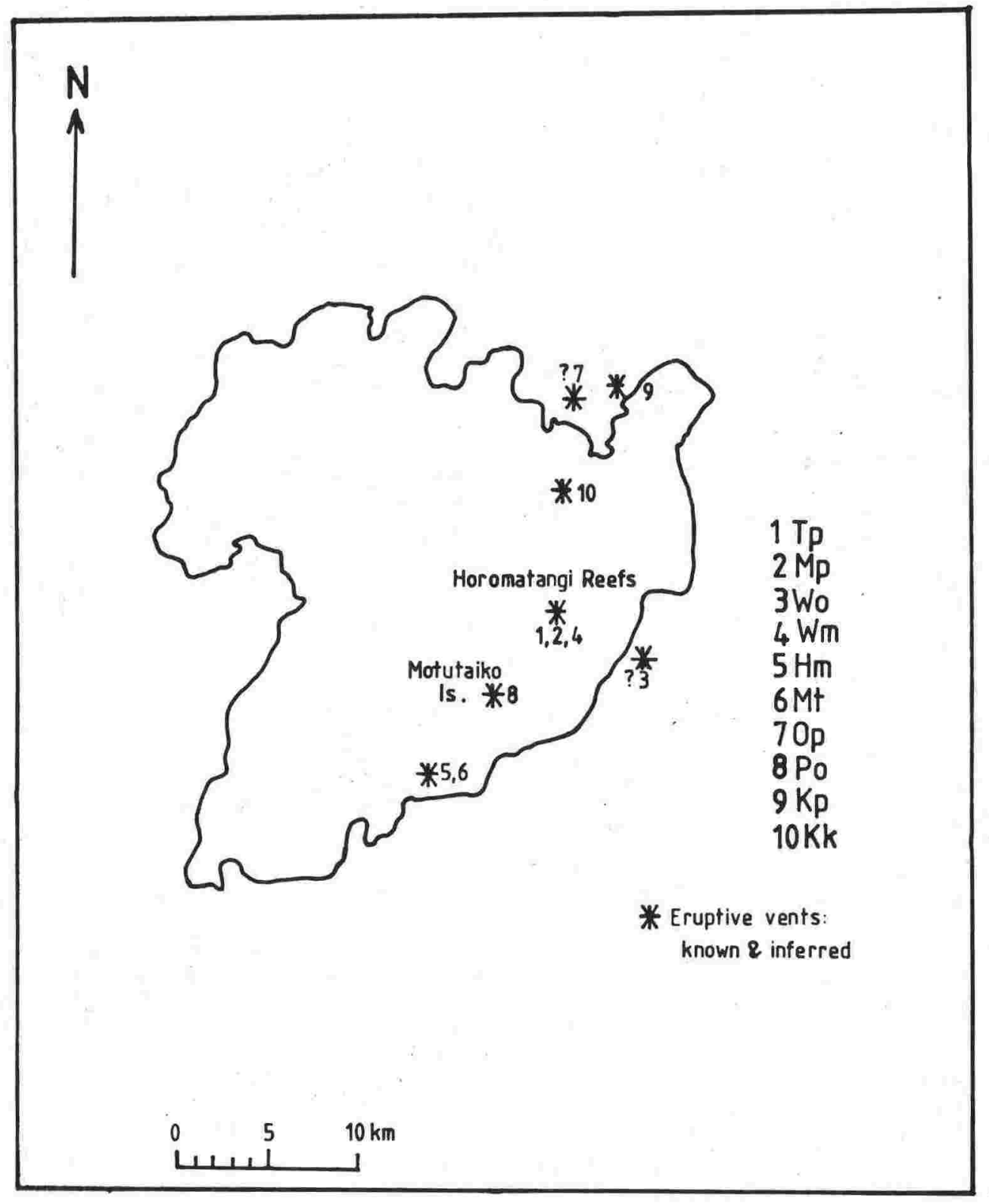

FIGURE 3.2.1: Locations of known and inferred eruptive vents for Kawakawa Tephra and Taupo Subgroup tephras based on isopach, grainsize and bathymetric data. 


\section{CHAPTER 4.}

VOLUME OF MAGMA ERUPTED FROM TAUPO VOLCANIC CENTRE. 


\section{5}

\section{CHAPTER 4}

\section{VOLUME OF MAGMA ERUPTED FROM TAUPO VOLCANIC ZONE}

4.0

\section{Introduction}

Detailed knowledge of tephra stratigraphy and numerous measurable sections lead to reliable isopach maps of the TSG tephras. These can be used to calculate the volume of each plinian tephra, but isopach maps seldom extend beyond the $5 \mathrm{~cm}$ or $1 \mathrm{~cm}$ isopach and some extrapolation beyond this is necessary. As tephra thickness decreases approximately exponentially out from source, the volume of tephra beyond the minimum isopach is in most cases a small proportion of the total.

Walker (1980) developed an independent method of calculating the volume of plinian deposits by determining the total mass of free crystals in the tephra and assuming they were liberated by fragmentation of enclosing pumice. The mass of "lost" pumice is calculated and added to the observable amount. This method produced volumes much larger than previous estimates. Two assumptions are questionable:

The proportion of crystals to glass in crushed pumice represents the actual crystal content of the magma at the time of the eruption, and

for a crystal to be liberated from pumice, the pumice clast is completely fragmented to a particle size equal or less than the crystals (c. $2 \mathrm{~mm})$.

Any error in the first assumption is probably minor but the second clearly would produce an excess of fine ash. The tephras studied by Walker (1980, 1981) were Taupo Lapilli, Hatepe and Waimihia and the existence of a large quantity of fine ash cannot be demonstrated.

Alternative methods for calculating tephra volume are examined in the following manuscript. 
4.1 REVIEW OF METHODS FOR ESTIMATING RHYOLITIC TEPHRA VOLUMES; APPLICATIONS TO THE TAUPO VOLCANIC ZONE, NEW ZEALAND.

A manuscript in press with; Journal of Volcanology and Geothermal Research. 
REVIEW OF METHODS OF ESTIMATING RHYOLITIC TEPHRA VOLUMES;

APPLICATIONS TO THE TAUPO VOLCANIC ZONE, NEW ZEALAND.

\author{
P.C. Froggatt, \\ Geology Department \\ Victoria University of Wellington, \\ New Zealand.
}

\title{
ABSTRACT
}

There have been at least 35 rhyolitic plinian eruptions in the last 50 kyr from 2 volcanic centres in Taupo Volcanic Zone (TVZ), New Zealand. To determine the total volume of erupted material, calculation techniques are reviewed and further developed. All involve extrapolation from isopach maps. Three methods assume an exponential decay of thickness with distance from source and a further two are based on the area enclosed by each isopach. Comparison of methods shows those based on area to be more accurate except the log-log plot of area and thickness which requires excessive extrapolation. A log volume vs. thickness plot is considered superior because minimal extrapolation is needed. For most tephras, volumes calculated by the different methods are in reasonable agreement.

Volumes previously calculated by the "crystal concentration" method are 2-3 times greater than those from the six methods used here. Total pumice fragmentation is probably not required for the liberation of crystals, and this would decrease calculated volumes.

During the last $50 \mathrm{kyr}$ magma has been erupted at a constant mean rate in the Taupo Volcanic Zone. A simple step-function shows a strong relationship between deviations from the mean rate and either the 
next erupted volume or the time to the next eruption. Extrapolation of these step-functions suggests future eruptions in less than 400 years for okataina and about 8,000 years for Taupo.

The volume of rhyolitic material erupted from TVz within the last $50 \mathrm{kyr}$ is estimated at $36 \mathrm{~m}^{3}$ of tephra, $350 \mathrm{~km}^{3}$ of ignimbrite and $55 \mathrm{~km}^{3}$ of extrusive, equivalent to about $350 \mathrm{~km}^{3}$ of magma. At an average rate of eruption of $7 \mathrm{~km}^{3} / \mathrm{kyr}$ at least $4,200 \mathrm{~km}^{3}$ of rhyolitic magma has been erupted since the inception of TVZ about 0.6 million years ago. If "back-arc" spreading of TVZ at $7 \mathrm{~mm} / \mathrm{Yr}$ is compensated for by dyke intrusion into the upper $10 \mathrm{~km}$ of crust, $8,400 \mathrm{~km}^{3}$ of magma is required. The total volume of magma generated by partial melting is estimated at $12,600 \mathrm{~km}^{3}$. Removal of this melt would cause subsidence of 2. $1 \mathrm{~km}$; the present depth to subvolcanic basement in TVZ. 
INTRODUCTION

Determining the total volume of a tephra is an important aspect of volcanic studies and only a few examples of methods can be found in the literature (e.g. Rose et al. 1973; Suzuki et al. 1973; Vucetich \& Pullar 1973; Howorth 1975; Carey \& Sigurdsson 1980;

Walker 1980). Different methods are based on various assumptions and mathematical models, and when applied to New Zealand tephras by the author, gave different estimated volumes. Walker (1980) deduced volumes considerably larger than any previous estimates, so a reappraisal of all the methods was undertaken.

Five methods of calculating volumes from isopach maps are described and each is applied to 28 of the 35 rhyolitic plinian tephras erupted from TVZ since $50 \mathrm{kyr}$ B.P. The objective was to compare consistency between methods using tephras with a range of volumes and distributions. In addition, the total volume of material erupted from TVZ is useful to studies of subduction, back-arc spreading and magma genesis.

All tephras are rhyolitic and were erupted from Okataina and Taupo Volcanic Centres, North Island, New Zealand (Figure 1). Their stratigraphy, chronology and distribution has been documented by Healy et al. (1964); Vucetich \& Pullar (1969, 1973); Nairn (1972, 1980); Pullar (1973); Vucetich \& Howorth (1976) and Froggatt (1981a, b \& c). The stratigraphy and age of these tephras is in Table 1 . Several tephras have associated ignimbrites which are considered separately. Isopach maps have been published for all of the tephras and form the basis for the volumes calculated here. 


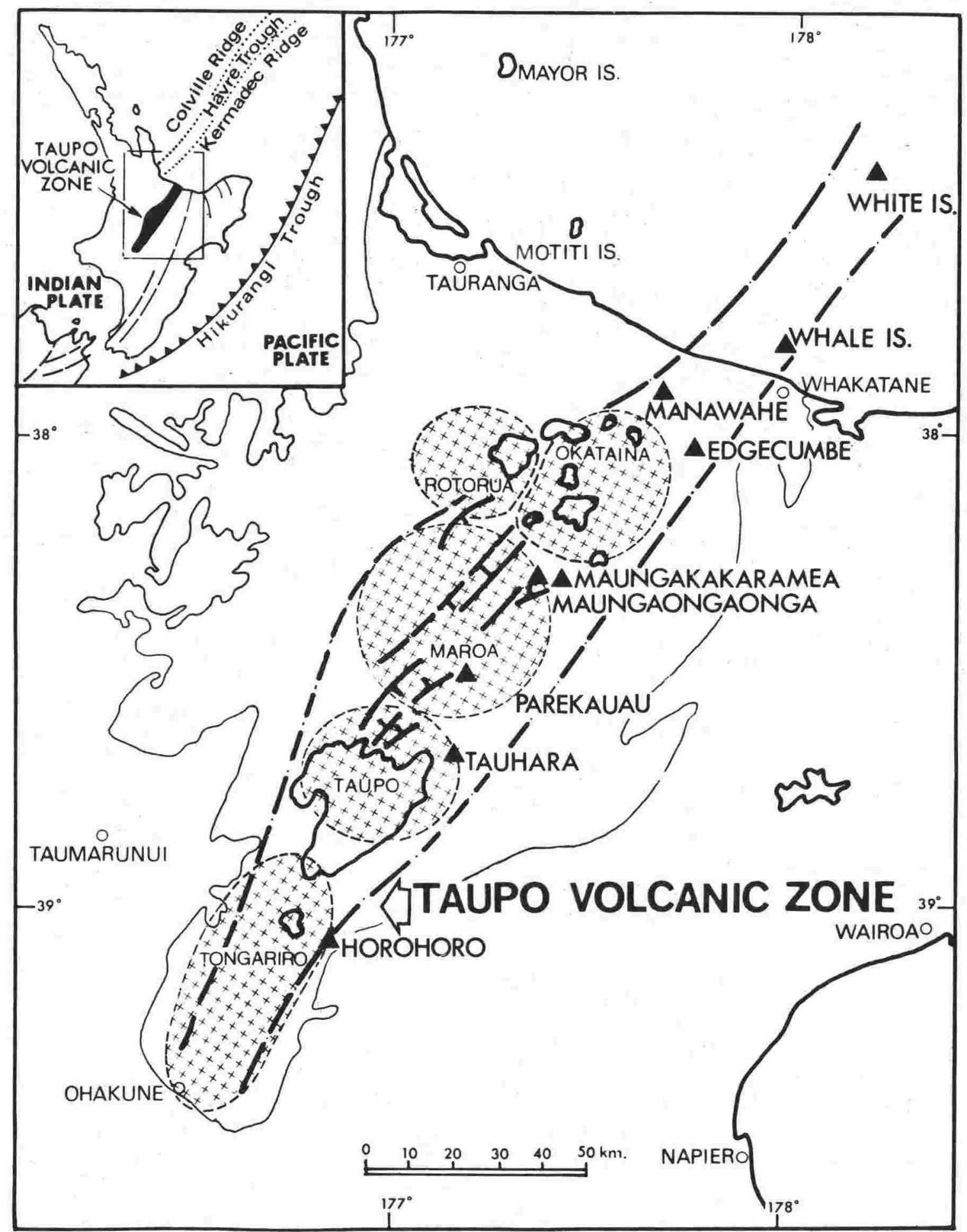

FIGURE 4.1.1: Volcanic Centres within Taupo Volcanic Zone, New Zealand ( after Cole 1979). 


\begin{tabular}{|c|c|c|c|c|c|}
\hline Taupo Volcanic & Centre & & Okataina Volca & $\operatorname{anic} \mathrm{Ce}$ & entre \\
\hline & & Yrs B.P. & & & Yrs B.P. \\
\hline Taupo Lapilli & TL ) & & Kaharoa & $\mathrm{Ka}$ & 650 \\
\hline Rotongaio Ash & Rt i & 1,820 & & & \\
\hline Hatepe Lapilli & Ht ) & & Whakatane & Wk & 5,000 \\
\hline Mapara & $\mathrm{Mp}$ & 2,200 & Mamaku & Ma & 7,000 \\
\hline Whakaipo & Wo & 2,800 & Rotoma & $\mathrm{Rm}$ & 9,000 \\
\hline Waimihia ${ }^{*}$ & Wm & 3,200 & Waiohau & Wh & 11,000 \\
\hline Hinemaiaia & $\mathrm{Hm}$ & 4,700 & Rotorua & Rr & 13,000 \\
\hline Motutere & Mt & 5,400 & Rerewhakaaitu & Rk & 14,700 \\
\hline Opepe & Op & 8,800 & Okareka & OK & 17,000 \\
\hline Poronui & Po & 9,500 & Te Rere & $\mathrm{Te}$ & 19,000 \\
\hline Karapiti & $\mathrm{Kp}$ & 9,800 & Omataroa* & Om & 28,000 \\
\hline Kawakawa * & $\mathrm{KK}$ & 20,000 & Awakeri & Aw & 30,000 \\
\hline Poihipi & $\mathbf{P}$ & 21,000 & Mangaone & $\mathrm{Mn}$ & 31,000 \\
\hline Okaia & 0 & 22,000 & Hauparu & Hu & 36,800 \\
\hline Tihoi & $\mathrm{Ti}$ & 38,000 & Te Mahoe & $\mathrm{Tm}$ & 37.000 \\
\hline Waihora & W & 39,000 & Maketu & Mk & 37,200 \\
\hline \multirow[t]{3}{*}{ Otake } & Oe & 40,000 & Tahuna & $\mathrm{Ta}$ & 38,000 \\
\hline & & & Ngamotu & $\mathrm{Ng}$ & 38,500 \\
\hline & & & Rotoehu * & Re c. & 45,000 \\
\hline
\end{tabular}

TABLE 4.1.1: Stratigraphy and chronology for tephras erupted from Taupo and Okataina Volcanic Centres post-50 000 years B.P. Symbols following each tephra name are used in Figures 2 to 4 . Asterisked tephras have associated ignimbrites. 


\section{1.}

\section{CALCULATION METHODS}

Volume determination methods considered here fall into three groups :

1.

Determination based on mathematical models of isopach shape assuming exponential decay of thickness and either

A. a circular isopach shape; or

B. an elliptical isopach shape.

2. Determining isopach areas and extrapolating to total volume by

A. $\log -\log$ plot of area and thickness;

B. calculation of equivalent circular radius of measured area then using $1 \mathrm{~A}$ above; or

C. plot of log-volume against thickness.

3. Determination based on crystal concentration in tephras based on a detailed component study.

\section{MATHEMATICAL MODELS OF ISOPACH SHAPE}

As isopachs are concentric and generally approximate to either circular or elliptical shape, the simplest approach is to assume the isopach contours are circles or ellipses of increasing size. The two mathematical models are particularly useful to obtain approximate volumes when only a sector of the full tephra distribution is known and other methods cannot be used.

Both mathematical methods assume an exponential decrease of thickness with distance from source. Some tephras do not strictly follow this distribution, for instance the May 18 th 1980 plinian deposit from Mt. St. Helens. The comparison of St. Helens to TVZ, involving 
different types of volcanoes erupting ash of different properties and volumes, may not be valid, nor may st. Helens be typical of the plinian pumice eruptions from TVZ.

Exponential decay of thickness with distance from source can be shown from an isopach map by plotting isopach thickness against distance from source. The rate of exponential decay varies for different tephras and generally also varies on different radial lines within any one tephra. Some examples are shown on Figure 2 where values along the dispersal axis $(X)$ and at right angles $(Y)$ to it have been plotted. The distribution of most tephras fits an exponential, but two exceptional tephras are thicker at distances beyond $100 \mathrm{~km}$ than the exponential would predict, leading to an underestimated volume.

Correlation coefficient values for the exponential curves shown in Figure 2 and for other examples (Table 2) indicate how well an exponential fits the data.

From the thickness/distance plot the extrapolated maximum thickness and the rate of exponential decay can be obtained. These values are the data for two methods of determining total volume.

1A. Circular Isopachs

Several examples of circular isopachs are known, e.g. Topping (1973), Geddes et al. (1981). Assuming circular isopachs, Cole \& Stephenson (1972) derived a formula as follows:

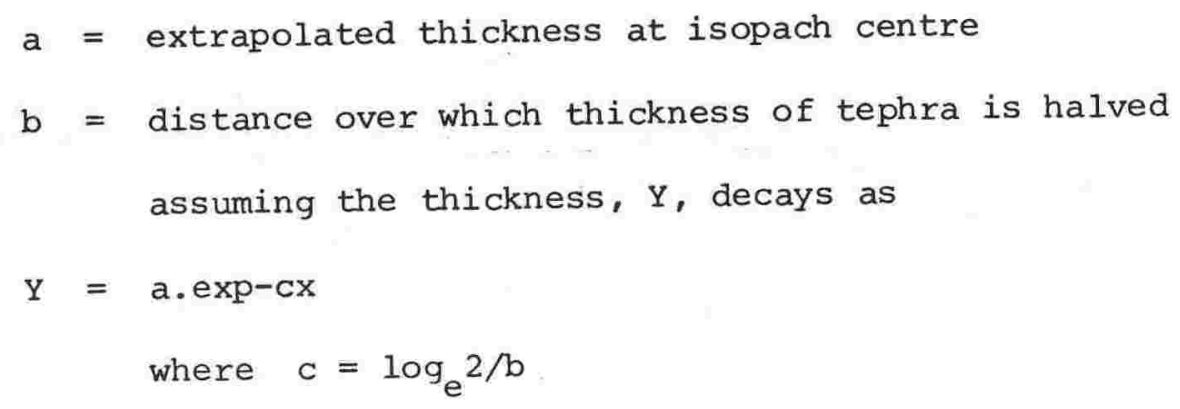




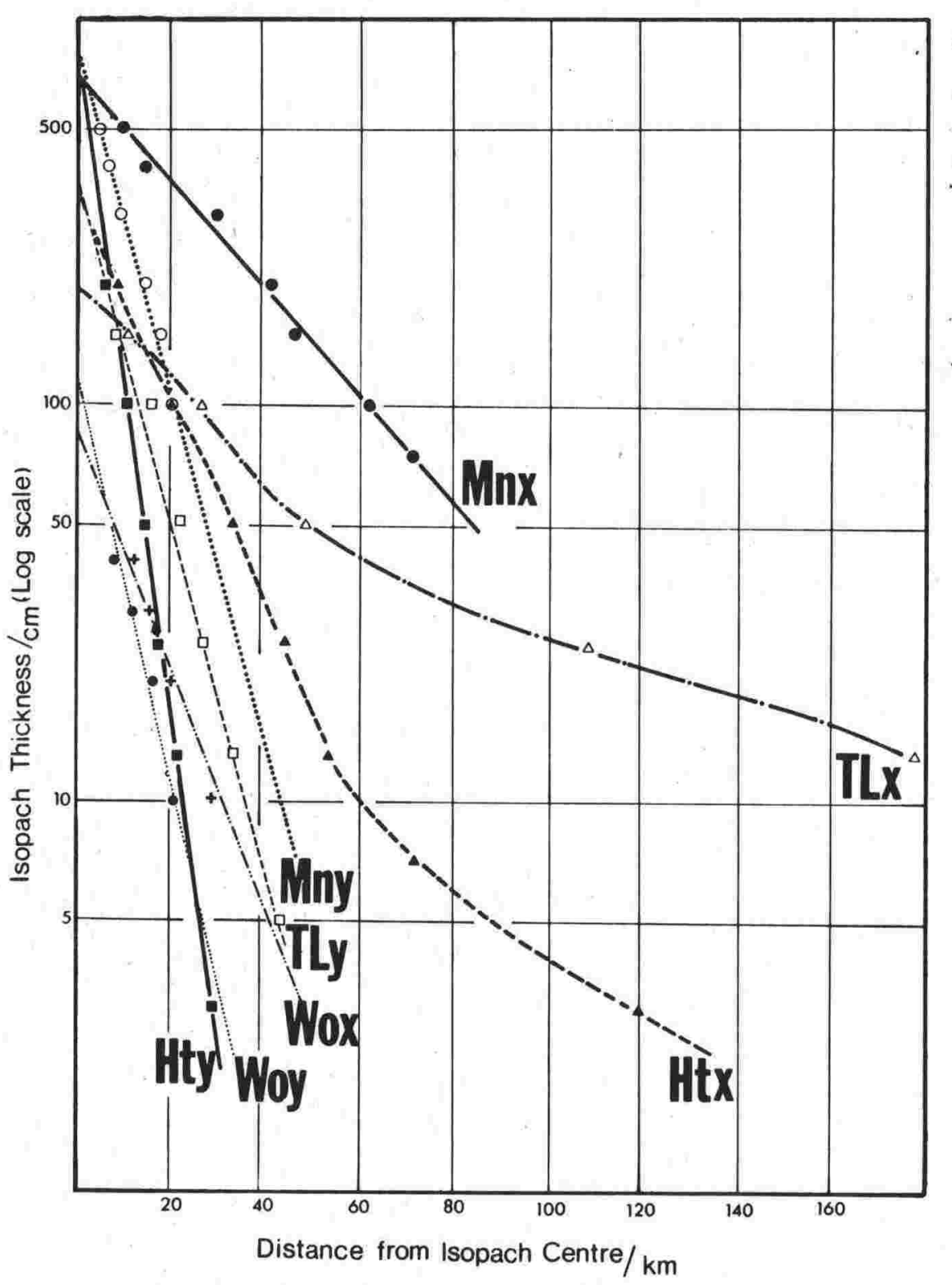

FIGURE 4.1.2: Plot of isopach thickness against distance from source showing general exponential relationship Symbols for tephras are in Table 4.1.1. 


\begin{tabular}{|c|c|c|c|c|c|}
\hline Tephra & & $\mathbf{r}$ & $\mathbf{a}$ & $\mathrm{b}$ & Volume \\
\hline \multirow[t]{2}{*}{ Taupo Lapilli } & $\mathrm{x}$ & 0.9983. & 2.06 & 23.8 & 15.2 \\
\hline & $\mathrm{Y}$ & 0.9877 & 3.73 & 6.86 & 2.3 \\
\hline \multirow[t]{2}{*}{ Hatepe Lapi11i } & $\mathrm{x}$ & 0.9994 & 3.25 & 11.5 & 5.65 \\
\hline & $\mathbf{Y}$ & 0.9971 & 6.65 & 3.7 & 1.22 \\
\hline \multirow[t]{2}{*}{ Whakaipo } & $\mathbf{x}$ & 0.9847 & 0.85 & 9.9 & 1.11 \\
\hline & $Y$ & 0.9802 & 1.17 & 5.8 & 0.52 \\
\hline \multirow[t]{3}{*}{ Hinemaiaia } & $\mathrm{x}$ & 0.9980 & 0.89 & 16.9 & 3.32 \\
\hline & $Y$ & 0.9952 & 0.50 & 21.8 & 3.10 \\
\hline & & & & & \\
\hline \multirow[t]{2}{*}{ Mangaone } & $\mathrm{x}$ & 0.9955 & 6.72 & 22.2 & 43.13 \\
\hline & $\mathbf{Y}$ & 0.9894 & 7.37 & 6.9 & 4.64 \\
\hline \multirow[t]{2}{*}{ Haupuru } & $\mathrm{x}$ & 0.9955 & 1.00 & 14.32 & 26.84 \\
\hline & $\mathbf{Y}$ & 0.9924 & 1.18 & 6.04 & 5.64 \\
\hline
\end{tabular}

TABLE 4.1.2: : Examples of volume calculations based on an exponential decay of thickness along the major $(x)$ and minor ( $y$ ) axes of the isopach ellipses where ' $a$ ' is the extrapolated thickness at source, ' $b$ ' is the distance over which the thickness halves and ' $r$ ' is the negative correlation coefficient from Figure 2 . 
then Volume $(V)=\int_{0}^{\infty} \pi x^{2} a \cdot \exp -c x \cdot d x$

which on integration and substitution gives

$V=13.08 \mathrm{ab}^{2}$

Equation 2 indicates that half the total volume of tephra is within an area of radius $4 \mathrm{~b}$ from the isopach centre. The method is, however, inappropriate for tephras not forming a circular distribution.

\section{B. Elliptical Isopachs}

Most of the isopachs studied approximate to ellipses in form rather than a circle so the volume can be calculated assuming ellipses of constant shape. The minor and major axes of the ellipses are at right angles and if their ratio $(\alpha)$ is assumed constant at

$$
\alpha=\left(1-e^{2}\right)^{\frac{1}{2}}
$$

and the ellipses are aligned with major axis along $\mathrm{x}$ axis and minor axis along $y$ axis then thickness (T) of tephra decreases exponentially outwards as

$$
T=c \cdot \exp -k\left(x^{2}+y^{2} / 1-e^{2}\right)^{\frac{1}{2}}
$$

where $c=$ extrapolated thickness at isopach centre and $\mathrm{k}$ is a constant, then

$$
\text { Volume }(V)=\int_{0}^{\infty} \int_{0}^{\infty} c \cdot \exp -k\left(x^{2}+y^{2} / 1-e^{2}\right)^{\frac{1}{2}} \cdot d x \cdot d y
$$

which on integration becomes

$$
\mathrm{V}=2 \pi c \alpha / \mathrm{k}^{2}
$$

and for an ellipse with $\alpha=\frac{b}{a}\left(=\sqrt{1-e^{2}}\right)$,

$$
\mathrm{T}=\mathrm{c} \cdot \exp -\mathrm{ka}
$$


In practice, $\mathrm{k}$ is calculated for each isopach line and a mean value taken. Volumes using this formula are included in Table 4.

\section{VOLUME BASED ON AREA OF ISOPACHS}

Perhaps the most realistic method of determining volumes is based on the area contained within each isopach. Data seldom extend to the thin distal parts of the deposit making some form of extrapolation necessary to determine the total volume.

A convenient method to determine the area within each isopach is to enlarge the isopach map to a suitable scale, then to cut out and weigh each isopach annulus; the mass is easily converted to area and then volume. Total volume within the outermost (minimum) isopach could then be calculated by summing individual volumes. Only a minimum volume can be obtained in this way (Table 3), dependent on the extent of the isopach maps. Volume of tephra contained within each isopach was calculated from the area using a mean thickness of 0.6 of the value of the bounding isopachs based on an exponential decay of thickness, (i.e. for isopachs of $100 \mathrm{~mm}$ and $200 \mathrm{~mm}, 160 \mathrm{~mm}$ was used).

2A. Log-Log Plot of Thickness against area

Rose et al. (1973) and walker (1980) calculated volume from a log-log plot of thickness against area. Rose et al. fitted two straight lines to the data whereas walker drew a curve through each point then extrapolated this to an arbitrary 1 micron thickness. Six examples from TVZ (Figure 3) give different curves. In each case the curves need extrapolation over 4 to 5 orders of magnitude on the log-log plot to reach 1 micron, which can lead to large volume errors.

The following two methods of extrapolation were examined in an attempt to reduce the uncertainty by extrapolating over much shorter intervals. 


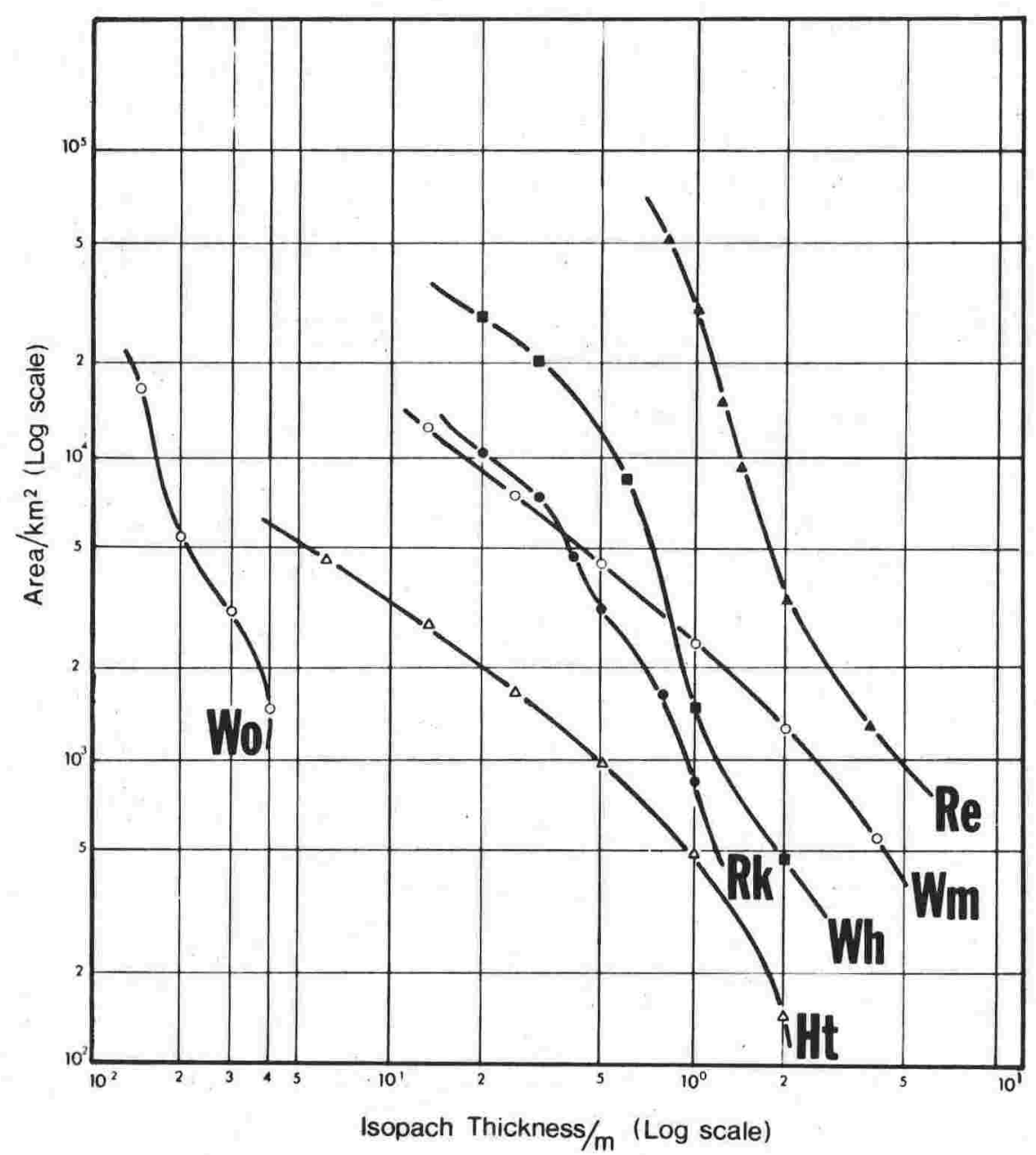

FIGURE 4.1.3: Log-log plot of area enclosed by each isopach against isopach thickness. Symbols for tephras are in Table 4.1.1. None of the tephras plotted show simple relationships which can be easily extrapolated. 
2B. Equivalent Circular Radius

Assuming an exponential decay of thickness with distance, the volume of material within each isopach was redistributed into a circular annulus by calculating an equivalent radius for that area. A plot of log thickness against radius allowed the total volume to be found using equation 3 above. Area and equivalent radius for several tephras is given in Table 3 as well as the correlation coefficients of the curve $\log \mathrm{T}$ vs. D on which equation 3 is based.

\section{C. Volume-Thickness Plot}

Cumulative volume within each isopach is plotted against thickness on Figure 4. This produces an exponential decay of volume with thickness, and extrapolation to $\mathrm{T}=0$ gives the total volume ( $\mathrm{Table} 4$ ). This plot is considered to be superior to plotting log area against log thickness as on Figure 3 as it requires much less extrapolation (cf.

Walker 1980, Figure 8) and gives the volume out to any thickness directly.

\section{VOLUME FROM CRYSTAL CONCENTRATION}

This method is detailed by walker (1980) based on the following assumptions :

(i) crystal content of large pumice blocks is representative of the crystal content of the magma and all crystals are smaller than $2 \mathrm{~mm}$.

(ii) during eruption, some crystals are liberated by total fragmentation of enclosing magma/pumice to particles smaller than $2 \mathrm{~mm}$. Liberation does not occur by abrasion of pumice.

(iii) liberated crystals are concentrated nearer the vent than pumice fragments that released them. (For Taupo material 


\begin{tabular}{|c|c|c|c|c|}
\hline & Vol. & Area & $\begin{array}{l}\text { Equival } \\
\text { radius }\end{array}$ & $\begin{array}{l}\text { ent } \\
\mathrm{s}\end{array}$ \\
\hline \multicolumn{5}{|l|}{ Hatepe Lapilli } \\
\hline 200 & 0.42 & 150 & 6.9 & $\log T$ vs $D . \quad r=0.9947$ \\
\hline 100 & 0.99 & 507 & 12.7 & $a=3.99 \mathrm{mb}=6.2 \mathrm{~km}$ \\
\hline 50 & 1.42 & 1041 & 18.2 & $\mathrm{~V}=2.00 \mathrm{~km}^{3}$ \\
\hline 25 & 1.67 & 1676 & 23.1 & $\log \mathrm{V}$ vs $\mathrm{T} . \mathrm{I}=0.9987$ \\
\hline 13 & 1.89 & 2771 & 29.7 & $\mathrm{v}=2.13$ \\
\hline 6 & 2.10 & 4827 & 39.2 & \\
\hline \multicolumn{5}{|l|}{ Whakaipo } \\
\hline 40 & 0.94 & 1466 & 21.61 & $\log T$ vs $D . r=0.9930$ \\
\hline 30 & 1.50 & 3019 & 31.0 & $a=0.70 b=25.1$ \\
\hline 20 & 2.11 & 5385 & 41.4 & $\mathrm{~V}=5.74$ \\
\hline 10 & 3.86 & 16331 & 72.1 & $\log V$ vs T. $r=0.9922$ \\
\hline & & & & $v=1.47$ \\
\hline \multicolumn{5}{|l|}{ Waimihia Lapilli } \\
\hline 400 & 3.61 & 564 & 13.4 & $\log T$ vs D. $r=0.9903$ \\
\hline 200 & 6.06 & 1333 & 20.6 & $\mathrm{a}=8.42 \mathrm{~b}=9.93$ \\
\hline 100 & 7.84 & 2445 & 27.9 & $\mathrm{~V}=10.86$ \\
\hline 50 & 9.51 & 4536 & 38.0 & lot $V$ vs $T . r=0.9924$ \\
\hline 25 & 10.76 & 7636 & 49.3 & $\bar{v}=11.38$ \\
\hline 13 & 11.74 & 12548 & 63.2 & \\
\hline \multicolumn{5}{|l|}{ Waiohau } \\
\hline 200 & 0.99 & 491 & 12.5 & $\underline{\log T \text { vs } D .} r=0.9798$ \\
\hline 100 & 1.9 & 1452 & 21.5 & $a=2.25 b=26.64$ \\
\hline 50 & 5.6 & 8758 & 52.8 & $v=20.9$ \\
\hline 30 & 9.4 & 21330 & 82.4 & $\log V$ vs T. $r=0.9989$ \\
\hline 20 & 10.8 & 28353 & 95.0 & $\mathrm{v}=17.4$ \\
\hline \multicolumn{5}{|l|}{ Rerewhakaaitu } \\
\hline 100 & 0.85 & 855 & 16.5 & $\underline{\log T \text { vs } D .} r=0.9966$ \\
\hline 80 & 1.5 & 1676 & 23.1 & $\mathrm{a}=1.91 \mathrm{~b}=17.64$ \\
\hline 50 & 2.3 & 3237 & 32.1 & $\log V$ vs T. $r=0.9938$ \\
\hline 40 & 3.0 & 4778 & 39.5 & $\mathrm{v}=6.58$ \\
\hline 30 & 3.7 & 7482 & 48.8 & \\
\hline 20 & 4.3 & 10207 & 57.0 & \\
\hline \multicolumn{5}{|l|}{ Rotoehu } \\
\hline 400 & 2.3 & 573 & 13.5 & $\log T$ vs $D . r=0.9473$ \\
\hline 380 & 5.1 & 1320 & 20.5 & $a=4.58 b=40.7$ \\
\hline 200 & 9.4 & 3463 & 33.2 & $\bar{V}=98.9$ \\
\hline 140 & 17.7 & 9366 & 54.6 & $\log V$ vs T. $r=0.9586$ \\
\hline 120 & 24.9 & 15394 & 70.0 & $\mathrm{~V}=82.3$ \\
\hline 100 & 40.7 & 31165 & 99.6 & \\
\hline 80 & 49.6 & 42346 & 116.1 & \\
\hline
\end{tabular}

TABLE 4.1.3: Data for representative tephras as used in the volume calculations. The area bounded by each isopach (column 2) is converted to volume (column 1 ) and also equivalent circular radius (column 3) from which volumes were calculated using Figure 4.1.2 $(\log T$ vs $D)$ or Figure 4.1 .4 ( $\log V$ vs $T$ ). " $a$ ' and'b' as for Table 4.1.2 ' $r$ ' is the correlation coefficient of each regression line. 


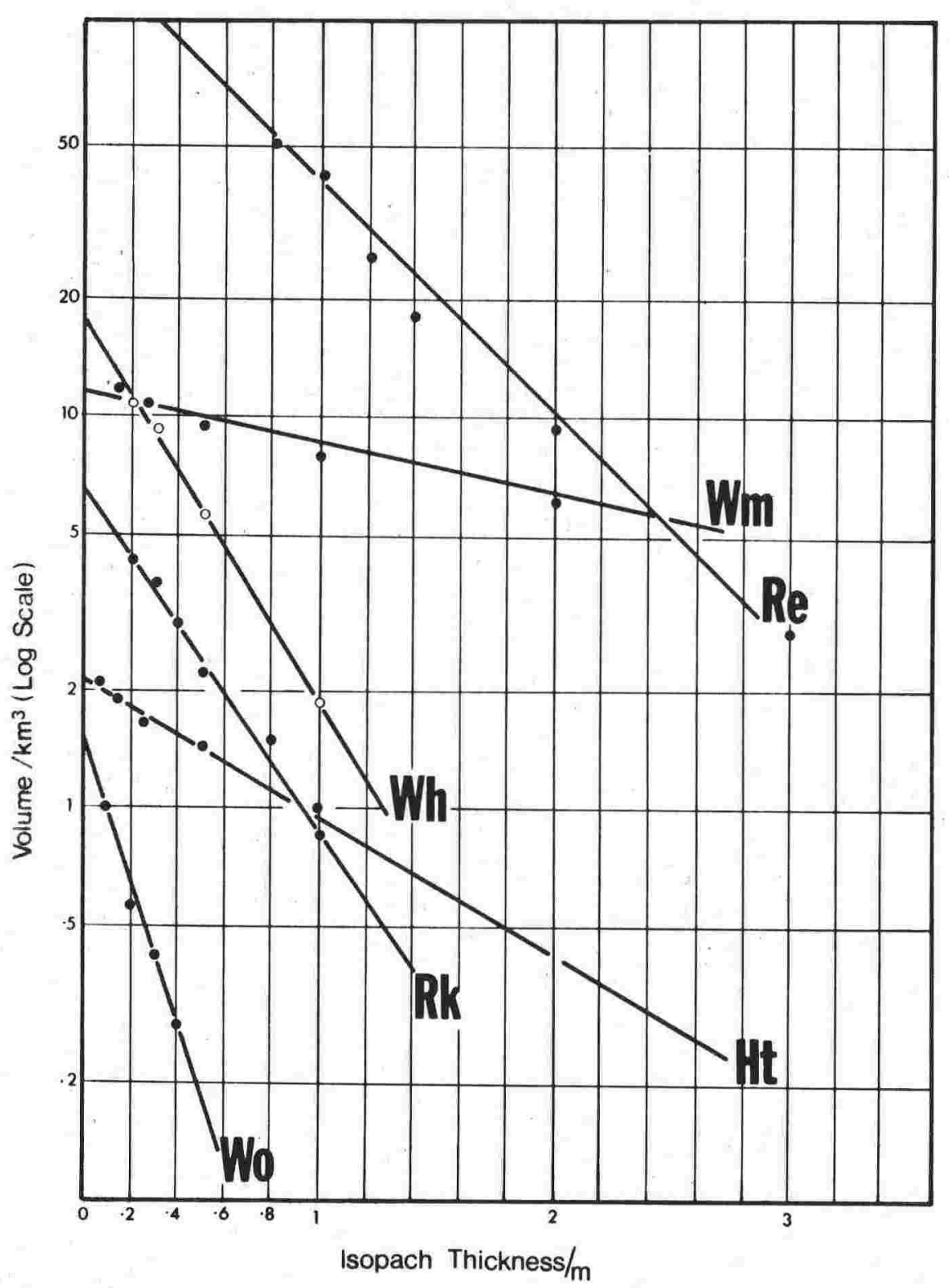

FIGURE 4.1.4: Log volume plotted against thickness, used to calculate the total erupted volume at $T=0$. 
the crystals are on land whilst the fine ash is not).

(iv) by determining the total mass of liberated crystals the total mass of tephra that released them is calculable. Thus the total erupted volume can be determined.

Using this method a volume for Taupo Lapilli was determined as $22 \mathrm{~km}^{3}$ (Walker 1980), $80 \%$ of which is deduced to be finer than $2 \mathrm{~mm}$ and fell beyond land, presumably to the east of New Zealand. Volumes for Waimihia Lapilli of $30 \mathrm{~km}^{3}$ and Hatepe Lapilli of $6 \mathrm{~km}^{3}$ with $60 \%$ dispersed outside New Zealand have also been determined (Walker 1981).

\section{RESULTS}

Tephra volumes calculated by the methods described above are listed in Table 4. There is good agreement between the different methods for most tephras but the most accordant volumes are those based on area of dispersal. Tephras with moderate volumes of $5-10 \mathrm{~km}^{3}$ give the most consistent results; for example, Karapiti Tephra with totals of 1.0 , $1.3,1.5$ and $1.6 \mathrm{~km}^{3}$. In all cases the error in the accepted volume is quite large, probably about $10-15 \%$ and all volumes are undoubtedly conservative.

At least $50 \%$ of the total extrapolated volume is contained within the plotted isopachs, so the methods based on isopach area are more reliable than the mathematical function methods, as long as extrapolation beyond the data is minimal. For this reason the plots of logvolume against thickness (Figure 4) and log-thickness against equivalent radius are considered to be the more reliable methods, whereas the loglog plot of area and thickness requires extrapolation of at least $10^{4}$ units and is here discarded.

From the volume in Table 4 total airfall material erupted from Taupo Volcanic Centre is in excess of $115 \mathrm{~km}^{3}$ in the last $20 \mathrm{kyr}$ and from 


\begin{tabular}{|c|c|c|c|c|c|c|c|c|}
\hline Tephra & $\begin{array}{l}\text { Circl } \\
\text { Min. }\end{array}$ & $\begin{array}{l}\text { Eular } \\
\text { Max. }\end{array}$ & $\begin{array}{l}\text { Formula } \\
\text { Average }\end{array}$ & $\begin{array}{l}\text { Ellipse } \\
\text { Formula }\end{array}$ & $\begin{array}{c}\text { Min.Volume } \\
\text { inside } \\
\text { isopachs }\end{array}$ & $\begin{array}{l}\text { Equivalent } \\
\text { circular } \\
\text { radii }\end{array}$ & $\begin{array}{l}\text { log.vol./ } \\
\text { distance }\end{array}$ & $\begin{array}{l}\text { Accepted } \\
\text { Volume }\end{array}$ \\
\hline Taupo Lapilli & 2.3 & 15.2 & 8.8 & 7.2 & 6.4 & 12.8 & 11.5 & $12+$ \\
\hline Rotongaio Ash & 0.3 & 1.2 & 0.8 & 0.7 & 0.6 & 0.6 & 0.5 & 1 \\
\hline Hatepe Lapilli & 1.2 & 5.7 & 3.5 & 3.6 & 2.1 & 2.0 & 2.1 & 2 \\
\hline Mapara $T$ & 0.03 & 5.4 & 2.5 & 1.3 & 1.0 & 1.6 & 1.9 & 2 \\
\hline Whakaipo $T$ & 0.5 & 1.1 & 0.8 & 1.0 & 1.0 & 1.4 & 1.5 & 1.5 \\
\hline Waimihia $\mathrm{T}$ & 0.3 & 36.3 & 18.3 & 16.4 & 11.7 & 11.0 & 13.6 & 14 \\
\hline Hinemaiaia $T$ & 3.1 & 3.3 & 3.2 & 3.1 & 1.0 & 3.2 & 2.7 & 3 \\
\hline Motutere $\mathrm{T}$ & 0.5 & 0.8 & 0.7 & 0.5 & 0.15 & 0.5 & 0.5 & 0.5 \\
\hline Opepe $T$ & 2.4 & 16.6 & 9.5 & 7.0 & 2.5 & 3.8 & 3.9 & 4 \\
\hline Poronui T & 1.5 & 2.2 & 1.9 & 1.6 & 1.7 & 2.3 & 2.6 & 3 \\
\hline Karapiti T & 0.4 & 6.0 & 3.2 & 1.0 & 1.3 & 1.6 & 1.5 & 2 \\
\hline Kawakawa T & 10.81 & 100.0 & 55.4 & " & * & " & * & 70 \\
\hline Kaharoa & 2.2 & 9.9 & 6.1 & 4.0 & 2.9 & 3.3 & 3.3 & 4 \\
\hline Whakatane & 4.9 & 10.3 & 7.6 & 7.1 & 4.7 & 7.6 & 5.6 & 6 \\
\hline Mamaku & 2.6 & 13.2 & 7.9 & 4.1 & 4.3 & 5.6 & 5.2 & 6 \\
\hline Rotoma & 6.5 & 42.3 & 24.4 & 16.7 & 10.5 & 16.5 & 11.0 & 12 \\
\hline Waiohau & 10.5 & 56.6 & 33.6 & 18.8 & 10.8 & 20.9 & 17.4 & 18 \\
\hline Rotorua & 1.7 & 14.1 & 7.9 & 6.6 & 4.7 & 6.7 & 8.3 & 7 \\
\hline Rerewhakaaitu & 4.4 & 13.3 & 8.9 & 11.1 & 4.3 & 7.8 & 6.6 & 7 \\
\hline Okareka & 6.6 & 7.8 & 7.2 & 8.3 & 5.13 & 8.3 & 10.7 & 8 \\
\hline Te Rere & 8.5 & 15.9 & 12.2 & 9.9 & * & - & - & 9 \\
\hline Onataroa & 1.1 & 23.0 & 12.1 & 7.61 & $\min .1$ * & - & - & 16 \\
\hline Awakeri & 0.8 & 2.0 & 1.4 & 1.4 & 0.3 & 1.1 & 1.5 & 2 \\
\hline Mangaone & 4,6 & 43.1 & 23.9 & 14.8 & 7.9 & 13.1 & 18.9 & 16 \\
\hline Hauparu & 5.6 & 26.8 & 16.2 & 13.2 & 6.1 & 10.7 & 10.0 & 10 \\
\hline Maketu & 10.3 & 13.3 & 11.8 & 10.9 & 5.4 & 15.9 & 21.9 & 15 \\
\hline Ngamotu & 1.1 & 3.4 & 2.3 & 2.1 & * & - & - & 2 \\
\hline Rotoehu & 80.91 & 176.9 & 128.9 & 47.5 & 49.6 & 99.0 & 82.3 & 90 \\
\hline
\end{tabular}

TABLE 4.1.4: Tephra volumes calculated by various methods described in the text. All volumes in $\mathrm{km}^{3}$. 
Okataina is $230 \mathrm{~km}^{3}$ in $50 \mathrm{kyr}$.

\section{DISCUSSION}

Volumes calculated by methods described here are based entirely on the isopach maps of tephra thickness. This represents the material actually visible and measurable, but has taken account of most postdepositional erosion since the isopach contours have been derived by smoothing the measured thickness. From knowledge of Late Pleistocene climate and erosion only Kawakawa, Te Rere and Okareka Tephras (17-20,000 yrs B.P.) have been seriously eroded (Vucetich \& Pullar 1969), and by smoothing the isopachs, the calculated volumes have allowed for this. Nearly all the tephras studied here show an exponential decay of thickness (and grainsize) with distance from source so that at increasing distances the volume within bounding isopachs also decreases, despite the increasing area of dispersal. This relationship was shown by Rose et al. (1973) and Walker (1980) when the gradient of their log-log plots of area and thickness increases for decreasing thickness (see Figure 3). In addition, agreement between the methods employed here for calculating volume indicates that the total obtained closely approximates the actual volume of material that was deposited to form an "exponentialsided cone". It does not include any extremely fine ash that may have been dispersed around the earth.

Despite the volumes for plinian eruptions contained in Table 4 being minimums, they are 2 to 3 times less than those derived by Walker $(1980,1981)$ from crystal concentration. Walker suggests that of the erupted material, 60-80\% (which equals $16 \mathrm{~km}^{3}$ for Taupo Lapilli, $18 \mathrm{~km}^{3}$ for Waimihia and $4 \mathrm{~km}^{3}$ for Hatepe) did not add to the exponential cone but fell beyond land and that this percentage may be typical of plinian eruptions. Many of the medium volume plinian tephras $\left(1-5 \mathrm{~km}^{3}\right)$, including 
Hatepe, can be traced for their full extent on land. Recent work in peat swamps (Howorth et al. 1980; Lowe et al. 1980) has identified and correlated many thin tephras and indicates that the distribution of the identified tephras is greater than previously mapped. Exponential extrapolation from the previously known distribution accounts for this extra material. An exceptional volume of fine ash as predicted by Walker (1980) cannot yet be substantiated for these plinian eruptions. Tephras found in cores taken offshore, east of New Zealand (Lewis \& Kohn 1973) correlate to eruptive episodes with associated pyroclastic flows and for these events, widespread "co-ignimbrite airfall ash" is expected. Similarly, the identification of ash from the Taupo and older ignimbrite eruptions (Froggatt M.S.) in cores taken $1000 \mathrm{~km}$ east of New Zealand (Watkins \& Huang 1977) confirms that pyroclastic flows are currently the only eruption mechanism that satisfactorily produces large volumes of widely dispersed fine rhyolitic ash other than the $\stackrel{h}{\text { Ireato-plinian }}$ mechanism of Self \& Sparks (1978). Whilst there is still doubt that large quantities of fine ash correlate to plinian eruptions, the volumes calculated by Walker $(1980,1981)$ may be excessive. A lesser volume of fine ash would result if only partial pumice fragmentation is assumed, and as admitted by Walker (1981), volumes may be at least 20\% overestimated by this technique.

\section{Total Volume of Erupted Magma from Taupo Volcanic Zone}

(a) Plinian tephras: From the calculated volumes of airfall deposits the amount erupted from Taupo Volcanic Centre in the last 20 kyr is at least $115 \mathrm{~km}^{3}$ and that from Okataina in the last $50 \mathrm{kyr}$ is $230 \mathrm{~km}^{3}$. If the $18 \mathrm{~km}^{3}$ erupted from Taupo between 50 to $20 \mathrm{kyr}$ B.P. (Vucetich \& Howorth 1976) is included, the sum of rhyolitic airfall material from TVZ in $50 \mathrm{kyr}$ is at least $360 \mathrm{~km}^{3}$. This is about $110 \mathrm{~km}^{3}$ of magma, assuming 


\section{5}

densities of $0.7 \mathrm{~g} / \mathrm{cm}^{3}$ for the tephra and $2.3 \mathrm{~g} / \mathrm{cm}^{3}$ for magma (Bottinga \& Weill 1969).

(b) Ignimbrite and Extrusive Volumes: Many eruptive episodes in the last $50 \mathrm{kyr}$ also produced pyroclastic flows which formed unwelded ignimbrites and almost all had associated extrusive phases. Tephras known to have associated ignimbrites are shown on Table 1. Estimations of the volumes of these ignimbrites (Table 5) is exceedingly difficult due to their highly irregular distribution and thickness. The method used for Taupo Ignimbrite is given in Froggatt (1981) whereas the others are estimated, from their known distribution, using Taupo Ignimbrite for scale. The volumes may be underestimated. Total volume of ignimbrite in the last $50 \mathrm{kyr}$ is about $350 \mathrm{~km}^{3}$, equivalent to $180 \mathrm{~km}^{3}$ of magma assuming a bulk density of $1.2 \mathrm{~g} / \mathrm{cm}^{3}$ for the ignimbrite.

Nearly all the tephra eruptions in the last $50 \mathrm{kyr}$ were followed by extrusion of magma to form rhyolite domes (Cole 1970; Nairn 1980; Froggatt 198la, b). Much of this material is now obscured by overlying tephras and volume estimates are difficult. Conservative values of $5 \mathrm{~km}^{3}$ for Taupo and $50 \mathrm{~km}^{3}$ for Okataina (Nairn 1981) are here accepted.

The total volume of rhyolitic eruptives in the last 50 kyr from TVZ is $360 \mathrm{~km}^{3}$ of airfall tephra, $350 \mathrm{~km}^{3}$ of ignimbrite and $55 \mathrm{~km}^{3}$ of other extrusives. This totals about $350 \mathrm{~km}^{3}$ of magma. Cole (1979) has estimated that at least $95 \%$ of all magma erupted from TVZ is rhyolitic, the rest being basalt, andesite and dacite.

\section{Rate of Eruption of Magma}

Volumes calculated for the tephras from each volcanic centre have been summed and plotted against time to give the long-term rate of magma eruption (Figure $5 \mathrm{a}, \mathrm{b}$ ). For both centres this long-term rate appears remarkably uniform but each centre has distinctive trends. 


\begin{tabular}{|lc|}
\hline \multicolumn{2}{|c|}{ Estimated volume of Ignimbrite } \\
\hline Taupo Pumice & $70 \mathrm{~km}^{3}$ \\
Waimihia & 5 \\
Kawakawa & 100 \\
Omataroa & 5 \\
Mangaone & 6 \\
Rotoehu & 150 \\
\hline
\end{tabular}

TABLE 4.1.5:The estimated volumes of ignimbrites erupted from TVZ post - $50 \mathrm{kry}$ B.P. The method of calculation for Taupo Ignimbrite is given in Froggatt (1981). The remainder are scaled estimates. 
Okataina (Figure 5a), with 18 eruptions post-50 kyr, has maintained a steady rate of magma eruption following the extremely large event $\underline{c}$. 42 kyr B.P. Fluctuations do occur, but for volumes which plot off the mean line there appears to be a good relationship between the volume erupted and either the succeeding volume or the time interval to the following event. For instance the cumulative volume at $38 \mathrm{kyr}$ B.P. falls well below the mean rate line so the next eruption (Maketu Tephra) is relatively large $\left(15 \mathrm{~km}^{3}\right)$, plotting close to the mean rate line. The Omataroa Tephra at 28 kyr plots well above the mean line, consequently a long quiescent period follows before Te Rere Tephra, which plots close to the line.

The post-50 kyr cumulative volume data for Taupo Volcanic Centre has 16 eruptions plotted (Figure $5 b$ ), through which a step-function can be constructed. These data more clearly show the dependence of individual volumes on the volumes of, and time intervals between, previous eruptions. Thus following Poihipi and Okaia Tephras at 21 kyr B.P. a large deficiency from the mean total erupted volume existed, overcorrected soon afterwards by the eruption of Kawakawa Tephra. A long quiet period followed, until the eruption of Karapiti Tephra at $10 \mathrm{kyr}$ B.P., which plots close to the mean. The quiet period is analogous to the Omatatoa-Te Rere pause at Okataina.

On the basis of the step-function, the 1,800 yr B.P. Taupo event is expected to be followed by up to $10 \mathrm{kyr}$ of quiescence when the mean rate will again be restored by a relatively small eruption. Okataina at present has a volume deficit which would be corrected by the eruption of up to $16 \mathrm{~km}^{3}$ of tephra. The past record suggests this should occur less than 1,000 years after the previous event or in less than 400 years time. 


\section{8}

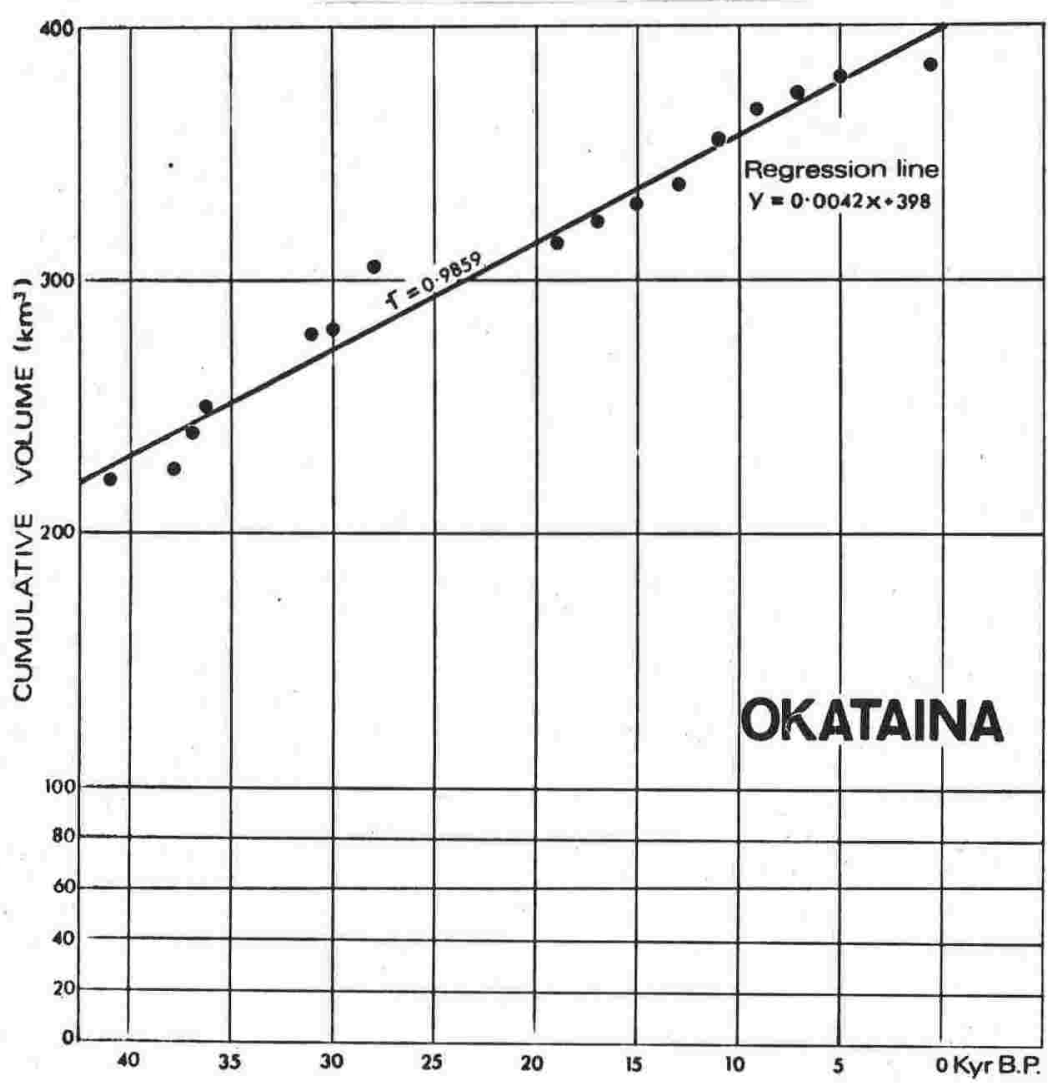

(a)

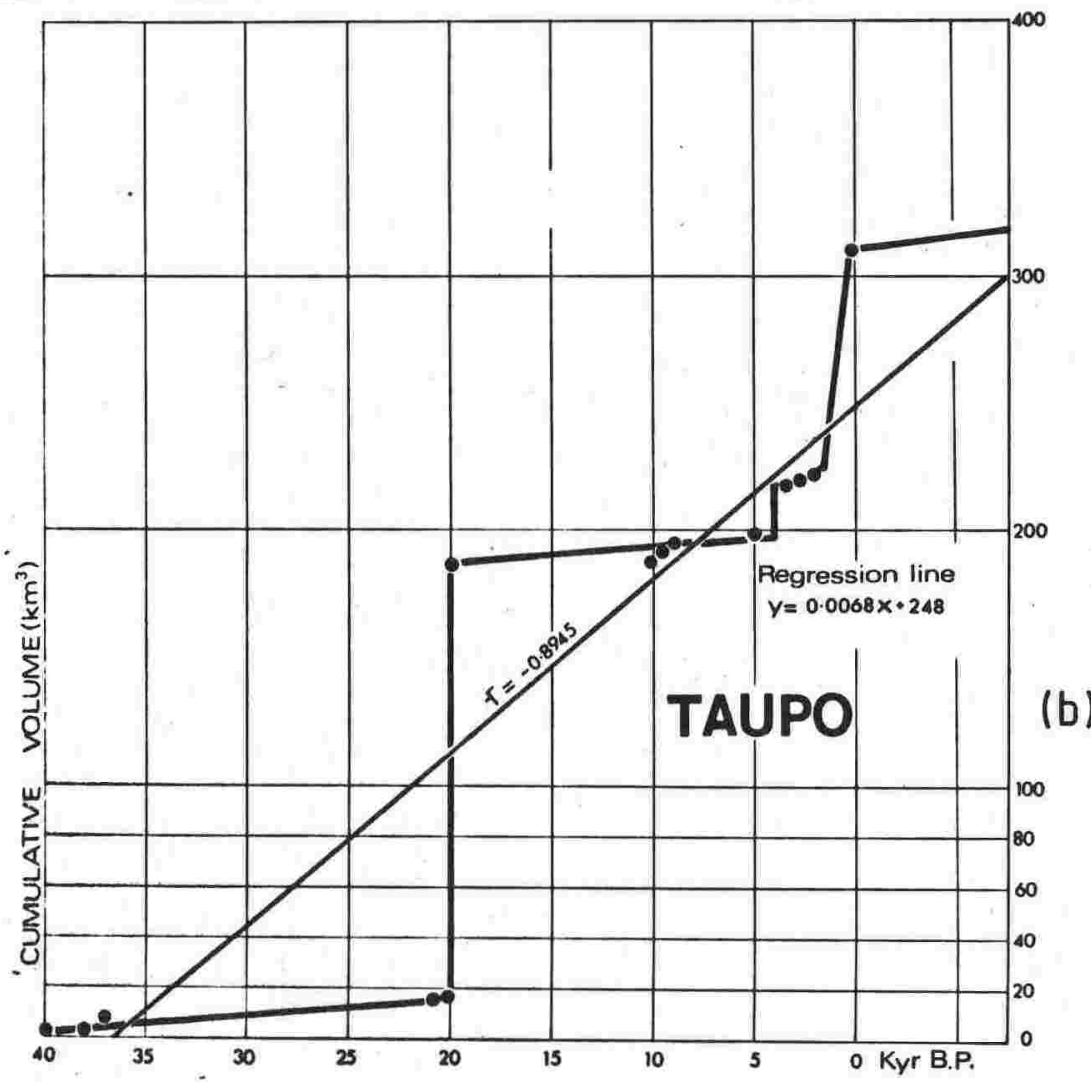

FIGURE 4.1.5: Cumulative volume plotted against age for the tephras from (a) Okataina and (b) Taupo Volcanic Centres.

Equations and correlation coefficients for least-squares regression lines using all data. Near-horizontal steps in (b) are regression lines through relevent points only. 
The total volume of magma erupted from Taupo and Okataina Centres in $50 \mathrm{kyr}$ is $350 \mathrm{~km}^{3}$. The Maroa Centre (Figure 1) has been virtually inactive during this time (Vucetich \& Pullar 1973) but is older than both Taupo and Okataina. Activity now appears to have moved south to Taupo, so if Taupo and Okataina are representative of past activity then magma has been erupted from TVZ at an average rate of $7 \mathrm{~km}^{3} / \mathrm{kyr}$.

Eruptions began from TVZ about 0.6 million years ago (Kohn 1973). Prior to this time eruptions were centred to the west of TVZ on a more northerly trending line (Cole 1979). If TVZ has been, on average, erupting magma at $7 \mathrm{~km}^{3} / \mathrm{kyr}$ then the total magma erupted would be about $4,200 \mathrm{~km}^{3}$. Cole (1979) estimated the total volume of volcanic material within TVZ at $12,000 \mathrm{~km}^{3}$ (about $7,200 \mathrm{~km}^{3}$ corrected for density) but this includes older pyroclastics from outside TVZ. The generation, storage and eruption of such a large volume of magma is discussed in part by Ewart et al. (1975) and Cole (1979, 1981).

\section{Magma Genesis and Mass Balance Estimates}

Rhyolitic magma erupted in TVZ is almost certainly generated by partial melting of crustal sedimentary rocks, probably Mesozoic greywacke and argillites, and is related to a westward dipping subduction zone to the east of New Zealand (Ewart et al. 1975; Cole 1979, 1981). Recent modelling studies (Reid pers. comm. 1981) suggest a $30 \%$ partial melt is sufficient to derive rhyolitic magma from parent greywacke and could be accomplished at depths of $15 \mathrm{~km}$ or 1 ess.

Related to subduction is northwest-southeast spreading of TVZ ("back-arc spreading") . Present day spreading, determined by geodetic resurveying, is about $7 \mathrm{~mm} / \mathrm{yr}$ at the Bay of Plenty coast (Sissons 1979) and at this rate, $4.2 \mathrm{~km}$ of spreading will have occurred in 0.6 Myr (the 
age of TVZ). If all this spreading is accommodated by vertical intrusions into the upper $10 \mathrm{~km}$ of crust and is spread over the length of the zone $(200 \mathrm{~km})$, then about $8,400 \mathrm{~km}^{3}$ has been intruded, twice the erupted volume $\left(4,200 \mathrm{~km}^{3}\right)$.

Assuming most of the intruded dyke material is rhyolitic, the total volume of magma generated by partial melting is the sum of the erupted and intruded material, so is about $12,600 \mathrm{~km}^{3}$. With a $30 \%$ partial melt, this volume is generated by $42,000 \mathrm{~km}^{3}$ of greywacke. The area of TVZ is $6,000 \mathrm{~km}^{2}(200 \times 30 \mathrm{~km})$ so $7 \mathrm{~km}$ thickness of the crust beneath $10 \mathrm{~km}$ depth has been involved in melting. Upward migration of the melt to compensate for spreading, or to be erupted, will create a void that must be filled by crustal subsidence.

Removal of $12,600 \mathrm{~km}^{3}$ of magma would cause $2.1 \mathrm{~km}$ of subsidence over the area of TVZ. Sub-volcanic basement in TVZ is at about $2 \mathrm{~km}$ depth (Cole 1981), and generally confirms the partial melting model. If the model is valid, basement under TVZ is mostly rhyolitic intrusions with minor greywacke.

\section{CONCLUSIONS}

Comparison of 6 methods for the calculation of the total volume of plinian deposits shows generally good agreement between the methods based on extensive isopach data. In all methods, extrapolation beyond the minimum isopach is required and assumptions of exponential decay of thickness or linearity on a log plot appear adequate. However, use of the log-log plot of area and thickness is regarded as unsatisfactory as excessive extrapolation over $10^{4}$ to $10^{5}$ units is needed. A plot of thickness and log-volume is shown to be superior in being linear and requiring minimal extrapolation. 
The crystal concentration method gives volumes $2-3$ times greater than those determined here, with 60-80\% of the total as fine ash (< 2mm, Walker 1980). Such a large volume of fine ash has not been demonstrated for any of the 28 plinian eruptions studied here so the assumption of total pumice fragmentation on crystal release is considered excessive. Ignimbrite eruptions, however, may produce up to $50 \%$ of their total volume as fine "co-ignimbrite ash", and this accounts for the fine ash found in marine sediments east of New Zealand. Total volume of rhyolitic plinian eruptives from Taupo Volcanic Zone (TVZ) in the last $50 \mathrm{kyr}$ is in excess of $360 \mathrm{~km}^{3}$ of pumice $\left(110 \mathrm{~km}^{3}\right.$ of magma, density $2.3 \mathrm{~g} / \mathrm{cm}^{3}$ ). When ignimbrite and other extrusive volumes are included the total in $50 \mathrm{kyr}$ is about $770 \mathrm{~km}^{3}$ or $350 \mathrm{~km}^{3}$ of dense rock, giving an average rate of magma eruption of $7 \mathrm{~km}^{3} / \mathrm{kyr}$. Extrapolated over the 0.6 million year life of TVZ, this rate gives a total erupted magma volume of $4,200 \mathrm{~km}^{3}$.

Assuming back-arc spreading of TVZ at $7 \mathrm{~mm} / \mathrm{yr}$ is accommodated by rhyolite intrusions into the upper crust, the total volume of magma is $12,600 \mathrm{~km}^{3}$. Removal of this volume after formation by a $30 \%$ partial melt of Mesozoic greywacke-argillite at $15 \mathrm{~km}$ depth would cause $2.1 \mathrm{~km}$ of subsidence in TVZ, consistent with sub-volcanic basement at $2 \mathrm{~km}$ depth and providing a general confirmation of the basis for the mass-balance calculations.

\section{ACKNOWLEDGEMENTS}

Encouragement and valuable comments on this work were provided by Dr. J. Cole, C. Vucetich and Professor H. Wellman. Professor P. Vella reviewed the manuscript. I am especially grateful to $T$. Blithe who derived the formula for volume based on elliptical isopachs. 


\section{CHAPTER 5.}

TOPOGRAPHY AS AN INDICATOR OF CALDERA SUBSIDENCE

AND STRUCTURAL CONTROL OF VOLCANISM AT TAUPO. 


\section{CHAPTER 5}

\section{CALDERA SUBSIDENCE AND STRUCTURAL CONTROL OF VOLCANISM AT TAUPO}

\subsection{Introduction}

The source vents for the three most voluminous eruptions in the last $50 \mathrm{kyr}$ (total erupted magma volume c. $100 \mathrm{~km}^{3}$ ) are in the northeast part of Lake Taupo so volcanic related features, especially caldera subsidence, are to be expected. However most of this area is obscured by Lake Taupo.

To the north of Lake Taupo, a series of NNE trending, subparallel normal faults (Grindley 1960) has created a series of horsts and gravens that decrease in prominence to the north. Most of the horsts are elongate rhyolite domes and many of the faults are still active (Grange 1932). The eastern margin of this fault system appears to be immediately west of Taupo Borough near the line of basaltic scoria cones that form the K-Trig basalts. All topography east of this line is mantled by a thick sheet of Taupo Ignimbrite that has smoothed the topography and created a new landform. Eight to ten kilometres east of Lake Taupo a scarp of welded ignimbrite (mapped as Rangitaiki Ignimbrite by Grindley 1960) rises 30m above a smooth westwards dipping surface. East of the scarp, the topography is gently convex, rising from 2,000 ft a.s.1. up to a crest of $2,500 \mathrm{ft}$ at Iwitahi then dropping down to the Rangitaiki River at 2,200ft.

Topography of the areas to the west and east of the northern half of the lake slopes towards the lake, suggesting subsidence of the lake depression. The drainage pattern and topography of the surface east of the lake is examined to delineate the nature and timing of this subsidence. 
In the Waitahanui area, east of Lake Taupo, between Mt. Tauhara and the Hinemaiaia River all the drainage radially converges towards a point (Fig. 5.1.1a). Topography of the area is distinctly smooth and "saucer" shaped (see Fig. 5.1.1b) and the drainage flows at right-angles to the contours. All these stream valleys are "box-canyons" with vertical sides and flat floors, typical of drainage cut into Taupo Ignimbrite, but these valleys today carry little water and most are permanently dry. Catchment area is at least $250 \mathrm{~km}^{2}$ and annual rainfall exceeds $1200 \mathrm{~mm}$ so a large amount of water must drain into the lake. The valleys could have been cut to their present size soon after the Taupo Pumice eruption, while run-off was not impeded by vegetation, but this does not explain the apparent absence of water in many of the valleys today. Several streams enter Lake Taupo between Taupo and Lake Rotongaio but only Waitahanui stream and some southern tributaries flow a long distance. When several of the smaller streams are traced upstream they abruptly disappear into caves at the foot of cliffs $3-30 \mathrm{~m}$ high. Such caves are known at $\mathrm{N} 103 / 581238, \mathrm{~N} 103 / 565271$ and $\mathrm{N} 103 / 569230$ but many others are

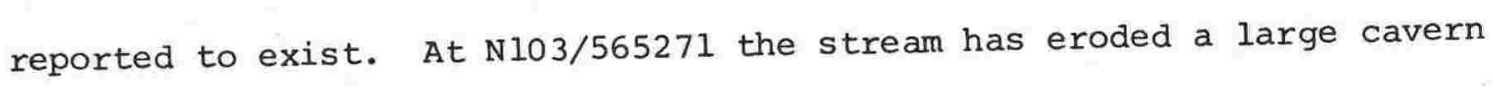
at least $10 \mathrm{~m} \times 20 \mathrm{~m}$ and $2-4 \mathrm{~m}$ high entirely with Waimihia Lapilli. Pumice clasts reach $250 \mathrm{~mm}$ across and grey pumice is conspicuous throughout the tephra. At all three caves studied, Waimihia Lapilli was the aquifer, capped by the relatively impermeable Waimihia Ignimbrite, a palessol then Taupo Pumice Formation. Evidently, streams in the Waitahanui area began to cut down through soft Taupo Ignimbrite after the "saucer" shape deformation had occurred. Downcutting continued through the impermeable Waimihia Ignimbrite until the underlying thick highly porous and permeable Waimihia Lapilli was reached. At this stage, the majority of the water carried by these streams flowed underground, through the lapilli, to emerge 

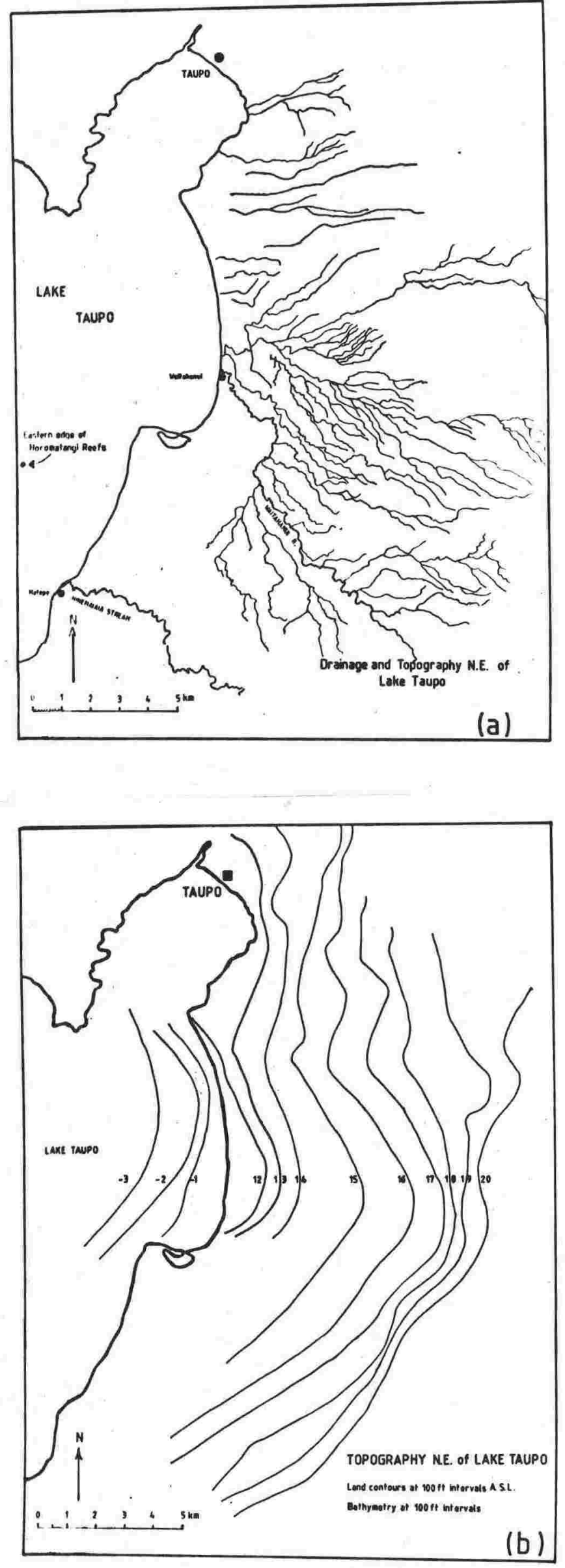

FIGURE 5.1.1: Drainage (a) and topography (b) of the area northeast of Lake Taupo defining the "saucer-like" upper surface of Taupo Ignimbrite. 
near Lake Taupo in springs and caves. Today, most of the water in this catchment flows underground, leaving the stream valleys dry or with grossly underfit streams.

\subsection{Evolution of the Present Topography About the North-East Margin of Lake Taupo}

\subsubsection{Taupo Pumice Caldera Subsidence}

Contours on the land between the lake and ignimbrite scarp are remarkably parallel and evenly spaced, in contrast to the irregular topography that elsewhere typifies the Taupo area. Smoothed contours in the area considered are reproduced in Fig. 5.1.1b, which includes bathymetry from Irwin (1972). The semi-circular, inverted cone shape defined by the contours is accentuated by the radiating drainage pattern described in Section 5.1. The "saucer-like" land form has a centre about $2 \mathrm{~km}$ north of Horomatangi Reefs. This area is underlain by at least $30 \mathrm{~m}$ of Taupo Ignimbrite and it is presumed that this would have been initially emplaced with a flat, horizontal upper surface, as it was where filling valleys elsewhere. The present saucer-like surface must then be due to postTaupo Pumice subsidence, that is radially symmetric about a maximum north of Horomatangi Reefs. Caldera type subsidence consequent on the eruption of magma is the most probable cause but is not radially symmetrical. The saucer shape forms only about a $90^{\circ}$ sector (from $030^{\circ}$ to $120^{\circ}$ azimuth). Bathymetry of Lake Taupo (Irwin 1972), shows a nearly rectangular, flat-bottomed area with Horomatangi Reefs in the south east corner, lying about $40 \mathrm{~m}$ below the level of the remaining lake floor. The south side of this depression is a linear and steep sided scarp, cut by a number of linear depressions strongly resembling stream channels. At the foot of this scarp a number of coalescing fans are indicated by the bathymetry 
and confirmed by seismic refraction profiles (Northey pers. comm. 1980). The scarp must have formed soon after eruption of Taupo Pumice and the channels and fans formed during the refilling of the lake. All the northern half of the Lake Taupo depression is floored by $200 \mathrm{~m}$ or more of Taupo Pumice (Northey pers. comm. 1980). The rectangular depression probably also formed by caldera subsidence.

By approximating the area of caldera subsidence to a rectangular prism $(8 \mathrm{~km} \times 10 \mathrm{~km} \times 40 \mathrm{~m})$ and inverted cone (radius $15 \mathrm{~km}$, central height $400 \mathrm{~m}$ and $90^{\circ}$ segment) the minimum total volume of subsidence is about $27 \mathrm{~km}^{3}$ (Fig. 5.2.1). Subsidence of the valleys to the north of the lake (Kaiapo and Whakaipo Bays) which has occurred as recently as 1922

(Grange 1932) is probably also related to the post Taupo Pumice caldera, involving a further $1.5 \mathrm{~km}^{3}$. The total volume of the Taupo Pumice "caldera" is about $28.5 \mathrm{~km}^{3}$; close to the estimated erupted magma volume of $30 \mathrm{~km}^{3}$ (see Section 4).

\subsubsection{Kawakawa Tephra Caldera Subsidence}

South of Hinemaiaia River, Taupo Ignimbrite is typically less than $5 \mathrm{~m}$ thick and occurs mostly as the "veneer facies". This area has accordant ridge heights at about $2100 \mathrm{ft}$ a.s.1., but is extensively disected. Welded Ignimbrite (Rangitaiki Ig.) outcrops in the present river bed above Lake Hinemaiaia (N103/570119, 1650ft elevation) and is overlain by Oruanui Breccia. This unwelded ignimbrite created a flat, horizontal topography when emplaced c. $20 \mathrm{kyr}$ B.P. but in the area north of Hinemaiaia River, Oruanui Breccia is absent. Sparse outcrops, especially those at Blake Road (N103/569230), Centre Road (N103/581238) and Waioratene Stream ( $103 / 563267)$ indicate that the base of Waimihia Tephra Formation is close to, or below, present lake level so that Oruanui Breccia is presumed to be even lower. Apparently, the area 


\section{8}

involved in post-Taupo Pumice caldera collapse must also have subsided after Kawakawa Tephra was erupted. This is consistent with the inferred vent position for Kawakawa Tephra being north of Horomatangi Reefs (Chapter 3.1). No data on post-Kawakawa caldera collapse are available for the area beneath Lake Taupo as $200 \mathrm{~m}$ or more of Taupo Ignimbrite blanket the area. Based on the figures calculated for Taupo Pumice above, post-Kawakawa collapse probably involved $100 \mathrm{~km}^{3}$ or more, consistent with the estimated erupted volume.

Only the section of the lake north of a line joining Karangahape Cliffs and Hatepe was apparently formed by recent caldera collapse and this is also the deepest area of the lake. Elsewhere, formation of the lake depression was probably structurally or fault controlled subsidence. Only the eruptions that produced ignimbrite phases appear to have caused caldera-type subsidence and these are by far the most voluminous eruptions (see Fig. 8.2.2).

Clearly, the caldera-type collapse that followed the major eruptions of Kawakawa, Taupo and probably Waimihia was not radially symmetrical about the eruptive vents but was largely controlled by an underlying structural framework of faults. 


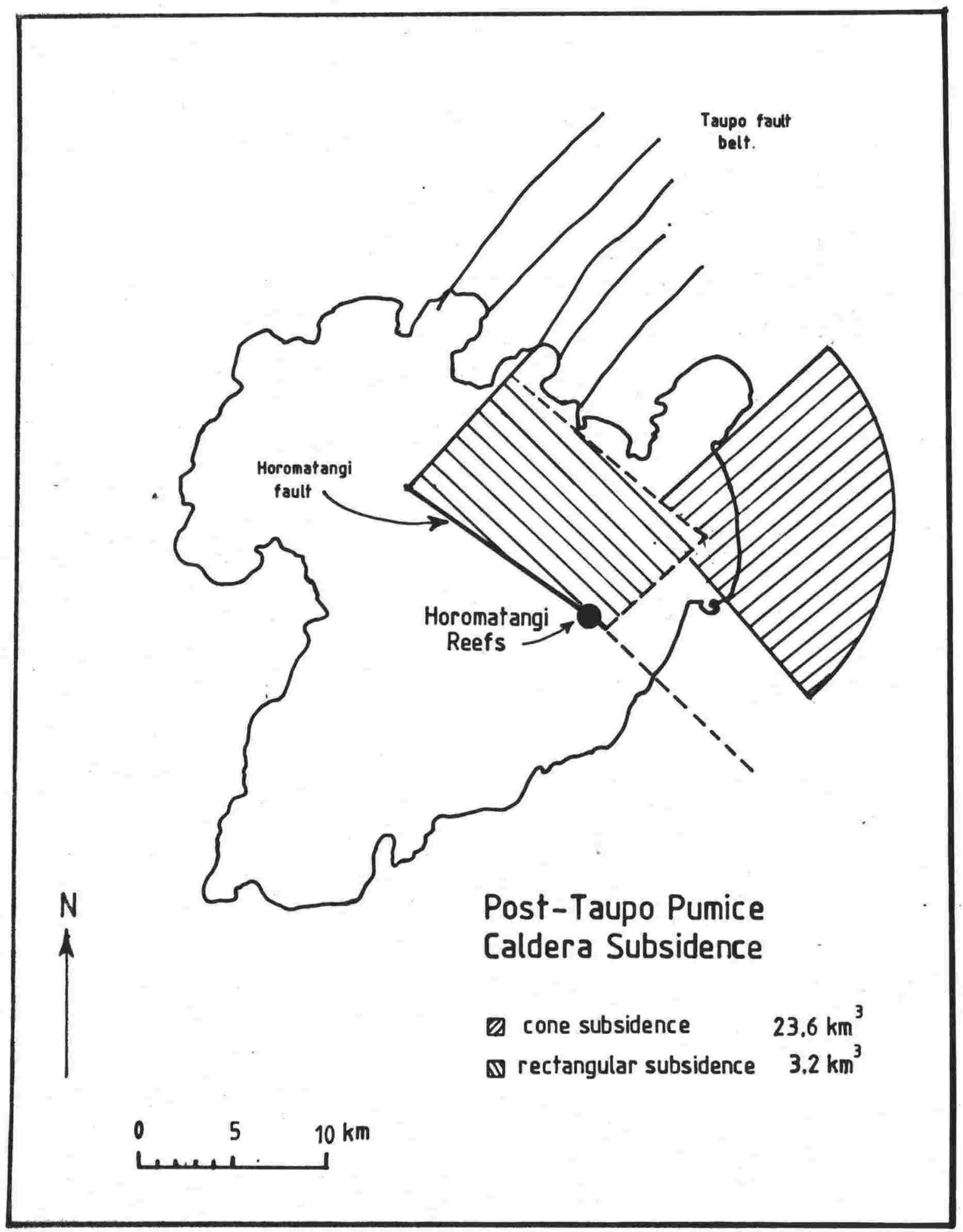

FIGURE 5.2.1: Areas of post-raupo Pumice caldera subsidence approximated to a cone and rectangle. 
CHAPTER 6.

ASPECTS OF THE MINERALOGY AND CHEMISTRY

OF THE

LAKE TAUPO GROUP ERUPTIVES. 


\section{CHAPTER 6}

ASPECTS OF THE MINERALOGY AND CHEMISTRY OF LAKE TAUPO GROUP ERUPTIVES

\subsection{Introduction}

Hochstetter (1864) was the first to report a chemical analysis of a New Zealand rhyolitic tephra, sampled from a white layer outcropping around Manakau Harbour, Auckland. Analyses, mostly on Taupo Ignimbrite were published by Grange $(1927,1937)$ as an aid to soil surveys of the central North Island. Numerous analyses on rhyolitic lavas and ignimbrites are now available, collated by Challis (1971) and Cole (1979) but of these few have been on stratigraphically controlled tephra samples. The first detailed chemical and petrological study of the Holocene Taupo tephra sequence was by Ewart (1963) who analysed samples from the stratigraphic type section at the "Terraces pumice pit", described by Baumgart (1954). These analyses, together with others on samples collected from Okataina and Maroa are quoted by Ewart $(1966,1967$, 1968, 1969, 1971); Ewart et al. (1968, 1971, 1975), and Ewart \& Stipp (1968). Unfortunately, correlation of the stratigraphy in the Terraces pumice pit to either that established by Vucetich \& Pullar (1973) or to that used here cannot be established so that the exact stratigraphic position of Ewart's samples is in some doubt. In addition, Member 19 of Ewart (1963) is now known to be contaminated by an andesitic tephra from Tongariro (Vucetich \& Pullar 1973; Kohn 1973) and Member 2, not examined by Ewart (1963) but apparently later analysed, probably corresponds to the Lithic Lag Layer of Taupo Pumice Formation (see Chapters 1.2 and 2.4.3) composed predominantly of accessory lithic material derived from numerous sources. Whether lithic or pumice material from this bed was sampled is unknown. Ewart (1963) found Taupo Lapilli to be free of clinopyroxene but later (Ewart et al. 1971, 1975) lists it as present. 


\section{3}

Ewart and co-workers have analysed glass and all major mineral phases within C.V.R. rhyolitic eruptives, so that the overall chemistry of the rhyolites is well defined. Consequently it was considered unnecessary to further define this chemistry. Detailed comparisons with Ewart's work, based on stratigraphically uncertain samples is clearly of limited value and is not pursued.

All samples of LTG tephras analysed in this study were collected strictly within the stratigraphic framework described in Chapter 1 and are discussed in the context of the present stratigraphy and chronology. The aim was to examine whole rock, glass and mineral chemistry within a stratigraphic framework that might detect any trends or variations with time. Such trends might aid in "fingerprinting" tephras.

Many examples of chemically zoned rhyolitic tephras are documented (e.g. Hildreth 1979), so the two most voluminous and widespread TSG tephras were examined to check for any systematic variations in chemistry. To properly sample the instantaneous bulk magma composition, whole rock major element analyses by $\mathrm{x}$-ray fluorescence were undertaken on selected pumice clasts.

The Holocene and late Pleistocene tephras from Taupo have two distinctive mafic mineralogies; hypersthene-dominant and hornblende-rich respectively. This distinction is reflected in contrasting glass and Fe-Ti oxide mineral chemistries. Detailed examination of the Holocene Taupo Subgroup tephras reveals subtle differences in whole rock, glass and mineral chemistry that may indicate inhomogeneities or changes in the composition of the magma body with time. 
6.1.1 Whole Rock Chemistry: - What Constitutes a "Whole Rock" Analysis? Whole rock chemistry of fresh, unweathered and unwelded pyroclastic deposits should closely reflect the chemistry of the magma immediately prior to eruption. However, bulk samples of both plinian and ignimbrite deposits contain minor amounts of free crystals and accessory lithic material in addition to pumice clasts. The proportion of free crystals is governed by sorting mechanisms and varies throughout the deposits (e.g. Walker 1971; 1980), and the free crystals are additional to those contained in pumice clasts. Lithics are predominantly banded and spherulitic rhyolites and are clearly xenolithic material unrelated to the erupting magma. Only selected pumice clasts were used for "whole rock" XRF analyses in this study, avoiding the free crystals and lithics. Likewise, samples of welded ignimbrite would be equivalent to a bulk tephra sample including free crystals and xenolithic clasts. Chemical analysis of such a sample would be of doubtful value for accurately defining the magma chemistry of that eruption.

Selected samples from unweathered, near-source outcrops were washed and lithics and free crystals removed. Pumice was powdered in a "TEMA" mill for 10 seconds. Blocks too big for the mill were first broken between two wooden blocks. Major elements were determined by $x$-ray fluorescence on samples fused in lithium tetraborate flux, with loss on ignition determined by the weight lost after heating to $1000^{\circ} \mathrm{C}$ for 3 hours. Mean analyses are given in Appendix 3.

Trace elements were determined by $\mathrm{X}$-ray fluorescence on whole rock and also residual glass samples from the De Bretts type section and other stratigraphically controlled sites. Means were calculated for samples from the same tephra and are listed in Appendix 3 . Duplicate 
analyses indicate a precision of $\pm 5-10 \mathrm{ppm}$ on $\mathrm{Rb}, \mathrm{Sr}, \mathrm{Ba}, \mathrm{Zr}, \mathrm{Ti}$;

$\pm 3-5 \mathrm{ppm}$ on $\mathrm{Pb}, \mathrm{Zn}, \mathrm{Y}$; and \pm 2-3ppm on the other elements analysed.

This is equivalent to $2-10 \% ; \quad 5-15 \%$ and $10-50 \%$ respectively. For

calibration, several international standards were used (Kennedy et al. 1981).

The range of trace elements found in TSG tephras falls within those listed in Cole (1979) for Taupo Volcanic Zone lavas and rhyolites and the average $\mathrm{Rb} / \mathrm{Sr}$ ratio of 0.66 is also similar. Most elements are in low concentration and only $\mathrm{Ti}, \mathrm{Rb}, \mathrm{Sr}$ and $\mathrm{Zr}$ show a range in values.

\subsubsection{Glass Major Element Chemistry}

Selection of an analytical procedure for the chemical analysis of rhyolitic glass in this study was governed by three considerations:

the difficulty of obtaining a pure glass separate, free from inclusions and crystals; removal of weathering products such as clay minerals and iron staining from glass and especially from vesicular shards; the selection of one technique that is as equally applicable to large near-source clasts as to fine, thin distal deposits with less abundant glass shards.

The electron microprobe was considered superior to $\mathrm{X}$-ray fluorescence for the glass analysis as it is equally applicable to coarse or fine grained samples and analyses were comparable to those used for tephra identification in Chapter 7. Details of the analytical technique are in Chapter 7 and Appendix 1.

Wherever possible, pumice clasts were selected, then crushed and the 63-250 micron sized shards analysed. Between-sample variations were checked by analysing 7 samples from Taupo Ignimbrite (Table 6.1.1). 


\section{6}

\begin{tabular}{|c|c|c|c|c|c|c|c|c|c|c|c|c|c|c|}
\hline \multirow[b]{2}{*}{$\mathrm{SiO}_{2}$} & \multicolumn{2}{|c|}{50222} & \multicolumn{2}{|c|}{50476} & \multicolumn{2}{|c|}{50465} & \multicolumn{2}{|c|}{50469} & \multicolumn{2}{|l|}{50467} & \multicolumn{2}{|c|}{50582} & \multicolumn{2}{|c|}{50583} \\
\hline & 77.25 & $(0.24)$ & 76.28 & $(1.06)$ & 75.87 & $(0.85)$ & 75.53 & $(0.36)$ & 75.68 & $(0.67)$ & 75.91 & $(0.21)$ & 76.26 & $(0.48)$ \\
\hline $\mathrm{AI}_{2} \mathrm{O}_{3}$ & 13.35 & $(0.13)$ & 13.21 & $(0.40)$ & 13.18 & $(0.33)$ & 13.29 & $(0.33)$ & 13.29 & $(0.35)$ & 13.65 & $(0.18)$ & 13.67 & $(0.18)$ \\
\hline $\mathrm{TiO}_{2}$ & 0.24 & $(0.03)$ & 0.23 & $(0.06)$ & 0.24 & $(0.05)$ & 0.24 & $(0.06)$ & 0.22 & $(0.05)$ & 0.25 & $(0.04)$ & 0.22 & $(0.02)$ \\
\hline $\mathrm{FeO}$ & 1.96 & $(0.08)$ & 1.71 & $(0.34)$ & 1.93 & $(0.41)$ & 1.93 & $(0.35)$ & 1.88 & $(0.13)$ & 1.92 & $(0.09)$ & 1.94 & $(0.08)$ \\
\hline Mno & 0.07 & $(0.03)$ & 0.09 & $(0.03)$ & 0.10 & $(0.04)$ & 0.12 & $(0.12)$ & 0.08 & $(0.03)$ & 0.11 & $(0.05)$ & 0.07 & $(0.05)$ \\
\hline MgO & 0.27 & $(0.03)$ & 0.22 & $(0.06)$ & 0.26 & $(0.18)$ & 0.29 & $(0.10)$ & 0.23 & $(0.06)$ & 0.28 & $(0.02)$ & 0.27 & $(0.02)$ \\
\hline $\mathrm{CaO}$ & 1.18 & $(0.03)$ & 1.41 & $(0.21)$ & 1.42 & $(0.09)$ & 1.52 & $(0.07)$ & 1.46 & $(0.20)$ & 1.49 & $(0.06)$ & 1.46 & $(0.06)$ \\
\hline $\mathrm{Na}_{2} \mathrm{O}$ & 3.22 & $(0.17)$ & 4.03 & $(0.15)$ & 4.07 & $(0.41)$ & 4.34 & $(0.20)$ & 4.36 & $(0.18)$ & 3.59 & $(0.21)$ & 3.27 & $(0.53)$ \\
\hline $\mathrm{K}_{2} \mathrm{O}$ & 2.46 & $(0.05)$ & 2.83 & $(0.14)$ & 2.93 & $(0.39)$ & 2.73 & $(0.11)$ & 2.79 & $(0.19)$ & 2.80 & $(0.08)$ & 2.82 & $(0.21)$ \\
\hline WATER & 2.23 & $(0.79)$ & 2.60 & $(1.01)$ & 1.20 & (1.15) & 0.80 & $(0.38)$ & 1.84 & (1.01) & 3.55 & $(2.92)$ & 3.01 & $(1.80)$ \\
\hline $\mathbf{N}$ & 11 & & 9 & & 8 & & 9 & & 10 & & 8 & & 6 & \\
\hline D.I. & 86.44 & & 88.14 & & 87.79 & & 87.47 & & 88.09 & & 86.12 & & 85.75 & \\
\hline
\end{tabular}

\section{TABLE 6.1 .1}

Probe analyses on 7 samples of Taupo Ignimbrite. Standard deviations on $N$ analyses in brackets. Water by difference; D.I. = differentiation Index. 
The sample from De Bretts reference section (50222) was the natural 63-250 micron sized material and may include xenolithic shards. Comparison of the means in Table 6.1 .1 using the ' $t$ ' test shows that all elements in all samples are not significantly different at the $95 \%$ level. The high standard deviations on some elements in samples 50476 and 50465 are probably due to the very high vesicularity of the shards probed from these samples compared to shards from other samples. The fine, cellular nature of these two samples increases element mobility during microprobe analysis and also increases the difficulty of obtaining large enough polished surfaces for analysis.

Standard deviations on the means are comparable to those obtained by XRF on whole rock samples; in particular $\mathrm{SiO}_{2}$ and $\mathrm{Na}_{2} \mathrm{O}$ show the most variation.

\subsubsection{Phenocrysts}

Pumice clasts, selected and crushed for glass analyses were separated into titanomagnetite and ferromagnesian mineral plus ilmenite fractions as described in Appendix 1. Individual mineral grains were analysed by electron microprobe.

\section{Pyroxenes}

Pyroxene analyses of Kawakawa Tephra by Howorth (1976) showed a considerable range in composition from $\mathrm{Mg}_{45}$ to $\mathrm{Mg}_{75}$, based on $6-8$ grains per sample. To detect if this range occurs in the Taupo tephras, 10 or more individual phenocrysts were analysed. Core and rim analyses on orthopyroxenes showed no detectable zoning and each grain appears homogeneous. 
Fe-Ti oxides

Titanomagnetite occurs in all the ITG tephras, as discrete phenocrysts in glass and as microphenocryst inclusions in pyroxenes. In both occurrences, phenocrysts are euhedral. Kohn $(1970,1973)$ found trace elements in bulk titanomagnetite separates as a useful but not always unique tool for distinguishing tephras. Bulk sample separates were analysed, but as shown by Howorth (1975), variable amounts of inclusions especially apatite and zircon may limit their value for correlation.

Polished grains of magnetite from TSG tephras revealed common, euhedral apatite inclusions and rare, rounded blebs of yellow pyrrhotite, which have been used to estimate sulphur fugacity (Rutherford \& Heming 1978). Exsolution in titanomagnetite was only found in Karapiti Lapilli of the TSG tephras and was restricted to a few lamellae. Exsolution increases in degree and abundance in the older tephras and is common in the ignimbrites older than $0.2 \mathrm{My}$ (Rutherford \& Heming 1978). These observations suggest that either the magnetites in ignimbrites cooled under different conditions, or exsolution may require about 10,000 years at ambient conditions before becoming visible.

Ilmenite is present in small quantities in all LTG tephras and was observed only as inclusions in glass. Ilmenite is assumed to coexist and to be in equilibrium with the titanomagnetite in glass so estimates of magma temperatures and oxygen fugacities are possible.

6.2 Between Sample Variations in "Whole Rock" Major Elements

6.2.1 Random errors

Samples from De Bretts type section and other stratigraphically controlled sites were analysed by $\mathrm{X}$-ray fluorescence as described in 
Appendix Al. Samples were prepared and analysed in several batches over a 12 month period. To provide a check on operator and machine precision one sample was rerun with each batch, a new fused disc being prepared each time. These analyses, together with their mean are in Table 6.2.1. This sample was chosen because of the low LOI value. Standard deviations on the mean in Table 6.2 .1 show $\mathrm{SiO}_{2}$ and $\mathrm{Na}_{2} \mathrm{O}$ as the most variable elements, and establish the random error variation of each element. This random error is the sum of operator weighing errors to determine LOI, flux loss, and sample weight in making the fused disc; XRF calibration and measurement variations.

\subsubsection{Hydration of Glass and Normalising of Analyses}

Volcanic glass invariably contains water, ranging up to about 6\% in the tephras studied. Many workers have shown that glass hydration increases with time (e.g. Steen-MacIntyre 1973) but the rate is dependent mostly on climate, chemistry and porosity of the pumice (Friedman et al. 1966; Chapter 8.3). One tephra formation may show considerable areal variation in hydration that is probably related to grainsize, thickness or geographic location. High LOI values reduce the measured weight percent of all elements, especially $\mathrm{SiO}_{2}$ and $\mathrm{Al}_{2} \mathrm{O}_{3}$, as they are of highest concentration. Values measured today will thus be lower than those immediately post-eruption, and their "loss" should correspond to the amount of hydration (=LOI). To satisfactorally compare whole rock and glass analyses in which the LOI values differ, all analyses are "normalised" to a $100 \%$ loss free basis. The normalised values should then closely approximate the chemistry at the time of eruption. One marked effect of using normalised analyses is the lowering of the standard deviation on mean values, especially for $\mathrm{SiO}_{2}$. Table 6.2.1 lists normalised values for the internal XRF standard, and the standard deviation for $\mathrm{SiO}_{2}$ drops from 


\begin{tabular}{|c|c|c|c|c|c|c|c|c|c|}
\hline & 1 & 2 & 3 & 4 & 5 & 6 & Mean & $1 \mathrm{sd}$. & Std Error \\
\hline $\mathrm{SiO}_{2}$ & 72.89 & 73.82 & 73.72 & 72.37 & 73.21 & 72.32 & 73.06 & 0.65 & 0.26 \\
\hline $\mathrm{Al}_{2} \mathrm{O}_{3}$ & 13.39 & 13.61 & 13.42 & 13.51 & 13.61 & 13.49 & 13.51 & 0.09 & 0.04 \\
\hline $\mathrm{TiO}_{2}$ & 0.31 & 0.32 & 0.31 & 0.31 & 0.31 & 0.31 & 0.31 & 0.01 & 0.002 \\
\hline $\mathrm{Fe}_{2} \mathrm{O}_{3}$ & 2.61 & 2.71 & 2.69 & 2.66 & 2.62 & 2.61 & 2.65 & 0.04 & 0.02 \\
\hline Mno & 0.10 & 0.13 & 0.11 & 0.09 & 0.10 & 0.10 & 0.11 & 0.01 & 0.006 \\
\hline MgO & 0.48 & 0.48 & 0.45 & 0.39 & 0.38 & 0.42 & 0.43 & 0.04 & 0.02 \\
\hline $\mathrm{CaO}$ & 1.79 & 1.85 & 1.83 & 1.85 & 1.81 & 1.81 & 1.82 & 0.02 & 0.01 \\
\hline $\mathrm{Na}_{2} \mathrm{O}$ & 4.19 & 4.33 & 4.00 & 4.46 & 4.03 & 3.94 & 4.16 & 0.21 & 0.08 \\
\hline $\mathrm{K}_{2} \mathrm{O}$ & 2.72 & 2.78 & 2.76 & 2.67 & 2.60 & 2.59 & 2.69 & 0.08 & 0.03 \\
\hline $\mathrm{P}_{2} \mathrm{O}_{5}$ & 0.06 & 0.03 & 0.06 & 0.03 & 0.06 & 0.06 & 0.05 & 0.01 & 0.006 \\
\hline LOT & 0.61 & 0.61 & 0.61 & 0.77 & 0.97 & 0.97 & - & - & - \\
\hline TOTAL & 99.15 & 100.67 & 99.96 & 99.11 & 99.69 & 98.59 & - & - & - \\
\hline Recal & ulated & to $100 \%$ & loss free & basis. & & & & & \\
\hline $\mathrm{SiO}_{2}$ & 73.97 & 73.78 & 74.20 & 73.59 & 74.16 & 74.06 & 73.96 & 0.24 & 0.10 \\
\hline $\mathrm{Al}_{2} \mathrm{O}_{3}$ & 13.59 & 13.60 & 13.51 & 13.74 & 13.79 & 13.81 & 13.68 & 0.12 & 0.05 \\
\hline $\mathrm{TiO}_{2}$ & 0.31 & 0.32 & 0.31 & 0.31 & 0.31 & 0.32 & 0.31 & 0.01 & 0.002 \\
\hline $\mathrm{Fe}_{2} \mathrm{O}_{3}$ & 2.65 & 2.71 & 2.71 & 2.70 & 2.65 & 2.67 & 2.68 & 0.03 & 0.01 \\
\hline Mno & 0.10 & 0.13 & 0.11 & 0.09 & 0.10 & 0.10 & 0.11 & 0.01 & 0.006 \\
\hline Mgo & 0.49 & 0.48 & 0.45 & 0.40 & 0.38 & 0.43 & 0.44 & 0.04 & 0.02 \\
\hline $\mathrm{CaO}$ & 1.82 & 1.85 & 1.84 & 1.88 & 1.83 & 1.85 & 1.85 & 0.02 & 0.008 \\
\hline $\mathrm{Na}_{2} \mathrm{O}$ & 4.25 & 4.33 & 4.03 & 4.54 & 4.08 & 4.03 & 4.21 & 0.20 & 0.08 \\
\hline $\mathrm{K}_{2} \mathrm{O}$ & 2.76 & 2.78 & 2.78 & 2.72 & 2.63 & 2.65 & 2.72 & 0.07 & 0.03 \\
\hline $\mathrm{P}_{2} \mathrm{O}_{5}$ & 0.06 & 0.03 & 0.06 & 0.03 & 0.06 & 0.06 & 0.05 & 0.01 & 0.006 \\
\hline D.I. & 86.67 & 86.55 & 86.27 & 86.86 & 86.25 & 85.97 & 86.43 & 0.32 & 0.13 \\
\hline
\end{tabular}

\section{TABLE 6.2.1}

Duplicate analyses on Waitahanui "Protopumice" as a measure of intra-sample variations in XRF major elements.

D. I. = Differentiation Index. 
0.65 to 0.24 , (see also Tables 6.2 .2 and 6.2 .3 ).

Included in the "hydration" value for recalculating analyses is the analytical error expressed by the "raw" analysis total differing from 100\%. For most XRF analyses quoted here, analytical error values are less than 0.5 weight percent compared to the LOI values averaging 3-4 weight percent. Additional volatiles such as fluorine, chlorine and $\mathrm{CO}_{2}$ may have been lost on fusion of the sample. Analyses in Ewart (1963) show these elements sum about $0.1 \%$. Glass is hygroscopic after being heated to $105^{\circ} \mathrm{C}$, (the temperature at which samples were dried) and then finely powdered. Measured LOI's are generally underestimates, being measured well before the sample is fused, so adding to the XRF analysis deficiency from 100\%. It should be noted that high LOI values and hygroscopic problems are uncommon in most major element analytical work so that analyses are not usually recalculated to $100 \%$ loss free.

\subsubsection{Analysis of Size-Graded Pumice}

Samples of Taupo Lapilli and Taupo Ignimbrite were sieved at $1 \varnothing$ intervals and pumice clasts hand-picked for analysis. Minimum clast size chosen was $-1 \varnothing(=2 \mathrm{~mm})$; below this size separation of pumice from lithics and free crystals is difficult. Analyses of two plinian and three ignimbrite samples are in Table 6.2.2. No systematic variations are evident and the range in each element is less than the range recorded for the internal standard in Table 6.2.1.

6.2.4 Analysis of Pumice Sampled Vertically Through Waimihia Lapilli

Many examples are known in the literature (e.g. Lipman et al. 1966; Hildreth 1979) of vertical variations in whole rock chemistry of pyroclastic deposits, generally interpreted as reflecting zoned magma chambers. Although most data are on ignimbrites or pyroclastic flow 
Q ผ ๗ 卉

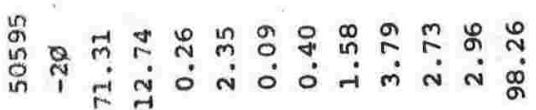

ช ㄷํำ

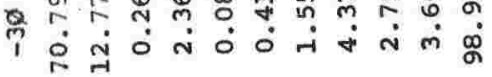

จे

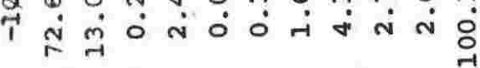

윤

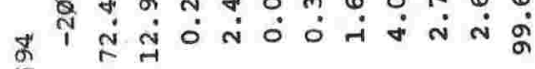
in

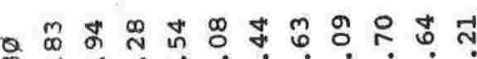

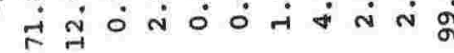

จ $\stackrel{\infty}{\rightarrow}$ คิ ๆ

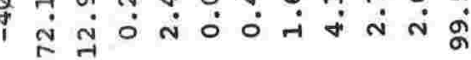

Q โิ

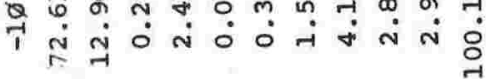

๓

ग

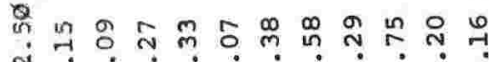

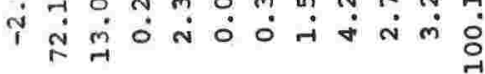

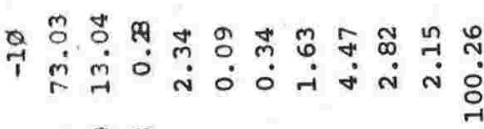

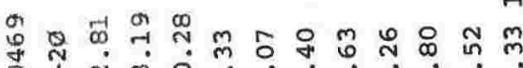

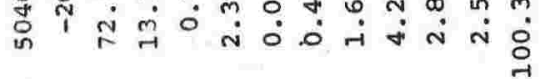

ㄴำ

$\underset{N}{\sim} \underset{\sim}{\sim} \dot{0} \dot{0} \dot{\sim} \dot{\sim} \dot{\sim}$ i

Q ๑) भ †

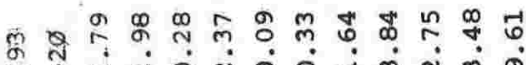

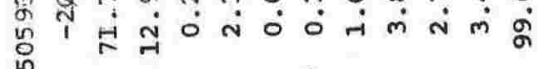

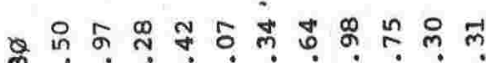
†ित

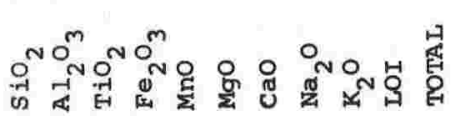

๓

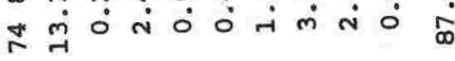
๓ $+\underset{r}{\sim} \dot{0} \dot{0} 0 \dot{\sim} \dot{m} \dot{\sim} \dot{0}$ สิ सं

กิ

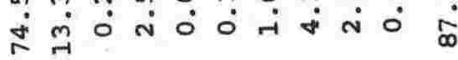

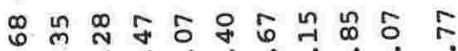
+i m 익 우

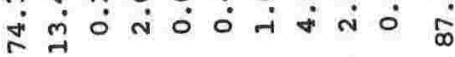

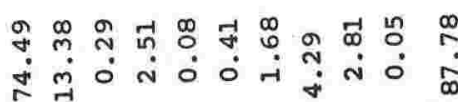
$\stackrel{\infty}{0}_{m}^{m} \stackrel{\infty}{\sim} \stackrel{\infty}{*}$ 。 華 กี $\underset{\sim}{\sim} \dot{\sigma} \dot{\sim} \dot{0} \dot{0} \dot{-} \dot{i} \dot{0} \dot{\infty}$

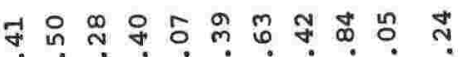

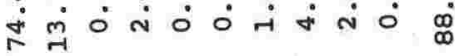

Ұ ิำ

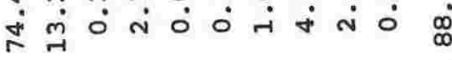
Ұ

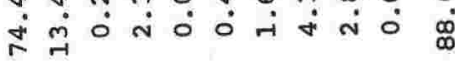

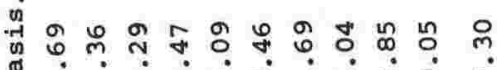

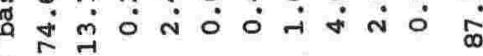
ఖ

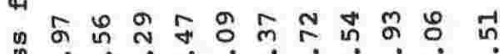
尊華

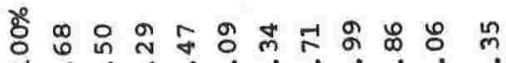
$\dot{+} \underset{\sim}{\sim} \dot{m} \dot{0} \dot{0} \dot{0} \dot{0}-\dot{m} \dot{N} \dot{0}$

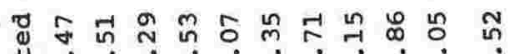

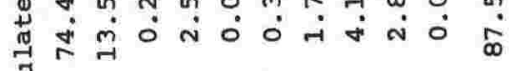

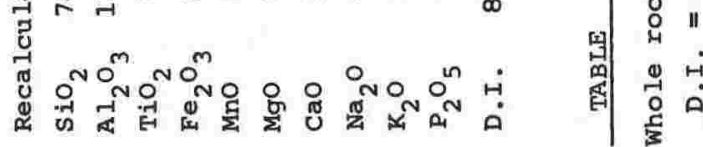


deposits, plinian (airfall) deposits are here considered to provide the best samples to check for vertical variations, as they have not undergone the mixing and reworking that occur in pyroclastic flows. Waimihia Lapilli was chosen as it provides the thickest exposures and the upper half is characterised by clasts of grey and mixed grey/white pumice. If any vertical variation does occur it was expected to be most apparent in Waimihia Lapilli.

Samples were collected at 1 metre vertical intervals from the base upwards of a 6 metre outcrop of Waimihia Lapilli at N103/695201. Pumice clasts, either pure white or pure grey were selected from each sample. Whole rock major element analyses are in Table 6.2.3. No clear systematic variations are discernable and the range for all major elements except $\mathrm{Fe}_{2} \mathrm{O}_{3}$ is less than in Table 6.2.1. Some mobility of $\mathrm{Fe}_{2} \mathrm{O}_{3}$ was noted in the outcrop sampled, as lithic clasts in the upper part were heavily coated in $\mathrm{Fe}_{2} \mathrm{O}_{3}$. No staining was obvious on the pumices analysed.

\subsubsection{Taupo Ignimbrite Sampled Areally}

Whole rock samples from 15 sites, selected to give an areal and stratigraphic distribution in Taupo Ignimbrite, were analysed (Table 6.2.4). Standard deviations on the mean for each element are comparable to those in Table 6.2 .1 but with $\mathrm{SiO}_{2}$ and $\mathrm{Al}_{2} \mathrm{O}_{3}$ slightly higher. Varying amounts of hydration, reflecting the degree of weathering, may account for this increase. All 15 analyses appear consistent with no areal variation.

\subsubsection{Conclusions}

Data presented in Sections $6.2 \cdot 1-6.2 .5$ confirm that there are no apparent systematic variations in whole rock major element chemistry through a rhyolitic plinian tephra. Howorth (1976) also concluded this 


\section{4}

\begin{tabular}{|c|c|c|c|c|c|c|c|}
\hline & 1 & 2 & 3 & 4 & 5 & 6 & 7 \\
\hline $\mathrm{SiO}_{2}$ & 72.74 & 72.11 & 72.32 & 71.53 & 72.21 & 69.72 & 7151 \\
\hline $\mathrm{Al}_{2} \mathrm{O}_{3}$ & 13.27 & 12.90 & 12.84 & 12.90 & 12.96 & 13.70 & 12.82 \\
\hline $\mathrm{TiO}_{2}$ & 0.25 & 0.23 & 0.24 & 0.26 & 0.23 & 0.48 & 0.23 \\
\hline $\mathrm{Fe}_{2} \mathrm{O}_{3}$ & 2.39 & 2.21 & 2.24 & 2.46 & 2.26 & 3.34 & 2.22 \\
\hline Mno & 0.09 & 0.09 & 0.09 & 0.08 & 0.07 & 0.11 & 0.09 \\
\hline Mgo & 0.29 & 0.29 & 0.29 & 0.29 & 0.25 & 0.73 & 0.21 \\
\hline $\mathrm{CaO}$ & 1.53 & 1.47 & 1.47 & 1.51 & 1.46 & 2.35 & 1.40 \\
\hline $\mathrm{Na}_{2} \mathrm{O}$ & 4.32 & 4.27 & 4.35 & 4.29 & 4.36 & 4.27 & 3.95 \\
\hline $\mathrm{K}_{2} \mathrm{O}$ & 2.82 & 2.76 & 2.75 & 2.7 & 2.75 & 2.50 & 2.65 \\
\hline$P_{2} \mathrm{C}$ & 0.01 & - & 0.01 & .01 & 0.01 & 0.13 & 0.03 \\
\hline LOI & 3.02 & 3.22 & .22 & 3.09 & 0.25 & 3.47 & 3.14 \\
\hline TOT. & 100.23 & 99.55 & 99.82 & 99.12 & 99.81 & 100.80 & 98.25 \\
\hline \multicolumn{2}{|c|}{ Recalculated } & to $100 \%$ & loss $f x$ & basis. & & & \\
\hline $\mathrm{SiO}_{2}$ & 74.44 & 74.86 & 74.87 & 74.49 & 74.78 & 71.63 & 75.19 \\
\hline $\mathrm{Al}_{2} \mathrm{O}_{3}$ & 13.58 & 13.39 & 13.29 & 13.43 & 13.42 & 14.08 & 13.48 \\
\hline $\mathrm{TiO}_{2}$ & 0.26 & 0.24 & 0.25 & 0.27 & 0.24 & 0.49 & 0.24 \\
\hline $\mathrm{Fe}_{2} \mathrm{O}_{3}$ & 2.45 & 2.29 & 2.32 & 2.56 & 2.34 & 3.43 & 2.33 \\
\hline Mno & 0.09 & 0.09 & 0.09 & 0.08 & 0.07 & 0.11 & 0.09 \\
\hline MgO & 0.30 & 0.30 & 0.30 & 0.30 & 0.26 & 0.75 & 0.22 \\
\hline $\mathrm{CaO}$ & 1.57 & 1.53 & 1.52 & 1.57 & 1.51 & 2.41 & 1.47 \\
\hline $\mathrm{Na}_{2} \mathrm{O}$ & 4.42 & 4.43 & 4.50 & 4.47 & 4.52 & 4.39 & 4.15 \\
\hline $\mathrm{K}_{2} \mathrm{O}$ & 2.89 & 2.87 & 2.86 & 2.81 & 2.85 & 2.57 & 2.79 \\
\hline $\mathrm{P}_{2} \mathrm{O}_{5}$ & 0.01 & - & 0.01 & 0.01 & 0.01 & 0.13 & 0.01 \\
\hline 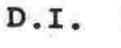 & 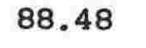 & 88.93 & 89.14 & 88.53 & 89.20 & 82.96 & 88.70 \\
\hline
\end{tabular}

TABLE 6.2.3: Whole rock major element analyses on samples collected at 1 metre intervals vertically through Waimihia Lapilli at N103/695201. Number 1 is from the base. 


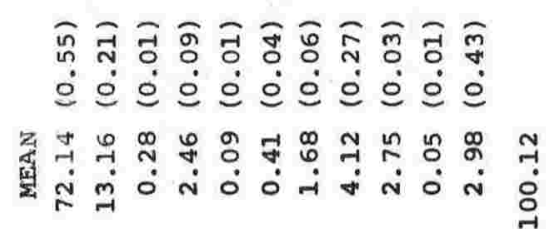

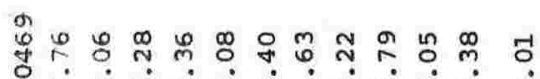

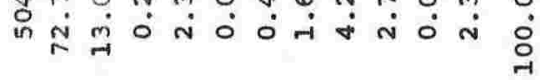

ริ

茯

ภิ 茛 สำ 敬

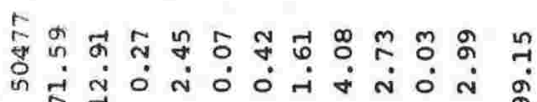
गิำ

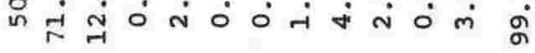

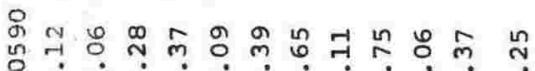

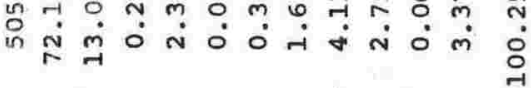

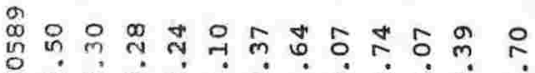

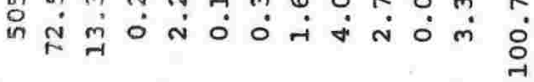
悉

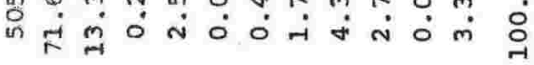
苑

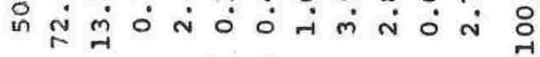

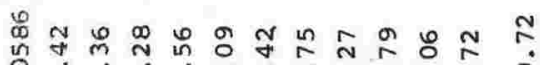

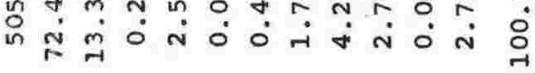

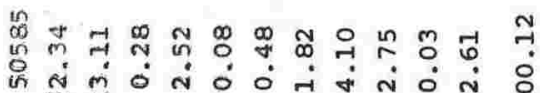
番

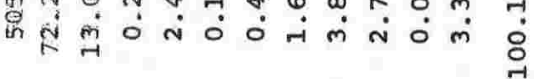
赵

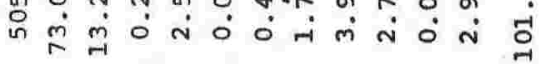

m

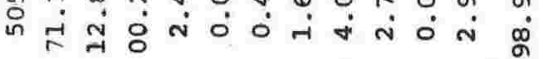

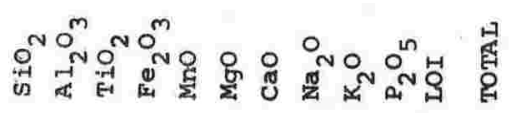

न्ल

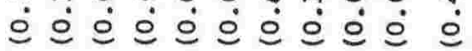

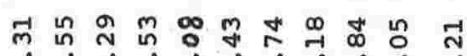

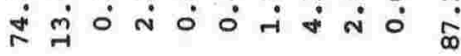

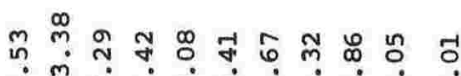

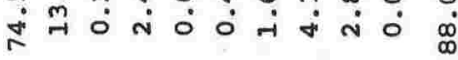

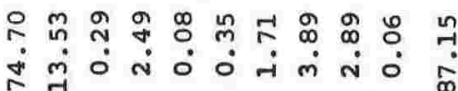

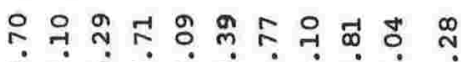

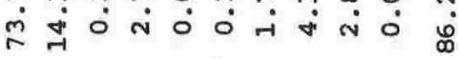

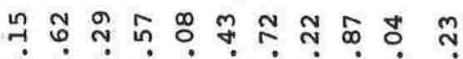

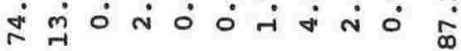

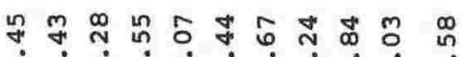

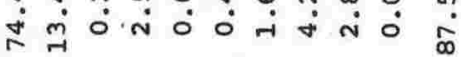

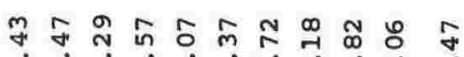

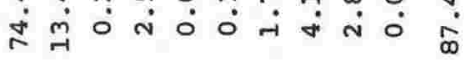

オำ

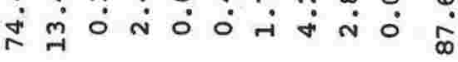

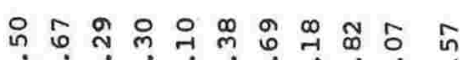
$\underset{\sim}{\sim} \dot{\sim} \dot{0}$ n 0 O

ㄷำ กิ

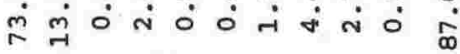

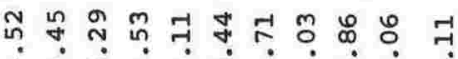

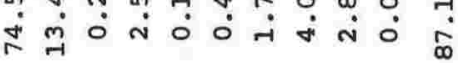

옹 ำ

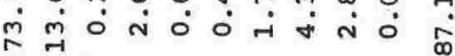

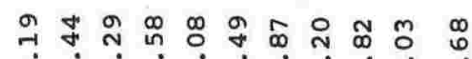
d น 党 总

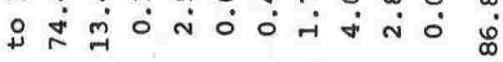
苟 चु 苟

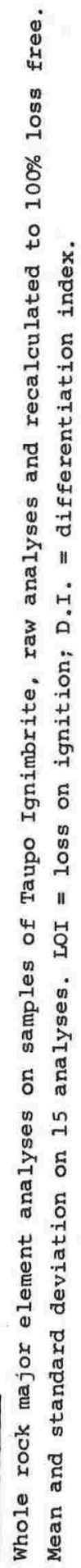




\section{$10 \ddot{\circ}$}

in studying Okataina plinian tephras. Samples collected over the full distribution of Taupo Ignimbrite have consistent chemistry and no variation was found between different size graded pumice clasts, indicating that phenocrysts are uniformly distributed throughout pumice clasts.

Variations between analyses of the one tephra are mostly random errors due to the machine and the operator. Between-sample scatter for the one tephra in the more abundant elements, especially $\mathrm{SiO}_{2}, \mathrm{Al}_{2} \mathrm{O}_{3}$ and $\mathrm{Na}_{2} \mathrm{O}$, are accentuated by variable amounts of water, acquired as the glass hydrates with time. The rate and degree of hydration is site specific and not uniform, even for one tephra. To allow for variable hydration, all analyses are normalised before comparison by recalculation to $100 \%$ loss free. Normalisation markedly reduces the standard deviation on $\mathrm{SiO}_{2}$ and $\mathrm{Al}_{2} \mathrm{O}_{3}$ to produce an analysis that is assumed to closely approximate magma composition at the time of eruption.

Vertical and horizontal uniformity of composition in the most widespread of the TSG tephras indicates their eruption from a magma body showing no discernable variation in bulk composition. Ewart (1966) reported vertical compositional zoning in Whakamaru Ignimbrite. Whole rock chemistry of welded ignimbrite is affected by the process of welding, vapour phase alteration (Scott $1971 \mathrm{a}, \mathrm{b})$ and the proportion of crystal and lithics to glass which is a function of sorting in the pyroclastic flow. Briggs (1973) concluded that all variation in the whole rock chemistry of Whakamaru Ignimbrite could be satisfactorily explained by post-depositional alteration and the proportion of phenocrysts and xenolithic clasts in the sample. Uniformity of composition for this and other welded ignimbrites is suggested by extrapolation of the data for the smaller, unwelded Taupo Ignimbrite, that presumably had similar magmatic origins, so no evidence of a compositionally zoned magma body has been found in New Zealand. 
6.3 Comparison of the Mineralogy and Chemistry Between the Lake Taupo Group Tephras

Ferromagnesian Mineral Assemblages

All rhyolites in TVZ contain phenocrysts of plagioclase and magnetite with lesser, variable amounts of ilmenite, pyroxene, amphibole and biotite as well as minor amounts of zircon, apatite and rutile. Ewart (1966) found variations in the ferromagnesian minerals between tephras which he grouped into five assemblages, and noted the amphibole cummingtonite, was only known from Okataina source material. Kohn (1973), Howorth (1976), Lowe et al. (1980) have used ferromagnesian mineralogy to help characterise and identify tephras and although each tephra is not unique, the method is a quick, useful, first approach. Plagioclase, magnetite and ilmenite are ubiquitous and of little value in tephra identification beyond confirming that material in distal, highly weathered exposures is tephric in origin.

Table 6.3.1 lists the variation in ferromagnesian minerals for the LTG tephras. All are orthopyroxene and amphibole dominant with minor clinopyroxene and biotite. No cummingtonite was found. Optical properties of the minerals are given by Ewart (1963) and were not further determined here. Vucetich and Howorth (1976b) summarised the ferromagnesian phenocryst assemblage of the Late Pleistocene Okaia Subgroup (OSG) tephras, examined in more detail by Roxburgh (1976). Their data are included in Table 6.3.1.

Relative proportions of orthopyroxene, clinopyroxene and amphibole are plotted on a ternary diagram (Fig. 6.3.1). For the TSG tephras, the dominance of orthopyroxene compared to the OSG tephras is distinctive, whereas the Okaia Subgroup tephras show considerable variation in the proportions of orthopyroxene and hornblende. Kawakawa 


\begin{tabular}{|c|c|c|c|c|c|}
\hline & Hyper & sthene & Hornblende & Augite & Biotite \\
\hline po Ignimbrite & 73 & -100 & $0-16$ & $0-14$ & - \\
\hline o Lapilii & & 100 & 0 & 0 & - \\
\hline epe Ash & 77 & -94 & $2-5$ & $4-17$ & - \\
\hline epe Lapilli & 95 & -99 & $0-1$ & $1-4$ & - \\
\hline ara & & 95 & 2 & 4 & - \\
\hline kaipo & 94 & -96 & $1-4$ & $0-3$ & - \\
\hline mihia Ignimbrite & 86 & -94 & $0-1$ & $5-13$ & - \\
\hline mihia Lapilli & 92 & -99 & $0-4$ & $1-4$ & - \\
\hline emaiaia \& Motutere & 98 & -99 & $0-1$ & $0-2$ & - \\
\hline & 80 & -100 & $0-4$ & $0-16$ & - \\
\hline onui & 84 & -100 & $1-10$ & $0-15$ & - \\
\hline piti & 95 & -98 & $1-3$ & $0-2$ & - \\
\hline akawa* & 44 & -52 & $22-29$ & $7-22$ & $0-3$ \\
\hline ipi $i^{\#}$ & 15 & -32 & $54-64$ & $8-16$ & $2-6$ \\
\hline$i a^{\#}$ & 42 & -63 & $36-57$ & $1-6$ & $0-4$ \\
\hline$i^{\#}$ & 56 & -68 & $30-41$ & $1-5$ & $0-2$ \\
\hline$\underset{\#}{\text { ora }}{ }^{\#}$ & 19 & -37 & $53-77$ & $3-10$ & $1-2$ \\
\hline & 50 & -67 & $26-31$ & $5-23$ & $0-1$ \\
\hline
\end{tabular}

Data from Vucetich \& Howorth (1976a)

Data from Roxburgh (1976).

TABLE 6.3.1: Ferromagnesian mineralogy of Lake Taupo Group Tephras based on point counts of 300-500 grains. 


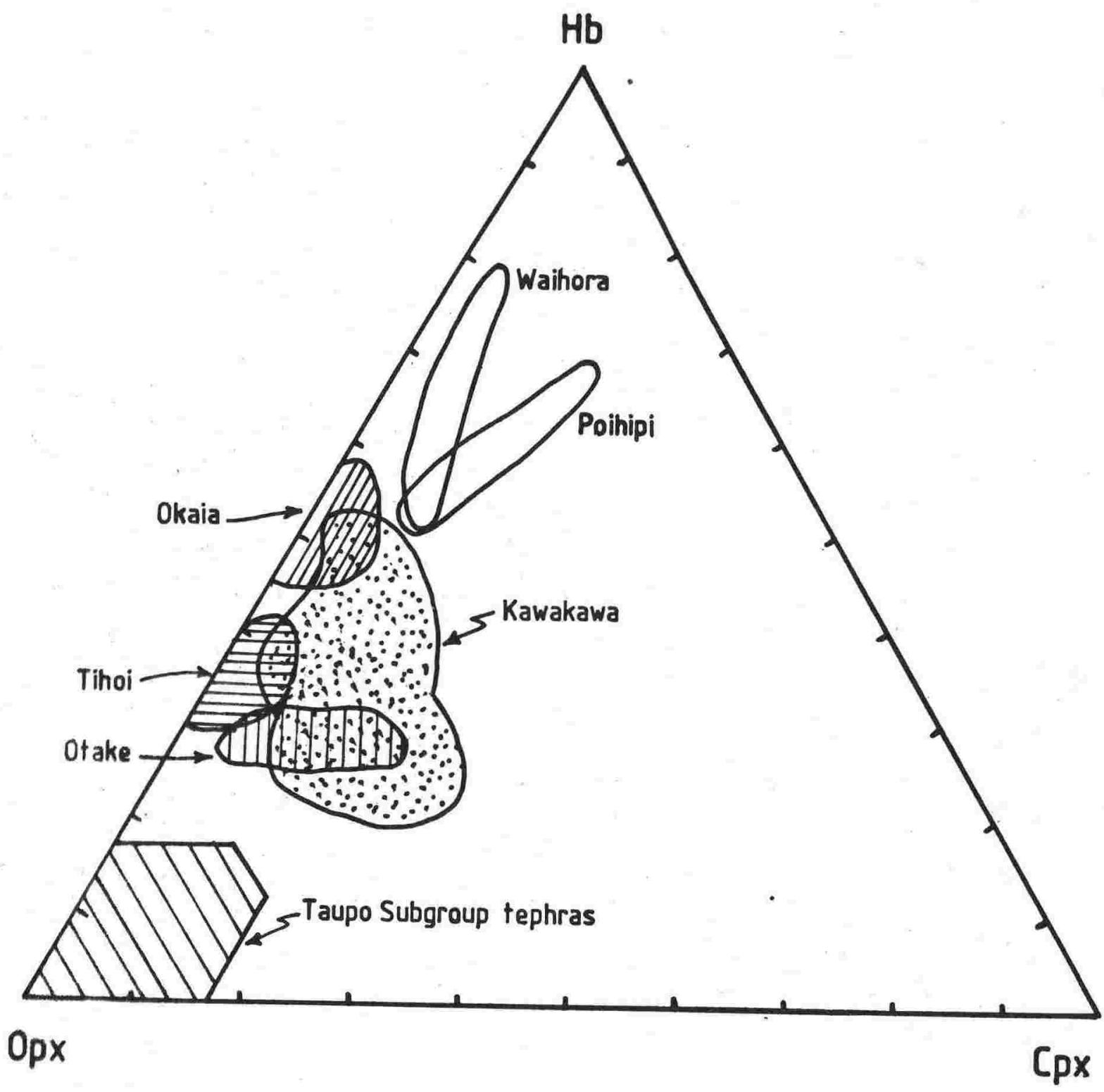

FIGURE 6.3.1: Ternary plot showing mafic mineralogy of Lake Taupo Group Tephras. Data for Kawakawa Tephra from Howorth et al. (1981) and for Okaia Subgroup from Roxburgh (1976). 
Tephra is similar to Okaia subgroup.

Clinopyroxene, found only rarely in rhyolitic tephras, occurs as subhedral to rounded grains full of inclusions of magnetite, apatite and occasionally glass. In addition, orthopyroxenes are typically larger and euhedral to subhedral, suggesting partial resorption of clinopyroxene has occurred. No reaction rims or exsolution were found, although Kohn (1973) found some clinopyroxene lamellae in orthopyroxene from Waimihia Lapilli by use of the electron microprobe. No optical evidence of zoning of mafic minerals has been reported although zoning is marked in plagioclase. The discrepancy between the zoning in plagioclase and the homogeneity of pyroxene is not examined here and has yet to be resolved.

Glass and Fe-Ti Oxide Chemistry

Glass major element chemistry of the LTG tephras (Appendix 3)

shows considerable differences between the younger Taupo and older Okaia subgroups summarised in Fig. 6.3.2. TSG tephras are characterised by lower Differentiation Index values (D.I. = normative quartz + orthoclase + albite: Thornton \& Tuttle 1960) and reflects the differences found in ferromagnesian mineralogy. No systematic trends or clusters are evident in the Okaia tephras and the Taupo subgroup sequence will be examined in more detail below. The $\mathrm{FeO}$ and $\mathrm{TiO}_{2}$ contents of titanomagnetites from the LTG tephras also clearly separate the younger and older groups (Fig. 6.3.3). The Taupo subgroup tephras have lower FeO and higher $\mathrm{TiO}_{2}$ than the older sequence, the opposite of the glass data (Fig. 6.3.2), so that relatively Feo rich magnetites co-exist with Feo depleted glass. Ilmenites show a similar trend. The TSG tephras plot as a well defined continuous linear trend on Fig. 6.3.3, whereas the remainder form an irregular cluster. This suggests the TSG tephras were all erupted from 
LAKE TAUPO GROUP TEPHRAS

GLASS
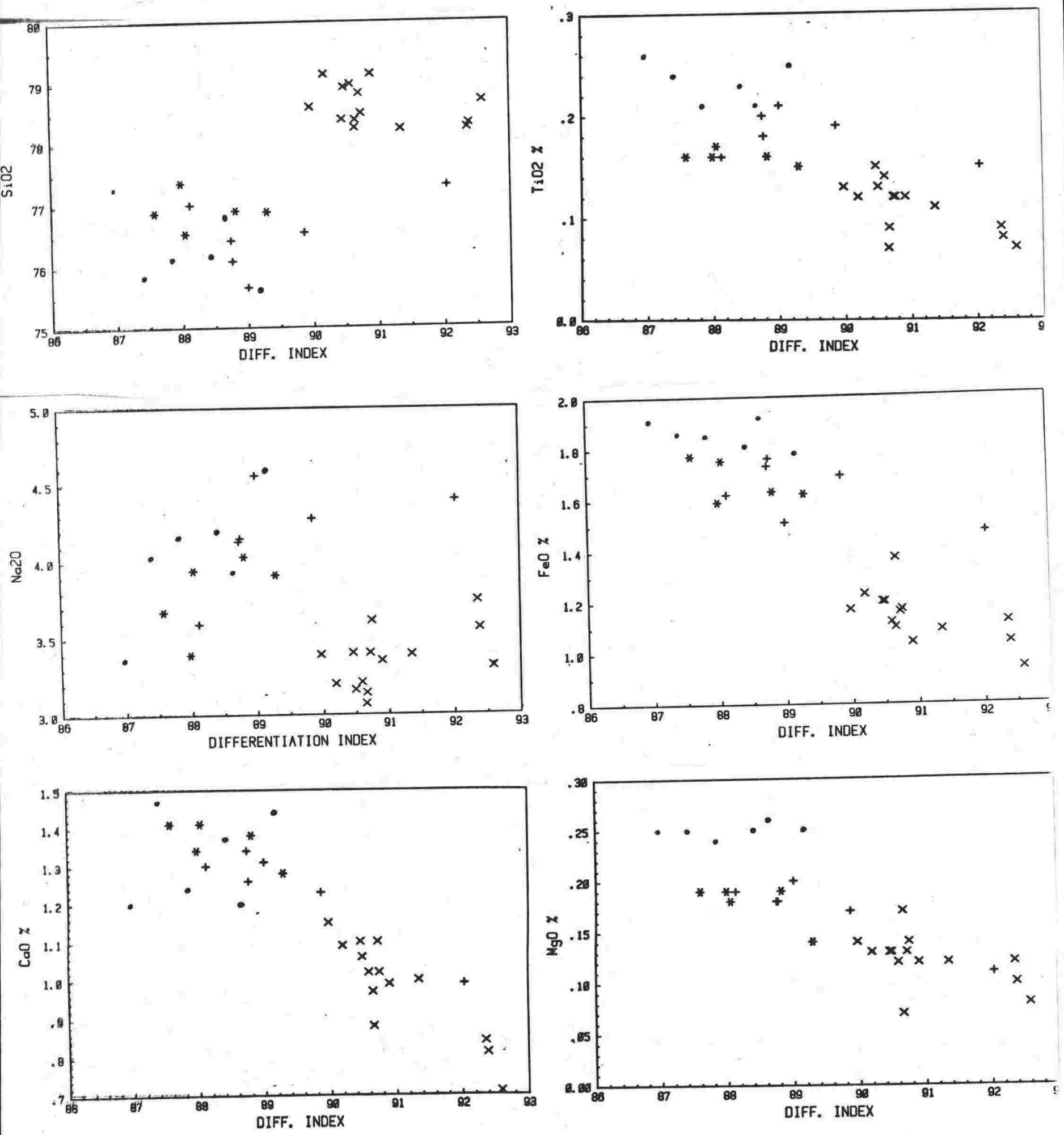

FIGURE 6.3.2: Summary of glass chemistry for the Lake Taupo Group Tephras. Symbols are Taupo Pumice-Mapara; + Whakaipo-Motutere; * Opepe-Karapiti; $X$ Kawakawa \& Okaia Subgroup. 
LAKE TAUPO GROUP TEPHRAS

MAGNETITES
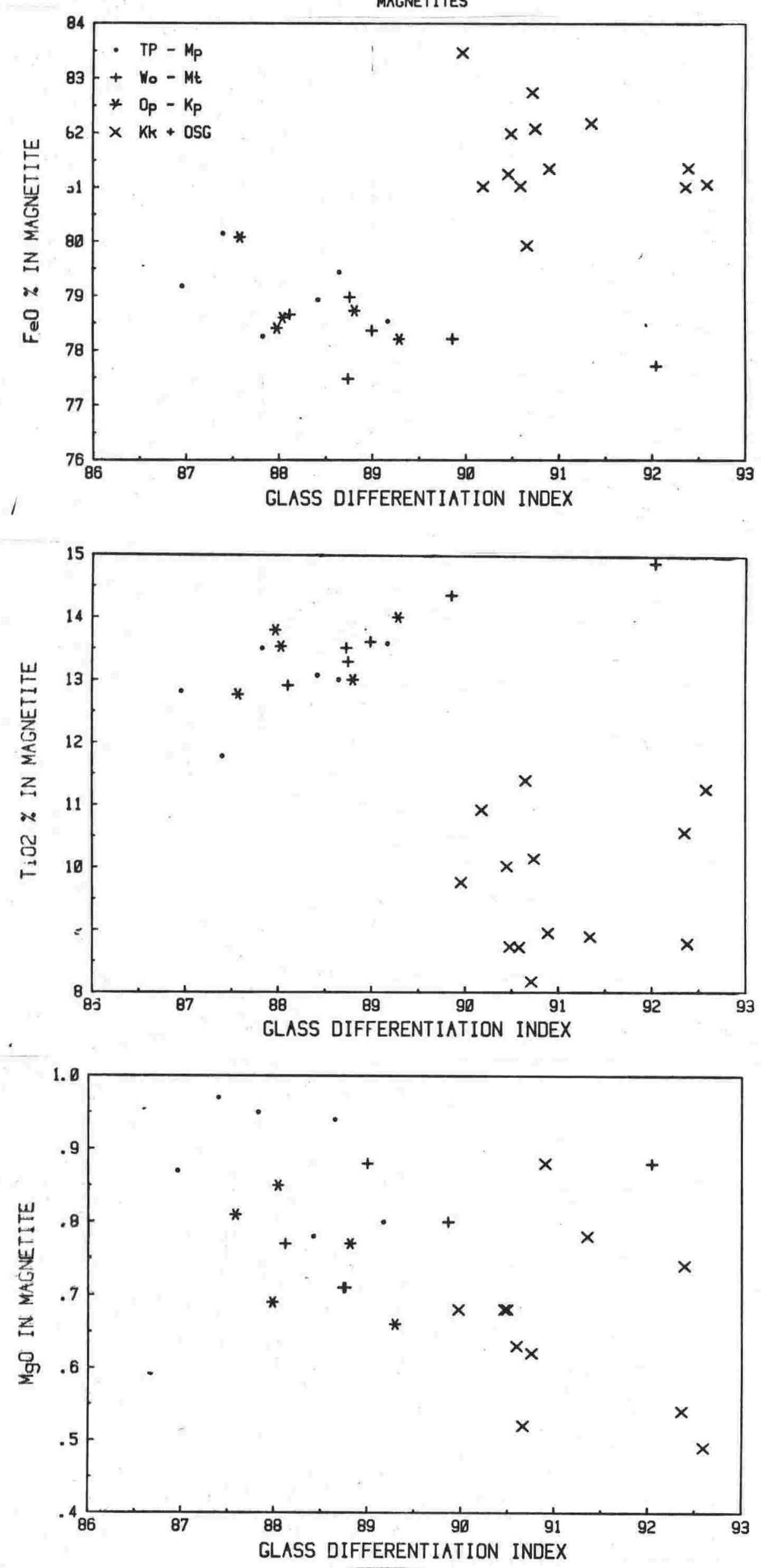

FIGURE 6.3.3: Comparison of glass and magnetite chemistry for

Lake Taupo Group tephras. Symbols as for Fig. 6.3.2. 


\section{3}

the same magma chamber in which processes of crystallisation and crystal fractionation were operative.

\subsection{Changes in the Chemistry Between the Taupo Subgroup Tephras}

The TSG tephras can be distinguished from Kawakawa and the Okaia Subgroup tephras by mineralogy, glass and mineral chemistry (Chapter 6.3). However linear trends of chemistry in the TSG tephras suggest they were all probably erupted from the same magma chamber.

\section{Whole Rock Chemistry}

Ewart $(1963,1966)$ concluded that phenocrysts contained in the pumice of TSG and other tephras were not xenocrystic but were in equilibrium with the magma (= glass) from which they had crystallised. If so, whole rock chemistry, on an anhydrous basis, should approach the magma composition immediately prior to eruption. Such analyses may detect changes in magma composition between or during each eruption. Previous studies in New Zealand of chemistry and hence magma composition have used analyses on glass (Ewart 1963, 1966; Howorth 1976). Glass is the rapidly chilled and non-crystalline magma fraction (residual liquid) co-existing with phenocrysts at the time of eruption. For any magma of given uniform composition, the formation and removal of different proportions of phenocrysts will produce batches with different residual liquid (= glass) chemistry. Glass chemistry may therefore show variations between "batches" that are related to phenocryst formation and not variations in original magma composition. Such variations in the glass may, however, be a potential method of fingerprinting each glass "batch" and Chapter 7 examines this possibility. 


\section{4}

\section{(a) Major Elements}

As Chapter 6.2 showed, no significant variations were found throughout one tephra, so between 1 and 15 samples of each TSG tephra were analysed for major elements by XRF. Analyses were recalculated to $100 \%$ on an anhydrous basis, and a mean calculated. The mean values together with mean LOI and raw analysis totals are listed in Appendix 3. Normative mineralogy was calculated by apportioning Fe (total) to FeO and $\mathrm{Fe}_{2} \mathrm{O}_{3}$ in the ratio $2: 1$. FeO was not determined analytically. Glass analyses by Ewart (1963) have this $\mathrm{FeO} / \mathrm{Fe}_{2} \mathrm{O}_{3}$ ratio. All tephras are dominantly Q-Or-Ab normative as shown by Ewart (1963), who also suggested the chemistry of the older tephras was higher in normative quartz, orthoclase and anorthite than the younger members. Of the older tephras, only his analyses on members 24 and 25 (both probably Karapiti Tephra) are reliable, member 19 possibly being contaminated by andesite. To compare analyses, the Thornton \& Tuttle (1960) Differentiation Index $(D I=$ normative $Q+$ Or $+A b)$ is used, values for TSG tephras ranging from 84.27 to 89.32 (Fig. 6.4.1). The assumed oxidation state of $\mathrm{Fe}$ does not relatively alter the DI values. Figure 6.4 .1 plots individual elements against DI values for all TSG tephras. General linear trends for components with increasing DI reflect a more salic composition or more "differentiated" magma. Plots on Fig. 6.4.1 form a continuous trend, but can be subdivided into three groups on the basis of age and differences in DI values; Taupo Ignimbrite to Mapara: Whakaipo to Motutere, and Opepe to Karapiti.

\section{(b) Trace elements}

Trace elements determined by XRF (Appendix A3.1) show little variation between tephras except for $\mathrm{Rb}, \mathrm{Sr}$ and $\mathrm{Zr}$. A plot of $\mathrm{Sr}$ and $\mathrm{Zr}$ (Fig. 6.4.2) distinguishes the same three groups of tephras as the major 


\section{TAUPO SUBGROUP TEPHRAS \\ WHOLE ROCK}
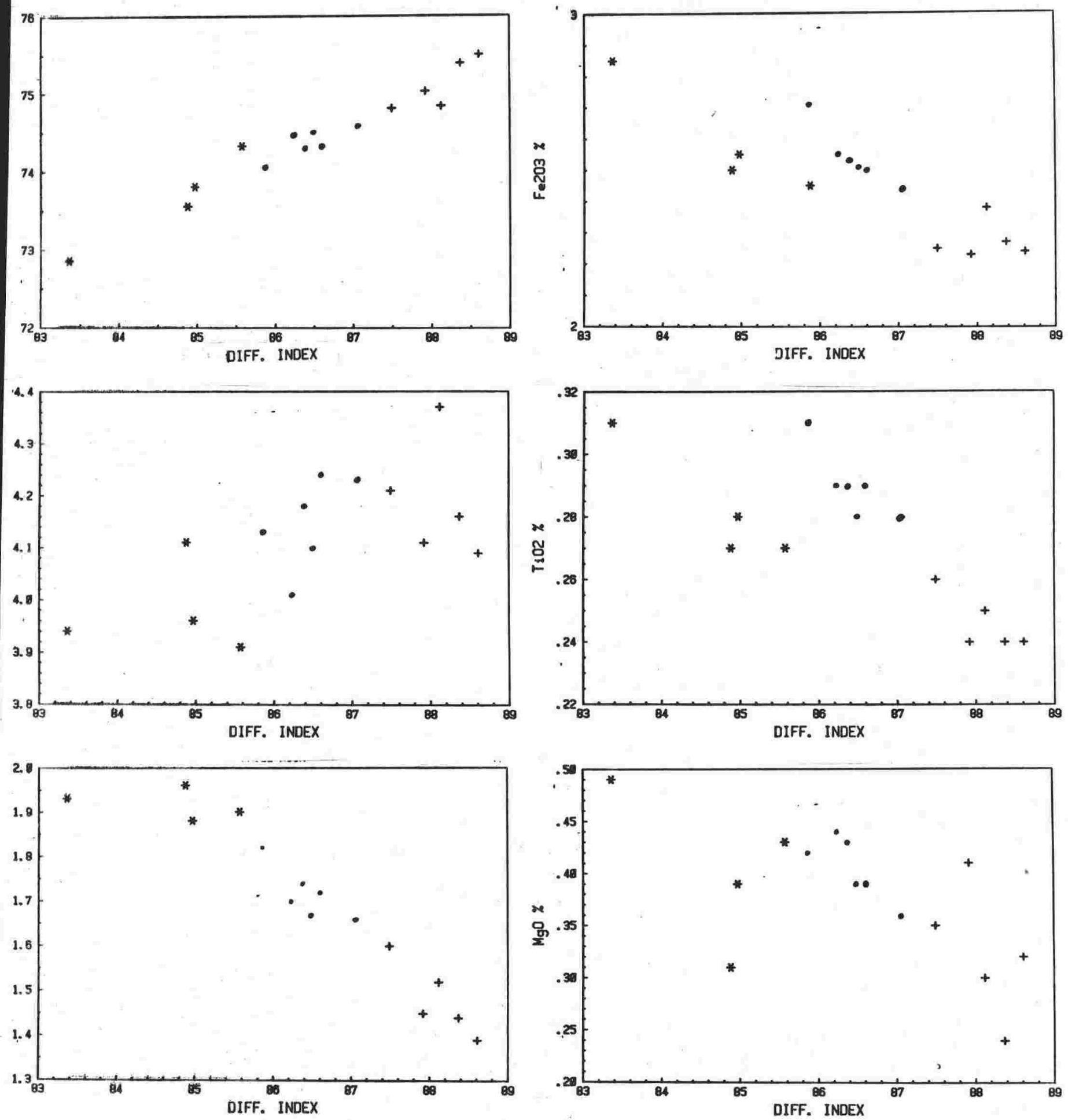

Figure 6.4.1: Summary of whole rock chemistry for Taupo Subgroup tephras. Symbols are - Taupo Pumice-Mapara;

+ Whakaipo-Motutere; $\quad$ Opepe-Karapiti. 


\section{TVZ HOLOCENE TEPHRAS}

WHOLE ROCK

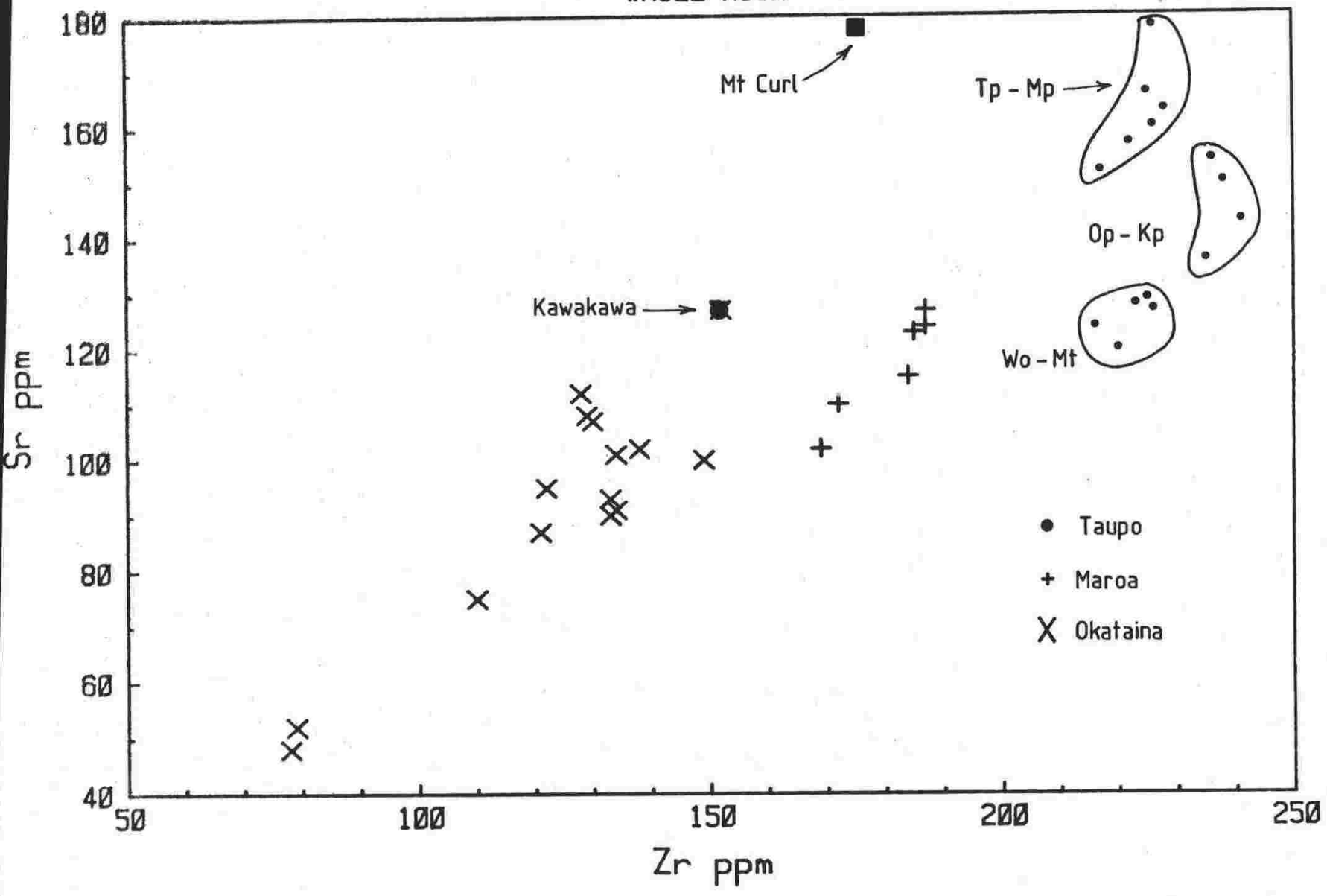

FIGURE 6.4.2: Whole rock $\mathrm{Sr}$ and $\mathrm{zr}$ trace elements for Taupo Subgroup tephras, with data from Maroa and

Okataina for comparison. 


\section{7}

elements. Included for comparison on Fig. 6.4.2 are analyses from Puketarata Ash (Maroa Volcanic Centre; Lloyd 1972) and Rotorua Subgroup Tephras from okataina, each of which form a distinctive group. The okataina analyses plot over a wide range, but show a trend towards lower Sr and $\mathrm{Zr}$ in the younger tephras. With further work, $\mathrm{Sr}$ and $\mathrm{Zr}$ may be a useful aid in "fingerprinting" tephras.

\section{Changes in Differentiation Index with Time}

Variation of the whole rock DI with time (Fig. 6.4.3) displays the differences between the three groups of tephras. The oldest group, Karapiti, Poronui and Opepe have the lowest DI values, which decrease steadily through the sequence. During the long time interval from Opepe to Motutere, the DI rises, probably caused by fractionation of mafic phenocrysts, and in the second group, DI rises to a maximum for the TSG sequence.

Conspicuous grey pumice, which appear only within the upper part of Waimihia Lapilli, is not of basaltic composition as assumed by Walker (1981) but is dark coloured due to abundant titanomagnetite phenocrysts, and may represent an accumulate fraction formed by crystal fractionation. A marked drop in DI to Mapara Tephra and Taupo Pumice suggests the addition of more mafic magma, after the moderately voluminous Waimihia episode.

\section{Glass Chemistry}

Glass chemistry of the TSG tephras was shown on Fig. 6.3 .2 by plotting element concentrations against DI. The three tephra groups defined by whole rock analyses are not clearly distinguished by the glass analyses. Only the youngest group (Mapara to Taupo Pumice) is distinctive with consistently high values of the mafic elements Mgo, FeO and $\mathrm{TiO}_{2}$. 
TSG TEPHRAS

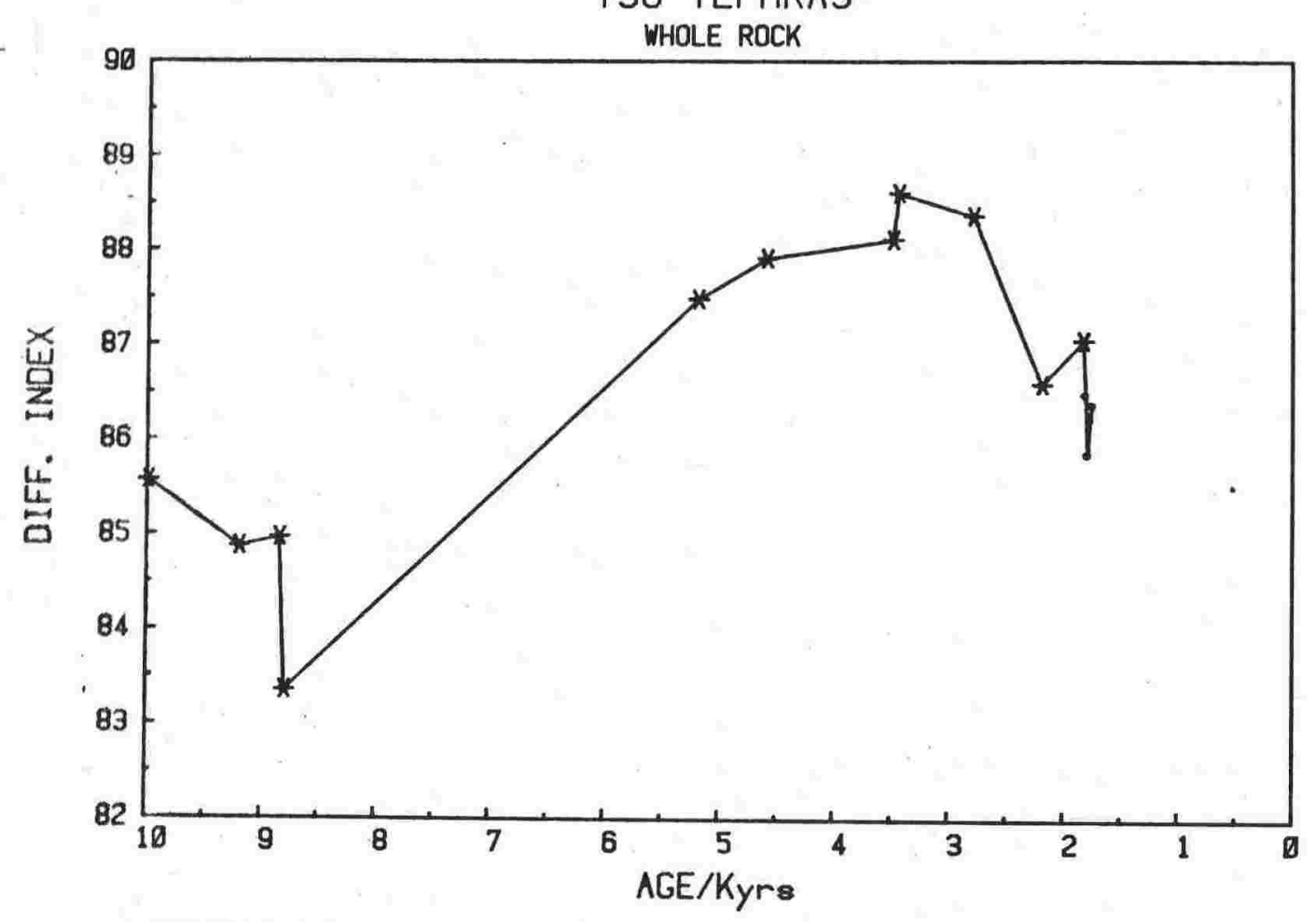

FIGURE 6.4.3: Change of Whole Rock Differentiation Index with time for the last lokyrs.

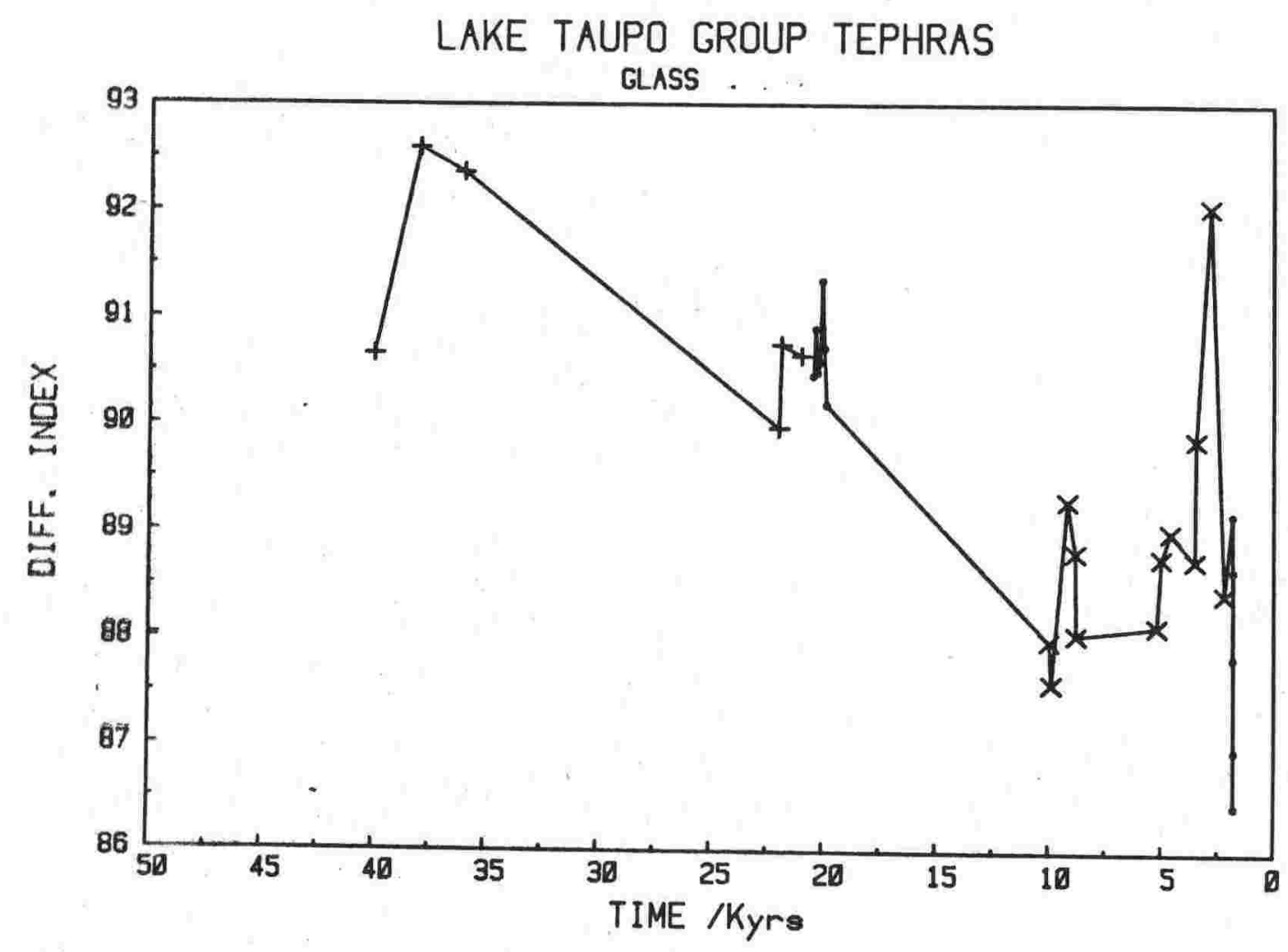

FIGURE, 6.4.4:

Change of glass Differentiation Index with time for the last 50kyrs. 
Within this group the two youngest tephras, Taupo Lapilli and Taupo Ignimbrite, have the lowest DI values suggesting a more mafic magma. Changes in glass DI with time (Fig. 6.4.4) for all the LTG tephras show a general decrease from Waihora Tephra to Taupo Pumice. Changes in glass DI do not show a clear relationship to whole rock values (Fig. 6.4.3).

\section{Iron-Titanium Oxides}

Chapter 6.3 indicated a relationship between Fe-Ti oxide chemistry and glass chemistry for the LTG tephras; the oxide minerals higher in FeO coexisting with glass lower in FeO. This relationship holds for $\mathrm{TiO}_{2}$ in the TSG tephras but the 'inverse applies to FeO and MgO, titanomagnetites higher in FeO and MgO (e.g. Taupo Ignimbrite) coexisting with glass higher in these elements (Fig. 6.4.5). The Feo, MgO and $\mathrm{TiO}_{2}$ content of the titanomagnetites clearly distinguishes the youngest group of tephras, Mapara to Taupo Pumice, which are relatively enriched in these elements.

Ilmenite chemistry shows less variation than the titanomagnetites but the same trends of $\mathrm{FeO}, \mathrm{MgO}$ and $\mathrm{TiO}_{2}$ contents can be discerned. In particular, the $\mathrm{TiO}_{2}$ content of ilmenite and glass clearly separates the Mapara-Taupo Pumice group (Fig. 6.4.6).

Recalculation of the Fe-Ti oxide analyses (Appendix A3.2) by the method of Carmichael (1967) permits the calculation of mole of ulvospinel (USP) and mole $\% \mathrm{R}_{2} \mathrm{O}_{3}$ proportions. Both sets of data show a good linear relation to the DI of the coexisting glass (Fig. 6.4.7); mole $\%$ USP increasing and $\% \mathrm{R}_{2} \mathrm{O}_{3}$ decreasing. However, quench temperatures calculated from the USP and $\mathrm{R}_{2} \mathrm{O}_{3}$ contents bear no direct relation to glass DI but scatter between $750^{\circ} \mathrm{C}$ and $916^{\circ} \mathrm{C}$. 

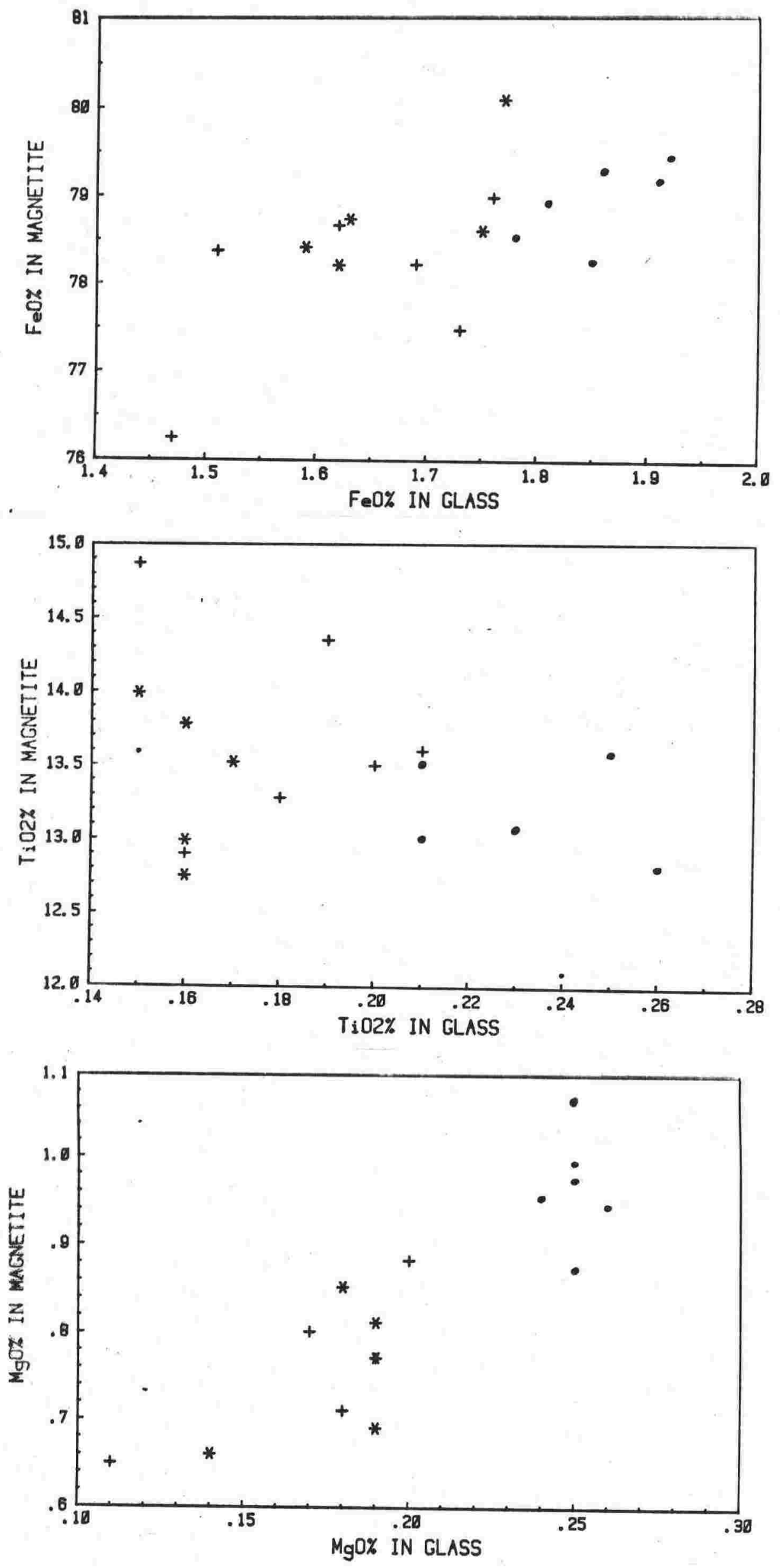

FIGURE 6.4.5: Distribution of mafic elements between glass and magnetite for Taupo Subgroup tephras. Symbols as for Fig. 6.4.1. 

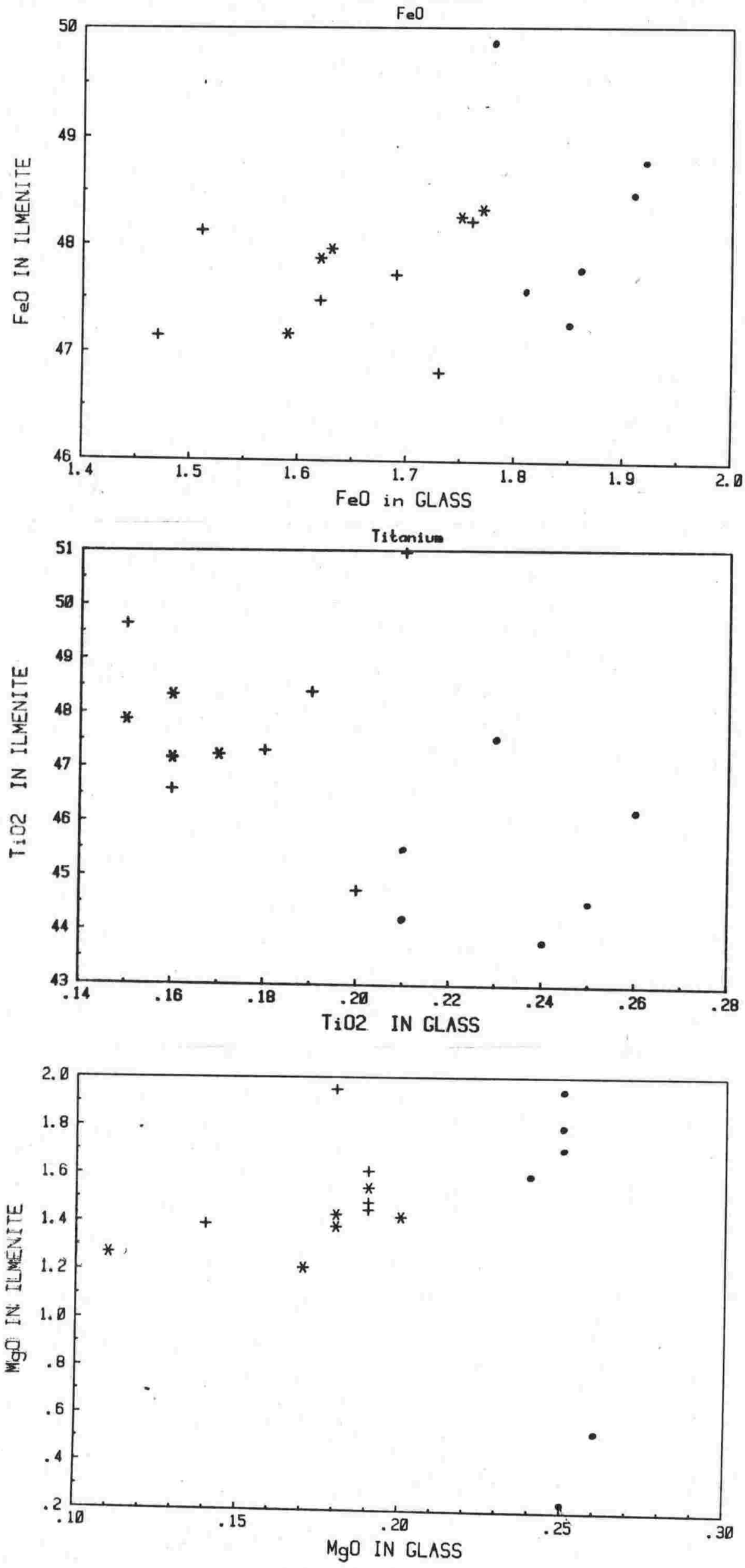

FIGURE 6.4.6: Distribution of mafic elements between glass and ilmenite, for Taupo subgroup tephras. Symbols as for Fig. 6.4.1. 
TSG TEPHRAS
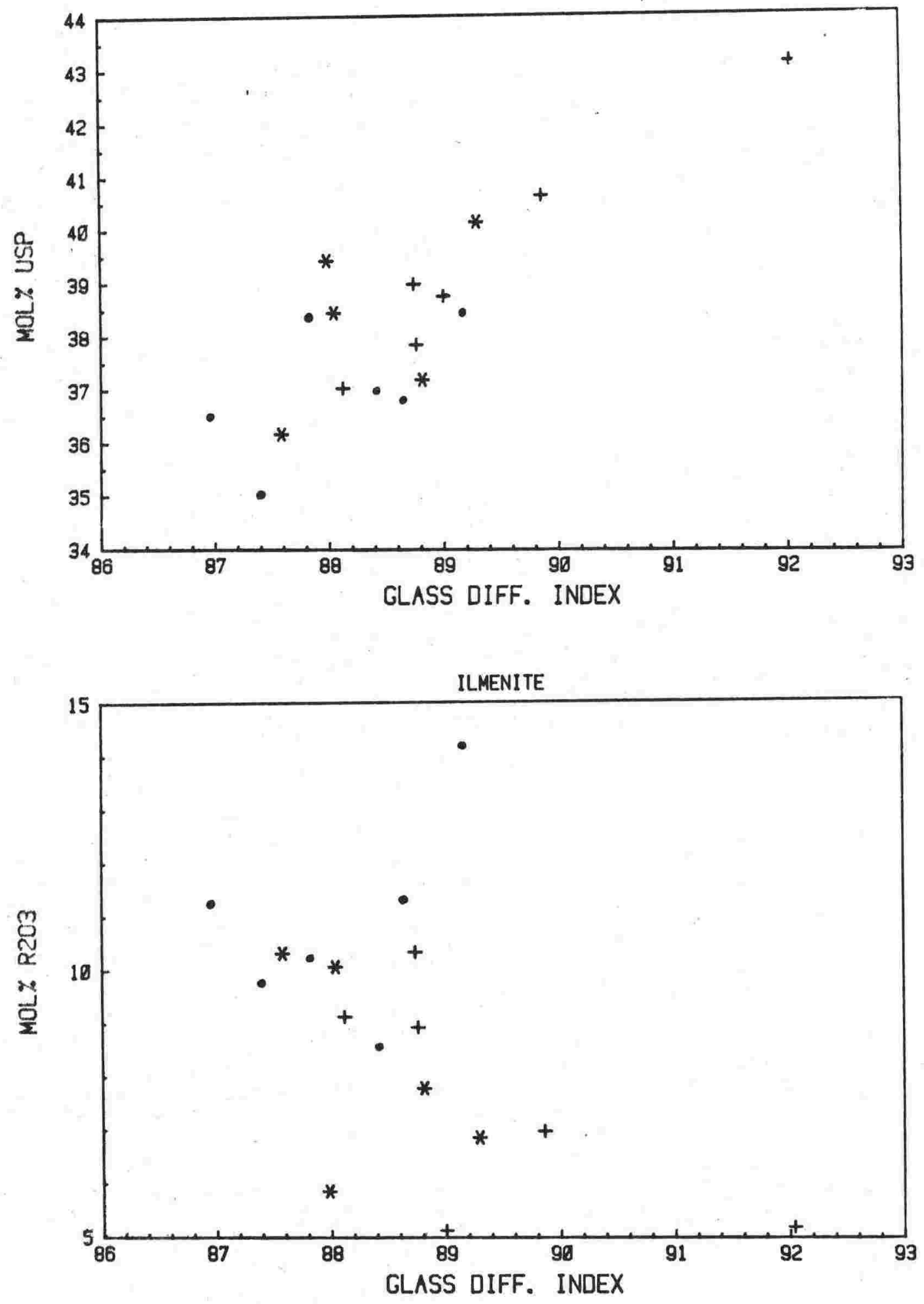

FIGURE 6.4.7: Relationship between the mole\% ulvospinel and mole\% $\mathrm{R}_{2} \mathrm{O}_{3}$ in magnetite and ilmenite, compared to the Differentiation Index of the co-existing glasses. 
Temperatures for each tephra are plotted against time in Fig. 6.4.8 where several consistent trends are apparent. The upper (younger) part of Karapiti and Opepe Tephra is hotter than the base of the tephra by $70^{\circ} \mathrm{C}$ and $50^{\circ} \mathrm{C}$ respectively, consistent with having been erupted from deeper within the magma chamber. Karapiti and Opepe glass analyses show a consistent small increase in FeO and decrease in $\mathrm{K}_{2} \mathrm{O}$ from base to top of the tephras. The drop in temperature from opepe to Motutere and Hinemaiaia agrees with the increasing whole rock DI values for these tephras (Fig. 6.4.3), as the magma cools and crystallises.

The increase in temperature to Mapara Tephra and Hatepe Lapilli coincides with the change to a more basic magma chemistry. The gradual decrease in temperature up through Taupo Pumice is not consistent with the tapping of successively deeper levels of a magma chamber but indicates that heat was rapidly lost from the magma. The high degree of vesiculation of pumice clasts is due to a high volatile content of the magma. Exsolution and eruption of the volatiles might remove enough heat to cool the magma by $100^{\circ} \mathrm{C}$. The cooling effect in Taupo Pumice is not common in other tephras, but Kawakawa Tephra, the previous large volume eruption from Taupo shows a gradual decrease of temperature through the plinian phases but a $180^{\circ} \mathrm{C}$ rise to the pyroclastic flow phase (Howorth 1976).

Orthopyroxene Chemistry

Analyses on orthopyroxenes from TSG tephras (Appendix 3) range in composition from $\mathrm{Mg}_{40}$ to $\mathrm{Mg}_{75}$ with the full range being found within one tephra. A similar range was determined by Howorth (1976) in Kawakawa Tephra.

Analyses for each tephra are plotted as molecular proportions of $\mathrm{Ca}, \mathrm{Mg}$ and $\mathrm{Fe}$ (Fig. 6.4.9), and the following points are noted: 


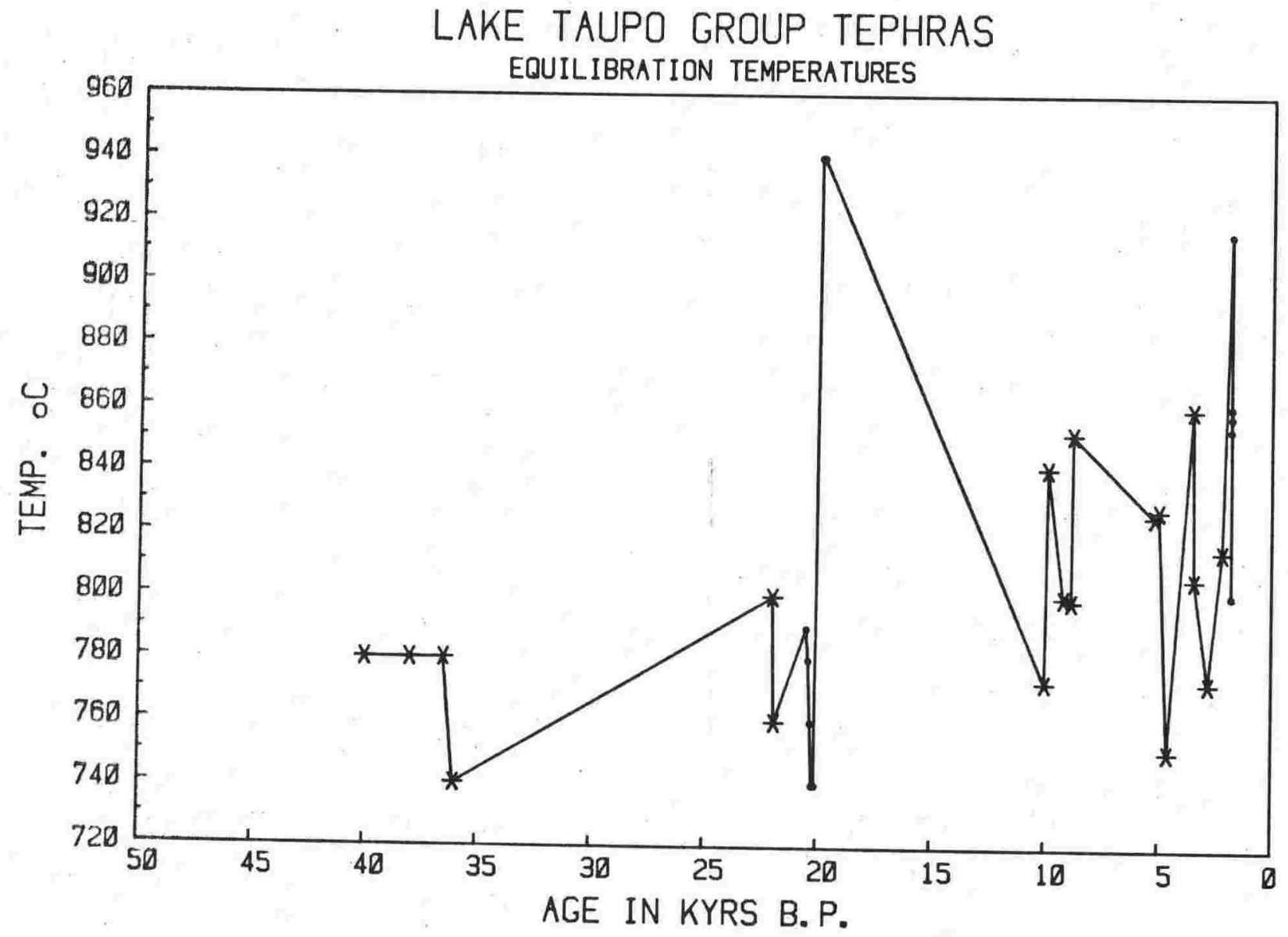

FIGURE 6.4.8: Changes in magma temperature with time for all Lake Taupo Group tephras. Data for 50-21kyr tephras from Roxburgh (1976) and for 20kyx tephras from Howorth (1976). Dots for samples from the same formation. 
1.

All orthopyroxenes examined appeared homogeneous with no consistent trend of zonation.

2. As substitution of $\mathrm{Fe}$ for $\mathrm{Mg}$ is controlled by magma temperature and composition, a wide range of opx compositions suggests some magma inhomogeneities especially in Mg.

3. The high - Mg cluster for Hinemaiaia and Motutere Tephras are probably the result of sample contamination, caused by the eruption of andesitic tephra from Tongariro contemporaneously with Motutere Tephra (see Chapter 1.3). However the spread in data for tephras not known to be contaminated, such as Opepe Lapilli, Waimihia Lapilli and Taupo Ignimbrite, suggest that orthopyroxene in these tephras are part of a continuous chemical range in the magma body, but has not been fully sampled.

4. In contrast to the maximum Mg contents, the minimum Mg contents in opx for each tephra have a small range and lie between $\mathrm{Mg}_{40}$ and $\mathrm{Mg}_{49}$. Consistent trends of higher minimum Mg in tephras with higher Fe-Ti oxide equilibration temperatures is shown by Karapiti Lapilli and associated dome obsidian, and by opepe Lapilli. The marked increase in $\mathrm{Mg}$ content between basal opepe Lapilli and the overlying ash coincides with a change to more basic whole rock chemistry of the ash (Fig. 6.4.3). 5. Orthopyroxenes from grey pumice within the upper part of Waimihia Lapilli range up to $\mathrm{Mg}_{71}$; consistent with the grey pumice being an accumulate fraction from deeper within the magma chamber. 6. The change to a more basic opx composition between Whakaipo and Mapara tephras indicates a more basic magma as shown by whole rock, glass and Fe-Ti oxide chemistry and an increase in magma temperature. 7. Plinian tephras mostly have a very narrow range in opx composition, but the voluminous events such as Taupo Lapilli and in particular the ignimbrites have more spread in the data. 


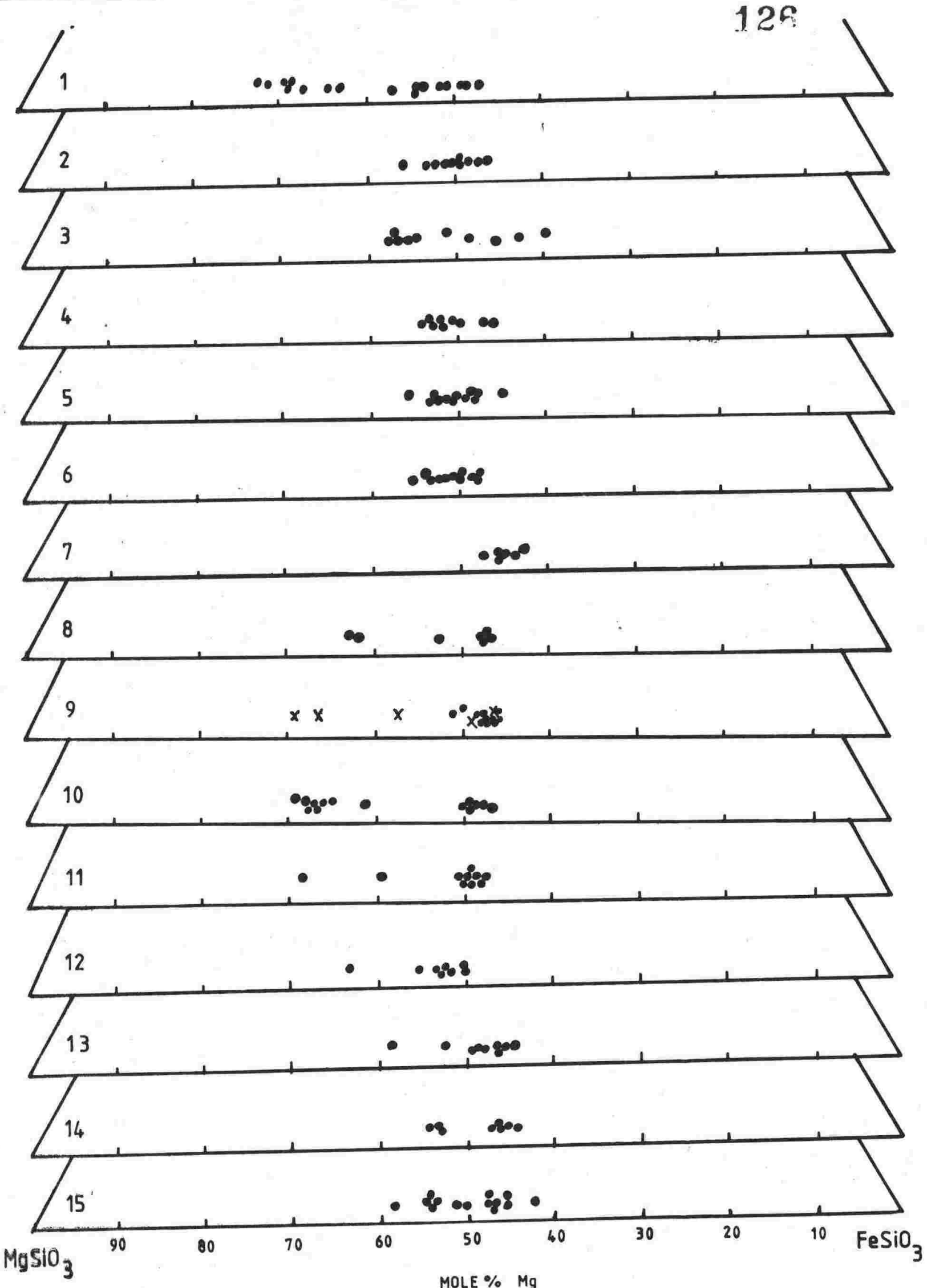

MOLE \% Mg

FIGURE 6.4.9: Orthopyroxene analyses plotted as molecular proportions of $\mathrm{Ca}, \mathrm{Mg}$ and $\mathrm{Fe}$. Tephras in stratigraphic order are;
1 Taupo Ignimbrite
2 Taupo Lapilli
3 Rotongaio Ash
4 Hatepe Tephra (ash)
5 Hatepe
9 Waimihia Lapilli ( $x=g r e y$ )
10 Hinemaiaia Tephra
11 Motutere Tephra
12 Opepe Tephra (upper)
6 Mapara Tephra
13 Opepe Tephra (lower)
14 Poronui Tephra
7 Whakaipo Tephra
15 Karapiti Tephra
8 Waimihia Ignimbrite 
8.

The wide range in opx composition shown by Waimihia and Taupo Ignimbrites may be related to the size and intensity of these eruptions, which could cause intense magma convection. This would homogenise any compositional variations in the magma. Such a process would also account for the range in compositions found in Kawakawa Tephra by Howorth (1976).

\subsection{Conclusions}

1. Taupo Subgroup Tephras are mineralogically and chemically distinct from the earlier Kawakawa and Okaia Subgroup Tephras.

2. Tephras within Taupo Subgroup are mostly uniform in composition but show small, consistent changes in whole rock major and trace elements and also mineral chemistry. The tephras form a continuous chemical range but the youngest tephras, Mapara and Taupo Pumice, consistently plot at the extreme of this range with a more mafic type of chemistry. 3. Continuous, linear trends shown by some aspects of the TSG chemistry suggest all the TSG tephras were derived from a common magma chamber. Similar trends are not apparent for the late Pleistocene tephras. 4. Chemical differences between some tephras indicate differentiation of the magma, presumably by crystallisation and crystal fractionation, but a continuous trend with time has not formed. New magma, added regularly to the chamber, and mixed with existing material has halted or reversed differentiation trends.

5.

No tephra exhibits clear chemical zonation but small variations, especially in $\mathrm{MgO}, \mathrm{FeO}, \mathrm{CaO}$ and $\mathrm{TiO}_{2}$ suggest that the magma was not entirely homogeneous. Greater chemical variation in the larger tephras (Waimihia and Taupo Ignimbrites) may be caused by intense convection homogenising the magma. Only the large eruptions would tap the full range of chemistry in the magma chamber. 


\section{3}

6. Karapiti and Opepe Tephras show a consistent upward increase in temperature, MgO and Feo content and more Mg rich orthopyroxenes, that are consistent with the progressively deeper tapping of compositional gradients in the magma. The younger tephras do not show this trend whereas Waimihia and Taupo are reversed. This may be the result of increased instability in the magma causing rapid convection and leading to the particularly violent and volatile rich eruptions of the Taupo Pumice episode. 


\section{CHAPTER 7.}

CORRELATION OF UPPER QUATERNARY TEPHRAS AND IGNIMBRITES:

FINGERPRINTING USING THE ELECTRON PROBE MICROANALYSER. 


\section{CHAPTER 7}

CORRELATION OF UPPER QUATERNARY TEPHRAS AND IGNIMBRITES: FINGERPRINTING USING THE ELECTRON PROBE MICROANALYSER

\subsection{Introduction}

The ability to uniquely identify a tephra regardless of the stratigraphic setting has long been one aim of tephra studies. Many approaches are possible, mostly relying on the glass or mineral components of the tephra.

Steen-MacIntyre (1973) examined the physical properties of glass shards, documenting morphology, transparency, vesicularity, microphenocryst content, hydration and refractive index. Hodder (1978) precisely determined refractive indices on some New Zealand glasses but the technique is susceptible to hydration rates differing between sites and between pumiceous and platy shards.

Mineral assemblage is a useful tool, restricted by the extent of sedimentary fractionation and winnowing during eruption and transport. Where possible, use of crushed pumice for mineral studies partly overcomes this problem. Mineral species in a given tephra have been found to persist throughout the known tephra distribution (Westgate and Gorton 1981) even though proportions may change (Howorth et al. 1980). Uncommon minerals, such as biotite, cummingtonite or rarely riebekite (Lowe et al. 1980) may be particularly diagnostic.

Chemical parameters have been found useful by many workers. Borchardt et al. (1971) used instrumental neutron activation analysis to determine a range of minor and rare earth elements in glass, whereas Howorth \& Rankin (1975) used a spark source mass spectrometer for a similar group of elements. Kohn $(1970,1973)$ analysed titanomagnetites by optical emission spectrography and found as few as four elements could 


\section{0}

distinguish some New zealand tephras. The only single grain technique to date is electron microprobe analysis of glass shards and mineral phases, first used with success in distal Pacific northwest United States tephras (Smith \& Westgate 1969; Westgate \& Fulton 1975; Westgate 1977; Westgate \& Evans 1978). Single grain techniques avoid problems of contamination (e.g. Kohn 1979) and inclusions and may identify multiple populations of glass or minerals (Westgate \& Evans 1978).

Previous attempts to identify New zealand tephras were all bulk sample techniques using titanomagnetite (Kohn 1970, 1973, 1979; Topping \& Kohn 1973; Neall \& Kohn 1973; Lewis \& Kohn 1973; Kohn \& Glasby 1975; Kohn \& Pullar 1976), glass separates (Howorth \& Rankin 1975; Rankin et al. 1976) or refractive index (Hodder 1978). To overcome problems inherent in bulk separates of glass or minerals, electron microprobe analysis of glass shards was undertaken to test if the technique was capable of discriminating New zealand tephras especially where some stratigraphy was known.

Analyses on glass shards from Lake Taupo Group Tephras have already been discussed in Section 6. Tephras closely spaced in time have similar chemistry, but samples from Taupo Subgroup tephras are clearly distinct from the older Kawakawa and Okaia Subgroup tephras (see Fig. 6.3.1). Using this technique, a large number of samples of older ignimbrites and tephras mostly exposed in distal areas and in non-volcanic deposits were analysed. Results are presented here as two manuscripts, preceded by a discussion of the analytical technique. 


\section{probe Analysis of Rhyolitic Glass}

\subsubsection{Introduction}

Problems encountered in electron-probe microanalysis of glass are well documented and are mostly dependent on the operating characteristics of the electron probe used. Volatilisation of light elements, especially the alkali metals, resulting in permanent damage to the glass has been extensively discussed by, for example, Varshneya et al. (1966); Goodhew \& Gulley (1974) and Nielsen \& Sigurdsson (1981). Loss of alkalis is caused either by volatilisation or electron induced migration away from the analysis area (Lineweaver 1962). Nielsen \& Sigurdsson (1981) showed measured alkali concentration decreased as the negative exponential of bombardment time, but this could be slowed by reducing the sample temperature. Rather than use a "cold finger" on the probe they used a sequence of 2 second counts, extrapolating to zero time on an empirical exponential curve. However, the strength of the electron beam (accelerating voltage and current) and beam diameter which are known to affect the loss of alkalis were not considered by Nielsen \& Sigurdsson (1981). Smith \& Westgate (1969) continuously moved the sample during analysis and used about 20 grains to establish each analysis, but this requires numerous large shards and continuous operator presence.

As different instrumental settings affect the final analysis, it was important to use the same set of conditions for analyses that are to be directly compared. Several samples collected for analysis in this study are from highly weathered, distal deposits where glass shards are small and scarce so the method of Smith \& Westgate (1969) was not suitable. Also, the electron probe available, a JEOL 733, is fully automated and the irregular shape of glass shards makes automated sample movement 
during analysis difficult to programme for each shard. The computer control does however lend itself to performing a large number of analyses with minimal operator attention. Consequently, a technique was desired that resulted in minimal alkali loss and that performed a full, automatic analysis on each selected point. The small shard size limits the beam diameter to 20 microns or less. With this procedure, a number of analyses can be easily performed on individual shards and values then meaned to give a better estimate of the range of chemistry for each sample.

\subsubsection{Effect of the Probe Beam on Alkalis in Glass}

Three instrumental settings adjust the strength of the electron probe beam; accelerating voltage, beam current and beam diameter. Normal accelerating voltage is $15 \mathrm{kV}$ but Goodhew (1975) showed that increasing the voltage excites the sample to a greater depth and slows the rate of alkali loss. In the case of tephras, some glass shards are so thin that the embedding resin may also be excited, and high voltages are not compatible with the Bence-Albee correction scheme used. The JEOL 733 is fitted with a TAP crystal for determining light elements and this produces sharp, high intensity peaks that allows lower beam currents (typically 12nA for the JEOL 733) whereas other instruments normally use 20nA or greater. The effect of changing beam current on peak intensity is nearly linear but as fewer counts reduce analytical precision a longer counting time is desirable. For analysis of a stationary sample, beam diameter is the most crucial variable. Fig. $7.1 .1($ a) shows that an increase from 3 to 10 microns doubles the $\mathrm{Na}_{2} \mathrm{O}$ value and increases $\mathrm{CaO}$ by $50 \%$ but $\mathrm{K}_{2} \mathrm{O}$ and MgO show no change. Further increases in beam diameter to 30 microns have little significant effect. 
FIGURE 7.1.1: Effects of the electron probe beam on volcanic glass:

(a) change in measured concentration of 4 elements with increasing beam diameter.

(b) dependence of the count rate for the $\mathrm{Na}$ peak on beam current and size.

(c) the decrease in count rate for the $\mathrm{Na}$ peak for 3 and 20 micron diameter beams 


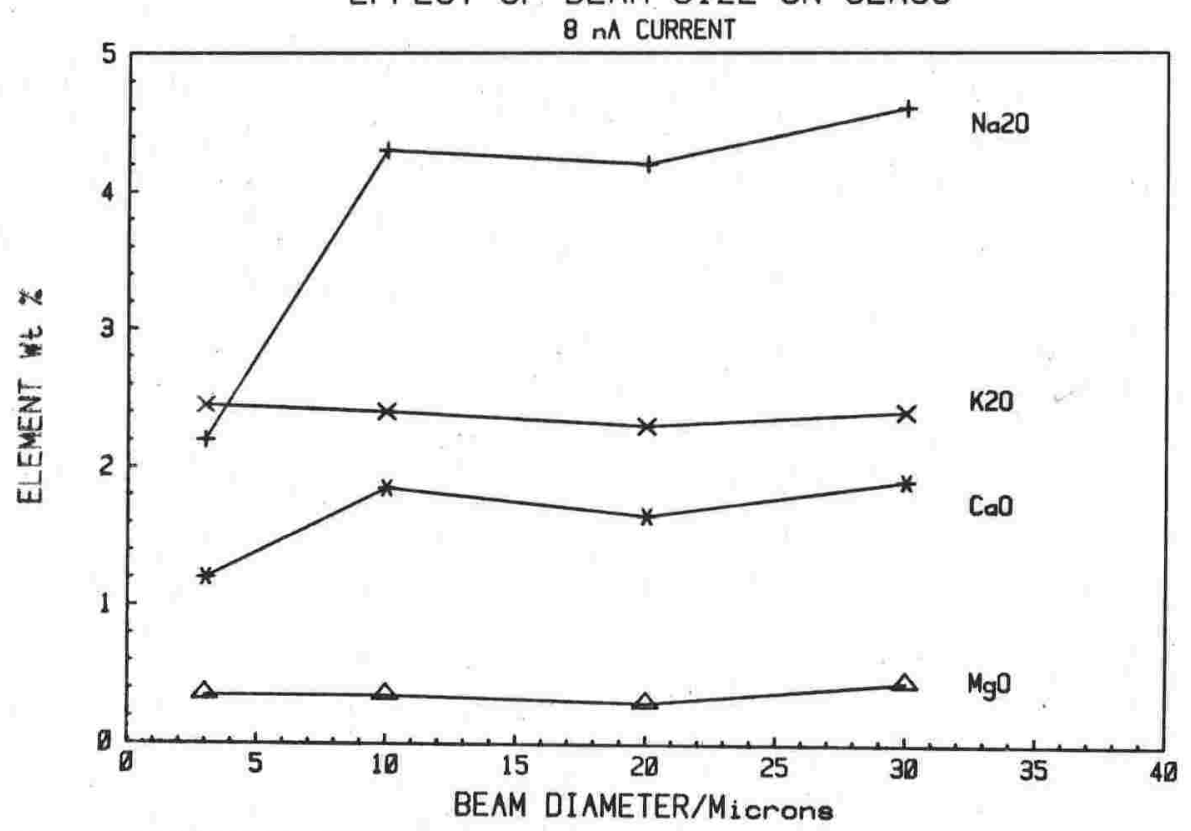

EFFECT OF BEAM ON GLASS

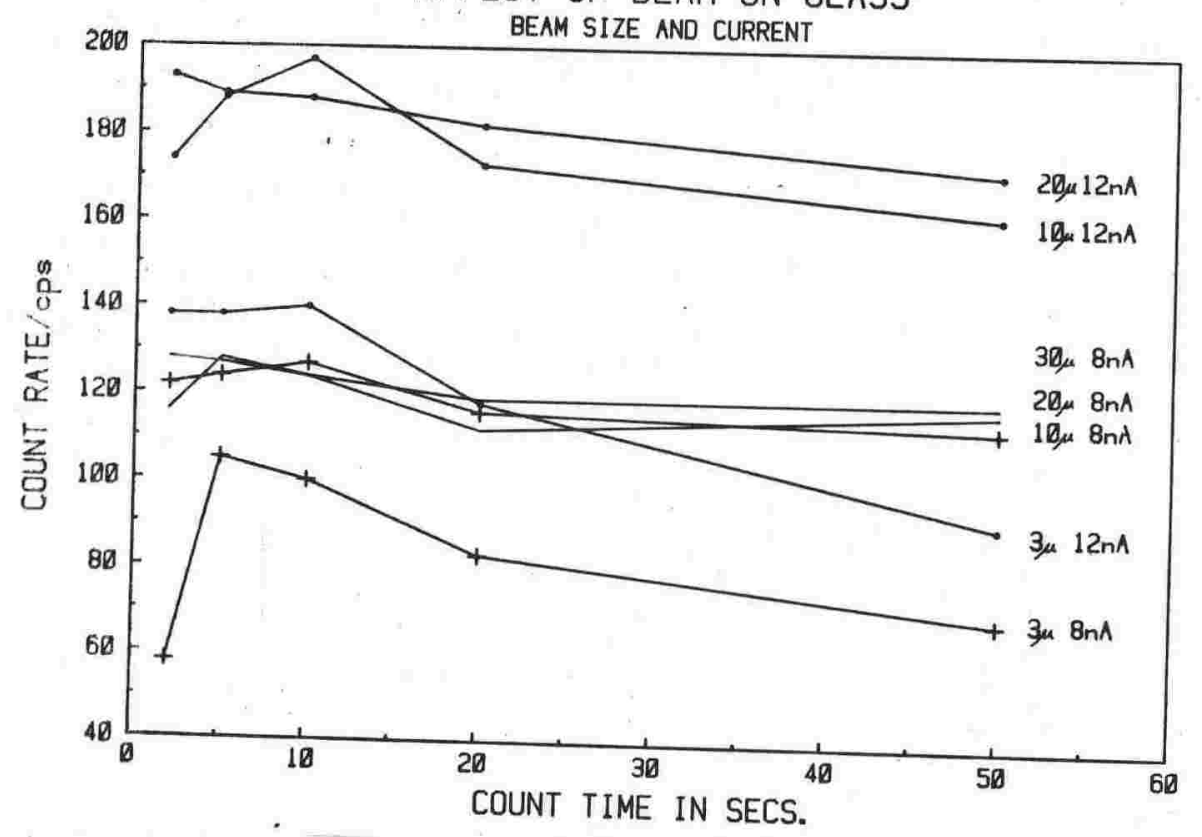

EFFECT OF BEAM ON GLASS

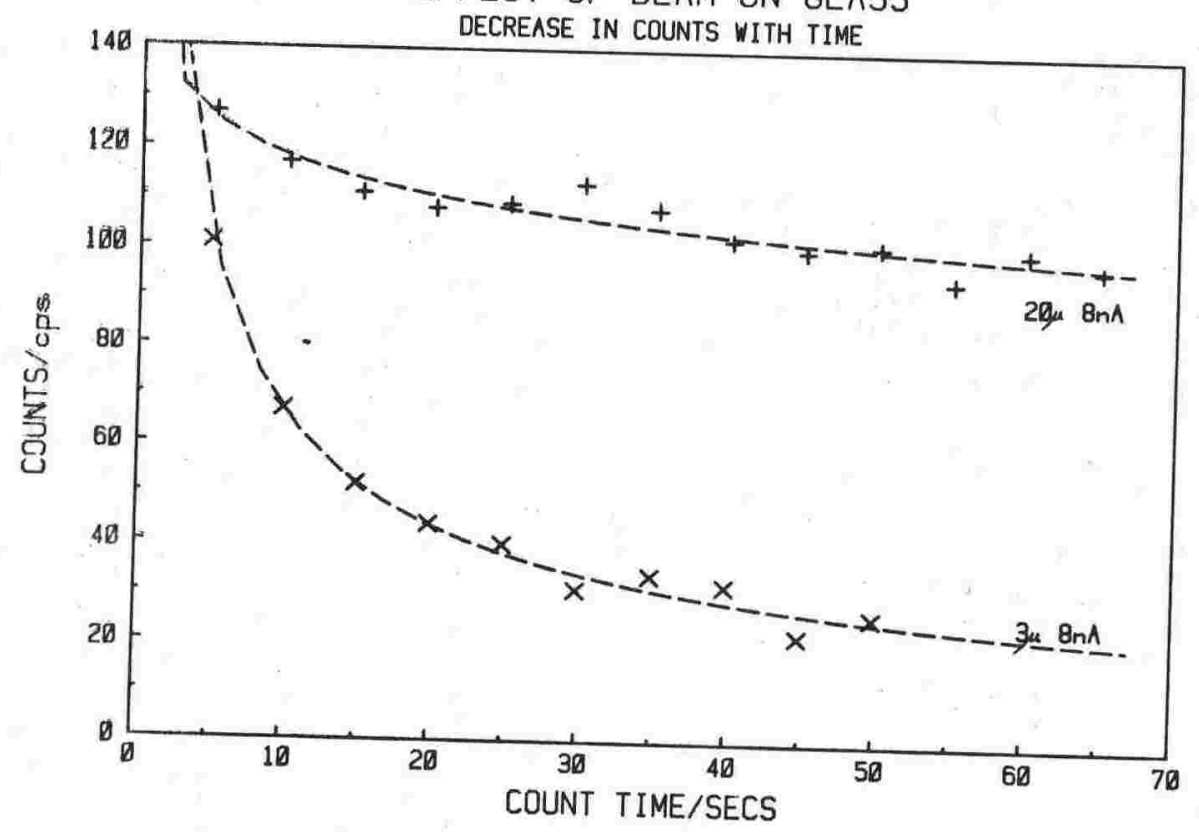




\section{4}

Count rate is dependent on beam current and Fig. 7.1 .1 (b) compares counts for $8 \mathrm{nA}$ and $12 \mathrm{nA}$ beams and various beam sizes. The count rate decreases with time, particularly with a 3 micron beam, but there is a steady decrease in counts for up to 50 seconds total time even for a 20 micron beam. This is not the case for $8 \mathrm{nA}$, where after a small initial decrease, the count rate is almost constant after 20 seconds. The difference between a 3 and 20 micron beam is further shown in Fig. 7.1.1(c). An additional feature evident on Fig. 7.1.1(b) is the increase in count rate up to the first 10 seconds, shown by several curves, especially 3 microns at $8 \mathrm{nA}$. This suggests that full fluorescence and X-ray production, or counter response, may take up to 5 seconds so that the technique of 2 second counts developed by Neilsen \& Sigurdsson (1981) is only valid if the sample is continuously irradiated. The drastic cut in counts caused by use of a 3 micron beam makes the method of Neilsen \& Sigurdsson unsuitable for this study.

The range of alkali values for the rhyolitic glasses examined is limited to about 2-4\% for $\mathrm{Na}_{2} \mathrm{O}$ and $2-5 \%$ for $\mathrm{K}_{2} \mathrm{O}$. It is not known if the loss of alkalis is proportional to the initial concentration, or is a constant amount under the analysis conditions used, as standard glasses, or glasses with known $\mathrm{Na}$ and $\mathrm{K}$ compositions were not available. It is considered, however, that because of the narrow range of compositions studied and the comparative use of data, the effect of proportional loss is minimal.

The effect of increasing glass hydration is probably to accelerate alkali loss, as permanent damage to glasses with 6-10\% water can occur. The study of Mt. Curl Tephra, discussed in Chapters $7.2,7.3$ and 8.3, shows comparable alkali values for a wide range of hydration. 


\section{5}

Accepted Standard Analysis Conditions

On the basis of the data and discussion in Chapter 7.1, analytical conditions were standardised at a 10 micron beam and lowered probe current of $8 \mathrm{nA}$. Counting times were set at $3 \times 10$ second peak counts and $1 \times 10$ second background on each side of the peak. A peak search routine was used before measurement of each element at a point offset from the analysis position. The order of measurement and crystals used were:

$\begin{array}{lllll}\text { Channel } & \mathrm{CH} 1 & \mathrm{CH} 2 & \mathrm{CH} 3 \\ \text { Crystal } & & \text { TAP } & \text { PET } & \text { LiF } \\ \text { Element sequence } & 1 & \mathrm{Na} & \mathrm{K} & \mathrm{Mn} \\ & 2 & \mathrm{Si} & \mathrm{Ca} & \mathrm{Fe} \\ & 3 & \mathrm{Al} & \mathrm{Ti} & \\ & 4 & \mathrm{Mg} & & \end{array}$

$\mathrm{Na}$ and $\mathrm{K}$ were always measured first to further minimise loss. All analyses were corrected using the method of Bence \& Albee (1968) as well as for dead-time and probe current drift. Analyses were computed as element oxides but both hydration and the non-crystalline structure of glass would suggest excess oxygen in the sample. No attempt was made to recalculate for excess oxygen as the correction is empirical for non-crystalline material and all analyses would need to be similarly corrected.

Selection of a 10 micron beam, rather than the more desirable 20 or 30 microns, allowed analysis of samples with small or highly vesicular shards, as such shards produce an irregular shaped polished surface often only 15-20 microns across.

Standard calibration of the electron probe was by use of mineral or synthetic standards for each element. These were: 


\section{6}

$\begin{array}{llc} & & \begin{array}{c}\text { Assumed wto } \\ \text { in Standard }\end{array} \\ \mathrm{SiO}_{2} & \text { synthetic } \mathrm{SiO}_{2} & 100 \\ \mathrm{TiO}_{2} & \text { synthetic } \mathrm{TiO}_{2} & 100 \\ \mathrm{Al}_{2} \mathrm{O}_{3} & \text { synthetic } \mathrm{Al}_{2} \mathrm{O}_{3} & 100 \\ \mathrm{FeO} & \text { synthetic } \mathrm{Fe}_{2} \mathrm{O}_{3} & 100 \\ \mathrm{MnO} & \text { synthetic } \mathrm{MnO} & 100 \\ \mathrm{MgO} & \text { synthetic } \mathrm{MgO} & 100 \\ \mathrm{CaO} & \text { natural Wollastonite } & 48.28 \\ \mathrm{Na}{ }_{2} \mathrm{O} & \text { natural albite } & 11.67 \\ \mathrm{~K}_{2} \mathrm{O} & \text { natural orthoclase } & 14.92\end{array}$

Calibration of the JEOL 733 was checked before each run of analyses (at least once per day) by analysis of the mineral standard Kakanui augite or the glasses $\mathrm{KN}-18$ and UA5831 (see Chapter 7.1.4). 120 consecutive analyses on Mt. Curl Tephra glass shards (see Table 7.1.2) demonstrate the analytical precision of the probe.

\subsubsection{Detection Limits of the Microprobe}

The theoretical limits of detection of an element peak above the background level is given by

$$
\mathrm{DL}=\frac{3}{\mathrm{~m}_{0}} \sqrt{\mathrm{R}_{\mathrm{b}} / \mathrm{T}_{\mathrm{b}}}
$$

where $\mathrm{m}=$ counts per second per $\%$ on peak

$\mathrm{R}_{\mathrm{b}}=$ cps on background

$\mathrm{T}_{\mathrm{b}}=$ time on background.

Typical DL values, determined for a single analysis on glass $\mathrm{KN}-18$ and a hypersthene and titanomagnetite from Whakamaru Ignimbrite are given in Table 7.1.1. For $\mathrm{KN}-18$, only $\mathrm{MnO}$ and MgO are near the detection limits. 


\section{7}

\begin{tabular}{lrr|rr|rr} 
& \multicolumn{2}{c|}{ GLASS } & KN-18 & \multicolumn{2}{|c|}{ HYPERS THENE } & \multicolumn{2}{c}{ TI TANOMAGNE TI TE } \\
\cline { 2 - 7 } $\mathrm{SiO}_{2}$ & 74.60 & 0.076 & 53.26 & 0.088 & 0.09 & 0.093 \\
$\mathrm{Al}_{2} \mathrm{O}_{3}$ & 10.53 & 0.058 & 0.43 & 0.060 & 1.19 & 0.071 \\
$\mathrm{TiO}_{2}$ & 0.18 & 0.051 & 0.11 & 0.130 & 7.55 & 0.160 \\
$\mathrm{FeO}$ & 3.45 & 0.124 & 25.24 & 0.236 & 80.50 & 0.243 \\
$\mathrm{MnO}$ & 0.06 & 0.040 & 1.24 & 0.191 & 0.96 & 0.228 \\
$\mathrm{MgO}$ & 0.01 & 0.003 & 19.07 & 0.075 & 0.30 & 0.077 \\
$\mathrm{CaO}$ & 0.15 & 0.031 & 0.88 & 0.089 & - & 0.107 \\
$\mathrm{Na}_{2} \mathrm{O}$ & 5.68 & 0.067 & - & 0.096 & - & 0.113 \\
$\mathrm{~K}_{2} \mathrm{O}$ & 4.39 & 0.047 & - & 0.078 & - & 0.092
\end{tabular}

TABLE 7.1.1

Typical detection limits on standard glass $\mathrm{KN}-18$ and mineral phasesfrom Whakamaru Ignimbrite, as determined on the JEOL 733 microprobe. 


\section{8}

Mgo values in this glass are lower than found in New Zealand tephras (typically $0.1-0.2 \%$ ) so measured concentrations are considered significant. The low level of Mno in all tephras analysed places this element near to, or in some samples below, the detection limit. Although Mno is quoted for all glass analyses, it has not been used in any comparisons. Detection limits on the mineral phases indicate $\mathrm{SiO}_{2}$ in titanomagnetite and $\mathrm{TiO}_{2}$ in pyroxene are near the limit of detection but neither element is of critical importance in these minerals.

\subsubsection{Establishing Mean Values}

Variations in glass shard type (platy, pumiceous or vesicular), size and hydration all contribute to inherent differences in glass chemistry between shards from one sample. No shard type or size was preferentially selected for analysis beyond the requirement of a polished surface at least 15 microns across. Each analysis can be considered a randomly selected measurement and several analyses on individual shards should be normally distributed about the mean. To test this, glass from the Mt. Curl Tephra type section was split into 4 sub-samples and each was polished for analysis. Between 10 and 40 shards per sub-sample were analysed. For all shards, the mean and the standard deviation on each element are comparable so all 120 analyses were combined. Up to 4 individual element determinations were discarded as being grossly in error and statistical data calculated (Table 7.1.2). All elements have a low skewness indicating near normal distribution. Many skewness values are negative so the normal curve has a tail skewed towards low values. Kurtosis, a measure of the peakedness. of the distribution is moderately high with most values between 2 and 6 . A normal curve has a kurtosis of 1.0 .

To check if 120 analyses produce a statistically different result from only 10 or 20 analyses, the means in Table 7.1 .2 are compared 


$\begin{array}{lcccccccl} & 1 & 2 & 3 & 4 & 5 & 6 & \mathrm{~N} & \\ \mathrm{SiO}_{2} & 78.06 & 0.31 & 0.40 & 0.224 & 2.377 & 0.097 & 120 & 1=\text { MEAN } \\ \mathrm{Al}_{2} \mathrm{O}_{3} & 12.32 & 0.21 & 1.69 & -0.460 & 3.492 & 0.043 & 120 & 2=1 \text { standard deviation. } \\ \mathrm{TiO}_{2}{ }^{2} & 0.14 & 0.03 & 23.49 & -0.150 & 3.220 & 0.001 & 117 & 3=\% \text { relative deviation. } \\ \mathrm{FeO}^{2} & 1.01 & 0.09 & 8.72 & -0.873 & 4.129 & 0.008 & 119 & 4=\text { skewness } \\ \mathrm{MnO} & 0.04 & 0.05 & 116.58 & 3.45 & 24.600 & 0.002 & 120 & 5 \text { = kurtosis } \\ \mathrm{MgO} & 0.12 & 0.02 & 19.27 & -0.348 & 3.743 & 0.001 & 118 & 6 \text { = variance } \\ \mathrm{CaO} & 0.78 & 0.05 & 6.66 & -2.49 & 13.04 & 0.003 & 116 & \\ \mathrm{Na}_{2} \mathrm{O} & 3.31 & 0.13 & 3.61 & -1.16 & 6.64 & 0.016 & 119 & \\ \mathrm{~K}_{2} \mathrm{O} & 4.23 & 0.16 & 3.85 & 0.508 & 4.174 & 0.003 & 118 & \\ \mathrm{H}_{2} \mathrm{O} & 4.49 & 1.33 & 29.60 & 0.022 & 2.131 & 1.768 & 120 & \end{array}$

\section{TABLE 7.1 .2}

Statistics on 120 probe analyses of Mt. Curl Tephra. Water by difference from $100 \%$.

$\mathbf{N}=$ number in mean; wild values discarded. 
to the means previously derived from a separate sample also collected from the Mt. Curl type section (see Table 7.2.3). The statistical ' $t$ ' test for each element shows that at the 95\% level $(P=0.05)$ differences in the means are not significant. Only $\mathrm{Al}_{2} \mathrm{O}_{3}(\mathrm{P}=0.08)$ and $\mathrm{Na}_{2} \mathrm{O}$ $(P=0.06)$ values are close to being significantly different. Analysis of glass shards sampled from marine sediments at Cape Kidnappers revealed multiple chemical populations (Chapter 7.2, Fig. 7.2.2). Mixing and reworking of glass from two or more tephras was postulated to occur in shallow, high energy marine environments and should be expected in any sample from such marine deposits. From analyses on only 10 shards, mixed samples from Cape Kidnappers were initially identified. Additional analyses were then obtained to better quantify each chemical group.

As Table 7.1 .3 shows, a mixed sample is indicated by higher than usual standard deviations, especially on $\mathrm{SiO}_{2}, \mathrm{TiO}_{2}$, $\mathrm{FeO}$ and $\mathrm{CaO}$. Plotting individual elements from each analysis against Differentiation Index (Fig. 7.2.2) was found to clearly distinguish each group. Recalculated means for each group have standard deviations typical of pure samples (Table 7.1.3).

In summary, the natural spread in element values is normally distributed about a mean value which is well determined by 10 analyses. The recognition of contamination or mixed glass assemblages from only 10 analyses, further confirms this number as the most practical initial determination. With current operating procedures, 10 analyses represents about $1 \frac{1}{2}$ hours of probe time with a further $\frac{1}{4}$ hour of calculating time to derive the mean. 
aㅡ

\begin{tabular}{|c|c|c|c|c|c|c|c|c|c|c|c|c|c|}
\hline & & TUFF. & Basal & & at Cape & & & & & & & & \\
\hline $\mathrm{SiO}_{2}$ & 77.90 & 78.45 & 78.69 & 78.52 & 78.73 & $78.56^{\circ}$ & 79.06 & 78.38 & 78.55 & 78.37 & 78.37 & 78.21 & 77.99 \\
\hline $\mathrm{Al}_{2} \mathrm{O}_{3}$ & 12.55 & 12.27 & 11.99 & 12.21 & 12.33 & 12.27 & 12.11 & 12.61 & 12.27 & 12.23 & 12.36 & 12.26 & 12.34 \\
\hline $\mathrm{TiO}_{2}$ & 0.12 & 0.14 & 0.13 & 0.13 & 0.10 & 0.16 & 0.09 & 0.10 & 0.12 & 0.11 & 0.10 & 0.15 & 0.07 \\
\hline $\mathrm{FeO}$ & 1.29 & 1.13 & 1.06 & 1.13 & 1.27 & 1.20 & 1.20 & 1.12 & 1.08 & 1.25 & 1.10 & 1.22 & 1.10 \\
\hline Mno & 0.09 & 0.03 & 0.03 & 0.03 & - & 0.02 & 0.10 & - & 0.11 & 0.01 & 0.01 & 0.06 & 0.03 \\
\hline Mgo & 0.11 & 0.10 & 0.07 & 0.08 & 0.11 & 0.12 & 0.09 & 0.06 & 0.07 & 0.13 & 0.13 & 0.10 & 0.14 \\
\hline CaO & 0.98 & 0.93 & 0.94 & 0.91 & 0.93 & 0.89 & 0.91 & 0.73 & 0.90 & 0.98 & 0.90 & 0.97 & 0.87 \\
\hline $\mathrm{Na}_{2} \mathrm{O}$ & 3.41 & 3.43 & 3.17 & 3.41 & 3.18 & 3.27 & 2.97 & 3.31 & 3.45 & 3.47 & 3.27 & 3.65 & 3.33 \\
\hline $\mathrm{K}_{2} \mathrm{O}$ & 3.54 & 3.52 & 3.93 & 3.57 & 3.35 & 3.50 & 3.45 & 3.70 & 3.45 & 3.44 & 3.76 & 3.38 & 4.11 \\
\hline WATE & 2.23 & 3.04 & 3.00 & 2.46 & 4.37 & 2.74 & 4.54 & 4.99 & 3.66 & 5.35 & 4.00 & 5.03 & 4.11 \\
\hline .1 & 3.07 & 3.84 & 94.33 & 3.99 & 92.97 & 93.43 & 92.96 & 93.88 & 93.85 & 93.56 & 93.80 & 3.80 & 94.27 \\
\hline
\end{tabular}

$\begin{array}{lrrrr}\mathrm{SiO}_{2} & 78.06 & 77.82 & 78.20 & 78.49 \\ \mathrm{Al}_{2} \mathrm{O}_{3} & 12.32 & 12.64 & 12.40 & 12.08 \\ \mathrm{THO}_{2} & 0.15 & 0.13 & 0.09 & 0.10 \\ \mathrm{FeO}^{2} & 1.19 & 1.11 & 1.14 & 1.18 \\ \mathrm{MnO} & 0.07 & - & - & 0.04 \\ \mathrm{MgO} & 0.11 & 0.12 & 0.11 & 0.11 \\ \mathrm{CaO} & 1.01 & 0.92 & 0.93 & 0.96 \\ \mathrm{Na}_{2} \mathrm{O} & 3.51 & 3.64 & 3.58 & 3.18 \\ \mathrm{~K}_{2} \mathrm{O} & 3.57 & 3.62 & 3.55 & 3.86 \\ \text { WATER } & 5.81 & 5.96 & 5.04 & 4.53 \\ \text { D.I. } & 93.68 & 93.98 & 94.01 & 93.83\end{array}$

Mean of 17 analyses:

$$
\begin{array}{rr}
\hline 78.19 & (0.22) \\
12.33 & (0.16) \\
0.11 & (0.03) \\
1.16 & (0.06) \\
0.03 & (0.03) \\
0.12 & (0.01) \\
0.94 & (0.05) \\
3.45 & (0.18) \\
3.66 & (0.24) \\
4.98 & (0.73)
\end{array}
$$

\begin{tabular}{|c|c|c|c|c|c|c|c|c|c|c|c|c|}
\hline $\mathrm{SiO}_{2}$ & 77.99 & 76.07 & 76.91 & 76.79 & 76.90 & 75.51 & 75.72 & 75.11 & 75.94 & 76.63 & 76.35 & 政 \\
\hline $\mathrm{Al}_{2} \mathrm{O}_{3}$ & 12.10 & 13.37 & 12.80 & 13.04 & 12.94 & 12.97 & 13.72 & 14.00 & 12.97 & 12.66 & 13.06 & . \\
\hline $\mathrm{iO}_{2}$ & 0.05 & 0.09 & 0.17 & 0.13 & 0.09 & 0.39 & 0.40 & 0.29 & 0.37 & 0.23 & 0.22 & \\
\hline Feo & 1.52 & 1.81 & 1.62 & 1.72 & 1.81 & 2.03 & 1.91 & 2.00 & 2.07 & 1.66 & 0.81 & \\
\hline uno & - & 0.05 & 0.06 & 0.01 & 0.04 & 0.12 & - & 0.09 & 0.09 & 0.02 & 0.05 & (0. \\
\hline 0 & 0.06 & 0.02 & 0.12 & 0.09 & 0.07 & 0.37 & 0.37 & 0.33 & 0.32 & 0.26 & 0.20 & 10 \\
\hline 10 & 0.98 & 1.33 & 1.09 & 1.28 & 1.18 & 1.54 & 1.52 & 1.46 & 1.64 & 1.48 & 1.35 & \\
\hline $\mathrm{Na}_{2} \mathrm{O}$ & 3.78 & 3.63 & 3.62 & 3.44 & 3.75 & 3.92 & 3.46 & 3.74 & 3.47 & 3.64 & 3.64 & 10.1 \\
\hline $\mathrm{K}_{2} \mathrm{O}$ & 3.53 & 3.62 & 3.61 & 3.50 & 3.22 & 3.14 & 2.90 & 3.00 & 3.14 & 3.43 & .31 & \\
\hline ATER & 1.93 & 3.75 & 3.65 & 3.55 & 2.70 & 4.07 & 4.12 & 3.74 & 5.22 & 6.35 & 3.91 & $(1.2)$ \\
\hline . I. & 94.01 & 91.70 & 92.55 & 91.69 & 91.94 & 90.37 & 89.06 & 89.21 & 89.64 & 91.77 & 91.19 & (1. \\
\hline & & & $\cdot$ & & & & & \multicolumn{3}{|c|}{ Mean of 8 , } & Mean o & of 18 \\
\hline $\mathrm{iO}_{2}$ & 78.51 & 78.31 & 78.13 & 78.02 & 79.03 & 78.13 & 78.15 & 77.96 & 78.28 & $(0.34)$ & 77.17 & $(1.17)$ \\
\hline $\mathrm{Al}_{2} \mathrm{O}_{3}$ & 12.17 & 12.45 & 12.51 & 12.80 & 11.73 & 12.37 & 12.37 & 12.34 & 12.34 & $(0.31)$ & 12.73 & $(0.58)$ \\
\hline $\mathrm{TiO}_{2}$ & 0.03 & 0.02 & 0.12 & 0.06 & 0.09 & 0.17 & 0.16 & 0.11 & 0.09 & $(0.06)$ & 0.16 & $(0.12)$ \\
\hline FeO & 0.72 & 0.89 & 1.17 & 0.93 & 1.09 & 1.18 & 1.07 & 1.19 & 1.03 & $(0.17)$ & 1.47 & $(0.44)$ \\
\hline $4 n c$ & 0.05 & 0.10 & 0.01 & - & - & - & 0.02 & 0.07 & 0.03 & & 0.04 & \\
\hline MgO & 0.06 & 0.16 & 0.09 & - & 0.05 & 0.13 & 0.13 & 0.13 & 0.09 & $(0.05)$ & 0.15 & $(0.12)$ \\
\hline Caó & 0.68 & 0.94 & 1.00 & 0.77 & 0.75 & 0.95 & 0.90 & 0.88 & 0.86 & $(0.11)$ & 1.13 & $(0.31)$ \\
\hline N⿳亠े⿵冂⿱八口𧘇 & 3.36 & 3.19 & 3.51 & 3.29 & 3.52 & 3.56 & 3.56 & 3.52 & 3.44 & $(0.14)$ & 3.55 & $(0.18)$ \\
\hline $\mathrm{K}_{2} \mathrm{O}$ & 4.42 & 3.95 & 3.47 & 4.12 & 3.75 & 3.51 & 3.63 & 3.80 & 3.83 & $(0.32)$ & 3.54 & $(0.39)$ \\
\hline WATER & 3.36 & 3.56 & 2.96 & 2.37 & 2.73 & 4.60 & 5.58 & 3.20 & 3.55 & $(1.06)$ & 3.69 & $(1.01)$ \\
\hline & 95.89 & 93.91 & 93.60 & 94.58 & 95.22 & 93.82 & 94.15 & 94.02 & 94.40 & $(0.79)$ & 92.62 & (2.07 \\
\hline
\end{tabular}

b TEPHRIC HORIZON at base of Trig $\mathrm{N}$ beds, Cape Kidnappers (50218)

TABLE 7.1.3: (a) Mean and standard deviation on 17 consequitive analyses of Kidnappers Tuff typical of pure tephra samples.

(b) Data for 18 analyses of a reworked tephra from Cape Kidnapoers. Analyses grouped into 2 clusters on the basis of D.I. FeO and $\mathrm{TiO}_{2}$. With additional analyses, the group of 10 may possikly be subdivided further. 


\subsubsection{Analysis of Glass Standards}

For the "fingerprinting" and discrimination of tephras, analyses must be obtained under identical analytical conditions and comparable calibration so that all analyses are internally consistent. Determination of absolute concentrations is desirable but not essential. Repeated analysis of two glass standards (Table 7.1.4) indicates the measured values are close to the accepted concentrations for all elements except $\mathrm{Na}_{2} \mathrm{O}$ and the calibration has not changed with time. In view of the compromise instrumental settings used, some loss of $\mathrm{Na}_{2} \mathrm{O}$ is expected and the measurements on the two standards are considered satisfactory. However all probe glass analyses were obtained for comparative purposes within the context of this study only and should not be directly compared to samples analysed under other conditions.

\subsubsection{Comparing Analyses}

Analyses may either be compared graphically or statistically. It is considered here desirable to choose the least sophisticated method that adequately meets the need of the study: i.e. if two tephras can be discriminated graphically, there is little benefit to be gained in using a complex statistical routine. Graphical methods were successfully used by Westgate \& Fulton (1975) who distinguished tephras by a FeO-CaO- $\mathrm{K}_{2} \mathrm{O}$ ternary plot of glass data and also plots of individual elements against the Differentiation Index for the glass. Kohn (1970) compared ratios of elements for titanomagnetite analyses and found the ratios of $\mathrm{Co} / \mathrm{Mn}$, $\mathrm{V} / \mathrm{Mn}$ and $\mathrm{Ti} / \mathrm{V}$ could separate tephras. Graphical methods provide for the reader an immediate appreciation of any separation or grouping of data but cannot make use of all analytical data at one time. At best, three elements can be plotted on a ternary graph or four elements if two sets of ratios are compared. 


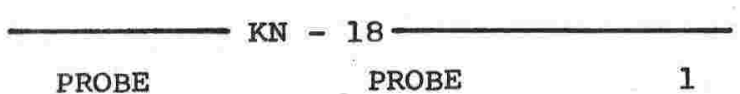

$\begin{array}{llllll}\mathrm{SLO}_{2} & 74.45 & (0.56) & 75.32 & (0.66) & 74.60\end{array}$

$\begin{array}{llllll}\mathrm{Al}_{2} \mathrm{O}_{3} & 10.60 & (0.15) & 10.56 & (0.19) & 10.53\end{array}$

$\begin{array}{llllll}\mathrm{TiO}_{2} & 0.15 & (0.03) & 0.17 & (0.03) & 0.18\end{array}$

FeO $\quad 3.40(0.11) \quad 3.55(0.10) \quad 3.45$

$\begin{array}{llllll}\text { MnO } & 0.06 & (0.04) & 0.06 & (0.04) & 0.06\end{array}$

$\begin{array}{llll}\text { MgO } & 0.01 & 0.01 & 0.01\end{array}$

$\begin{array}{llllll}\mathrm{CaO} & 0.15 & (0.06) & 0.14 & (0.04) & 0.15\end{array}$

$\begin{array}{llllll}\mathrm{Na}_{2} \mathrm{O} & 5.05 & (0.18) & 4.92 & (0.18) & 5.68\end{array}$

$\begin{array}{llllll}\mathrm{K}_{2} \mathrm{O} & 4.24 & (0.15) & 4.28 & (0.12) & 4.39\end{array}$

TOTAL $\quad 98.10$

N

48
99.02

48

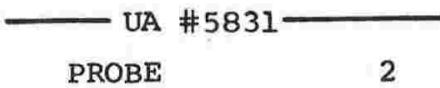

$74.21 \quad(0.71) \quad 74.09$

$13.21 \quad(0.19) \quad 13.12$

$0.06 \quad(0.02) \quad 0.09$

$1.49(0.10) \quad 1.72$

$0.06(0.03) \quad 0.06$

$0.05 \quad(0.02) \quad 0.07$

$0.72(0.03) \quad 0.76$

$4.32(0.17) \quad 4.06$

$4.78(0.16) \quad 5.04$

98.90

99.01

25

TABLE 7.1.4:

Means and standard deviations on 2 glass standards as determined by microprobe. Duplicate sets of analyses on KN -18 performed in March 1981 and September 1981.

1. Analysis from Nielsen \& Sigurdsson (1981)

2. Analysis from Smith \& Westgate (1971)

$N=$ number of analyses in mean. 
Statistical techniques are superior to graphical methods by using all data; up to 8 elements for probe analyses, or more if trace elements are available. Cluster analysis, a complex computer based matching technique, was used by Howorth \& Rankin (1975).

Borchardt et al. (1971) devised a percentage coefficient of variation (CV) that compared two sets of data. Values for one sample are divided, element by element, by values for the second, the quotients meaned and the CV calculated from the mean and standard deviation thus: For analyses $\mathrm{A}$ and $\mathrm{B}$, and elements $1,2, \ldots, \mathrm{n}$, the mean,

$$
\bar{x}=\left(\frac{A_{1}}{B_{1}}+\frac{A_{2}}{B_{2}}+\cdots \frac{A_{n}}{B_{n}}\right) \div n
$$

the standard deviation,

$$
s=\left(\frac{\sum(x-\bar{x})^{2}}{n-1}\right)^{\frac{1}{2}}
$$

and the coefficient of variation $\%$

$$
C V=100 \cdot s \cdot \sqrt{\bar{x}}
$$

For identical analyses the $\mathrm{CV}$ is 1.00. Borchardt et al. (1971), using neutron activation analyses deduced that CV values less than 15.0 indicated chemical similarity; i.e. the two analyses were indistinguishable. Coefficients of variation are more simple and direct than cluster analysis so are preferred here for an initial comparison of data.

To empirically set the upper limit on CV values for the glass probe analyses in this study, 7 analyses on Taupo Ignimbrite (Table 6.1.1) are compared. The samples were from sites which showed considerable variation in grain-size, thickness and apparent weathering. All were from crushed blocks except sample 1 from De Bretts where the natural 2-4 


\section{5}

shards were analysed. For all analyses, standard deviations for each element, especially $\mathrm{SiO}_{2}, \mathrm{FeO}$, and $\mathrm{CaO}$, are considerably higher than for most other tephras analysed. This is due to the wide range of shard types present, especially the high proportion of extremely vesicular, pumiceous shards that are difficult to probe. The 7 analyses are regarded as representing the extremes in analytical variation, and hence will produce maximum $\mathrm{CV}$ values. $\mathrm{CV}$ values comparing the 7 analyses are in Table 7.1 .5 and range from 4.84 to 17.70 with a mean of 9.72 . Only two values are over 15.0 and eleven values are below 10.0. All the CV's over 12 are due to comparisons with sample 1, from De Bretts; the only sample possibly contaminated by xenolithic material. Excluding sample 1, all CV values are less than 12.0 with a mean of 8.29. Comparisons to a non-correlative tephra - Mt. Curl (Table 7.1.2) - produces much greater CV's. They lie between 29 and 33 (Table 7.1.5) except for Sample $1(\mathrm{CV}=20.31)$ which further confirms that this analysis is not typical of Taupo Ignimbrite. 


\begin{tabular}{l|rrrrrrrr} 
& \multicolumn{1}{|c}{1} & \multicolumn{1}{c}{2} & 3 & 4 & 5 & 6 & 7 & 8 \\
\hline 1 & 1.00 & & & & & & & \\
2 & 15.82 & 1.00 & & & & & & \\
3 & 12.88 & 7.04 & 1.00 & & & & & \\
4 & 12.87 & 11.57 & 5.80 & 1.00 & & & & \\
5 & 17.70 & 4.98 & 5.99 & 7.32 & 1.00 & & & \\
6 & 9.88 & 11.54 & 6.01 & 6.75 & 11.56 & 1.00 & & \\
7 & 10.43 & 12.39 & 7.96 & 9.00 & 11.64 & 4.84 & 1.00 & \\
\hline 8 & 20.31 & 29.72 & 29.82 & 33.35 & 30.91 & 32.60 & 32.38 & 1.00
\end{tabular}

TABLE 7.1.5:

coefficient of variation values comparing 7 analyses of Taupo Ignimbrite from Table 6.3.2. Analysis 8 is Mt Curl Tephra (from Table 7.1.3) for comparison. 
7.2 TOWARDS A COMPREHENSIVE UPPER QUATERNARY TEPHRA AND IGNIMBRITE STRATIGRAPHY IN NEW ZEALAND USING ELECTRON MICROPROBE ANALYSIS OF GLASS SHARDS. A manuscript in press with; Quaternary Research. 


\title{
$14 i$
}

TOWARDS A COMPREHENSIVE UPPER QUATERNARY TEPHRA AND IGNIMBRITE STRATIGRAPHY IN NEW ZEALAND USING ELECTRON MICROPROBE ANALYSIS OF GLASS SHARDS

\author{
P.C. Froggatt, \\ Department of Geology, \\ Victoria University of Wellington, \\ Wellington, \\ New Zealand.
}




\section{$\underline{\text { ABST RACT }}$}

New Zealand Quaternary marine and terrestrial sequences contain numerous tephras or volcanic-ash horizons that are the distal correlatives of voluminous welded ignimbrite sheets, erupted from the central North Island. Electron microprobe analyses of glass shards from the distal tephras demonstrate their homogeneity and are shown to identify each tephra examined. By matching tephras from stratigraphically controlled sequences, the first comprehensive tephra stratigraphy spanning 50,000 to 700,000 years ago and covering the New Zealand region is advanced.

Analyses on glass shards from the unwelded base of ignimbrite sheets are comparable to the distal tephra analyses and allow correlation between ignimbrites and to the distal tephras. The better exposed tephra record constrains the number of separate eruptive events and the stratigraphy of the ignimbrites, both of which were previously confused by lack of outcrop.

Samples from pumiceous marine sediments were found to contain two or more chemically distinct populations of glass. The pumice is in cross-bedded sands or sand lenses within conglomerate, attesting to a shallow, high-energy environment where reworking could occur. However, each glass population could be matched to older, known tephras. 
INTRODUCTION

Widespread, voluminous tephras in New Zealand are commonly composed of two eruptive phases; a plinian (airfall) phase and an ignimbrite (pyroclastic flow deposit). Beyond the extent of the ignimbrite, fine-grained tephras are a common component of many upper Quaternary marine and terrestrial sequences, but it has not been possible to establish a firm correlation of the distal tephras to either of the eruptive phases. The distal tephras form distinctive marker horizons, especially valuable as widespread, geologically instantaneous time-planes. Numerous tephras, only occasionally preserved, and in a diversity of environments, means direct correlation is generally not possible. Identification of all these tephras would provide a strong stratigraphic and chronologic framework for many Quaternary studies, but physical appearance of tephras older than 50,000 years is seldom distinctive and only rarely an aid to identification.

The younger New Zealand tephras $(0-50,000$ years) are extensively preserved and well exposed in many outcrops and can be readily identified by direct stratigraphic control. older tephras that only crop out in a few sections can seldom be stratigraphically related with sufficient precision to correlate each tephra. Radiometric (fissiontrack) and paleomagnetic dating (Cox, 1969, 1971) of New Zealand ignimbrites and distal tephras has previously provided the only method of establishing relative stratigraphic 


\section{0}

positions and has been used to confirm tephra identification and to suggest possible tephra and ignimbrite correlations (Seward, 1974, 1975, 1976; Watkins and Huang, 1977; Naeser et al. 1980). Data for the tephras presented here suggest that similarity or dissimilarity of radiometric dates is not always a sufficient discriminator and that further information is required.

Many approaches to tephra "fingerprinting" based on glass or mineral chemistry have been documented, including electron probe analysis of glass (e.g. Smith and Westgate, 1969; Westgate and Fulton, 1975), neutron activation of glass (Borchardt et al., 1971), titanomagnetite trace elements (Kohn, 1970), and rare earth elements in glass (Howorth and Rankin, 1975). The latter two methods have been applied to New Zealand tephras but as both are bulk-sample-analysis techniques they are limited in application by problems of contamination or weathering, both common in the older terrestrial tephra sequences. These problems are minimised by using the electron microprobe which analyses polished internal surfaces of individual glass shards or minerals.

To test the usefulness of the probe for New Zealand tephra identification, samples of glass from tephras and ignimbrites from a wide range of stratigraphically controlled sites and in a variety of weathering environments have been analysed. The present study has been limited to tephras younger than 700,000 years but analysis of older tephras is 
proceeding.

\section{ANALYTICAL PROCEDURES}

Limited chemical data on the welded portion of New Zealand ignimbrites indicates vertical and lateral chemical zonation dependent entirely on the process of welding (Ewart, 1965; Briggs, 1973). Detailed studies of the mineral and glass chemistry of 2 unwelded ignimbrites and numerous plinian tephras (Froggatt, unpublished data, 1982) found no evidence for compositional zonation and this appears typical of New Zealand tephras.

For this study, samples of welded ignimbrites were considered unsuitable to characterise the glass chemistry of the deposits. However, most New Zealand welded ignimbrite sheets have an unwelded basal vitric ash zone of 1 to $5 \mathrm{~m}$ thickness that grades up to welded ignimbrite. Samples were collected from near the base of this zone where post-depositional alteration is visibly minimal. These basal ignimbrite sections are rare, and only one site is known for most sheets. Samples of airfall tephras were collected from the basal third to avoid potential contamination by reworking of the upper part.

\section{Sample Preparation.}

The 60 to 250-micron-size fraction of tephras, or crushed pumice where possible, was wet-sieved through nylon 
cloth, then the glass was concentrated using a Frantz isodynamic magnetic separator. The Frantz was used in preference to heavy liquids for speed and ease of operation and to avoid any contamination from the liquids. High purity separates were not necessary although these can be achieved on the Frantz (Rankin et al., 1975). Up to 7 glass shard samples per mount were embedded in epoxy resin then ground to about $0.1 \mathrm{~mm}$ thickness and polished. This polished thin section allowed samples to be viewed in transmitted light and optically pure glass to be selected during probe analysis.

\section{Microprobe Analysis.}

During analysis of glass, it is possible for the electron beam to alter element concentrations, especially alkalis, by either volatilisation and physical damage to the glass or $\mathrm{Na}^{+}$migration within the glass (Nielsen and Sigurdsson, 1981). This can result in unacceptably low Na values. To achieve optimum operating conditions with minimal $\mathrm{Na}$ loss, analyses were performed at various beam current and diameter settings. Sodium values were found to increase markedly as beam diameter was increased or beam current was lowered. However, as the current was lowered the count rate decreased, affecting counting statistics. This could be compensated for by increased counting times, but this too caused $\mathrm{Na}$ loss. 


$\begin{array}{ll}\text { Beam current: } & 8.0 \text { nanoamps } \\ \text { Beam diameter: } & 10 \text { microns } \\ \text { Peak counts: } & 3 \times 10 \text { sec counts, meaned. }\end{array}$

The fully automated JEOL JXA-733 "Superprobe" maintains a very steady beam current during analysis and use of a TAP crystal for $\mathrm{Si}, \mathrm{Na}, \mathrm{K}$ and $\mathrm{Mg}$ gives good results at the low current used. Calibration was made using mineral and synthetic standards and analyses were corrected for absorption, fluorescence, and atomic number after Bence and Albee (1968), alpha correction factors from Kushiro and Nakamura (1970) and A.L. Albee (pers. Comm., 1972), and corrections for dead time, background and probe current drift. Repeated analysis of glass standards (Table 1) provided a check on probe calibration and operation. At least 10 shards per sample were fully analysed as a check on homogeneity of samples, with the mean and standard deviations being used for all comparisons. All analyses are regarded as internally consistent and valid for comparison, but the representative analyses given in Table 3 should be used with caution for other purposes.

In general, the probe glass analyses did not total $100 \%$ but ranged down to $92 \%$. Low analysis totals are typical of volcanic glass and are regarded as the result of hydration (Smith and Westgate, 1969; Federman and Carey, 1980). This is confirmed in Table 2 where the mean difference from $100 \%$ for analyses on 8 tephras of various ages agrees within 1 standard deviation with the weight lost when heated 


\section{4}

TABLE 1. ANALYSES OF GLASS STANDARDS AND DETECTION LIMITS DETERMINED ON JEOL 733 MICROPROBE.

\begin{tabular}{|c|c|c|c|c|c|c|c|}
\hline & $\begin{array}{l}\text { - UA } \\
\text { PROBE }\end{array}$ & \#5831- & -1 & PROBE & - KN - & 2 & $\overline{\mathrm{D}}_{\mathrm{L}}$ \\
\hline $\mathrm{SiO}_{2}$ & 74.21 & $(0.71)$ & 74.09 & 74.45 & $(0.56)$ & 74.60 & 0.076 \\
\hline $\mathrm{A}_{2} \mathrm{O}_{3}$ & 13.21 & $(0.19)$ & 13.12 & 10.60 & $(0.15)$ & 10.53 & 0.058 \\
\hline $\mathrm{TiO}_{2}$. & 0.06 & $(0.02)$ & 0.09 & 0.15 & $(0.03)$ & 0.18 & 0.051 \\
\hline FeO* & 1.49 & $(0.10)$ & 1.72 & 3.40 & $(0.11)$ & 3.45 & 0.124 \\
\hline Mno & 0.06 & $(0.03)$ & 0.06 & 0.06 & $(0.04)$ & 0.06 & 0.040 \\
\hline $\mathrm{MgO}$ & 0.05 & $(0.02)$ & 0.07 & 0.01 & & 0.01 & 0.003 \\
\hline $\mathrm{CaO}$ & 0.72. & $(0.03)$ & 0.76 & 0.15 & $(0.6)$ & 0.15 & 0.031 \\
\hline $\mathrm{Na}_{2} \mathrm{O}$ & 4.32 & $(0.17)$ & 4.06 & 5.05 & $(0.18)$ & 5.68 & 0.067 \\
\hline $\mathrm{K}_{2} \mathrm{O}$ & 4.78 & $=(0.16)$ & 5.04 & 4.24 & $(0.15)$ & 4.39 & 0.047 \\
\hline TOTAL & 98.90 & & 99.01 & 98.10 & & 99.05 & . \\
\hline $\mathrm{N}$ & 25 & & & 48 & & & \\
\hline
\end{tabular}

* A11 Fe calculated as FeO

1. Reference analysis from Smith \& Westgate (1969)

2. " " Nielsen \& Sigurdsson (1981)

$\mathrm{N}=$ number of analyses

Numbers in brackets are 1 standard deviation.

$\mathrm{D}_{\mathrm{L}}=$ detection limit.

TABLE 2. COMPARISON OF PROBE ANALYSIS DEFICIENCY FROM $100 \%$ WITH LOSS ON IGNITION DATA.

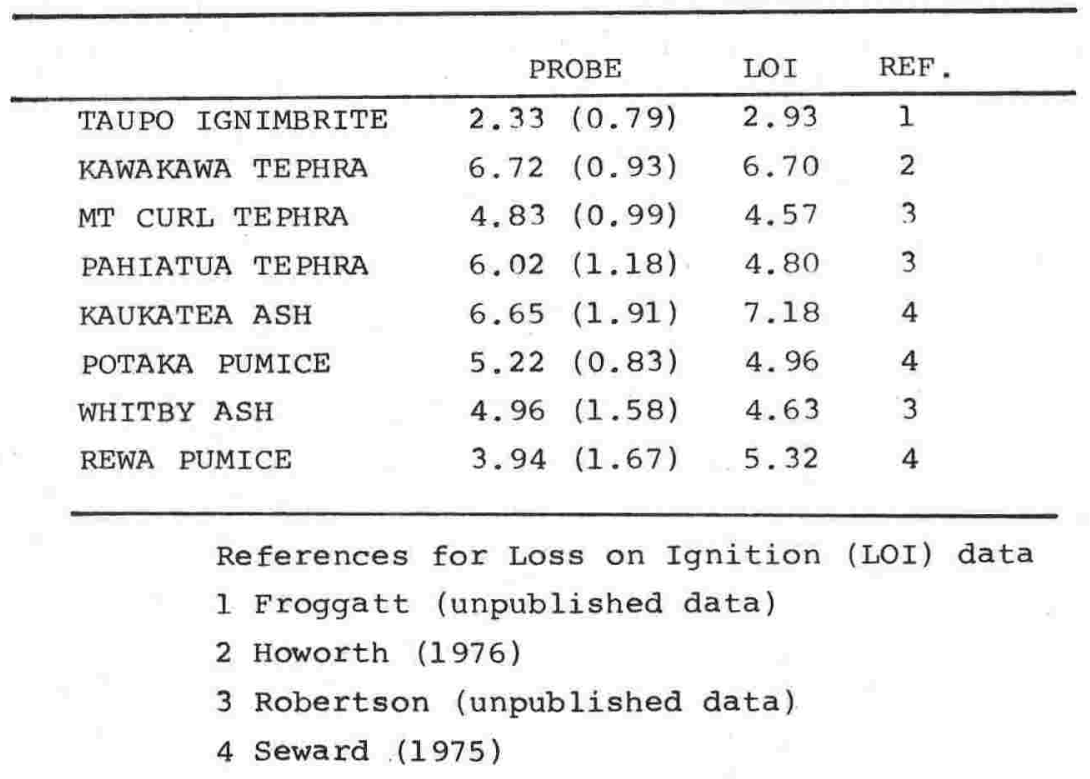




\section{5}

to $1000^{\circ} \mathrm{C}$.

STRATIGRAPHY OF TEPHRAS AND IGNIMBRITES

Stratigraphy of all rhyolitic tephras up to 50,000 years old is known in detail (Howorth et al., 1981), but knowledge for the older tephras and ignimbrites is sparce (Seward, 1976; Martin, 1961; Milne, 1973). Four important widespread tephras have been correlated on stratigraphy and field appearance and provide a stratigraphic framework for other tephras. These are Taupo Pumice (1800 yr), Kawakawa Tephra $(20,000 \mathrm{yr})$, Rotoehu Ash (about 45,000 yr), and Mt. Curl Tephra (about 230,000 yr). The three younger tephras have previously been mapped with associated ignimbrites. Taupo Pumice is the youngest eruptive from Taupo Volcanic Center (Healy et al., 1964) so is easily recognisable. Kawakawa Tephra (Vucetich and Howorth, 1976) is extremely widespread (Vucetich and Pullar, 1969; Kohn, 1979) and is commonly found in the youngest (Ohakean) loess in central New zealand. It typically has a white, very-fine ash at its base that is overlain by coarser pumiceous ash. Rotoehu Ash is a fine white bedded tephra, often overlying a prominent dark-brown paleosol. Mt. Curl Tephra has a distinctive, coarse, crystal-rich base that grades up to fine ash (Milne, 1973) and also has a wide distribution.

The stratigraphic position of the other tephras studied here is known or was inferred, where possible, 


\section{6}

relative to the above 4 tephras. Sections peripheral to the volcanic source area are important in preserving only the more widespread tephras. Also with lower accumulation rates in these sections compared to those nearer the source, more tephras and a longer timespan are exposed in accessible outcrops. Sections with two or more tephras provide important stratigraphic constraints and many such sections are used to establish the major stratigraphic framework. Detailed descriptions of the sites may be obtained from the author. Sections examined are scattered over most of the central part of New Zealand including the northern part of South Island (Fig. 1), but sections in Bay of Plenty, Wanganui Basin, Cape Kidnappers, and Rangitikei River provide the most stratigraphic data.

\section{STATE OF PRESERVATION OF THE TEPHRAS}

Most sections examined contain terrestrial sequences composed predominantly of loess or tephras with interbedded paleosols. In this environment, with rare exception only, the younger tephras $(<50,000 \mathrm{yr})$ are relatively fresh and unweathered. In older tephras, much of the glass has weathered to allophane or halloysite, so that in the Bay of Plenty, especially, isotropic glass shards are rare or absent. In these cases, finding sufficient polished shards for probe analysis was difficult, even after further concentration of the shards using bromoform. 


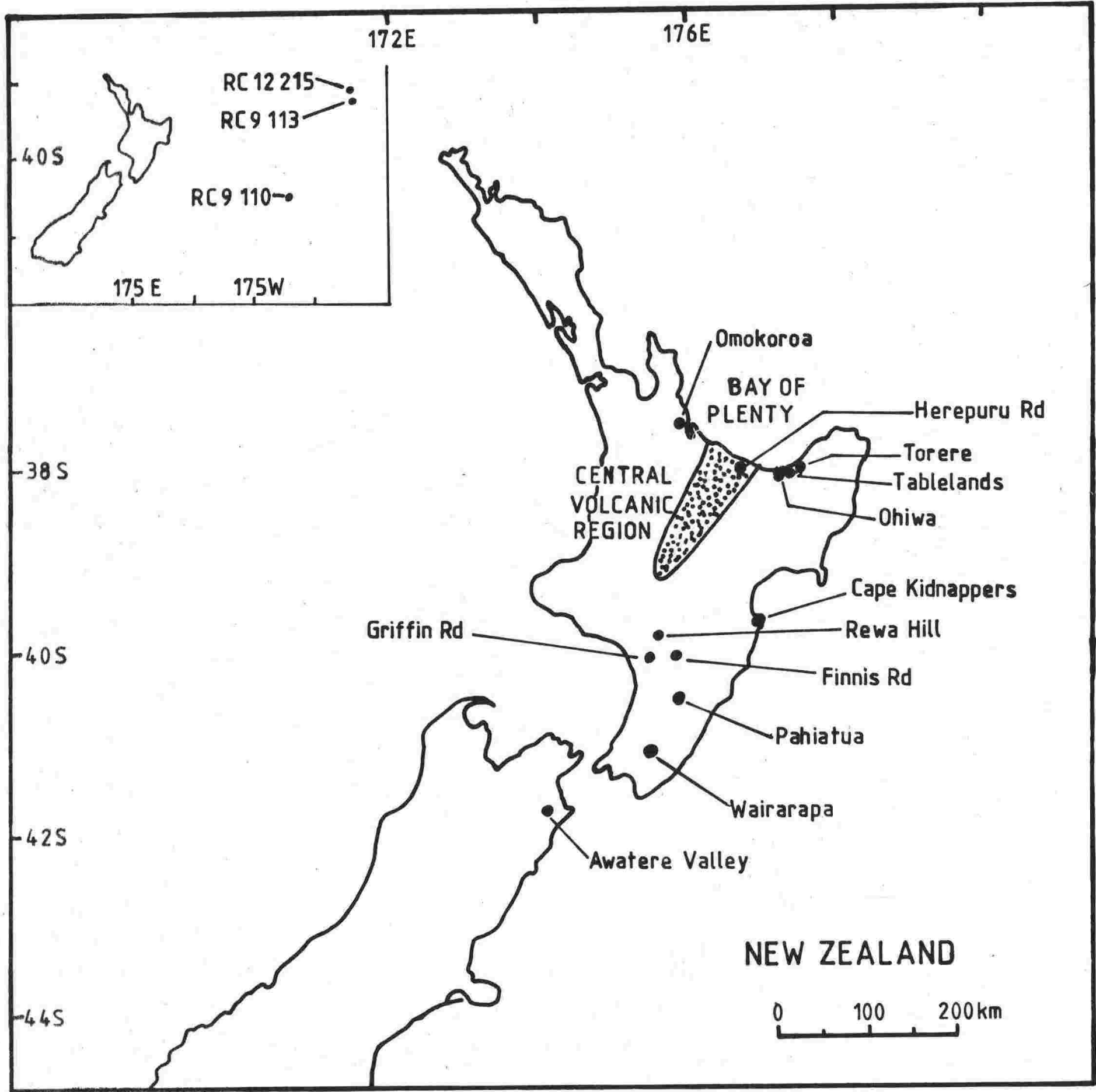

Figure 1: Location of sections and cores in the New Zealand region from which tephras have been analysed in this study. 
such as at Finnis Road and Herepuru Road were wellpreserved, with some hydration being the only detected weathering. However, tephras depositẹ in a shallow marine environment are susceptible to reworking and a pumiceous horizon formed by the mixing of two or more tephras is possible. Two chemically distinct populations of glass were recognized in several of the marine deposits, and the Cape Kidnappers samples are examined in more detail as an example of this.

TEPHRAS REWORKED IN A SHALLOW MARINE ENVIRONMENT

Cape Kidnappers provides over $6 \mathrm{~km}$ of continuous coastal exposure of gently westward-dipping marine and terrestial sediments (Kingma, 1971). Numerous pumiceous horizons crop out with one near the base being dated by fission-track analysis at about 850,000 yr (Seward, 1975). The four oldest tephras rest on beach sands or peat and are primary airfall material. A further eight pumice horizons analysed here are all within marine strata and commonly occur as layers or lenses of cross-bedded pumice-rich sands or silts. None are here considered primary. To test if the pumiceous sediment in each layer originated from more than one eruption, up to 20 or more shards were analysed. Mixed populations were suspected for samples where the meaned values had standard deviations higher than usual on the critical oxides of $\mathrm{SiO}_{2}, \mathrm{TiO}_{2}, \mathrm{FeO}$ and $\mathrm{CaO}$. The four oldest tephras are each chemically pure, as expected from their primary nature and as shown on Figure 2a. By regrouping 
Figure 2: Plots of FeO against Differentiation Index for individual glass shard analyses.

(a) The basal two tephras from Cape Kidnappers

(+ is oldest), that field evidence establishes

as primary, form tight clusters.

(b) Analyses on pumiceous horizons that are not primary airfall. Multiple glass populations indicate intimate reworking of tephras in their shallow marine environment. Glass from these horizons has been dated at $320,000 \mathrm{yr}(\mathrm{X})$ and 360,000 yr (0) respectively (Seward, 1975). 


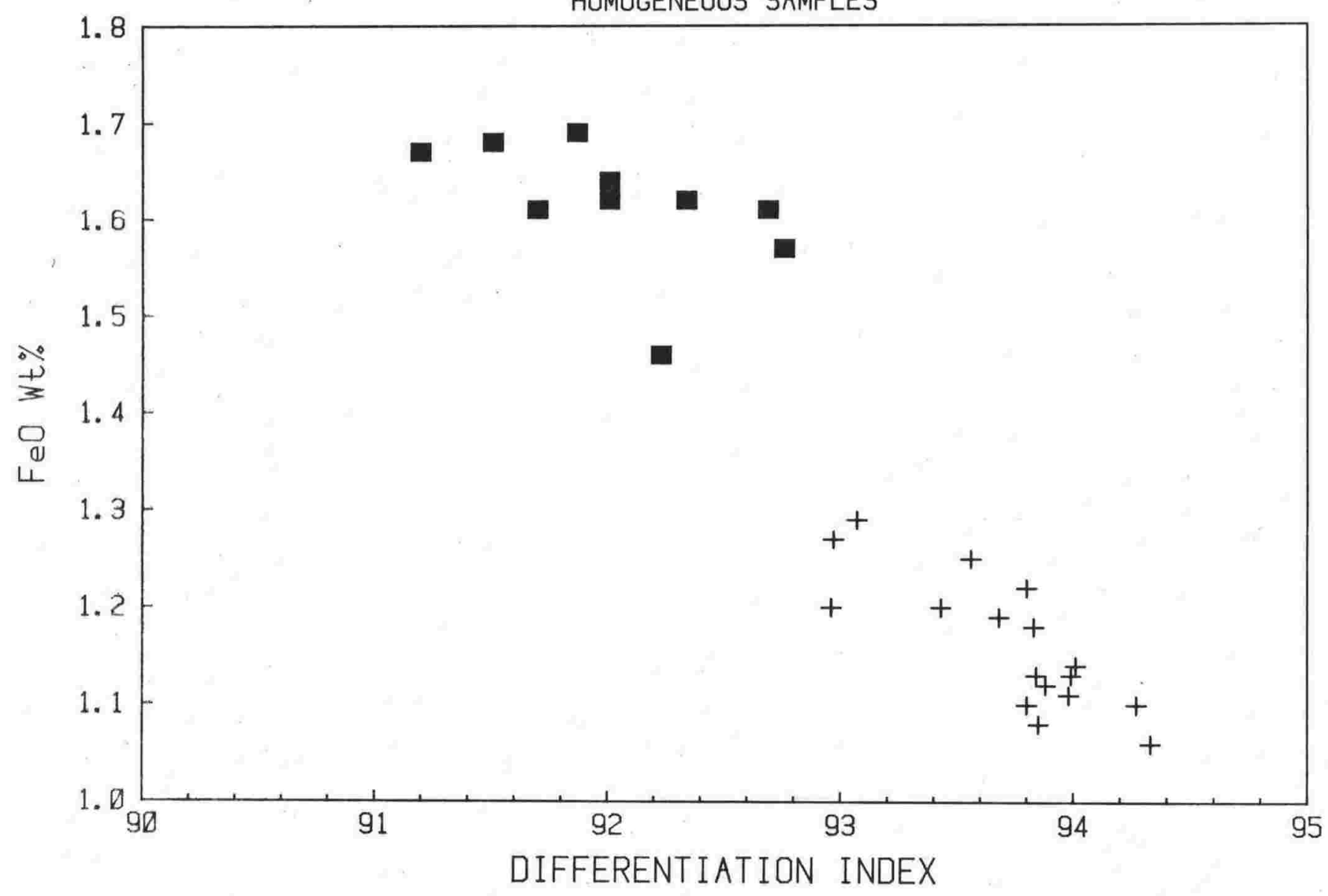

CAPE KIDNAPPERS TEPHRAS

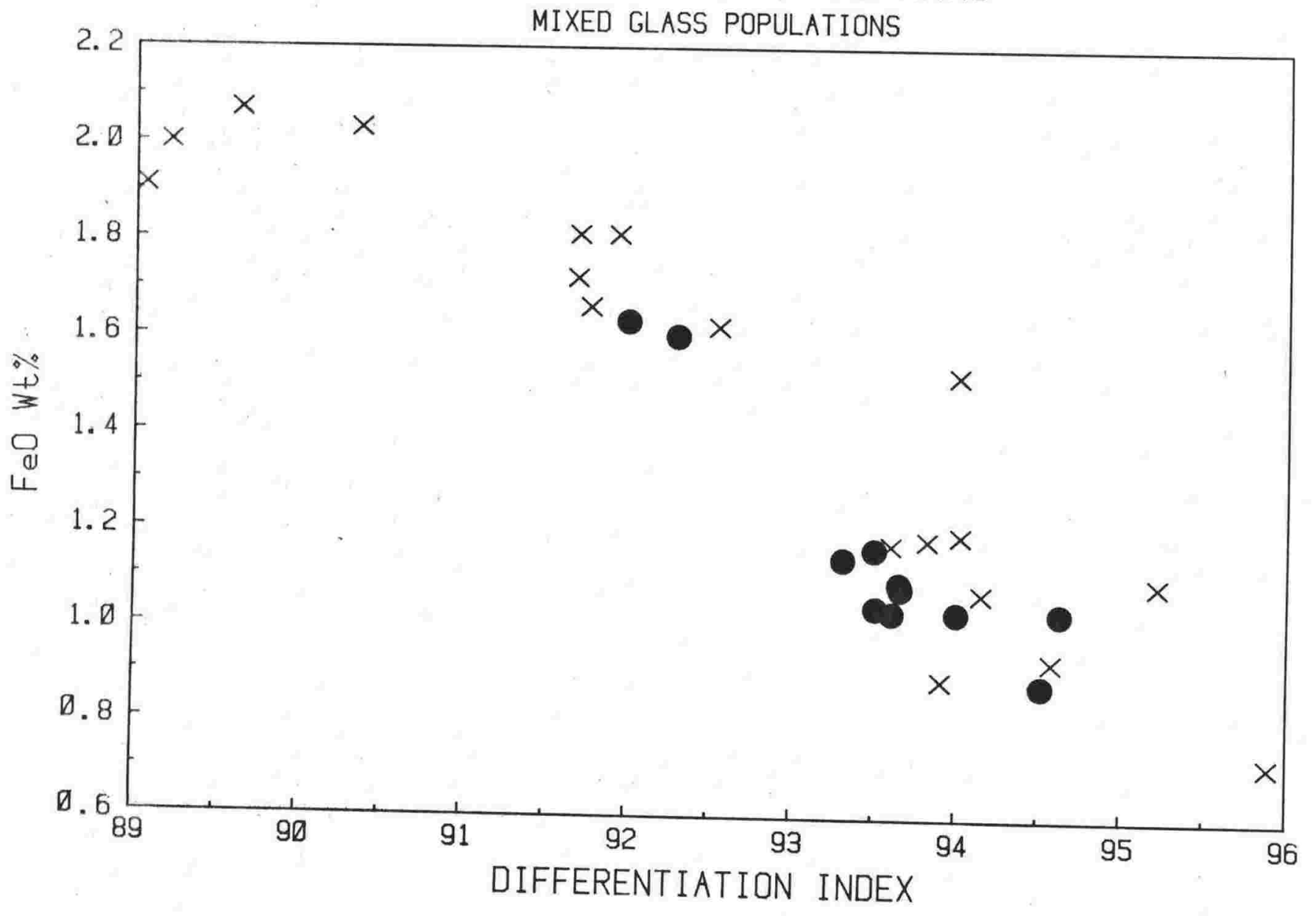


the analyses and calculating new means on each population, the identity of each group has been identified. Five samples are mixed, and from their chemical identity three others are reworked from older primary tephras. Multiple glass populations are confirmed by Figure $2 \mathrm{~b}$ where individual analyses on each sample cluster into several groups. A similar approach (Cerling and Cerling, 1978) showed the KBS Tuff of Kenya originated from several sources.

Multiple populations of glass have not been noted in any of the 200 tephra samples analysed from terrestrial sequences. Reworking of tephras must be common in a nearshore, high-energy environment where pumice often occurs in cross-bedded coarse sands or sand lenses within gravels. Pumice horizons in such sequences should be treated with caution if chemistry or radiometric dating is being attempted.

\section{TEPHRA CHEMISTRY}

Glass analyses indicate that all samples are rhyolitic $\left(>72 \% \mathrm{SiO}_{2}\right)$ with similar chemistry but varying amounts of most elements, especially alkalis. Representative analyses are given in Table 3, and further analyses are available from the author. In particular the $\mathrm{Na} / \mathrm{K}$ ratio varies considerably but is much less than 1.0 only for Whakamaru Ignimbrite, Mt. Curl Tephra, and their correlatives. To check if these values are consistent for one specific tephra and thus are significant and a useful criterion for identification, several samples of Mt. Curl Tephra from stratigraphically con- 


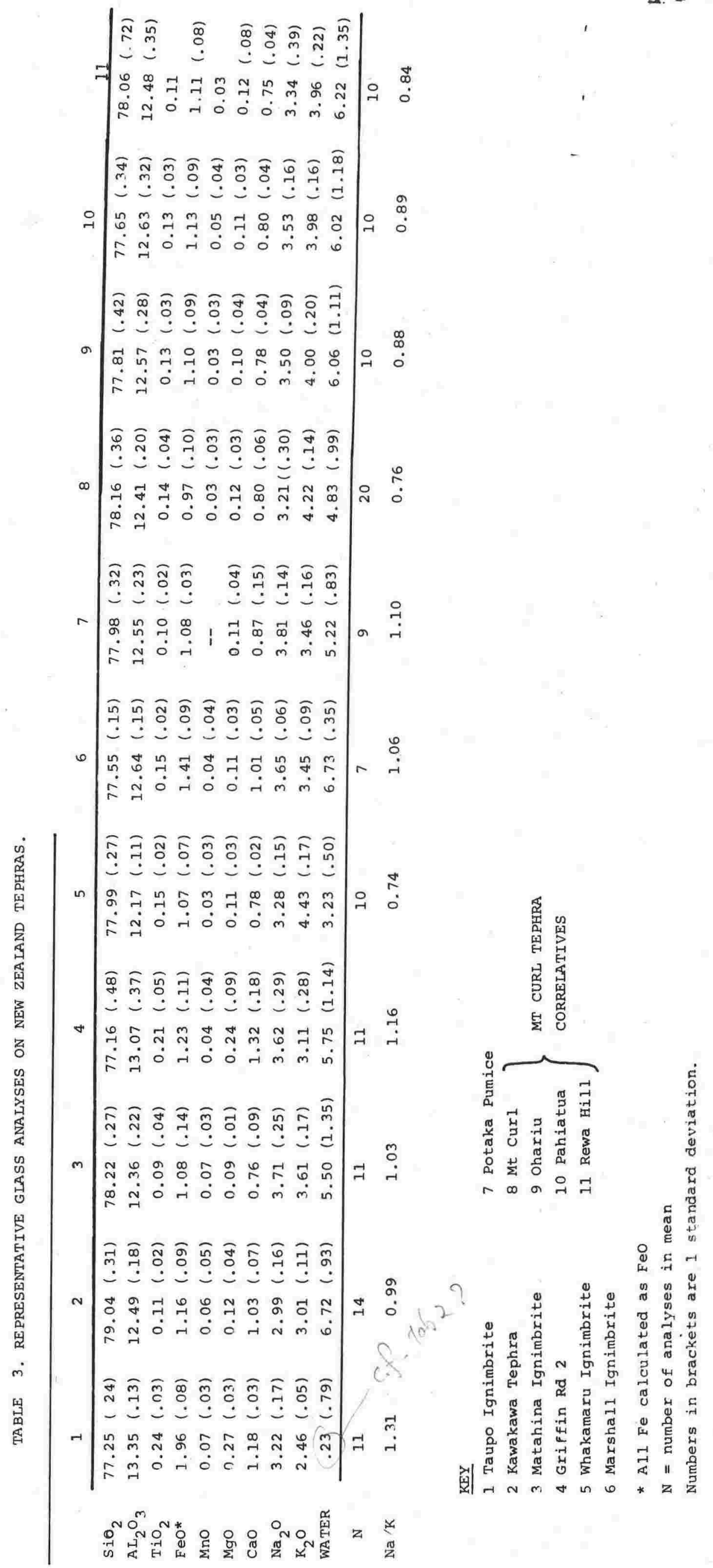


trolled sites in a variety of weathering environments were analysed. Despite differences in hydration (Table 3) due to weathering, the analyses are consistent within 1 standard deviation. Only Mno is too low in concentration and too variable to be useful for comparison. Using all elements except MnO, two analyses were compared by calculating a coefficient of variation. Pairs of analyses are divided, element by element, and from the mean $(\bar{x})$ and standard deviation $(\sigma)$ of the quotients, the coefficient of variation is calculated as $C V \%=100 \sigma \sqrt{x}$ (Borchardt et al., 1971). The smaller CV is, the more similar the analyses, and from comparison of analyses on a stratigraphically correlated tephra (Table 4) values less than about 12 are regarded as a good match. Experience in this study has shown that CV values are particularly sensitive to small differences in $\mathrm{TiO}_{2}, \mathrm{FeO}, \mathrm{MgO}$ and $\mathrm{CaO}$, all elements with small standard deviations. This simple statistical test, always in conjunction with available stratigraphic data is used here to establish chemical similarity and correlation of the tephra analyses. These criteria are considered sufficient to match and correlate samples of tephras from the same eruption and thus the same stratigraphic horizon.

\section{TEPHRAS IN ABYSSAL SEDIMENTS}

Rhyolitic tephras in piston cores taken to the east of New Zealand were first described and attributed a New Zealand source by Ninkovich (1968). Five tephras, named A to $\mathrm{E}$, were identified in core RC9-113. Further cores from 
TABIE 4. COEFFICIENT OF VARIATION VALUES FOR 6 SETS OF ANALYSES ON TAUPO IGNIMBRITE, ESTABLISHING A MAXTMUM VALUE OF 12.

\begin{tabular}{|c|c|c|c|c|c|c|}
\hline & 1 & 2 & 3 & 4 & 5 & 6 \\
\hline $\bar{I}$ & 1.0 & & & & . & \\
\hline 2 & 7.04 & 1.0 & & & & \\
\hline 3 & 11.57 & 5.80 & 1.0 & & & \\
\hline 4 & 4.98 & 5.99 & 7.32 & 1.0 & & \\
\hline 5 & 11.54 & 6.01 & 6.75 & 11.56 & 1.00 & \\
\hline 6 & 12.39 & 7.96 & 9.00 & 11.64 & 4.84 & 1.0 \\
\hline
\end{tabular}

TABLE 5. LOCATION DATA FOR THE THREE CORES AND DEPTHS OF TEPHRA SAMPLES STUDIED.

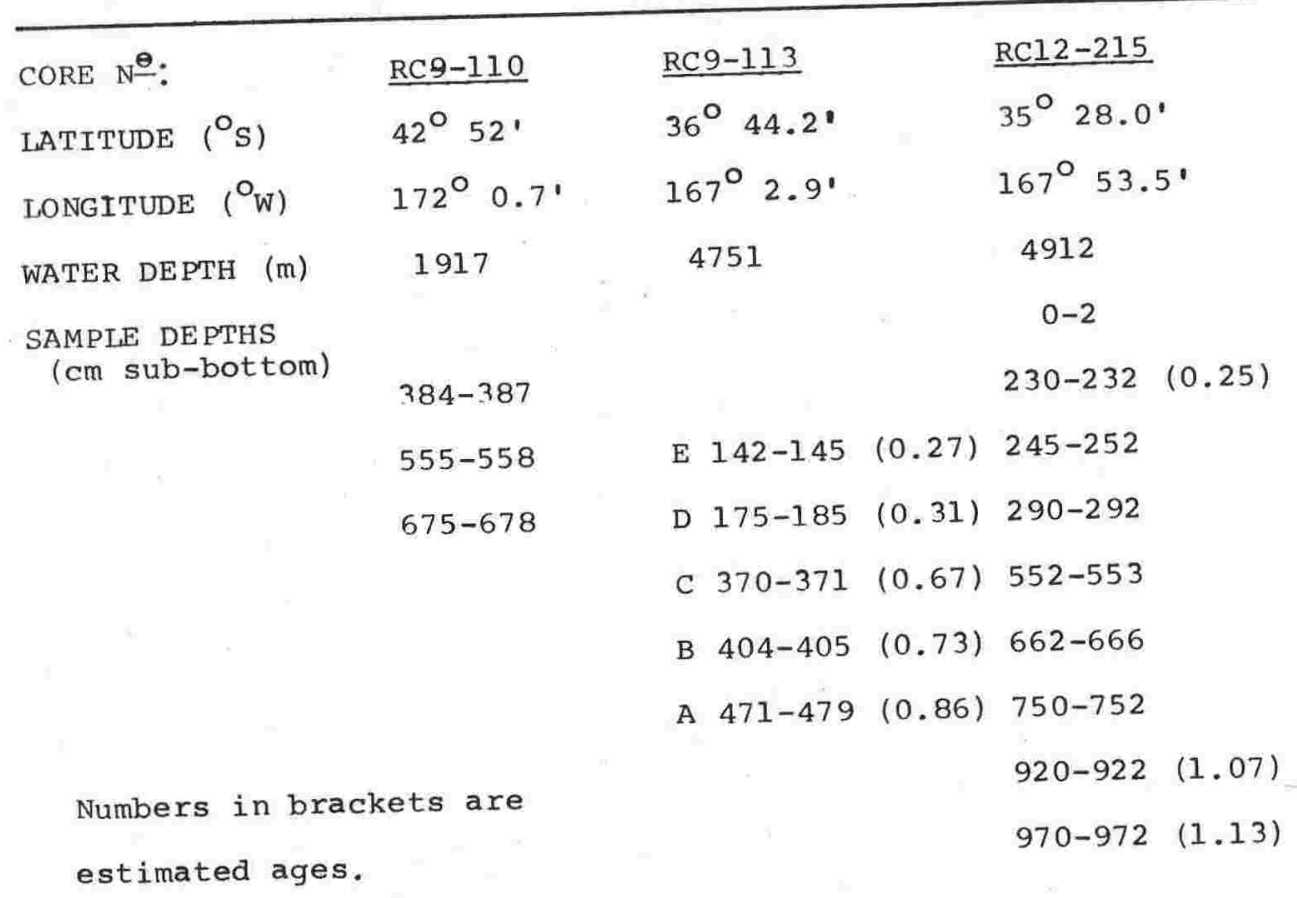


this region, studied by Watkins and Huang (1977) contain at least 17 visible tephras spanning 4 million years. Tephras were dated by sedimentation rates based on the paleomagnetic timescale and confirmed by two fission-track dates (Seward, 1974).

Glass samples of tephras from three cores (RC9-110, RC9-113 and RC12-215; see Table 5 for sample positions and estimated ages) have been analysed in this study. Coefficient of variation (CV) comparisons of glass analyses on the tephras in cores RC9-110 and RC12-215 with the "type" tephras (A to E) from core RC9-113 is given in Table 6 . Several stratigraphically distinct tephras have very similar glass chemistry (CV <12) but tephra $D$ is unique in having a high value of $\mathrm{K}_{2} \mathrm{O}$ $(>4.00 \%)$ and $\mathrm{Na}_{2} \mathrm{O} / \mathrm{K}_{2} \mathrm{O}$ ratio much less than 1.0 (typically 0.8). These analyses, together with the stratigraphic constraints that the cores provided lead to satisfactory correlations that confirm those of Watkins and Huang (1977).

\section{TEPHRA CORRELATIONS}

Using coefficient of variation (CV) values, all probe analyses were compared to establish stratigraphically consistent tephra correlations. Similar tephra chemistry was occasionally found to be repeated at different stratigraphic levels but most tephras were uniquely identified by their glass chemistry. Analyses of the "type" sample of each stratigraphically separate tephra are compared in Table 7. Kaingaroa Ignimbrite when compared to other tephras pro- 


\section{5}

TABLE 6. COEFFICIENT OF VARIATION VALUES COMPARING ANALYSES ON DEEP-CORE SAMPLES, TO THE 5 'TYPE' TEPHRAS.

\begin{tabular}{|c|c|c|c|c|c|c|c|c|c|c|c|c|}
\hline \multirow[b]{2}{*}{ RC 9-11.3 } & \multicolumn{9}{|c|}{$\mathrm{RCl} 2-215$} & \multicolumn{3}{|c|}{ RC9-110 } \\
\hline & 0 & 230 & 245 & 290 & 552 & 662 & 750 & 920 & 970 & 384 & 555 & 675 \\
\hline E & 29.58 & 6.40 & 4.48 & 14.85 & 6.83 & 8.74 & 14.15 & 18.05 & 6.18 & 14.06 & 5.62 & 7.83 \\
\hline D & 34.51 & 11.25 & 10.47 & 3.25 & 10.03 & 8.41 & 15.54 & 22.29 & 7.32 & 15.83 & 12.72 & 9.14 \\
\hline C & 28.60 & 5.27 & 5.31 & 13.15 & 3.62 & 3.82 & 13.82 & 17.30 & 7.29 & 15.92 & 5.41 & 11.39 \\
\hline B & 31.95 & 11.86 & $15 \quad 24$ & 11.74 & 13.67 & 7.41 & 10.79 & 22.26 & 13.70 & 21.38 & 13.57 & 13.90 \\
\hline A & 31.66 & 7.48 & 11.86 & 12.14 & 11.61 & 9.95 & 375 & 21.19 & 10.85 & 15.91 & 11.21 & 13.63 \\
\hline
\end{tabular}


166

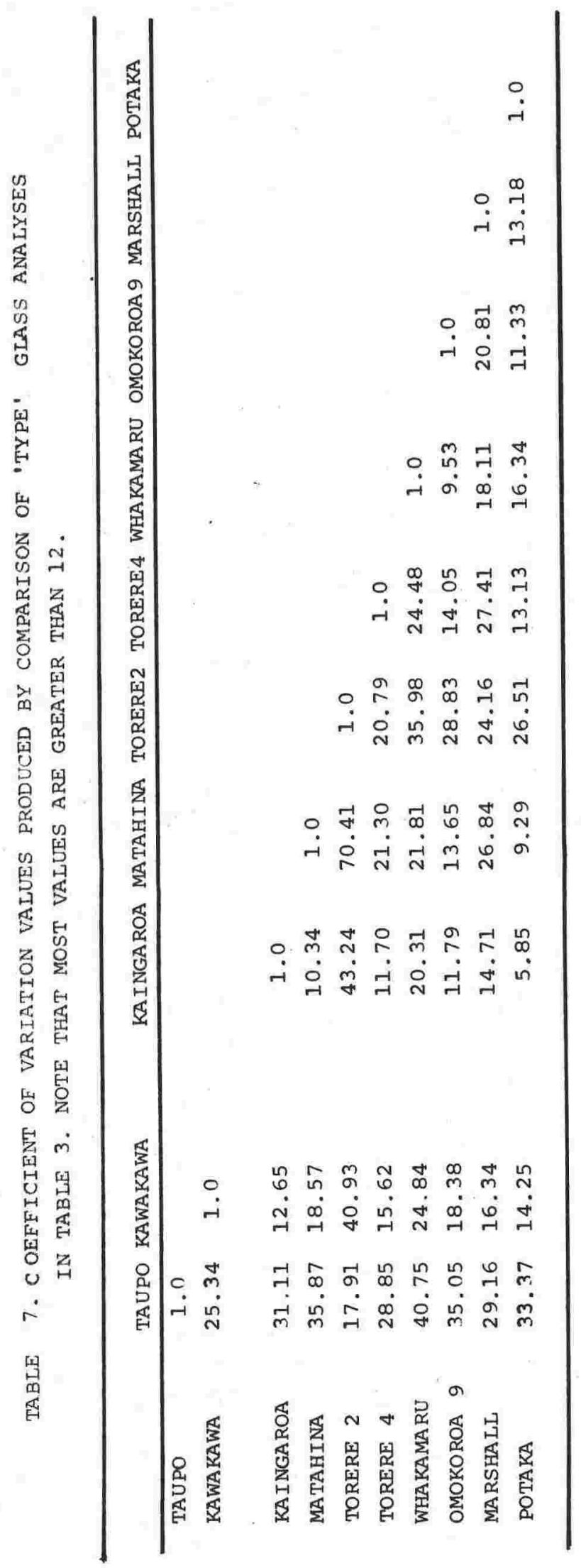




\section{7}

duces $4 \mathrm{CV}$ values less than 12 but with additional information only the similarity with Matahina Ignimbrite has the potential for mismatching. The other tephras are regarded as being uniquely "fingerprinted" by their glass chemistry. Resolution of any of the dual matching problems is aided by key tephras, especially Mt. Curl, that is readily identified by the low $\mathrm{Na} / \mathrm{K}$ ratio.

$\mathrm{CV}$ values that establish the tephra correlations between sections examined here are shown in Table 8 . They range from 4 to 15 but are mostly less than 12. Correlations based on the higher CV values in Table 8 are consistent with the stratigraphic positions of the tephras. The full stratigraphy and between site correlations are shown on Figure 3 .

Two other items lend support to the stratigraphic consistency of the correlations in Figure 3. Chemistry of the Griffin Rd 2 tephra is unique, with $\mathrm{TiO}_{2}, \mathrm{MgO}$, and $\mathrm{CaO}$ in particular almost double the values in all other tephras (Table 3). This chemistry is very distinctive and could not be easily miscorrelated. Also the tephra immediately above Mt. Curl Tephra: in the Bay of Plenty (e.g., at Torere and Tablelands) has a distinctive ferromagnesian mineralogy consisting of $90 \%$ cummingtonite, a mineral not yet found in any tephra older than Rotoehu Ash. Cummingtonite is, however, common in Rotoehu Ash and some younger tephras from okataina Volcanic Center (Ewart, 1968). These additional data add further weight to the tephra correlation techniques as a whole. 


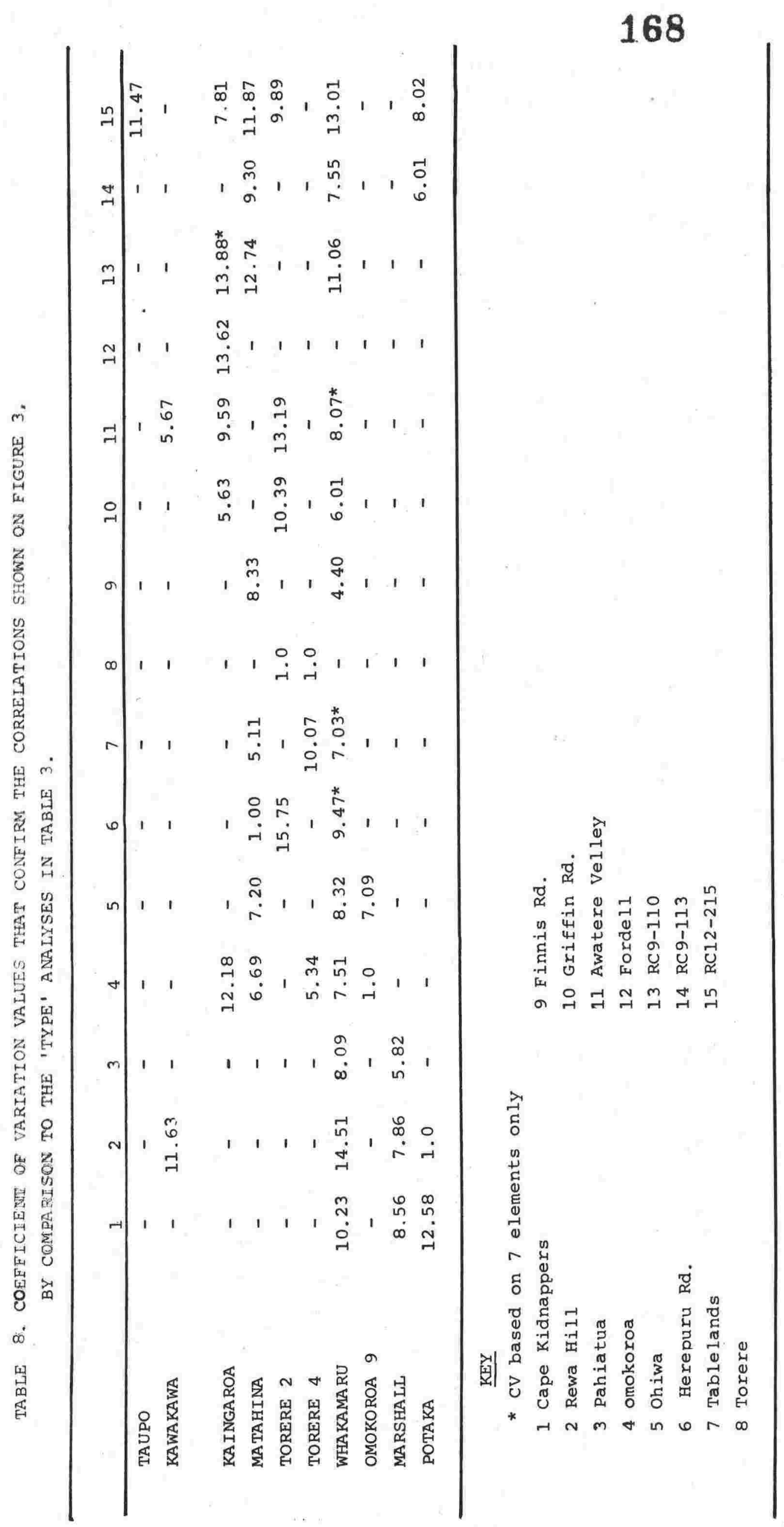


Figure 3: Correlation of tephras in the sections studied as developed from the glass analyses. Location of sections on Fig. 1. Columns are schematic only and not to scale. The unnamed right-most column is composite and shows named ignimbrites sampled at reference sections near to source. Tephras C, D, E on Core RC9-113 as named by Ninkovich (1968). 
169

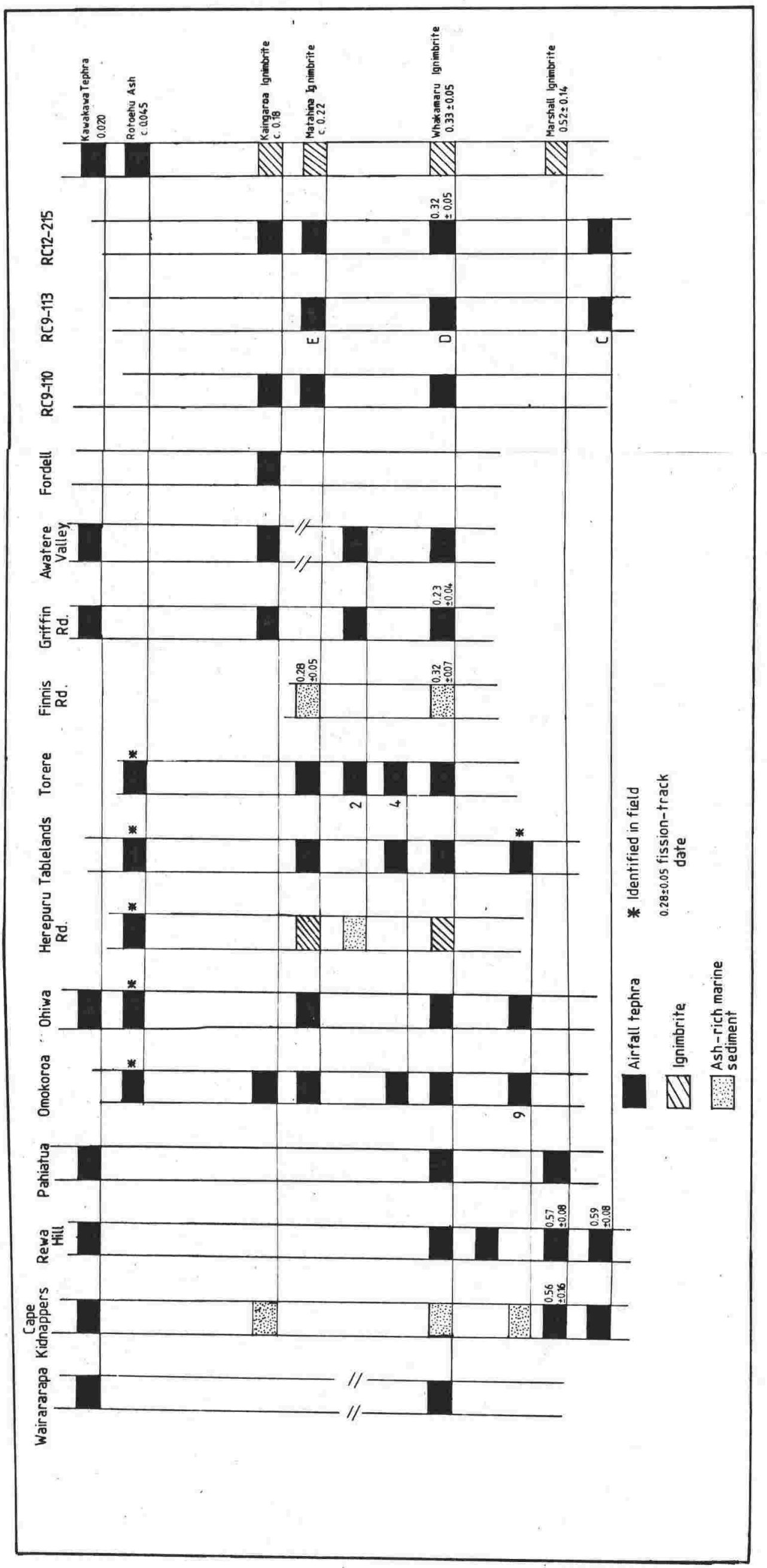


Included in Figure 3 are relevant published radiometric dates on these tephras. The dates are consistent with the chemical matching and agree with the ages estimated for the distal tephras in core RC9-113 (Ninkovich, 1968; Watkins and Huang, 1977).

\section{DISCUSSION}

The major purposes of this study were to establish a technique for microprobe analysis of glass and to attempt chemical discrimination of major widespread silicic tephras. The technique has shown differences in all major elements, and these are sufficient to characterise most of the tephras examined. By using sections with several tephras in known stratigraphic order a detailed tephra stratigraphy is built up that is consistent with other available data.

Use of the electron microprobe allows individual glass shards to be analysed and an initial analysis of about 10 shards per sample was found sufficient for characterisation. Chemically distinct, multiple populations of glass were recognised in some samples but only from pumiceous horizons in marine sediments. In all cases, the glass shards were not in a primary deposit but had been reworked into coarse cross-bedded sands or sand lenses within conglomerates. Some of these "tephras" from Cape Kidnappers have been fission-track dated (Seward, 1975, 1979), but such dates, on material derived from two or more distinct 
sources, are clearly of limited value. This problem will be faced by any bulk-sample analysis technique such as neutron activation or mass spectrometry but can only be resolved by the microprobe. Fortunately, such intimate reworking of two tephras is rare and at present only known in New Zealand from marine sediments. All other samples analysed appear to be homogeneous, validating bulk sample and dating analyses.

Samples from the unwelded basal layer of welded ignimbrite sheets contain abundant fresh glass shards whose chemistry is comparable to distal airfall tephras. Some of the widespread tephras are the airfall correlatives of ignimbrites but for others, no chemically similar ignimbrite is yet known. The stratigraphy of ignimbrites is less wellknown than the distal airfall tephras due to poor exposure, so the establishment of a detailed tephra stratigraphy and technique for matching distal tephras and ignimbrites will aid more detailed mapping of the ignimbrites.

Precise correlation of the distal airfall tephras to either the near-source plinian or pyroclastic flow phases is not yet possible. The majority of the distal tephras studied are correlated to an eruptive episode with a minor plinian phase but with a widespread pyroclastic flow phase. Many eruptive episodes are known with only a major plinian phase, and these have not produced a recognisable widespread distal airfall tephra on the scale of those studied here, suggesting the distal tephras are the product of pyroclastic 


\section{2}

flows. The widespread distal tephras may be equivalent to a co-ignimbrite airfall ash (Sparks and Walker, 1977).

Recognition of the Mt. Curl Tephra over much of New Zealand and correlation of this tephra to Whakamaru Ignimbrite indicates that this eruptive event was exceptionally large and voluminous. Mt. Curl Tephra is an important stratigraphic marker in the New Zealand region and is found in a critical position relative to a glacial/interglacial boundary. It is the subject of a further study, in which its widespread nature and stratigraphic importance are examined (Froggatt, unpublished ms.).

\section{CONCLUS IONS}

Use of the electron microprobe has allowed, for the first time, the establishment of a comprehensive volcanic stratigraphy for the upper Quaternary in New Zealand. The ability to identify widespread tephras found in a diversity of environments will allow the integration of work on marine and river terrace correlations, loess stratigraphy, palynology and a detailed paleoclimate analysis to be made. New Zealand, lying across the Indian-Pacific plate boundary, has been subjected to rapid and intense tectonic deformation, with much of the present topography being created in the last half million years. The preservation and exposure of the tephra sequences is largely due to recent rapid uplift and deformation. Identification of the tephras will provide a 
more precise chronology on the tectonic events.

\section{ACKNOWLEDGEMENTS}

Many people have provided comments and ideas

and assisted during the development of the work but I must especially thank C.G. Vucetich and R. Howorth for continual support and encouragement and J.A. Westgate for comments on the manuscript. Mr. K. Palmer instructed in the use and abilities of the microprobe; K.W. Calder and J. Brown prepared the probe mounts. Fieldwork was funded by the Internal Research Committee, Victoria University. Samples from the three deep sea cores were provided by B.P. Kohn. 
IDENTIFICATION AND CORRELATION OF

MT CURL TEPHRA AND WHAKAMARU IGNIMBRITE

USING ELECTRON MICROPROBE ANALYSIS OF GLASS.

A manuscript submitted to;

New Zealand Journal of Geology and Geophysics. 
IDENTIFICATION AND CORRELATION OF MT. CURL TEPHRA AND WHAKAMARU IGNIMBRITE USING ELECTRON MICROPROBE ANALYSES OF GLASS.

P.C. Froggatt Department of Geology, Victoria university of Wellington, New Zealand. 


\section{ABSTRACT}

Samples of Late Quaternary tephras preserved in a variety of terrestrial and marine environments have been examined for mineralogy and mineral and glass chemistry. Use of the electron probe to analyse single grains overcomes problems associated with bulk sample techniques. Few of the tephras can be correlated by stratigraphic methods but major element probe analyses of the glass identifies them all.

Chemical "fingerprinting" establishes the existence of only one demonstrably,stratigraphically separate tephra in the period 150-500 kyr, that matches Mt. Curl Tephra. Consequently, only one voluminous eruption with this chemistry has been preserved. Several ignimbrites of this age have identical chemistry, including Whakamaru, Rangitaiki and Te Whaiti, implying they were all formed from the same eruptive episode as Mt. Curl Tephra.

It is proposed to formally define Whakamaru Tephra Formation as consisting of the airfall Mt. Curl Tephra Member and the Whakamaru Ignimbrite Member which includes all deposits, both welded and unwelded, of pyroclastic flow origin. It is probably desirable to informally retain some existing names to designate location of a particular welding or weathering facies of Whakamaru Tephra Formation. 


\section{6}

Radiometric dates on Whakamaru Tephra range from 0.22 to 0.38 Myr with a mean of 0.30 Myr. The position of the tephra with respect to the Penultimate Interglacial sea level suggests an age of about 0.26 Myr for one of the largest and most widespread late Quaternary tephras in the New Zealand Region. 
INTRODUCTION

A widespread distinctive tephra preserved in loess in the Rangitikei River valley is named Mount Curl Tephra (Milne, 1973). The diagnostic field criteria of Mt. Curl Tephra are a coarse, crystal-rich base grading up to a fine ash top, the conspicuous phenocrysts being quartz, plagioclase and rare biotite. Milne also reported a $\mathrm{K}-\mathrm{Ar}$ date of $0.25 \pm 0.15 \mathrm{Myr}$ and a fission-track date of $0.23 \pm$ 0.04 Myr for the tephra at the type section.

Based on the characteristic field appearance of Mt. Curl Tephra, rhyolitic tephras of similar age preserved in loess or fluvial sediments at sites scattered over much of the southern North Island have been tentatively correlated to Mt. Curl Tephra. Each site has considerable local importance for stratigraphic correlation and chronology of late Quaternary cover beds that are essential to interpretation of paleoclimate, tectonics, and correlation of river terraces. Although the field appearance of the primary deposit is distinctive enough for nearly certain identification, examples of Mt. Curl Tephra preserved in marine sediments or reworked in loess lack this distinctive character and require some other means of identification. Direct dating can establish a chronology at each site, but the dates do not provide a positive tephra identification.

Direct correlation of distal airfall tephras to their near source correlatives, including ignimbrites, is 
extremely difficult due to lack of suitable exposures and to changes in the character of the tephra over a wide area. Correlatives may vary from a thick, welded ignimbrite to a thin unwelded unit, or to a sorted airfall deposit.

Several methods of identification based on chemistry have been used previously in an attempt to "fingerprint" Mt. Curl Tephra. Kohn (1973) analysed titanomagnetites from the tephra at Mt. Curl and from many central North Island ignimbrites but in contrast to younger tephras, made no correlations. Initial work involving bulk sample glass analyses of major and rareearth elements produced equivocal but encouraging results (R. Howorth, pers. comm.). Electron microprobe analysis of glass from many New zealand ignimbrites and their distal tephras was found by the writer to "fingerprint" each stratigraphically separate event and this enabled many tephra correlations throughout central New Zealand to be established (Froggatt, in press). Mt. Curl Tephra was shown to have a distinctive chemistry, not repeated by an demonstrably separate airfall tephra in the time range considered (150-500 $\mathrm{Kyr})$. Whakamaru Ignimbrite produced identical chemistry to Mt. Curl Tephra to which it was tentatively correlated.

Samples thought to be Mt. Curl Tephra and others of similar age are here examined and identification 
proposed. The extremely widespread dispersal of Mt. Curl Tephra is confirmed and the relationship between Mt. Curl, Whakamaru Ignimbrite and other North Island ignimbrites is discussed.

\section{TERMINOLOGY OF PYROCLASTIC DEPOSITS}

Tephra was defined by Thorarinsson (1974) as all the pyroclastic material ejected from a volcano including airfall and pyroclastic flow (ignimbrite) deposits. Ignimbrite is the deposit formed by one or more pyroclastic flows during one eruptive episode and may consist of several mappable units or "sheets". As originally proposed by Marshall (1935), ignimbrite is used here as a genetic term and does not imply a particular lithology. Usage in a lithostratigraphic sense (e.g. Martin, 1961) for the welded part of the sheet only, ignored or only tacitly implied the existence of a significant amount of unwelded material that is laterally or vertically continuous with the welded portion and clearly formed from the same flow(s). Welding is a post-depositional, "diagenetic" effect that forms new minerals, mostly tridymite and cristobalite, and causes intense chemical alteration and devitrification of glass. In many respects welding is analogous to weathering of thin airfall tephras.

Recent work on ignimbrites and coeval airfall tephras requires a redefinition of pyroclastic formations to include airfall and flow tephra, irrespective of welding or weathering. The concept of a Tephra Formation (Vucetich 
and Pullar, 1973) as a stratigraphic unit of variable lithology and very short time span is accepted. stratigraphically, the most important part of a tephra formation is the base which is regarded as geologically synchronous and defines a timeplane irrespective of the overlying lithologies. In welded ignimbrite facies, it is normally represented by an unwelded basal vitric ash. It is here proposed that each formation name that has been given to an ignimbrite (e.g. Whakamaru Ignimbrite) now be redefined as a tephra formation, to include all of the tephra deposits of the corresponding eruption or eruptive episode (e.g. Whakamaru Tephra Formation).

\section{STRATIGRAPHY}

\section{(a) Airfall Tephras}

In most exposures, the airfall tephras considered here are in isolated outcrops of limited stratigraphic context and stratigraphically based correlation from one site to another is not generally possible. Tephra morphology alone is not sufficient for positive correlation, over the large distances involved.

Only at 4 sites is a complete stratigraphy well enough preserved and documented to enable confident correlation of overlying loess unițs and hence the tephra. Direct correlation of loess units and Mt. Curl Tephra at Mt. Curl, Rangitikei (Milne, 1973), Rangitatau Road, Waverley (Wilde1979), Pahiatua, north Wairarapa (Keawyana, 1980) and Haywards, Wellington (Jakobsson, 1976) is established. (See 

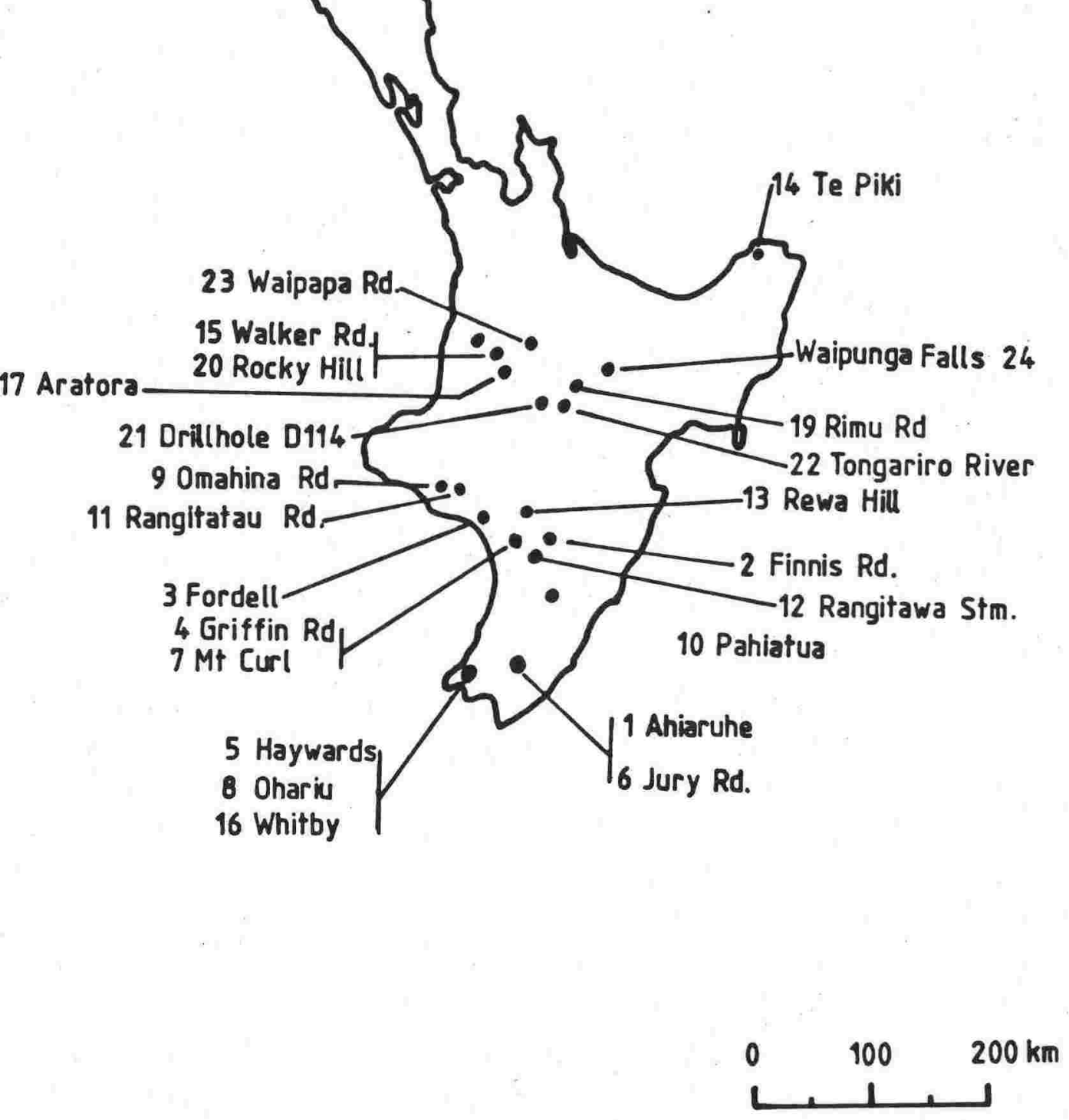

FIGURE 7. 3.1:

Location of sampling sites in North Island, New Zealand.

Site numbers refer to descriptions in Appendix 1. 
Fig. 1 for location of sites). In the 4 sections, 6 loess units paraconformably overlie a rhyolitic tephra that has Mt. Curl characteristics. From the stratigraphy and loess correlations, the tephra at each site is here accepted to be Mt. Curl Tephra.

The terrestrial depositional record preserved in the Rangitikei Valley and at Pahiatua is apparently complete back to the Waituna (Milne, 1973) or Ridge Road 3 (Keawyana, 1980) loess. In both regions, Mt. Curl Tephra is the oldest and largest tephra preserved. To occur over such a wide area it must be the product of an exceptionally large Central North Island eruption. If the loess and tephra record is complete then the Mt. Curl Tephra is the oldest tephra to be preserved in these terrestrial sequences. Several sites preserve Mt. Curl and stratigraphically younger tephras but no section is currently known that has a tephra lying close to, but stratigraphically below Mt. Curl Tephra. At Saddle Road, Pahiatua and at Rewa Hill, a tephra preserved in marine sediments lies immediately beneath a thick sequence of coarse greywacke gravels that underlie Mt. Curl Tephra. In both cases the tephras are considered to be much older than Mt. Curl and both have different glass chemistry: the Pahiatua saddle Road tephra matching the glass chemistry of Kaukatea Ash dated at $0.57 \pm 0.08$ Myr (Seward, 1976), but a correlative of the Rewa Hill ash is at present unknown. 
(b) Ignimbrites

The stratigraphic relationship of Whakamaru and other similarly aged ignimbrites, is largely inferred from limited outcrops. Several formally and informally named ignimbrites at various places are recognised as possible correlatives. Whakamaru, Rangitaiki, Te Whaiti, Manunui, Wairakei and Rocky Hills Ignimbrites are all closely related in stratigraphic position, radiometric age and chemistry (Kohn, 1973). Each ignimbrite was defined in a geographically separate region and no stratigraphic section has shown their precise stratigraphic positions or equivalence.

Grindley (1960) separately mapped and defined. Whakamaru and Rangitaiki Ignimbrites, formations previously regarded (Grindley, 1959) as one entity. Manunui Ignimbrite (Martin, 1961) was mapped to the west of Whakamaru Ignimbrite and some field evidence led Martin (1961), Blank (1965) and Briggs (1976) to regard Manunui as a lateral facies of Whakamaru Ignimbrite. Te Whaiti Ignimbrite (Grindley, 1960) is considered to be a lateral facies of Rangitaiki Ignimbrite (Martin, 1961; Kohn, 1973) as is the Wairakei Ignimbrite of Beck and Robertson (1955). Rocky Hills Ignimbrite was defined by Martin (1961) from the type section at Rocky Hill (N83/816747)* and was mapped as isolated remnants scattered over the western king country at sites where Manunui Ignimbrite is absent. Martin (1961)

* Grid references based on national 1000 yd grid of $1: 63,360$ map series. 
stated that the Rocky Hills Ignimbrite "... unconformably overlies the Ahuroa and presumably the Manunui Ignimbrites ..." but near "... Tokoroa it forms inliers projecting above the surface of the younger Whakamaru". Rocky Hills Ignimbrite rests with marked discordance on an erosion surface on older ignimbrites or greywacke and is not known in stratigraphic contact with Whakamaru Ignimbrite (Blank, 1965). Whakamaru, Rangitaiki, Te Whaiti and Manunui similarly rest on a marked unconformity (Martin, 1961; Blank, 1965). Whakamaru is observed resting on a strong paleosol at Waipapa Road (N84/192787); Rangitaiki on a cut greywacke surface at Rimu Road (N112/392988) and Waipunga Falls (NI04/963055). Field relations suggest Rocky Hills Ignimbrite as mapped may be a lateral correlative of Manunui (= Whakamaru) in western-most sections but may be an older ignimbrite in the central region of Arapuni and Tokoroa.

\section{TEPHRA SITES STUDIED}

Sites examined are described in Appendix 1 and located on Fig. 1. The tephras sampled range from pure fresh glassy coarse ash to silty clay (allophane or halloysite) with almost no glass remaining. In all cases, subhedral phenocrysts of quartz, feldspar, pyroxene, amphibole and magnetite, clearly visible in the field attested to a volcanic origin. In outcrops of considerable lateral extent (50m or more) the tephra generally may be followed as a semicontinuous horizon, conformable or paraconformable with enclosing beds. At many sites, the upper part of the tephra 


\section{5}

is apparently overthickened. Samples were collected from the coarse "sugary" basal layer because this is regarded as the purest part of the tephra. Where the tephra is strongly weathered and volcanic glass rare, the basal layer can often be identified by the presence of large quartz and feldspar crystals; at such sites a larger channel sample was taken in order to extract enough glass for analysis.

Ignimbrites were sampled by collecting from the basal unwelded vitric ash layer, as near to the lower contact as possible. It is assumed that glass from this position is unaltered and not affected by post-depositional alteration or welding of the overlying material. For the few samples from unwelded ignimbrite outcrops, only large pumice clasts were collected.

\section{ANALYTICAL TECHNIQUES}

As discussed in Froggatt (in press), a probe current of $8 \times 10^{-9}$ amps and 10-20 micron beam diameter was used for all glass analyses to minimise alkali loss. Wherever possible at least 10 shards were analysed and the results meaned. Between 4 and 10 individual phenocrysts of pyroxenes and Fe-Ti oxides were also analysed. Only the mean and standard deviation for each is listed here (see Table 3). Further data may be obtained from the author. Feo has been recalculated for the Fe-Ti oxide minerals assuming stochiometry, after the method of Carmichael (1967). 


\section{6}

\section{MINERALOGY}

For all tephras studied, phenocrysts constituted about $10 \%$ of the original tephra; plagioclase, magnetite and ilmenite being ubiquitious. varying proportions of pyroxenes, amphibole and biotite were noted and sanidine has been reported in some outcrops of Whakamaru Ignimbrite (Martin, 1961).

Variation in mafic mineralogy between different tephras is well established as one technique for identification and correlation (Martin, 1961; Ewart, 1967a, b, 1968; Kohn, 1973; Howorth et al., 1980). Mineral percentages for the tephra at each locality (Table 1) are similar except for the absence of biotite in some samples. The assemblage hypersthene-hornblende-biotite is not common in central North Island exuptives (Martin, 1961; Kohn, 1973) so the presence of biotite is significant. The biotite varies from black to pale golden-yellow, apparently dependent on intensity of weathering, but many optical properties are unaffected, especially the optic-2V angle of $5-10^{\circ}$.

The intensity of chemical weathering at the sites studied is clearly reflected by both the stage of preservation of each mineral species and the variations in the mineral species. In the more weathered samples hypersthene is severaly corroded, often with only joined bi-pyramidal forms remaining. Similarly the biotites exhibit rounded forms, massive degradation and pale gold colours, whereas hornblende, magnetite and ilmenite show few weathering 


\section{$18^{7}$}

\section{SAMPLE}

1 Ahiaruhe

2 Finnis Rd (lower)

4 Griffin Rd (upper)

(lower)

6 Jury Rd

7 Mt Curl (type sect)

8 Ohariu Valley

9 Omahina Rd

10 Pahiatua tephra

11 Rangitatau Rd

12 Rangitawa Pumice

13 Rewa Hill

15 Walker Rd

16 Whitby ash

17 Aratora

18 Ellis Rd

19 Rimu Rd

20Rocky Hill (top)

22 Tongariro River

23 Waipapa Rd

24 Waipunga Falls

\section{HYPERSTHEN}

70

50

36

40

71

77

55

52

56

39

65

45

84

66

39

74

53

41

65

48

67
AUGITE BIOTITE Hyp/Hornb

23

50

44

51

23

20

41

31

32

30

24

35

15

33

60

26

44

59

32

27

33

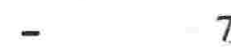

7

- *

- 20

$-9$

- 6

tr 3

tr 4

- 17

12

tr

10

20

1

tr

1

tr

3

tr

2

25

tr
3.00

1.00

0.82

0.78

3.17

3.76

1. 34

1.68

1.78

1. 30

2.71

1.27

5.60

2.00

0.65

2.96

1.21

0.70

2.03

1.78

2.03

* Abundant biotite, not counted.

tr $=$ trace amount observed.

\section{TABLE 7, 3.1:}

Ferromagnesian mineral proportions based on at least 300 counts per sample. Sample locations are shown on Figure 1 and described in Appendix 1. 
effects except perhaps an increase in surface pitting. Chemical dissolution of hypersthene will have lowered the proportion in the size fraction studied $(63-250 \mu)$, shown by a decrease in the hypersthene/hornblende ratio (Table 1). Samples with the lower ratios have the more corroded hypersthenes.

\section{GLASS CHEMISTRY}

(a) Bulk sample analyses

Differences in major element analyses on Mt.

Curl Tephra were considered not significant or consistent enough for positive correlation given the errors in bulk sample analysis. Table 2 lists some of these analyses, also recalculated on a loss-free basis for comparison. The high value of $\mathrm{Al}$ in the Pahiatua Tephra suggests some feldspar contamination, which would also affect Na. This highlights the problem of bulk glass analyses. The Mt. Curl and Haywards analyses are similar, in particular potassium is at least 0.5 weight $\%$ greater than sodium for both samples. This distinguishes these tephras from Whitby Ash which has $\mathrm{Na}>\mathrm{K}$. Note that the $\mathrm{Na} / \mathrm{K}$ ratio could easily be affected by feldspar contamination, as in the Pahiatua tephra, a problem avoided by microprobe analysis.

(b) Probe Analyses

Raw probe analyses for each tephra do not total $100 \%$ but ranged down to $92 \%$. Low analysis totals are typical of rhyolitic glass and are regarded as the results 


\begin{tabular}{|c|c|c|c|c|}
\hline & i.t Cus I & irivands & Felliatue & anitby \\
\hline $\mathrm{S}^{\mathrm{C}_{2}}$ & 73. & 73.55 & 63.72 & 72.33 \\
\hline $\mathrm{TiO}_{2}$ & 0.14 & 0.15 & 0.25 & 0.21 \\
\hline $\mathrm{Al}_{2} \mathrm{O}_{3}$ & 11.74 & 11.38 & 17.14 & 12.14 \\
\hline $\mathrm{Fe}_{2} \mathrm{O}_{3}$ & 1.16 & 1.14 & 1.03 & 1.71 \\
\hline I.no & 0.02 & 0.02 & 0.02 & 0.05 \\
\hline I.gO & 0.17 & 0.54 & 0.13 & 0.42 \\
\hline $\mathrm{CaO}$ & 0.79 & 0.75 & 0.64 & 0.95 \\
\hline $11 a_{2} \mathrm{O}$ & 3.47 & 3.65 & 4.07 & 4.21 \\
\hline $\mathrm{K}_{2} \mathrm{O}$ & 4.23 & 4.15 & 3.10 & 3.20 \\
\hline $\mathrm{P}_{2} \mathrm{O}_{5}$ & - & 0.01 & 0.10 & 0.03 \\
\hline LOI & 4.57 & 4.63 & 4.30 & 4.63 \\
\hline TOTAL & 99.34 & 100.19 & 100.70 & 99.38 \\
\hline $\mathrm{H} E / \mathrm{K}$ & 0.320 & 0.330 & 1.313 & 1.316 \\
\hline U & 2.2 & 2.7 & 3.6 & 1.3 \\
\hline Th & 12.6 & 14.5 & 14.0 & 9.9 \\
\hline $\mathrm{Pb}$ & 17.5 & 23.1 & 33.0 & 17.5 \\
\hline Hf & 3.1 & 3.4 & 4.3 & 5.3 \\
\hline Yb & 2.3 & 2.6 & 2.4 & 3.4 \\
\hline $\operatorname{Er}$ & 1.3 & 1.3 & 2.0 & 3.0 \\
\hline : & 0.6 & 0.6 & 0.63 & 1.3 \\
\hline Dy & 3.4 & 3.3 & 3.1 & 4.7 \\
\hline $\mathrm{Tb}$ & 0.5 & 0.5 & 0.6 & 1.0 \\
\hline Gd & 3.3 & 3.3 & 3.2 & 4.7 \\
\hline Ëu & 0.5 & 0.5 & 0.7 & 1.0 \\
\hline Sa & 3.6 & 3.6 & 2.3 & 5.2 \\
\hline Itd & 19.2 & 20.3 & 12.0 & 27.4 \\
\hline $\begin{array}{l}\mathrm{Pr} \\
\mathrm{Ce} \\
\mathrm{La}\end{array}$ & $\begin{array}{r}6.4 \\
43.4 \\
29.7\end{array}$ & $\begin{array}{r}6.7 \\
46.4 \\
23.6\end{array}$ & $\begin{array}{r}3.3 \\
23.0 \\
16.0\end{array}$ & $\begin{array}{r}7.4 \\
61.9 \\
30.1\end{array}$ \\
\hline $\mathrm{Ba}$ & 1125 & 997 & 640 & 839 \\
\hline $\mathrm{Cs}$ & 10.2 & 3.3 & 7.4 & $4 \cdot 3$ \\
\hline Sn & 2.0 & 2.3 & 5.6 & 2.5 \\
\hline$\therefore b$ & 10.4 & 10.1 & 5.3 & 15.7 \\
\hline $\mathrm{Zr}$ & 106 & 152 & 250 & 370 \\
\hline$Y$ & 32.4 & 26.0 & 15.0 & 54.0 \\
\hline $\mathrm{Sr}$ & 53.0 & 46.9 & 60.0 & 71.1 \\
\hline $\mathrm{Ga}$ & 23.1 & 17.0 & nd. & 21.3 \\
\hline $\mathrm{Cu}$ & 14.4 & 0.2 & nd & 15.5 \\
\hline $1 i i$ & 3.2 & 1.3 & nd & \\
\hline v & 9.2 & 3.6 & nd & 4.7 \\
\hline $\mathrm{Sc}$ & 14.9. & 4.7 & nd & 13.6 \\
\hline 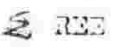 & $117.3^{\circ}$ & 122.1 & 72.0 & 156.9 \\
\hline
\end{tabular}

TABLE $7.3 .2:$

Chemistry of bulk glass separates from 4 samples. Major elements by XRF and others by spark source mass spectrometer (Howorth and Rankin, 1975). $\mathrm{High} \mathrm{Al}_{2} \mathrm{O}_{3}$ and $\mathrm{TiO}_{2}$ in the Pahiatua sample suggests some contamination. All data from Howorth (unpublished). 


\begin{tabular}{|c|c|c|c|c|c|c|c|c|c|c|c|c|c|c|}
\hline \multirow[b]{2}{*}{$\mathrm{SiO}_{2}$} & \multicolumn{2}{|c|}{1} & \multicolumn{2}{|c|}{$3 / 1$} & \multicolumn{2}{|c|}{$3 / 2$} & \multicolumn{2}{|l|}{$3 / 3$} & \multicolumn{2}{|l|}{5} & \multicolumn{2}{|l|}{6} & \multicolumn{2}{|l|}{7} \\
\hline & 77.45 & $(0.30)$ & 78.83 & $(0.28)$ & 79.08 & $(0.24)$ & 78.69 & $(0.47)$ & 78.48 & $(0.11)$ & 77.89 & $(0.22)$ & 78.06 & $(0.31)$ \\
\hline $\mathrm{Al}_{2} \mathrm{O}_{3}$ & 12.58 & $(0.18)$ & 12.06 & $(0.14)$ & 12.07 & $(0.10)$ & 12.29 & $(0.21)$ & 12.13 & $(0.14)$ & 12.30 & $(0.10)$ & 12.32 & $(0.21)$ \\
\hline $\mathrm{TiO}_{2}$ & 0.14 & $(0.03)$ & 0.09 & $(0.04)$ & 0.07 & $(0.03)$ & 0.12 & $(0.03)$ & 0.14 & $(0.04)$ & 0.15 & $(0.03)$ & 0.14 & $(0.03)$ \\
\hline $\mathrm{FeO}$ & 1.13 & $(0.06)$ & 1.07 & $(0.11)$ & 1.01 & $(0.10)$ & 1.17 & $(0.14)$ & 1.02 & $(0.04)$ & 1.06 & $(0.07)$ & 1.01 & $(0.09)$ \\
\hline Mno & 0.03 & & 0.04 & $(0.04)$ & 0.05 & $(0.04)$ & 0.04 & $(0.04)$ & 0.06 & & 0.06 & & 0.04 & $(0.04)$ \\
\hline MaO & 0.11 & $(0.07)$ & 0.05 & $(0.03)$ & 0.05 & $(0.02)$ & 0.09 & $(0.03)$ & 0.10 & $(0.03)$ & 0.12 & $(0.02)$ & 0.12 & $(0.02)$ \\
\hline (a) & 0.79 & $(0.02)$ & 0.53 & $(0.06)$ & 0.50 & $(0.02)$ & 0.78 & $(0.08)$ & 0.75 & $(0.03)$ & 0.80 & $(0.04)$ & 0.78 & $(0.05)$ \\
\hline $\mathrm{Na}_{2} \mathrm{O}$ & 3.55 & $(0.19)$ & 3.55 & $(0.12)$ & 3.46 & $(0.18)$ & 3.38 & $(0.41)$ & 3.22 & $(0.14)$ & 3.35 & $(0.26)$ & 3.31 & $(0.13)$ \\
\hline $\mathrm{K}_{2} \mathrm{O}$ & 4.13 & $(0.16)$ & 3.78 & $(0.15)$ & 3.72 & $(0.18)$ & 3.44 & $(0.26)$ & 4.10 & $(0.11)$ & 4.30 & $(0.19)$ & 4.23 & $(0.16)$ \\
\hline Water & 4.95 & $(0.92)$ & 5.79 & $(0.53)$ & 5.55 & $(0.70)$ & 6.40 & $(0.88)$ & 5.93 & $(0.49)$ & 4.66 & $(0.65)$ & 4.49 & (1.33) \\
\hline$N$ & 10 & & 11 & & 11 & & 12 & & 10 & & 20 & & 120 & \\
\hline \multirow[t]{2}{*}{$\mathrm{Na} / \mathrm{K}$} & 0.86 & & 0.94 & & 0.93 & & 0.98 & 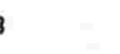 & 0.79 & & 0.78 & . & 0.78 & \\
\hline & \multicolumn{2}{|l|}{8} & \multicolumn{2}{|l|}{9} & \multicolumn{2}{|c|}{10} & \multicolumn{2}{|c|}{11} & \multicolumn{2}{|c|}{12} & \multicolumn{2}{|l|}{13} & \multicolumn{2}{|l|}{14} \\
\hline $\mathrm{SHO}_{2}$ & 77.81 & $(0.42)$ & 78.44 & $(0.41)$ & 77.65 & $(0.34)$ & 78.19 & $(0.54)$ & 78.17 & $(0.32)$ & 78.06 & $(0.72)$ & 77.16 & $(0.55)$ \\
\hline $\mathrm{A}_{2} \mathrm{O}_{3}$ & 12.57 & $(0.28)$ & 12.22 & $(0.12)$ & 12.63 & $(0.32)$ & 12.30 & $(0,33)$ & 12.41 & $(0.13)$ & 12.48 & $(0.35)$ & 12.77 & $(0.16)$ \\
\hline $\mathrm{TiO}_{2}$ & 0.13 & $(0.04)$ & 0.14 & $(0.03)$ & 0.13 & $(0.03)$ & 0.13 & $(0.04)$ & 0.13 & $(0.05)$ & 0.11 & $(0.03)$ & 0.16 & $(0.04)$ \\
\hline$F \subset O^{\circ}$ & 1.10 & $(0.09)$ & 1.06 & $(0.08)$ & 1.13 & $(0.09)$ & 1.02 & $(0.13)$ & 1.02 & $(0.10)$ & 1.11 & $(0.08)$ & 1.39 & $(0.13)$ \\
\hline Mno & 0.03 & & 0.08 & & 0.05 & $(0.04)$ & 0.04 & $(0.03)$ & 0.04 & & 0.03 & & 0.03 & \\
\hline MgO & 0.10 & $(0.04)$ & 0.11 & $(0.01)$ & 0.11 & $(0.03)$ & 0.11 & $(0.03)$ & 0.12 & $(0.03)$ & 0.12 & $(0.08)$ & 0.23 & $(0.04)$ \\
\hline $\mathrm{CaO}$ & 0.78 & $(0.04)$ & 0.73 & $(0.02)$ & 0.80 & $(0.04)$ & 0.73 & $(0.11)$ & 0.77 & $(0.09)$ & 0.75 & $(0.04)$ & 1.31 & $(0.13)$ \\
\hline $\mathrm{Na}_{2} \mathrm{O}$ & 3.50 & $(0.09)$ & 3.18 & $(0.20)$ & 3.53 & $(0.16)$ & 3.29 & $(0.20)$ & 3.23 & $(0.25)$ & 3.34 & $(0.39)$ & 3.70 & $(0.09)$ \\
\hline $\mathrm{K}_{2} \mathrm{O}$ & 4.00 & $(0.20)$ & 4.05 & $(0.15)$ & 3.98 & $(0.16)$ & 4.20 & $(0.22)$ & 4.11 & $(0.18)$ & 3.96 & $(0.22)$ & 3.26 & $(0.08)$ \\
\hline Water & 6.06 & $(1.11)$ & 6.37 & $(0.53)$ & 6.02 & $(1.18)$ & 5.81 & $(1.94)$ & 5.20 & $(0.90)$ & 6.22 & $(1.35)$ & 5.93 & $(0.78)$ \\
\hline $\mathrm{N}$ & 10 & & 10 & & 10 & & 11 & & 16 & & 10 & & 5 & \\
\hline $\mathrm{Na} / \mathrm{K}$ & 0.88 & & 0.79 & & 0.89 & & 0.78 & & 0.79 & & 0.84 & & 1.13 & \\
\hline & 15 & & 16 & & 17 & & 18 & & 19 & & 20 & & 21 & \\
\hline $\mathrm{SiO}_{2}$ & 77.87 & $(0.22)$ & 76.24 & $(0.64)$ & 78.16 & $(0.25)$ & 78.14 & $(0.21)$ & 78.24 & $(0.15)$ & 78.04 & $(0.50)$ & 78.27 & $(0.25)$ \\
\hline $\mathrm{Al}_{2} \mathrm{O}_{3}$ & 12.30 & $(0.10)$ & 13.16 & $(0.38)$ & 12.33 & $(0.20)$ & 12.28 & $(0.15)$ & 12.26 & $(0.14)$ & 12.50 & $(0.50)$ & 12.20 & $(0.12)$ \\
\hline $\mathrm{TiO}_{2}$ & 0.15 & $(0.03)$ & 0.21 & $(0.02)$ & 0.12 & $(0.02)$ & 0.15 & $(0.03)$ & 0.16 & $(0.03)$ & 0.12 & $(0.04)$ & 0.12 & $(0.03)$ \\
\hline Feo & 1.06 & $(0.07)$ & 1.75 & $(0.04)$ & 1.02 & $(0.11)$ & 1.01 & $(0.08)$ & 1.10 & $(0.07)$ & 1.06 & $(0.12)$ & 1.03 & $(0.06)$ \\
\hline $\mathrm{MnO}$ & 0.02 & & 0.07 & $(0.03)$ & 0.04 & & 0.03 & & 0.03 & & 0.03 & & 0.05 & $(0.03)$ \\
\hline Mgo & 0.12 & $(0.02)$ & 0.14 & $(0.08)$ & 0.07 & $(0.05)$ & 0.10 & $(0.04)$ & 0.14 & $(0.03)$ & 0.09 & $(0.09)$ & 0.12 & $(0.03)$ \\
\hline $\mathrm{CaO}$ & 0.80 & $(0.04)$ & 1.02 & $(0.06)$ & 0.65 & $(0.09)$ & 0.67 & $(0.03)$ & 0.75 & $(0.04)$ & 0.88 & $(0.09)$ & 0.72 & $(0.04)$ \\
\hline $\mathrm{Na}_{2} \mathrm{O}$ & 3.35 & $(0.26)$ & 4.44 & $(0.20)$ & 3.29 & $(0.09)$ & 3.23 & $(0.30)$ & 2.96 & $(0.13)$ & 3.51 & $(0.52)$ & 3.15 & $(0.14)$ \\
\hline $\mathrm{K}_{2} \mathrm{O}$ & 4.30 & $(0.19)$ & 2.97 & $(0.22)$ & 4.31 & $(0.14)$ & 4.39 & $(0.11)$ & 4.36 & $(0.13)$ & 3.76 & $(0.11)$ & 4.32 & $(0,25)$ \\
\hline Water & 4.66 & $(0.65)$ & 4.96 & $(1.58)$ & 3.81 & $(0.86)$ & 3.11 & $(0.70)$ & 2.88 & $(0.46)$ & 4.04 & $(0.44)$ & 4.52 & $(0.63)$ \\
\hline $\mathrm{N}$ & 20 & & 6 & & 11 & & & & 10 & & & & 12 & \\
\hline $\mathrm{Na} / \mathrm{K}$ & 0.79 & & 1.495 & & 0.76 & & 0.74 & & 0.68 & & 0.93 & & 0.73 & \\
\hline & 22 & & 23 & & 24 & & & & & & & & & \\
\hline $\mathrm{SiO}_{2}$ & 78.01 & $(0.33)$ & 77.99 & $(0.27)$ & 77.66 & $(0.26)$ & & & & & & & & \\
\hline $\mathrm{Al}_{2} \mathrm{O}_{3}$ & 12.35 & $(0.15)$ & 12.17 & $(0.11)$ & 12.42 & $(0.31)$ & & & & & & & & \\
\hline $\mathrm{TiO}_{2}$ & 0.15 & $(0.04)$ & 0.15 & $(0.02)$ & 0.13 & $(0.03)$ & & & & & & & & \\
\hline $\mathrm{FeO}$ & 1.06 & $(0.09)$ & 1.07 & $(0.07)$ & 1.05 & $(0.05)$ & & & & & & & & \\
\hline Mno & 0.04 & $(0.02)$ & 0.03 & & 0.01 & & & & & & & & & \\
\hline Mgo & 0.11 & $(0.05)$ & 0.11 & $(0.03)$ & 0.12 & $(0.01)$ & & & & & & & & \\
\hline Caó & 0.78 & $(0.04)$ & 0.78 & $(0.02)$ & 0.79 & $(0.05)$ & & & & & & & & \\
\hline $\mathrm{Na}_{2} \tilde{\mathrm{O}}$ & 3.06 & $(0.16)$ & 3.28 & $(0.15)$ & 3.73 & $(0.10)$ & & & & & & & & \\
\hline $\mathrm{K}_{2} \mathrm{O}$ & 4.47 & $(0.10)$ & 4.43 & $(0.17)$ & 4.10 & $(0.18)$ & & & & & & & & \\
\hline Water & 2.36 & $(0.88)$ & 3.23 & $(0.50)$ & 3.20 & $(0.59)$ & & & & & & & & \\
\hline $\mathrm{N}$ & 10 & & 10 & & 13 & & & & & & & & & \\
\hline $\mathrm{Nā} / \mathrm{K}$ & 0.68 & & 0.74 & & 0.91 & & & & & & & & & \\
\hline
\end{tabular}

TABLE 7.3.3:

Microprobe analyses on glass shards from airfall and

ignimbrite samples. Mean and standard deviation values

only listed. Analysis numbers refer to sample descrip-

tions in Appendix 1. 
of hydration (Smith and Westgate, 1969; Federman and Carey, 1980; Froggatt, in press). To compensate for variable hydration, all raw analyses were normalised to $100 \%$ on an anhydrous basis, then meaned. The "water" values in Table 3 are the deficiencies of the raw analyses from $100 \%$

One of the most conspicuous features of the probe data is that Mt. Curl and known tephra correlatives all have $\mathrm{Na} / \mathrm{K}$ ratios less than 1 . Invariably $\mathrm{K}$ is greater than $\mathrm{Na}$ by 0.5 - 1.0 weight $\%$ which is much greater than either instrumental error or individual standard deviations. The same feature was noted, for the bulk glass analyses (Table 2). Probe analyses on at least 20 other stratigraphically separate late Pleistocene rhyolitic tephras and ignimbrites in Central North Island (Froggatt, in press) all have $\mathrm{Na} / \mathrm{K}$ greater than 1, suggesting that the ratio of less than 1 is unusual. On the basis of these 2 elements alone a strong similarity of several unknown samples to Mt. Curl Tephra and Whakamaru Ignimbrite is evident. To examine this further and use the other elemental data, coefficient of variation (CV\%) values were determined (Borchardt et al., 1972; Froggatt, in press). Identical analyses produce a $\mathrm{CV}$ of 1.0. Comparison of analyses on known stratigraphic correlatives produce CV values less than 12.0 (Froggatt in press), giving an arbitrary maximum for sample matching based on the chemistry alone. A CV value of 15 was adopted as acceptable for correlation by Borchardt et al. (1972). 


\section{MINERAL CHEMISTRY}

Averaged microprobe analyses on orthopyroxene and amphibole phenocrysts from several tephra and ignimbrite samples show little variation. Individual analyses are plotted on a Ca-Mg-Fe ternary diagram (Fig. 2) where intra-sample variations are greater than any differences between samples. The orthopyroxene are mostly hypersthene with a few of ferrohypersthene composition and the amphiboles are compositionally hornblendes, confirming bulk sample analysis data by Ewart (1967b, 1968, 1971).

The Fe-Ti oxides, titanomagnetite and ilmenite, occur in all the samples examined and average microprobe analyses are presented (Table 1,3\%). Occasional titanomagnetites showing massive exsolution were avoided during analysis. Equilibration or quench temperatures, calculated using the data of Buddington and Lindsley (1964) are in the range 770$810^{\circ} \mathrm{C}$, consistent with the hypersthene-hornblende-biotite mineral assemblage (Ewart et al., 1971, 1975).

Neither ferromagnesian nor Fe-Ti oxide mineral chemistry distinguishes between any of the tephras or ignimbrites studied.

\section{TEPHRA CORRELATIONS}

Only 3 sites (Pahiatua, Haywards and Rangitatau Road) are presently known where a tephra can be directly correlated to Mt. Curl Tephra on solely stratigraphic evi- 


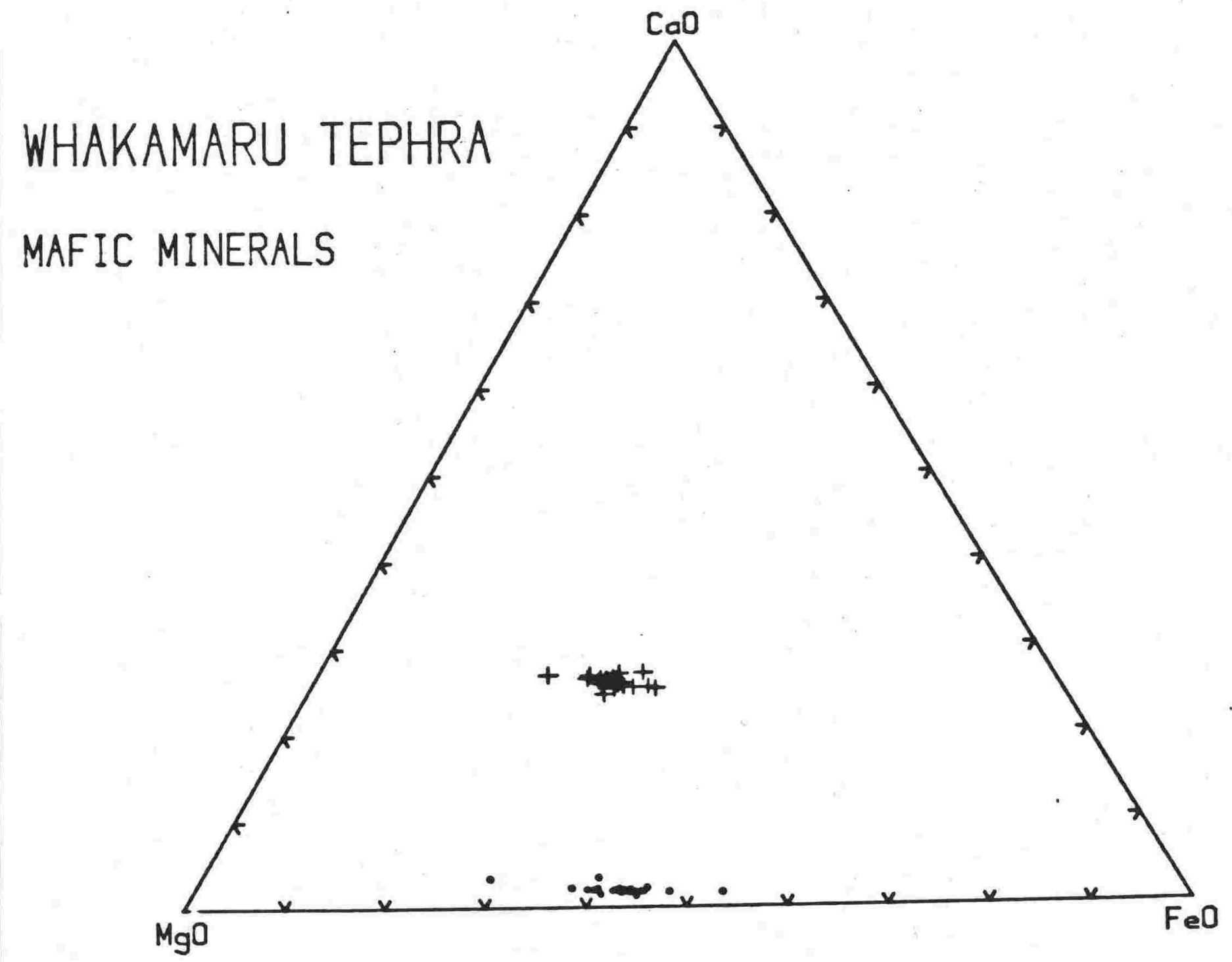

\section{FIGURE 7.3 .2 :}

Microprobe analyses on pyroxenes and amphiboles from Mt. Curl Tephra and Whakamaru Ignimbrite plotted as molecular proportions of $\mathrm{Ca}$ - Mg - Fe. The spread of data is typical of New Zealand rhyolitic tephras. 


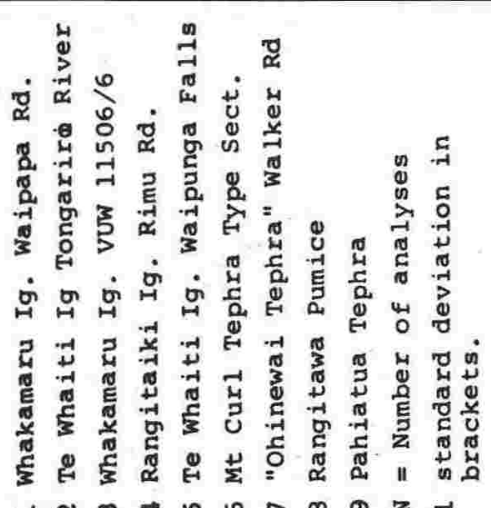

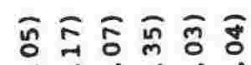

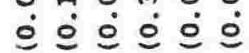

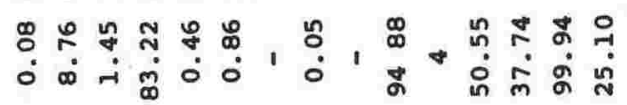

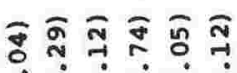

$\dot{0} \dot{9} \dot{0} \dot{0}$

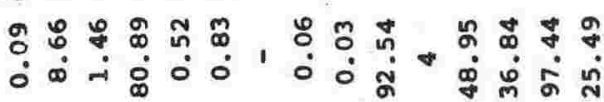

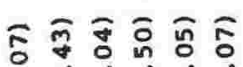

$\dot{0} \dot{0} \dot{0} \dot{0}$

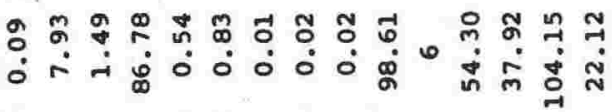

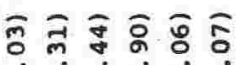

$\dot{0} \dot{0} \dot{0} \dot{0}$

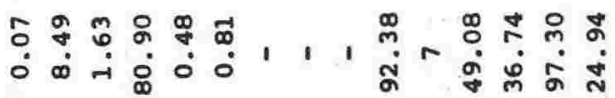

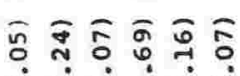

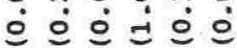

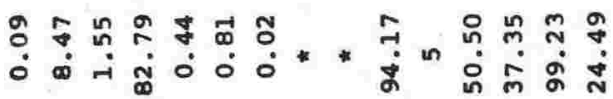

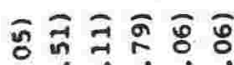

$\dot{0} \dot{0} \dot{\varphi} \dot{0}$

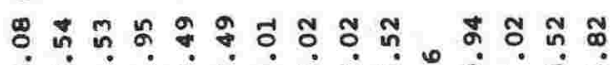
○ं -

ลิ

$\dot{0} \dot{0} \dot{0} \dot{0}$

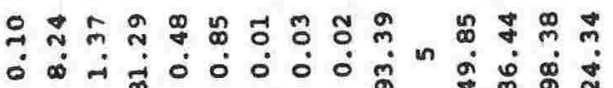

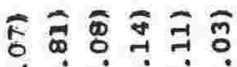

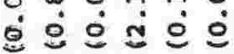

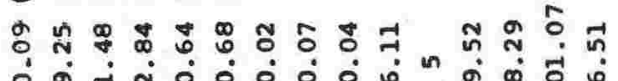

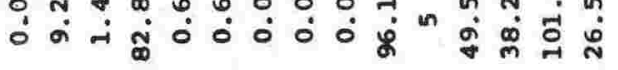

ธิธ

$\dot{9} \dot{9} \dot{0} \dot{0}$

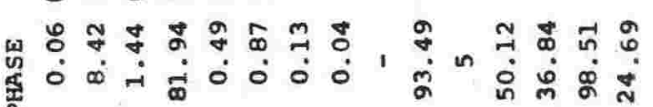

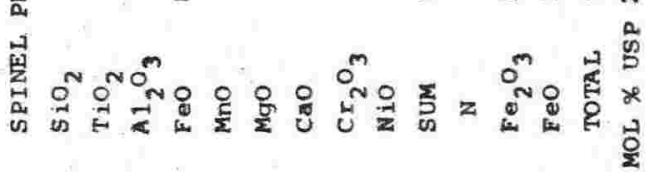

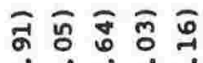

\section{¿ $\dot{0} \dot{0}$}

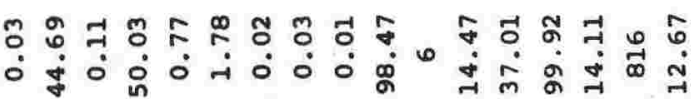

సิ

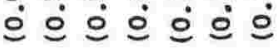

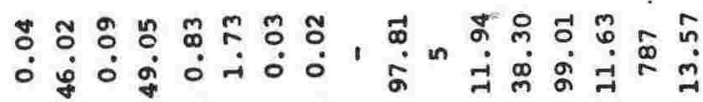

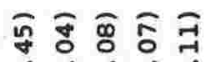

ㅇำㅇำ

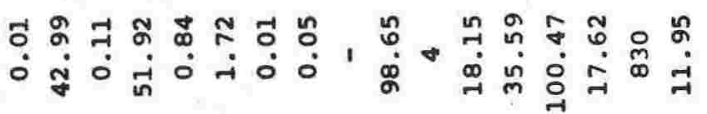

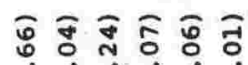

过宇这远

น้ำ

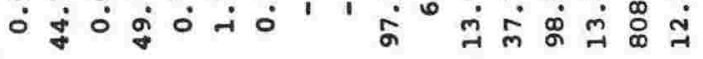

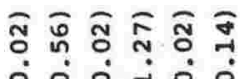

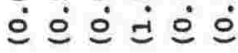

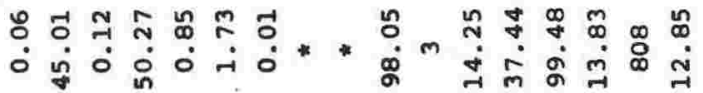

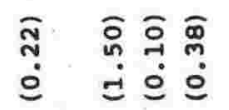

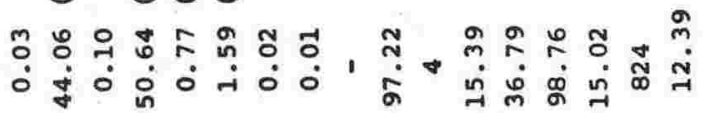

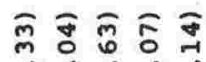

웡ㅇㅇ

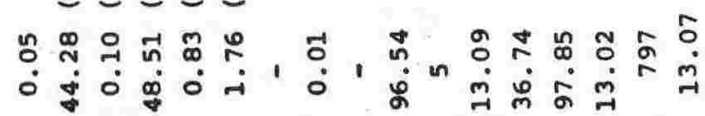

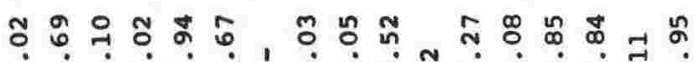
ठำ

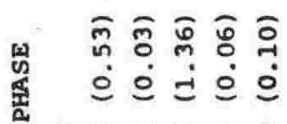

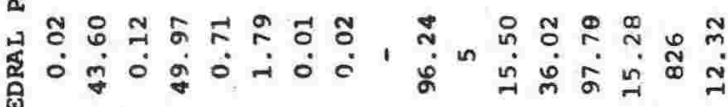

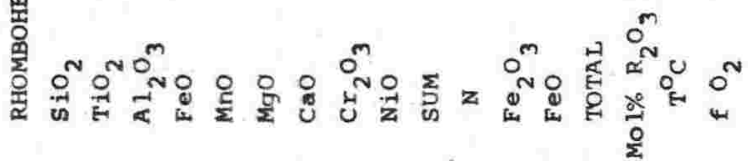


dence. At all 3 sites the mineralogy (Table 1), and the chemical data (Tables 2,3 and 4) presented here are consistent with the stratigraphic correlation. The glass chemistry determined by electron microprobe analyses is consistent, despite the tephra being strongly weathered at some sites (e.g. at Rewa Hill). This is especially critical for Mt. Curl Tephra because of its distinctive $\mathrm{Na}$ and $\mathrm{K}$ values.

From the general stratigraphic position of each tephra sampled and the mineralogy and chemistry, the following samples are regarded here as correlatives of Mt. Curl Tephra:

$\begin{array}{ll}\text { Ahiaruhe tephra } & \text { Omahina tephra } \\ \text { Finnis Road (lower) } & \text { Pahiatua tephra } \\ \text { Haywards tephra } & \text { Rangitatau Road } \\ \text { Jury Road tephra } & \text { Rangitawa Pumice } \\ \text { Manakau tephra } & \text { Rewa Hill } \\ \text { Ohariu tephra } & \text { Walker Road }\end{array}$

For all the above samples, comparison of glass analyses produces CV values less than 12 .

In addition to the above list, samples from Cape Kidnappers, Bay of Plenty, Áwatere Valley and 3 deep sea cores (RC9-110, RC9-113 and RC12-215: Watkins and Huang, 1977) have been matched chemically to Mr. Curl Tephra (Froggatt, in press). A tephra in cores taken on the 
Chatham Rise and in the Bounty Trough (provided by $L$. Carter and C. Landis) also match Mt. Curl, further extending the known area of distribution.

The tephra at Walker Road, Te Kuiti, is regarded as a correlative of Ohinewai Tephra (Vucetich et al., 1978) so that Ohinewai Tephra also is probably Mt. Curl. Ward (1967) defined "Ohinewai Ash" as the basal part of "Hamilton Ash Formation" which overlies a marked unconformity on older beds. This is consistent with the interpretation of several tephra and ignimbrite sections where the tephra invariably overlies either a strong paleosol or an unconformity.

Two of the tephras correlated to Mt. Curl occur in marine sediments attributed to the Castlecliffian stage and have not previously been associated with Mt. Curl Tephra. At both localities, Finnis Road lower tephra (Seward, 1976) and Rangitawa Stream, a tephra with the field appearance of Mt. Curl could not be found in overlying terrestrial deposits. The Rangitawa stream outcrop has a coarse, crystalrich base like that at Mt. Curl, grading up to $\underline{c} .2 \mathrm{~m}$ of tephric silt. At Finnis Road, the tephra was deposited in a high energy environment, and occurs as pumice clasts up to $8 \mathrm{~cm}$ diameter, in coarse, cross-bedded sands. Preservation in marine sediments does not appear to have affected the glass chemistry of these samples. In neither sample were multiple chemical populations of glass detected as was found in some other marine samples (Froggatt, in press). 
Te Punga (1973) and Naeser et al. (1980) tentatively correlated the highly weathered Mangaroa Ash (Te Punga, 1963) outcropping near Wellington with Rangitawa Pumice now considered to be a correlative of Mt. Curl Tephra (see above). Insufficient glass shards were obtained for reliable chemistry from a sample collected at the type section (Te Punga, 1953) but 2 shards gave analyses comparable to Mt. Curl Tephra. At the type section Mangaroa Ash overlies a thin layer of clay (loess) resting unconformably on red-weathered greywacke gravels and is almost certainly Mt. Curl Tephra.

Several of the tephras analysed do not correlate chemically with Mt. Curl Tephra. Whitby Ash is probably much older than Mt. Curl, and its analyses suggest a match to Rewa Pumice, fission-track dated at $0.74 \pm 0.09$ Myr (Seward, 1976). The stratigraphic position of the Fordell Ash is uncertain but it chemically correlates to the upper Griffin Road tephra (Froggatt, in press) and probably also to Kaingaroa Ignimbrite so is younger than Mt. Curl.

The tephra preserved in fossiliferous, shallow marine sediments at Te Piki, East Cape is chemically distinct from Mt. Curl (Table 3) and matches a tephra lying between Mt. Curl Tephra and. Matahina Ignimbrite in several Bay of Plenty sections (Froggatt, in press). Tephrostratigraphy at East Cape is the subject of continuing study. 


\section{IGNIMBRITE CORRELATIONS}

Each airfall tephra examined is rhyolitic and is presumed to have originated from a large eruptive episode in the Central Volcanic Region, probably in each case those forming an ignimbrite. Samples from the basal layer of each of the younger, recognised ignimbrites have been analysed on the electron probe by the methods used here and chemical correlation of some tephras to these samples is reported elsewhere (Froggatt, in press). To summarise, the following correlations, which are all consistent with the tephra and ignimbrite stratigraphy, have been made:

$\begin{array}{llll}\text { Griffin Road (upper) } & - & \text { Kaingaroa Ignimbrite } \\ \text { Finnis Road (upper) } & - & \text { Matahina Ignimbrite } \\ \text { Mt. Curl Tephra } & - & \text { Whakamaru Ignimbrite } \\ \text { Kaukatea Ash } & - & \text { Marshall Ignimbrite }\end{array}$

Each of the known voluminous Late Pleistocene ignimbrites has a widespread but often poorly preserved airfall tephra component that has not been previously recognised. This "co-ignimbrite airfall ash" is to be expected (Sparks and Walker, 1977). Identification of widespread tephras in a stratigraphic context outside the volcanic region places constraints on the stratigraphy and number of separate ignimbrite-forming eruptions. Although it might be possible for a large ignimbrite sheet to be emplaced without an associated widespread airfall tephra, the above correlations suggest this is an unlikely event. 
The stratigraphy of the numerous named ignimbrite sheets of similar age to Whakamaru has been discussed above. Samples were collected from the basal layer of each ignimbrite, except the Manunui and Wairakei Ignimbrites, at previously documented sites (see Appendix 1). Glass from each sample is chemically indistinguishable (Table 3) as are orthopyroxenes (Table 4) and Fe-Ti oxides (Table 5). Comparable Fe-Ti oxide equilibration temperatures were obtained for each magnetite-ilmenite pair analysed. Kohn (1973) concluded from magnetite trace element data that Whakamaru, Rangitaiki and Te Whaiti were "co-magmatic". The similarity of data in Tables 3,4 and 5 , the distinct chemistry of ignimbrites demonstrably younger (Matahina) and older (Marshall) and the absence of stratigraphic evidence for superposition suggests the 4 not only are "comagmatic" but also were emplaced by the same eruptive episode and are stratigraphically equivalent. This is consistent with the observed radial distribution of ignimbrites around a source vent (e.g. Taupo Ignimbrite, Froggatt, 1981) and the deduced source of both Whakamaru and Rangitaiki ignimbrites under Lake Taupo.

Each stratigraphically separate ignimbrite younger than 500 kyr has a known airfall correlative (Froggatt, in press), and only one known airfall tephra (Mt. Curl) chemically matches Whakamaru. This accords with the model of only one eruptive episode that produced Whakamaru, Rangitaiki, Te Whaiti, Wairakei, Rocky Hills and Manunui Ignimbrites. The distal ignimbrites, Te Whaiti and Manunui, 
are finer grained and less welded than the near vent facies of Whakamaru and Rangitaiki (Martin, 1961) which is consistent with the ignimbrite welding zonation model of Smith (1960).

An ignimbrite near Tokoroa, mapped as Rocky Hills, forms ridges and inliers surrounded by Whakamaru, suggesting a younger age for the latter (Martin, 1961; Blank, 1965) although the evidence is equivocal. It is possible the inliers are cored by an older ignimbrite and capped by a finer, less-welded facies of Whakamaru, analogous to the "veneer-facies" of Taupo Ignimbrite (Walker et al., 1980; Froggatt, 1981). Possibly more than one ignimbrite has been mapped as "Rocky Hills" with the one sampled here being a distal facies of Whakamaru. Eastward, nearer the source another, presumably older, ignimbrite may also have been mapped as Rocky Hills but no exposures of the unwelded base were available to sample for analysis. The identity of Rocky Hills Ignimbrite cannot yet be determined.

\section{CHRONOLOGY OF MT. CURL TEPHRA}

The widespread occurrence of Mt. Curl Tephra in a variety of deposits, especially loess, has great potential for correlation and absolute dating of many late Quaternary sequences in central New Zealand. An age on Mt. Curl Tephra is here considered less critical than the stratigraphic position of the tephra, especially in relation to climatic changes. At Mt. Curl and Omahina Rd, the tephra is overlain by $20 \mathrm{~cm}$ of reworked tephra or "tephric" loess then dune 
sands, and is underlain by loess presumably resting on a marine-cut bench. At Pahiatua, Mt. Curl Tephra overlies loess and has a strong paleosol developed directly above it. Assuming loess accumulation represents cold climate conditions, Mt. Curl Tephra fell near the end of a glacial period, identified by Milne (1973) as the Antipenultimate Glacial. Mt. Curl Tephra has recently been identified in marine sediments in Bounty Trough, where its position is identified near the top of a layen correlated to oxygen isotope state 8 (Griggs, pers. comm., 1982). By correlation to the "glacial stratigraphy" of Hayes et al. (1976) an age of 0.25 to 0.26 Myr is indicated. The importance of the age of Mt. Curl Tephra was recognised by Milne (1973) who reported dates of $0.23 \pm 0.03 \mathrm{Myr}$ (fission-track, glass) and $0.25 \pm 0.12$ Myr $(\mathrm{K} / \mathrm{Ar}, \mathrm{glass})$ on samples from the type section. More recent published fission-track dates on zircons from Mt. Curl Tephra are $0.24 \pm 0.05$ and $0.23 \pm 0.06 \mathrm{Myr}$ (Mt. Curl; Pillans and Kohn, 1981; Seward, 1979); $0.21 \pm 0.06$ Myr (Haywards; Seward, 1979); $0.37 \pm 0.05$ Myr (Rangitawa; Pillans and Kohn, 1981) and $0.35 \pm 0.13 \mathrm{Myr}$ (Mangaroa; Naeser et al.' 1980). An additional date of 0.31 Myr was obtained from sedimentation rates in core RC9-113 by Ninkovich (1968). All but one of these dates overlap at $2 \sigma$ and are not significantly different at the $3 \sigma$ level. The radiometric dates are thus in agreement with the independently derived glacial chronology and substantiate an age of about 0.25 Myr for Whakamaru Tephra Formation. 
STATUS OF MT. CURL TEPHRA AND WHAKAMARU IGNIMBRITE AS

\section{FORMATION NAMES, AND PROPOSAL TO ESTABLISH WHAKAMARU}

\section{TEPHRA FORMATION}

Milne (1973) correlated a widespread rhyolitic tephra in the Rangitikei Valley as far west as Mt. Curl, where he found it best preserved and well exposed. He was unable to carry the correlation further west to the similarly aged Fordell Ash locations (Fleming, 1953) one of which he showed to be diatomite (the others shown here to be younger), nor to the previously named Rangitawa Pumice (Te Punga, 1952) or Ohinewai tephra (Ward, 1967). Milne (1973) established Mt. Curl Tephra as a formal unit with the type section at Mt. Curl. Correlation of the previously named tephras, Rangitawa Pumice and Ohinewai Tephra but not Fordell Ash, with Mt. Curl Tephra has been established here with the aid of glass chemistry. A problem therefore arises as to what formal stratigraphic name should be applied to the tephra.

Rangitawa Pumice is known only at 1 locality in the upper part of the Wanganui basin marine sequence (Te Punga, 1952; Seward, 1974) and cannot be easily correlated to the terrestrial sequences of similar age, so is of limited value for stratigraphic correlation. Ohinewai Tephra at the type section is intensely weathered with no glass remaining and could not be positively correlated to Mt. Curl Tephra in this study. Consequently neither of these sections is here regarded as suitable for the type section for a widespread and stratigraphically important tephra. 
It is here proposed to use the name Mt. Curl Tephra of Milne (1973) for all correlative airfall tephras and to retain the type section as designated by Milne (1973) on Mt. Curl Road. All other formal tephra names of Mt. Curl Tephra correlatives should thus lapse. Despite precedence, Rangitawa Pumice and Ohinewai Tephra should also lapse in favour of Mt. Curl Tephra. However, additional names (e.g. Ohinewai) may be useful to indicate location of the site examined or a particular weathering facies of Mt. Curl but the writer considers that these should be treated as informal.

Establishment of the stratigraphic equivalence of Whakamaru, Rangitaiki, Te Whaiti, Manunui, Rocky Hills and Wairakei Ignimbrites requires the rationalisation of nomenclature. Whakamaru Ignimbrite (Hatherton, 1954) takes precedence so it is proposed that all correlatives be formally known as Whakamaru Ignimbrite. As with the airfall tephra, retention of informal names that indicate location or a particular facies may be useful.

As Mt. Curl Tephra and Whakamaru Ignimbrite are correlatives, it is here proposed to group them into Whakamaru Tephra Formation comprising Whakamaru Ignimbrite Member and Mt. Curl Tephra Member. This nomenclature convention is the same as demonstrated for Rotoiti Breccia and Rotoehu Ash by Nairn (1972) and Nairn and Kohn (1973). Subdivisions within Whakamaru Ignimbrite Member (Briggs, 1976) would be retained as lesser units. The type section 


\section{4}

for Whakamaru Ignimbrite was designated by Healy (in Fleming, 1959, p. 476) as Maraetai Gorge where about 100m of welded ignimbrite outcrop although the base is not exposed. As the base of ignimbrites is critical to their stratigraphy and to the chemical matching used here, a standard section exposing the base is desirable. Four such sections have been examined: Waipapa Road, Waipunga Falls, Tongariro River and Rimu Road. Waipunga Falls was designated the type section for Rangitaiki Ignimbrite (Martin, 1961), but the Waipapa Road outcrop is near the Maraetai-Waipapa sections on the Waikato River and so is the best standard section, with the surrounding region designated the type area following the practice of Vucetich and Pullar (1973). The other 3 sections are useful reference sections, especially the one on Tongariro River, which exposes $20 \mathrm{~m}$ of older material, mostly andesites.

The stratigraphic formalities of Whakamaru Tephra Formation are summarised thus:

Whakamaru Tephra Formation

Type section: Waipapa Rd. N84/192787; T16/461135. Standard sections: Tongariro River N112/298825; T19/533253. Waipunga Falls N104/963055; V19/147446.

Whakamaru Ignimbrite Member

Type section: Maraetai Gorge N84/228787

Mt. Curl Tephra Member

Type section: Mt. Curl Rd., Hunterville. N138/956822; 


\section{CONCLUSIONS}

Late Quaternary tephras are found in a variety of terrestrial and marine sediments throughout New Zealand. They mark widespread, instantaneous time-planes and are important marker beds because they occur in stratigraphic sequences which often contain little other evidence for correlation. Use of bulk sample analysis formajor, trace or rare-earth elements is confounded by contamination or glass weathering especially in the older tephras - problems overcome by single grain electron microprobe techniques, as the probe analyses a fresh internal glass surface.

Major element probe analysis of glass has shown Mt. Curl Tephra to have a distinctive chemistry with $\mathrm{K}_{2} \mathrm{O}$ $>\mathrm{Na}_{2} \mathrm{O}$. On the basis of stratigraphic position and glass chemistry many samples were identified as Mt. Curl, including Ohariu, Haywards, Pahiatua and Omahina tephras and Rangitawa Pumice. Whitby ash is older and Fordell ash younger, probably correlating to Rewa Pumice and Kaingaroa Ignimbrite respectively.

In the many sequences examined, none contained 2 tephras with the same glass chemistry as Mt. Curl Tephra. If an origin from ignimbrite-forming eruptions for Mt. Curl and other widespread tephras is accepted, only 1 eruption or eruptive episode is represented by Mt. Curl Tephra. Samples from the unwelded base of Whakamaru, Rangitaiki, Te Whaiti and Rocky Hills have a glass chemistry identical to Mt. Curl implying that these together with Manunui and 


\section{6}

Wairakei Ignimbrites were formed by the same eruptive episode. Nomenclature difficulties caused by correlation of several formally named tephras and ignimbrites is resolved by use of Mt. Curl Tephra for the airfall phase and Whakamaru Ignimbrite for the pyroclastic flow deposit phase (which includes distal, non-welded material). The coeval relationship of these 2 deposits is embodied in the definition of Whakamaru Tephra Formation to consist of the airfall Mt. Curl Tephra Member and Whakamaru Ignimbrite Member.

Evaluation of radiometric dates and the position of Mt. Curl Tephra with respect to Penultimate Interglacial sediments gives an age for Whakamaru Tephra Formation of $0.24-0.25$ Myr. In many of the sections studied Whakamaru Tephra Formation rests with marked unconformity on much older beds - often an eroded surface on older ignimbrites or greywacke that was probably cut during the Antepenultimate Glacial interval.

\section{ACKNOWLEDGEMENT'S}

For continual encouragement, assistance in the field, discussion and criticism of several drafts of this manuscript, I am grateful to Mr. C.G. Vucetich. Some tephra sections were examined and discussed with Drs. McGlone, Milne and Pillans. Professor P. Vella and Dr. R. Howorth discussed the stratigraphy and proposed correlations and reviewed the manuscript. Probe mounts were polished by K. Calder and J. Brown; K. Palmer maintained the electron 


\section{$20 \%$}

microprobe and instructed in its abilities.

Field work was financed by the Internal Research Committee of Victoria University. 


\section{APPENDIX 1}

\section{$\underline{\text { Site descriptions }}$}

Many of the sites sampled have been described elsewhere in the course of Quaternary research and detailed descriptions may be found in the references. All samples are identified by a Victoria University 50,000 number and lodged in the Geology Department collection.

\section{Ahiaruhe Road (N162/081458; S27/274095) 50088}

The detailed stratigraphy and a description of the Ahiaruhe Road section is given in Vella and Collen (unpublished ms.).

2. Finnis Road (N144/253585; T23/460121) 50515,50516 The tephras outcrop on Finnis Road, west of the township of Pohangina (Seward, 1974). They are separated by $95 \mathrm{~m}$ of coarse well sorted marine sands with largescale cross-bedding. Both tephras were reworked in a high energy, sediment laden environment. The lower tephra has rounded pumice clasts up to $8 \mathrm{~cm}$ in diameter and the upper tephra is distinctively biotite rich (Seward, 1976). The lower has been correlated on the basis of glass chemistry to Whakamaru Ignimbrite and the upper to Matahina Ignimbrite (Froggatt, in press).

\section{Fordell.}


Milne (1973) to be stratigraphically younger than Mt. Curl Tephra and in some exposures to be fine silt or diatomite. Three outcrops of presumed Fordell Ash were examined:

1. At N138/760838, (S22/015365) above the Whangaehu River, where the tephra is well preserved in organic-rich silt overlying marine sands and overlain by at least $20 \mathrm{~m}$ of aeolian cover-beds. 50057

2. Kauangaroa Road (N138/771851; S22/026376) where $\underline{\mathrm{c}}$. $0.4 \mathrm{~m}$ of tephric silt is separated from a tephra by $4 \mathrm{~m}$ of sand, silts and diatomite. The tephra is preserved in a discontinuous lens $0.2 \mathrm{~m} \times 3 \mathrm{~m}$ in size. 50058

3. On a farm track off Denlair Road (N138/762873; S22/019397), $0.4 \mathrm{~m}$ of uniform white ash is overlain by a sequence of loess and sands.

50052

All three samples have identical glass chemistry and are presumed correlatives.

4. Griffin Road (N143/929781; S22/169308) 50060, 50061

A gravel borrow pit on Griffin Road $5 \mathrm{~km}$ south-west of Mt. Curl exposes two tephras in loess overlying alluvial gravels. The gravels and tephras are stratigraphically younger than Mt. Curl Tephra (Milne, pers. comm., 1981). Froggatt (in press) correlated both tephras to Bay of Plenty sections on the basis of glass chemistry. 


\section{Haywards Hill (N160/511416; R27/752072) 50063}

A deep road cutting on Haywards Hill, $25 \mathrm{~km}$ northwest of Wellington, exposes $10 \mathrm{~m}$ of loess overlying a strongly weathered rhyolitic tephra, resting on alluvial gravels (Nicol, 1972; Jakobsson, 1976). The loess can be subdivided into 6 units and correlated to the sequence at Mt. Curl and Pahiatua. Near the base of the upper (Ohakean) loess, Aokautere Ash has been recognised from the presence of allophane and a concentration of glass shards.

\section{Jury Road (N162/033447; S27/229086) 50518}

A tephra "couplet", preserved in loess overlying gravels, outcrops on the true left bank of the Ruamahunga River. The tephra and loess dip steeply upstream, indicating considerable tectonic folding since deposition. The couplet is considered to be one tephra and was examined in detail by O'Brien (1980).

\section{Mount Curl Road (N138/956822; S22/195345) 50103}

This is the type section for Mount Curl Tephra Formation defined and described by Milne (1973).

\section{Ohariu Valley (N160/342330; R27/595998) 50122}

Two outcrops of a tephra preserved in carbonaceous silty sand at Ohariu Valley were described by Mildenhall et a1. (1977).

\section{Omahina Road (NI38/953820; S22/192343)}

50131

This is one of several sections in the Wanganui 
area described by Pillans and Kohn (1981) and is one of the least weathered sites.

10. Pahiatua (N149/298249; T24/492812)

50157

The Ridge Road section, first described by Robertson (1976) and redescribed by Keawyana (1980) is one of the most complete sections of terrestrial Quaternary deposits yet studied and one of the few that can be confidently correlated to Mt. Curl Road. At least 3 rhyolitic tephras are preserved in loess overlying Mt. Curl Tephra.

11. Rangitatau Road (N137/466033; R22/753561) 50167

A detailed description of this section (Wilde, 1979) identifies 6 loesses overlying a pale yellow horizon subsequently sampled and shown here to be a tephra. This tephra is considered (Pillans and Kohn, 1981) a correlative of the better preserved tephra at Omahina Road.

\section{Rangitawa Stream (N143/962624; S23/195164) 50168}

The type and only known locality of Rangitawa Pumice has been described by Te Punga (1952), Seward (1974) and Pillans and Kohn (1981). The tephra outcrops in a continuous section over about $1 \mathrm{~km}$ of the true right bank of Rangitawa Stream and lies in estuarine sediments at the very top of the $1035 \mathrm{~m}$ thick marine Wanganui Basin Castlecliffian Stage sediments (Boellstorff and Te Punga, 1977). Overlying the tephra is Im of tephric silt then a major unconformity to coarse greywacke gravels of "Hawera" age. Both Seward (1974) and Boellstorff and Te Punga (1977) have reported fission-track 
dates on glass for this tephra.

13. Rewa Hill (N144/133779; T22/355301) 50105

Seward (1976) described the marine sequence with numerous tephras that is well exposed on the road at Rewa Hill. Unconformably overlying marine sediments are gravels capped by a thick but poorly exposed loess sequence containing Mt. Curl Tephra near the base and Aokautere Ash near the top.

14. Te Piki N62/463693; Y14/560904)

50203

The Te Piki section, described by Chapman-Smith and Grant-Mackie (1971) is richly fossiliferous Castlecliffian marine sediments containing a rhyolitic tephra. Palynology of this section indicates a warm humid climate (Wilson, 1973).

\section{Walker Road (N83/743809; S16/051159)}

50207

A succession of strongly weathered beds interpreted as rhyolitic and andesitic tephras with interbedded loess outcrops extensively in the Aratora-Te Kuiti district. A complete section on Ahuroa Road (N83/755784) has been described by Vucetich et al. (1981) where the lowest airfall tephra in this sequence was correlated to a less weathered outcrop on Walker Road. As this tephra is at the base of a strongly weathered sequence of beds it is in the same stratigraphic position as Ohinewai Tephra (Ward, 1967), to which it probably correlates.

16. Whitby (N160/436438; R27/684094)

50209

Development of the Whitby subdivision, Wellington, 


\section{3}

exposed a sequence of silts and gravels with an interbedded tephra, preserved in an infilled gully. A full description of the stratigraphy is given in Sinclair (1973). The bed lying beneath the tephra contains abundant lignitic wood of either Dacrydium colensoi or D. Bidwillii.

17. Aratora (N83/725604; S17/030980)

50089

The new road deviation of Aratora exposes welded ignimbrite, probably ongatiti, overlain by at least $3 \mathrm{~m}$ of unwelded ignimbrite, but the base is not exposed. Martin (1961) describes Rocky Hill Ignimbrite from this locality.

18. Ellis Road (N93/026590; T17/307960) 50054

Kohn (1973) sampled the section on the corner of Ellis and Maraeroa Roads as Rocky Hill Ignimbrite. A thin (3-5m) welded sheet overlies about 1-2 metres of unwelded crystal-rich ash.

19. Rimu Road (N112/392988; T19/023399)

50165

This logging road in Lake Taupo Forest exposes about 10 metres of Rangitaiki Ignimbrite unconformably overlying an eroded surface on red - weathered greywacke sandstone. The section is about $2 \mathrm{~km}$ south of the Rangitaiki Ignimbrite section in the Waimarino River described by Marshall (1935).

20. Rocky Hill (N83/816747; S16/117108)

50171

Rocky Hill is the type section for the Ahuroa and Rocky Hill Ignimbrites, separated by several metres of airfall pumice named Puketoka Formation by Kear (1960). The top of 
Rocky Hill is capped by a thin welded ignimbrite, skirted, and presumably underlain, by unwelded ash that overlies Puketoka Formation. This ash was sampled as Rocky Hill Ignimbrite but may be younger.

21. Tongariro Power Development Drillhole D114 (N112/111991) Sample VUW 11506/6 described by

Briggs (1973) was collected from the basal unwelded zone of Whakamaru Ignimbrite, $56.7 \mathrm{~m}$ below the top of the ignimbrite.

22. Tongariro River (N112/298825; T19/533252)

50191

Tongariro River has cut through at least $30 \mathrm{~m}$ of welded ignimbrite, mapped as Te Whaiti by Grindley (1960) and a further 30 metres of underlying rhyolitic tephra and andesitic lahar and lava flows. The basal 5 metres of the ignimbrite is unwelded ash, rich in coarse phenocrysts, mostly plagioclase, resting on well-sorted sands.

23. Waipapa Road (N84/192787; T16/461135)

The Maraetai-Waipapa highway exposes the base of "sheet 2" of Whakamaru Ignimbrite resting unconformably on deeply weathered fine ash and unwelded ignimbrite, possibly Marshall Ignimbrite. The lowermost 2 metres of Whakamaru is unwelded ash with abundant coarse phenocrysts which grades up over about 1 metre to welded material.

\section{Waipunga Falls (N104/963055; V19/147446)}

Waipunga Falls was described as the type section for Te Whaiti Ignimbrite by Martin (1961) but re-alignment of the Napier-Taupo Highway beside the falls has exposed the base of the ignimbrite resting on an eroded surface of greywacke. 
CHAPTER 8.

DISCUSSION OF RELATED TOPICS. 
8.1 DID TAUPO'S ERUPTION ENHANCE EUROPEAN SUNSETS?

\section{Reprinted from;}

NATURE VOI 293 pp491-2. 1981. 
Did Taupo's eruption enhance European sunsets?

A NEW precise date of $186 \mathrm{AD}$ has been postulated for a series of large rhyolitic pliniar and pyroclastic flow eruptions at Taupe, New Zealand. Evidence came troftit Chinese and Roman records of a brilliant red Sun and Moon and of clouds dimming the Sun. Although the Taupo eruption was one of the largest within the perien AD 100-200, there is evidence that this eruption did not disperse enough fine tephra into the atmosphere, let alone into the Northern Hemisphere, to produce the phenomena described.

Evidence suggesting that the Taupo
Eventions eruption and the recorded Sun phenomena are unrelated is as follows: (1) The Chinese excerpt $t^{\prime}$ describes the Sun and Moon themselves as being "red as bloog "when they rose and set and do no descritive glow phenomena or "sunse colours". Direct red colouration of the Sun followed the eruptions of Krakatau 1883 and Bali 1963 and was generally restricted to near the volcanic source and restricted to near the volcanic source and colouration of the Sun is due to very small particles $(<0.5 \mu \mathrm{m})$ or smoke haze scattering short-wavelength light. Thus the Chinese record is more consistent with atmospheric dust or smoke haze in the atmospheric dust or smoke haze in the lower troposphere than higher-altitude
volcanic dust. Similarly, one Roman volcanic dust. Similarly, one Roman account of a widespread red colour is also smore.

(2) Although the Taupo eruptions were large, they were not as exceptional as large, they were not as exceptional as implied by Walker. I have recalculated the vin deposil "to be $14 \mathrm{~km}^{3}$, in contrast to the $24 \mathrm{~km}^{\prime}$ calculated by Walker, who (19 km) was ill fullen keyond land this is excessive, all fillen (deyond land: is is based on an incorrect assumption of crystal hiberation and fine ash generation in the plimian eruption column
Furthermore, if $16 \mathrm{~km}^{3}$ of fine ash had Furthermore, if $16 \mathrm{~km}^{3}$ of fine ash had beet generated, hen a more extensive distribution of this rephra should have been found in offshore cores . Ideduce (3) Tote realistic flgare or $20 \%$ or fine ash. (3) The height reached by the eruption column is controlled by convective strengh and heal outpul, not total eruplion volume. The total column density tain fiever be greater than surrounding atmosphere density, as wh zero shear strength the columh would then collapse. Thus $16 \mathrm{~km}$ (i) $55 \mathrm{~km}$ ash could not rise beyond $50-55 \mathrm{~km}$ (ref. 7 ) and no large quantities could reach the mesosphere. At
thiese heights, particles would fall to lower elevations within a few weeks ${ }^{2}$, before the widespread dispersal claimed by Wilson et al.' could occur. Thus Lamb's deduction of material reaching the Northern Hemisphere only if erupted north of $20^{\circ} \mathrm{S}$ latitude is considered valid. For comparison, an eruption on Bali $\left(8^{\circ} 5^{\circ} \mathrm{S}\right)$ in March. 1963 produced an observed
column up to $50 \mathrm{~km}$ high which had fallen to $31-35 \mathrm{~km}$ by November 1963, when 'sunset phenomena' were observed from Australia to England'. Particles with diameters of $\sim 1 \mu \mathrm{m}$ were being concentrated in the equatorial region at 20 $22 \mathrm{~km}$ up to April $1964^{3}$. Thus the Taupo material would also be expected to fal rapidly from $\sim 55 \mathrm{~km}$ height to the lowe stratosphere and, being erupted from $39^{\circ} \mathrm{S}$, would spread over the Southern Hemisphere. As large quantities of fine ash could not have reached the Norther Hemisphere, the chances of this material causing red Sun phenomena witnessed by Europeans are slight.

(4) Confirmation of the Taupo date could be sought in polar ice cores'. Acidity profiles in the Greenland ice sheet ${ }^{*}$ are incomplete for between $A D 0$ and 500 . In the Greenland ice cores, an earlier and larger eruption from Taupo (Waimihia Tephra, $1640 \pm 130 \mathrm{BC})^{3.10}$ has not been noted, so the Taupo event may not be represented either. Consequently, migration of volcanic acids and hence micro particles into the Northern Hemisphere following the Taupo eruption is doubtful. (5) Finally, and most importantly, Wilso et al quoted a date for only one of the Roman accounts (AD 186) and a range of AD 168-189 for the Chinese record. They did not attempt to substantiate that the three accounts were describing the same event. Thus the ancient writers were probably describing different events, possibly the results of dust-storms or fires.

\section{P. C. FROGGATT}

Geology Deparment,

Victoria University,

Wellington, New Zealand

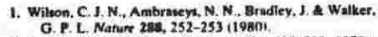
2. Lamb. H. H Phit. Tranes $R$ Soc. A226, 425-533,1970

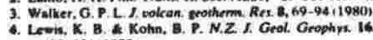

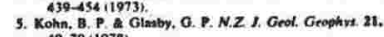
6. Woutina, N. D. \& Husne. T. C. N.Z. J. Geol Geophys. 20 1. Witton. L, Sparts. R. S I. Huanne. T.C. A Wattim. N. D.

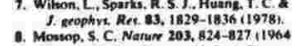

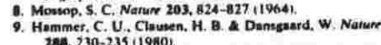

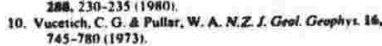

WILSON ET AL. REPLY-We answer Froggatt's five objections to our interFroggatt's five object
pretation' as follows:

pretation as follows: sky colouration would have been caused sky colouration would have been caused by the finest particies (mostly $\leqslant 0$ other than and that particles from sources other than Taupo could have been responsible. We believe that a close temperal correlation exists between optical effec's recorded by Chinese and Roman historians, and volcanic eruption which seems to be one of the outstanding explosive eruptions of the past 2 millenia. The optical phenomena are consistent with the arrival in the Northern Hemisphere of significant quantities of the finest particles from the Taupo eruption.

(2) We stand by our figure for the volume of the Taupo ultraplinian pumice-fall deposit, and cannot comment on Froggatt's estimate as we do not know its basis. However, the absolute volume of ash released to the atmosphere is much less important in determining the dispersal than the height to which the material is injected. Regarding the apparent absence of significant amounts of Taupo eruptive material in offshore sediment cores, two of the three studies quoted were in areas well north ${ }^{3}$ and well south ${ }^{4}$ of the seaward extension of the mapped dispersal axis. The third offshore study $y^{3}$ was centred $>1,600 \mathrm{~km}$ downwind from source where the expected thickness of Taupo eruptive material would be $<1 \mathrm{~mm}$; because of bioturbation, such an ash layer is unlikely to survive as a discrete bed d. $^{6}$.

(3) We have never claimed that the eruption column height was controlled by the eruption volume, or that $16 \mathrm{~km}$ of fine ash rose higher than $50-55 \mathrm{~km}$. However. two methods indicate that the height of the ultraplinian eruption column was $50 \mathrm{~km}$ or more (ref. 8 and L. Wilson, personal communication). Material of a grain size appropriate to cause the atmospheric effects recorded in the Northern Hemisphere, if injected 10 $55 \mathrm{~km}$ height, might be expected to take
up to several years to fall even to $30 \mathrm{~km}$ (ref. 9) and would not fall significantly "within a few weeks". The 1963 eruption of Mi Agung was a much smaller and less violent even than the Taupo eruption; its violent even than the Taupo eruption; its was only $\sim 13 \mathrm{~km}$ and the first 3 months wastivity produced only $0.28 \mathrm{~km}^{3}$ of material' ${ }^{\prime n}$ (4) We agree that the bulk of the ash
resulting from the Taupo ultraplinian phase, as well as from earlier and later explosive phases of the same cruption, would probably have been confined to the would probably have been confined to the not preclude the dispersal of significan not preclude the dispersal of significan amounts of the finest particles to the
Northern Hemisphere. Regarding the

$0028-10836 / 81 / 000001-0280100$

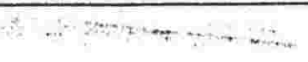

O 1981 Mecmiliea Joumenb Let

apparent absence of an acidity anomaly for the Waimihia eruption (dated at for the Waimihia eruption (dated the $-3,800 \mathrm{yr}$ BP (ref. 11)), we note that the Greenland ice-core study ${ }^{12}$. from the period $3,050-4,650$ yr BP. considered only acidity levels greater than 2.6 pequil f per kg of ice. As the far larger Northern Hemisphere eruptions of Santorin endy produced acidity ignals of 5.3 and 6.0 uequiv $H$ per $\mathrm{kg}$ of ice, respectively, then the absence of marked peak a tributable to the Waimihia Whe Weposis, moreover, implies that the Wowerful than the Taupo eruption. pow Froget sue Taupo errection. Froggat summarily dismisses the historical evidence and concludes that the observed phenomena were possibly the results of hires or dust storms. However. internal evidence suggests that none of these alternatives seems likely, although the probability of one of the early writers cannot be ruled out.

In conclusion, none of Froggatt's objections invalidate the grounds on which we proposed a correlation between the Taupo eruption and the optical effects bserved in AD 186 in both China an Rome.

C. J.N. WILSON

Geology Department,

University of Auckland,

Auckland, New Zealand

N. N. AMBRASEYS Civil Engineering Department.

Imperial College.
London SW72BU, UK

18 Juniper Lane.

J. BRADLEY

Massachusetts 01002, USA

G. P. L. WALKER

Department of Geology and Geophysics,

University of Hawaii,

2525 Correa Road,

Honolulu,

Hawaii 96822, USA

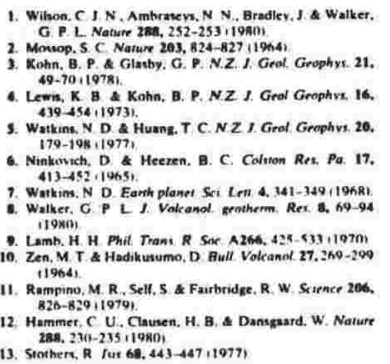

G P I Nature $28 \pi, 252-253,19801$

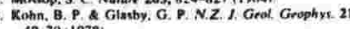

Wo

C. Ninkovich, D \& Heenen, B. C. Coltron Rer, Pa. 17,

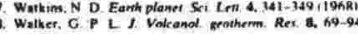

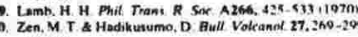

12. Hammer, C U.,Chausen. H. B. \& Dansasard. W. Nature

3. Stothers, $R$ for 68. 443-447, 1977) 


\section{6}

8.2 EVALUATION OF THE HAZARDS CAUSED BY VOLCANIC ACTIVITY IN THE TAUPO REGION,

NORTH ISLAND, NEW ZEALAND.

A report prepared for the National Committee on

Civil Defence.

May, 1981. 


\section{7}

EVALUATION OF THE HAZARDS CAUSED BY VOLCANIC ACTIVITY IN

THE TAUPO REGION (TAUPO VOLCANIC CENTRE), NORTH ISLAND,

NEW ZEALAND.

P.C. FROGGATT

C.G. VUCETICH

Geology Department,

Victoria University.

\section{CONTENTS}

1. General Volcanic Geology.

2. Eruptive history of Lake Taupo Volcanic Centre:

(i) $0-40,000$ years B.P.

(ii) Pre-40,000 years B.P.

3. Frequency of eruptions.

4. Types of eruptions and Nature of the Volcanic Hazard:

(i) Hydrothermal eruption.

(ii) Scoraceous basalt eruption.

(iii) Dacite, cumulo-dome formation.

(iv) Rhyolite dome extrusion.

(v) Rhyolitic plinian eruption (airfall tephra).

(vi) Phreatoplinian eruption (Plinian interacting

(vii) Pyroclastic flows forming an ignimbrite.

5. Precursory signs of eruptions.

6. Civil Defence considerations.

7. What to do in the event of an eruption.

8. Scenario of possible events consequent on volcanic eruption.

9. Glossary of terms. 


\section{8}

NATIONAL CIVIL DEFEINCE PLANNING COMMITTEE

ON VOLCANIC HAZARDS

\section{TERMS OF REFERENCE}

As approved by the National Civil Defence Committee at the meeting of its Executive Sub-Committee on 30 October 1980, the Committee is to assess, report and where appropriate recommend -

(a) The likely areas and types of future volcanic activity.

(b) The risk to public safety in each case.

(c) Those areas which warrant special precautions for public safety.

(d) Precursory indicators and monitoring systems including the likely notice of eruption to be expected.

(e) The likely effects of eruption upon populated areas and essential services.

(f) The civil defence measures to be undertaken and the functions to be exercised by government agencies and other organisations before and during an emergency arising out of volcanic hazards.

(g) Government resources which may be called upon in a volcanic emergency.

(h) The practical steps that regional government and local authorities should take against volcanic hazard where a specific threat is identified.

(i) The matters to be included in regional and local civil defence plans in preparation for possible disasters arising out of volcanic hazards.

(j) Procedural steps for validation of warning signs and recommendation for action by higher authority.

Although the Planning Committee is required by Section 12 of the Civil Defence Act 1962 to prepare a plan for approval by the Minister, it was considered that the National Civil Defence Committee should be kept informed by periodic progress reports during the drafting of the plan. 


\section{PREFACE}

This is a draft document prepared in response to a request by the National Civil Defence Committee on Volcanic Hazards, established by the Minister of Civil Defence.

All conclusions expressed here are the responsibility of the authors alone, based on information currently available to them. It is possible that future research or further information may alter some conclusions.

Much of the data on which this hazard evaluation is based has only recently been obtained by the authors and is at present unpublished. Reference to the information contained herein and outside the context of this report should only be made with due acknowledgment and with the authors' knowledge and permission.

P.C. Froggatt

C.G. Vucetich

Wellington

5 May 1981. 
Lake Taupo Volcanic Centre (abbreviated here to TVC) is here loosely defined as the region of volcanism encompassing Lake Taupo from the rhyolitic domes about Tokaanu in the south to Wairakei in the north (as shown in Fig. 1). This division arbitrarily excludes andesitic volcanism to the south (Tongariro Volcanic Centre) and the extensivedome terrane of Maroa Volcanic Centre to the north.

Many types of volcanoes are found in TVC but the most conspicuous volcanic features are the rhyolitic domes clustered on the south-west and south-east margin and those forming promontories along the northern edge of Lake Taupo. Only Mount Tauhara resembles the classic "volcano-shape" (e.g. Mounts Egmont, Ngaruhoe). Less conspicuous are the other "volcanoes" having low, or negative, relief and known to be submerged in Lake Taupo.

The general volcanic geology of LTVC shown in Fig. 1, includes visible volcanoes or domes as well as volcanic vents without domes inferred beneath Lake Taupo. Only some of these features are at present positively dated, the remainder are assumed to be Late Pleistocene. The general stratigraphy and thickness of the volcanic deposits is known, mostly from geothermal drill-cores taken in Wairakei valley but due to the intense hydrothermal alteration of these rocks positive correlation beyond this area is poor. Fission-track dating of some ignimbrites suggests TVC is no older than 0.5 Myr. 


\section{$-2-221$}

2. Eruptive History of Lake Taupo Volcanic Centre

- (i) $0-40,000$ years B.P.

Numerous exposures, road cuttings, etc. have enabled a particularly complete tephra stratigraphic record for the last 40,000 years to be compiled, as well as isopach maps on which tephra volume estimates are based. Radiocarbon dating has enabled a detailed chronology to be constructed, particularly for the post-20,000 year record. Table 1 contains the stratigraphy, chronology and estimated volume, as well as the types of eruption inferred for these tephras. There are 19 airfall tephras in this time period as well as 3 ignimbrites. A comparison of total erupted volumes however shows the ingimbrites totalling $175 \mathrm{~km}^{3}$ to be more voluminous

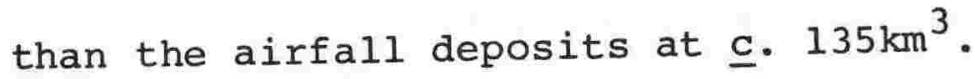

Following most violent eruptive events, a rhyolite dome has been extruded. These domes are located, with their respective tephras, on Fig. 1. The post-20 kyr domes are small in comparison to older TVC domes and also to those in other volcanic centres. Many young domes are now submerged beneath Lake Taupo.

Some young, prominent domes in TVC have not yet been associated with particular tephras. Those shown on Fig. 1 are the rhyolitic domes of Motuoapa Island and Manganamu and the dacitic Koroi dome. None of these domes have been directly dated but the mantling tephras and undisected form indicate an age less than 20 kyr. 


\section{$-3^{22}-$}

(ii) Pre- C. 40,000 years B.P.

The pre-40,000 year eruptions from TVC are poorly exposed near source and very few sections or drill-cores expose the critical unwelded base of, or zonation within, ignimbrite sheets. Major eruptions are known in limited stratigraphic content distal from source. Some attempts have been made to correlate between welded ignimbrite outcrops and to distal unwelded tephras well preserved in marine and terrestrial sequences, but fission-track dates and paleomagnetic chronology are inadequate. There is a stratigraphic record of numerous tephras preserved in sediments peripheral to this area. These tephras indicate there has been far more eruptions from TVC than have been documented. Due to this lack of correlation between individual ignimbrite outcrops and also the more distal portions, the precise number, volume and extent of pre40 kyr eruptive events is unknown. This has serious implications for long-term hazard and return period calculations.

A chronology for most of the welded ignimbrites has been established by fission-track dating on glass or zircons. A tentative stratigraphy and chronology of pre-40 kyr tephras in Table 1 shows also probable correlation between separately named sheets. Lack of data prohibits volume estimates but by comparison to the better known post-40 kyr events each welded ignimbrite is of the order of $100-500 \mathrm{~km}^{3}$. The source vent for these ignimbrites is unknown but is probably in the northern part of Lake Taupo.

A few exposures in TVC show that pre-40 kyr and also between each major ignimbrite eruption smaller, plinian-type eruptions 


\section{3

have occurred.

\section{Frequency of Eruptions}

To determine a statistical (empirical) frequency or "return period" for each eruption type, it is necessary to know the number of eruptions over a specified period of time. The post 40-kyr record plotted on a Time-Volume diagram Fig.2 shows that eruptions were episodic over about 10,000 years with repose periods up to 10,000 years. To derive a reliable frequency or return period, data over a time interval of 10 times this sequence or 200,000 years is desirable and may possibly be attained in the near future. Currently, detailed data are available only for the last 40,000 years so frequency estimates are necessarily "order of magnitude" only. To illustrate this, Table 1 shows 11 plinian eruptions in $10 \mathrm{kyr}$ or a return period of 910 years, compared to 16 in 40 kyr or a return period of 2500 years, double the 10 kyr figure. Given the incompleteness of the pre-40 kyr data, general return period estimates are in Table 2 .

The best long-term return period estimate for all types of plinian eruptions is about 2200 years. The same period applies to dome extrusion. With less data for the ignimbrites their period appears to be between 10 and 70,000 years with a general relationship between size and frequency. These values do not mean that a plinian eruption will occur every 2200 years. Rather, this is the long-term mean frequency of eruptions and as shown on Fig. 2, both long intervals of quiescence and shorter intervals intense activity are possible. 
In view of the cyclic nature of the post-40 kyr record, and with each period of activity culminating in an ignimbrite it is possible that TVC has entered another several-thousand year repose period.

4 Types of Eruptions and Nature of the Volcanic Hazard Magma ranging in composition from basalt to rhyolite has been erupted from TVC so the full spectrum of eruptive types has occurred. A study of the deposits allows the type of eruption to be determined. These are here grouped into 7 classes which, in order of increasing magnitude and hence hazard are:

1. Hydrothermal eruption (explosion).

2. Scoraceous basalt cone eruptions.

3. Dacite, forming a cumulo-dome.

4. Extrusion of rhyolite dome.

5. Rhyolitic plinian (airfall) eruption.

6. Phreatoplinian (= plinian + lake water $)$.

7. Pyroclastic flows producing an ignimbrite.

It should be emphasised that two or more of these deposits can be formed in the one eruptive episode. A description of the type of eruption and eruptive products follows together with the nature of the volcanic hazard.

\section{Hydrothermal Eruption.}

Hydrothermal eruptions are most common in active thermal areas. They consist of a single explosion or series of explosions at shallow depth caused by the flashing of superheated water into steam. No fresh magma is normally erupted although such 


\section{$-6-225$}

eruptions may be caused by emplacement of magma at shallow depth prior to a major eruption. Material may be ejected up to 500 - 1000 metres from the vent but usually much less. Hydrothermal eruptions in TVC area are known only from presently active thermal areas. One of the biggest known was from Lake Rotokawa about 4,500 years ago, probably forming the present lake depression. Material including $10 \mathrm{~cm}$ blocks of ignimbrite was ejected up to $800 \mathrm{~m}$ from the lake. The area of hazard is up to $2 \mathrm{~km}^{2}$ and other than destruction of tourist attractions the hazard is small. Within Tauhara thermal area, bordering Taupo town, such an explosion would create a high risk.

\section{Scoraceous Basalt Eruption.}

Known occurrence of scoraceous basalt eruptions in TVC is restricted to 3 major outcrops at Karangahape cliffs, the 'K-trig' line of cones $1 \mathrm{~km}$ west of Taupo and a small cone north of Kinloch. Age of these cones is uncertain but the latter 2 are about 35 - 50,000 years old. Volume of material erupted is small, totalling less than $2 \mathrm{~km}^{3}$ and is restricted to small scoria cones a few hundred metres across and about $100 \mathrm{~m}$ high. Ejected material has not been recognised beyond about $1-2 \mathrm{~km}$ from the cones although small amounts of fine ash probably fell over an area of $10-20 \mathrm{~km}$ radius. This ash has not been found thicker than about $\frac{1}{2} \mathrm{~m}$. Although no lava flows have been recognised from these cones lava flows are commonly associated with basalt eruptions and are particularly fluid and mobile.

Except for the area directly covered by the cone building the 


\section{6}

hazard to the surrounding area is low, and no major hazard is forseen from any airborne tephra unless the quantity is large and thicknesses exceed $\frac{1}{2} \mathrm{~m}$.

\section{Dacite, Cumulo-dome Formation.}

Dacite is a relatively rare magma type in the central Volcanic Region, although both Mt. Tauhara and Mt. Edgecumbe are of moderate size. Tauhara and the small dome of Manganamu $3 \mathrm{~km}$ to the south are the only two examples of this eruption type in the Taupo area and like all other dacite eruptives lie on the eastern margin of the Volcanic zone. No tephra has been identified with the eruption of Tauhara which is K-Ar dated at about 35,000 years ago. Eruption of Tauhara and Manganamu is apparently largely an extrusive process similar to rhyolite dome building. Tauhara comprises 3 coalescing domes. No lava flows have been recognised. The hazard from this type is similar to the basalt cone eruptions except a larger volume of extrusives is involved.

\section{Rhyolite Dome Extrusion.}

Formation of a rhyolite dome most frequently follows an initial explosive tephra eruption (see 5 below) but some dome building has occurred with only minimal tephra production. A dome grows by the slow extrusion of viscous magma into the centre of the dome which swells outwards. The rate of growth has been measured from $1-10 \mathrm{~m}$ per day. This results in a typical, concentric "onion-ring" structure and as the dome grows the hard outer "skins" crack and break up into large blocks. Rock avalanches on the sides of the growing dome are 


\section{$-8227$}

common but these would seldom extend much beyond the base of the dome. There are many, perhaps hundreds of rhyolite domes in TVC. They range in size from $200 \mathrm{~m}$ across and $100 \mathrm{~m}$ high to very large domes $5 \mathrm{~km}$ or more across and 5-600m high. Most of these are associated with tephra eruptions, for example Acacia Bay dome was extruded 10,000 years ago following eruption of Karapiti Tephra.

The hazard from dome building is confined to the immediate area of the dome as it grows slowly. Minor quantities of fine tephra would also be erupted but the hazard from this is low especially if dome growth is preceeded by a major tephra eruption.

\section{Rhyolitic Plinian Eruption (airfall tephra).}

Plinian or explosive magma eruptions are the most common type in TVC. Moderate to large quantities of pumiceous tephra with minor dense "lithics" are erupted in a continuous, sustained eruption that may last from a few hours to several days. These eruptions occur from a single, probably circular vent several hundred metres across. Erupted material rises above the vent in a plume that may reach $50 \mathrm{~km}$ height. Particles fall from this column accoridng to their size and density so that coarser or denser particles fall closer to the vent and smaller or lighter particles fall furthef away. The maximum particle size is different for each eruption but ranges from $10 \mathrm{~cm}$ to about $30 \mathrm{~cm}$ for pumice and up to $15-20 \mathrm{~cm}$ for the denser lithics. 


\section{$-228$}

been compiled for all Taupo tephras younger than 40,000 years. Maximum recorded thickness ranges from $5 \mathrm{~m}$ to about $\frac{1}{2} \mathrm{~m}$ but the rate of thinning of the deposit varies with the eruption intensity.

The temperature at which this material falls is not well known. The magma before eruption is at about $700-900{ }^{\circ} \mathrm{C}$ but upon eruption cools rapidly in the air. Plinian type falls do not appear to char vegetation indicating a temperature on landing of $10-30^{\circ} \mathrm{C}$. Charcoal is occasionally found in these fall deposits but the charring has been related to natural fires within the damaged forest postdating the eruptions.

This violent eruption of tephra is commonly followed by the relatively quiet extrusion of a dome as described above, and in known cases this is at the site of the plinian eruption.

Plinian deposits from TVC vary in volume from less than $1 \mathrm{~km}^{3}$ up to $70 \mathrm{~km}^{3}$ for the post 40,000 year events. The hazard from plinian eruptions is considerable, as a large area $\left(20,000 \mathrm{~km}^{2}\right.$ or more) may be buried by up to $1 \mathrm{~m}$ of tephra, depending on the eruption size.

An estimate of the area covered by a given thickness of tephra can be determined from Fig. $3 a, b$ where generalised isopachs are plotted such that the thickness halves between each contour. These can be converted to thickness by assuming a maximum thickness at the vent. Past eruptions indicate a maximum thickness of $3-5 \mathrm{~m}$ and not exceeding $10 \mathrm{~m}$. Two isopach distributions are 
chosen to cover the varying rate of thickness decrease, Fig. 3a being more applicable to the larger eruptions than Fig. $3 \mathrm{~b}$.

The direct hazard of plinian eruptions is burial by tephra. Within about $5 \mathrm{~km}$ of the vent however large lithic blocks 20$50 \mathrm{~cm}$ across and following a ballistic trajectory are also possible with attendant higher momentum. Beyond $5 \mathrm{~km}$, tephra fall should be survivable by a well clad person wearing a protective helmet. Poisonous gases appear to be rare with plinian eruptions but very fine pumice particles can be lethal if breathed.

Pumiceous tephra has a low density $\left(0.2-0.9 \mathrm{~g} / \mathrm{cm}^{3}\right)$ but $1 \mathrm{~m}^{3}$ weighs $200-900 \mathrm{~kg}$ so $1 \mathrm{~m}$ thickness on a building roof of $100 \mathrm{~m}^{2}$ would weigh 20-90 tonnes. The steeper pitched the building roof the less tephra would settle so the risk of roof collapse lessens. However, roof collapse is a considerable risk as very few steep-pitched roofs exist in Taupo.

\section{Phreatoplinian Eruption (Plinian interacting with Lake Water).} With a large volume of water in Lake Taupo and at least 6 eruptions in the last 10,000 years being centred under the present lake, this type of eruption must be considered as a high possibility. Interaction of water with a body of hot magma creates a large explosive force as the water flashes to steam, which fragments the erupting magma as well as vapouring the water. Condensation in the eruption column may rapidly flush fine tephra out of the atmosphere forming a dense, wet, 


\section{- 213t)}

sticky deposit, as occurred at Tarawera in 1886. The youngest example from TVC was the Rotongaio Ash erupted 1800 years ago to form part of Taupo Pumice Formation, and like other plinian deposits is widespread.

The hazard of this eruptive type is greater than the plinian type as the wet and sticky material has a greater density $\left(2.0-2.5 \mathrm{~g} / \mathrm{cm}^{3}\right)$. For a roof area of $100 \mathrm{~m}^{2}, 1 \mathrm{~m}$ would weigh 200-250 tonnes. The tephra fall would be less easily survived due to the wet sticky nature of the tephra. A further hazard created by an eruption within Lake Taupo is the possible creation of a large Tsunami or seche that may reach $10 \mathrm{~m}$ or more height in the shallow bays at the north end of Taupo.

\section{Pyroclastic Flows forming an Ignimbrite.}

A pyroclastic flow is the most voluminous and destructive eruptive phase, and is often preceeded by a large plinian eruption. It is a mass of pumice blocks and ash fluidised by gases and behaves as a fluid, flowing radially outward from the eruptive vent. The direction of flow is controlled by topography, being channelled within valleys and depressions. Thickness of resulting deposits is thus greatest in valleys, and is thinner on ridges and hills. Material "ponds" in valleys, resulting in a flat-topped deposit. Velocity of flow is in the order of $30-200 \mathrm{~km} / \mathrm{hr}$ depending on the size of eruption, although few accurate measurements have been made. Unlike plinian eruptives, pyroclastic flows retain much of their heat during transport and temperatures in excess of $200-$ $400^{\circ} \mathrm{C}$ are possible. Charred tree remains, common in some 
deposits, attest to this heat retention.

The deposit from pyroclastic flows is termed an IGNIMBRITE and some of the larger ignimbrites have maintained enough heat for the particles to fuse together or WELD. These are termed "welded ignimbrites" and form hard, flat-topped "sheets" to the west and east of the Central Volcanic Region.

The size and extent of ignimbrites varies considerably from small single flows of less than $0.5 \mathrm{~km}^{3}$ volume and covering about $100 \mathrm{~km}^{2}$ up to the multiple bedded, welded sheets of $100-$ $500 \mathrm{~km}^{3}$. Contemporary with ignimbrite emplacement is a widespread airfall deposit, generally of fine ash. Volume of this material may reach as high as 30-50\% of the ignimbrite volume and has been found up to $1,000 \mathrm{~km}$ away from source.

A well studied example is Taupo Ignimbrite, erupted 1800 years ago and preceeded by a large plinian eruption (Taupo Lapilli, $12 \mathrm{~km}^{3}$ ). Taupo Ignimbrite mantles all topography out to a radius of about $80 \mathrm{~km}$ from the source but is thickest in the valleys and thins rapidly onto ridges. Appreciably thick ignimbrite extends down major valleys possibly a further $50 \mathrm{~m}$ from source. Although not welded, it contains abundant charred vegetation attesting to an emplacement temperature of $300-400^{\circ} \mathrm{C}$.

The hazard from a pyroclastic flow is immense. Total destruction in the path of the flow is almost inevitable and valley floors may be buried up to $100 \mathrm{~m}$ deep. No trees would remain standing nor buildings and if the initial flow was not fatal the 
engulfing hot gases and fine tephra would be. Fortunately, the frequency of these events in the TVC is low.

\section{Precursory signs of Eruptions}

Lake Taupo Volcanic Centre is an area of generally low relief, mostly now beneath Lake Taupo, in marked contrast to most other volcanic areas (e.g. NW U.S.A.) where volcanic massifs predominate. Thus some of the precursory signs observed elsewhere may not be detectable at Taupo.

Precursors are grouped here into two classes:

(i) Phenomena best detected by instruments.

(ii) Phenomena or changes visible to an observant person.

Those in class (i) include (a) an increase in seismicity, especially microearthquakes, with hypocentres clustering at a shallow depth. A long-term continuous record of seismicity in the region against which changes can be compared is vital. This record is not at present available. (b) Recording of changes in regional or local tilting caused by tumescence or "swelling" of the area surrounding the volcano. The regional extent of such tilting is unknown but Lake Taupo hampers a good regional coverage of past eruptive vents. (c) Rise of magma prior to an eruption could be reflected by increased heat flow but again Lake Taupo may buffer any rise.

(ii) Observed changes may include (a) change in the level of Lake Taupo or change in water outflow - perhaps best observed 


\section{- 1433}

by NZED. (b) Change in topography or islands within the lake caused by swelling. (c) Change in thermal activity, especially an increase; hydrothermal eruptions or development of new thermal areas. (d) Short lived phenomena such as was observed immediately prior to the Tarawera 1886 eruption should not be discounted. The most important of these was the increase in the number and intensity of earthquakes felt over a wide area. Non-volcanic earthquake "swarms" have occurred previously at Taupo (e.g. 1922) so a sequence of felt earthquakes is not necessarily an eruption precursor. Therefore, instrumental records of any earthquake swarms are essential to determine their type and character as well as their origin. The Tarawera experience indicates that this precursor may be short lived (2 weeks or less).

\section{Civil Defence Considerations.}

The most likely precursors or warnings of an impending eruption are a marked increase in felt earthquakes. Immediate interpretation of instrumental recordings is essential to quantify these earthquakes, to determine their type and to locate their origin. Precise location of eruption precursors is essential to determining the site of an impending eruption. This will be of immeasurable assistance to Civil Defence.

In the event of this and other precursors indicating an eruption is imminent, evacuation of people from within the zone of maximum risk is essential prior to an eruption commencing. Once a major airfall eruption has begun, erupted material will totally obscure the sun, creating darkness, and tephra fall will 
quickly prohibit any transport or ground movement. Even when the eruption is finished, all roads with more than $10 \mathrm{~cm}$ of tephra will be impassable until cleared. This may take some time. Evacuation after the eruption could only be by helicopter. During the eruption, all communication from within the fallout area will be cut, as telephone lines will be broken and radio reception will be impossible due to the disturbed and tephraladen atmosphere. VHF transmission via a repeater station may, however, be possible, if the repeater aerial can withstand the tephra fall.

The siting of Civil Defence headquarters is also worthy of mention. The present Taupo area HQ is on the Lake front at Taupo, an area of high risk in an eruption, and an area vulnerable to Tsunami or seches in Lake Taupo. An HQ beyond the risk area should be established prior to an eruption so that all CD coordination both before and after the event can be coordinated from the one site. All CD facilities such as communications, maps, documents and equipment should be capable of removal to a low risk site with the minimum of warning.

Practical experience from Mt. St. Helens suggests the need to keep the public fully informed of all information and possible events, without creating panic. Self-determined evacuation would greatly assist $C D$. Mt. St. Helens also showed the problems of clearing away the tephra. Fine ash, easily stirred up is dangerous if inhaled but can be overcome by simple surgicaltype masks. Vehicles also suffer this problem and airfilters will require frequent changing. 


\section{$-235$}

Emission of toxic gases may not be a problem following the eruption but it is likely that Lake Taupo and groundwater will be seriously polluted and unfit for consumption. All fish-life within the lake may also be killed, and with consequent further pollution.

7. What to do in the event of an eruption.

If an eruption begins without warning and immediate evacuation is not possible, the safest place will be indoors, away from windows in case they break. A dust mask of some sort should be on hand. If daytime, the sun will become completely obscured, with resulting darkness. In a tephra-fall eruption that may last for several hours, material will fall continuously but will not accumulate rapidly and there will be no immediate risk. However, if accumulation approaches 1 metre, then the weight of material on a house roof may be sufficient to collapse it, unless the roof is steep-pitched. This in particular applies to large buildings as these usually have flat roofs. In multi-storey buildings, the upper floor at least should be evacuated. 
8. Scenario of possible events consequent on volcanic eruption.

To integrate the foregoing sections, a scenario of possible volcanic events is presented.

The actions of Civil Defence and other organisations described here are speculative but based on present circumstances of manpower, planning and current levels of research and knowledge. The nature and timing of volcanic events is also speculative and dependant largely on the record interpreted of past events. 14 out of the last 20 eruptive events have followed a similar pattern. As a basis for this scenario an eruption with the least complex set of events was selected; no pyroclastic flow phase and no direct lake involvement on the eruption is assumed.

This scenario discusses the possible sequence of events leading up to and following a moderate sized plinion eruption (airfall tephra) and extrusion of a rhyolite dome. It is modelled on the Karapiti Tephra sequence erupted 10,000 years ago, from a vent behind Acacia Bay, Taupo, but it is emphasised that a future eruption would be unlikely to have this same source.

A sequence of perhaps 6-10 small earthquakes occur, felt locally about Taupo Borough. Further sequences of earthquakes occur at 3-4 week intervals. Sequences similar to this have often occurred in historic time and do not arouse much interest other than passing comment. These earthquakes are not recorded by any seismograph as they are too small to reach the instruments sited at Karapiro or the Chateau, the nearest recording 
stations so their centre, type and magnitude is unknown. After several months a few residents on the lake edge at Acacia Bay notice that the lake level is apparently dropping slowly and rocks previously submerged are visible." As the lake is controlled by NZED for hydroelectric power generation no significance is attached to this change. However, the apparent local level change continues and is eventually detected as a local bulging by periodic relevelling of the bench marks already installed by DSIR in the Taupo VC. Further bench marks are then installed in this area,. and levelled to measure the extent and rate of change of the doming. The incidence of earthquakes increases and coupled with the level changes convinces DSIR to install a network of 3-6 portable seismographs for an initial investigation. This enables them to locate the position and depth of each earthquake and to determine its type. Several weeks after this study the results become available which suggest the possible rise of magma in the Acacia Bay area.

At this stage local authorities and Civil Defence are officially briefed on the possible volcanic significance of the events and the public are then informed by press releases and public notices. The appointment of a scientific press officer ensures all official information comes through one source and frees all other personnel from continual questioning by the press. The public are informed of the significance of measurements being undertaken and the possibility of an eruption occurring near Acacia Bay within a few months. All are urged to consider the need for evacuation and what action to take if an eruption does occur before evacuation. 
Meanwhile, Civil Defence prepares detailed evacuation plans and establishes an evacuation centre at Rotorua and readies to move their $\mathrm{HQ}$ to a safe area North or West of Taupo. Earthquakes continue to increase in frequency and magnitude and further recording on seismographs shows their depth of origin has decreased to about $4-5 \mathrm{~km}$. Ground deformation about Acacia Bay has reached several metres in uplift and surface cracks have appeared, damaging roads and some houses. Many residents of Acacia Bay decide to leave. It is now perhaps 6 months since the earthquakes began.

Scientific opinion agrees that an eruption is imminent and the eruptive vent will be near Acacia Bay. At this point the exact timing of the eruption and the type and magnitude are still being debated. With the possible eruptive vent being near Lake Taupo NZED is urged to lower the level of Lakes Taupo and Aratiatia to the absolute minimum. Thermal activity around Taupo has increased and several new areas of hot springs and steam vents have appeared. Hydrothermal eruptions ociur at Wairakei and east of Taupo, causing public concern.

Dut to increased ground deformation, now reaching 20 metres or more, local authorities decide to completely evacuate Acacia Bay area and to prohibit further access. Residents of Taupo are urged to leave (after due notification) as soon as possible, and those remaining are to be ready for immediate evacuation. Stock on farms near Acacia Bay and east of Taupo are to be removed from the Taupo area to reduce the losses of these animals. Many more earthquakes are now felt each day and their depth has 
decreased to around $3 \mathrm{~km}$ or less. Taupo Hospital is closed and patients moved to Rotorua. CD moves all operations to new HQ but maintains a forward post at Taupo with VHF communication via a new aerial (strengthened) on Tauhara. A decision to completely evacuate all people living between Motuoapa, Rangitaiki, wairakei and Kinloch is now considered by $C D$ and local authorities. If agreed upon people are moved north and west except those south of Hatepe who must move further south. Rotorua is chosen as the best evacuation site. Now 7 months after the earthquakes began, evacuation is ordered before onset of eruption begins because during eruption, transport will be quickly halted by accumulation of tephra on all roads leading out of Taupo. All trucks and bulldozers are ordered out of the risk area by $C D$ and assembled north of Taupo ready for any clean-up operations.

The eruption begins quietly by the ejection of a small amount of fine tephra (fine ash grade material) from a vent at Acacia Bay, forming a layer about $5 \mathrm{~cm}$ thick at Taupo. Evacuation is not complete by this time and must be accomplished immediately. It is assumed that the major eruptive phase immediately follows and no more than 30 minutes is available to complete evacuation. Major earthquakes herald the beginning of the violent eruption of tephra that quickly rises in a plume to $20 \mathrm{~km}$ or more in height, completely obliterating the sun. Coarse pumice begins to fall and continues for many hours. Heavy gases may concentrate within valleys and in pockets along the lake shore. The prevailing winds are NW to $\mathrm{W}$ (as usual) and the eruption cloud drifts east towards Napier and Gisborne. It is several hours 


\section{$-240$}

before fine tephra falls on these towns. Within a few hours a metre or more of tephra covers Taupo borough and some house roofs collapse. There is no action CD can take until the eruption has ceased and all tephra has fallen. As total evacuation had not been achieved the rescue of persons is CD's first priority. Immediately after the eruption, heavy rain falls, helping to settle the fine tephra but this eventually dries and only occasional rain is experienced after this. Ground transport is now quite impossible so helicopters must be used. These have been organised by $C D$ before the eruption began and are now on standby. Further eruptions of tephra are possible but these will probably be small. Continued recording of earthquakes from seismographs still operating indicates if any further activity is due. Meanwhile, CD evaluates the damage; Taupo Borough is buried by 1-2 metres of tephra and all roads are impassable. About 2 million cubic metres of tephra needs to be removed from Taupo and the army is brought in to assist. Lake Taupo and the Waikato River are choked with pumice causing problems for NZED. Many trout are dead and most farm stock dead, many are buried, posing a health problem. Taupo Borough can not be inhabitable for many weeks until the tephra has been cleared. At the eruptive vent, a rhyolite dome has begun to grow and growth of the dome is accompanied by occasional small eruptions of fine tephra. Growth will take several weeks but eruptions become less frequent. These eruptions do not cause further damage but are dangerous to workers in the immediate area if the fine ash is inhaled. All workers have been issued with protective helmets, facial masks and gas masks. Vehicles, trucks and bulldozers require several spare airfilters and 
these should be changed frequently to avoid being blocked by fine ash. The immediate aerial sowing of selected seeds such as lupin, clovers and grasses, pelletised with appropriate fertilizers, is undertaken over the whole of the damaged area to help stabilise the tephra, re-establish vegetation and to reduce erosion.

Only after the dome has ceased growing and earthquakes have ceased, all tephra is cleared from Taupo and water and sewerage services re-established are residents permitted to return to live. They have now been evacuated for several months and pressure on $C D$ and the government has been building up to allow them to return. Prior to this decision a "restricted access area" has been declared and the Army has been enforcing the $C D$ requirements mainly for people's own protection from the unconsolidated tephra, and from damaged buildings and from trees. Group of scientists, however, have travelled widely over the damaged area studying the effects of the eruption.

Final assessment of damage shows nearly all houses at Acacia Bay are destroyed and about $25 \%$ of buildings in the Taupo Borough are condemned. A further $60 \%$ suffered major, but repairable damage. All buildings require thorough cleaning of fine tephra. Insurance claims are met by the Earthquake and War Damage fund, especially boosted by Government funds. All stock and pasture within the area were destroyed and are a further insurance claim. Vegetation is quickly re-established on the new tephra and areas of pine forest that were damaged 
(mainly Waimihia and Tauhara Forests) are replanted. Ecology of Lake Taupo is quickly restored and trout re-introduced. Within 5 years most effects of the eruption are repaired. 
Andesite: Type of magma with silica content 57-63\%.

Basalt: Type of magma with silica content $<57 \%$.

Dacite: Type of magma with silica content 63-68\%.

Hazard: The potential of a volcano to create damage. Hydrothermal eruption: A small, single or series of explosions caused by superheated water flashing to steam. A crater full of boiling water is produced, and tephra may be ejected up to $1000 \mathrm{~m}$ from this site. These eruptions are generally confined to active thermal areas.

Ignimbrite: The initially hot deposit formed from a pyroclastic flow. Ignimbrites form thickest in depressions often with a flat upper surface. The particles in some larger ignimbrites have fused together, forming a WELDED IGNIMBRITE.

Isopach Map: Map showing lines of equal tephra thickness for air-fall tephra deposits, drawn by plotting the total thickness of that tephra as measured in many sections.

Plinian eruption: A violent, continuous discharge of magma, rising vertically into a plume up to about $50 \mathrm{~km}$ height. Pyroclastic flow: A hot, gas-fluidised flow of pyroclastic material that moves horizontally across the ground surface at great speed: The deposit formed by this flow is an IGNIMBRITE.

Rhyolite: A type of magma, with high silica content $(>68 \%$ Rhyolite dome: A generally steep-sided volcanic 
Risk: The potential for destruction of features of importance to Man.

Tephra: Fragmental material erupted from a volcanic vent and transported through the air. It may consist of fresh vesicular pumice, dense glassy rock fragments, crystals or usually a mixture of all three. In addition pieces of pre-existing rock may be included. All non-vesicular tephra is here termed lithics.

Volcano: The vent for one or more eruptions. It may be represented by a cone, a crater, or a rhyolite dome.

Volcanic Centre: An area of intense volcanism with many volcanoes in a more-or-less geographically distinct area. 


\section{5 \\ $-26-$}

\section{CAPTIONS}

Table 1: Stratigraphy, chronology erupted volume and type of eruption for pyroclastic deposits from TVC. Stratigraphy prior to 40,000 years is tentative. All volumes given as unconsolidated material, density $0.8 \mathrm{~g} / \mathrm{cm}^{3}$.

Table 2: Calculated return periods for various eruption types for which sufficient data are available.

Figure 1: Generalised volcanic geology map of TVC, showing rhyolite domes, known eruptive centres and boundary of TVC used here.

Figure 2: Volumes of rhyolitic tephra erupted in the last 40,000 years from TVC.

Figure 3: Generalised isopach maps for rhyolitic plinian tephras with the thickness interval between lines halving. Large eruptions (a) have maximum thicknesses of $3-10 \mathrm{~m}$ and smaller eruptions (b) 0.1-3m. These figures can be overlain on Fig. 3cto determine the thickness of tephra at any place for an eruption of chosen size and vent location. 
TABLE 1

\begin{tabular}{|c|c|c|c|}
\hline & Type: & Age: & Volume* : \\
\hline Taupo Ignimbrite) & Ignimbrite $+\mathrm{D}$ ? & ) & $70 \pm$ \\
\hline Taupo Lapilli ， Taupo & & ) & $12+$ \\
\hline Rotangaio Ash / Pumice & $\mathrm{PP}$ & ) 1800 & \\
\hline Hatepe Ash . ) Formation & PP & ) & 2 \\
\hline Hatepe Lapilli ) & & ) & 2 \\
\hline Mapara Tephra & $P+D ?$ & 2200 & 2 \\
\hline Whakaipo Tephra & $P+D$ & 2800 & 2 \\
\hline $\begin{array}{l}\text { Waimihia Ignimbrite } \\
\text { Waimihia Lapilli }\end{array}$ & $\begin{array}{l}\mathrm{Ig}+\mathrm{D} \\
\mathrm{P}\end{array}$ & $\{3400$ & $\begin{array}{l}5 \\
14\end{array}$ \\
\hline Hinemaiaia Tephra & $P+D$ & 4600 & 3 \\
\hline Motutere Tephra & $\mathrm{P}$ & 5200 & 1 \\
\hline Opepe Tephra & $P+D$ & 8800 & 4 \\
\hline Poronui Tephra & $P+D$ & 9200 & 3 \\
\hline Papanetu Tephra & $P+D$ & 9800 & 1 \\
\hline Karapiti Tephra & $P+D$ & 10000 & 2 \\
\hline Oruanui Breccia ) & Ig & ) & 100 \\
\hline $\begin{array}{l}\text { Scinde Island Ash) } \\
\text { Aokautere Ash ) }\end{array}$ & $\begin{array}{l}\mathrm{PP} \\
\mathrm{P}\end{array}$ & 20500 & 70 \\
\hline Poihipi & $P$ & 20800 & 1 \\
\hline Okaia & PP & 21000 & 7 \\
\hline Tihoi & $\mathrm{P}$ & 38000 & 5 \\
\hline Waihora & $\mathrm{P}$ & 39000 & 1 \\
\hline Otake & P & 40000 & 2 \\
\hline $\begin{array}{l}\text { ? } \\
\text { Rangitaiki Ignimbrite } \\
\text { (= Te Whaiti and Rocky Hills) }\end{array}$ & Ig & $0.23 \pm 0.04 \mathrm{Myr}$ & . \\
\hline $\begin{array}{l}? \\
\text { Whakamaru Ignimbrite }\end{array}$ & Ig & $0.33 \pm 0.03 \mathrm{Myr}$ & \\
\hline
\end{tabular}

*Unconsolidated volume,

$\rho=0.8 \mathrm{~g} / \mathrm{cm}^{3}$. 


\section{$-2847$}

TABLE 2: Return Periods.

\begin{tabular}{|c|c|c|c|c|}
\hline & Type: & $\begin{array}{l}\text { er of } \\
\text { tions: }\end{array}$ & $\begin{array}{l}\text { Time } \\
\text { interval: }\end{array}$ & $\begin{array}{c}\text { Return period/ } \\
\text { yrs.: }\end{array}$ \\
\hline (i) & $\begin{array}{l}\text { Dome } \\
\text { Building }\end{array}$ & 9 & $0-10,000$ & 1,100 \\
\hline (ii) & $\underset{"}{\text { Plinian }}$ & $\begin{array}{l}11 \\
16\end{array}$ & $\begin{array}{l}0-10,000 \\
0-40,000\end{array}$ & $\begin{array}{r}910 \\
2,500\end{array}$ \\
\hline iii) & Phreatoplinian & $\begin{array}{l}2 \\
5\end{array}$ & $\begin{array}{l}0-10,000 \\
0-40,000\end{array}$ & $\begin{array}{r}5,000 \\
18,000\end{array}$ \\
\hline (iv) & Ignimbrite & $\begin{array}{r}2 \\
3 \\
? 6\end{array}$ & $\begin{array}{l}0-10,000 \\
0-40,000 \\
0-400,000\end{array}$ & $\begin{array}{r}5,000 \\
13,300 \\
66,700\end{array}$ \\
\hline
\end{tabular}




\section{8}

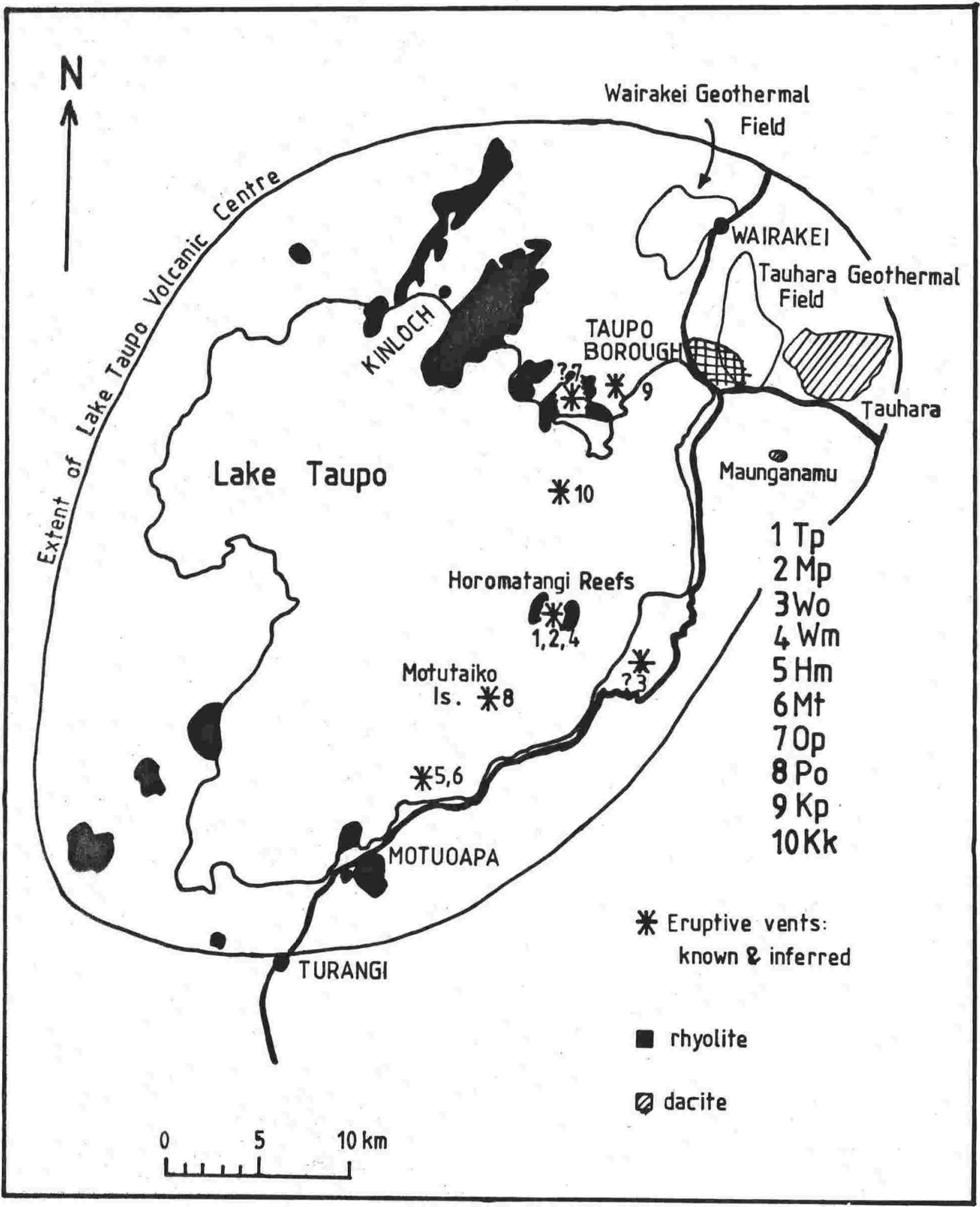

FIGURE 8.2.1: Generalised volcanic geology map of Taupo Volcanic Centre, showing rhyolite domes, known eruptive vents and the boundary to TVC as used here. 
249

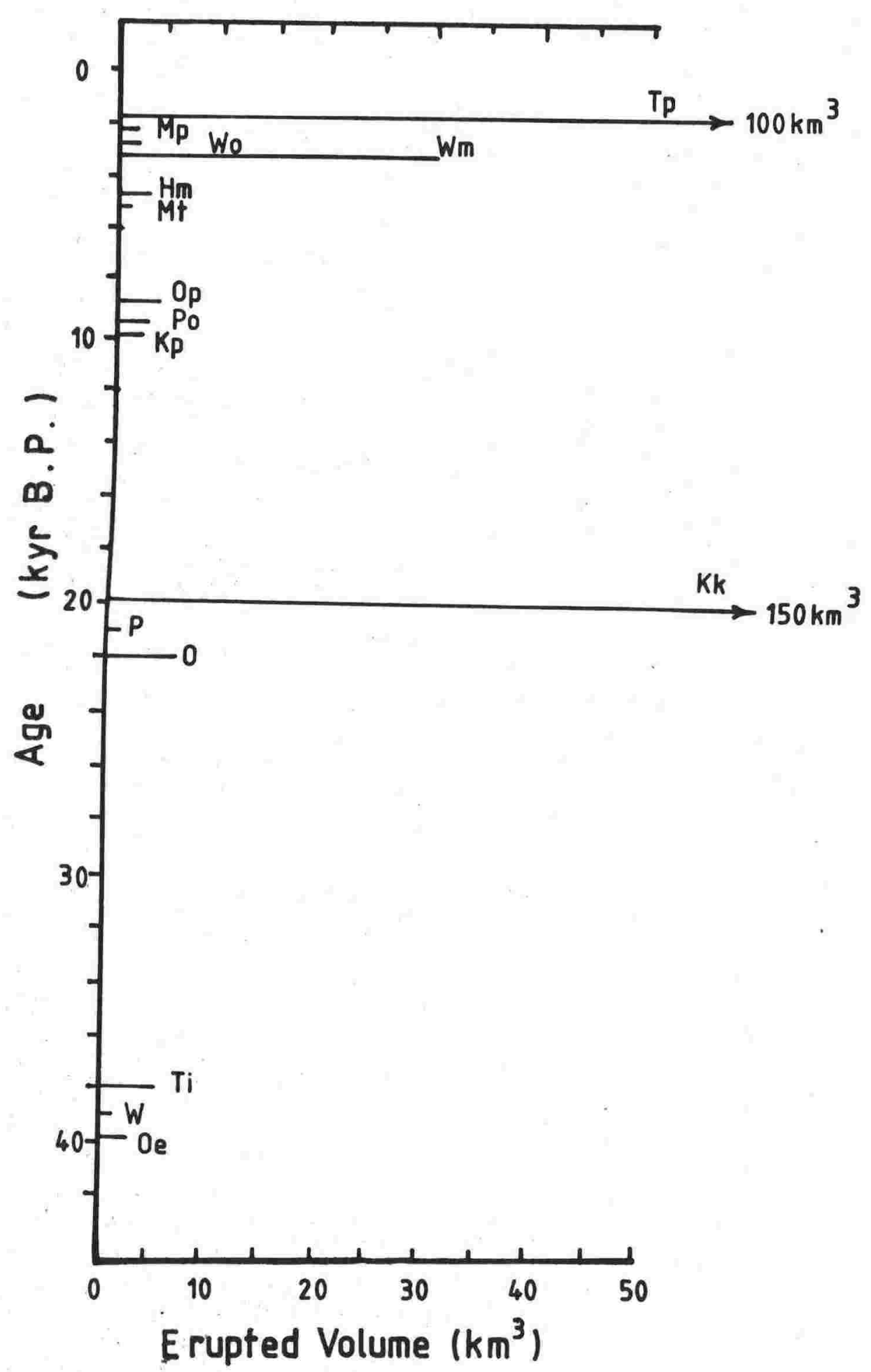

FIGURE 8.2.2: Time-volume relationships of rhyolitic tephras erupted in the last 40,000 years from TVC. 


\section{0}

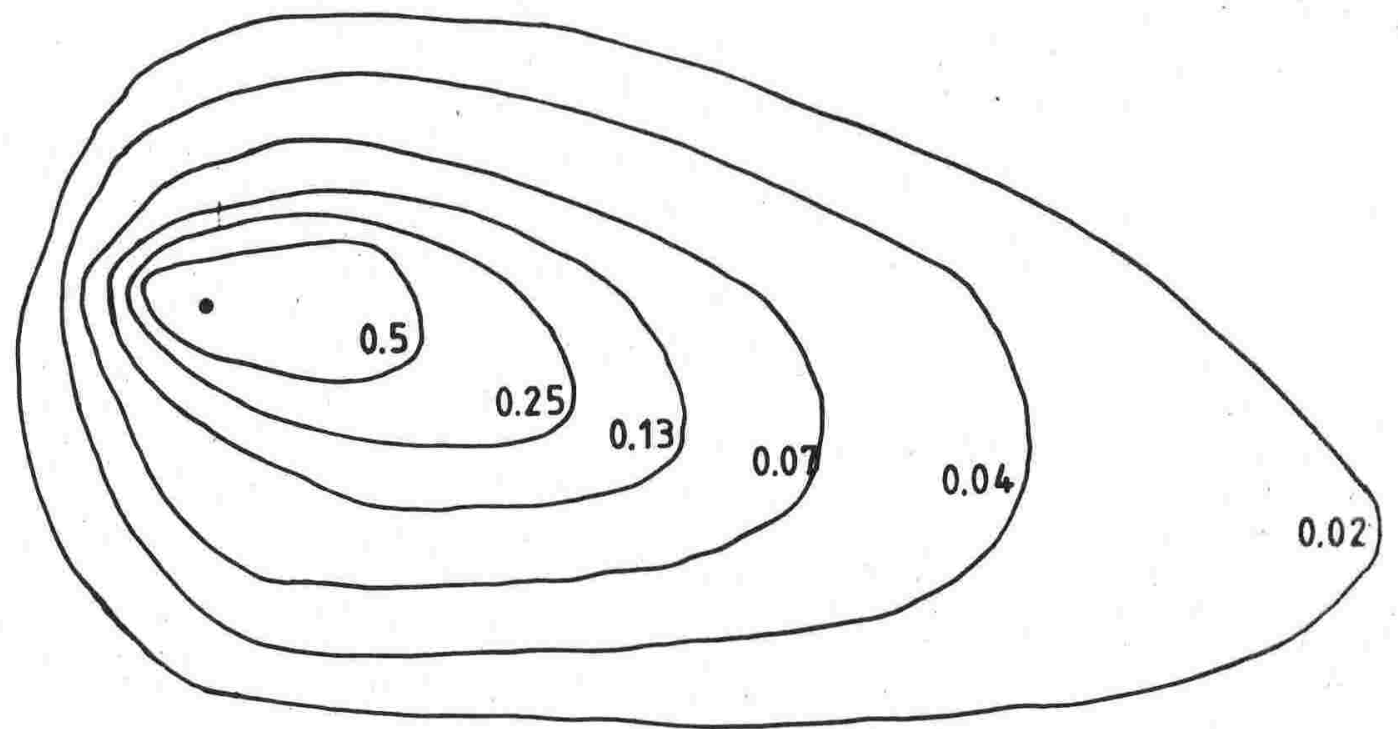

(a)

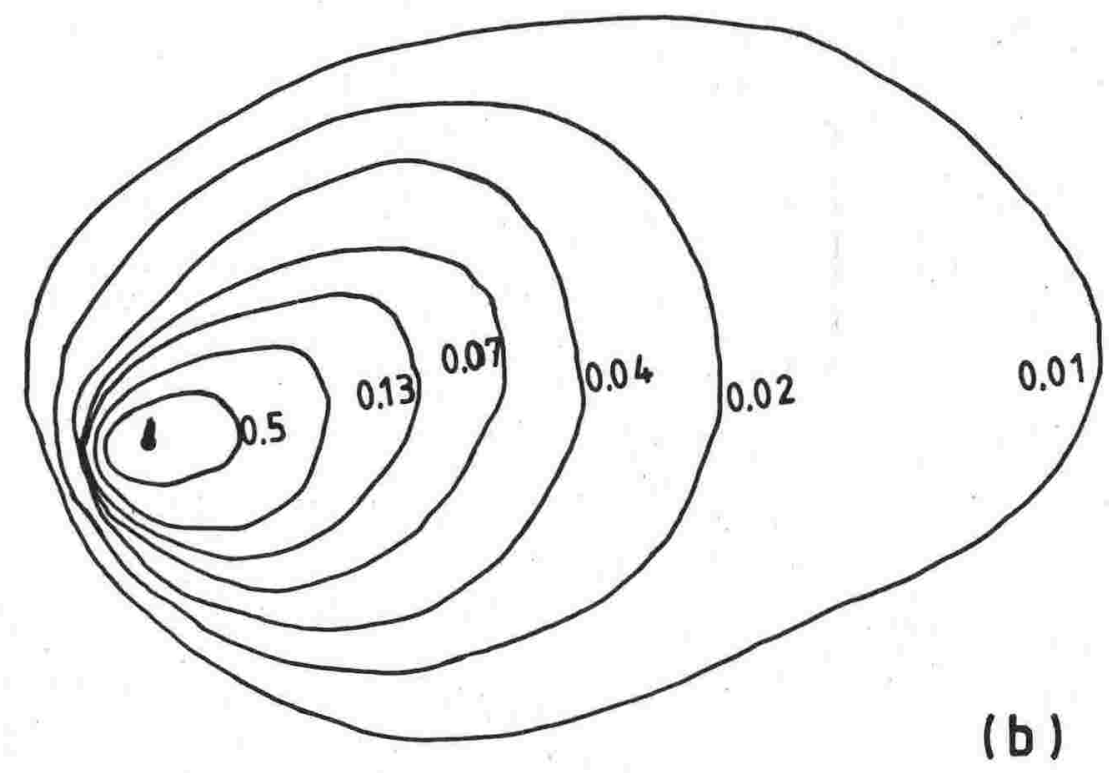

FIGURE 8.2.3: Generalised isopach maps for plinian tephras with the thickness interval between lines halving. Map (a) for large eruptions with maximum thickness of $3-10 \mathrm{~m}$; (b) for smaller eruptions with maximum thickness of $0.1-3 \mathrm{~m}$. 


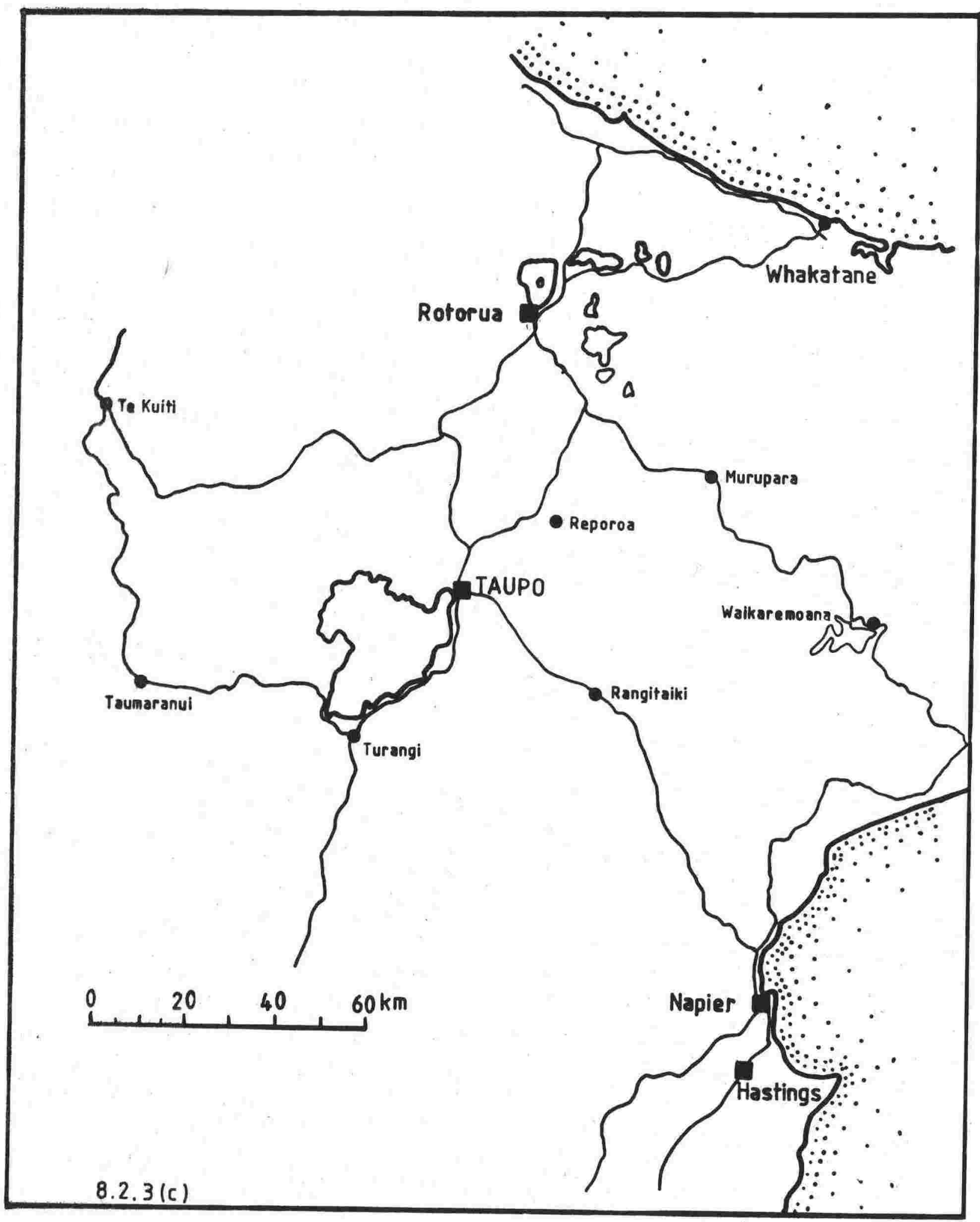


8.3 HYDRATION OF GLASS AND IMPLICATIONS FOR THE WEATHERING OF RHYOLITIC TEPHRAS. 


\section{2}

8.3 Hydration of Glass and Implications for the Weathering of Rhyolitic Tephras

Introduction

Weathering of glass in rhyolitic tephras involves both hydration and "degradation" or alteration to clay. The most common clay products are halloysite and the amorphous clays allophane and imogolite. As halloysite is better structured than allophane, it is commonly assumed that glass, the most structureless solid, alters to allophane, then to halloysite and finally kaolin. Hydration has not previously been considered as an integral part of this process, so the following discussion will concentrate on hydration, with implications for the formation of clays.

The water content of natural volcanic glasses has been extensively investigated and shown to be mostly the result of post-eruptive hydration (Ross \& Smith 1955), so that perlite has formed by the hydr= 
stage technique to accurately determine R.I. of glass shards and successfully correlated samples within the uniform environmental setting of the Hamilton region. A different weathering regime for a tephra preserved in loess at Amberley, North Canterbury, resulted in misidentification by Hodder (1974). The tephra was subsequently shown to be Kawakawa Tephra (Kohn 1979). Empirical relationships between glass chemistry, refractive index and hydration were examined for New Zealand tephras by Hodder (1978) using equations developed from published data on North American obsidians and perlites. It is considered here that the limited applicability and accuracy of the raw data does not support meaningful conclusions.

\section{Water in Rhyolitic Glass}

Water constitutes the major volatile in rhyolitic glass. It is often analytically determined as $\mathrm{H}_{2} \mathrm{O}^{-}$and $\mathrm{H}_{2} \mathrm{O}^{+}$, being the weights lost at $105^{\circ} \mathrm{C}$ and $1000^{\circ} \mathrm{C}$ respectively. Determination of $\mathrm{H}_{2} \mathrm{O}^{-}$in rhyolitic glass is sensitive to variations in temperature, duration of heating and grainsize of the sample, so conventional $\mathrm{H}_{2} \mathrm{O}^{-}$values are considered unreliable (Drysdale 1963). This water is clearly secondary and hygroscopic in nature as shown by the regain of weight after heating to $105^{\circ} \mathrm{C}$ (Ewart 1963). The deuterism content of $\mathrm{H}_{2} \mathrm{O}^{+}$in glass confirms the major water content in glass as meteoric in origin (Friedman \& Smith 1958), and not magmatic as assumed by Hodder (1978).

As $\mathrm{H}_{2} \mathrm{O}^{-}$always amounts to less than 1 wt\% (in contrast to $1-6 \%$ $\mathrm{H}_{2} \mathrm{O}^{+}$), is loosely bound and is easily regained by glass shards, it is almost certainly present as a surface film on glass. Weathering of glass increases the $\mathrm{H}_{2} \mathrm{O}^{-}$content and rehydration properties, attributed by Ewart (1963) to the development of amorphous clay on the surface of the glass. These observations confirm $\mathrm{H}_{2} \mathrm{O}^{-}$is not a part of the hydration of glass shards proper, and does not affect the optical and chemical properties as 


\section{4}

assumed by Hodder (1978). Consequently, Hodder's calculations of refractive index and activation energy for diffusion of water into glass, based on $\mathrm{H}_{2} \mathrm{O}^{-}$values, are suspect.

\section{Parameters Controlling Hydration}

Rhyolitic tephras exupted from the Central Volcanic Region, have very similar glass chemistry, typically about $74 \% \mathrm{SiO}_{2}, 12-13 \% \mathrm{Al}_{2} \mathrm{O}_{3}$, $10 \%$ alkalis, $3 \%$ other elements and varying amounts of water. For this study, the glass chemistry is assumed to be uniform and to have no effect on differences in hydration. At each site sampled, the rate of hydration is mostly controlled by temperature, water availability and by physical properties of the tephras such as thickness, grainsize, porosity (degree of vesiculation) of the glass shards and porosity and permeability of the tephra and enclosing beds.

Weathering situations where one or more of these parameters can be constrained, allows the relative role of each parameter to be studied. To pursue this aim, three situations are studied:

A deep sea sedimentary environment provides saturated, constant temperature conditions. Sites $1000 \mathrm{~km}$ east of New Zealand are far enough away from the tephra source for preserved tephras to be of nearly uniform thickness (about 20mm) and of similar shard size. Tephras in the cores described by Watkins \& Huang (1977) are assumed to have all hydrated with time under uniform conditions. The terrestrial weathering environment is much more varied than the deep sea but the De Bretts section at Taupo (Vucetich \& Pullar 1973) contains a sequence of tephras all of similar thickness and grainsize, ranging in age from 1800 to 10,000 years old. Here the effects of time and pumice clast porosity (= glass surface area) can be studied. 


\section{5}

Correlation of the members of Whakamaru Tephra Formation (Mt. Curl Tephra and Whakamaru Ignimbrite) over most of central New Zealand provides data on the variations in weathering and hydration of one tephra in a variety of environments.

Determination of the Water Content of Glass

For most of the samples studied it was not possible to extract a sufficient quantity of pure glass shards to perform standard loss on ignition (LOI) analyses. This was due either to small sample size or because some of the samples examined contained only minor amounts of glass shards and were predominantly clay. Electron microprobe analyses of individual glass shards seldom total $100 \%$ and the difference is attributed to water of hydration and minor loss of volatiles during analysis. Carey \& Sigurdsson (1981) and this study (Chapter 7), have established this by comparison to LOI and thermo-gravimetric data. Recent microprobe analyses by the author have shown that chlorine is not lost during probe analysis and so is not included in the probe analysis deficiency from $100 \%$. The values obtained from the microprobe analyses are here considered to accurately represent the water content of the glass shards. All analyses were performed on shards in the 2 to $4 \varnothing$ size range to minimize the effect of shard size on hydration.

\section{RESULTS}

1.

\section{Deep Sea Sedimentary Environment}

Within abyssal sediments east of New zealand numerous rhyolitic tephras are preserved (Ninkovich 1968; Watkins \& Huang 1977). Core RC 12-215 contains 8 macroscopic tephras, all dated by paleomagnetism and sedimentation rates up to 1.13 Myr (Watkins \& Huang 1977). The water content of these tephras increases linearly $(R=0.957)$ to a maximum of $6.2 \%$ 


\section{9}

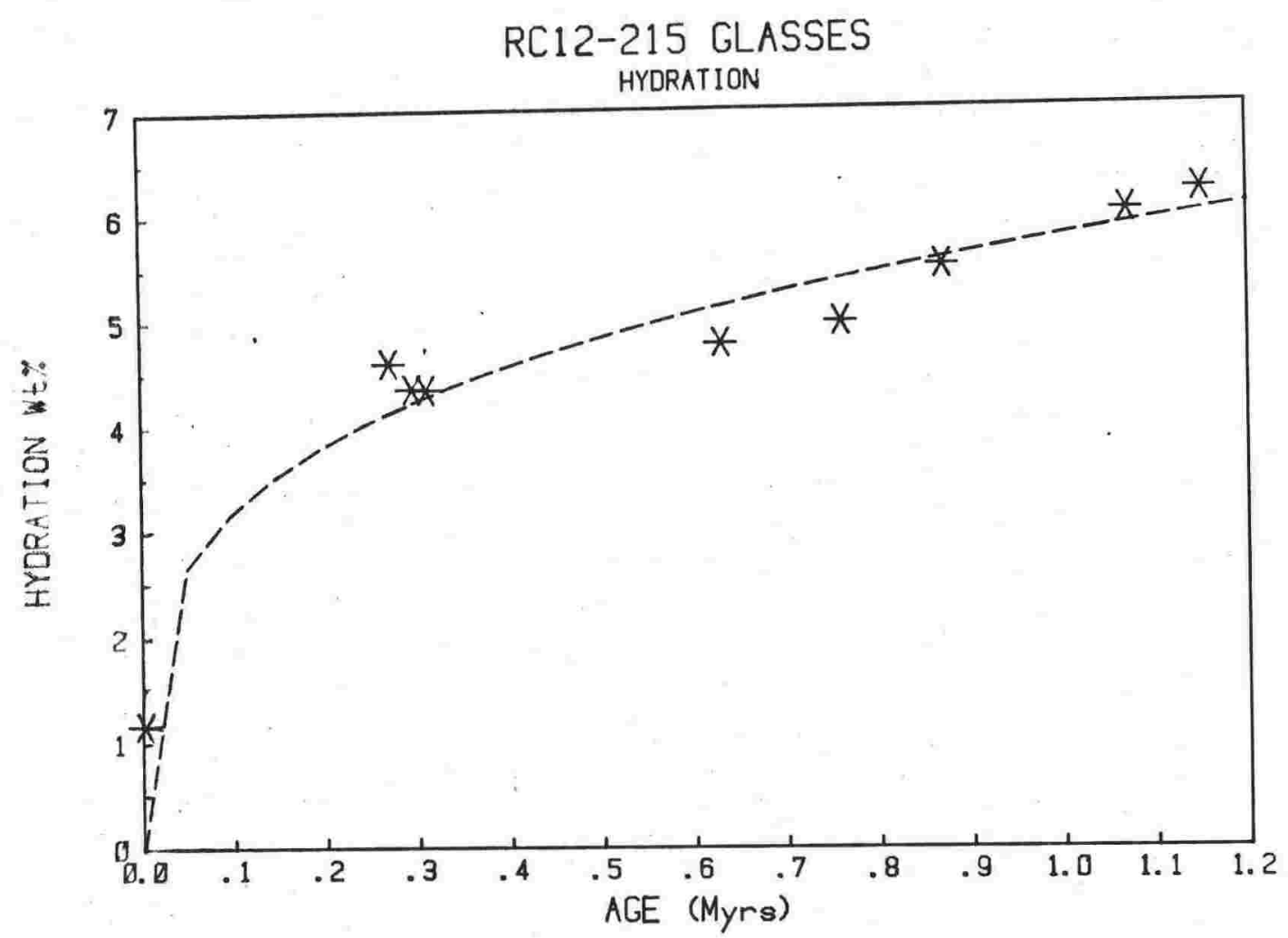

FIGURE 8.3.1: Weight 8 water in glass shards from tephras in deepsea core RC12-215 plotted against interpolated ages. 
at 1.13 Myr (Fig. 8.3.1) at a rate of about $2 \times 10^{-3}$ wto per Kyr. The youngest tephra (Taupo Pumice) at $0-2 \mathrm{~cm}$ in the core is $1.8 \mathrm{Kyr}$ old and only has 1.28 water. It is included in the regression line of Fig. 8.3.1. The apparent low water content of Taupo Pumice may be due to its youth, as it is not yet buried, which implies that in this environment, hydration may involve "momentum" in the breaking of weak atomic bonds. It is also possible that the environment at the sample site may have changed since the deposition of Kaingaroa Tephra. Once started, hydration in a constant environment appears uniform with time.

\section{Terrestrial Tephra Sequence at De Bretts, Taupo}

A thick sequence of Holocene tephras are preserved in a humid, temperate climate at Taupo. Over $6 \mathrm{~m}$ of tephra from 9 eruptive episodes spanning 10 kyr has been examined in detail (Vucetich \& Pullar 1973; this study, Chapter 1) and the glass chemistry determined on crushed pumice blocks. A plot of hydration against age (Fig. 8.3.2) shows a general linear trend, but two tephras, Hinemaiaia and Poronui (4.6 and 9.7 kyr) comprising predominantly poorly vesicular obsidian, are less hydrated and they form their own trend (Fig. 8.3.2, Line A). Taupo Pumice and Waimihia Lapilli ( 1.8 and $3.4 \mathrm{kyr}$ ) both have highly vesicular glasses and are more hydrated for their age in comparison to other tephras. They form a trend with a higher rate of hydration, (Fig. 8.3.2, Line C). Excluding the above four tephras, the remainder form a linear trend $(R=0.965)$ with a rate of about 0.33 wto per kyr (Fig. 8.3.2, Line B), closely paralleling the obsidian trend.

Differences in the rate of hydration of the Taupo Tephras are apparently influenced by the vesicular nature of the pumice. Poorly vesicular pumice hydrates at almost the same rate as most other pumices but has a lag time of almost 3,000 years before hydration begins. The 


\section{1}

hypersthene/hornblende ratio in Whakamaru Tephra should be a measure of the intensity of weathering.

Samples of Whakamaru Ignimbrite were collected from the unwelded, vitric ash, basal layer and do not appear to have been affected by welding of the overlying material. Comparison of the weathering parameters of glass hydration and the hypersthene/hornblende ratio in Fig. 8.3.4 for airfall tephra and ignimbrite samples confirms that increasing hydration coincides with a decrease in the hypersthene/ hornblende ratio, but airfall and ignimbrite samples plot on separate trends. Regression analysis of the airfall data indicates a better fit for an exponential curve $(r=0.947)$ than for a straight line $(r=0.908)$. An exponential also fits the ignimbrite data, but is less certain $r=0.750$ compared with $r=0.673$ for a straight line. Samples from the ignimbrite are less weathered than the airfall correlative, presumably because they were sampled from the base of extensive outcrops that are capped by a welded unit. The three most weathered ignimbrite samples came from distal localities where no welded unit had formed. The trend in weathering is very similar for airfall and ignimbrite despite major differences in field preservation, but the intensity is higher for the airfall samples. Assuming a constant rate of glass hydration, the negative exponential relationships on Fig. 8.3.4 indicate an initial rapid dissolution of hypersthene as weathering progresses but the rate of dissolution decreases with time.

\section{$\underline{\text { Discussion }}$}

In the constant environment of the deep sea, the long term rate of hydration of glass is uniform but very slow with the addition of $10^{-2}$ wto of water per kyr. With increased temperature and greater flow of ground-water in terrestrial sequences, hydration is much faster, between 
280
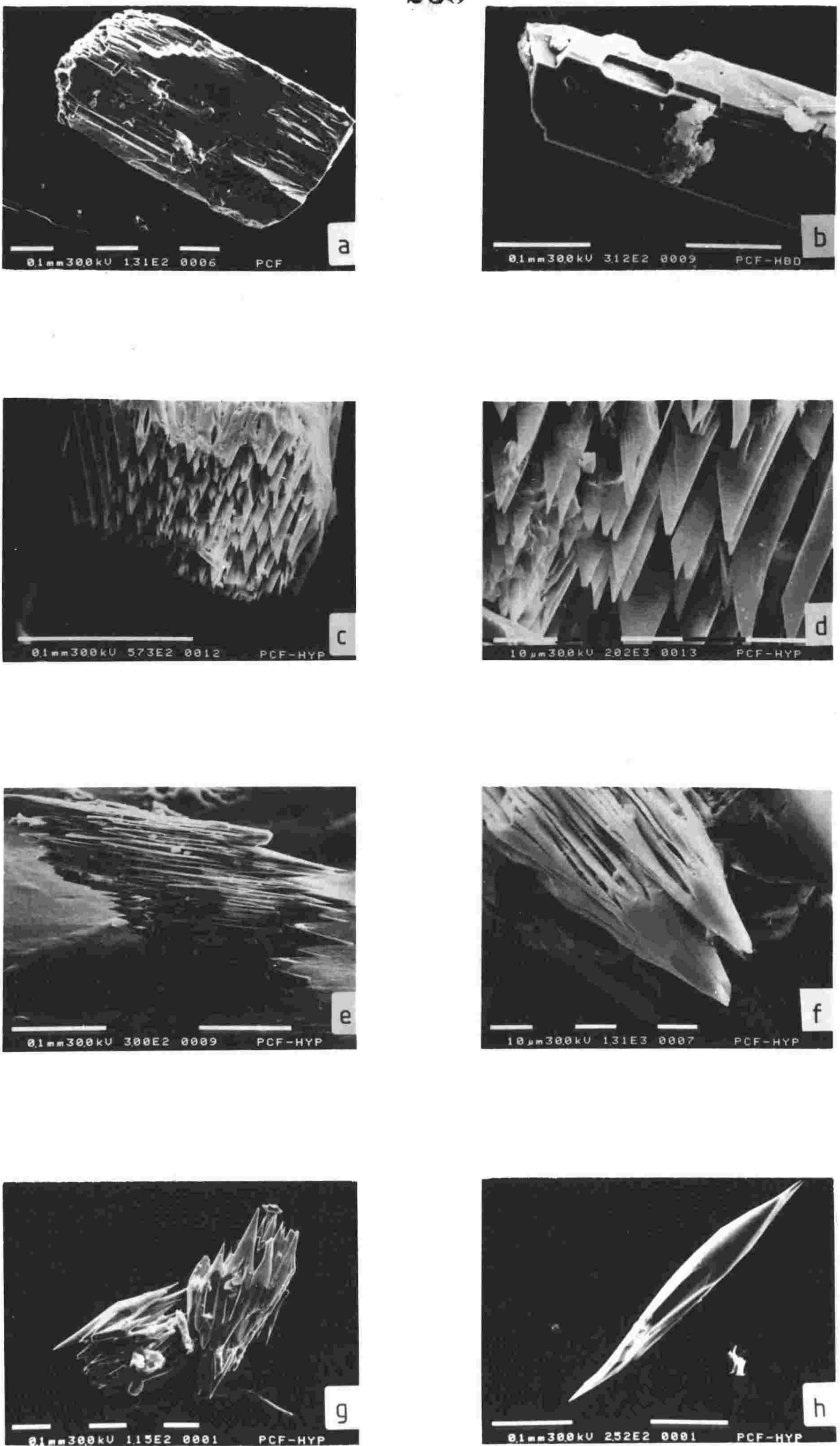
FIGURE 8.3.3: Scanning electron microscope photograpbs demonstrating the increasing effect of dissolution on minerals in Mt Curl Tephra. Hornblende (b) appears unaffected, but hypersthene (a), develops short teeth on the ends (c) and (d), which extend to elongated points (e). The points then dissolve (f), until joined bipyramidal forms remain $(g)$, and finally separate $(h)$. 
highly vesicular pumices (80-90\% porosity) in the same environment hydrated at twice the rate and would reach $10 \%$ water content in only 14,000 years. The typical rate of about 0.3 wto per kyr (Fig. 8.3.2) for the Taupo sequence is 100 times faster than for the deep sea environment, but temperatures are higher and the flow of ground water would be much higher.

3. Whakamaru Tephra Formation

Whakamaru Tephra Formation was defined in Chapter 7.3 to include a widespread airfall member (Mt. Curl Tephra) and an extensive, predominantly welded ignimbrite (Whakamaru Ignimbrite) and was erupted from Taupo about 260 kyr ago. Whakamaru Tephra occurs in a diversity of weathering environments where the state of weathering ranges from negligible to complete alteration of the glass to clay.

Minerals show varying stages of weathering and have suffered the same weathering conditions as the glass shards. The mafic phenocrysts in Whakamaru Tephra are hypersthene, hornblende, biotite and rare augite, but the proportions of each species vary greatly. Hypersthene commonly occurs with extremely jagged ends and in some samples only joined bipyramidal forms remain, whereas hornblende shows no change in appearance in the samples. Scanning electron microscope (SEM) examination of phenocrysts suggested a progression in the degree of jaggedness to a stage where single 'needles' of hypersthene were formed, presumably by chemical dissolution. Stages in the dissolution of hypersthene are in Fig. 8.3.3. Hornblende is apparently unaffected by this form of weathering (Fig. 8.3.3(b)). Dissolution will decrease the size of hypersthene grains so that sieving of samples prior to mineral examination will decrease the relative abundance of hypersthene in more weathered samples. Assuming uniform mafic mineral proportions throughout the primary tephra, the 


\section{3}

0.30 and 0.62 wt\% per kyr, increasing with the degree of vesiculation of the glass. The combined effect of temperature and ground water changes the rate of hydration by a factor of 10 , whereas vesicularity only affects the rate by a factor of 2 .

Both thickness of a tephra and the nature of the enclosing sediments have a marked effect on hydration. As an example, hydration of Kawakawa Tephra (c. $20 \mathrm{kyr}$ old) ranges from $1.9 \%$ for glass from a large pumice block in a $40 \mathrm{~m}$ thick outcrop to $6.7 \%$ for glass from a $30 \mathrm{~mm}$ layer $3 \mathrm{~m}$ from present ground surface and interbedded within loess. Whakamaru Tephra Formation also shows the effect of thickness of the deposit and ground-water flow regime.

The environments and tephras examined suggest that for shards of a given grainsize, the dominant factors affecting glass hydration and weathering are site characteristics, especially mean temperature and the flow of ground water. The role of through-flowing ground water has only recently been recognised as an important parameter (Stevens pers. comm.) but which aspects of ground water movements are critical to weathering is as yet uncertain. The quantity of ground water moving with time through the tephra is influential and is controlled by climate as well as tephra permeability, depth of burial, permeability of overlying beds, slope and continuity of the tephra. Fluctuations in the water flow and alternate wetting and drying may be important, as is the relative ion concentrations in the ground water. The most weathered samples of Whakamaru Tephra Formation examined came from sites where the tephra is either thin (<200mm); dipping steeply; preserved in strongly weathered loess or is thinly bedded within other tephras. Most sites receive moderate $(800-1,000 \mathrm{~mm})$ well distributed rainfall but a few receive highly seasonal rainfall. 


\section{4}

All shards analysed were 2 to $4 \varnothing$ in size, but the more vesicular shards from Taupo Pumice and Waimihia Lapilli have an effective glass area much more than this, perhaps explaining their more rapid hydration. Although not tested in this study, smaller shards (less than $4 \varnothing)$ would be expected to hydrate more rapidly than larger shards and would explain the occurrence of small amounts of amorphous clay and even halloysite in young tephras (MacIntosh 1979, 1980a). MacIntosh (1980b) also found significant amounts of clay-sized glass in Taupo Ignimbrite and these shards would be expected to rapidly hydrate and alter to clay, as shown by the presence of allophane in this tephra (Kirkman 1975). In a sequence of airfall tephras from both Taupo and Okataina, Kirkman (1975, 1976) reported allophane and imogolite throughout but halloysite was not found in tephras or paleosols younger than Rerewhakaaitu ( $\underline{\text { c. }}$ 15 kyr B.P.). This he interpreted as confirming the weathering sequence of Fieldes (1955) of glass - allophane - halloysite, but could equally be climatically controlled as the climate significantly ameliorated at about 14 kyr B.P. (Vucetich \& Pullar 1969).

Variations in chemistry of the tephras examined is minimal, with all tephras between $75-77 \% \mathrm{SiO}_{2}$ (anhydrous). Dacitic and andesitic tephras have not been similarly analysed by microprobe but have a higher content of mafic elements $\left(\mathrm{FeO}, \mathrm{MgO}, \mathrm{TiO}_{2}\right)$. The basic tephras weather more rapidly than the rhyolites (Fieldes 1955) probably due to the higher content of oxidisable iron. However, Friedman \& Long (1976) related the rate of hydration rim thickness to $\mathrm{SiO}_{2}, \mathrm{MgO}$ and $\mathrm{CaO}$ contents; the rate being increased by increasing $\mathrm{SiO}_{2}$ and reduced by increasing $\mathrm{MgO}$ and $\mathrm{CaO}$. This chemical dependence is the reverse of that noted above but the obsidians of Friedman \& Long (1976) were all rhyolitic with limited chemical variations. Further work is necessary to quantify the role of chemistry on glass hydration. 


\section{5}

Mechanisms of Glass Hydration

Processing of samples to extract glass for probe analysis from highly weathered tephras composed dominantly of clay material, showed that in most cases some clear, isotropic glass shards were still intact and could be successfully analysed. Most of such shards were extremely hydrated but none exceeded 98 water, suggesting the maximum hydration possible before glass converts to clay is about $9-10 \% \mathrm{H}_{2} \mathrm{O}$. The presence of a few isotropic (pristine) shards in highly weathered tephras raises the question of why a few shards survive. Glass shards from rhyolitic tephras show a variety of shapes and forms from extremely porous to flat, platy and non-porous. The high porosity shards weather rapidly and it is the flat shards that weather more slowly and may remain in weathered tephras. Differences in weathering are caused by the larger surface area and a more disordered state of the vesicular glass. Different states of disorder have been demonstrated by DTA (Ewart \& Fieldes 1965). Incorporation of $10 \%$ water into glass shards is a significant addition to a structureless solid and it is not known how the water is contained in the glass. It may be accomplished by either (i) glass being porous at the atomic level; (ii) loss of elements from the glass to accommodate water; (iii) an increase in volume equal or less than the added water, or a combination of these factors. The density of anhydrous rhyolitic glass is about $2.4 \mathrm{gm} . \mathrm{cm}^{-3}$ and is not increased by fusion. A porosity of $10 \%$ would allow water to freely diffuse through obsidian glass, making diffusion a rapid process. As shown above, obsidian is not porous. Probe analysis of stratigraphically correlated tephras show a uniform major element chemistry regardless of hydration so loss of elements has not occurred unless the loss is in proportion to the original concentrations, which is unlikely. The only possible 


\section{6}

means of hydration is for the glass to increase in volume by up to the amount of added water. This is confirmed by perlitic cracks in obsidian shown to be the result of expansion due to hydration (Ross \& Smith 1955).

Also the measured density of hydrated glass is about 2.1 to $2.3 \mathrm{gm}^{\mathrm{cm}^{-3}}$ (see Chapter 2; Hodder 1977).

\section{Conclusions}

A uniform increase of total water content with time clearly demonstrates that a large proportion of water in glass is due to post eruptive hydration by meteoric water. Analytically, this water corresponds to $\mathrm{H}_{2} \mathrm{O}^{+}$and is firmly bound in the glass. In contrast, water expelled at low temperatures $\left(\mathrm{H}_{2} \mathrm{O}^{-}\right)$is loosely bound and quickly regained by glass, suggesting it forms a surface layer, is not internally bound and so does not affect chemical or physical properties, especially density and refractive index.

Hydration rate of rhyolitic volcanic glass shards is controlled by the vesicularity of the shards and environmental conditions of temperature and ground water. In the constant environment of the deep sea, at a site $1000 \mathrm{~km}$ from their source, shards between $0.2 \mathrm{Myr}$ and 1.13 Myr in age show a uniform rate of hydration about $2 \times 10^{-3}$ wto water per kyr. In contrast, shards in the humid terrestrial environment hydrate at between 0.3 and 0.6 wto per kyr depending on porosity of the shards. Hydration and weathering conditions vary between sites even for one tephra. Water ranges from 2.7-6.3\% in Whakamaru Tephra Formation and hydration is inversely related to the degree of weathering of hypersthenes in the tephra. Consequently, the assertion of Hodder (1978) that the refractive index of glass, related to chemistry and water content, can be used as a means of identifying tephras, is suspect if applied over a wide area and to samples from different weathering environments. 


\section{7}

More rapid weathering of hypersthene relative to hornblende alters the ratio of these two minerals in the 2-4ø fraction studied so that mineral proportions can only be a guide to tephra identification. Intense weathering could entirely remove hypersthene from the 2-4ø mineral assemblage. Samples of strongly weathered tephras from Omokoroa Point, Tauranga were devoid of isotropic glass and hypersthene was absent or rare. Hormblende and magnetite were common, suggesting total loss of hypersthene by chemical dissolution.

Glass must become hydrated before conversion to either allophane or halloysite. Up to $10 \%$ water may be added before conversion, but the amount necessary is probably dependent on the internal state of ordering of the glass shards. Addition of water is accompanied by an increase in the volume of the glass, confirmed by perlitic cracks in obsidian and lowered density of glass shards. Increasing hydration will affect the bonding that exists between $\mathrm{Si}$ and other elements in glass, mostly Al, and bonding strength will be reduced if some bonds are replaced by $\mathrm{H}^{+}$or $\mathrm{OH}^{-}$bonds. At $10 \%$ hydration, the glass "structure" has been sufficiently weakened for hydrolysis to cause extensive si loss into solution and for the glass to convert to either halloysite or allophane. Small grainsize and more basic chemistry accelerate this process. 


\section{5}

8.4

Future Fingerprinting Possibilities

Electron microprobe studies in Chapters 7.2 and 7.3 show the potential for major element analyses on glass to fingerprint many widespread tephras. Some tephras were not easily distinguished on this basis (e.g. Kaingaroa and Matahina) and further data are required. The Taupo Holocene tephra sequence likewise could not be separated on chemistry or mineralogy alone although the bulk analytical approach of Kohn $(1970,1973)$ was partly successful. Rare earth element values on bulk glass separates discriminated some tephras (Howorth and Rankin 1974) but cannot be used on weathered samples. The probe study of pumiceous horizons from Cape Kidnappers highlights the possibility of sample mixing and contamination that is not apparent in the field and mixing would not be detected by bulk sample analytical techniques.

Future fingerprinting research should initially concentrate on single grain techniques using the electron probe. Different analytical routines for major elements in glass using longer count times for some elements $-\mathrm{TiO}_{2}, \mathrm{CaO}, \mathrm{MgO}, \mathrm{FeO}-$ may improve precision and detection limits. The sensitivity of the JEOL 733 suggests it has the capacity to determine a range of minor and trace elements in glass, including $\mathrm{Rb}, \mathrm{Sr}, \mathrm{Ba}, \mathrm{Zr}, \mathrm{Zn}$ if suitable analytical routines are developed. Glass standards may need to be developed to determine calibration curves but these could be analysed with sufficient precision by XRF.

The Fe-Ti oxides magnetite and ilmenite contain a wide range of elements in differing concentrations. It may be possible to use the probe to analyse for some elements - e.g. Ni, Cr, V, Co, Mn, Si, etc. by modification of the ZAF correction routine, longer counting times and higher beam voltage and current.

Unweathered tephras can usually be processed to obtain a sufficient quantity of glass shards for bulk sample trace element analyses by XRF. Comparison of trace element data for bulk sample and glass separates (see Appendix 3) shows that most elements except $\mathrm{Ti}, \mathrm{Cu}, \mathrm{Ni}, \mathrm{Cr}$ are of similar abundance in whole rock and glass due to the low phenocryst content of the tephras. High purity separates may not be essential for 


\section{9}

discrimination. In particular, the elements $\mathrm{Sr}$ and $\mathrm{Zr}$ show promise in tephra fingerprinting (Fig. 6.4.2).

Despite the inclusions of apatite, zircon and pyrrhotite in titanomagnetites, bulk separate analysis by XRF for trace elements may provide an additional tool for tephra discrimination. This technique would be especially useful for highly weathered samples where titanomagnetite is the only remaining primary component.

The most promising non-chemical approach to tephra identification is the establishment of a detailed paleomagnetic inclination/ declination record or secular curve for the New Zealand region. Sufficient sites containing tephras can now be reliably correlated to provide a continuous sedimentary record for the last one million years and possibly the last five million years.

A combination of the above approaches, beginning with the single grain techniques to check for sample homogeneity, and always in conjunction with stratigraphy, has the potential to uniquely identify most pyroclastic eruptives in the New Zealand region. 
CHAPTER 9.

SUMMARY OF CONCLUSIONS. 


\section{CHAPTER 9}

SUMMARY OF CONCLUSIONS

The format of the thesis requires conclusions to be incorporated with each section or published paper but the more significant conclusions are summarised here.

1. Detailed fieldwork has established that Taupo Pumice Formation and in particular Taupo Ignimbrite can be mapped on a stratigraphic basis. Variations in Taupo Ignimbrite cover a continuous spectrum of lithologies but can be described as three lithofacies: valley facies, veneer facies and fines-depleted facies. The formation of all three facies is attributed to variations in the passage of a pyroclastic flow whose flow regime was dominantly laminar but occasionally became locally turbulent.

2. Rhyolitic pyroclastics erupted from the Taupo area in the Holocene are mapped as 9 tephra formations. Ignimbrites are only demonstrable with two formations, Taupo Pumice and Waimihia, but Lake Taupo covers a large part of the near-vent area and small flows may be obscured. Extrusion of a rhyolite dome has only been substantiated for the oldest Holocene formation, Karapiti, but is inferred for the others.

3. A source vent for each formation is inferred from isopach and grainsize data, and bathymetric evidence for an extruded dome. Inferred vents are uniformly distributed along a $\mathrm{NE}$ trending lineation at the sites of intersections with a NW set of lineations. The NW lineations probably reflect a deep, crustal structure that is controlling the sites of volcanism at Taupo. 
4.

The distribution and thickness of material within plinian

tephras follows an exponential decrease with distance from source and mathematical models reliably calculate the total volume. The possible existence of a large quantity of fine ash (up to 4 times the observable volume) that fell beyond the mappable distribution of plinian tephras has not yet been resolved. A widespread distal fine ash is only demonstrable for eruptive episodes with a pyroclastic flow phase, suggesting the flow and not the plinian column is responsible for the fine ash. Ignimbrites have an irregular thickness distribution that cannot be modelled, so calculation of their volume is not precise. Estimates suggest volumes much greater than for plinian tephras.

The total volume of rhyolitic magma erupted from Taupo in the last $50 \mathrm{kyr}$ is about $175 \mathrm{~km}^{3}$, mostly as three ignimbrites at 1.8 , 3.4 and $20 \mathrm{kyr}$ ago. Cumulative erupted volume with time shows steady increments, with large steps for the ignimbrites. The nature of the steps suggests a period of quiescence of about 8 kyr at Taupo. The same procedure for Okataina Volcanic Centre indicates a large eruption may occur within 400 years.

5. Topography and bathymetry about the northern part of Lake Taupo indicates repeated subsidence following each major ignimbrite eruption. Eruption of Whakamaru Ignimbrite probably initiated collapse and formation of the lake depression with the present topography being created by post-Kawakawa and Taupo Pumice collapse. "Caldera" collapse after Taupo Pumice was not symmetrical about the vent but was controlled by an orthogonal fault system, so that collapse consists of a rectangular block and a conical downwarp. Total volume of subsidence is about $30 \mathrm{~km}^{3}$, the volume of magma erupted during the Taupo episode. 
6. A simple model of the crustal structure beneath Taupo Volcanic Zone assumes rhyolitic magma is generated by a $30 \%$ partial melt of the crust, below lokm depth. Only a third of the magma generated is erupted, the remainder is intruded into the crust to compensate for spreading of the zone. Crustal structure of Taupo Volcanic Zone is thus crustal (greywacke) "blocks", separated by granitic intrusions.

7. All tephras erupted from Taupo since $50 \mathrm{kyr}$ B.P. are rhyolitic with similar major and trace element chemistry. The older tephras, from 50 to $20 \mathrm{kyr}$ are more silicic and hornblende rich whereas the Holocene tephras have hypersthene dominant ferromagnesian mineralogy. Within each group of tephras, chemical variations are minor. The Holocene group shows subtle differences in $\mathrm{FeO}, \mathrm{TiO}_{2}$ and $\mathrm{MgO}$ within glass, pyroxene and Fe-Ti oxide phases that suggests some magma inhomogeneities but none of the tephras studied showed any evidence for compositional zonation of the magma body.

8. Electron microprobe analysis of glass shards provides an indirect determination of the water of hydration as the deficiency of the analysis from 1008. Glass samples from tephras up to 1.1 Myr old, preserved in a variety of weathering environments, allows parameters controlling hydration to be quantified. Assuming a uniform glass chemistry and a given set of parameters, hydration proceeds linearly with time, but the rate is modified by shard size and vesicularity, ground temperature and groundwater flow. Of the mafic mineral phases, orthopyroxene weathers most readily by undergoing chemical dissolution. This decreases phenocryst size and hence the ratio of hypersthene to hornblende in the 63 to 250 micron size fraction studied, which shows good correlation with hydration of the co-existing glass. No shards were found with more than $9 \%$ water 


\section{3}

suggesting that once glass has reached this level of hydration, internal bonding is weakened so that hydrolysis could break up the glass "structure", leading to the formation of secondary clay products.

9. Despite the overall chemical and mineral similarity of the Taupo Volcanic Zone rhyolites electron microprobe analysis of glass shards can discriminate between widespread airfall tephras and ignimbrites. Not all tephras are chemically distinctive, especially those closely spaced in time, but recognition of key tephras in a stratigraphic context allows a comprehensive distal tephra stratigraphy to be developed. Correlation of ignimbrites to their distal airfall tephras constrains the number of separate ignimbrite-forming eruptions and establishes a definitive nearsource ignimbrite stratigraphy. Whakamaru Ignimbrite, erupted from the northwest part of Lake Taupo, is shown to be much more extensive than previously mapped, as it has been differently named in separate areas. Mt. Curl Tephra is the distal airfall correlative of Whakamaru Ignimbrite and has been identified over a large area in the New Zealand region. Products of this eruptive episode are formally redefined as Whakamaru Tephra Formation, comprising Whakamaru Ignimbrite Member and Mt. Curl Tephra Member.

Stratigraphy and correlations of named ignimbrites and distal tephras, erupted from Taupo Volcanic zone as now established are: 


\section{4}

Ignimbrite

Taupo Ignimbrite

Oruanui Breccia

Rotoiti Breccia

Kaingaroa

Matahina

Whakamaru

(= Rangitaiki, Manunui,

Te Whaiti, Wairakei,

?Rocky Hill)

Marshall

Ongatiti
Volcanic Centre Distal Tephra

Taupo

Taupo

Okataina

Okataina

Okataina

Taupo

?

?
Taupo Pumice

1.8

Aokautere

20

Rotoehu

c. 45

Fordell

c. 180

Finnis Rd. (upper)

c. 220

Mt. Curl

c. 260

(= Ohariu, Rangitawa)

Ohinewai, Haywards

Mangaroa)

Kaukatea Ash

c. 570

Rewa Pumice

c. 730 
APPENDIX AI.

TECHNIQUES FOR THE PREPARATION OF TEPHRA SAMPLES

FOR MINERAL AND CHEMICAL ANALYSIS

AND

RADIOMETRIC DATING.

Geology Department, Victoria University Publication Nọ 23. 


\title{
275
}

TECHNIQUES FOR THE PREPARATION OF TEPHRA SAMPLES FOR MINERAL AND CHEMICAL ANALYSIS

AND

RADIOMETRIC DATING

\author{
P.C. Froggatt \\ and \\ G.J. Gosson
}

Department of Geology,

Victoria University of Wellington, Private Bag,

WELLINGTON,

New Zealand.

Department of Geology Publication No. 23

Victoria University of Wellington. 


\section{6}

ii

1. INTRODUCTION

2. FIELD SAMPLING

3. SIEVING AND SAMPLE FRACTIONATION

3.1 Disaggregation

3.2 Sieving

3.3 Sonic Probe cleaning

3.4 Chemical cleaning of $\mathrm{Fe} / \mathrm{Mn}$ oxides

3.5 Drying the sample

3.6 Dry sieving

4. HEAVY LIQUID APPARATUS

5. SEPARATION OF BIOTITE

6. RADIOMETRIC DATING

6.1 Radiocarbon

6.2

$\mathrm{K}-\mathrm{Ar}$

6.3 Fission-track

7. BULK CHEMICAL ANALYSIS

8. MINERALOGY

9. ELECTRON MICROPROBE ANALYSIS OF GLASS AND MINERALS 


\section{INTRODUCTION:}

Studies of the mineralogy, chemistry and chronology of New Zealand tephras have been carried out at victoria university for many years and a number of preparation techniques have been developed. The techniques are described below, together with the equipment built or modified for tephra studies and the rationale and reasons why a particular technique is employed. Modifications are continually being made to increase efficiency and cut down preparation time and costs without sacrificing sample purity. The techniques described here have been developed and modified by the authors from techniques previously used by Drs. R. Howorth and D. Seward. Assistance with ideas came from many people especially Jeff Ashby, Ken Palmer, Dr. J. Gamble and Mr. C.G. Vucetich whose help is acknowledged.

\section{FIELD SAMPLING:}

The method used for field sampling depends mostly on the grainsize and thickness of the tephra. To be representative, a large sample is needed, normally about $1 \mathrm{~kg}$ or up to $2-3 \mathrm{~kg}$ if zircons are required for dating. Wherever possible, pumice lapilli and blocks are preferred for analysis rather than finer ash. crystal sorting and incorporation of xenolithic material is possible in fine ash and fine material weathers more rapidly than coarse material.

(i) Coarse grained lapilli: Airfall or unwelded ignimbrite (pumice c. 50mm average). Very coarse tephras can be sampled by collecting a sufficient number of individual clasts or pieces cut of clasts selected from throughout the outcrop. Wherever possible, select clasts that are unweathered.

(ii) Finer grained tephras: First clean off the surface of the outcrop to remove vegetation and any weathered material. The practise normally adopted is to sample the lower $1 / 3-1 / 2$ of the tephra, starting at least $10 \mathrm{~mm}$ above the base. The very base may be contaminated from the material below and the top 1/3 may be reworked. Very thin tephras or those occurring in pockets or "cream-cakes" require special care in sampling. Use of a knife to cut out the centre of each pocket is recommended.

(iii) Rhyolitic glass in loess or sediments: Rhyolitic glass shards are often found scattered through New Zealand loess, especially the last stadial (Ohakea) loess. Tephras are seldom macroscopically preserved in an active loess accumulation environment. A concentration of glass shards - often about $5 \%$ or more of the sand fraction - indicates the presence of a tephra. The stratigraphic position of a tephra can be found by sampling through the loess section at 50 or $100 \mathrm{~mm}$ intervals. To obtain a large enough sample of glass for microprobe analysis, a channel sample covering the 100-200mm with maximum glass abundance will be necessary. Probe analysis of 10-20 shards will generally indicate whether a glass sample is a mixed assemblage. 


\section{8}

\section{SIEVING AND SAMPLE FRACTIONATION:}

Steps to be followed are summarised thus:

1. Hand pick pyroclastic material.

2. Disaggregate or crush using porcelain pestle and mortar.

3. Wet sieve to retain 63-250 micron fraction.

4. Chemically treat if necessary and resieve.

5. Sonic probe and resieve.

6. Wet sieve 63-125 micron if sample is for dating.

7. Air dry sample (or oven dry only if sample is not being dated).

8. Dry sieve to remove flocculated fines.

9. Frantz isodynamic separation.

10. Heavy liquid separation.

The most convenient grainsize range for tephra studies is 2 to $4 \phi$ (250 to 63 microns), which includes nearly all the phenocrysts. Few zircons or apatites are larger than 125 microns. Grains larger and smaller than the 2 to $4 \phi$ range are difficult to separate with the Frantz separator and cause problems in grain mounts. The smaller grains cannot readily be identified under the microscope or reliably analysed with the electron probe. zircons and apatites smaller than 63 microns are unsatisfactory for fission-track dating as they tend to fall out of the mounting medium during etching, have small surface areas and cause orientation problems. Most fine grained tephras and tuffs have a large proportion of glass shards in the $2-4 \phi$ range.

\subsection{Disaggregation.}

Carefully hand pick blocks or chunks of pumice, cleaning and washing them if necessary. Disaggregate material using a large porcelain mortar and pestle to liberate phenocrysts from volcanic glass. Usually 2-3kg of material must be processed to yield $1.5 \mathrm{~kg}$ of $2-4 \varnothing$ fraction, which may be expected to yield 1000 to 2000 zircons and 100 to 200 apatites.

\subsection{Sieving.}

\section{0-63 micron fraction.}

Wet sieving is preferred for speed, ease of operation and to avoid clouds of dist. Brass sieves should not be used as they can cause chemical contamination and are difficult to clean. Nylon or monolen cloth held in plastic frames (Fig. 1) is suitable and can be purchased from screen printing suppliers. The cloth can be cleaned by a jet of water or by folding in half and rubbing between the hands and is durable. Once worn or difficult to clean, the cloth is discarded. Monolen cloth is the more expensive but can be cleaned in conc. HF. Dimensions for the sieve holders are in Fig. 1 .

Initially, wet sieve to retain the 63-250 micron fraction. Most samples need to be sieved and crushed repeatedly until all material passes the 250 micron leve so use this size first, catching the material <250 microns in a large bowl or bucket. Weathered or clay rich samples need further disaggregation with the sonic probe after sieving to remove the fraction $<63$ microns, then must be resieved. 


\section{Wet sieving $125-63$ micron fraction.}

Samples being dated should be further wet sieved and the 125-63 micron fraction retained. About 998 of zircon and apatite crystals in New zealand pyroclastic material are in this size range. The time spent reducing the sieved fraction at this stage is saved several times over during Frantz and heavy liquid separations.

\subsection{Sonic probe cleaning.}

The sonic probe vibrates the sample at high frequency, disaggregating material and cleaning glass and minerals. Place 200 to $300 \mathrm{ml}$ of sample in a 1 itre beaker with $500 \mathrm{ml}$ of water. Set the probe at 80-100\% maximum power and run continuously for 2 to 5 minutes with the probe tip about lcm below the liquid level. Check that all the sample is being agitated, otherwise rotate the beaker. CAUTION: The probe should be housed in a sound-proof cupboard and ear-muffs should be worn when adjusting it.

\subsection{Chemical cleaning of $\mathrm{Fe} / \mathrm{Mn}$ oxides.}

Some samples that are visibly iron stained or strongly weathered must be chemically treated to ensure efficient fractionation on the Frantz, and mineral identification with the microscope. If the sonic probe is insufficient, they may be treated with hydrochloric acid or citrate - dithionate reagents. Both reagents are more efficient when heated but if minerals are being extracted for dating NO HEAT should be applied. In this case, cold $\mathrm{HCl}$ treatment is easiest but prolonged reaction time may etch the glass, and the citrate-dithionate treatment should normally be used.

(i) Hot hydrochloric acid for samples not being dated: Add sufficient water to about $100 \mathrm{ml}$ of sample to make volume up to $500 \mathrm{mls}$. Too much sample will cause "burping" and violent loss of the beaker's contents. Bring to the boil, add $20 \mathrm{ml}$ of conc. $\mathrm{HCl}$, leave for 1 to 2 minutes depending on the severity of $\mathrm{Fe}$ staining then quench beaker and contents in a large bowl of clean water. Wash several times.

(11) Cold citrate-dithionate treatment: If zircons or apatites are to be extracted from a weathered sample for dating, a cold treatment to remove Fe oxides is essential. In a 2 litre beaker add sample, 1 litre of citrate reagent, $20 \mathrm{ml}$ of $1 \mathrm{M} \mathrm{NaHCO}_{3}$ and $4-5 \mathrm{gm}$ of $\mathrm{Na}$ dithionate. Agitate the sample with compressed air by attaching a micro-pipette or glass tube to an air hose. The reaction may take several hours and a visible colour change from orange to green-grey occurs. Manually stir and agitate the sample occasionally. The citrate reagent is made up of $75 \mathrm{gm}$ of sodium citrate in 1 litre of water. Adjust the $\mathrm{pH}$ to 7.3 by adding a few drops of saturated citric acid.

\subsection{Drying the sample.}

Samples for dating must NOT be oven dried or annealing of tracks may result, especially in apatites. Air dry by spreading the sample over a large plastic tray in a cupboard under a flow of air (see Fig. 2). Samples will dry in 24 hours. other samples may be dried in a $105^{\circ} \mathrm{C}$ oven. 


\subsection{Dry sieving.}

With some samples, especially marine tuffs, fine particles flocculate during wet sieving and will not pass the 63 micron sieve. These aggregates lower the efficiency of the Frantz and will contaminate heavy liquids used for zircon extraction: The dry sieving stage is usually only necessary with samples for dating as large quantities are processed.

A FRITSCH sieve shaker is used to hold and vibrate a nest of nylon sieves in plastic frames. Set the machine on intermittent, maximum intensity and sieve for a total of 45 minutes. The 63 micron sieve must be brushed every 15 minutes to clear fine particles from the mesh.

\subsection{Magnetic Separation.}

The Frantz isodynamic separator is the easiest and most efficient means of separating bulk samples. The separator balances the downward force of gravity (density) against the pull of a magnetic field (proportional to the magnetic susceptibility for each mineral) so that fine adjustments can be made. Samples will generally need to be run through the Frantz on at least 3 settings depending on the purity of the split required. Table 1 gives Frantz settings found to be useful.

Magnetite must first be removed from the sample using a hand magnet otherwise the poles of the Frantz will quickly become clogged. The easiest technique is to clamp a hand magnet about $20 \mathrm{~cm}$ above the bench, lay a creased sheet of clean paper vertically between the poles and slowly pour the dry sample onto the paper, above the poles so the grains slide down the paper into a beaker. Magnetite will be held back by the magnet. Gently shake the paper to free non-magnetic grains. For mafic rocks with abundant magnetite, first spread the sample on a tray, wrap a sheet of paper around the magnet poles and move the magnet over the sample. This method is less efficient but the sample can be run over the folded paper after most of the magnetite has been removed.

Notes on the use of the Frantz separator.

(i) When separating large volumes of sample, position a large glass or plastic funnel on a clamp stand over the Frantz feed funnel so that the tip of the large funnel is $1 / 3$ of the way down and just touching the Frantz funnel. The instrument's vibrator will feed sample out of the large funnel. To catch the sample, replace the Frantz's small buckets with $300 \mathrm{ml}$ conical flasks held in $600 \mathrm{ml}$ beakers.

(ii) Cool the electromagnets by wedging a hose connected to the compressed air supply between the coil and behind the discharge chute. Only a low air flow is necessary but it prevents the coils heating, which increases resistance and drops amperage with a consequent loss in efficiency.

(iii) Frantz vibrator: If the vibrator runs hot $\left(60^{\circ} \mathrm{C}\right)$ then disassembly and cleaning of the moving parts with emery paper may improve the operation. Prolonged use at high temperatures will burn out the coil.

(iv) The Frantz is best cleaned by blowing, using the compressed air hose, starting with the funnels and moving down the chute. 
(v) The purity of each Frantz split should be checked with a binocular microscope set up adjacent to the Frantz. A permanent record of each split can be retained by mounting a small sample on double-sided cellotape on an index card.

Operating hints:

Note: Forward slope is set high at first because the magnetic field holds material in the less-magnetic chute. This can build up and spill over the edge of the chute. The higher forward slope reduces this effect. If it still occurs, reduce the amperage setting and reduce the side slope.

Vibrator setting: Generally run at 8 on the dial. The desired effect is to have the grains thrown off the frictional surface of the chute without them skidding too fast down the chute. Check this by the following: Shut vibrator power switch off. The grains should stop immediately. If they bounce a few mm further down the chute then the vibrator is too intense for that forward slope. A higher vibrator setting also speeds the rate of feed and separation of the sample.

During the first run of the sample, magnetite crystals, ilmenite with exsolved magnetite, and glass with magnetite inclusions will cling to the electromagnet. After a while this will block the moremagnetic chute. Therefore, every half hour shut off the flow in the feed funnel. Remove the more-magnetic and less-magnetic buckets. Turn off the power to the coils. The magnetic material will drop off the electromagnet and flow down both chutes. Clean the chutes with the air hose. No amount of hand magnet separation will eliminate the need for this operation. It must be done repeatedly on the first run of each sample and at the end of each run after that.

Flow rate: The ideal flow rate from the funnel is difficult to quantify. The higher the flow rate, the faster the run, but check the efficiency of the separation by the following: Set the flow rate and allow the Frantz to run for a minute, then shut off the vibrator. Unhinge the lower end of the chute and carefully swing the chute out so that the zone where separation takes place can be seen. The grains should be evenly spread out on the chute and not be layered on top of each other.

The flow rate for the first two runs can be quite high since the percentage of relatively strongly magnetic material is low. Later runs have a higher percentage of more- and less- material separating and the flow rate should be reduced.

If insufficient more-magnetic material is being separated, then reduce the side slope or increase the amperage. It is better to reduce the side slope first. Often a 1 or 2 degree change makes a significant difference in the amount and purity of the separation.

\section{HEAVY LIQUID APPARATUS:}

It is best to use heavy liquids only for final separation of small sample volumes, to extract zircons and apatites or glass shards. Heavy liquids are expensive and dangerous and must be used carefully, in an efficient fume cupboard. A downdraft 
cupboard is best, but a $150 \mathrm{~mm}$ air dam at the bottom front of a normal fume cupboard will prevent the heavy liquid from spilling into the lab. Tetrabromoethane (TBE) or bromoform separates zircons and apatites, and di-jodomethane separates zircons from this fraction. Add the sample to the heavy liquid in a tapering separating funnel and stir with a glass rod. After the grains have settled, open the tap and flush out the settled grains into a sinter glass filter funnel. The heavy liquid is drawn through the filter under vacuum then returned to the stock bottle. Remove the funnel and invert into a small beaker. Wash out the grains with acetone, using compressed air to force the acetone through the filter. Decant the acetone/heavy liquid mixture and set aside for purifying. Wash the sample several times with acetone then AIR DRY and store in a phial. A camel hair brush is useful to brush grains from the beaker onto a creased paper sheet.

Note: Di-odomethane oxidises to an orange colour when exposed to the air. A piece of copper wire in the stock bottle will inhibit this and a cover should be placed over the separating funnel.

At this stage the sample splits should be magnetite, ferromagnesian minerals, glass-quartz-feldspar, zircons and apatites.

\section{SEPARATION OF BIOTITE:}

Biotite is a useful mineral for K-Ar dating but extraction of a sufficient quantity $(14 \mathrm{gm}+)$ is often difficult. In tephras, most biotite grains are between about 60-300 microns in size. The following 3 steps may produce a reasonably pure sample:

(i) Wet sieve the sample and retain the 60-300 micron fraction. First crush the sample gently if necessary.

(ii) Taking 100-200ml of sample at a time, add to a gold pan or large bowl. Fill the bowl with water until gently overflowing into a 60 micron sieve, then gently agitate the sample with a stirring rod or compressed air hose. Flakes of biotite will be flushed into the sieve together with some pumice.

(iii) Air dry the concentrate and further purify with the Frantz or a cardboard sheet. Take a large, thick unpolished cardboard sheet about $600 \mathrm{x} 400 \mathrm{~mm}$, tilt at about $30^{\circ}$ with the base resting in a tray. Spread some sample across the top of the sheet and gently vibrate with the fingers. Flat biotite flakes will rest on the sheet while other grains roll off. Vary the tilt and vibration to give the best separation. The Fritsch sieve shaker, which has a variable vibrator, can be used to vibrate the sheet.

\section{RADIOMETRIC DATING:}

Three radiometric methods of dating are currently employed in New zealand: Radiocarbon (0-40 kyr), K-Ar (>200 kyr) and fission-track dating (>100 kyr). In addition, the U-Th disequilibrium method has been attempted (Hendy, pers. carm., 1981) with 
encouraging results. The sample requirements are described below.

\subsection{Radiocarbon.}

'A C14 date requires a minimum of $6 \mathrm{gm}$ of carbon but at least $12 \mathrm{gm}$ is preferred to enable the date to be duplicated. Most datable material contains less than $20 \%$ carbon. For dating tephras, associated peat, organic rich paleosols, small twigs and charcoal have all been dated. Peat and twigs generally have least potential for contamination; charcoal and paleosols the most. Wherever possible, collect a sequence of samples, especially two that bracket the tephra. Peat should be collected from a horizontal slice $2 \mathrm{~cm}$ or less in thickness. An even better method is to collect separate lcm slices so the dating lab can combine as few slices as is necessary for a reliable date.

\subsection{K-Ar.}

Tephras have been successfully $\mathrm{K}-\mathrm{Ar}$ dated using glass and biotite. A minimum of $30 \mathrm{gm}$ of glass or $14 \mathrm{gm}$ of biotite is required but twice these amounts are desirable. Avoid acid pre-treatment and prolonged heating of the sample if possible. Glass can be purified using the Frantz separator but biotite cannot easily be separated from other mafic minerals. Use of a vibrated cardboard sheet (Section 5) is recommended.

\subsection{Fission-track.}

Zircons and apatites are most suitable for $\mathrm{F}-\mathrm{T}$ dating of young rocks because of their high uranium content and relatively high annealing temperatures. The number of grains required for a statistically acceptable date depends on the age of the sample and the $U$ content of the grains. As well, grains are lost during mounting, polishing and etching. The procedures described here should yield about 1000-2000 zircon grains and 50-200 apatite grains for most tephras. Some tephras are noticeably phenocryst poor, and distal airfall or waterlain tephra may have had free mineral grains winnowed out. Heating of the sample to $100^{\circ} \mathrm{C}$ will cause annealing of fission-tracks in glass and apatite. Zircon anneals at temperatures above $600^{\circ} \mathrm{C}$ but a routine principle is NEVER to heat a sample that is being processed for F-T dating. Although you may only be interested in zircons, heating the sample will prevent any future check on the date by using the apatite.

\section{BULLK CHEMICAL ANALYSIS:}

Major and trace element chemistry using $\mathrm{X}$-ray fluorescence (XRF) can be obtained on bulk samples and on the glass fraction by itself. Separation of the glass fraction should use the Frantz as described above to minimise contamination. The bulk chemistry of tephras is best obtained from selected large pumice lapilli collected from a thick section near to source in order to minimise errors caused by weathering and contamination.

Lapilli and glass require powdering in a TEMA mill before analysis. If lapilli are too large for the TEMA barrel, first break them down between two blocks of wood to avoid contamination from a steel hammer. 
Analysis for major elements on the XRF uses a fused disc whereas trace elements are determined on a boric acid backed pressed powder pellet. Pressed pellets of high silica material, especially glass, often shatter on release of pressure from the press. This can be overcome by mixing the correct weight of sample with a few drops of distilled water with an agate mortar and pestle before pressing the pellet. If cracking persists, mix the sample with a known proportion of cellulose.

\section{MINERALOGY:}

The ferromagnesian minerals mentioned below are useful aids in identifying tephras. Grains are mounted in Canada Balsam. Point-counting should use the "ribbon method" where all the grains cutting a vertical cross-hair are counted as the slide is manually moved in a mechanical stage. About 300-500 grains are normally sufficient for reliable estimate.

The ferromagnesian species most commonly observed in New Zealand rhyolitic tephras are hypersthene, augite, hornblende, biotite and cummingtonite. The latter is currently known only in tephras from okataina.

To help identify each mineral species, brief notes on the most useful optical properties as seen in $2-4 \varnothing$ grain mounts are:

Hypersthene: Clear, light green to yellow brown subhedral grains with rounded or jagged ends and a few inclusions. Markedly pleochroic, straight extinction (a few grains may show extinction up to $10^{\circ}$ ). Birefringence low but varies with grain thickness. Cleavage seldom seen.

Augite: Rare in most New Zealand rhyolitic tephras. Occurs in irregular or equant shaped grains: clear, deep green, full of inclusions, non-pleochroic. Birefringence high, extinction oblique at $40-60^{\circ}$.

Hornblende: Usually deep greenish-brown or brown, strongly pleochroic but deep colours may mask pleochroism. Grains usually more acicular than hypersthene. Extinction oblique at $5^{\circ}-15^{\circ}$. Mineral colour often masks birefringence.

Biotite: In grain mounts only basal sections parallel to cleavage occur so cleavage and pleochroism are seldom seen. Irregular or sometimes hexagonal grains often with flaky appearance; dark brown to light golden brown, high birefringence. Optic axis figures easily obtained usually with $2 \mathrm{~V}$ of $0^{\circ}-10^{\circ}$. Optic figure will distinguish weathered biotite from weathered glass. Extinction commonly undulose or "birdseye".

Cummingtonite: Grains similar in outline to hornblende, usually long and narrow. Absent or faint pleochroism, colourless or pale green to green but without brown tinge or intensity of colour as in hornblende. Dispersion often marked. Extinction oblique at $0^{\circ}-15^{\circ}$; extremely high birefringence not masked by mineral colour, bright blues, purples or greens commonly seen, colour persists to edge of grain, unlike hornblende which fades as grain becomes thinner. Thicker grains often confused with hornblende. 


\section{ELECTRON MICROPROBE ANALYSIS OF GLASS AND MINERALS:}

\subsection{Sample Preparation.}

After sample fractionation using the Frantz, small splits of glass shards, magnetite, and ferromagnesian minerals can be mounted for the probe. Polished thin sections are preferable so that glass can be checked for inclusions and mineral species identified prior to analysis. Epoxy resin blocks (either Araldite or Epofix) about 10-20mm thick are drilled with 7 holes then one face ground flat, but not polished, on a diamond lap. Blocks are fixed with the flat ground face to glass slides with a smear of epoxy glue (either Araldite or Epofix) a small sample placed into each hole using a small funnel then the holes filled with glue. Check that no air bubbles are trapped in the holes. They can be removed by stirring with a small probe. After curing, the blocks are cut, ground down to expose the grains, then polished, finishing with 5 microns powder. Polished mounts should be checked optically for finish and grain identity then arrows and numbers marked on the polished face to enable location and identity during probe analysis:

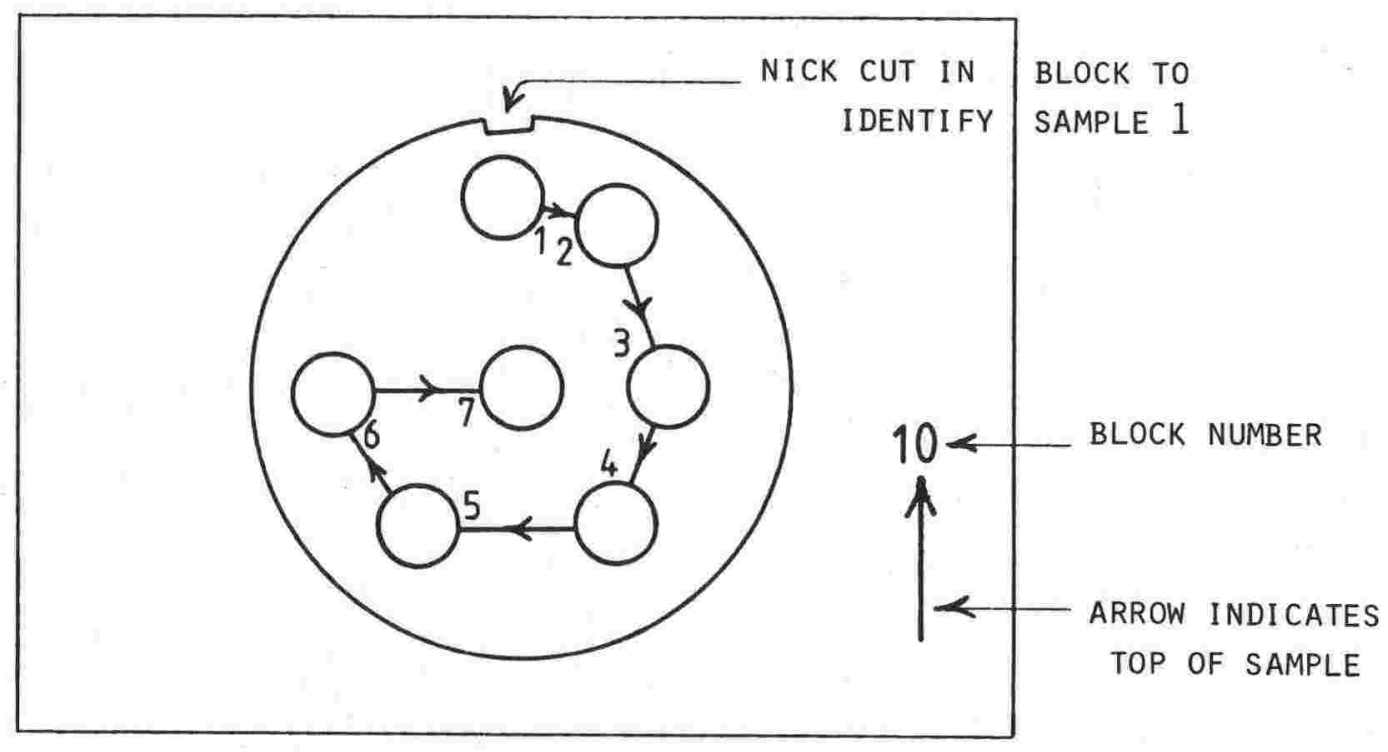

Samples are identified by block and location number, e.g. 10/1 and each analysis on that safniple by a further digit: $10 / 1 / 1,10 / 1 / 2$, etc.

\section{2 Analysis Techniques.}

Mineral analyses performed on the JEOL 733 Superprobe at Victoria University normally use a $12 \mathrm{nA}$ beam current at $15 \mathrm{kV}$ and a 3 or 10 micron beam. These conditions are acceptable for analysis of mineral phases but not volcanic glass. All glass samples have been analysed with a beam of $8 \mathrm{nA}$ at $15 \mathrm{kV}$ and a 10 micron beam. Some alkäli metal loss occurs at these settings but is considered minimal.

Prior to mineral analysis, the probe calibration is checked against Kakanui Augite or other minerals of known composition and any element standards are rerun if necessary. Calibration for glass analyses is against rhyolitic glass standards.

At least 10 individual glass shards per sample should be probed. Glass ghould be carefully examined in reflected and transmitted light to check for inclusions 
or vesicles although discrepancies in the probe analysis caused by these features is usually obvious. Use of a 10 or 20 micron beam requires the analysis point to be carefully chosen, especially if a peak search routine is being used. The policy usually adopted with a 10 micron beam is to select a point in the lower left corner of a shard with a polished surface extending beyond the 10 micron cross-hair graticule in all directions:

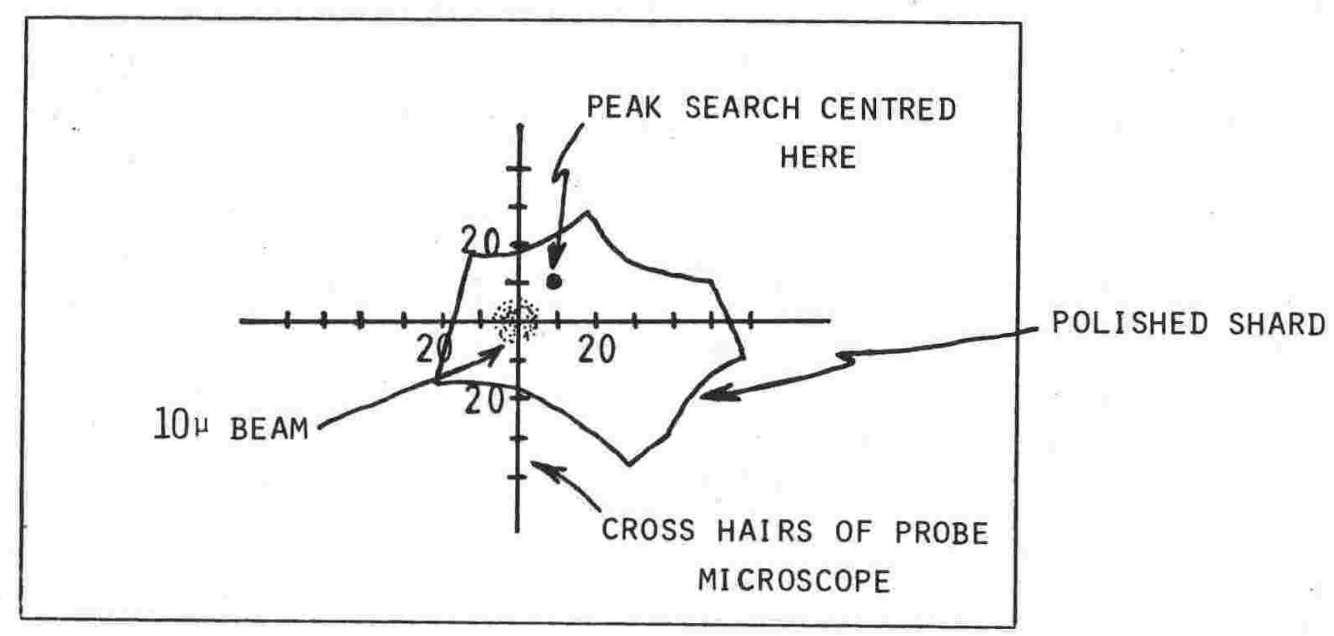

A peak search may be routinely performed for each analysis, but a large number of analyses can be obtained more efficiently by performing a peak search after every 10 analyses. No peak drift has been noted with this procedure.

Hydration of glass, ranging from 0-108 requires the analysis to be recalculated to 1008 anhydrous basis before comparison. A computer programme in BASIC on the HP 85 in the Analytical Facility VUW recalculates and means the analyses for each sample. High standard deviations on the mean analysis may indicate a mixed assemblage of glass. The most critical elements are $\mathrm{SiO}_{2}, \mathrm{TiO}_{2}, \mathrm{FeO}$ and $\mathrm{CaO}$, and it may be possible for the individual analyses to be split into 2 or more populations. In that event 20 or 30 shards should be analysed to confirm the splits. Typical standard deviation values for unmixed assemblages are:

$\begin{array}{llllll}\mathrm{SiO}_{2} & 0.15-0.30 & \mathrm{FeO} & 0.05-0.12 & \mathrm{CaO} & 0.03-0.08 \\ \mathrm{Al}_{2} \mathrm{O}_{3} & 0.15-0.25 & \mathrm{MnO} & 0.02-0.05 & \mathrm{Na}_{2} \mathrm{O} & 0.10-0.30 \\ \mathrm{Ti}_{2} & 0.02-0.04 & \mathrm{MgO} & 0.01-0.04 & \mathrm{~K}_{2} \mathrm{O} & 0.05-0.25\end{array}$

\subsection{Glass Standards.}

A variety of glass standards, including natural obsidians, glass shards and fused tephra glass are used for the JEOL 733. The comendite obsidian KN-18 (supplied by H. Sigurdsson, 1981) is the main glass standard and is used as a check on individual elêment calibrations except $\mathrm{MgO}$ and $\mathrm{MnO}$. It is especially useful for $\mathrm{Na}, \mathrm{K}$ and $\mathrm{Cl}$. Other glasses, including UA 5831 and a basaltic glass VG 99 are available. Glass shards from Mt. Curl Tephra have been repeatedly analysed as an internal standard and samples are available from the Geology Department for analysis on request. Standard analyses on each sample together with the 733 probe analyses are listed in Table 2. 


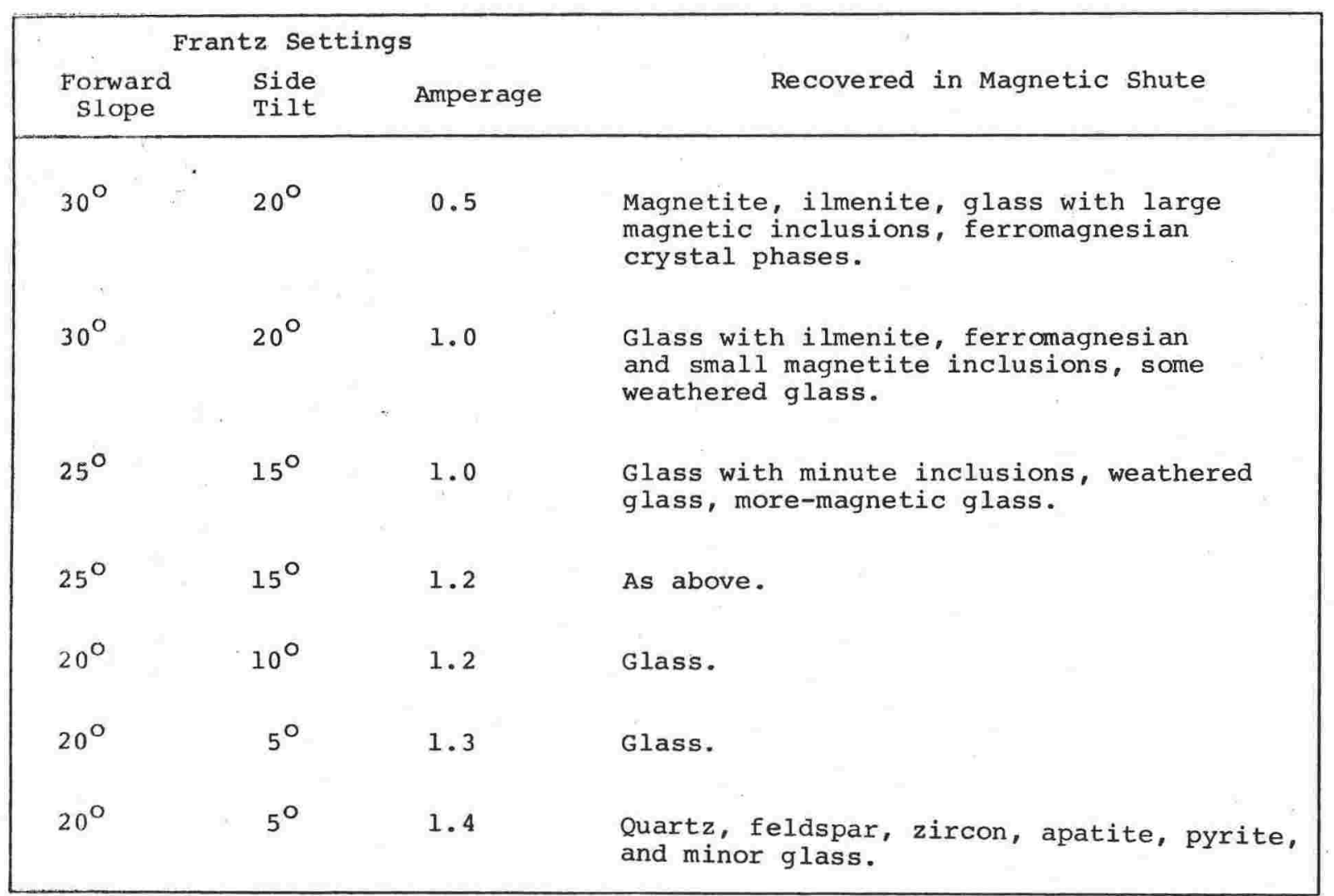

$\underline{T A B L E} 1$

\begin{tabular}{|c|c|c|c|c|c|}
\hline & \multicolumn{2}{|l|}{$\mathrm{KN}-18$} & \multicolumn{2}{|l|}{ UA\# 5831} & $\begin{array}{l}\text { MT . CURL TEPHRA } \\
\text { PROBE }\end{array}$ \\
\hline $\mathrm{SiO}_{2}$ & $74.45 \quad(0.56)$ & 74.60 & $74.21 \quad(0.71)$ & 74.09 & $78.06(0.31)$ \\
\hline $\mathrm{A}_{2} \mathrm{O}_{3}$ & $10.60(0.15)$ & 10.53 & $13.21 \quad(0.19)$ & 13.12 & $12.32(0.21)$ \\
\hline $\mathrm{TiO}_{2}$ & $0.15(0.03)$ & 0.18 & $0.06 \quad(0.02)$ & 0.09 & $0.14 \quad(0.03)$ \\
\hline $\mathrm{F} e \mathrm{O}$ & $3.40(0.11)$ & 3.45 & $1.49(0.10)$ & 1.72 & $1.01(0.09)$ \\
\hline $\mathrm{MnO}$ & $0.06 \quad(0.04)$ & 0.06 & $0.06 \quad(0.03)$ & 0.06 & $0.04 \quad(0.05)$ \\
\hline $\mathrm{MgO}$ & $0.01-$ & 0.01 & $0.05 \quad(0.02)$ & 0.07 & $0.12 \quad(0.02)$ \\
\hline $\mathrm{CaO}$ & $0.15(0.06)$ & 0.15 & $0.72(0.03)$ & 0.76 & $0.78 \quad(0.05)$ \\
\hline $\mathrm{Na}_{2} \mathrm{O}$ & $5.05 \quad(0.18)$ & 5.68 & $4.32(0.17)$ & 4.06 & $3.31 \quad(0.13)$ \\
\hline $\mathrm{K}_{2} \mathrm{O}$ & $4.24 \quad(0.15)$ & 4.39 & $4.78 \quad(0.16)$ & 5.04 & $4.23(0.16)$ \\
\hline C1 & N.D. & 0.37 & N.D. & 0.36 & N.D. \\
\hline $\mathrm{H}_{2} \mathrm{O}$ & - & & - & & $4.49 \quad(1.33)$ \\
\hline Total & 98.10 & 99.05 & 98.90 & 99.01 & - \\
\hline $\mathrm{N}$ & 48 & & 25 & & 120 \\
\hline
\end{tabular}

TABLE 2: Analyses on Glass Standards. 


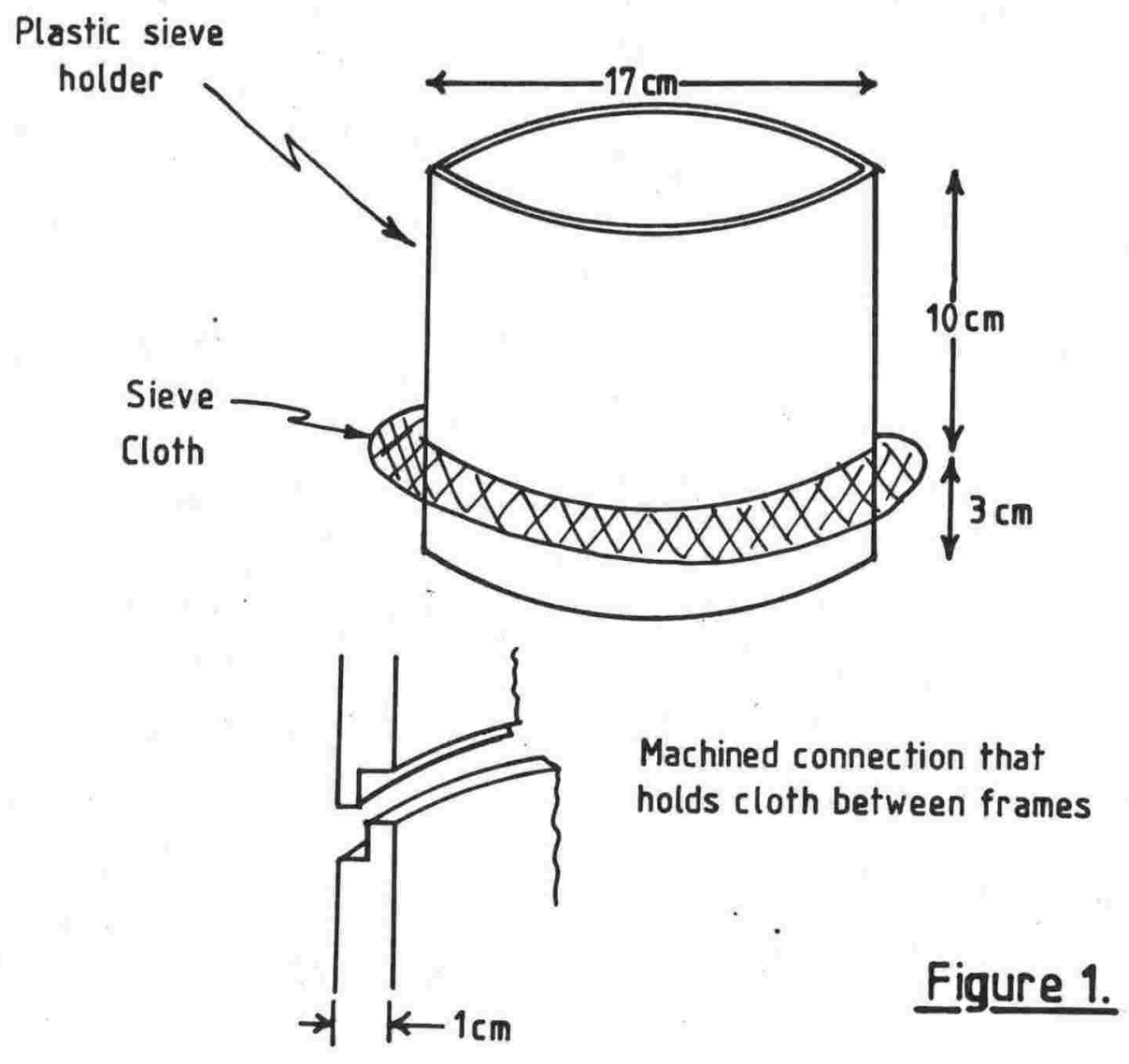

Figure 1. Dimensions of plastic sieve holder used to hold nylon or monolen cloth. Sieves can be stacked if machined top and bottom.

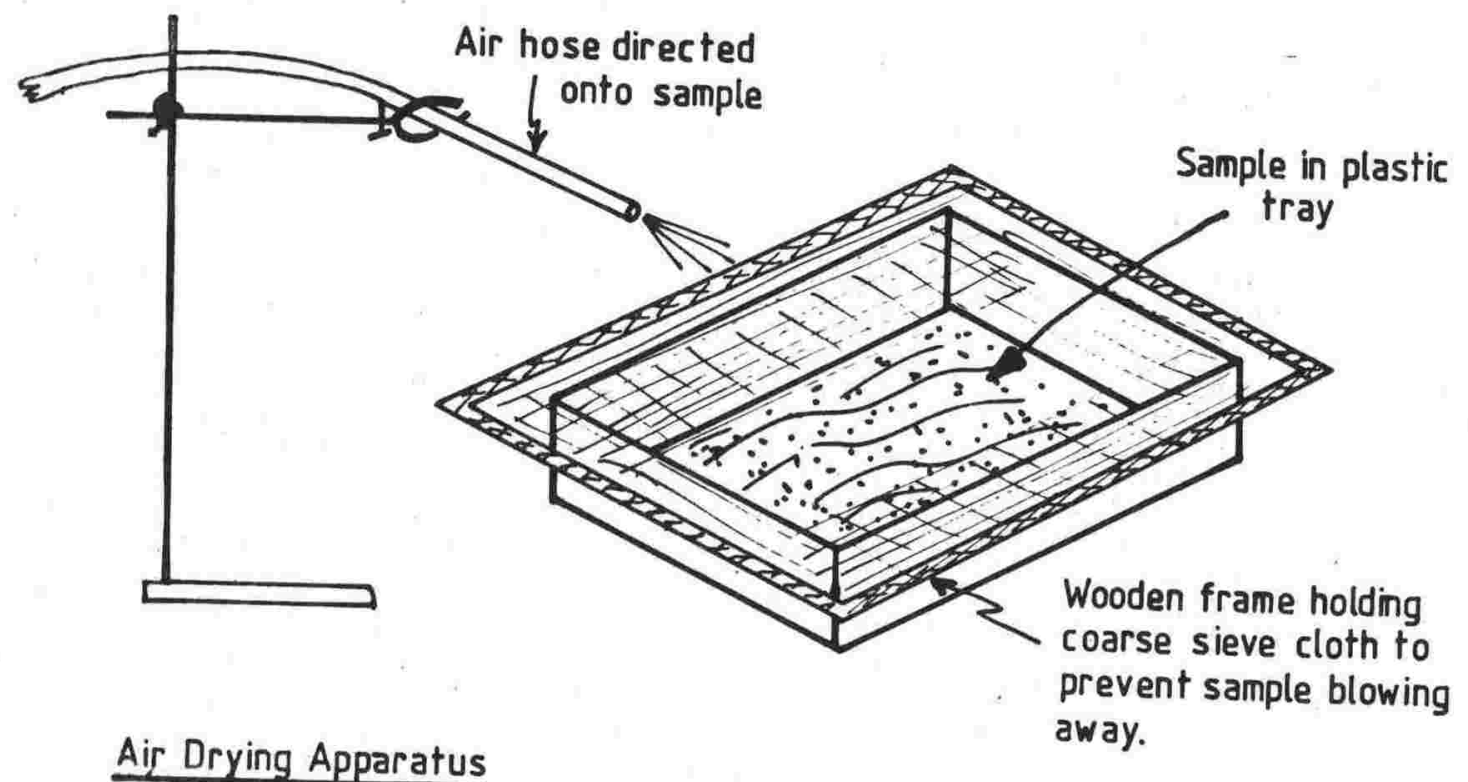

Figure 2

Eigure 2. Schematic layout for airdrying tephra samples. Typical dimensions of tray about $250 \times 350 \mathrm{~mm}$. 
Papers published jointly by the author and others examine in more detail aspects of physical volcanology discussed in the main text. These, together with the application of tephra stratigraphy to the study of recent tectonics, constitute the seven papers presented in this appendix. 


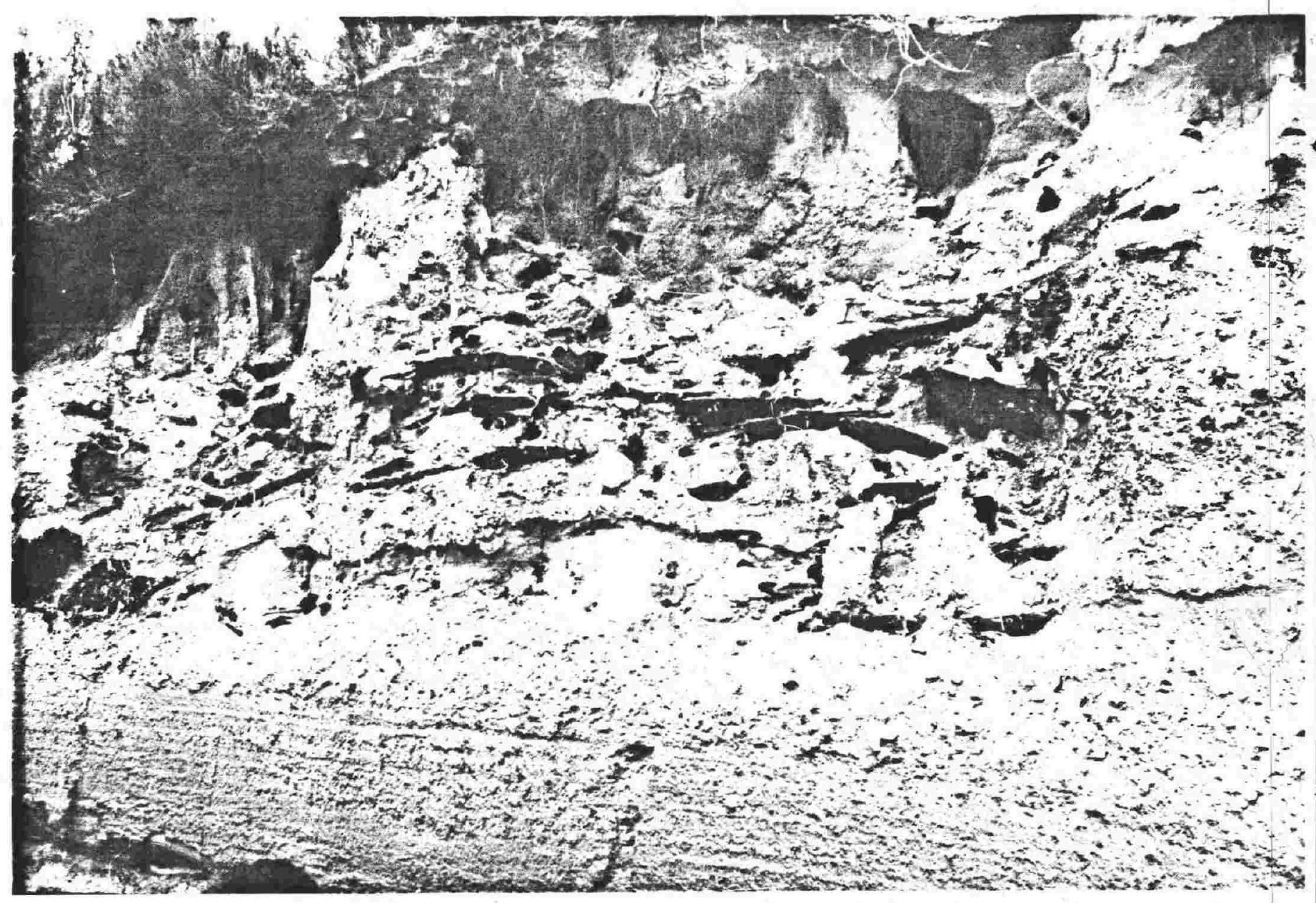

Figure 1. Section through Taupo Ignimbrite about $60 \mathrm{~km}$ south of source, showing aburdance of carbonized logs common in this deposit. Note that charcoal is lying horizontal and above base of flow unit. Lower, weakly bedded unit can be mapped as separate flow unit, indicating that charcoal has been transported into this site by succeeding flow. Total thickness of section shown is about $4 \mathrm{~m}$.

a finding fully in agreement with the other lines of evidence given above. East of the source, data are scarce because the preignimbrite air-fall deposits were thick enough to bury totally and thus protect the forest before the ignimbrite was erupted. However, in spite of this, the radial pattern about the vent is obvious. Felling of trees and their alignment parallel to blast direction are well known for hot surges, as, for example, the Mt. Lamington eruption of 1951 (Taylor, 1958). However, to our knowledge, such felling has not been reported for prehistoric eruptions, especially where the logs have become incorporated and oriented within the flow or completely converted to charcoal.

Elsewhere, transport and flow direction of pyroclastics have previously been determined by fabric studies of clasts or crystals (Elston and Smith, 1970). This procedure is unsuited to the Taupo Ignimbrite, because the pumice clasts are coarse and well rounded and the unwelded ignimbrite is incoherent.

The sense of flow direction of the Taupo
Ignimbrite is determined only from the overall radial distribution of the $\log$ axes, shown in Figure 2. However, flow directtion could in some cases be determined in the field when the logs were slightly imbricate (less than $15^{\circ}$ ) in the "upcurrent" direction. Two of us (Wilson and Walker) have seen logs inclined at a much steeper angle in an ignimbrite near Guimar in Tenerife. The sense of flow in the Taupo Ignimbrite is also given by the direction of upturning of root plates.

Furthermore, lenses of coarse pumice are concentrated in the downvent or lee side of obstacles such as sharp ridges or large tree trunks. In a few places, we found the source of ripped-up soil clasts, even after they had been incorporated in the flow and transported several metres away from the vent.

\section{IMPLICATIONS FOR FLOW MECHANICS}

The log-orientation data suggest two features of the flow mechanics of the Taupo Ignimbrite. Radial log orientations indicate circular collapse of the eruption column and that the pyroclastic flow moved radially outward across the landscape. Logs close to the source are commonly transverse to pre-existing valleys. Only in deep valleys do the logs parallel the valley trend. Farther from the source, the flow became more confined to the val leys, and the logs are aligned with the long axis of the valley. However, the flow covered all of the landscape, as evidenced by a mantling deposit. Beyond about $65 \mathrm{~km}$ from the source, the flow was entirely valley bound, and its direction of movement was valley controlled.

All observed logs lie subhorizontal withir the ignimbrite and have no attached roots. Thus, radial orientation was not a result of an initial blast toppling the trees or the anchoring effect of trailing roots. Orienta. tion must then have been by transport within the flow. We believe that only a laminar flow is capable of orienting the logs in this ignimbrite. Turbulent flow would probably have fragmented the carbonized logs and in the "fines-depleted 


\title{
Orientation of logs in the Taupo Ignimbrite
}

\section{as an indicator of flow direction and vent position}

\author{
P. C. Froggatt \\ Geology Department, Victoria University, Wellington, New Zealand \\ C.J.N. Wilson, G.P.L. Walker \\ Geology Department, Imperial College, London SW7, England
}

\begin{abstract}
The Taupo Ignimbrite is an unwelded rhyolitic ignimbrite that originated about $1,820 \mathrm{yr}$ ago from an eruptive vent within Lake Taupo in the Taupo Volcanic Zone, New Zealand. This ignimbrite is rich in carbonized plant matter, including many logs. The logs lie subhorizontally throughout all levels of the ignimbrite but are especially common in the lower half. Regionally the logs show a strong radial orientation, indicating flow directions and position of the source vent. Log orientation is thus a reliable indicator of vent position.
\end{abstract}

\section{NTRODUCTION}

The Taupo Volcanic Zone (Healy, 1962) is a terrain of dominantly rhyolitic olcanic rocks trending northeastiouthwest through the North Island of Vew Zealand and is associated with a westJlunging subduction zone (Cole, 1979). Jne of several eruptive centers in this zone s the Taupo Volcanic Centre (Healy, 1964), from which the unwelded Taupo ignimbrite and the immediately preceding air-fall pyroclastic material were erupted about 1,820 yr ago (Vucetich and Pullar, 1973; Froggatt, 1981). The ignimbrite has a volume estimated at about $70 \mathrm{~km}^{3}$ and zovers an approximately circular area of nore than $10,000 \mathrm{~km}^{2}$. Beginning with a series of Plinian-type eruptions, the erupive sequence culminated in several large jyroclastic flows (Taupo Ignimbrite). The erm "ignimbrite" is used here for the deposits from a pyroclastic flow or series of flows, whether welded or not. The location of the eruptive vent for these pyroclastics has been deduced to lie within the northeast part of Lake Taupo (Froggatt, 1979; G.P.L. Walker, S. Self, and P. C. Froggatt, in prep.). This source position is indicated py the following evidence: (1) isopach and lispersal pattern data of the preceding Plinian phases (Walker, 1980); (2) distripution of maximum lithic clast sizes vithin these Plinian phases and also the pasal layer of the Taupo Ignimbrite itself
(Walker, Self, and Froggatt, in prep.); (3) absence of lithic clasts of ballistic origin in the Taupo Ignimbrite; ballistic lithics are blocks generally larger than 20 $\mathrm{cm}$ that have followed a parabolic-like trajectory away from the vent and are often found associated with impact features; they are almost ubiquitous in Plinian eruptive deposits up to a maximum of 3 to $5 \mathrm{~km}$ from their vents (Booth and others, 1978); absence of proven ballistics suggests that all exposures of Taupo Ignimbrite are at least $3 \mathrm{~km}$ from the source; the lack of ballistics, in conjunction with items 1 and 2 above, points to the vent being at least $3 \mathrm{~km}$ lakeward of the present eastern lake shore; and (4) bathymetry of this area of the lake, indicating a prominent reef system called Horomatangi Reefs, surrounding a circular depression (Irwin, 1972); we regard this reef as the eruptive vent.

\section{ORIENTATION OF LOGS}

The Taupo Ignimbrite contains many carbonized (converted to charcoal) logs as much as $1 \mathrm{~m}$ in diameter and $5 \mathrm{~m}$ long. These lie subhorizontal at all levels in the ignimbrite, but they are especially common both in the middle and toward the base (Fig. 1). The logs appear to have been charred in situ by the hot pyroclastic flow, because they show radial fissures and deformed cell structures and commonly have lithic-rich "pipes" above them where streaming gases have flushed out fine pumice ash. No trees have been found in growth position. All trees were broken off by the pyroclastic flow or preceding blast and then incorporated into the flow. In a few sections are trees that were uprooted and, although the attached root plates are preserved, the trees have disappeared, either because of complete combustion or by incorporation and then removal in the flow. Few branches remain attached to trunks; most were broken off by the initial blast or by transport in the flow. Radiocarbon dating of some of these logs indicates an average age of about $1,820 \mathrm{yr}$ (Healy, 1964). Most logs are podocarps (Dacrydium) or beeches (Nothofagus sp.) (Pullar and Patel, 1972), but a few undergrowth species such as tree ferns have also been noted.

Orientations of more than 100 logs were measured and the log axes plotted on a map as lines passing through each locality (Fig. 2). Where several measurements could be made at a site, the variation is shown by a pair of bounding lines. Only axis direction is shown, because it usually was not possible to determine the flow direction from the logs.

Figure 2 illustrates that the log orientations are radial about the eastern part of Lake Taupo. These orientations clearly show the vent to have been in this region, 


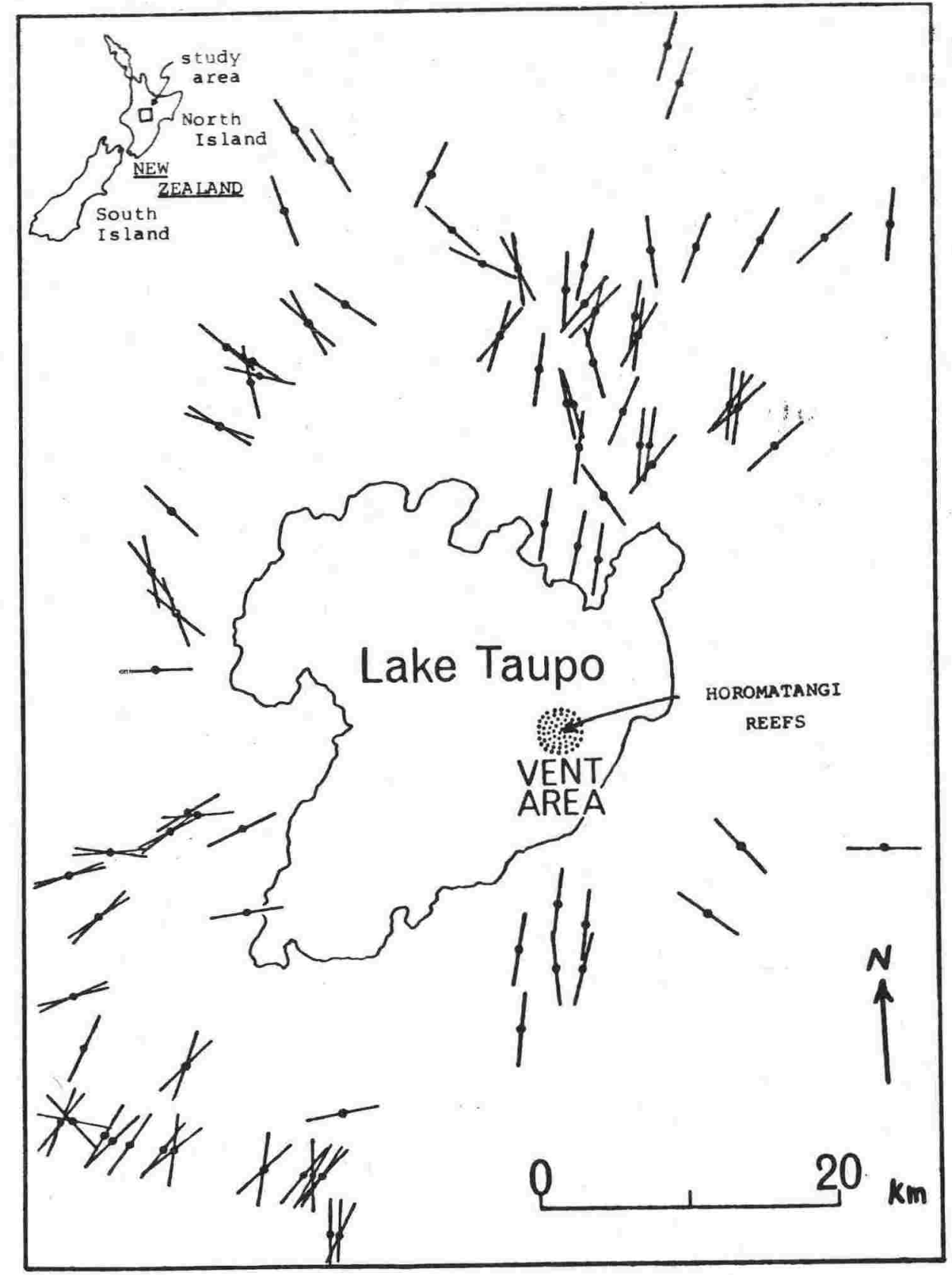

Figure 2. Map of area around Lake Taupo, North Island, New Zealand, showing orientations of carbonized logs within Taupo Ignimbrite. Pairs of lines through some sites indicate range of orientations measured.

ignimbrite" facies (Walker and others, 1980) would account for the fragmented charcoal and loss of fine material in parts of this ignimbrite. In this facies, log fragments were apparently randomly oriented. Intact logs within the ignimbrite would thus indicate laminar flow over nearly all the distance traveled by the flow.

\section{CONCLUSIONS}

Field studies of carbonized logs within an unwelded ignimbrite (pyroclastic flow deposit) show the logs to have been distance traveled (more than $70 \mathrm{~km}$ ). The radial pattern of $\log$ distribution provides a reliable method of deducing the position of the source vent for prehistoric eruptions in places where the initial volcanic relief is now obscured or destroyed.

\section{REFERENCES CITED}

Booth B., Croasdale, R., and Walker, G.P.L., 1978, A quantitative study of five thousand years of volcanism on Sao Miguel, Azores : Royal Society of London Philosophical Transactions, ser. A, v. 288, p. 271-319.

Cole, J. W., 1979, Structure, petrology and genesis of Cenozoic volcanism, Taupo

Volcanic Zone, New Zealand: New Zealand Journal of Geology and Geophysics, v. 22. p. 631-657.

Elston, W. E., and Smith, E. J., 1970, Deter. mination of flow direction of rhyolitic ashflow tuffs from fluidal textures: Geological Society of America Bulletin, v. 81, p. 3393-3406.

Froggatt, P. C. 1979, Lake Taupo: Probable source of the Taupo Pumice: New Zealand Journal of Geology and Geophysics, v. 22, p. 763-764.

- 1981. Stratigraphy and nature of Taupo Pumice Formation: New Zealand Journal of Geology and Geophysics (in press).

Healy, J., 1962, Structure and volcanism in the Taupo Volcanic Zone, New Zealand: American Geophysical Union Geophysical Monograph 6, p. 151-157.

- 1964, Stratigraphy and chronology of late Quaternary volcanic ash in Taupo, Rotorua, and Gisborne districts. Part 1: New Zealand Geological Survey Bulletin 73, 88 p.

Irwin, J., 1972, Lake Taupo, provisional bathymetry, $1: 50,000$ : New Zealand Oceanographic Institute Chart, Lake Series.

Pullar, W. A and Patel, R. N., 1972, Identification of tree-stumps and driftwood associated with tephra layers in alluvium, peat and dune sands: New Zealand Journal of Botany, v. 10, p. 605-614.

Taylor, G. A., 1958, The 1951 eruption of Mount Lamington, Papua: Australia Bureau of Mineral Resources Bulletin 38, $117 \mathrm{p}$.

Vucetich, C. G., and Pullar, W. A., 1973, Holocene tephra formations erupted in the Taupo area, and interbedded tephras from other volcanic sources: New Zealand Journal of Geology and Geophysics, v. 16, p. 745-780.

Walker G.P.L 1980, The Taupo Pumice: Product of the most powerful known (ultraplinian) eruption?: Journal of Volcanology and Geothermal Research, v. 8, p. 69-94.

Walker, G.P.L., Wilson, C.J.N., and Froggatt, P. C., 1980, Fines-depleted ignimbrite in New Zealand-The product of a turbulent pyroclastic flow: Geology, v. 8, p. 245-249.

\section{ACKNOWLEDGMENTS}

Reviewed by W. A. Pullar, B. McKelvey, and ignimbrite rather than at the base of the deposit. This observation indicates incorporation of trees into and transportation by the pyroclastic flow rather than the flow toppling and overriding the trees. The orientation of the logs indicates the direction and position of the volcanic vent. This vent position is coincident with a site deduced independently from textural evidence. Orientation of logs indicates that the pyroclastic flow maintained a laminar flow regime over most of the
G. Grindley. Field work by Froggatt was sup ported by Victoria University of Wellington. Wilson was supported by a British Natural Environment Restearch Council research studentship and Walker by the Royal Society of New Zealand as a Captain James Cook Fellow at Auckland University.

MANUSCRIPT RECEIVED MARCH 31, 1980 REVISED MANUSCRIPT RECEIVED

DECEMBER 10, 1980

MANUSCRIPT ACCEPTED DIC. 18, 1980 


\title{
AN IGNIMBRITE VENEER DEPOSIT: THE TRAIL-MARKER OF A • PYROCLASTIC FLOW
}

\author{
G.P.L. WALKER ${ }^{1, *}$, C.J.N. WILSON ${ }^{1, *}$ and P.C. FROGGATT ${ }^{2}$ \\ ${ }^{1}$ Geology Department, Uniwersity of Auckland, Auckland (New Zealand) \\ ${ }^{2}$ Geology Department, Victoria University, Wellington (New Zealand)
}

(Received March 12, 1980; revised version accepted August 1, 1980)

\section{ABSTRACT}

Walker, G.P.L., Wilson, C.J.N. and Froggatt, P.C., 1981. An ignimbrite veneer deposit: the trail-marker of a pyroclastic flow. J. Volcanol. Geotherm. Res., 9: 409-421.

The term "ignimbrite veneer deposit" (IVD) is proposed for a new kind of pyroclastic deposit which is found associated with, and passes laterally into, Taupo ignimbrite of valley pond type in New Zealand. It forms a thin layer mantling the landscape over 15,000 $\mathrm{km}^{2}$, and is regarded as the deposit from the trailing "tail" of a pyroclastic flow, where a relaxation of shear stress favoured the deposition of the basal part of the flow. The IVD differs little in grain-size from the associated ignimbrite, but it shows a crude internal stratification attributed to the deposition of a succession of layers, one after the passage of each pulse of the pyroclastic flow. It locally contains laterally-discontinuous lenses of coarse pumice ("lee-side lenses") on the far-vent side of topographic obstacles. In nearvent exposures the Taupo IVD shows lensoid and cross-stratified bed-forms even where it stands on a planar surface, attributed to deposition from a flow travelling at an exceedingly high velocity.

An IVD can be distinguished from a poorly sorted pyroclastic fall deposit because the beds in it show more rapid lateral variations in thickness, it may show a low-angle crossstratification, and it contains carbonised wood from trees not in the position of growth; from the deposit of a wet base surge because it lacks vesicles and strong antidune-like structures and contains carbonised vegetation, and from a hot and dry pyroclastic surge deposit because it possesses a high content of pumice and "fines".

The significance of an IVD is that it records the passage of a pyroclastic flow, where the flow itself has moved farther on.

\section{INTRODUCTION}

The non-welded Taupo ignimbrite is remarkably well preserved, partly because of its youth - it has a ${ }^{14} \mathrm{C}$ age of only 1800 years (the Upper Taupo Pumice: Baumgart and Healy, 1956; Healy et al., 1964) - and partly because the vegetation which flourishes in the New Zealand climate rapidly stabilises any loose pyroclastic deposits. In the way that is typical of ignimbrites, it

\footnotetext{
*On leave from Geology Department, Imperial College, London SW 7, England.
} 


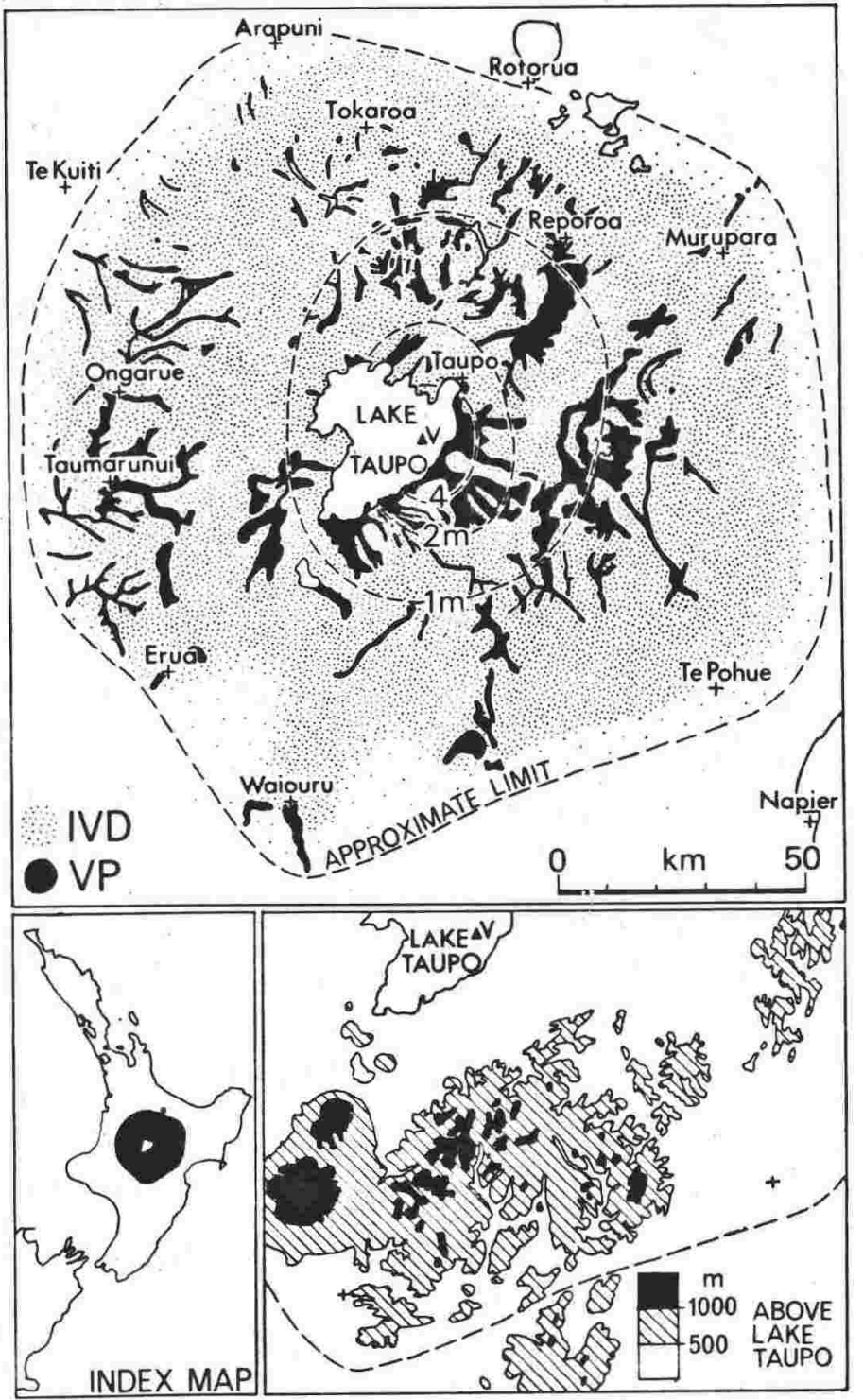

Fig.1. Map of the Taupo ignimbrite distinguishing semi-schematically between ignimbrite veneer deposit (IVD; stippled) and valley pond ignimbrite (VP; solid black). The dashed lines are isopachs of the approximate average thickness of IVD. $V=$ vent position. The extent of the pond areas is based on N.Z. Geological Survey maps, on which pumiceous alluvium is included with the ignimbrite. Not all ponds have been visited by the authors; and not all of the multiplicity of ponds are shown. Note that the ponds are not erosional remnants of a more complete ignimbrite, and in many cases the pyroclastic flow had to cross quite high ground to reach them. Lower right: The southern part of the area, on the same scale, showing topography. Note that the ignimbrite extends over the mountainous country S and SE of vent the same distance as over the much flatter ground NW and NE from vent, showing that topography was not a major factor determining the distance reached. Lower left: Index map of New Zealand showing location of the Taupo ign im brite outcrop. 
has ponded in local topographic depressions and forms a flat-floored valleybottom terrace in a multitude of valleys within a roughly circular area $165 \mathrm{~km}$ across centred on its vent concealed below Lake Taupo (Fig.1).

The distinctive feature of the Taupo ignimbrite is that the valley slopes and ridges between the ignimbrite "ponds" are covered by a pyroclastic surface layer (Fig.2) that appears to be complete and more or less unbroken (except where locally cut by subsequent erosion) within a roughly circular area at least $130 \mathrm{~km}$ across centred on the same vent. This layer mantles the landscape even to a height of more than $1000 \mathrm{~m}$ above the level of Lake Taupo.

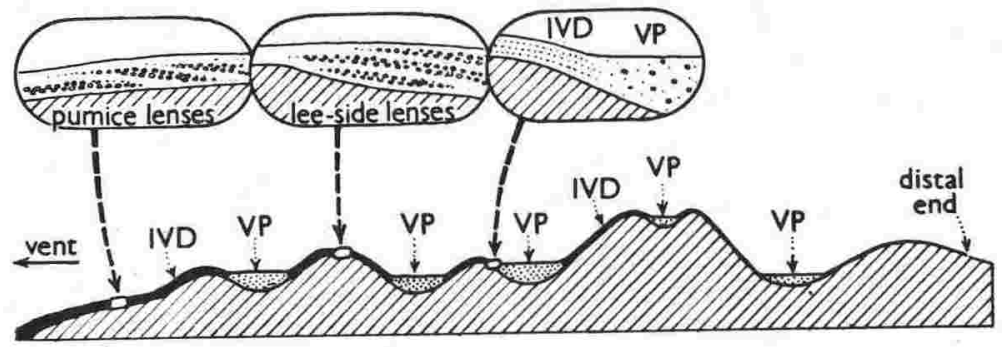

Fig.2. Schematic section across the Taupo ignimbrite from vent (extreme left) to distal end (extreme right), showing relationship between the ignimbrite veneer deposit and the valley pond ignimbrite. Note the gradual outward thinning of the IVD, suggesting that the factor which governed the distance travelled was the amount of material in the ash flow. Because of the material that was continuously being left behind, the flow travelled outwards only as far as the point at which all the material in it was used up.

This pyroclastic layer which occurs between the ignimbrite ponds is closely similar in character to the ignimbrite, and there are many road cuttings and natural exposures where it visibly passes into normal ponded ignimbrite, without any sign of a break. It is thus demonstrably a part of the ignimbrite, and is interpreted as a portion of it which failed to drain into ignimbrite ponds.

The term "ignimbrite veneer deposit" (IVD) is proposed for this new type of pyroclastic rock (following Walker et al., 1980a, b; Fisher et al., 1980). In this paper its general characteristics are described, and criteria by which it may be distinguished from other types of pyroclastic rocks are discussed. We emphasize the point that, as more pyroclastic types come to be recognised, so the validity of diagnostic criteria must continually be questioned and the criteria updated to accommodate the new types.

\section{FIELD CHARACTERISTICS}

Although the IVD is much thinner than the valley pond ignimbrite, it covers a much bigger area, and its estimated volume of $15 \mathrm{~km}^{3}$ is approximately the same as the volume of ignimbrite contained in valley ponds. It is thus a major component of the Taupo ignimbrite. 

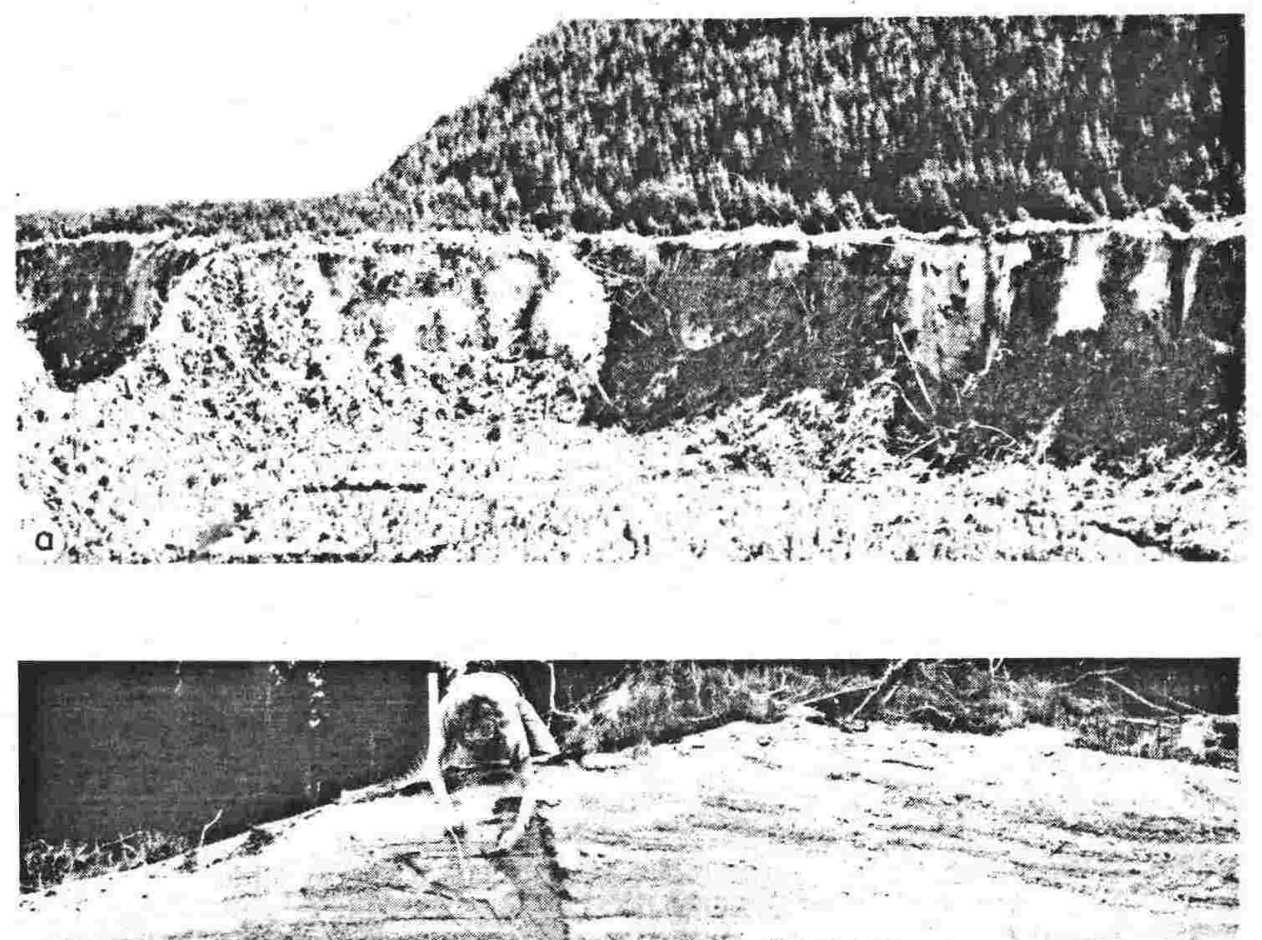

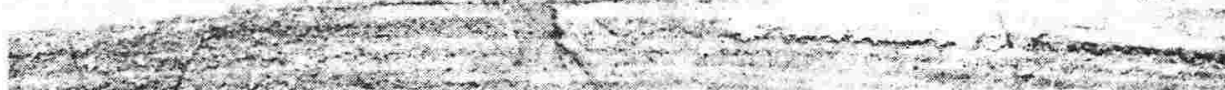

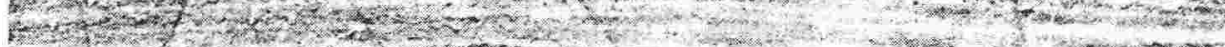

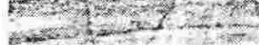
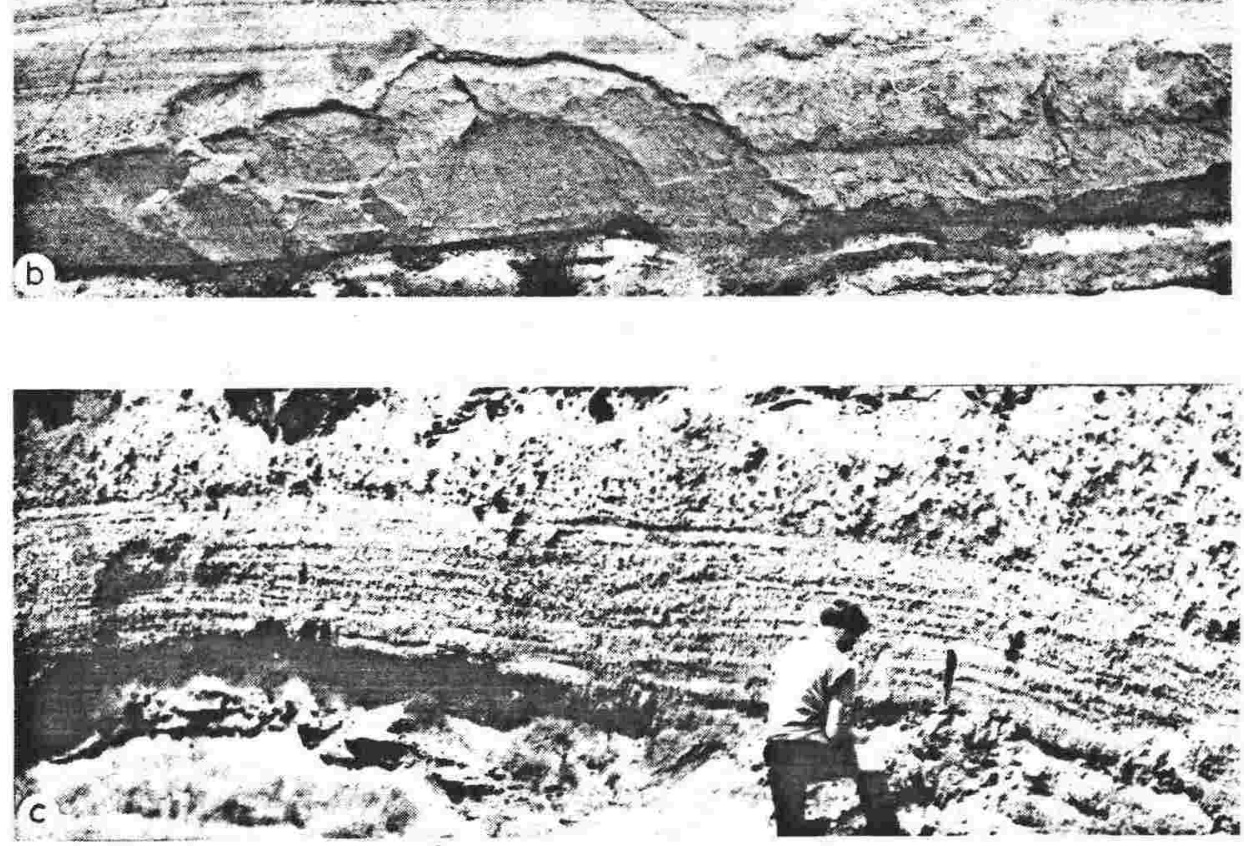
The IVD differs from the ponded ignimbrite in four important respects. First, it forms a more or less continuous layer mantling the topography; it commonly stands on slopes up to about $30^{\circ}$ with its upper surface parallel to the base, whereas the ponded ignimbrite has a sub-horizontal upper surface. Second, over most of its extent it is only $0.5-1 \mathrm{~m}$ thick, whereas the ponded ignimbrite is at least several metres thick and attains several tens of metres in the deeper ponds. Third, it shows a distinct internal banding (Fig. 3 ), the layers in which are commonly $5-20 \mathrm{~cm}$ thick and are marked by differences in maximum pumice size, whereas the ponded ignimbrite is relatively homogeneous and the flow units and coarse-tail-grading pumice concentration zones which do occur form gross layers typically more than $1 \mathrm{~m}$ thick. Fourth, the largest pumice in it is consistently smaller than in the ponded ignimbrite at the same distance from source (Fig.4).

The banding of the IVD is roughly parallel with the base and the top of the deposit, whatever the slope angle on which it stands. Where the IVD thickens and passes into normal ignimbrite at the margin of a pond, the banding in the former gradually becomes less distinct and then disappears. The lowermost fine layer in the IVD is continuous with the basal layer of the ignimbrite. The ground layer rich in lithics and crystals which underlies the ignimbrite is continuous with that at the base of the IVD. By "basal layer" is meant the layer 2a of Sparks et al. (1973), and the "ground layer" is equivalent to the layer 1 in the same paper as reinterpreted by Walker et al. (1981).

The IVD like the pond ignimbrite is rich in fine ash (Fig.5), and tends to become finer and poorer in macroscopic lithics upwards, while the banding is marked by variations in the content of coarse pumice and the maximum pumice size. The boundaries between bands are indistinct. Some bands show an ill-defined reverse coarse-tail grading. The bases of some bands truncate the underlying bands in the IVD to give rise to a low-angle cross-stratification. Where the banding is sufficiently clear, as many as 20-30 graded units can be counted; the number declines as the distance from vent increases, and farther out than about $50 \mathrm{~km}$ virtually no banding can be distinguished.

At many locations the IVD contains lenses (Fig.6) of coarse, well-rounded pumice having a clast-supported fabric and almost totally lacking fines. These lenses usually occur on the far-vent side of topographic elevations and we propose to call them "lee-side lenses". The largest are $1 \mathrm{~m}$ thick and have an aspect ratio (i.e. ratio of thickness to lateral extent) of about 1:10 or 1:20. The smallest are less than $10 \mathrm{~cm}$ thick. Typically the lenses consist almost exclusively of pumice having a median diameter between 32 and $128 \mathrm{~mm}$

Fig. 3 (a) Typical valley pond ignimbrite with its characteristic flat and near-horizontal upper surface, (b) (c) Typical exposures of ignimbrite veneer deposit, showing the internal layering and local low-angle cross-stratification. (b) is at a site $20 \mathrm{~km}$ SSE of vent (N.Z. Survey 1000 yard grid reference N103/529018), where it is $1 \mathrm{~m}$ thick. (c) is at a site $50 \mathrm{~km}$ SSW of vent (N112/222733) and is unusual in that IVD is overlain by ignimbrite of valley pond type. The probable reason is that after deposition of IVD, ignimbrite became ponded behind a dam (of pumice or logs) to a level higher than the IVD. 
and a graphic standard deviation $\left(\sigma_{\phi}\right)$ of less than 1.0. They are interpreted as having developed in low-solid-concentration vortices underneath the rapidly-moving pyroclastic flow where the flow locally leaped over the ground.

Towards vent the IVD thickens to more than $4 \mathrm{~m}$ and becomes coarser, having a maximum pumice size commonly of $10-15 \mathrm{~cm}$. It also becomes better stratified, and within about $25 \mathrm{~km}$ of vent it locally shows strongly developed bed forms including lensoid and cross-stratified units. Such bedforms can be developed even where the deposit rests on a planar surface (Fig.6a), unlike the lee-side lenses of the IVD farther from source in which the lenses are clearly topography-controlled. Our interpretation is that this
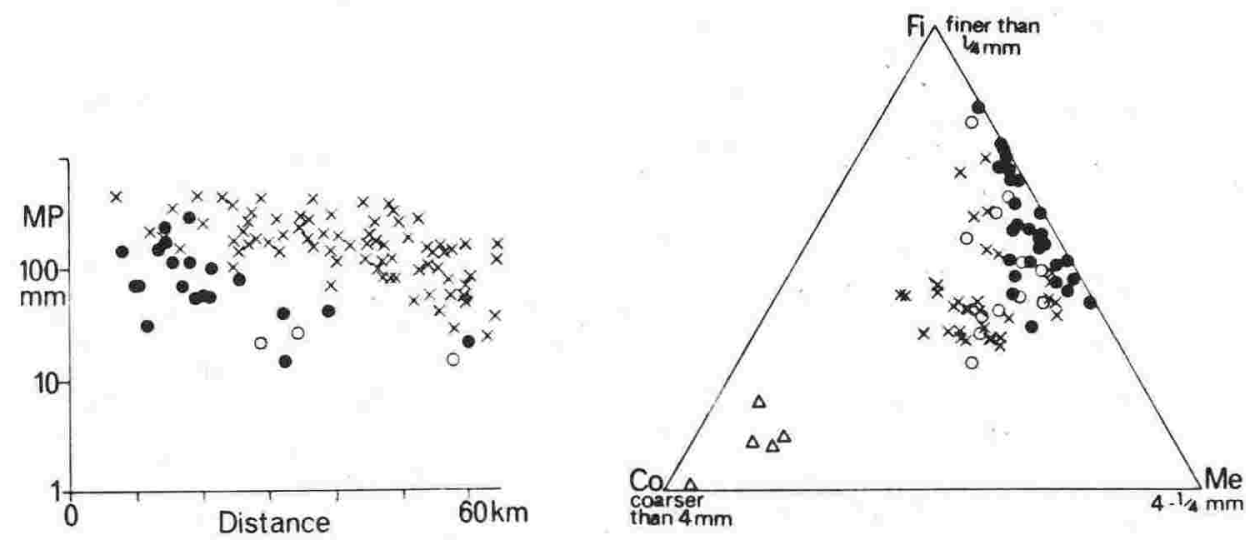

Fig.4. Average maximum diameter of the three largest pumice clasts in normal valley pond ignimbrite (excluding the pumice concentration zone) $(x)$, and its basal layer $(0)$, and in the ignimbrite veneer deposit $(\bullet)$. Note that the value in the IVD is consistently lower than in pond ignimbrite at the same distance from vent, but it is similar to that in the basal layer.

Fig. 5. Plot of sieve analyses of the Taupo ignimbrite summarising differences in grain-size between the ignimbrite veneer deposit $(\bullet)$ and its lee-side pumice lenses $(\Delta)$, and the valley pond ignimbrite $(x)$ and its basal layer $(0)$. The valley pond ignimbrite and IVD differ mainly in the lack of coarse pumice in the latter. The lee-side pumice lenses consist predominantly of coarse pumice. The rationale of this diagram is that $F i$ is a sensitive indicator of the retention, generation or loss of fine material, and $\mathrm{Co}$ is an indicator of the concentration or loss of coarse material (mainly pumice).

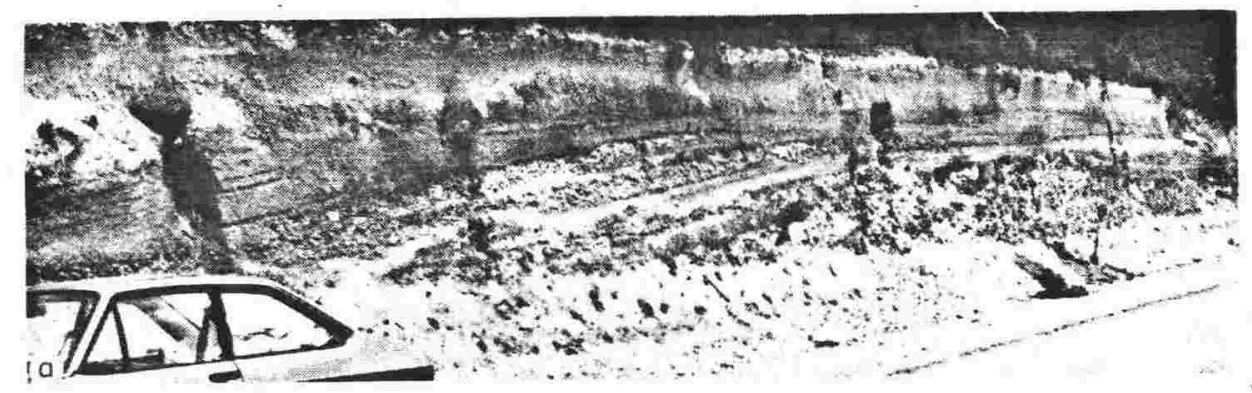



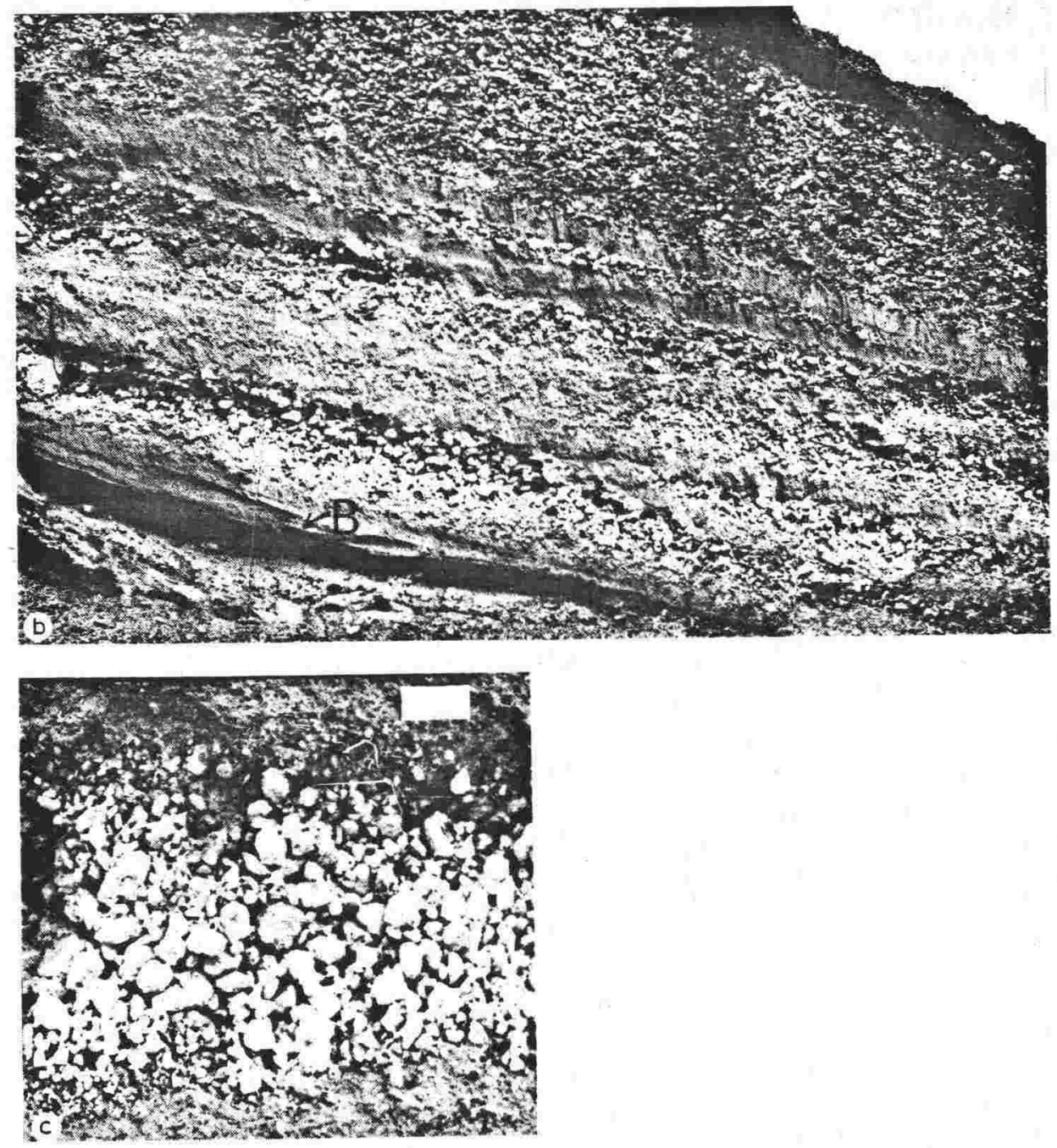

Fig.6. Lenses of coarse and well-sorted pumice in the ignimbrite veneer deposit (a) At a point $19 \mathrm{~km} \mathrm{~W}$ of $S$ of vent (grid reference N102/409019) where the IVD appears to rest on a flat surface; the lenses are attributed to waves in an ultra-high velocity flow. Height on a flat surface; the lenses are attion $3 \mathrm{~m}$. Flow was from right to left. (b) Lee-side pumice lenses at a point $18 \mathrm{~km}$ SSE of vent $(103 / 546037)$ Height of section $4.4 \mathrm{~m}$. Flow was from left to right. $B=$ base of deposit. (c) Detail of pumice in lee-side lenses showing good size sorting and fairly good rounding of the pumice; the bar is $10 \mathrm{~cm}$ long.

near-source variant of the IVD is a deposit from an ultra-high velocity pyroclastic flow.

\section{GRAIN-SIZE CHARACTERISTICS}

The grain-size characteristics have been studied by sieve analyses of many 
samples of IVD and associated normal ignimbrite, and the weight percentages of each constituent (pumice and shards, free crystals, and lithics) have been determined by grain separation or grain counting down to $1 / 4 \mathrm{~mm}$. The $\mathrm{Md}_{\phi}$ and $\sigma_{\dot{\phi}}$ parameters of Inman (1952) have been derived from cumulative curves.

IVD and ponded ignimbrite are closely similar (Figs.5, 7, 8) except for the smaller maximum pumice size in the former. The effect of the lack of coarse pumice is to reduce the values of both $\mathrm{Md}_{\phi}$ and $\sigma_{\phi}$ in comparison with ponded ignimbrite; except in near-vent exposures $\mathrm{Md}_{\phi}$ is rarely larger than +1.0 , and $\sigma_{\phi}$ varies between only 1.7 and 2.9 . The contents of crystals and lithics and the pumice density in Taupo ignimbrite vary with distance from source; those of the IVD are closely similar to those of pond ignimbrite at the same distance from source (Fig.7) except that where two or more samples were
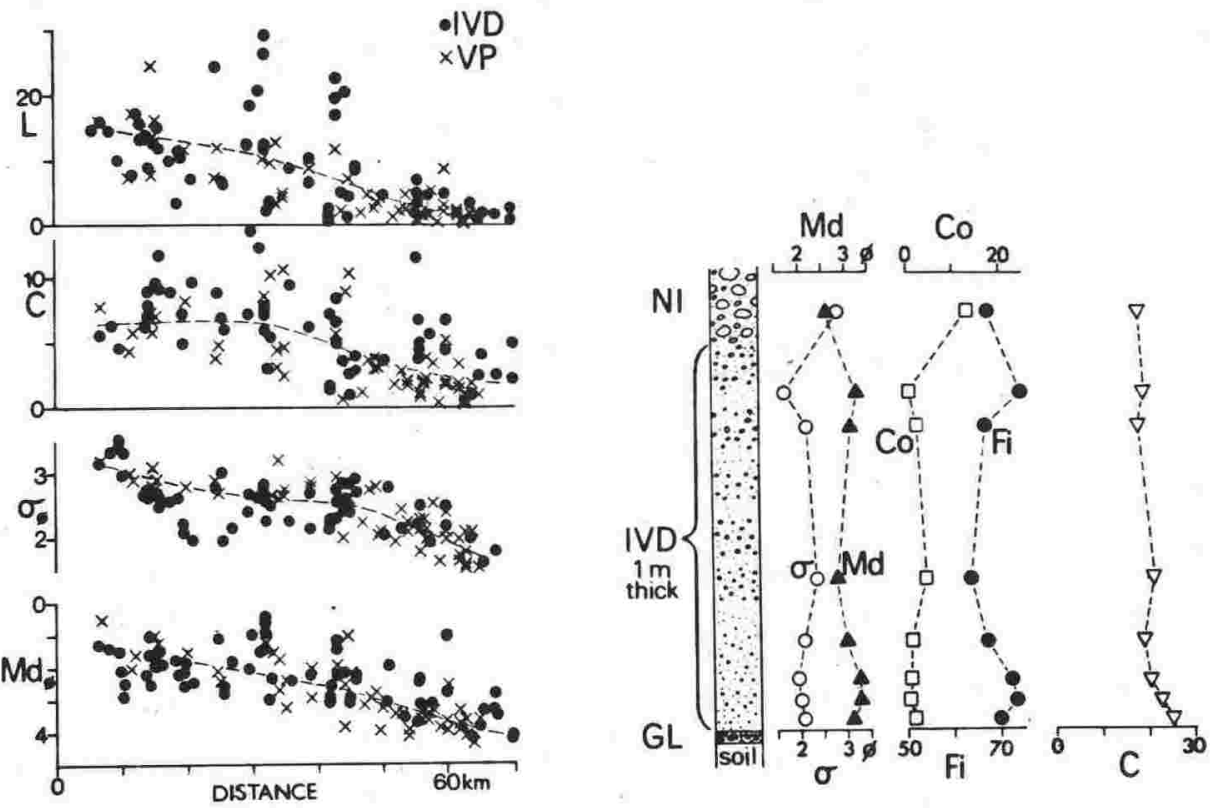

Fig. 7. Plots of sieve parameters (the median diameter, $\mathrm{Md}_{\phi}$ and the graphic standard deviation, $\left.\sigma_{\phi}\right)$, and contents of crystals $(C)$ and lithics $(L)$ in weight percent, for Taupo ignimbrite of ponded $(x)$ and veneer deposit type $(\bullet)$, against distance from vent. All the data have been recalculated to $100 \%$ after removal of the $8-\mathrm{mm}$ and coarser material, so eliminating the higher content of coarse pumice which is the main distinguishing character of the ponded ignimbrite. Note the close similarity of the recalculated data.

Fig.8. Profile through an exposure (Fig. 3c) of ignimbrite veneer deposit showing the internal variation and the similarity with normal ignimbrite which overlies it at this locality. $\mathrm{Md}_{\phi}$ and $\sigma_{\phi}$ are the median diameter and graphic standard deviation respectively, Co and $F i$ are as in Fig. 5, and $C$ is the content of crystals in the 1/4- to 4-mm fraction, expressed as a weight percentage of that fraction. Note that $\mathrm{Md}_{\phi}$ and $\sigma_{\phi}$ vary antipathetically, being both dependent on the content of coarse pumice; likewise $\mathrm{Co}$ and $\mathrm{Fi}$ 
taken from the IVD at one site those nearer to the base tend to be more crystal-rich. In short, the difference between IVD and ponded ignimbrite is small and is comparable with that between layers $2 a$ and $2 b$ respectively in a single ignimbrite flow unit.

\section{ORIGIN}

The IVD found at any given point, together with the underlying ground layer, are interpreted as the deposits laid down by a pyroclastic flow the bulk of which passed over that point and came to rest farther from source. The problem is to explain why some material was deposited while the bulk of the flow carried on.

The problem of origin seems to be best resolved by recognising different flow regimes in the active pyroclastic flow. One regime is that of the flow head where, because of the ingestion of air and vegetation, the flow is more strongly fluidised (Wilson, 1980). Another regime is that in the body of the flow following the head, where fluidisation is less strongly developed, but because the thickness of the flow is appreciable the momentum is high. A third regime is that in the flow tail where, because the thickness is much reduced, fluidisation is less effective and the momentum is low. The tail is the most likely place for deposition of the IVD.

It is well established that in many mudflows, the passage of the head is followed in the same mudflow by a succession of waves or pulses, all parts of the same flow (see, for example, Johnson, 1965); the behind-head part of the flow fluctuates in flow thickness. If a pyroclastic flow likewise fluctuates in thickness the IVD may be deposited layer by layer, one layer after the passage of each wave. Irrespective of whether the pyroclastic flow travels laminarly or turbulently or by plug flow, behind the head the basal layer will have a lower velocity than the overlying part of the flow; it will thus lag behind, and each wave will deposit a basal layer lagging behind it. As each pulse passes by, there is a relaxation of shear stress in the basal layer and this favours deposition of the layer. The deposit is built up thus, layer upon layer. As the next pulse passes, renewed shearing may cause the formation of a discontinuity at the base of the next-deposited layer. In the valley pond environment the thickness variation between pulses is so reduced that a layering is generally not produced.

Over part of the area encompassed by the Taupo ignimbrite, a distinctive fines-depleted ignimbrite variant takes the place of normal ignimbrite (Walker et al., 1980d). This variant, though quite extensive, exhibits to only a limited degree evidence of having flowed into topographic depressions; this is attributed to a rapid reduction in mobility caused when the loss of "fines" takes place. In the fact that it mantles the landscape it resembles an IVD, but it is otherwise quite different in character: it lacks internal stratification and "fines", and is rich in very coarse pumice and lithics. Where it occurs, a mantling fines-depleted ignimbrite layer is an alternative marker of the passage of the pyroclastic flow. 


\section{DISTINCTION FROM OTHER PYROCLASTIC TYPES}

For long, two broad primary pyroclastic types were recognised by volcanologists, namely the fall deposit and the pyroclastic flow, and a clear-cut set of diagnostic criteria were available to distinguish between them. Then, following the recognition of the base surge (Moore, 1969) a third type, namely the pyroclastic surge deposit, was added. The pyroclastic surge is a kind of flow, but it is very dilute, having a low volumetric particle/gas ratio. Following its recognition as a new type, the criteria had to be re-examined since the surge deposit shares some features of fall deposits and pyroclastic flows; this re-examination has not yet been completed.

The IVD now described is properly a pyroclastic flow facies, but in its field characteristics it is a distinct pyroclastic type, and the delay in its recognition may be attributed to the fact that it combines features of all three main types. Thus like a fall deposit it mantles the topography; like a flow it is poorly sorted; and like a surge deposit it shows internal crossstratification.

In these circumstances, it is necessary to set down very clearly the diagnostic features which enable an IVD to be identified. Undoubtedly the most reliable of these is the overall geometry of the deposit, and the way in which it passes laterally into normal ponded ignimbrite. There may well be very few cases where an IVD can be unambiguously identified as such from what is seen within the confines of a single limited-extent outcrop.

The distinction from a fall deposit is particularly difficult, and the Taupo IVD has in fact been interpreted as a kind of shower deposit (Vucetich and Wells, 1978). Both show a decrease in grain-size, and in the thickness and number of beds, as the distance from vent increases. A fall deposit can be equally poorly sorted if the eruption takes place in windless conditions, or if rain flushes out finer ash together with coarser material, or if the eruptive column is a rapidly pulsating one in which fine material coming from the column when it is low accumulates together with coarse material coming from the column when it is high.

Six features distinguish the Taupo IVD from a fall deposit. First, its beds are laterally discontinuous and from one exposure to another vary in number and thickness. Second, it shows local cross-stratification, and contains the highly distinctive lee-side pumice lenses. Third, it shows a roughly twofold enrichment in free crystals relative to the magma (as represented by large pumice clasts taken from the same deposit), whereas a poorly sorted fall deposit of comparable thickness should show no appreciable enrichment. Fourth, it contains carbonised wood fragments from trees not in the position of growth. Fifth, some of the lithics in it are locally-derived, picked up from the underlying floor. Six th, it lacks vesicles such as often occur in rain-flushed ashes.

The distinction of the Taupo IVD from the deposit of a low-temperature $\left(<100^{\circ} \mathrm{C}\right)$, wet or damp, pyroclastic surge (i.e. base surge) is based on dif- 
ferences in bed forms. The angle between cross-stratified beds in the former is much smaller than the angle of rest of the material, and is generally less than $10^{\circ}$, whereas in surge deposits it is often at the angle of rest (i.e. about $30^{\circ}$ ). Structures of the "antidune" type are lacking. The lee-side pumice lenses in IVD are found downflow from an obstacle, whereas the "antidunes" so commonly found in base surge deposits have grown by accretion on the upflow side. The differences in grain-size and sorting between successive beds in the IVD, lee-side lenses apart, are neglible compared with those commonly found in a surge deposit (Fig.8). Other differences are that the IVD lacks vesicles, and that plant remains in it are carbonised.

The distinction between the Taupo IVD and the deposit of a dry, hot pyroclastic surge (i.e. the dilute component of a nuée ardente) is quite clear, and is based on two important differences. First, the IVD deposit is rich in fines whereas the surge deposit is generally strongly depleted in them (although a fine air-fall ash which commonly rests on the surge deposit proper. may contain the fines, which settled out after the turbulent surge decayed or passed on). Second, the IVD is rich in pumiceous material, whereas the surge deposit has a high concentration of heavy constituents (crystals and lithics), and is correspondingly strongly depleted in pumiceous material. It is the ground layer commonly underlying the IVD that resembles the pyroclastic surge deposit, not the IVD itself.

\section{CONCLUSIONS}

The ignimbrite veneer deposit described in this paper is a facies of, and passes laterally into, normal Taupo ignimbrite of the valley pond type; it is the deposit from a pyroclastic flow, whereas the pond ignimbrite is better thought of as the trailing part of the body of the pyroclastic flow itself which has come to rest.

The significance and value of an IVD is that it enables the passage taken by a pyroclastic flow to be determined. In the Taupo example, the remarkably wide distribution of the IVD over $15,000 \mathrm{~km}^{2}$ of country, much of it mountainous, marks the passage of a pyroclastic flow having a most remarkably high mobility and capable of surmounting practically all the topographic obstacles in its path, even some standing more than $1000 \mathrm{~m}$ above the present level of the vent.

How common are ignimbrite veneer deposits? The thin Koya flow in Japan (Ui, 1973) shows many of the characteristics of an IVD, and what may be a welded example has been described from Fantale, Ethiopia (Gibson, 1970), as a layer $1-2 \mathrm{~m}$ thick on the slopes of the volcano and also mantling several upstanding lava domes there. The extensive and densely welded Skessa tuff of Tertiary age in Iceland (Walker, 1962) has the characters more of an IVD deposit than of ponded ignimbrite. We have observed examples of IVD similar to that of Taupo amongst the products of the Okataina volcanic centre in New Zealand, and the first two of us have seen IVD at the northeastern foot 
of Teide in Tenerife. Good examples occur associated with the 1500-year-old and older ignimbrites of Rabaul caldera, New Britain (G.P.L. Walker and R.F. Heming, in press). What is described as a "high sand mark" around the margin of the Valley of Ten Thousand Smokes ignimbrite in Alaska (Fenner, 1925), reaching $60 \mathrm{~m}$ or more above the ignimbrite towards which it slopes at $10-15^{\circ}$, may well be an IVD also.

One reason why the IVD has not hitherto been clearly recognised as a distinct type may be its poor preservation potential; being a relatively thin and normally non-welded deposit, it has a limited capacity to survive prolonged exposure to erosion. Another reason may be that it is especially well developed only associated with ignimbrites having a low aspect ratio (this being the ratio of average thickness to lateral spread: Walker et al., 1980a). Such ignimbrites have a wide lateral extent in relation to their thickness and do little to modify the existing topgraphy. Where a large and high-aspect ratio ignimbrite has created a new aggradational landscape in the form of a lowangle ignimbrite shield, any IVD that may locally drape upstanding topographic features will be a negligible part of the whole body, and may easily escape notice.

On a steep volcanic island such as Tenerife, there may well be instances where an IVD records the passage of a pyroclastic flow but there is no place in the path where the gradient is sufficiently low to allow the flow itself to come to rest. In such instances the IVD may be the only record of past activity of this type that is so hazardous to man.

\section{ACKNOWLEDGEMENTS}

G.P.L.W. was supported by the Royal Society of New Zealand as the fourth Captain James Cook Research Fellow, while on leave from Imperial College, London. C.N.J.W. was supported by a Natural Environment Research Council research studentship whilst on leave from Imperial College, London. Fieldwork by P.C.F. was supported by the Internal Research Committee of Victoria University of Wellington.

\section{REFERENCES}

Baumgart, I.L. and Healy, J., 1956. Recent voleanicity at Taupo, New Zealand. Proc. 8th Pacif. Sci. Congr., 2: 113-125.

Fisher, R.V., Smith, A.L., Wright, J.V. and Roobol, M.J., 1980. Ignimbrite veneer deposits or pyroclastic surge deposits? Nature (in press).

Fenner, C.N., 1925. Earth movements accompanying the Katmai eruption, II. J. Geol., 33 : $193-223$.

Gibson, I.L., 1970. A pantelleritic welded ash-flow tuff from the Ethiopian Rift Valley. Contrib. Mineral. Petrol., 28: 89-111.

Healy, J., Vucetich, C.G. and Pyllar, W.A., 1964. Stratigraphy and chronology of late Quaternary volcanic ash in Taupo, Rotorua, and Gisborne districts. N.Z. Geol. Surv. Bull., N.S., $73: 88$ pp. 
Inman, D.L., 1952. Measures if describing the size distribution of sediments. J. Sediment. Petrol., 22: 125-145.

Johnson, A.M., 1965. Physical Processes in Geology. Freeman, Cooper \& Co., San Francisco, Calif., 577 pp.

Moore, J.G., 1969. Base surge in recent volcanic eruptions. Bull. Volcanol., 30: 337-363.

Sparks, R.S.J., Self, S. and Walker, G.P.L., 1973. Products of ignimbrite eruptions. Geology, $1: 115-118$.

Ui, T., 1973. Exceptionally far-reaching, thin pyroclastic flow in southern Kyusyu, Japan. Bull. Volcanol. Soc. Jpn., 18: 153-168.

Vucetich, C.G. and Wells, N., 1978. Soils, agriculture and forestry of Waiotapu region, central North Island, New Zealand. N.Z. Soil Bur. Bull., 31 : 100 pp.

Walker, G.P.L., 1962. Tertiary welded tuffs in eastern Iceland. Q. J. Geol. Soc. London, 118: 275-293.

Walker, G.P.L., Heming, R.F. and Wilson, C.J.N., 1980a. Low-aspect ratio ignimbrites. Nature, 283: 286-287.

Walker, G.P.L., Heming, R.F. and Wilson, C.J.N., 1980b. Ignimbrite veneer deposits or pyroclastic surge deposits? - Reply. Nature (in press).

Walker, G.P.L., Heming, R.F., Sprod, T.J. and Walker, H.R., 1980c. Latest major eruptions of Rabaul volcano, Papua New Guinea. Geol. Surv. Mem., (in press).

Walker, G.P.L., Wilson, C.J.N. and Froggatt, P.C., 1980d. Fines-depleted ignimbrite in New Zealand: the product of a turbulent pyroclastic flow. Geology (in press).

Walker, G.P.L., Self, S. and Froggatt, P.C., 1981. The ground layer of the Taupo ignimbrite: a striking example of sedimentation from a pyroclastic flow. J. Volcanol. Geotherm. Res., 10 (in press).

Wilson, C.J.N., 1980. The role of fluidization in the emplacement of pyroclastic flows: an experimental approach. J. Volcanol. Geotherm. Res., 8: 231-249. 


\title{
Fines-depleted ignimbrite in New Zealand- The product of a turbulent pyroclastic flow
}

\author{
G.P.L. Walker, * C.J.N. Wilson* \\ Imperial College, London SW7. England \\ P. C. Froggatt
}

Geology Department, Victoria University of Wellington, Weilington, New Zealand

\section{ABSTRACT}

A new type of ignimbrite, a "fines-depleted ignimbrite," is largely depleted in the finer constituents and is clast-supported for all clasts exceeding about $2 \mathrm{~mm}$ in size. Its formation is attributed to the loss of fine (mostly submillimetre-sized) vitric material from the pyroclastic flow, by an amount equal to about half of the original mass of the flow. This loss, the large size and high content of lithic clasts, and the thorough intermixing of carbonized vegetation are believed to indicate that the pyroclastic flow, at least in part, traveled turbulently. Turbulent flow was partly a consequence of a high flow velocity, for which there is independent evidence (the same flow climbed $1,500 \mathrm{~m}$ up a mountain $46 \mathrm{~km}$ from source), and was partly caused by the ingestion of forest and the resulting high throughput of gas in the flow head. The implication is that normal ignimbrite is generated by laminar flow, whereas turbulent flows generate the significantly different, fines-depleted variant.

\section{INTRODUCTION}

The nonwelded Taupo ignimbrite, which has a ${ }^{14} \mathrm{C}$ age of $-1,800$ B.P. (Healy and others, 1964), is distributed over a nearly circular area $160 \mathrm{~km}$ across, near Lake Taupo (Walker and others, 1980). It shows great lithologic variations, and one of its most striking and well-defined variants is so lacking in fine material that all clasts coarser than about $2 \mathrm{~mm}$ are clastsupported [in normal ignimbrite (NI), clasts are always matrix-supported; see Fig. 1]. "Fines-depleted ignimbrite" (FDI) is proposed as a descriptive term for this variant, and evidence is presented that FDI is derived from NI material by the loss of fines during active pyroclastic flow.

*Present address: Geology Department, University of Auckland, Auckland, New Zealand.
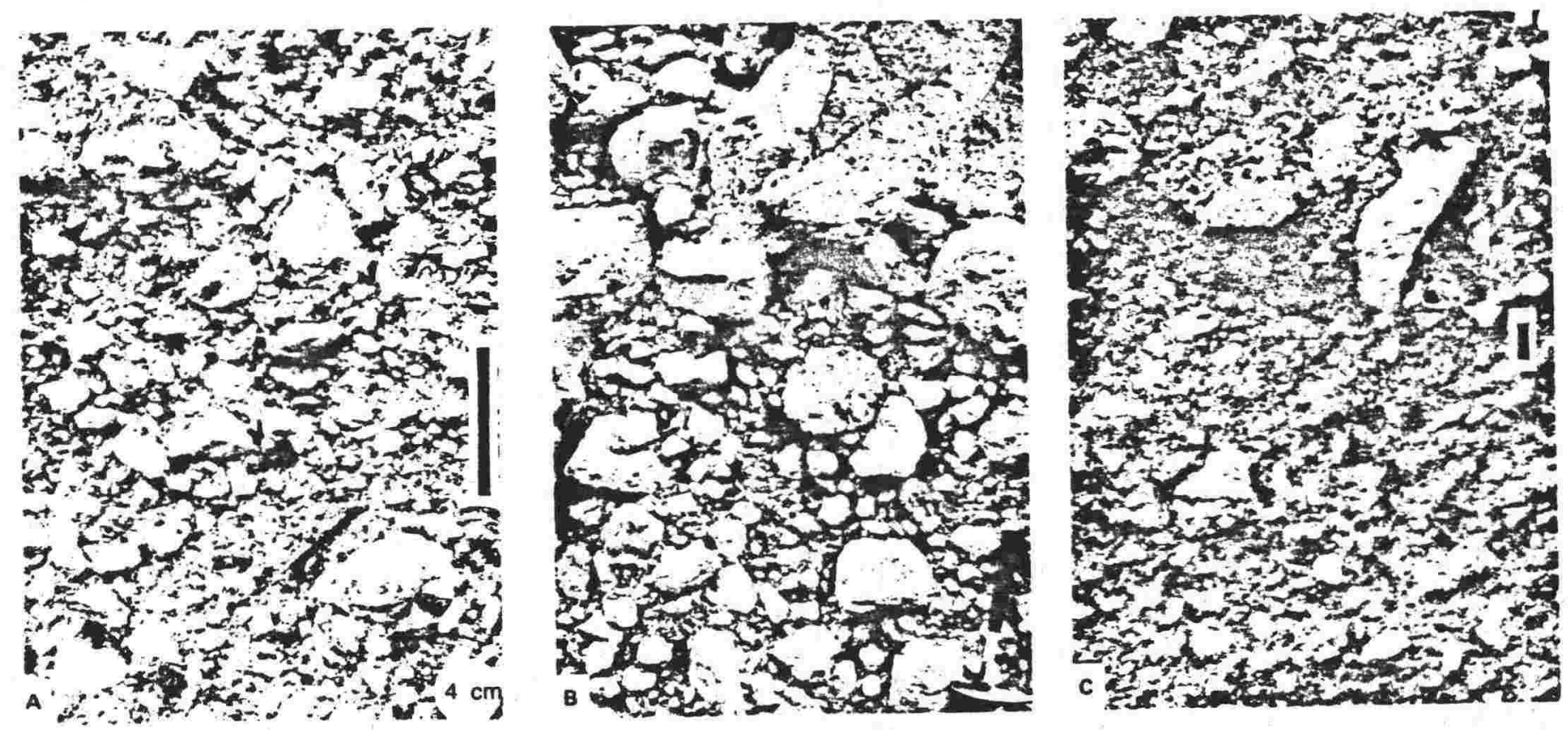

Figure 1. Lithology of the ignimbrite variants. The bar represents $10 \mathrm{~cm}$. (A) Typical FDI (no. 558: see Fig. 3 for location, and Fig. 4 for grainsize histogram). (B) Coarse-pumice-enhanced FDI (no. 623). (C) NI (no. 122). 


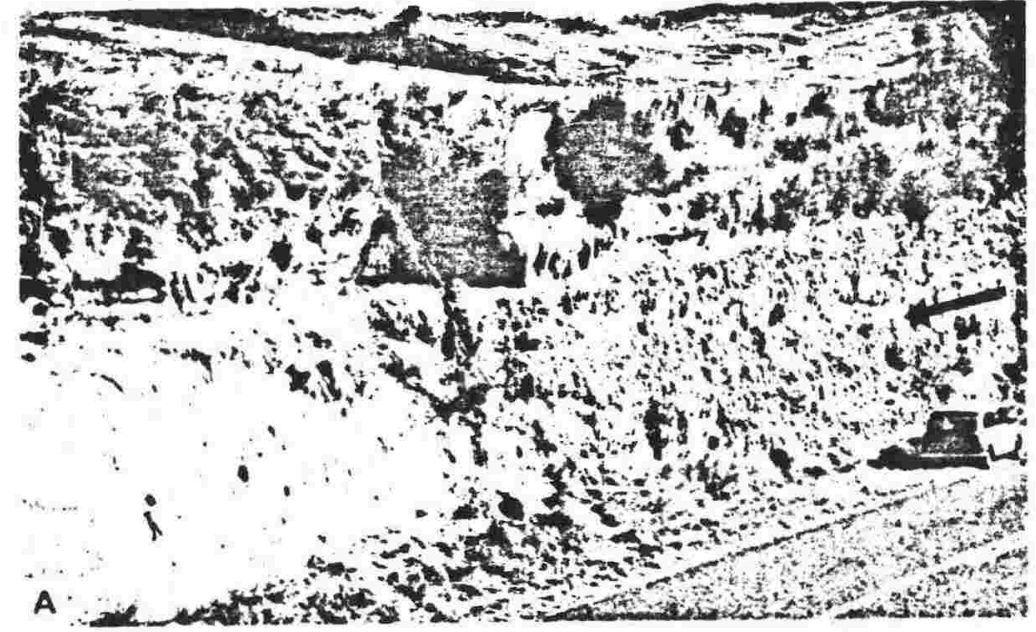

Figure 2. Field relationships of the FDI. (A) FDI (no. 3y; rough-textured material near vehicle; arrow indicates flow-unit boundary) shows ponding to a depth of $8 \mathrm{~m}$ in a topographic depression (older rocks form white unit on left; directly overlying, light-colored layered unit is NI). (B) Two flow units of FDI; the upper unit (no. 558) is $1.6 \mathrm{~m}$ thick.

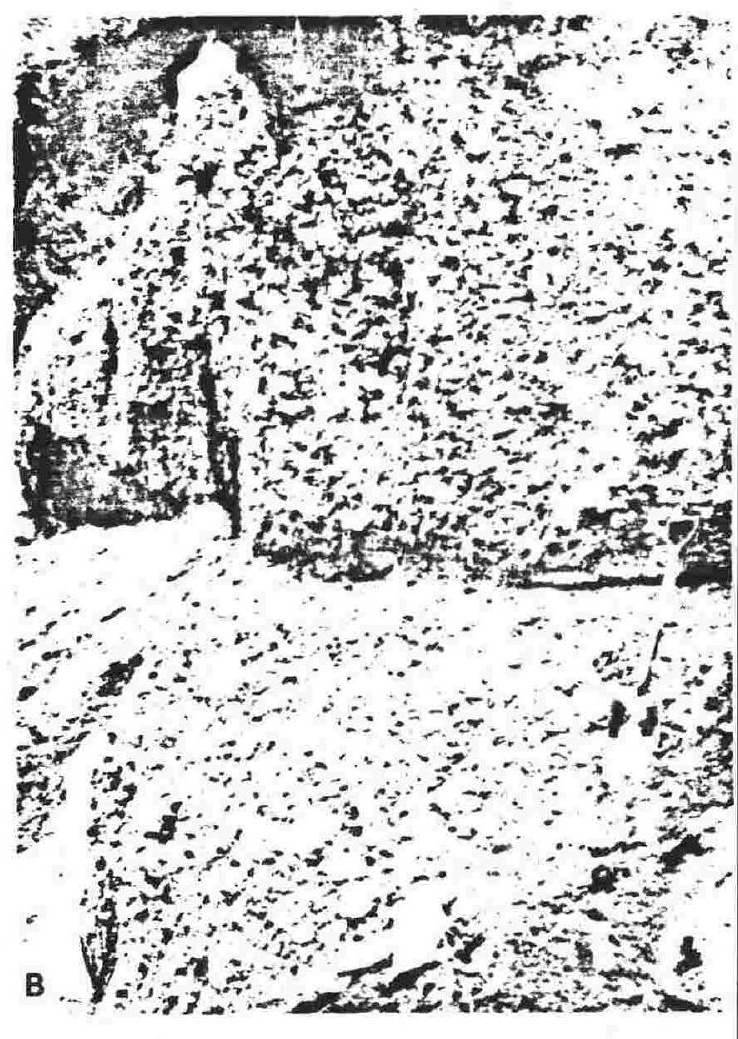

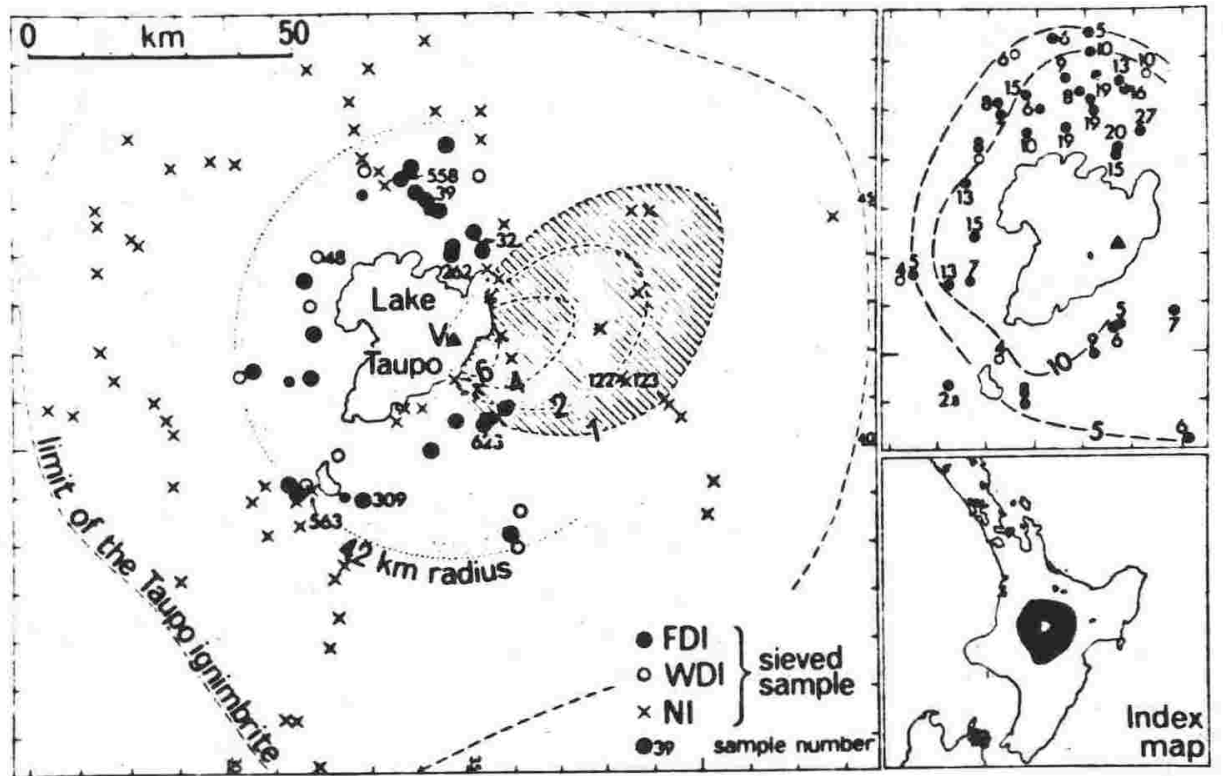

Figure 3. (Left) Distribution of FDI (stippled area) within the Taupo ignimbrite showing location of sieved samples. Numbers identify samples plotted in Figure 4, and exposures of Figures 1 and 2. $\mathrm{V}=$ vent. Ruled area is where the fall deposits immediately predating the ignimbrite exceed $1 \mathrm{~m}$ thick: isopachs give the thickness in metres. The lines and numbers on the margins relate to the 10,000-yd $(9,144-\mathrm{m})$ grid of the New Zealand Survey. (Top right) Map on same scale showing average maximum diameter (in centimetres) of the three largest lithic fragments in a sample. (Bottom right) The North Island, New Zealand, showing the location of the Taupo ignimbrite.

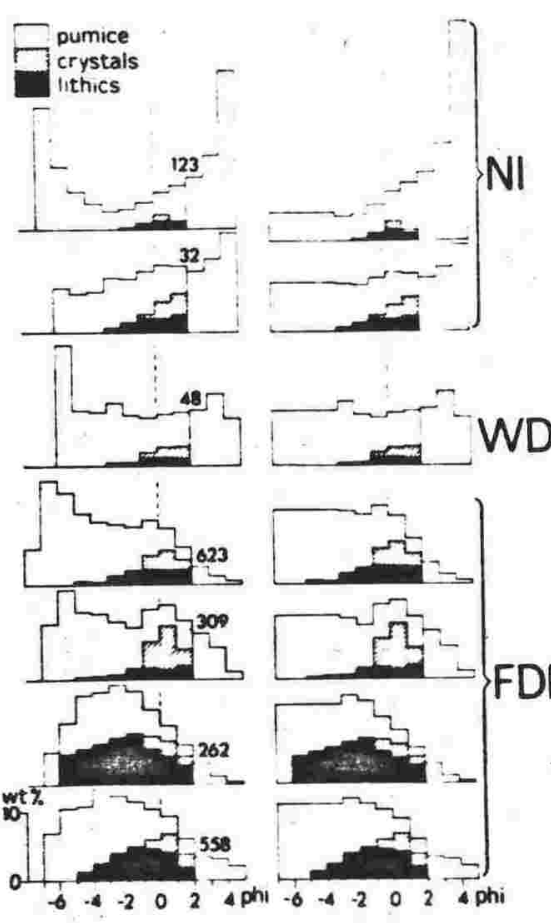

Figure 4. Grain-size histograms of typical examples of the three types of ignimbrite within $42 \mathrm{~km}$ of vent. Grain-size classes down to $0.25 \mathrm{~mm}$ are subdivided on their weight proportions of pumice, free crystais. and lithic fragments. Left, raw data ; right, normalized data. 
We apply "Taupo ignimbrite" as a volcanological term for the pumice-flow components in the stratigraphic unit known formally as the Upper Taupo Pumice Member of the Taupo Pumice Formation (Baumgart and Healy, 1956). We believe that the source vent was in or near the Horomatangi Reef in the eastern part of Lake Taupo and that the lake was either much smaller or absent at the time of the eruption.

A significant thickness of the Taupo FDI is found only between about 15 and $42 \mathrm{~km}$ of the vent and is distributed more or less uniformly around $250^{\circ}$ of arc north, west, and south of the lake. Within these bounds, the Taupo FDI is associated with NI and constitutes less than half of the total bulk; where both occur in the same exposure, a flow unit or group of units of FDI always underlies a flow unit of NI (Fig. 2).

\section{GRAIN-SIZE CHARACTERISTICS}

To gain an insight into the origin of the Taupo FDI, a grain-size study has been made of 30 samples, as much as $11 \mathrm{~kg}$ each, collected where shown in Figure 3. Each sample has been sieved into one-phi classes (that is, the aperture width in each sieve is half that in the sieve above) and the weight percentages of pumice plus shards, free crystals, and lithic fragments determined for all size classes down to $2 \phi$ $(0.25 \mathrm{~mm})$. For convenience, the size class is denoted by the aperture size of the sieve that retains it; thus, the $1-\mathrm{mm}$ class contains grains between 1 and $2 \mathrm{~mm}$ in size.

In Taupo NI, the larger pumice clasts tend to be concentrated toward the top of the flow unit to produce a locally spectacular upper pumice concentration zone, in which the clasts exceeding $32 \mathrm{~mm}$ may be clast-supported. Locally, the zone has become detached from the underlying ignimbrite. We accept the mechanism of Sparks and others (1973) and Sparks (1976) that the coarse pumice in the zone rose, because of its positive buoyancy, toward the top of the pyroclastic flow.

The great variability in coarse-pumice content makes difficult a comparison of size analyses of FDI with NI. The size analyses have therefore been normalized by adjusting the pumice content in each of the coarsest size classes (the 64-, 32-, 16-, and $8-\mathrm{mm}$ ones) so as to equalize them with the average total content in the 4-, $2-$, and $1-\mathrm{mm}$ classes. These normalized analyses were then recalculated to $100 \%$.
Size histograms for four typical samples of the Taupo FDI are given in Figure 4; when normalized, they are nearly identical. The amount of material in each class decreases steadily and consistently from $1 \mathrm{~mm}$ downward (the reverse is typical in NI), and this decrease is here adopted as the definitive criterion for FDI. At some localities, a variant (exemplified by sample 48, Fig. 2) occurs that resembles the FDI but shows a decreased content only in the finest class or classes. It is transitional between the FDI and NI and is referred to as "weakly depleted ignimbrite" (WDI).

The remarkably low fines content in sieved samples of the Taupo FDI is shown by Figure 5; material finer than 0.0625 $\mathrm{mm}$ constitutes less than $5 \%$ of the total weight. In NI, the fines content exceeds $10 \%$. On the $\sigma_{\phi}$ versus $\mathrm{Md}_{\phi}$ plot, where $\sigma_{\phi}=\left(\phi_{M 4}-\phi_{16}\right) / 2=$ graphic standard deviation and $M M=\phi_{30}=$ median diameter, the FDI samples occupy a field that overlaps the NI field, but they are, on the whole, coarser and better sorted, although less wel! sorted than the plinian deposit.

\section{FIELD CHARACTERISTICS}

The Taupo FDI is conspicuous in the field on account of its coarseness, the predominance of pumice, the distinct rounding of the pumice, and the abundance of contained carbonized logs and tree fragments. The pumice is commonly of a brown hue instead of the normal pale gray, evidently because of staining by products of the destructive distillation of vegetation.

The maximum thickness of the FDI is $\sim 8 \mathrm{~m}$, and it is often divisible into as many as seven flow units, each underlain by a ground layer rich in lithic fragments and crystals (G.P.L. Walker, S. Self, and P. C. Froggatt, in prep.). Superimposed flow units may differ somewhat from one another in grain size and lithic content, and some have a less-coarse basal layer about $10 \mathrm{~cm}$ thick of the WDI type.

The FDI mantles the land surface and locally rests on slopes as steep as $30^{\circ}$; it also thickens into topographic depressions (Fig. 2), although less than does NI. The thickness variations are so local and topography-dependent that drawing a meaningful isopach map would be difficult. From our thickness measurements, we estimate that the total volume of the FDI is of the order of $3 \mathrm{~km}^{3}$.
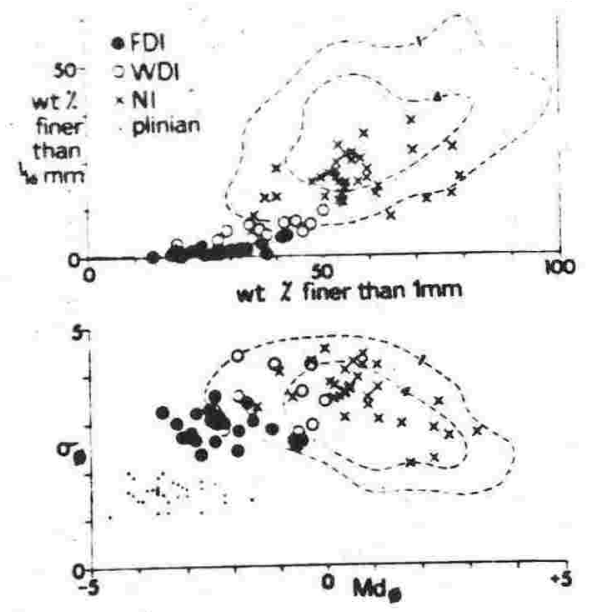

Figure 5. Grain-size characteristics of the ignimbrites and the pre-ignimbrite Taupo plinian pumice-fall deposit; all sampies from within $42-\mathrm{km}$ radius of the vent. The dashed lines are the 17 and $4 \%$ contours for the field of pyroclastic flows (above, from unpublished plot by G.P.L. Walker: below, updated from Walker, 1971). All strongly bimodal samples are omitted.

\section{ORIGIN}

The FDI superficially resembles a coarse pumice-fall deposit, and the reasons for deducing a flow origin instead are as follows: (1) The FDI is not areally continuous but tends to be concentrated in local pockets. (2) The FDI is strictly synchronous with NI. (3) It thickens toward and has evidently flowed into topographic depressions. (4) The thickness of the FDI does not vary systematically with distance from the source but is clearly controlled by the underlying topography. (5) The grain size does not vary systematically with distance from the source. (6) The carbonized tree fragments in the FDI are no longer in the position of growth and commonly show a subparallel alignment radial to the deduced vent (Froggatt and others, in prep.). (7) Units of the FDI lack internal stratification, tend to be homogerieous through their thickness, and vary greatly in number and individual thickness from place to place.

The mechanism that best explains the data is derivation of the FDI from a normal, moving pyroclastic flow by excessive loss of fines. The FDI then came to rest and was overridden by the remainder of the flow. Comparison of the histograms of Figure 4 shows that FDItype material could be generated from the 
VI material of sample 32 by a loss of submillimetre material totaling $50 \mathrm{wt} \%$ of the normalized sample or from sample 123 by a loss of 60 wt $\%$ of such material.

An independent check on the amount of fines lost is given by the content of free crystals (Fig. 6). When normalized, the crystal content of the FDI averages twice that of the NI and is consistent with the loss of $50 \%$ of vitric material. The crystal contents of individual grain-size classes (Fig. 7) show a like relationship; the crystal concentration is higher in the $0.5-\mathrm{mm}$ class from which the loss of vitric material was evidently greater.

A considerable loss of vitric fines occurs when pyroclastic flows are formed (Hay, 1959), and the consequent roughly twofold concentration of crystals is a normal feature of ignimbrite (Walker, 1972). In NI, however, enough fines are retained to permit effective fluidization by modest gas-flow rates, whereas in FDI, the loss is excessive and insufficient fines are retained to sustain fluidization.

Locally, the FDI has some of the characteristics of the pumice-concentration zone of NI. This is illustrated by samples 309 and 623 (Fig. 4), which have a high content of very coarse pumice, a bimodal pumice population, and a low content of lithic fragments (attributed to their settling out) like sample 123, which is coarsepumice-enhanced NI. In these samples, some segregation had evidently already taken place in the pyroclastic flow before the loss of fines occurred; the coarsepumice-enhanced mass became detached from, and flowed in advance of, the remainder of the pyroclastic flow before it became depleted in fines.

The fact that the FDI mantles the land surface, stands on slopes up to about $30^{\circ}$, and has an upper surface that can slope at the same angle is interpreted to mean that when the fines were lost, the pyroclastic flow rapidly ceased to be effectively fluidized. It was able to travel a short distance farther by grain flow (Lowe, 1976), but it drained only very incompletely into topographic depressions. The subdivision of the FDI into flow units is attributed to shearing when a part of the fines-depleted flow "froze" and was overridden by the still-moving part of the flow.

\section{THE CASE FOR TURBULENT FLOW}

The earlier ignimbrite literature generally maintained that pyroclastic flows travel turbulently, because their flow units are ill-sorted and relatively homogeneous
Figure 6. Weight proportions of pumice $(P)$, free crystals $(C)$, and lithic fragments $(L)$ for the $0.25-\mathrm{mm}$ and coarser classes. Symbols as in Figure 5. Left, raw data : right, data normalized as explained in text. The data for the plinian pumice fall are not normalized.

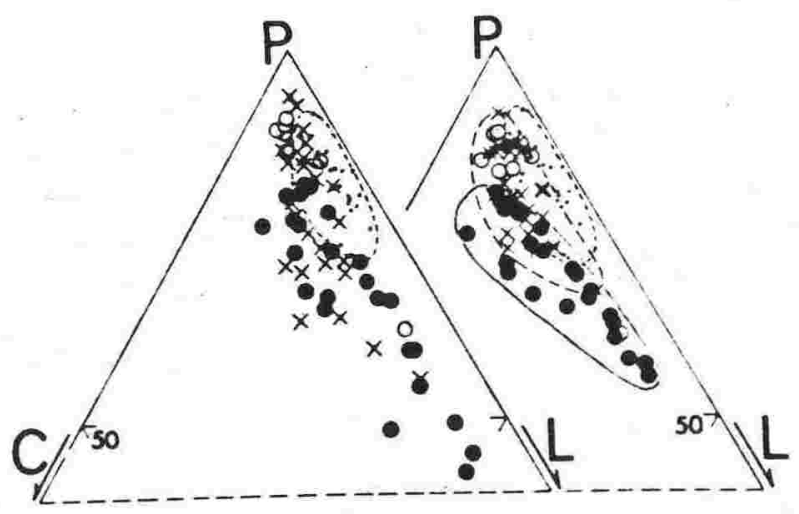

Figure 7. Contents of pumice (P) and free crystals $(C)$ in two size classes as a percentage of the whole sample. Symbols as in Figure 5. Above, the $0.5-\mathrm{mm}$ class: below, the $1-\mathrm{mm}$ class: left, raw data: right, data normalized as explained in text.

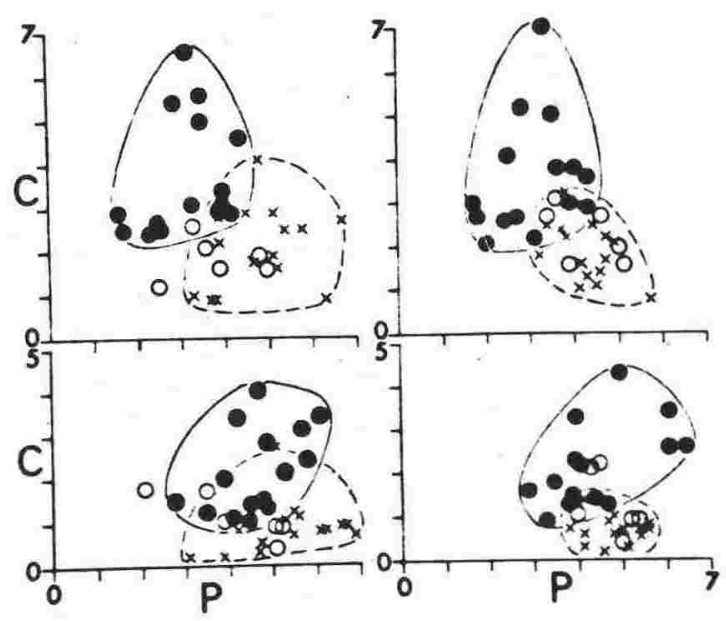

(that is, well-mixed) in character. The consensus has been summarized, for example, by Macdonald (1972). More recently, opinion has tended to swing in favor of laminar flow. The relevant arguments against turbulence, which we accept, are reviewed by Sparks (1976). Aḍditional evidence comes from the strong compositional zoning within a flow unit of one particular ignimbrite in Mexico (Wright and Walker, 1977).

We regard the Taupo FDI as the product of a turbulent pyroclastic flow for the following reasons: (1) Loss of fines is strongly favored by a high gas throughput that produces turbulent flow, and the retention of fines is favored by laminar or plug flow. (2) Large lithic fragments extend farther from the vent in the FDI than in the NI, and the content of lithic fragments at a given distance is also greater (after allowing for the concentrating effect of fines loss); remixing by turbulence can delay the settling of lithic fragments. (3) Strong erosion of the underlying surface has occurred, and many of the lithic fragments found in the FDI are derived from the ground; erosion and the "hoisting" of large lithic fragments to a high level in the flow are favored by turbulence. (4) Carbonized plant remains are very abundant at all levels in the FDI; the fact that groups of subparallel logs trend radially away from the source implies that even though the flow was turbulent, the final stages of its emplacement were dominated by laminar shear.

By "turbulence," we embrace both turbulence of the type analogous to that in liquids having a high Reynolds number and the agitation induced by a high throughput of gas within the flow head thickness, density, and viscosity and estimating the velocity from the height of obstacles climbed over by the flow, we arrive at a Reynolds number that greatly exceeds 2,000 (the absolute upper limit for laminar flow in water). However, the relevance of this number to a particulate flow that is probably of non-Newtonian rheology is uncertain. The agitation induced by violent fluidization seems to be the more significant cause of turbulence in this instance. (Wilson, in prep.). With reference to the former, taking plausible values of flow 


\section{WHY WAS THE FLOW TURBULENT?}

Why did part of the Taupo pumice flow travel turbulently? A high flow velocity was a major factor and was, in turn, a direct consequence of collapse from an exceptionally high plinian eruption column (Walker, 1980). An independent indication of the high velocity is that, on Tongariro Mountain, $46 \mathrm{~km}$ southwest of the vent, Taupo NI occurs $1,500 \mathrm{~m}$ above the present level of Lake Taupo. This represents a world record for height climbed by a pyroclastic flow. The absence of Taupo FDI farther than about $42 \mathrm{~km}$ (Fig. 8) from the source suggests that the pyroclastic flow had slowed down too much to generate FDI.

The facts that the FDI occurs only as a basal flow unit or units and that it contains an abundance of carbonized plant remains thoroughly mixed with it point to an additional factor-namely, the forest cover. At the time of the eruption, the entire area was thickly forested. A thick forest can have two effects on a pyroclastic flow moving through it: (1) it can greatly increase surface roughness, and (2) it can yield gases. Both effects contribute to turbulent flow.

It is particularly significant that the FDI is more or less absent from a broad sector east of the vent; this is the sector in which the fall deposits produced by the earlier phases of the Taupo eruption are

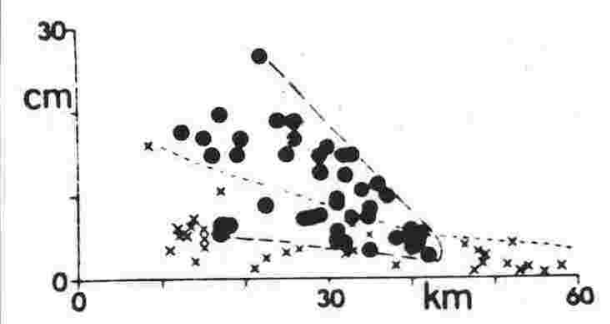

Figure 8. Plot of the average maximum diameter of the three largest lithic fragments in a sample against distance from the source. Symbols as in Figure 5. thickest (Fig. 3) and in which much of the vegetation had already been buried before the pyroclastic flow was generated. The FDI is also best developed in areas where the pre-existing topography was "bumpy" owing to dissection of an older nonwelded ignimbrite sheet by closely spaced streams.

As we envisage it, turbulence is a feature of the flow head; it is in the head that ingestion of the forest and air must take place.

\section{CONCLUSIONS}

How common are fines-depleted ignimbrites? Some anomalous pyroclastic flows having characteristics of FDI have been found by one of us (Walker) at San Vicente, at the foot of the steep northeastern slope of Tenerife in the Canary Islands. These flows presumably lost their fines as a result of rapid travel down a slope which averages $18^{\circ}$ over a vertical distance of $2,000 \mathrm{~m}$. Another example in St. Lucia, West Indies (R.S.J. Sparks, 1979, personal commun.), is a flow that evidently lost fines as a result of traveling through a forest. Another example of FDI is associated with the youngest ignimbrite around the Rabaul caldera in New Britain (G.P.L. Walker and R. F. Heming, in prep.); this FDI formed in forested country after a high-column plinian phase. FDI may well prove to be common in such situations. The extensive development at Taupo is due to the high flow velocity. In less extreme ignimbrite eruptions, FDI may be confined to the near-vent exposures (where it can easily be confused with a plinian pumice-fall deposit) or to special situations like Tonerife.

The implication is that pyroclastic flows from which normal ignimbrites form flow laminarly; turbulent flows (where turbulence results from a high throughput of gas) do not produce normal ignimbrite but produce instead the highly distinctive fines-depleted ignimbrite.

\section{REFERENCES CITED}

Baumzart. 1. L.. and Healy. J.. 1956. Recent voleanicity at Taups. New Zesland: Pacific Science Congress, 8th. University of the Philippines, Quezon City. Proceedings, v. 2. p. $113-125$

Hay, R. L., 1959. Formation of the crystal-rich glowing avalanche deposits of St. Vincent, B.W.1.: Journal of Geology, v. 67 , p. $540-562$.

Healy, J., Vucetich, C. G., and Pullar, W. A.. 1964. Stratizraphy and chronology of Late Quaternary volcanic ash in Taupo. Rotorua and Gisborne districts: New Zealand Geological Survey Bulletin, n.s. 73,88 p.

Lowe, D. R., 1976. Grain flow and grain flow deposits: Journal of Sedimentary Petrology. v. 46 , p. $188-199$.

Macdonald, G. A., 1972, Volcanoes: Englewood Cliffs, N.J.. Prentice-Hall, 510 p.

Sparks, R.S.J., 1976, Grain size variations in ignimbrites and implications for the trans. port of pyroclastic flows: Sedimentology. v. 23, p. 147-188.

Sparks, R.S.J.. Self, S., and Walker. G.P.L.. 1973. Products of ignimbrite eruptions: Geology, v. 1, p. $115-118$.

Walker, G.P.L., 1971, Grain-size characteristics of pyroclastic deposits: Journal of Geology . v. 79, p. 696-714.

- 1972. Crystal concentration in ignimbrites: Contributions to Mineralogy and Petrology. v. 36, p. $135-146$.

- 1980. The Taupo plinian pumice: Product of the most powerful known (ultraplinian) eruption?: Journal of Volcanology and Geothermal Research (in press).

Walker, G.P.L.. Heming. R. F.. and Wilson. C.J.N., 1980, Low-aspect ratio ignimbrites: Nature (in press).

Wright, J. V., and Walker, G.P.L.. 1977. The ignimbrite source problem: Significance of a co-ignimbrite lag fall Jeposit: Geology. v. 5, p. $729-732$.

\section{ACKNOWLEDGMENTS}

Reviewed by R.S.J. Sparks. Walker's research done as Captain James Couk Research Fellow of the Royal Society of New Zealand. Wilson supported by the British Natural Environment Research Council. Frogedit's field work supported by the Internal Research Committee of Victoria Liniversity of Wellington. H. R. Walker did most of the component analyses.

MANUSCRIPT RECEIVED AUG. 8, 1979 MANLSCRIPT ACCEPTED IE.B. 25, 1980 


\section{Motutere Tephra Formation and redefinition of Hinemaiaia Tephra Formation, Taupo Volcanic Centre, New Zealand.}

\author{
P. C. FROGGATT \\ Geology Department \\ Victoria University of Wellington \\ Private Bag \\ Wellington, New Zealand
}

\begin{abstract}
Motutere and Hinemaiaia Tephra Formations are moderately widespread rhyolitic tephras erupted from near the southeast margin of Lake Taupo. The 2 multiple-bedded formations constitute a prolonged eruptive sequence interrupted by a short hiatus. The eruptive sequence comprises a plinian-type eruption of coarse pumice lapilli (Motutere Tephra (new name), volume c. 1 $\mathrm{km}^{3}$ ), and further eruptions of a more widespread vitric ash (Hinemaiaia Tephra, volume c. $3 \mathrm{~km}^{3}$ ) apparently related to the growth of a rhyolite dome.

Isopach data for both tephras place the eruptive vent near the southeast margin of Lake Taupo in the vicinity of Te Rangiita. Bathymetry and geophysical data suggest the presence of a rhyolite dome $2 \mathrm{~km}$ offshore and within the vent area.

Two unpublished radiocarbon dates of $5370 \pm 90$ years B.P. (NZA846A) for Motutere Tephra and $4650 \pm 80$ years B.P. (NZ4574A) (old T $\frac{1}{2}$ ) for Hinemaiaia Tephra establish the age of these tephras.
\end{abstract}

Keywords Motutere Tephra Formation; Hinemaiaia Tephra Formation; new stratigraphic names; Taupo Volcanic Centre; Holocene; tephra; isopachs; mineralogy; C-14; stratigraphy

\section{INTRODUCTION}

Quaternary rhyolitic tephras are becoming increasingly useful as datable stratigraphic horizons. Their uses cover a wide range of contexts, including erosion studies (Gage \& Black 1979) tectonic rates (Froggatt \& Howorth 1980) rates of sedimentation (Pain \& Pullar 1968) and shoreline studies (Pullar \& Selby 1971; Gibb 1977). Consequently, detailed and accurate stratigraphy and chronology of these tephras is crucial.

\footnotetext{
Received 18 July 1980, revised 9 March 1981
}

Tephra stratigraphy is best examined near the source, usually in road cuttings, as few exposed sections occur naturally. As new roads are built, especially in forested areas where exposure is normally poor, stratigraphic problems can often be resolved. With the development of Lake Taupo State Forest, east of Lake Taupo, an extensive network of new roads has provided many sections which have allowed the mapping problems encountered by Vucetich \& Pullar (1973) to be resolved.

The purpose of this paper is to revise the Holocene tephra stratigraphy of Vucetich \& Pullar (1973) by redefining their Hinemaiaia Ash. At a new type section a new tephra, Motutere Tephra Formation, is defined lying stratigraphically immediately below Hinemaiaia Tephra. A new chronology for both tephras is established, and evidence for a source location is examined.

\section{PREVIOUS WORK}

Rhyolitic tephra beds erupted from Taupo Volcanic Centre (Healy 1964a) were first described in detail by Baumgart (1954) as Taupo Subgroup members. Subsequently, Healy (1964b) redefined and renumbered Taupo Subgroup beds from a road section opposite De Bretts Hotel, Taupo. In their major revision of the Taupo Holocene tephras, Vucetich \& Pullar (1973), defined 8 tephra formations, including Hinemaiaia Ash, and established their stratigraphy, distribution, and chronology. They defined Hinemaiaia Ash at the De Bretts type section as the "tephras lying conformably between the Whakatane and Rotorua Ash Formations" ("Rotorua Ash" should read Rotoma Ash as shown in their appendix description; C. G. Vucetich pers. comm.). They noted (p. 760) that in many sections "Hinemaiaia Ash occurs sandwiched within a multiple paleosol which has a 'blotchy' appearance". Neither Whakatane nor Rotoma Ash can be mapped as discrete tephra units south of De Bretts, both having an Okataina source (Vucetich \& Pullar 1973). Consequently, both Motutere and Hinemaiaia Tephras are here defined in relation to locally mappable Taupo source tephras. 


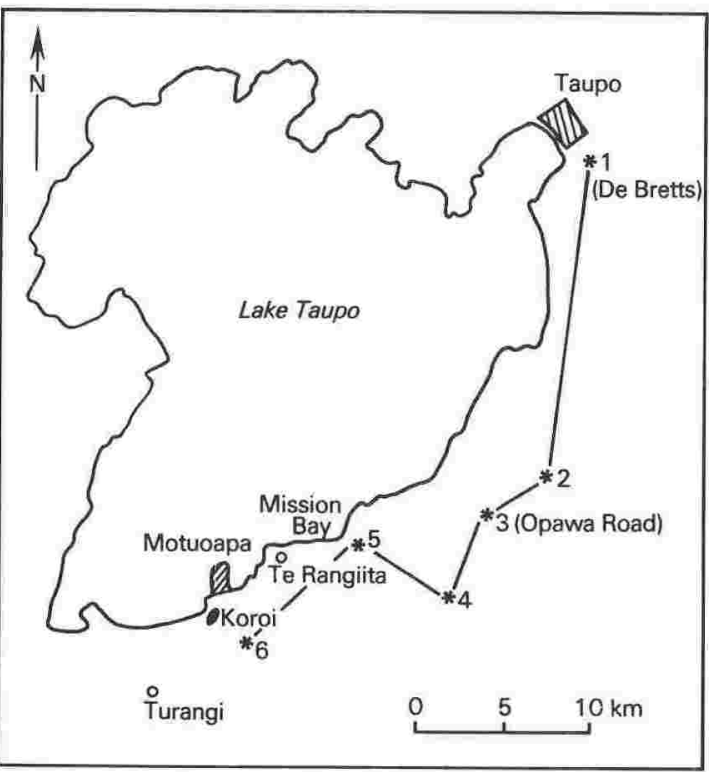

Fig. 1 Map of Lake Taupo area showing the sections and correlation lines of Fig. 2.

\section{PALEOSOLS}

A rhyolitic Tephra Formation in Late Quaternary context was defined by Vucetich \& Pullar (1973) and Howorth (1975) using the sharp contacts of paleosols at the top and base. For paleosols representing long periods of intervening quiescence or intense climatic weathering, the contacts are readily identified.

At the De Bretts section, Taupo, however, paleosols are either poorly developed, or bleached, and consequently difficult to recognise, especially in the older beds. As each paleosol is traced south its colour and degree of weathering becomes stronger indicating more intensive development for the same length of time. This is attributed to an input during each hiatus of darker and more rapidly weathered andesitic ash from Tongariro. Contamination of the soils with andesitic ash was also inferred by Birrell \& Pullar (1973) in their study on the chemistry of paleosol weathering. In the new type area here defined for Motutere and Hinemaiaia Tephras, all paleosols are particularly well developed and preserved. This greatly aids tephra mapping.

\section{MOTUTERE TEPHRA FORMATION $M t$}

DEFINTTION, TYPE AREA, AND TYPE SECTION: Motutere Tephra Formation is named after Motutere Bay on the southeast shore of Lake Taupo. This formation is here newly defined as the rhyolitic tephra lying conformably between the paleosol on
Table 1 Description of the type section for Motutere and Hinemaiaia Tephra Formations on Opawa Road, Lake Taupo State Forest (N103/518135).

\section{Waimihia Lapilli}

\section{Hinemaiaia Tephra $\mathrm{Hm}$}

$\mathrm{mm}$

120 Fine to medium ash (PALEOSOL, reddish grey 7.5R 5/1)flecks of charcoal, diffuse boundary.

55 Medium ash, dark brown (10YR 3/4) irregular 'blotchy' appearance, diffuse contact.

130 Fine to medium ash, yellowish brown (10YR 5/6) diffuse contact.

150 Fine to medium ash, dull yellow orange (10YR $7 / 3$ ) firm; irregular contact.

180 Medium to coarse ash, shower bedded with about 8 beds. Upper $60 \mathrm{~mm}$ coarse ash, mainly grey glassy essential lithics; lower $30 \mathrm{~mm}$ is light grey fine ash (2.5Y $7 / 1)$ remainder is light yellow (2.5 $7 / 4$ to $7 / 6)$. Sharp contact.

\section{Motutere Tephra $M t$}

mm

120 Fine to medium ash (PALEOSOL, dark brown 10YR 3/3) greasy with numerous charcoal flecks (sample U18/f1). Sharp contact.

110 Normally graded pumice lapilli to fine ash. Upper 20 mm of fine ash, bright yellowish brown (10YR 6/6). Lower $90 \mathrm{~mm}$ coarse ash and lapilli yellow-orange (10YR 7/8), pumice to $20 \mathrm{~mm}$. Abundant glassy lithics to $3 \mathrm{~mm}$. Sharp boundary.

130 Fine to coarse ash with scattered lapilli. Abundant charcoal fragments. (Light grey 10YR 7/1) diffuse boundary.

430 Coarse pumice ash and lapilli, lower $\frac{2}{3}$ reversely graded producing coarser pumice in middle of bed. Bright yellowish brown (10YR 7/6). Abundant lithics (30\%). Sharp boundary.

\section{Opepe Tephra}

\section{$\mathrm{mm}$}

350 Greasy fine ash, dark brown common charcoal fragments (U18/2) PALEOSOL (7.5YR 3/3) incorporating andesitic ash (Papakai Tephra).

Opepe Tephra Formation and the paleosol overlain by Hinemaiaia Tephra Formation at the type section on Opawa Road (N103/518135*) shown on Fig. 1 and 2 . The type area is defined within a $5 \mathrm{~km}$ radius of this section with the best sections lying in the south and west of this area. The type section is described in Table 1.

Motutere Tephra is interbedded with a bed of the andesitic Papakai Tephra (Topping 1973) to the east and south (Fig. 2) of the mapped area. The andesitic nature of this bed is confirmed by a mineralogy of abundant clinopyroxene phenocrysts. (Table 2)

* Grid references are based on the national 1000-yard grid of the 1:63 360 topographical map series (NZMS1). 


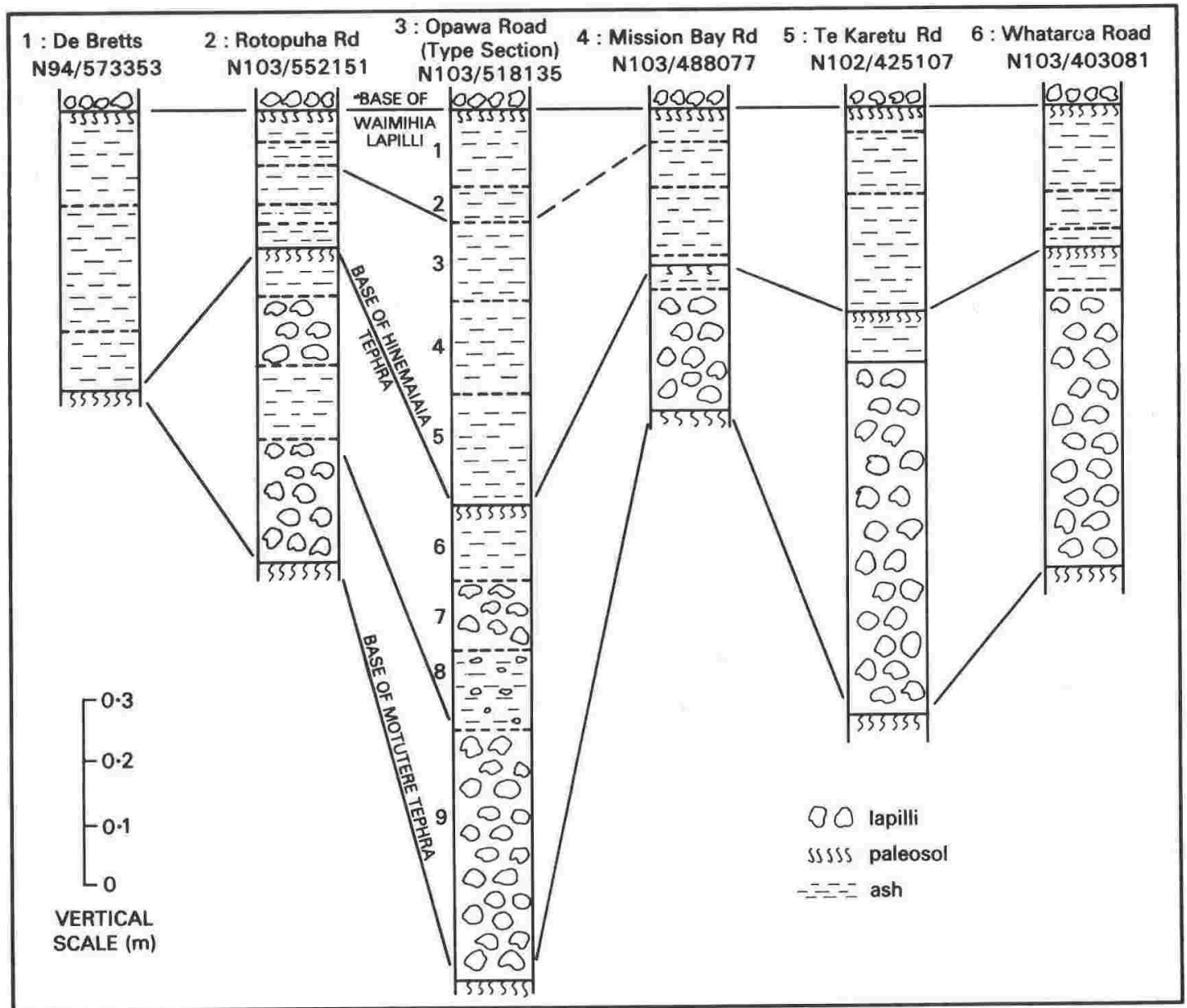

Flg. 2 Sections through Hinemaiaia and Motutere Tephras with probable bed correlation shown. Datum level for the sections is the base of Waimihia Lapilli. Only in a small area west of the type section on Opawa Road are all the beds distinguishable. Numbers against each bed in the Opawa Road section are to identify the samples in Table 2 only.

Table 2 Ferromagnesian mineral proportions based on 600 grain counts for each bed of Hinemaiaia and Motutere Tephra at the type section on Opawa Road. Numbers to identify each bed are as shown on Fig. 2 .

\begin{tabular}{|c|c|c|c|}
\hline \multirow{2}{*}{$\begin{array}{l}\text { Opawa Road type section } \\
\text { N103/518135 } \\
\text { Beds }\end{array}$} & \multicolumn{3}{|c|}{ Relative abundance (\%) } \\
\hline & Hypersthene & Hornblende & Augite \\
\hline \multicolumn{4}{|l|}{ Hinemaiaia Tephra } \\
\hline 1 & 100 & - & - \\
\hline 2 & 100 & 一 & - \\
\hline 3 & 95 & 4 & 1 \\
\hline 4 & 99 & - & 1 \\
\hline 5 & 98 & - & 2 \\
\hline \multicolumn{4}{|l|}{ Motutere Tephra } \\
\hline 6 & 100 & - & - \\
\hline 7 & 99 & - & 1 \\
\hline 8 & 68 & 1 & 31 \\
\hline 9 & 99 & - & 1 \\
\hline $\begin{array}{l}\text { De Bretts } \\
\text { (N94/573353) }\end{array}$ & 98 & - & 2 \\
\hline
\end{tabular}



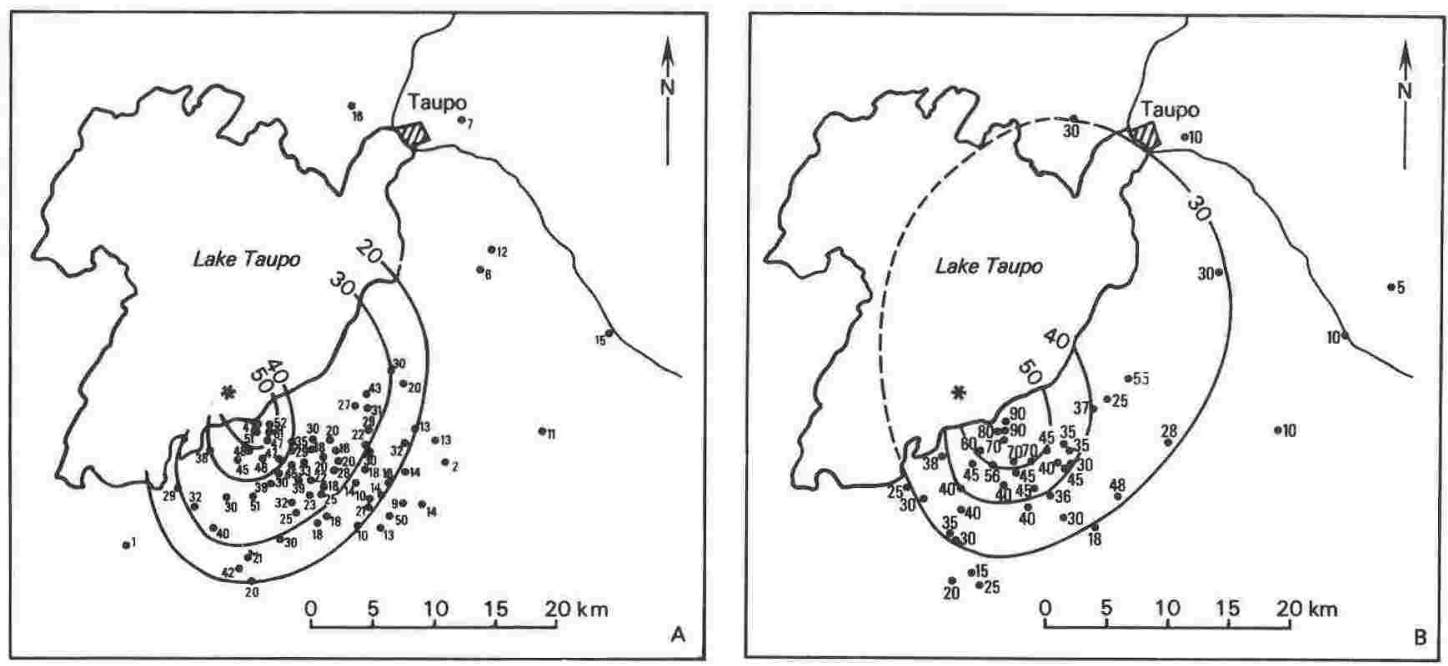

Fig. 3 Isopach maps of thickness (A) and maximum pumice size (B) on Motutere Tephra. Location of the probable vent and rhyolite dome is indicated by an asterisk.

At the Opawa Road type section, Papakai Tephra has common charcoal fragments. This, together with the dark brown paleosol-like form of the andesitic ash suggests an hiatus in the eruption of Motutere Tephra. This apparent weathering break is not widely recognised and is probably due to the differential weathering of fine andesitic ash contrasting with the interbedded coarse rhyolitic lapilli. The top of Motutere Tephra is defined by a darker coloured paleosol, with a distinctive greasy feel. Further, Topping \& Kohn (1973) noted that "Hinemaiaia Ash" was erupted at a time of intense andesitic ash production from Tongariro, so ensuring rapid burial and widespread preservation of Hinemaiaia Ash. It is thus possible that the apparent hiatus in the eruption of Motutere Tephra simply represents a concurrent eruption of Tongariro. This would also account for the rhyolitic lapilli scattered through the andesitic ash layer.

Mapped distribution of Motutere Tephra is mostly restricted to the area east of Lake Taupo as shown on the isopach and maximum pumice size maps Fig. 3A, B. Data on these maps are for Motutere Tephra excluding the andesitic Papakai Tephra where recognised. These 2 maps clearly indicate a source vent for Motutere Tephra within present Lake Taupo.

\section{HINEMAIAIA TEPHRA FORMATION $\mathrm{Hm}$}

Hinemaiaia Tephra Formation is here redefined as the rhyolitic tephra lying conformably between the Waimihia Lapilli Formation and the paleosol (incorporating a further bed of Papakai Tephra) that caps Motutere Tephra Formation at the type section on Opawa Road (N103/518135).

The type area is defined as for Motutere Tephra with the best sections lying in the north of this area. The type section is described in Table 1.

Hinemaiaia Tephra is multiple bedded and consists almost exclusively of fresh glassy obsidian or "essential lithics". At the De Bretts type section for Hinemaiaia Ash (Vucetich \& Pullar 1973), Motutere Tephra is considered to be absent as all the ash in this section is fresh glassy obsidian. Correlation of the new Opawa Road type section to the De Bretts site is shown in Fig. 2.

In the section description of Vucetich \& Pullar (1973, p. 757$)$ the middle $20-\mathrm{cm}$ unit containing charcoal was interpreted by them as a "flow unit". No evidence of a pyroclastic flow is seen in the new type area other than occasional charcoal fragments. The charcoal is probably the result of forest fires following the first eruptive phases as discussed by McGlone (1981). This phenomenon also accounts for the charcoal found within Motutere Tephra.

\section{CHRONOLOGY}

Due to a scarcity of datable material, Vucetich \& Pullar (1973) dated Hinemaiaia Tephra by correlation with a white ash in lake sediment at Tiniroto, Hawke's Bay, on which 2 radiocarbon dates were available (NZ1137* and 1247: Pullar \& Heine 1971).

"New Zealand Radiocarbon Dating Laboratory number. 



\section{FERROMAGNESIAN MINERALOGY}

Ferromagnesian mineralogy of the $63-250 \mu$ fraction of crushed samples from each bed at the Opawa Road type section is dominantly hypersthene (Table 2). Augite occurs as a minor constituent in most beds, but hornblende was found only in 2 beds. However, sample 8 has an anomalously high content of large augite phenocrysts (30\%) previously attributed to an input of Papakai Tephra.

At the De Bretts and Iwatahi reference sections, Vucetich \& Pullar (1973) mapped Whakatane Ash lying beneath Waimihia Tephra and within the paleosol on Hinemaiaia Ash, based on titanomagnetite chemistry. Whakatane Ash contains the distinctive mineral cummingtonite (Ewart 1966; Topping \& Kohn 1973). Absence of this mineral in the type section samples indicates Whakatane Ash is probably not present in this part of the Opawa section. Hence, all these rhyolitic beds have a Taupo source.

\section{SOURCE VENT LOCATION}

The isopach map of Vucetich \& Pullar (1973) shows "Hinemaiaia Ash" from which they suggested 1 source vent near Taupo, but a source further south is equally plausible. Maps of thickness and pumice clast size for Motutere are presented here (Fig. 3A, B). Absence of lithics greater than $20 \mathrm{~mm}$ in the exposed sections precluded the compilation of a lithic size map. Both maps in Fig. 3 clearly indicate a source in the area adjacent to Te Rangiita (Fig. 1) but the narrow sector of the data $\left(180^{\circ}\right)$ does not allow closure of the contours to the west. Hinemaiaia Tephra, thickest about Te Rangiita, almost certainly had the same eruptive source as Motutere Tephra.

Hinemaiaia Tephra consists dominantly of fresh glassy obsidian. These "essential lithics" are produced during the early phases of growth of a rhyolite dome, as demonstrated for Rotorua Ash (Nairn 1980) and Karapiti Tephra (Froggatt 1981, this issue). Consequently, a rhyolite dome marking the eruptive centre could be expected, although no rhyolitic extrusives are visible on land in this area.

Motuoapa Island, a large dome $5 \mathrm{~km}$ to the south of Te Rangiita (Fig. 1) is apparently older than Hinemaiaia Tephra, based on stratigraphy of the mantling tephras. The small hemispherical dome of Koroi, $2 \mathrm{~km}$ southeast of Motuoapa is dacitic (Cole 1979) so neither of these domes is apparently associatied with Hinemaiaia Tephra. Bathymetry of Lake Taupo (Irwin 1972) reveals an irregular elevated area $2 \mathrm{~km}$ offshore from Te Rangiita that rises from $-90 \mathrm{~m}$ to $-40 \mathrm{~m}$ relative to present lake level. This feature could be a rhyolite dome, although no direct evidence is available to confirm this. Residual magnetic anomalies (Roberts \& Williams 1966) appear to coincide with known eruptive vents, and one such anomaly coincides with the Te Rangiita feature. Consequently, it is suggested here that this offshore elevation is a rhyolite dome and was extruded about 4650 years ago.

\section{ACKNOWLEDGMENTS}

Valuable discussions were held with $\mathrm{Mr}$ C. G. Vucetich, Dr R. Howorth, and Mr I. Nairn. They also assisted in the field, along with Dr W. A. Pullar. Access to Lake Taupo Forest was provided by New Zealand Forest Service on behalf of the land owners. Fieldwork was funded by Victoria University Internal Research Committee Grants $118 / 79$ and $130 / 79$.

\section{REFERENCES}

Baumgart, I. L. 1954: Some ash showers of central North Island. New Zealand journal of science and technology B35 : 456-467.

Birrell, K. S.; Pullar, W. A. 1973: Weathering of paleosols in Holocene and Late Pleistocene tephras in Central North Island, New Zealand. New Zealand joumal of geology and geophysics 16: $687-702$.

Cole, J. W. 1979: Chemical analyses of lavas and ignimbrites of the Taupo Volcanic Zone. Geology Department, Victoria University of Wellington publication 13 : 31 p.

Ewart, A. 1966: Review of mineralogy and chemistry of the acidic volcanic rocks of Taupo Volcanic Zone, New Zealand. Bulletin volcanologique 29: $147-171$.

Froggatt, P. C. 1981: Karapiti Tephra Formation: a 10000 years B.P. rhyolitic tephra from Taupo. New Zealand journal of geology and geophysics 24 : (this issue).

Froggatt, P. C.; Howorth, R. 1980: Uniformity of vertical faulting for the last 7000 years at Lake Poukawa, Hawke's Bay, New Zealand. New Zealand joumal of geology and geophysics 23: 493-497.

Gage, M.; Black, R. D. 1979: Slope stability and geological investigations at Mangatu State Forest. Forest Research Institute technical paper 66:37 p.

Gibb, J. G. 1977: Late Quaternary sedimentary processes at Ohiwa Harbour eastern Bay of Plenty with special reference to property loss on Ohiwa Spit. Technical publication 5. Wellington, Water and Soil Division, Ministry of Works.

Healy, J. 1964a: Volcanic mechanisms in the Taupo Volcanic Zone, New Zealand. New Zealand journal of geology and geophysics 7 : 6-23.

1964b: Stratigraphy and chronology of late Quaternary volcanic'ash in Taupo, Rotorua and Gisborne districts. Part 1. New Zealand Geological Survey bulletin $73: 88 \mathrm{p}$. 
Howorth, R. 1975: New formations of late Pleistocene tephras from the Okataina Volcanic Centre, New Zealand. New Zealand journal of geology and geophysics $18: 683-712$.

Howorth, R.; Ross, A. 1981: Holocene tephra stratigraphy and chronology at Tiniroto, Cook County. In: Howorth et al. ed Proceedings of Tephra Workshop held at Geology Department, Victoria University of Wellington, June 30-July 1, 1980. Wellington, Geology Department, Victoria University of Wellington, New Zealand.

Howorth, R.; Froggatt, P. C.; Robertson, S. M. 1980: Late Quaternary volcanic ash stratigraphy of the Poukawa area, central Hawke's Bay New Zealand. New Zealand journal of geology and geophysics 23 : 487-491.

Irwin, J. 1972: Lake Taupo, provisional bathymetry, 1:50 000 New Zealand Oceanographic Institute chart, lake series.

Kohn, B. P.; Neall, V.; Stewart, R. B. 1981: Holocene tephra-stratigraphy revisited at Tiniroto, North Island, New Zealand. In: Howorth et al. ed. Proceedings of Tephra Workshop held at Geology Department, Victoria University of Wellington, June 30 - July 1, 1980. Wellington, Geology Department, Victoria University of Wellington, New Zealand.

McGlone, M. 1981: Forest fire following Holocene tephra fall. In: Howorth et al. ed. Proceedings of Tephra Workshop held at Geology Department, Victoria University of Wellington, June 30-July 1, 1980. Wellington, Geology Department, Victoria University of Wellington, New Zealand.
Nairn, I. 1980: Source, age, and eruptive mechanisms of the Rotorua Ash. New Zealand journal of geology and geophysics 23: 193-207.

Pain, C. F.; Pullar, W. A. 1968: Chronology of fans and terraces in the Galatea Basin. Earth science jourmal 2(i) : $1-14$

Pullar, W. A.; Heine, J. C. 1971: Ages, inferred from ${ }^{14} \mathrm{C}$ dates, of some tephra and other deposits from Rotorua, Taupo, Bay of Plenty, Gisborne and Hawke's Bay districts. Proceedings of Radiocarbon Users Conference, Wellington: 119-138.

Pullar, W. A.; Selby, M. J. 1971: Coastal progradation of Rangitaiki Plains, New Zealand. New Zealand journal of science 14: 419-434.

Roberts, N. L.; Williams, R. B. 1966: Magnetic survey of Lake Taupo. Geophysics Division report 39. Wellington, Department of Scientific and Industrial Research. 2 p.

Topping, W. W. 1973: Tephrostratigraphy and chronology of Late Quaternary eruptives from the Tongariro Volcanic Centre, New Zealand. New Zealnd journal of geology and geophysics 16:397-423.

Topping, W. W.; Kohn, B. P. 1973: Rhyolitic tephra marker beds in the Tongariro area, North Island, New Zealand. New Zealand journal of geology and geophysics 16: $375-395$.

Vucetich, C. G.; Pullar, W. A. 1973: Holocene tephra formations erupted in the Taupo area, and interbedded tephras from other volcanic sources. New Zealand journal of geology and geophysics 16: 745-780. 


\title{
THE GROUND LAYER OF THE TAUPO IGNIMBRITE: A STRIKING EXAMPLE OF SEDIMENTATION FROM A PYROCLASTIC FLOW
}

\author{
G.P.L. WALKER ${ }^{1, *}$, S. SELF ${ }^{2, * *}$ and P.C. FROGGATT ${ }^{2}$
}

${ }^{1}$ Department of Geology, University of Auckland, Auckland (New Zealand)

${ }^{2}$ Department of Geology, Victoria University, Wellington (New Zealand)

(Received October 16, 1979; revised and accepted August 18, 1980)

\section{ABSTRACT}

Walker, G.P.L., Self, S. and Froggatt, P.C., 1981. The ground layer of the Taupo ignimbrite: a striking example of sedimentation from a pyroclastic flow. J. Volcanol. Geotherm. Res., $10: 1-11$.

A "ground layer" rich in lithic fragments and crystals which underlies a young and widely-spread non-welded ignimbrite from Taupo, New Zealand, has formed by the sedimentation of heavy constituents from the pyroclastic flow. This origin is revealed by the progressive impoverishment of these constituents in the ignimbrite, and by the progressive decrease of lithic size in both ground layer and ignimbrite towards the distal end. The ground layer is separated from the ignimbrite by a sharp and near-planar erosive contact, suggesting that sedimentation of "heavies" took place in the more strongly fluidised head of the pyroclastic flow, and that the layer was then over-ridden by the remainder of the flow. It is thus distinct from the lithic-rich layer often present immediately above the basal layer of ignimbrites as an integral part of the flow unit. Near source, the Taupo ground layer contains metre-sized blocks and is akin to a co-ignimbrite lag-fall deposit.

\section{INTRODUCTION}

The products of ignimbrite eruptions are many and varied. Sparks et al. (1973), impressed by the frequent occurrence of the products in a particular order, proposed a "standard sequence" which includes a thin "layer 1" deposit rich in crystals and lithics interposed between the ignimbrite proper and the pre-ignimbrite plinian pumice. They interpreted this thin layer as a deposit from a kind of pyroclastic surge (a "ground surge"), which was envisaged to sweep outwards from the vent in advance of the main pyroclastic flow. This paper describes a striking occurrence of another kind of deposit found between a plinian deposit and an overlying ignimbrite, and

\footnotetext{
*Present address: Hawaii Institute of Geophysics, 2525 Correa Road, Honolulu, HA 96822 , U.S.A.

**Present address: Department of Geology, Arizona State University, Tempe, AZ 85281, U.S.A.
} 
proposes a different interpretation of its origin. The new and non-genetic name "ground layer" is proposed.

The ignimbrite discussed is rhyolitic and almost entirely non-welded, and is the latest exuptive product of the Taupo volcanic centre, New Zealand (Healy, 1964). Being so young (it is ${ }^{14} \mathrm{C}$ dated at about 130 A.D.; Healy, $1964,1971)$ the ignimbrite is extremely well preserved and exposed. In near-source exposures the ground layer is extremely coarse and contains boulders $1 \mathrm{~m}$ or more in size (Fig.1). Rhyolite boulders several metres across which may have been eroded out from the layer now lie on the surface near the northeast shore of Lake Taupo at Waitahanui, and have long excited interest. The layer in its coarser part has previously been named the Rhyolite Block Bed member of the Taupo Pumice Formation (TPF) by Baumgart and Healy (1956). It rests, often discordantly and with a demonstrable erosion surface, on the pre-ignimbrite plinian pumice known as the Taupo Lapilli member of the TPF (Baumgart and Healy, 1956) and it is overlain, often discordantly, by the ignimbrite, known as the Upper Taupo Pumice member of the TPF (Healy, 1964). It is convenient to have volcanological names as well as stratigraphic ones, and the volcanological name "Taupo ignimbrite" is proposed.

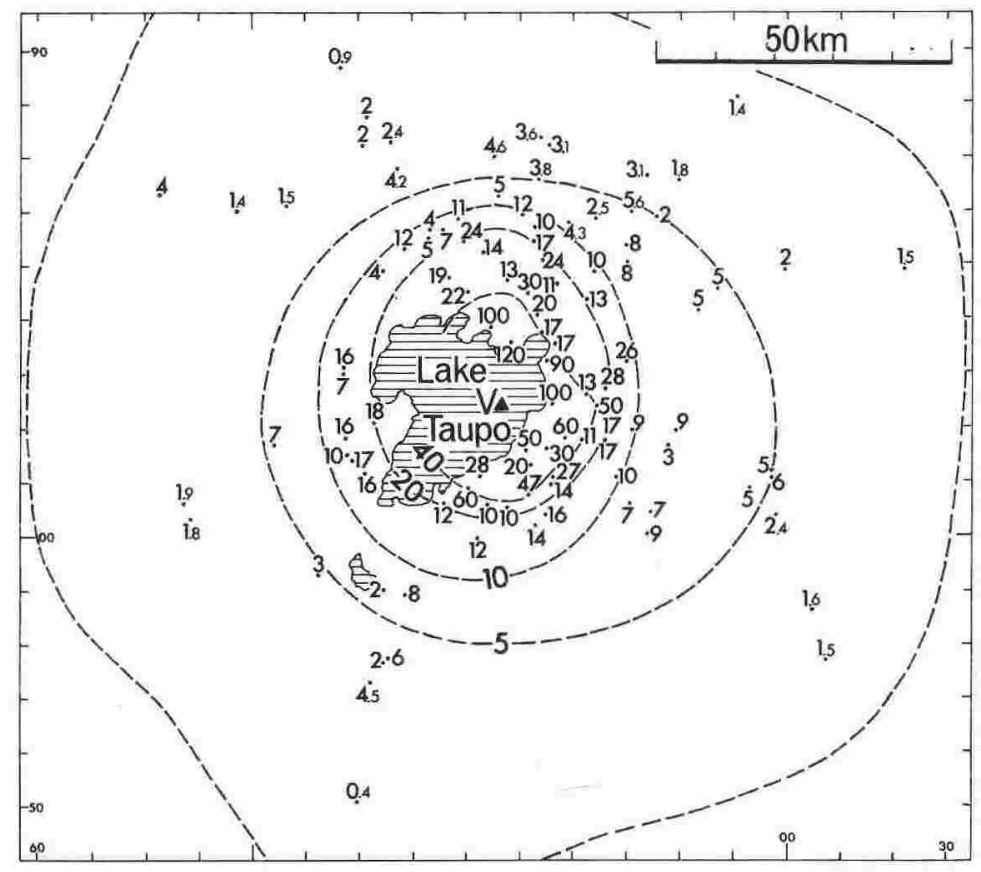

Fig.1. Map showing the approximate extent of the Taupo ignimbrite, and the average maximum diameter of the three largest lithic clasts in its ground layer. Values in centimetres. $V$ marks the position of the Horomatangi Reef vent. Bars around the margin refer to the 10,000-yard grid of the New Zealand survey maps. 
Boulders in the ground layer are mostly of phenocryst-poor rhyolite and include lithophysal, spherulitic, banded and glassy varieties. Other rock types include welded ignimbrite, hydrothermally altered rhyolite and occasionally mudstone and andesite. Carbonised tree trunks, branches and wood fragments are almost every where abundant and are often aligned radially from source in the flow direction.

The Taupo ignimbrite is, for its comparatively modest volume of about $30 \mathrm{~km}^{3}$, remarkably widely spread, being of the low-aspect ratio type (Walker et al., 1980a), and is distributed over a nearly circular area $160 \mathrm{~km}$ across centred on Lake Taupo. The lithic size distribution in the pre-ignimbrite plinian pumice, the ground layer (Fig.1) and the ignimbrite indicate that the vent lies within the present area of the lake, probably at or near the Horomatangi Reef. The ground layer extends to near the distal limits of the ignimbrite although it becomes very thin, fine-grained and discontinuous there. Its thickness varies from $3 \mathrm{~m}$ near source to less than $1 \mathrm{~cm}$ in distal exposures, but it is discontinuous and shows such rapid local thickness variations that no attempt has been made to plot an isopach map of it. Details of its occurrence at various localities are illustrated by Figs. 2 and 3.

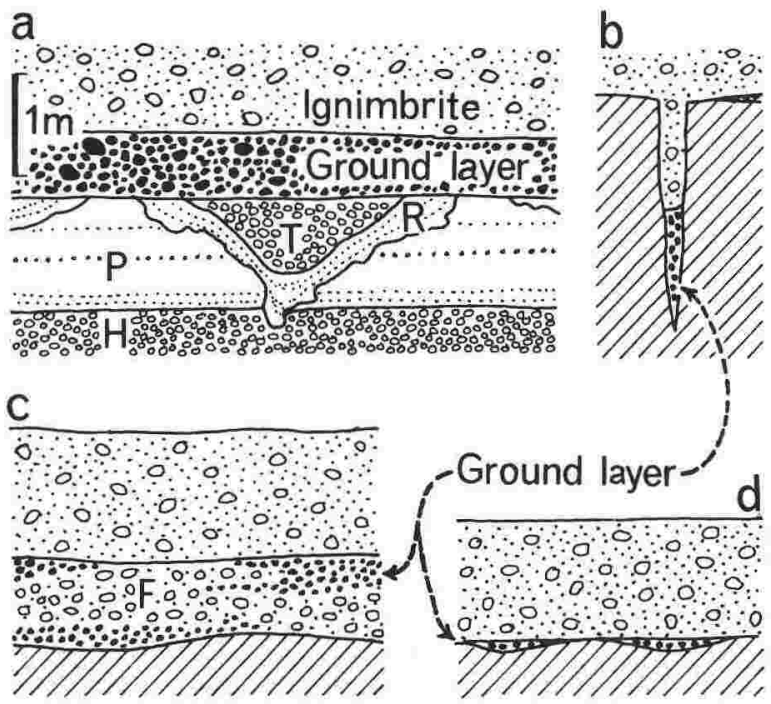

Fig.2. Sketch sections showing typical relationships between the Taupo ignimbrite and its ground layer. (a) Ground layer resting on a strongly discordant surface (see Fig. 3 in Walker, 1980). (b) Fissure of a type found at Kuratau, $22 \mathrm{~km}$ WSW of vent, penetrating the soil to a depth of ca. $2 \mathrm{~m}$ and infilled with ground layer material and ignimbrite. (c) Ground layer interdigitating with fines-depleted and kindred ignimbrite material $(F)$. $H, P, R$ and $T$ (the Hatepe plinian pumice, putty ash, Rotongaio ash, and Taupo plinian pumice deposits respectively) are air-fall deposits of earlier phases of the same eruption that produced the Taupo ignimbrite. 

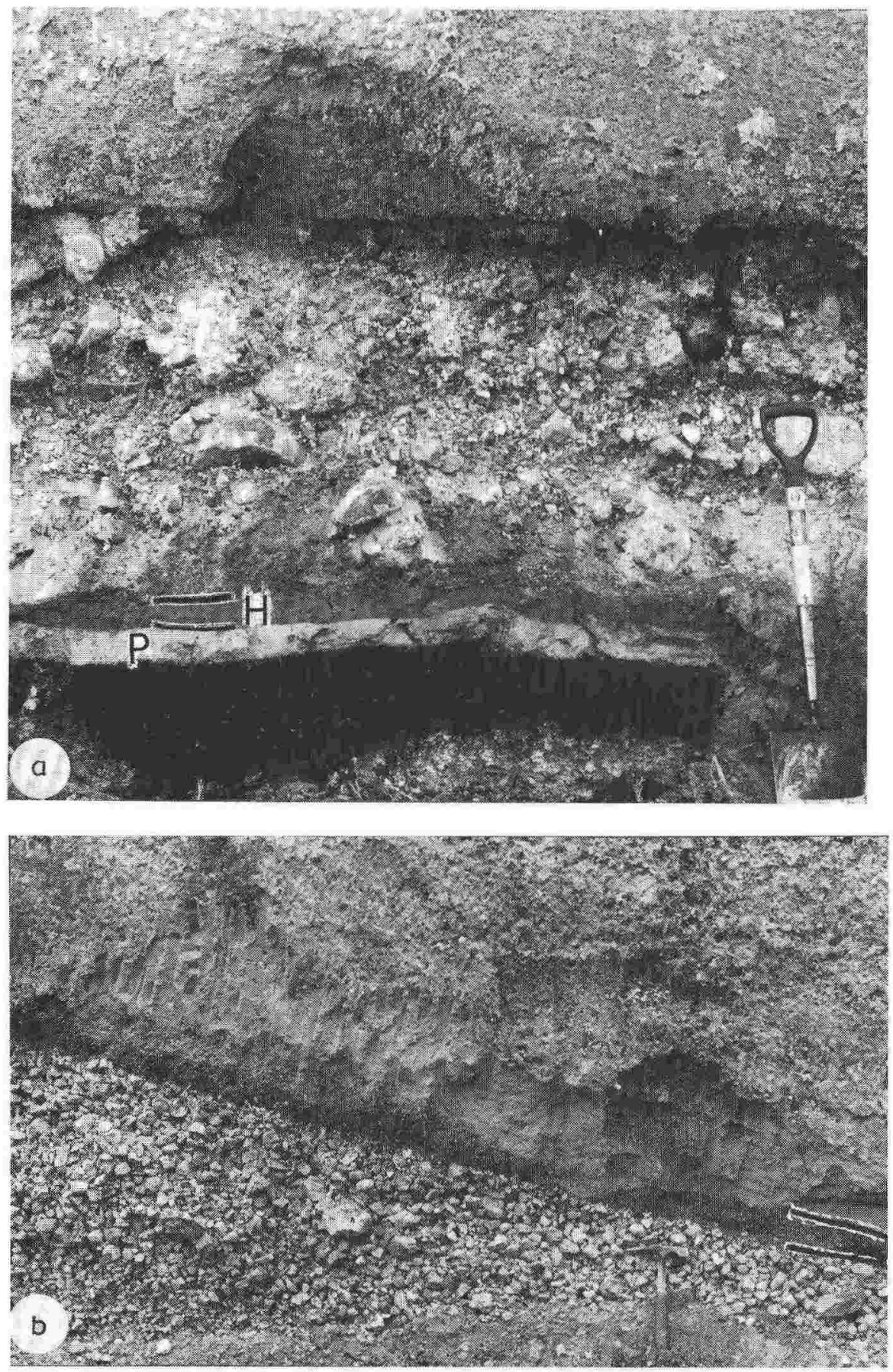

Fig.3. Exposures of ground layer: (a) At a point $14 \mathrm{~km} \mathrm{SSW}$ of source. It is $1 \mathrm{~m}$ thick and the maximum lithic size is $60 \mathrm{~cm}$. It rests on the Rotongaio ash $(R)$ and Putty ash $(P)$; the planar sheared contact at the base of the overlying ignimbrite is clearly shown. (b) At a point $14 \mathrm{~km}$ east of source. It rests on Taupo plinian pumice and varies from 0 to $15 \mathrm{~cm}$ thick. 
The ignimbrite is thickest in valleys, where it often exceeds $10 \mathrm{~m}$ thick, but it is evident that over a large area the pyroclastic flow which gave rise to it swept over the entire land surface, hills and valleys alike, reaching as high as $1500 \mathrm{~m}$ above present lake level, and everywhere left behind a thin deposit (an "ignimbrite veneer deposit"); the ground layer forms a discontinuous layer which underlies the valley pond ignimbrite and veneer deposits alike.

\section{GRAIN-SIZE CHARACTERISTICS AND CONSTITUTION}

Eighty samples of the ground layer have been sieved to characterise the deposit, and for 48 samples the weight percentages of components (pumice plus shards, free crystals and lithics) have been determined down to $1 / 4 \mathrm{~mm}$ size. Most samples have a lognormal size distribution (Fig.4), but the coarsest ones have a bimodal distribution with a coarser mode of boulder-sized clasts. Fig.5 summarises the character of the ground layer and shows that it is moderately well sorted (most samples plot within the pyroclastic fall field), and compared with the ignimbrite shows a noteworthy lack of "fines".

Fig. 6 plots the percentages of components in the classes $1 / 4 \mathrm{~mm}$ and
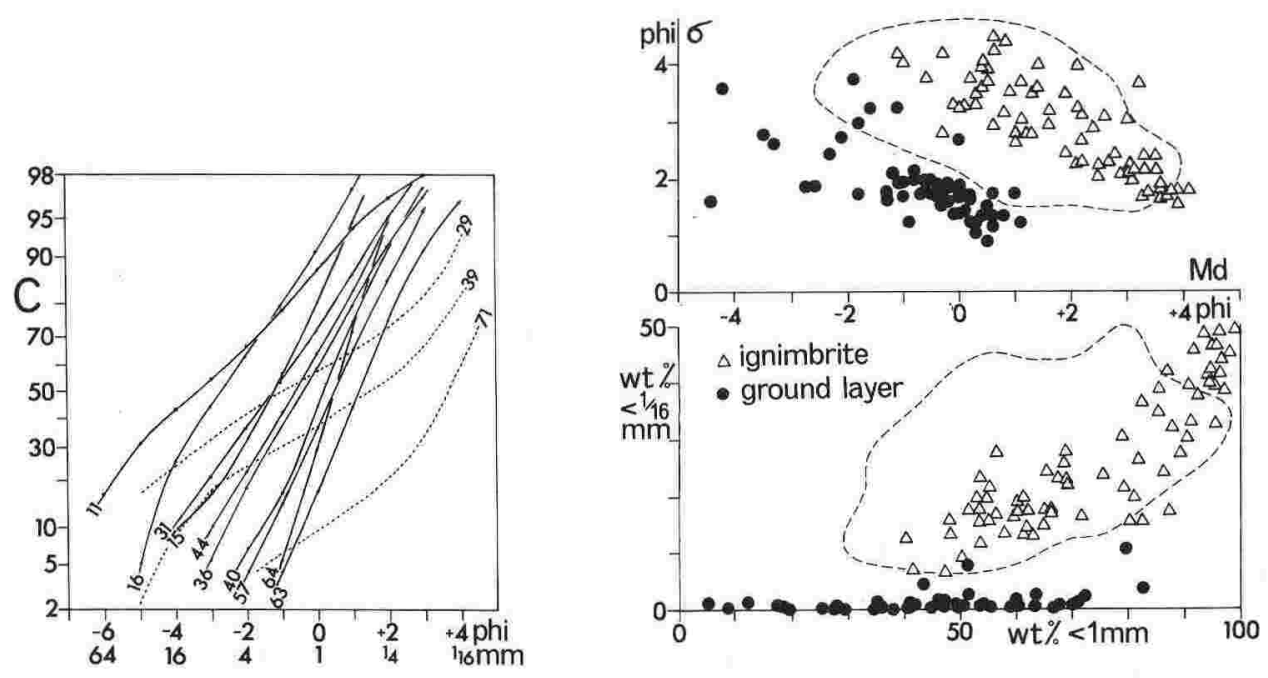

Fig.4. Representative probability curves of ground layer samples showing the cumulative weight percentage $(C)$ coarser than the grain-size indicated. Figures give the distance from vent in $\mathrm{km}$. The dashed lines are typical samples of Taupo ignimbrite for comparison.

Fig. 5. Summary and comparison of grain-size characteristics of the Taupo ignimbrite and its ground layer. Above is a plot of graphic standard deviation $\dot{\sigma}_{\phi}\left[=\left(\phi_{84}-\phi_{16}\right) ! 2\right]$ against median diameter $\mathrm{Md}_{\phi}\left(=\phi_{50}\right)$ showing that the ground layer is coarser and better sorted. The dashed line is the $1 \%$ contour for the pyroclastic flow field. Below is a grain-size plot showing the negligible content of ash finer than $1 / 16 \mathrm{~mm}$ in the ground layer samples. The dashed line is the $1 \%$ contour for the pyroclastic flow field. 


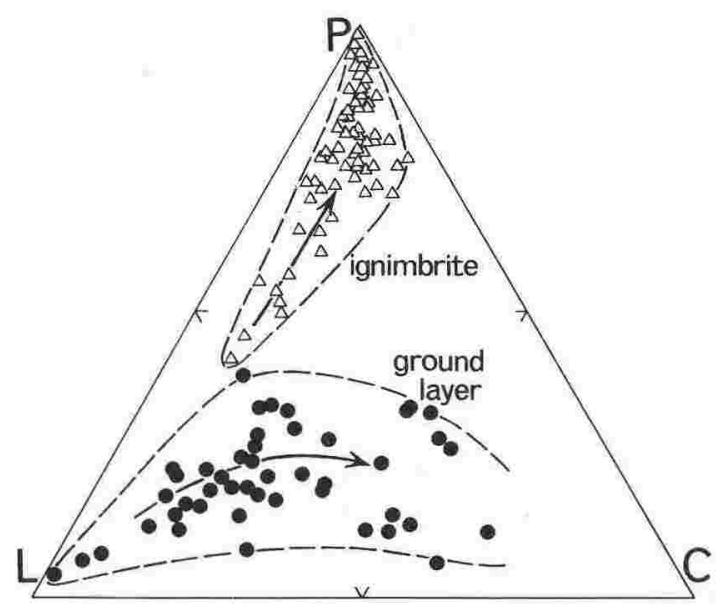

Fig.6. Plot of percentages of pumice $(P)$, lithics $(L)$ and free crystals $(C)$ in samples of the Taupo ignimbrite and its ground layer, for the classes $1 / 4 \mathrm{~mm}$ and coarser recalculated to $100 \%$ total. The arrows indicate compositional trends with increasing distance from vent.

coarser, recalculated to $100 \%$, for samples of the ground layer and ignimbrite, and shows that the ground layer is strongly enriched in dense components (crystals and lithics). The pumice in the ground layer moreover has an average density $30 \%$ higher than pumice of corresponding size in the ignimbrite.

\section{ORIGIN OF THE GROUND LAYER}

In view of the fact that a shower origin has previously been proposed (Baumgart and Healy, 1956), the following is evidence that the ground layer does not have this origin. First, the blocks never indent the underlying surface (whether it is plinian pumice or the underlying paleosol), showing that they cannot have fallen at a high velocity into their present position. Second, some of the large blocks are of relatively delicate rock such as mudstone, and could hardly have survived unbroken after falling from any appreciable height. Third, the area enclosed by any given lithic maximum size isopleth is much greater than is presently known for any deposit of proven airfall type; the $10 \mathrm{~cm}$ isopleth for example encloses $2750 \mathrm{~km}^{2}$, which compares with $130 \mathrm{~km}^{2}$ for the Fogo A plinian pumice in the Azores (Walker and Croasdale, 1971), and $700 \mathrm{~km}^{2}$ for the Taupo pumice (which is claimed to be the deposit of the most powerful plinian eruption presently known: Walker, 1980).

The large lithics, and presumably also the finer material associated with them, must therefore have been carried laterally into their present position, either by a pyroclastic flow or by a pyroclastic surge. We employ "pyroclastic flow" to denote a concentrated particulate flow (i.e. one having a high particle/gas ratio) and "pyroclastic surge" for a dilute, gas-rich, particulate flow. 
Consider now the evidence that it was a pyroclastic flow. Traced outwards from source the ignimbrite becomes at first impoverished in lithics (Fig.7), and then in crystals, and towards its distal end approaches $100 \%$ vitric material. Such a steady impoverishment in "heavies" must be accounted for, and is best explained by their loss into the ground layer. At the same time the maximum lithic size in both ignimbrite and ground layer steadily decreases outwards (Fig.8), compatible with the loss of the larger lithics first, the smaller ones being carried farther from source. More than about $60 \mathrm{~km}$ out, the maximum crystal size also begins to decrease from $2 \mathrm{~mm}$ to less than 1 $\mathrm{mm}$ at the distal end.

Lithics cover a much wider size range than crystals in the erupted mixture,
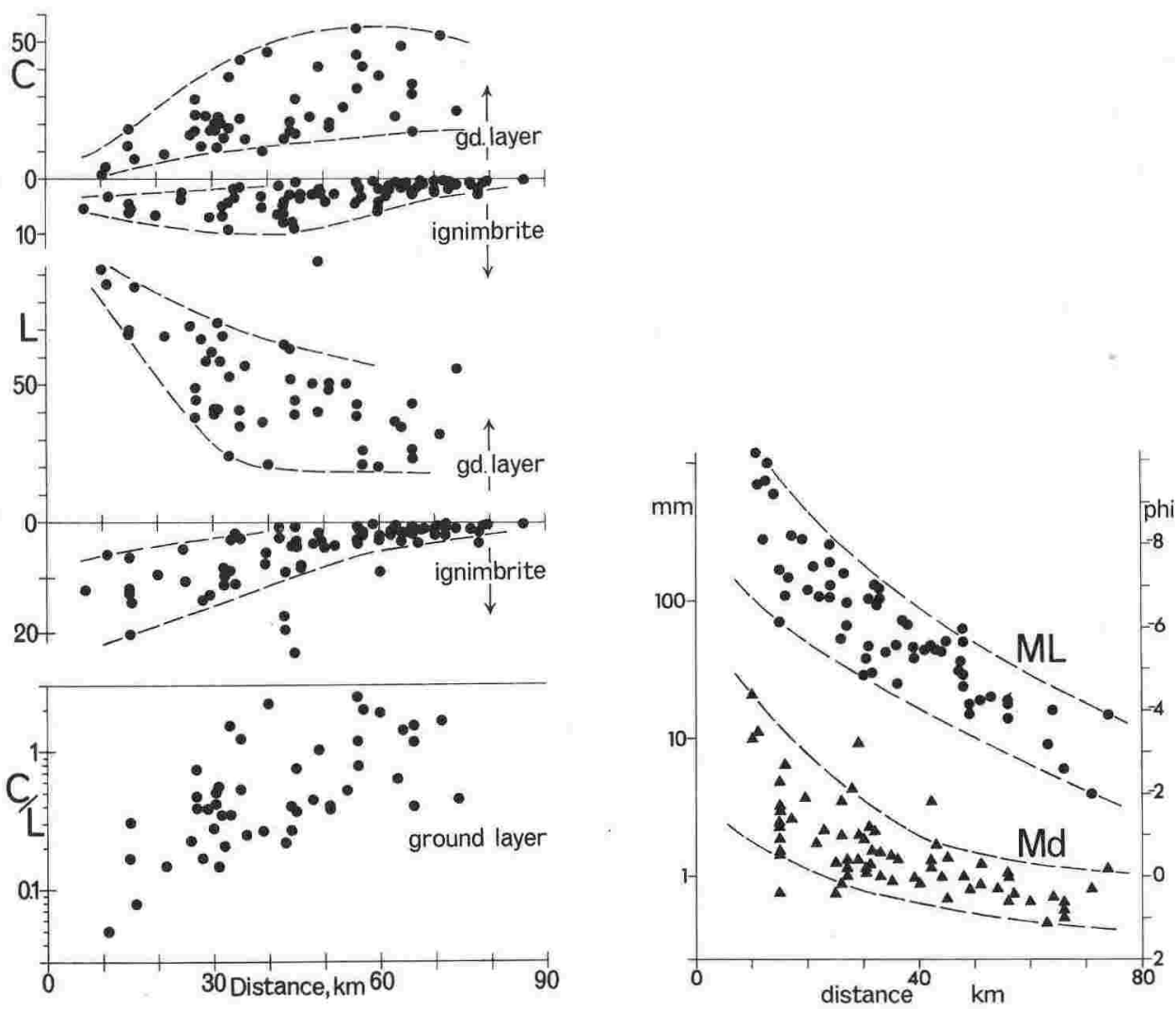

Fig.7. Variation in percentages of free crystals $(C)$ and lithics $(L)$ against distance from vent in the Taupo ignimbrite and its ground layer, and variation in the $C / L$ ratio in the ground layer. Note particularly the sympathetic variation of lithic content in ground layer and ignimbrite.

Fig.8. Variation in grain-size of the ground layer with distance from vent. $M L=$ average maximum diameter of the three largest lithic fragments; $M d=$ median diameter, from sieve analyses. 
and the crystal/lithic ratio accordingly varies as the grain-size of the "heavies" in the ground layer decreases from low near source where large lithics predominate, to high at the distal end where the median diameter of the ground layer is similar to that of the crop of crystals and the deposit is therefore strongly enriched in crystals. One complication arises since it is evident that some of the lithics in some samples of the ignimbrite and ground layer are of local origin and have been picked up from the underlying surface. Evidence for erosion of the base of the ignimbrite is very clear and probably indicates turbulence in the flow head. These secondarily-derived lithics include locally abundant andesite, well-rounded stream pebbles, and rounded pellets of soil.

There is one main argument against deposition from a pyroclastic surge. All historical hot pyroclastic surges have developed on high and steep volcanic cones, and it is only on a steep cone that gravity can sustain the high velocity on which the carrying power of the gas and distance reached by the surge depends. In contrast, at Taupo the present vent position is lower than any outcrop of the ignimbrite, and we believe that it was not appreciably higher at the time of the eruption since some earlier phases of the same eruption were phreatomagmatic and the vent must then, as now, have been in Lake Taupo. The carrying power of a surge on flat topography as at Taupo might be expected to decay very rapidly outwards. It is not easy to conceive of an ash hurricane on flat ground capable of moving metre-sized boulders nearly $10 \mathrm{~km}$, and $10 \mathrm{~cm}$ lithics $30 \mathrm{~km}$ from source (even the highly destructive 1902 nuée ardente in Martinique carried lithic clasts only $10 \mathrm{~cm}$ in maximum size into St. Pièrre, after descending $9 \mathrm{~km}$ down the steep side of Montagne Pelée). Only a highly concentrated pyroclastic flow seems capable of accomplishing this feat.

Another argument that might be used against a pyroclastic surge origin is the general absence of stratification and cross-stratification from the Taupo ground layer. If searched for carefully, instances of low-angle cross-bedding can be found, but such bedding is not in any way characteristic of the deposit. However the validity of this argument is uncertain since, although base surge deposits tend to be well-stratified and cross-stratified, these may be depositional features of fine damp or wet material; hot and dry pyroclastic surge deposits often lack these features. A large part of the May 8, 1902, pyroclastic surge deposit of Montagne Pelée, for example, is non-stratified.

\section{MECHANISM OF FORMATION}

A feature of the ground layer is that the ignimbrite rests on it discordantly and is separated from it by a nearly planar surface; this fact has undoubtedly delayed recognition of the ground layer as a part of the ignimbrite since it seems to indicate that the layer is the product of a separate eruptive act. Where the ground layer occurs at the base of the ignimbrite it often also itself rests on an eroded surface, and erosion and deposition of the 
layer seem to have occurred concurrently. These features, and the scarcity of "fines", seem to indicate that deposition of the ground layer took place in an environment rather different from that in the body of the pyroclastic flow, and the most logical place is the head of the advancing flow (Wilson, 1980).

A model which accounts for these features envisages a head which, due to entrapped over-ridden air, is more fluidised than the remainder of the flow and is highly turbulent. In this flow regime conditions are such that the floor is eroded, and where there is underly ing loose material, its top is churned up and mixed with the deposited material so that the ground layer grades down into it. "Heavies" are envisaged to settle relatively rapidly in the head as they do in a strongly fluidised experimental fluidised bed (Wilson, 1980), and they accumulate as a ground layer; the body of the flow then over-rides this layer, and a sharp and near-planar surface develops by shearing.

In some places the ground layer of the main ignimbrite flow unit grades downwards into a rather thin pumice-rich unit, which is strikingly heterogeneous and includes the fines-depleted ignimbrite variant (Walker et al.,. $1980 \mathrm{~b}$ ). This thin unit is laterally discontinuous, and shows rapid variations in thickness and character and a complex interdigitation with ground layer material (Fig.2c). Although not strictly relevant here, it might be added that the model adopted for this pumice-rich part envisages portions of the flow head becoming detached from and jetting in advance of the head. Being strongly fluidised, these portions rapidly lost fine constituents and in consequence soon came to rest as locally-developed flow units which were then overridden by the main flow unit. Evidence for and details of this mechanism will be presented elsewhere.

The settling of heavy constituents from the flow head rapidly impoverishes the head in these constituents, and a combination of two mechanisms is envisaged to maintain the supply of heavy particles to the head. One is a continuous exchange or recycling of material between the body of the flow and the head as the flow advances. The other is a continual loss of head material (e.g. to make fines-depleted ignimbrite); the very rapid replacement of material from behind to regenerate the head exceeds the rate that the head is used up, and hence the flow advances. It is not certain which is the more important of these two mechanisms.

\section{OTHER EXAMPLES}

The Taupo ignimbrite evidently had an unusually high mobility, and its well-defined and striking ground layer is an expression of this, yet it is in no way unique and merely occupies a position near one limit of a spectrum of ignimbrite types, some of which possess and some lack a ground layer.

The closest example in the literature appears to be the Ito flow (Yokoyama, 1974). This is described as having a basal lithic concentration, mainly in 
lenses, spread over wide areas of southern Kyushu. It is associated with the Kamuarizaka breccia (Aramaki, 1969) which is a 30 -m-thick proximal lithic concentration zone and may be a co-ignimbrite lag-fall deposit. Yokoyama demonstrates a steady decrease in lithic size out to $60 \mathrm{~km}$ from source. The outward decrease in lithic size in this and the Towada flow was earlier attributed to a progressive settling out of the larger lithics from the moving flow (Kuno et al., 1964).

Other examples known to the authors include the Povoacao ignimbrite, São Miguel (Walker, 1972), and the Lajes and Angra ignimbrites, Terceira (Self, 1976). Several ignimbrites of Vulsini volcano, Italy, are also underlain by a thin layer rich in crystals and lithics (Sparks, 1975) which may be a ground layer. In some of the Vulsini examples, however, an underlying layer made largely of fine vitric material is separated from the ignimbrite by an ash of air-fall type rich in accretionary lapilli, which suggests that in these instances the bed in question has a different origin and may be the product of a true pyroclastic surge generated at the vent. A fine example of a ground layer having all of the characteristics of the Taupo one has recently been found associated with the youngest ignimbrite of the Rabaul caldera, Papua, New Guinea (Walker et al., 1980c).

The "standard ignimbrite flow unit" of Sparks et al. (1973) includes a lithic concentration zone ("layer $2 \mathrm{bL}$ ") near the base of the flow unit, which differs from the ground layer in being an integral part of the flow unit; this zone is an alternative product of the settling of heavy constituents and may be attributed to the sinking of lithics within the body of the flow rather than in its head. This layer overlies the basal layer of the flow unit. We note that the Taupo ignimbrite lacks a clearly recognisable basal layer over much of its extent.

The Acatlan ignimbrite in Mexico (Wright and Walker, 1977) is associated in its vent area with a very coarse lithic accumulation, described as a co-ignimbrite lag-fall deposit, and interpreted as consisting of material too coarse and heavy to be carried an appreciable distance by the pyroclastic flow. It was deposited at the site of column collapse. The fine and pumiceous materials very largely escaped to leave the lithic accumulation behind as a lag deposit. At Taupo equally coarse lithic material appears to have been carried several kilometres from the site of column collapse before being deposited. It seems likely that a lag-fall deposit as at Acatlan, may pass laterally into a ground layer as described in the present paper.

\section{CONCLUSIONS}

A new mechanism has been proposed for a kind of layer 1 deposit underlying the Taupo ignimbrite; this layer is interpreted as a deposit from the same pyroclastic flow that gave rise to the ignimbrite, and is not the product of a separate eruptive act as might be inferred from the presence of a sheared contact between it and the ignimbrite. It is one kind of deposit from a con- 
centrated pyroclastic flow, and reasons are given why it cannot be an air-fall deposit or the product of a dilute pyroclastic surge.

Many examples of a lithic- and crystal-rich layer underlying ignimbrites, hitherto interpreted as pyroclastic surge deposits, may on re-examination prove to be a ground layer of similar type and origin as that described here.

\section{ACKNOWLEDGEMENTS}

Fieldwork by G.P.L.W. as fourth Captain James Cook fellow of the Royal Society of New Zealand, while on leave from Imperial College, London, and by S.S. during the tenure of a post-doctoral research fellowship at the Victoria University of Wellington. Fieldwork by P.C.F. was financed by the Internal Research Committee of Victoria University. H.R. Walker did most of the component analyses.

\section{REFERENCES}

Aramaki, S., 1969. Geology and pyroclastic flow deposits of the Korubu area, Kagoshima Prefecture. J. Geol. Soc. Jpn., 75: 425-442.

Baumgart, I.L. and Healy, J., 1956. Recent volcanicity at Taupo, New Zealand. Proc. 8th Pacif. Sci. Congr., 2: 113-125.

Healy, J., 1964. Volcanic mechanisms in the Taupo Volcanic Zone, New Zealand. N.Z. J. Geol. Geophys., 7: 6-23.

Healy, J., Vucetich, C.G. and Pullar, W.A., 1964. Stratigraphy and chronology of Late Quaternary volcanic ash in Taupo, Rotorua and Gisborne Districts. N.Z. Geol. Surv. Bull, New Ser., 73.

Kuno, H., Ishikawa, T., Katsui, Y., Yagi, K., Yamasaki, M. and Taneda, S., 1964. Sorting of pumice and lithic fragments as a key to eruptive and emplacement mechanisms. Jpn. J. Geol, Geogr., 35: 223-238.

Self, S., 1976. The Recent volcanology of Terceira, Azores. J. Geol. Soc. London, 132: 645-666.

Sparks, R.S.J., Self, S. and Walker, G.P.L., 1973. Products of ignimbrite eruptions. Geology, $1: 115-118$.

Sparks, R.S.J., 1975. Stratigraphy and geology of the ignimbrites of Vulsini volcano, Central Italy. Geol, Rundsch., 64: 497-523.

Walker, G.P.L., 1972. Crystal concentration in ignimbrites. Contrib. Mineral. Petrol., 36: $135-146$.

Walker, G.P.L., 1980. The Taupo pumice: product of the most powerful known (ultraplinian) eruption? J. Volcanol. Geotherm. Res., 8: 69-94.

Walker, G.P.L. and Croasdale, R., 1971. Two plinian-type eruptions in the Azores. J. Geol. Soc. London, 127: 17-55.

Walker, G.P.L., Heming, R.F. and Wilson, C.J.N., 1980a. Low-aspect ratio ignimbrites. Nature, 283: 286-287.

Walker, G.P.L., Wilson, C.J.N. and Froggatt, P.C., 1980b, Fines-depleted ignimbrite in New Zealand - the product of a turbulent pyroclastic flow. Geology, 8: 245-249.

Walker, G.P.L., Heming, R.F., Sprod, T.J. and Walker, H.R., 1980c. Latest major eruptions of Rabaul volcano. In: R.W. Johnson (Editor), Cooke-Ravian Volume of Volcanological Papers. Geol. Surv. Papua New Guinea, Mem. 10.

Wilson, C.J.N., 1980. The role of fluidization in the emplacement of pyroclastic flows. J. Volcanol. Geotherm. Res., 8: 231-249.

Wright, J.V. and Walker, G.P.L., 1977. The ignimbrite source problem: significance of a co-ignim brite lag-fall deposit. Geology, 5: 729-732.

Yokoyama, S., 1974. Flow and emplacement mechanism of the Ito pyroclastic flow from Aira caldera, Japan. Tokyo Kyoiku Daigaku Sci. Rep., Sect. C, 12: 1-62. 


\section{Stratigraphy and nature of Taupo Pumice Formation}

\author{
P. C. FROGGATT \\ Geology Department \\ Victoria University of Wellington \\ Private Bag \\ Wellington, New Zealand
}

\begin{abstract}
Tephras erupted from Taupo Volcanic Centre, North Island, New Zealand, during the most recent eruptive event (c. 1820 years ago) are defined as 4 members of Taupo Pumice Formation. From youngest to oldest these are Taupo Ignimbrite, Taupo Lapilli, Rotongaio Ash, and Hatepe Tephra. All are airfall in origin except Taupo Ignimbrite which is the product of pyroclastic flows.

Three stratigraphic units are here recognised within Taupo Ignimbrite. The Lower unit, restricted in occurrence mostly between Taupo and Turangi, is predominantly reddish brown in colour and has previously been included within Waitahanui Breccia. It is here recommended that use of the name Waitahanui Breccia be discontinued. The Middle unit is the most extensive and is discontinuously underlain by a "lithic lag layer", rich in accessory lithics and crystals. The Upper unit is widely distributed and noted for the large pumice blocks found at the top of the ignimbrite, as well as interbedded fine ash airfall layers containing chalazoidites (accretionary lapilli).

Each unit of Taupo Ignimbrite is highly variable in appearance and is described in terms of 3 lithofacies: "valley facies", "fines-depleted facies" and "ignimbrite veneer facies".

Charcoal, from branches and logs, is common within the Middle unit. Radial orientation of these logs, as well as grainsize and distribution of individual members, indicates Taupo Pumice Formation was erupted from within the present Lake Taupo, at Horomatangi Reefs. The total volume of tephra ejected during the eruptive sequence is estimated at about $100 \mathrm{~km}^{3}$. Approximately $20 \mathrm{~km}^{3}$ constituted the airfall beds of Hatepe Tephra, Rotongaio Ash, and Taupo Lapilli. The total volume represents about $20 \mathrm{~km}^{3}$ of magma.
\end{abstract}

Keywords Taupo Pumice Formation; Taupo Ignimbrite; Taupo Lapilli; Rotongaio Ash; Hatepe Tephra; tephrostratigraphy; chronology; tephra volumes

Received 17 September 1980, accepted 8 June 1981

\section{INTRODUCTION}

Pumice from the most recent series of eruptions (c. 1820 years ago) at Taupo is widespread throughout the central North Island as a primary pyroclastic deposit and around most of the coastline of New Zealand as sea-rafted pumice. Such rafted blocks have been found as far south as Campbell Island ( $P$. Morris pers. comm. 1978). Consequently Taupo Pumice has been used extensively as a chronological marker bed for such studies as shoreline movement (e.g., Pullar \& Selby 1971; Fleming 1972; Gibb 1977), archaeology (Wellman 1962; MacFadgen 1978), erosion rates (Gage \& Black 1979), tectonics (Froggatt \& Howorth 1981), and lake levels (Kennedy et al. 1978).

Despite such extensive usage, the Taupo Subgroup (TSG) nomenclature of Healy (1964) has not been revised. In particular, the uppermost layers have been variously mapped or described as: "Taupo Pumice" (e.g., Topping \& Kohn 1973; Vucetich \& Pullar 1973), TSG 1a, b, c, and TSG 2 (Vucetich \& Pullar 1964), "Taupo Pumice Alluvium" (Grindley 1960; Healy 1964), "Waitahanui Breccia" (Grindley 1960), and "Ngautuku Block and Ash" (Vucetich \& Wells 1978). It is here recommended that use of all these terms be discontinued in favour of Taupo Pumice Formation and Taupo Ignimbrite, which are defined below.

"Pumice" is retained in favour of the more general term "Tephra" in the formation name on the grounds of historical and current widespread usage. For similar reasons, the names Taupo Lapilli and Rotongaio Ash retain size connotations, although for Rotongaio Ash no material coarser than ash grade has been found.

The stratigraphy of Taupo Pumice Formation is revised and each member is described in relation to a type section and reference sections. Location of the source vent, erupted volumes, and the date of the eruption are discussed.

Exceptional preservation of Taupo Pumice was probably aided by a dense forest vegetation that was apparently re-established soon after devastation. Numerous sections through the tephra sequence are provided by road cuts, especially in new forest areas, but few sections expose the full stratigraphy near the source where the beds are thickest. Location and description of a type section for Taupo Ignimbrite has consequently been difficult, and the designated type section although visible is now virtually inaccessible. 


\section{Previous work}

Taupo Pumice was first descibed by early explorers such as Dieffenbach (1843, p. 128), Wakefield (1845, p. 236$)$, and Taylor (1855, p. 225$)$ and was believed to have been erupted from Tongariro volcano,

Many early writers (e.g., Smith 1877) acknowledged Tongariro as a possible source and considered most of Taupo Pumice to be water lain in extensive lakes. Evidence of horizontal beds and extensive, flat terraces were cited. Cotton (1922, p. 204) assumed an alluvial origin, as did Grange $(1927,1931,1937)$ in a series of papers dealing with the geology and soils of the central North Island. Grange described Taupo pumice as "sands" overlying coarser pumice which he distinguished from the older Taupo showers. He also considered much of the pumice to be water lain, but as alluvium redeposited soon after subaerial emplacement. Grange also examined the charcoal, abundant in Taupo Pumice, and concluded that charring was by coking after burial, at a minimum temperature of $250^{\circ} \mathrm{C}$ (Grange 1927). Grange was the first to place the source vent within the northeast area of Lake Taupo.

Detailed stratigraphy of Taupo Pumice was first described by Baumgart (1954) from a now disused quarry, where he identified and numbered 8 members and named 3 (Taupo Lapilli, Rotongaio Ash, and Hatepe Lapilli). Subsequently, Baumgart \& Healy (1956) named a further bed, Rhyolite Block Member. Healy (1964) retained Baumgart's numbers in describing the road section at De Bretts Hotel (N94/573353*) and placed the beds within Taupo Subgroup, as part of Arawa Group. He named the upper 8 beds from oldest to youngest as Hatepe Lapilli, "putty" coloured ash, Rotongaio Ash, Taupo Lapilli, Rhyolite Block Member, and Upper Taupo Pumice Members. The youngest was regarded as "glowing avalanche" deposits extensively redeposited as alluvium, and the rest as airfall in origin.

In their revision of Taupo Holocene tephras, Vucetich \& Pullar (1973) attempted no further extension of Healy's work, concentrating on the older deposits.

Baumgart (1954) published the first iospach maps for Taupo Lapilli, Rotongaio Ash, and Hatepe Lapilli. These maps were extended beyond the Taupo area by Vucetich \& Pullar (1964) who also plotted isopachs for "Upper Taupo Pumice Members" and "putty coloured ash". A map of all members combined was compiled by Pullar (1973).

\footnotetext{
* Grid references are based on the national thousand-yard grid of the 1:63 360 topographical map series (NZMS1).
}

Although much has been published on the chemistry and mineralogy of Taupo Volcanic Zone rhyolites, little attention has been paid to the tephras. Hochstetter (1864) confirmed the presence of quartz and feldspar in the pumices, and Grange $(1927,1931,1937)$ reported chemical analyses as related to soil studies.

Ewart (1963) systematically examined the Taupo sequence (after Baumgart 1954) for mineralogy and glass chemistry, but the stratigraphic context of his samples is now in doubt (Vucetich \& Pullar 1973, p. 747). Kohn (1970, 1973) and Topping \& Kohn (1973) reported analyses of titanomagnetites, and later Kohn \& Topping (1978) used these analyses to infer a mechanistic relationship between Holocene andesite and rhyolite eruptions.

\section{TERMINOLOGY AND DEFINITIONS}

Tephra is used to include all primary pyroclastic deposits of airfall or flow origin as defined by Howorth (1975). Ash, lapilli, and blocks are used to describe grainsize, after Fisher (1960). Tephra formation (rhyolitic) is a bed or sequence of beds deposited as part of the 1 eruptive event and separated from enclosing tephras by a paleosol. These paleosols define the top and base of the formation.

Type section and Type area are defined by the criteria established by Vucetich \& Pullar (1973). A plinian eruption is loosely defined as "a gas-blast eruption of great violence" (Lirer et al. 1972, p. 759) after the type example eruption of Somma-Vesuvius in A.D. 79 as described by the Roman scholar Pliny the Younger (see for instance Bullard 1962). The fall deposit produced by a plinian eruption is generally coarse, well-sorted pumice ("plinian pumice") arbitrarily classified by Walker (1973) on size and distribution of the pumice. Ignimbrite is here defined as all the primary deposits formed from pyroclastic flows, and is the product of 1 eruptive sequence commonly consisting of several flows. Welding of the ignimbrite, when it occurs, is a postdepositional effect and is not implicit in this definition; it is a logical extension to the general case of Marshall's (1934) genetic definition, covering the possibility of the ignimbrite failing to weld. This usage of ignimbrite emphasises the pyroclastic flow origin rather than the welding phenomena and is now commonly accepted (see, for instance, Sparks \& Wilson 1976; Wright et al. 1980; Walker et al. 1981a). In contrast to the sorted nature of plinian tephras, unwelded ignimbrites are commonly unsorted, matrix supported, and rich in fine ash. 


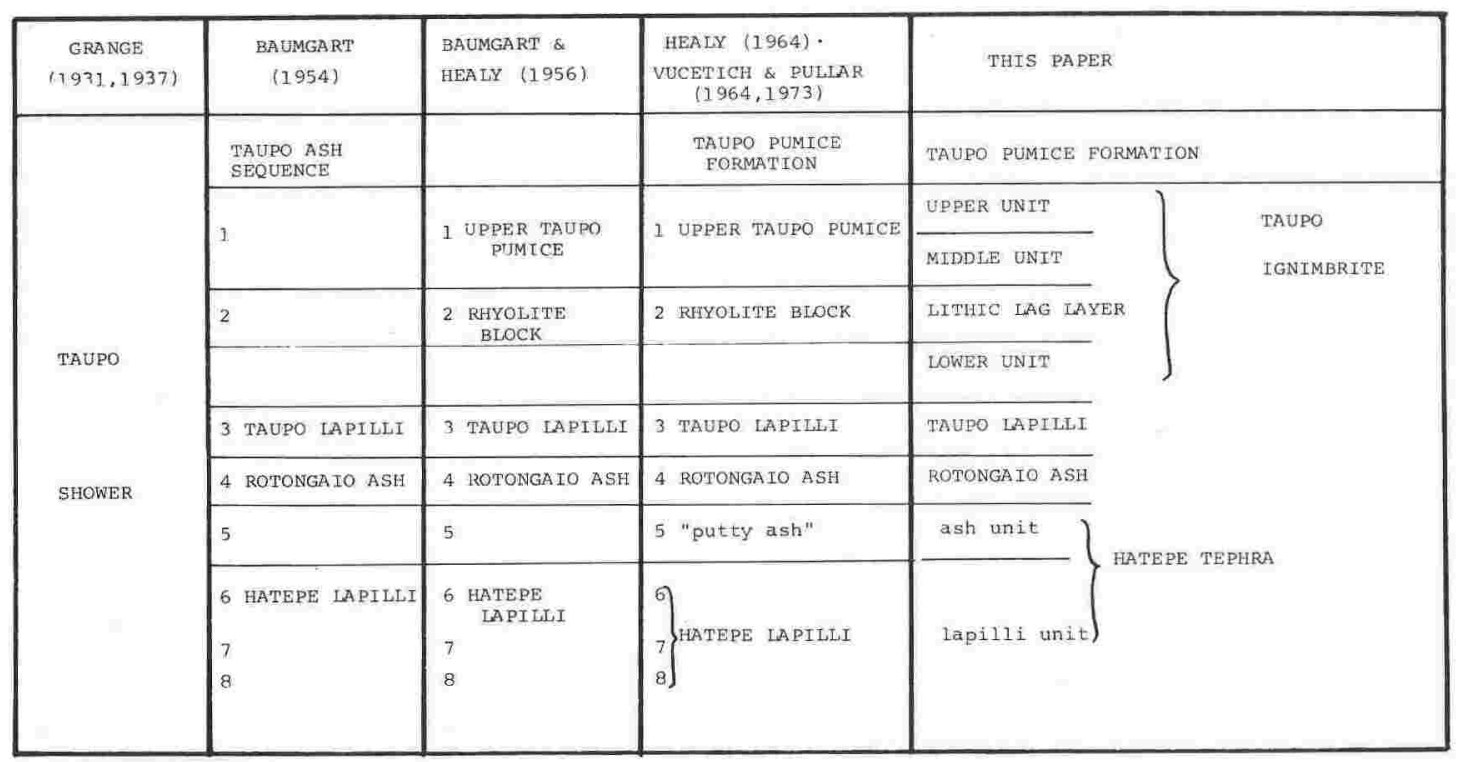

Fig. 1 Stratigraphy and nomenclature used in this paper compared to that of previous workers.

\section{TAUPO PUMICE FORMATION STRATIGRAPHY}

The stratigraphy of Taupo Pumice as presented here is a revision of that of Healy (1964) with some changes in terminology and the inclusion and definition of Taupo Ignimbrite. From oldest to youngest the members are defined as Hatepe Tephra, Rotongaio Ash, Taupo Lapilli, and Taupo Ignimbrite. Each of these is described and designated a type area and type section. Taupo Ignimbrite is described in terms of 3 units, the Lower ("pink") unit, the Middle unit forming the main body of ignimbrite, and an Upper ("bedded") unit. Each unit is described in relation to 3 lithofacies. Stratigraphy of this paper is compared to that of previous workers in Fig. 1.

\section{TAUPO IGNIMBRITE}

\section{Type section}

Taupo Ignimbrite in the type area consists of all the primary pyroclastic deposits overlying Taupo lapilli or those deposits occupying an equivalent stratigraphic position where Taupo Lapilli is absent. The ignimbrite comprises all the primary products of the pyroclastic flows that succeeded eruption of Taupo Lapilli. The area is a sector from northeast to southeast within a radius of $10 \mathrm{~km}$ of Taupo Borough, and the type section is an almost inacessible cliff beside Hatepe River (Fig. 2,
N103/569230) described in section 1, Appendix 1. Only 1 accessible section is known that conclusively demonstrates the full stratigraphy of Taupo Ignimbrite; it is a road cut on Te Heuheu Road (N103/488161), and preservation is doubtful. Further reference sections are nominated and described at localities where each unit is best developed and exposed and can be stratigraphically correlated to the type section.

\section{General description}

Taupo Ignimbrite (=Upper Taupo Pumice Members of Healy 1964) consists of all the primary deposits immediately overlying Taupo Lapilli and found over a roughly circular area of about $80 \mathrm{~km}$ radius, centred on Lake Taupo. Thickness ranges up to $100 \mathrm{~m}$ or more, the deposits always being thickest in valleys and thinning rapidly up slopes and ridges. The ignimbrite shows no systematic variation of thickness with distance from the source, unlike most other pyroclastic deposits. This deposit exhibits a remarkably wide variation in nature, which has led many people to postulate several different sources and extensive redeposition by mudflow and fluvial means (Grange 1937; Grindley 1960; Healy 1964).

Three pyroclastic flow units are recognised in Taupo Ignimbrite. The relationship and distribution of each of these units is shown schematically on Fig. 3 which also portrays important changes due to topography and distance from the source. 


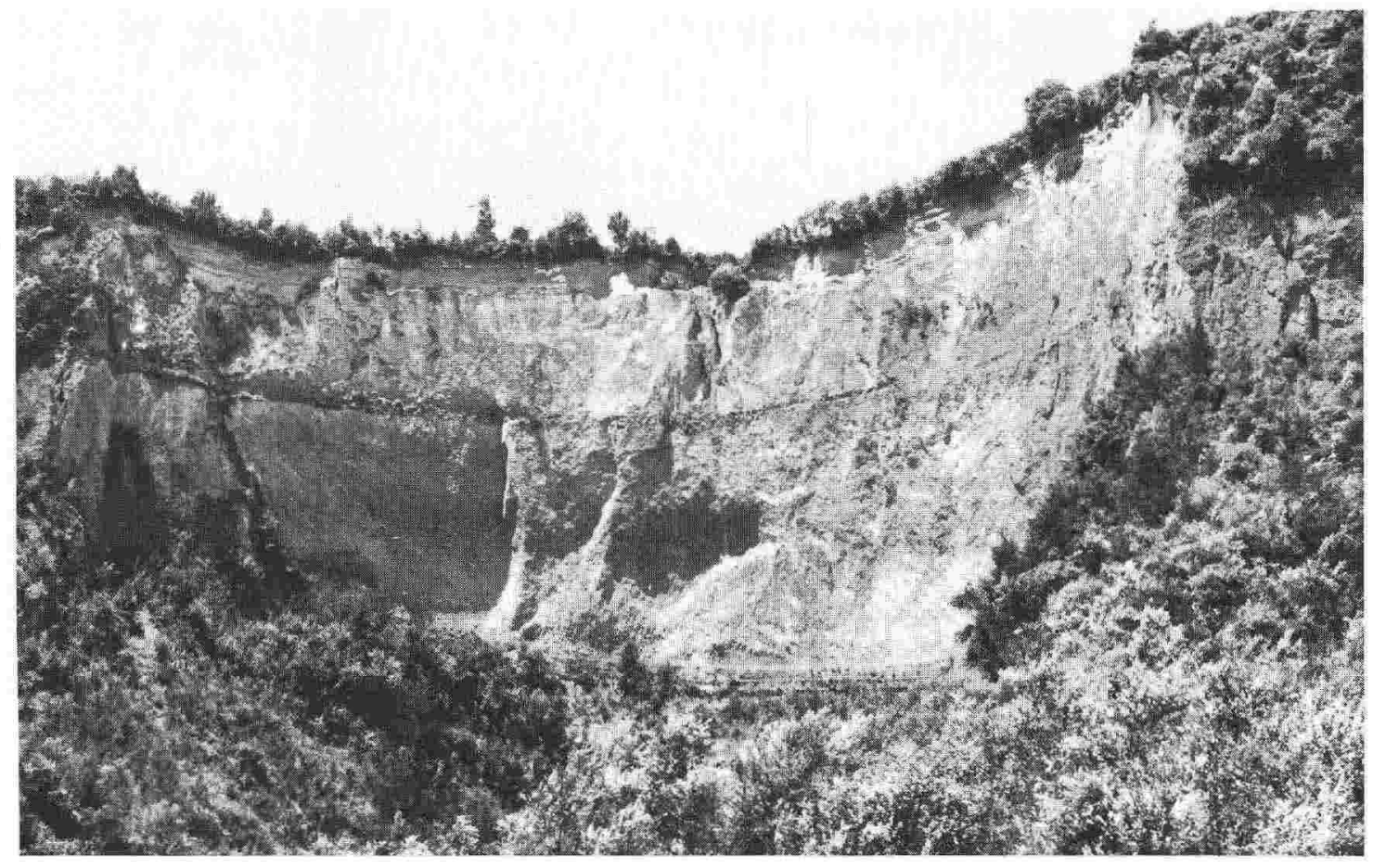

Fig. 2 Type section for Taupo Pumice Formation beside Hatepe River at N103/569230 (section 1). The bedded Upper unit at the top can be seen overlying the Middle unit, the lithic lag layer, and the Lower unit, which overlies a bedded sequence of Taupo Lapilli and Rotongaio Ash. Total section thickness shown is about $40 \mathrm{~m}$.

The Lower unit is restricted in occurrence to a sector from northeast to southeast of Lake Taupo and consists of typically pink to red-brown unsorted pumice lapilli with occasional interbedded layers of better sorted coarse lapilli. The unit is generally very firm and massive and stands in vertical sections. Approximate extent of the Lower unit is shown in Fig. 3.

The Middle unit forms the main body of the ignimbrite and is remarkably widespread and of a highly variable character. Despite its variable nature, the unit can be grouped into 3 broad "lithofacies" described below, but each is distinctive and they form lateral stratigraphic equivalents. The facies grade laterally and sometimes vertically into each other, usually over a short distance. Each is considered to have been formed as a result of a particular flow characteristic of the pyroclastic flow. The vertical and lateral relationships of these facies within the Middle unit is shown schematically in Fig. 3.

The basal part of the Middle unit is commonly enriched in denser lithics and crystals relative to the upper parts. This lithic lag layer or "ground layer" of Walker et al. (1981a), described below, is the Rhyolite Block Member of Baumgart \& Healy
(1956) and has formed from the same pyroclastic flow that formed the Middle unit of Taupo Ignimbrite. The layer is considered diagnostic of the Middle ignimbrite unit, being found only at the base of this unit, and it is a valuable marker bed when present.

Overlying the Middle ignimbrite unit is a usually thin discontinuous sequence of interbedded flow and airfall material, some of which has subsequently been removed by erosion or obscured by soil formation. Thickness is typically $0.3-0.4 \mathrm{~m}$, but ranges up to $5 \mathrm{~m}$ or more (see section 3, Appendix 1). Two notable features are the extensive distribution of chalazoidites (accretionary lapilli) in the fine ash airfall beds and the occurrence of large pumice blocks up to $0.4 \mathrm{~m}$ diameter in unsorted units only $1 \mathrm{~m}$ thick. This unit corresponds to the coarse blocks often seen in the top of the ignimbrite, especially on Kaiangaroa Plateau to the northeast of Taupo.

\section{A pyroclastic flow origin for Taupo Ignimbrite}

Implicit in the term "ignimbrite" is an origin from a widespread pyroclastic flow. The following features have been observed in this deposit, are regarded as 


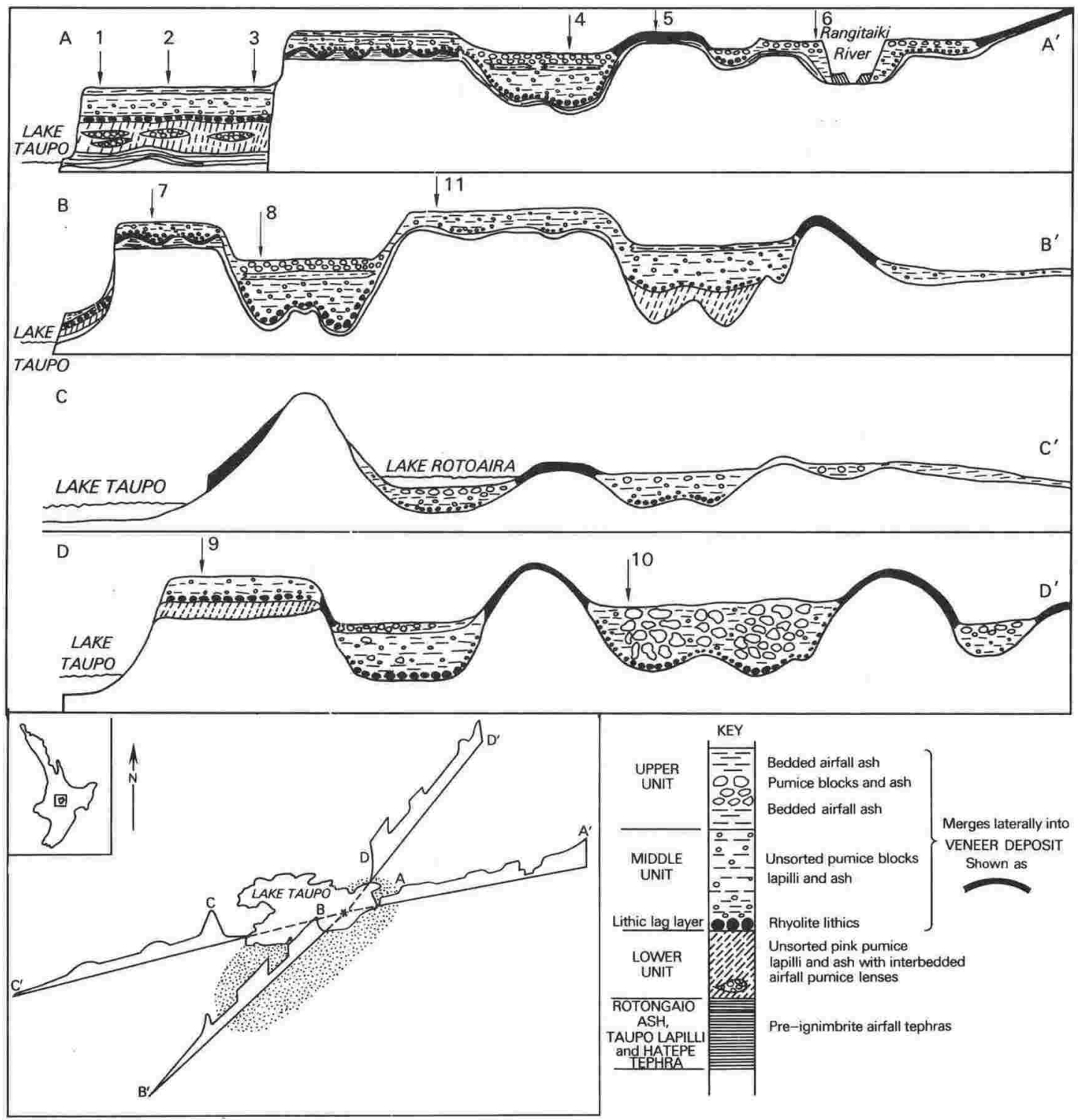

Fig. 3 Schematic cross-sections (not to scale) through Taupo Pumice Formation to show the relationship and distribution of each unit and facies of Taupo Ignimbrite as shown in the key. Thickness of Taupo Ignimbrite is largely topographically controlled with thick sequences in the valleys and thin "veneer deposits" on the ridges. Restricted occurrence of pumice alluvium is shown in the Rangitaiki River, Profile A. Stippled area on location map (upper right) indicates the approximate extent of the Lower unit. The numbered arrows refer to sections figured in the text or described in Appendix 1.

confirming a flow origin, and are generally inconsistent with other known eruptive mechanisms.

1. Highly variable thickness, grainsize, and sorting showing no regular relationship of these parameters with distance from the source, in contrast to the well sorted regular nature of plinian deposits.
2. In most sections the ignimbrite is completely unsorted with an abundance of pumiceous ash and large pumice clasts (i.e., matrix supported).

3. The ignimbrite does not conformably mantle the landscape, but smooths the topography by being thickest in valleys and rapidly thinning up 


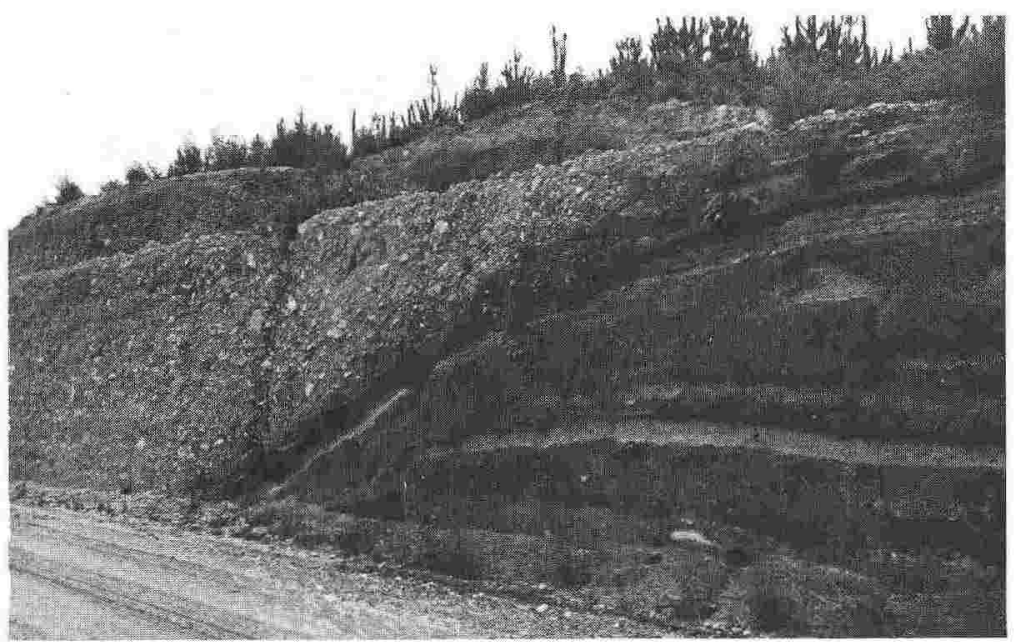

Fig. 4 Ignimbrite thins rapidly up slopes to maintain a near-level upper surface, shown here covering a ridge composed of older tephras at section 11, (N102/425080). Section thickness is about $3 \mathrm{~m}$.

slopes (Fig. 4), often with internal layering conformable with the base when on higher topography.

4. In most valleys the ignimbrite infills the valley floor forming a flat-topped aggradation surface of primary pyroclastic material (Fig. 5).

5. Near the source, occasional cross bedding and weakly developed duneforms within the ignimbrite on flat topography attest to deposition from a high velocity flow regime.

6. A smooth regular sloping basal contact consequent on widespread erosion and truncation of underlying beds (Fig. 6). This is not formed by wind or fluvial action, because the erosive products are not seen, except within the overlying bed (see 7 below).

7. Frequent incorporation of rounded clasts of older beds recognisable as Rotongaio Ash (Fig. 7) or older paleosols within the deposit (rip-up clasts), as evidence of widespread erosion.

8. Common occurrence of charcoal throughout the ignimbrite and not just at the base, charcoal being rare within plinian deposits.

9. Radial orientation of the charcoaled logs close to the source vent, and alignment parallel to the enclosing valley further away from the source (Froggatt 1980; Froggatt et al. 1981).

10. Marked segregation of dense lithic material towards the base of the Middle unit, forming the lithic lag layer.

11. Discontinuous nature of the basal lithic lag layer which is thickest in valleys and hollows and which can be best explained by deposition from a pyroclastic flow.

12. Vertical "pipes" composed of lithics and free crystals, which are features typically resulting from fluidisation (Wilson 1980).

\section{Ignimbrite facies}

Each unit of Taupo Ignimbrite is highly variable in thickness, grainsize, and sorting, with no apparent relationship of these parameters to distance from the source. However, there is a marked relationship with topography such that the distribution and appearance is almost totally topographically controlled. Apparently the pyroclastic flows which formed Taupo Ignimbrite were of high fluidity and high velocity so even small changes in the ground surface, or even forest cover, affected deposition from the flows.

Three lithofacies are used to describe the differing appearance of Taupo Ignimbrite: "valley facies" (VF), "fines-depleted facies" (FDF) and "ignimbrite veneer facies" (IVF). These facies are exceptionally well developed within the Middle ignimbrite unit, but the Upper and Lower units also show similar facies development.

Each facies is designated a reference section where the characteristics of the facies are particularly well developed and exposed.

\section{Valley facies (VF)}

VF is the typical unwelded, unsorted mixture of pumice ash, lapilli, and blocks found in valleys over a wide area of the central North Island. Reference section for VF is defined at Waitahanui River (N103/592177) where the deposit is $50 \mathrm{~m}$ thick (section 8 Appendix 1). The deposit is matrix supported due to an abundance of fine ash. Maximum grainsize varies markedly between sections and ranges from $0.01 \mathrm{~m}$ to $1 \mathrm{~m}$. The full thickness of VF is seldom exposed, and the deposit is thickest in valleys and thins rapidly upslope to grade laterally into IVF. Maximum exposed 


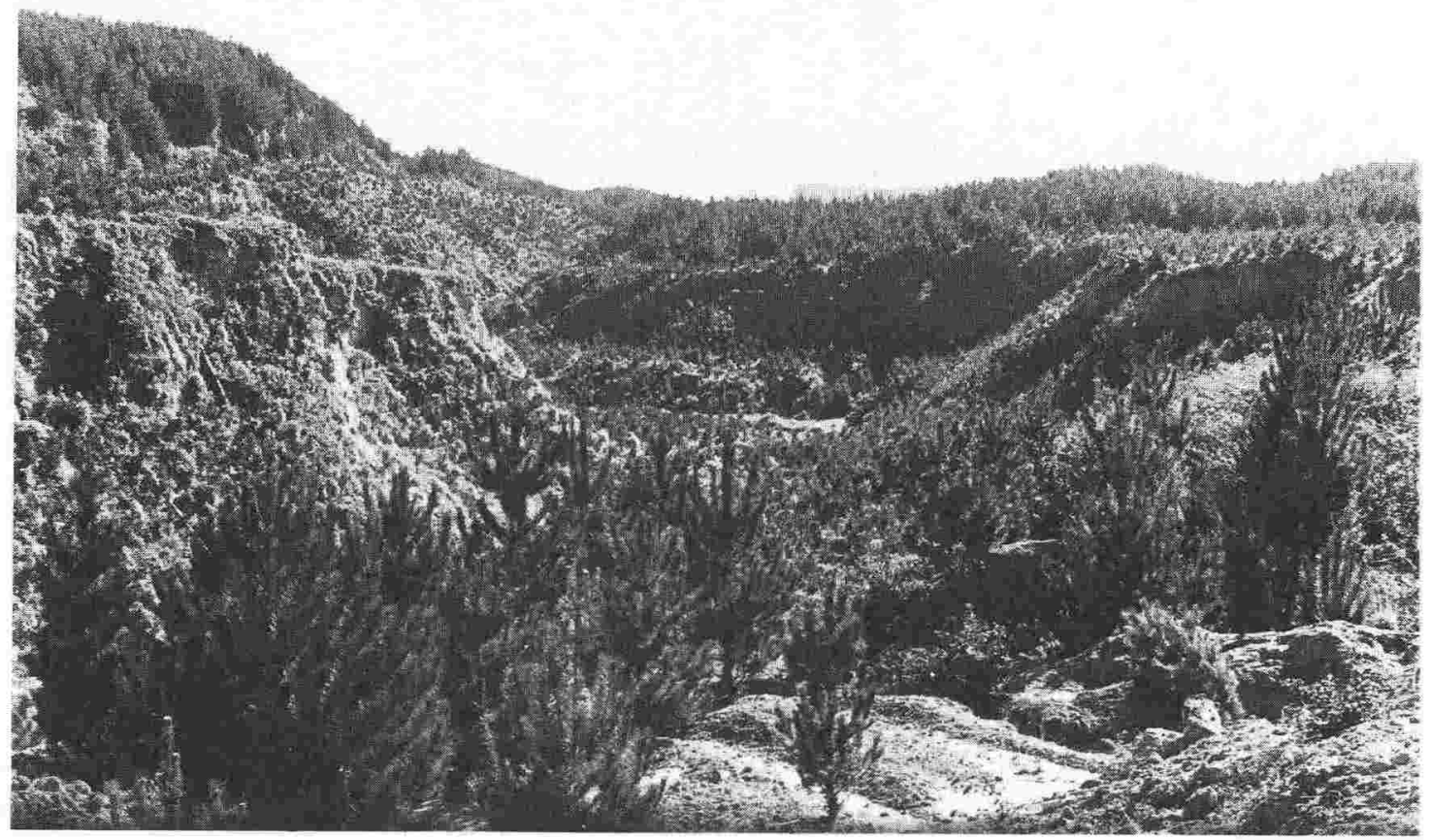

Fig. 5 A valley eroded into Taupo Ignimbrite at Maroa (N85/481625) accentuating the flat upper surface and the typical "box canyon" type of valley cut into this deposit.

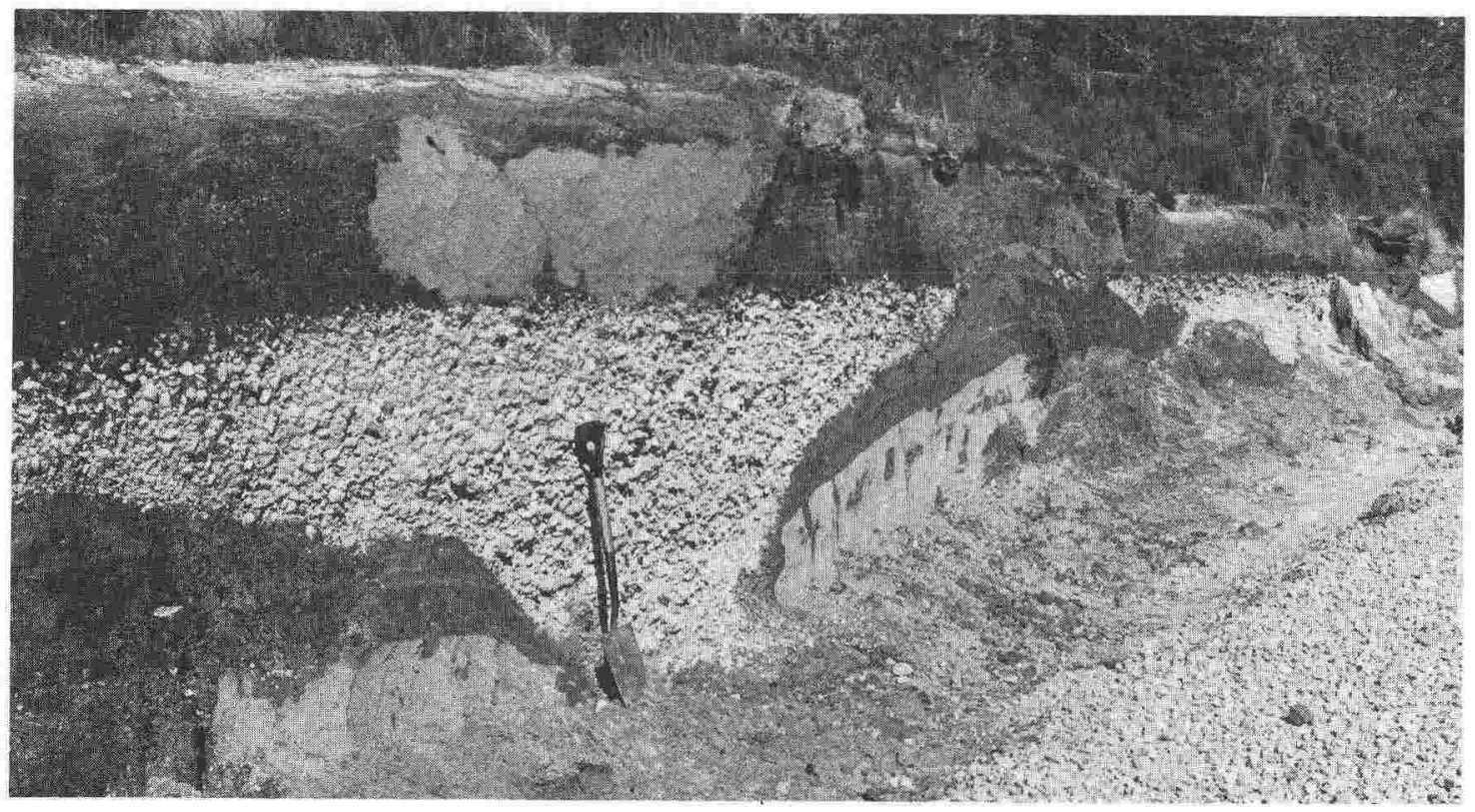

Fig. 6 Section 5 on Rotoakui Road (N103/662208) with thin "Ignimbrite veneer facies" (IVF) overlying Taupo Lapilli, Rotongaio Ash, and Hatepe Tephra. Note the strong erosion at the base of Taupo Ignimbrite and typical "rill" erosion in Hatepe Tephra mantled by Rotongaio Ash. Spade $1 \mathrm{~m}$ long. 
thicknesses are within the Taupo Ignimbrite type area, and are at least $100 \mathrm{~m}$ at White Cliffs (N103/509210). VF is the predominant facies of the Taupo Ignimbrite, and it is estimated as $>60 \%$ of the total volume.

This facies was formed by the pyroclastic flows "ponding" in valley floors and depressions thus producing a flat, near-horizontal upper surface (Fig. 2 , 5). This gives the facies a geomorphic resemblance to alluvium, especially in valleys where the dissected deposit resembles an aggradational terrace. Indeed, the terrace is aggradational, but has been built by pyroclastic flows and not a river. Alluvial pumice terraces can be distinguished from the ignimbrite terrace by being formed much lower in the present river valley. Today, the gradient on the ignimbrite terrace is often the reverse of the alluvial terraces. Alluvial terraces also have layers which often show cross-bedding in which lithics or sorted pumice clasts are concentrated, alternating with layers of compact fine ash with scattered lapilli. The elevation of the ignimbrite terrace is different for each valley system, and is directly controlled by

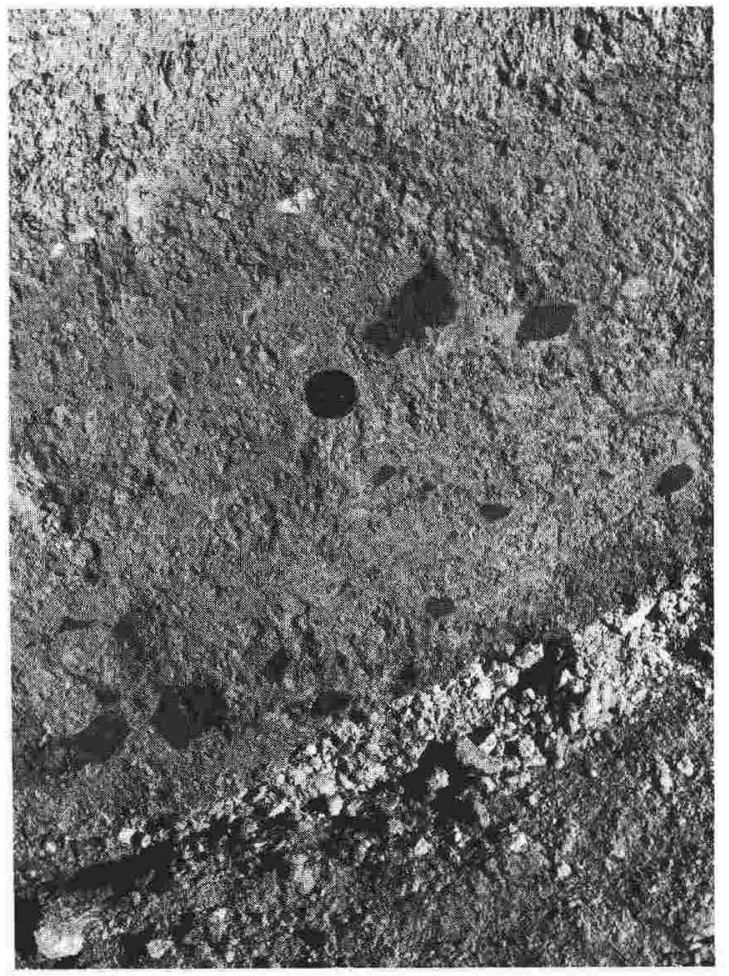

Fig. 7 Ripped up clasts of Rotongaio Ash within the basal part of Taupo Ignimbrite. A thin lens of Taupo Lapilli underlies the ignimbrite. Lens cap $50 \mathrm{~mm}$ diameter. (N103/522173). the volume of ignimbrite deposited in that valley and not by the local river base level. Charcoal is common in most sections of VF, usually as large or intact logs, but where found in pumice alluvium the charcoal has been broken into small rounded fragments.

\section{Fines-depleted facies (FDF)}

Within the Valley facies are pods of coarse, well rounded and highly porous pumice blocks lacking the usual fine ash matrix, and they are clast supported (Fig. 8). These pods grade both laterally and vertically into VF (see Fig. 2). They occur within about $40 \mathrm{~km}$ of the source and are generally found in the thickest, central part of the ignimbrite valley ponds. They vary from about $1 \mathrm{~m}$ to more than $10 \mathrm{~m}$ in lateral extent, and occasional discontinuous series of pockets extend up to $2 \mathrm{~km}$ across within the larger ponds. This block facies has been termed "Fines Depleted Ignimbrite" by Walker et al. (1980) who described this facies in detail and discussed the possible origin by engulfment of a moist forest and consequent extreme fluidisation and "flushing" out of the fine ash by the produced gas.

The most extensive area of FDF occurs within the large Maroa basin pond and in the valley floors east of Lake Taupo. A reference section for FDF is defined at a road cutting within Maroa basin (N85/527707) where this facies is well exposed.

FDF differs from an airfall deposit by being coarser grained, and from VF by being depleted in fine ash. FDF also differs from the coarse blocky top of the ignimbrite by being clast supported.

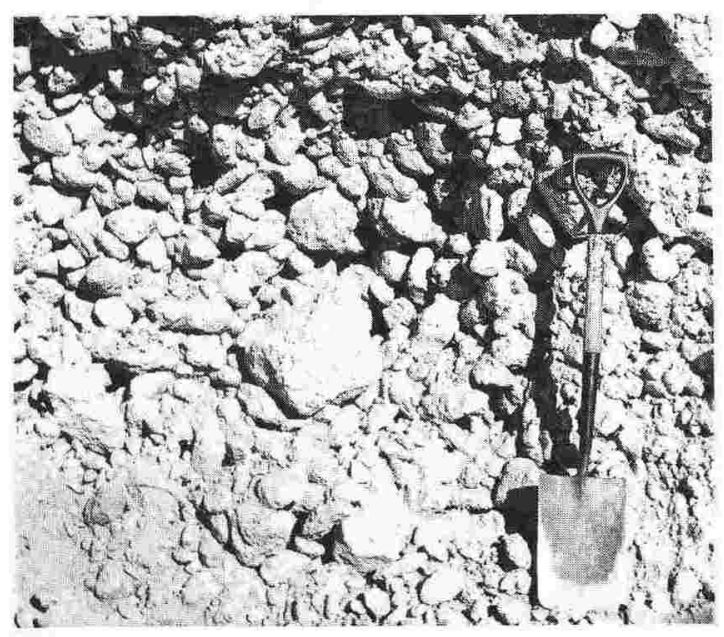

Fig. 8 Fines-depleted facies at section 10 on State Highway 1 (N85/526708). Note absence of fine ash, clast supported nature, and partial rounding of clasts. Spade $1 \mathrm{~m}$ long. 


\section{Ignimbrite veneer facies (IVF)}

As shown on Fig. 3 and 4, the thick valley filling deposits of Taupo Ignimbrite become thinner and apparently finer grained upslope, merging laterally into a compact ignimbrite facies that conformably mantles higher topography with a thin "veneer" of ignimbrite (Fig. 6). This "Ignimbrite Veneer Deposit" of Walker et al. (1980) records the passage of a thinner, more dilute part of the main pyroclastic flows. Lithic content is lower and the deposit lacks the pumice lapilli and blocks, compared with VF. The reference section for IVF is at the De Bretts section (N94/573353) where the deposit is up to $3 \mathrm{~m}$ thick (see Vucetich \& Pullar 1973).

Within about $20 \mathrm{~km}$ southeast of the source, IVF often contains pockets of well-sorted pumice lapilli and blocks concentrated in lenses and arranged on the down-vent side of small topographic obstacles. These pockets occur in the Upper unit, overlying the Middle unit (see Fig. 2). Walker et al. (1980) described these lenses as resulting from a high velocity laminar flow, and although they considered the lenses also formed on flat topography near the source, no conclusive examples have been seen by this author.

IVF is areally the most extensive facies of Taupo Ignimbrite and forms about 50\% or more of the total area, but only $30 \%$ of the total volume. This facies is readily identified by a position on higher topography above valley ponds and by a compact fine ash nature with no pumice lapilli (except discontinuous lenses of lapilli within $20 \mathrm{~km}$ of the source).

\section{Descriptions of units of Taupo Ignimbrite}

\section{Lower unit}

Reference section for the basal "pink" unit is on a forestry road cutting $2 \mathrm{~km}$ east of Waitahanui at N103/565260. Longterm preservation of this section is doubtful so an additional reference section on State Highway 1 at N94/560350 is also described, (sections 2 and 9 respectively, Appendix 1).

This unit has not previously been identified with the Taupo Pumice sequence, but has been grouped with Waitahanui Breccia (Grange 1937; Grindley 1960). Because of the stratigraphic uncertainty of Waitahanui Breccia, being in part Taupo Pumice, Waimihia Tephra Formation, and Oruanui Breccia, it is recommended that the term Waitahanui Breccia lapse.

The Lower unit, immediately overlying Taupo Lapilli, is predominantly unsorted pumice ash and lapilli with interbedded lenses of plinian pumice. It is characteristically pink to red-brown within the type area. Pumice lapilli and blocks are red throughout, indicating emplacement at a high temperature and slow cooling. Beyond the type area, the basal unit is yellow-white and distinguishable from the Middle unit by lacking a lithic lag layer. No such lag layer has yet been identified within the Lower unit. As with all ignimbrites, thickness is highly variable and ranges from 5 to 40 $\mathrm{m}$ within the type area. Thin pumice lapilli lenses, identical in appearance to the plinian Taupo Lapilli, vary in number, thickness, and extent and are attributed to alternating deposition of plinian pumice and ignimbrite before the pyroclastic flow phase became fully developed.

Within the type area the Lower unit is generally very firm and compact, but no indication of welding is seen. Old exposures have developed a firm crust or silica-cemented "skin" that helps the sequence to stand in prominant vertical cliffs and gives exposures an appearance of old age, as seen south of Taupo and especially east of Hatepe at Hinemaiaia River. Beyond the type area the Lower unit has been mapped north to Mapara Road (N94/495352) and south to Waimarino Road (N102/356058). At these sites the lithic lag layer separates 2 ignimbrite units of similar thickness (c. $3 \mathrm{~m}$ ) and appearance. Lack of exposure beyond these localities has restricted further mapping of this unit. However, emplacement by a pyroclastic flow of limited volume means these deposits are restricted to low-lying valley floors about the source, and they have been obscured by the succeeding pyroclastic flow deposits.

\section{Middle unit}

Middle unit of Taupo Ignimbrite appears to be the most extensive and voluminous of the 3 ignimbrite units, and has the most diverse lithologies. This unit is the major valley-filling deposit. The field appearance is best described by use of the 3 facies detailed above as they are exceptionally well developed in this unit. The interrelationship of all 3 facies is shown schematically on Fig. 3 for 4 radial transects.

Discontinuously underlying Middle unit is a thin layer of lithics and crystals-the "lithic lag layer" described below. This layer has only been recognised beneath the Middle unit and is considered diagnostic.

No separate reference section is proposed for the Middle unit as the sections described for each facies will suffice. Stratigraphic position is shown in the type section (section 1, Appendix 1).

North and west of Lake Taupo, Middle unit appears to be predominant over the other units, but east of Lake Taupo the Middle and Upper units predominate. South of Turangi a few sections show 2 units, and absence of the lithic lag layer between them suggests the presence of the Middle and Upper units. In many sections, however, conclusive evidence for identification of the units is absent. 


\section{Lithic lag layer of Taupo Ignimbrite}

Baumgart \& Healy (1956, p. 118) recognised that their Rhyolite Block Member was "an unusual type of shower". When well developed, the layer consists almost entirely of lapilli and blocks of banded and spherulitic rhyolite, obsidian, with minor andesite, mudstone, welded ignimbrite as well as occasional pumice. Carbonised tree material is abundant throughout, lying flat, but seldom seen at the base. Orientation of many of these charred logs is radial about the source (Froggatt 1980; Froggatt et al. 1981). Upper and lower contacts are strongly erosional and the upper is generally planar, even on irregular terrain.

The layer is discontinuous and highly variable in thickness over short distances. On irregular terrain, it almost entirely fills small hollows between ridges, while on more gentle terrain it thins and becomes finer grained upslope. Within $10 \mathrm{~km}$ of the source, blocks up to $3 \mathrm{~m}$ across and estimated to weigh 2-5 $\mathrm{t}$ are frequently found within the lag layer. They do not indent the underlying surface as would be expected if they fell ballistically into place. They are usually whole, but completely fractured, suggesting they did not impact and then bounce, otherwise they would have distintegrated, especially the more fragile mudstones. Maximum size of the lithics in the ground layer shows an overall decrease away from the source (Walker et al. 1981a), as do most pyroclastic products, but the distance that each maximum lithic size extends (e.g., $40 \mathrm{~km}$ for $50 \mathrm{~mm}$ lithics) is far greater than any known airfall lithic.

Considering the above features, origin of the lithic layer is best explained by simple sedimentation or gravity separation of the dense lithics from a pyroclastic flow. This model and the nature of the bed are discussed in detail by Walker et al. (1981a), who proposed an origin by sedimentation of lithics from the more highly fluidised nose of a pyroclastic flow. Sparks \& Walker (1973) considered the origin was from a type of pyroclastic surge preceding the ignimbrite-forming pyroclastic flow, but there is strong evidence against this origin for the layer in Taupo Ignimbrite.

\section{Upper bedded unit}

Over much of the Taupo Pumice type area the Middle ignimbrite unit is overlain by up to $8 \mathrm{~m}$ of the Upper bedded unit. Reference section for these beds is within Waimihia Forest on Straight Line Road (N103/621244) and is described in section 3, Appendix 1 and Fig. 9. The unit grades up from the Middle ignimbrite unit into a $0.45 \mathrm{~m}$ bed of uniform fine ash with common chalazoidites (accretionary lapilli), and these are assumed to indicate an airfall origin. This bed is overlain by alternating thin beds of flow and airfall origin. The lowermost of these

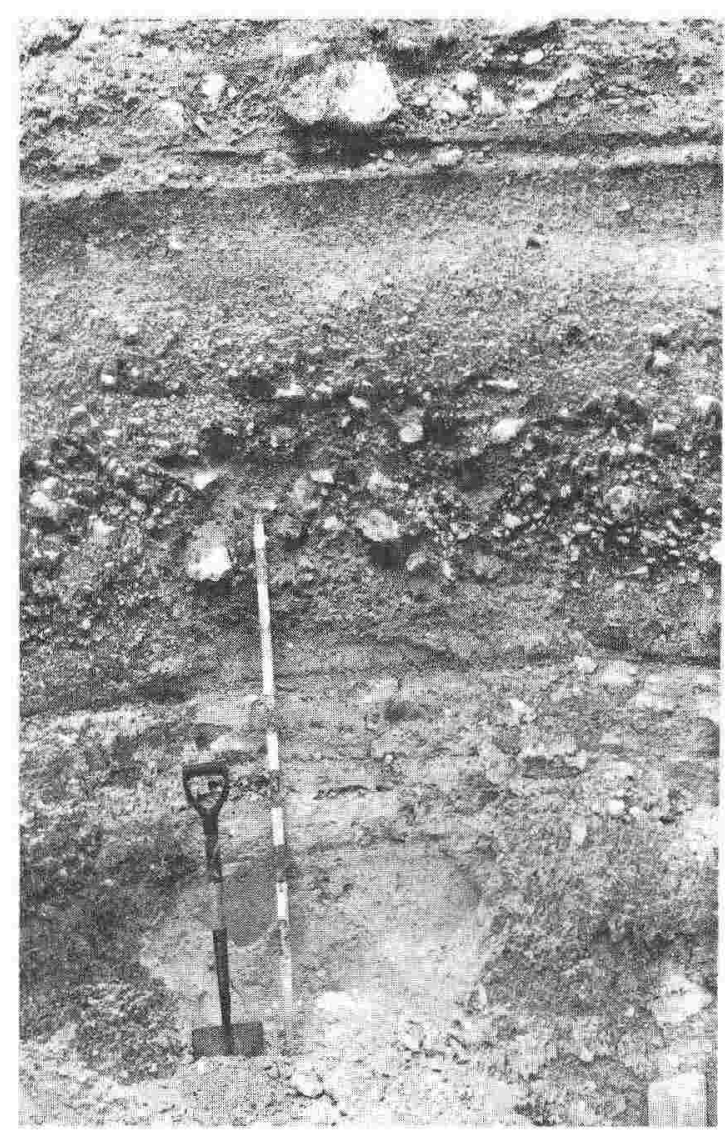

Fig. 9 Lower part of section 3 (N103/621244), reference section for the Upper unit of Taupo Ignimbrite. The top of the Middle unit is at the bottom of the photo and is overlain by bedded fine ash with chalazoidites which is overlain by the lower of several thin layers of flow-tephra. Scale marked in $0.2-\mathrm{m}$ divisions.

beds has common erosional channel fill and low angle cross-bedding features similar to surge deposits. Similarly, the uppermost of these beds has, at the reference section, numerous large pumice blocks in a coarse ash-lapilli matrix, an undulating, "dune-like" upper boundary, and internal bedding that may also be of surge origin or due to very high flow velocities.

Each of the fine ash layers intervening between the flow or airfall lapilli has numerous chalazoidites, indicating a short time interval between deposition of each bed. The ash in these beds was probably "flushed" out of the atmosphere by rain, and a few sections show evidence of contemporary erosion. Fisher (1979) has described a similar sequence of beds overlying the Bandelier Tuff in New Mexico to which he ascribes a surge origin. 
Fig. 10 A collapse feature interpreted as a gas vent within the top of the Middle unit. Collapsed layers of fine ash are chalazoiditebearing beds of the Upper unit, which indicates a time interval during deposition of the beds within the Upper unit. Section at N103/678226 (section 4). Spade 1 $\mathrm{m}$ long.

Fig. 11 Section 6, a road cutting through the upper part of Taupo Ignimbrite, beside Rangitaiki River (N94/1862328). Coarse blocky top with sharp lower contact correlates to the Upper unit and is particularly common at the southern part of Kaiangaroa Plateau. Spade $1 \mathrm{~m}$ long.
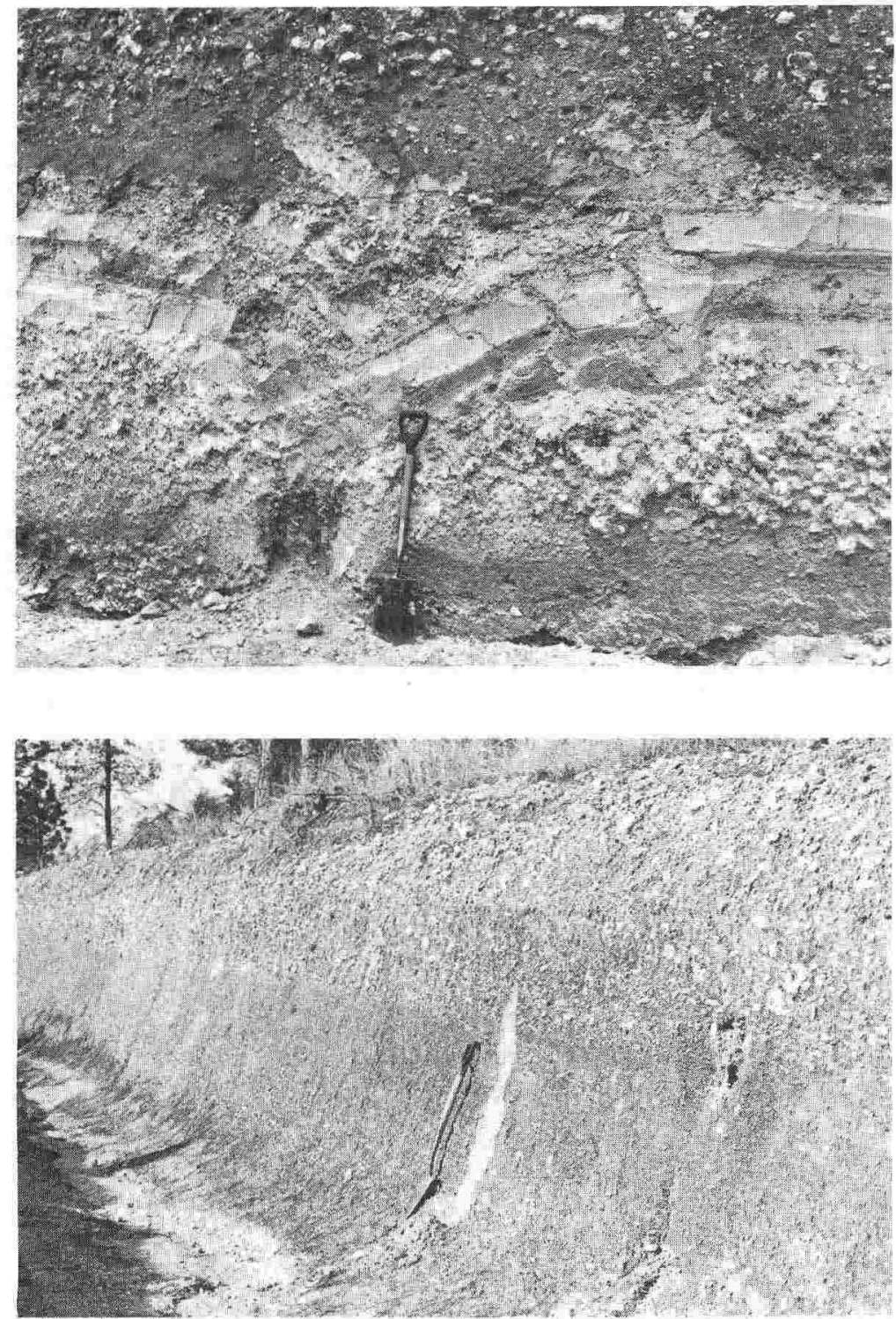

West (lakeward) of the reference section, exposures of the Upper unit are rare and in these, the fine ash, chalazoidite-bearing beds predominate. Eastward, beyond the Kaiangaroa Ignimbrite scarp (Kaiangaroa Fault of Grindley 1960) the Upper unit extends beyond Iwatahi where fewer of the airfall beds are present and the coarse pumice blocks predominate. One road cut exposure (N103/678226), now destroyed (section 5) showed a time relationship between the Middle unit and the Upper unit deposits. This section had a well developed "gas vent" or fumarole structure (Fig.
10) infilled by the overlying bed and into which the fine ash layers had collapsed.

Beyond the type area the ignimbrite commonly has a coarse blocky top with a distinct lower contact (Fig. 11) which is here correlated with the Upper unit. This coarse blocky top was described by Vucetich \& Pullar (1964, fig. 15) as Tsg 1a at a section near Mihi. Subsequently, Vucetich \& Wells (1978), impressed by the common occurrence of this bed north of Taupo, named it Ngautuku Block and Ash and inferred a local source. 


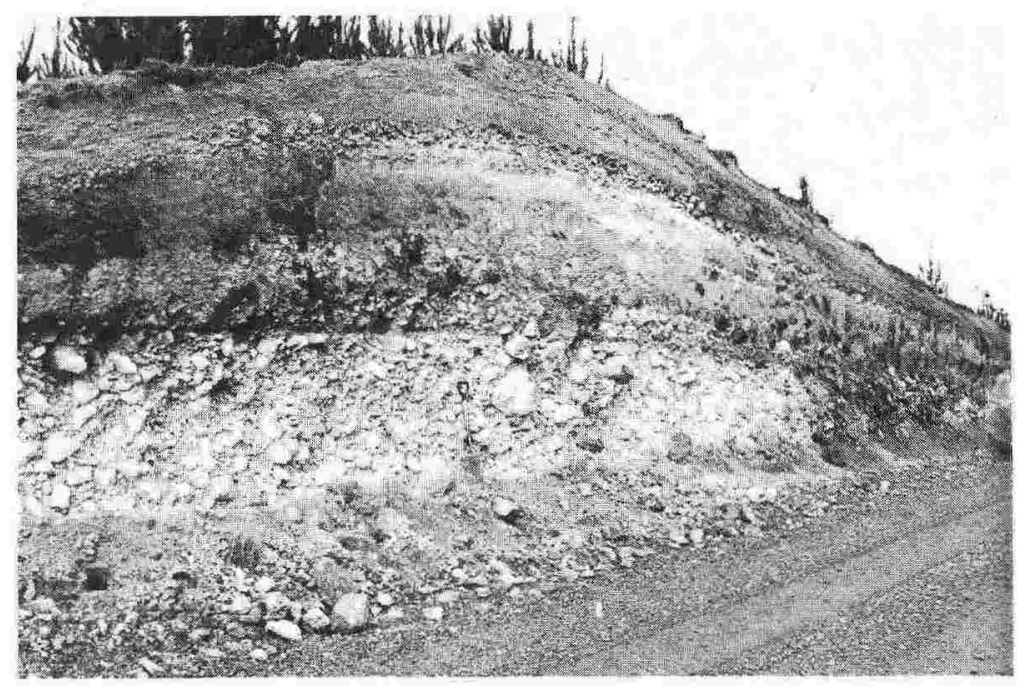

Fig. 12 A roadcut on Hingapo Road (N103/858330) with Taupo Ignimbrite Middle unit overlain by the Upper unit (veneer facies) containing lenses of pumice lapilli on the down-vent side. Spade $1 \mathrm{~m}$ long.

South of the type area, the Upper bedded flow sequence has been mapped to Hingapo Road (N103/858330, Fig. 12) where it is confined to the valley floors, further indicating a flow origin. A thick sequence exposed at Waikato Falls (N112/306838) has 2 flow units separated by fine, bedded ash. Absence of a lithic lag layer establishes these as the Middle and Upper units only. Possibly much of the coarse, blocky ignimbrite south of Turangi and about Lake Rotoaira is the Upper unit also.

Elsewhere within the Taupo area, a thin layer of fine ash often mantles the ignimbrite, including the blocky upper part, with occasional chalazoidites demonstrating the airfall nature of this bed. Sparks \& Walker (1977) described a similar layer which they termed "co-ignimbrite airfall ash", found overlying ignimbrite and constituting up to $50 \%$ of the erupted volume. For Taupo Ignimbrite, however, the volume of this airfall ash is small, probably not more than $5 \%$ of the total.

\section{TAUPO LAPILLI (TL)}

Throughout the type area between Taupo, Hatepe, and Iwatahi, and at the De Bretts type section, Taupo Lapilli occurs as a uniform, well sorted pumice lapilli and block bed up to $2 \mathrm{~m}$ thick. Pumice clasts are moderately vesicular (60-75\% porosity), yellowish white, and extremely angular. When broken, some of the largest blocks have bright pink interiors, apparently due to retained heat. Over all of the type area, varying amounts of Taupo Lapilli have been eroded by the succeeding pyroclastic flows which formed Taupo Ignimbrite (see Fig. 6), so that the true thickness of Taupo Lapilli is never seen.

Taupo Lapilli is the most widely spread member of Taupo Pumice Formation being found over most of central North Island. It has been recorded in Waikato Basin (Grange \& Taylor 1939; Pullar 1967; Tonkin 1967); in cores taken $90 \mathrm{~km}$ offshore in Bay of Plenty (Kohn \& Glasby 1978) and $90 \mathrm{~km}$ offshore in Hawke Bay (Lewis \& Kohn 1978); at Poukawa, south of Hastings (Froggatt \& Howorth 1980) and within loess in Wairarapa (A. Palmer pers. comm. 1980).

\section{ROTONGAIO ASH (Rt)}

Rotongaio Ash is a characteristic dark steel-grey to black, fine to coarse ash unconformably overlying Hatepe Tephra and conformably overlain by Taupo Lapilli. Type area is east of Lake Taupo between Taupo and Hatepe, with the type section at De Bretts. Rotongaio Ash is a finely and regularly bedded (laminated) fine ash with a persistent coarse ash layer up to $50 \mathrm{~mm}$ thick occurring one-third of the total thickness above the base. Nearly all the ash material is composed of fresh, glassy, non-hydrated obsidian, full of microlites and small inclusions; these produce the dark grey colour. Vesicular material is scarce, and free crystals of feldspar and hypersthene are rare.

Rotongaio Ash is remarkably widespread for such a fine grainsize, and is found from Turangi to Whakatane and across to Gisborne. Even when in small "balls" no more than $2 \mathrm{~mm}$ thick, Rotongaio 
Fig. 13 Slightly weathered section of Rotongaio Ash mantling the regularly undulating, eroded top of Hatepe Tephra and overlain by Taupo Ignimbrite. Section 7 on Hinemaiaia Hydro Road (N103/545175). Spade $1 \mathrm{~m}$ long.

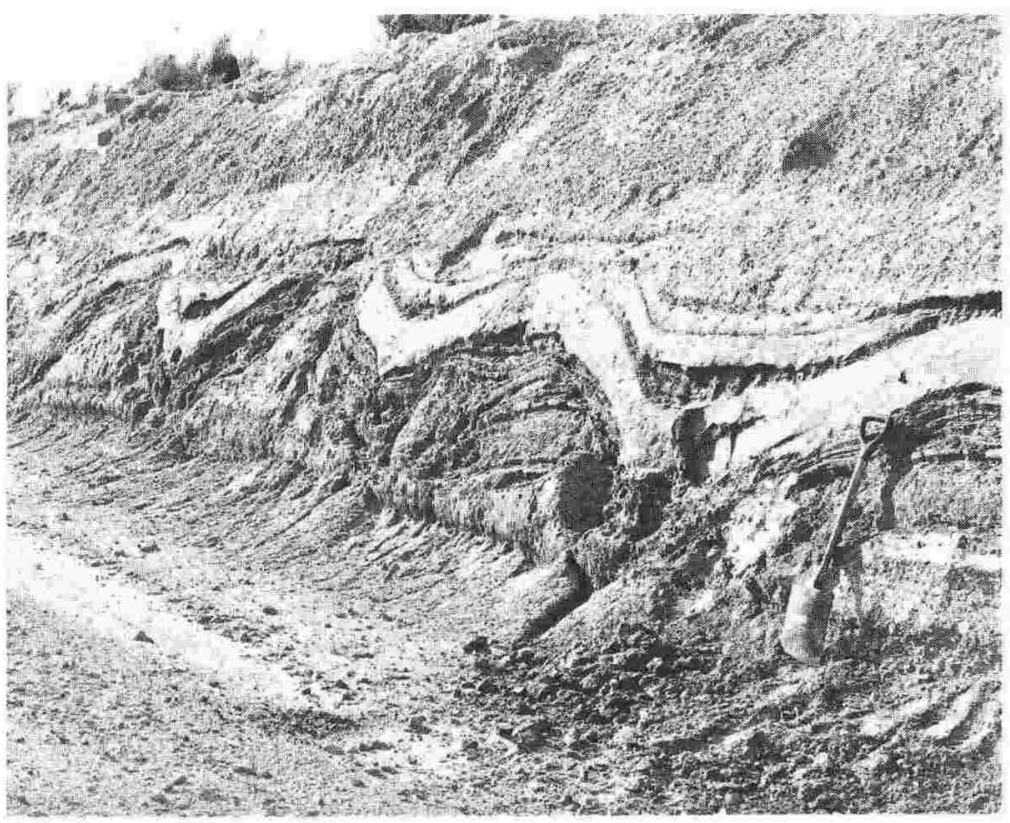

Ash is still recognisable due to the dark grey colour contrasting with surrounding white ash. This makes Rotongaio Ash an important diagnostic of Taupo Pumice Formation over a large area of the central North Island.

Extensive distribution and overall fine ash nature suggest an unusual mode of eruption. Consequently, Rotongaio has been described as one of the type examples of "phreatoplinian" eruptions (Self \& Sparks 1978), resulting from the reaction of silicic magma and water.

\section{HATEPE TEPHRA (Ht)}

Hatepe Tephra is the oldest of the Taupo Pumice sequence, being the ash and lapilli beds paraconformably overlying the paleosol on Mapara Tephra and overlain by Rotongaio Ash at the type section.

Type area is southeast of Taupo between Hatepe, Taupo, and Iwitahi. Type section is at De Bretts, but good exposures are seen on the road leading down to the Hinemaiaia power stations (e.g., N103/548174).

Hatepe Tephra comprises a coarse pumice lapilli lower bed (lapilli bed) conformably overlain by uniform fine white ash with scattered pumice lapilli (ash bed). In some sections within the type area, a thin (up to $0.1 \mathrm{~m}$ ) uniform fine ash underlies the hasal lapilli. The lapilli bed shows no grading and only minor or rudimentary shower bedding. Pumice in this bed is white or pale yellow, well sorted, angular, and moderately vesicular (porosity 60 $70 \%$ ). Lithic clast content is moderate at less than $10 \%$ with the clasts being predominantly banded spherulitic rhyolite with minor obsidian. Free crystals, mainly plagioclase and minor hypersthene, constitute about $2 \%$ of the tephra in the type area, but increase to near $20 \%$ at about $60 \mathrm{~km}$ from the source.

Conformably overlying the lapilli is a generally equal thickness of fine, cream to white ash with scattered white lapilli throughout. This fine-grained nature typifies the upper ash bed of Hatepe Tephra. Bedding is commonly seen, being generally marked by lines of pumice lapilli, conformable with topography, and is characteristic of an airfall origin. Lithic content is low, with clasts generally not conspicuous. The widespread distribution and fine nature of this bed indicate a type of phreatoplinian origin (Self \& Sparks 1978). Over much of the distribution of Hatepe Tephra, the upper surface is strongly eroded, and in sections in the type area this surface has a distinctive regular wavy appearance. Rotongaio Ash mantles this surface, accentuating the regular undulating form (Fig. 13). This rilled surface is very similar to the erosion pattern produced immediately after the Tarawera eruption of 1886 , and probably represents an eruptive break of several days, depending largely on the size of the rainstorms involved. 


\section{SOURCE OF TAUPO PUMICE FORMATION}

Even from the earliest descriptions of Taupo Pumice (e.g., Taylor 1855; Smith 1877) difficulty has surrounded the location of a source vent, first thought to be Tongariro volcano. Grange (1931) placed the source within Lake Taupo, then Baumgart \& Healy (1956) suggested multiple sources east and north of the lake. Finally, additional sources were postulated near Tongariro (Topping \& Kohn 1973). This is summarised by Froggatt (1980) who discusses the evidence for a single source within Lake Taupo at Horomatangi Reefs. Further work suggests that this area was the source for all members of the Taupo Pumice Formation.

Lake Rotongaio, on the eastern shore of Lake Taupo, was suggested as the source for Rotongaio Ash by Baumgart (1954), a site generally accepted since then. Self \& Sparks (1978) claimed Lake Rotongaio as the source, citing as evidence thickness and the occurrence of "many large rhyolitic lithic clasts" near the lake. These lithics actually form part of the Taupo Ignimbrite and no material coarser than ash grade has yet been found in Rotongaio Ash. In addition, the isopach map (Vucetich \& Pullar 1964) suggests a source within Lake Taupo, west of Lake Rotongaio, at Horomatangi Reefs. Similarly, Hatepe Tephra Formation isopachs and regular increase in grainsize up to the lake edge indicate a source west of Rotongaio at Horomatangi Reefs.

Circular depressions east of Waitahanui were proposed by Healy (1964) as source vents. Although their form is "crater like", no other evidence of a volcanic vent, such as large lithic blocks or a region of high temperatures or heat flow, is seen. Further, Waimihia Lapilli, older than Taupo Pumice, is observed in several outcrops to dip into these depressions. The holes are thus considered to be erosional in origin.

No evidence for any other sources outside Lake Taupo has been observed and the eruptive model developed for Taupo Pumice requires no further sources.
Table 1 Relevant ${ }^{14} \mathrm{C}$ dates on Taupo Pumice Formation assessed for reliability in dating the time of eruption. All dates expressed as old half life ( $\mathrm{T} \frac{1}{2}=5568$ years).

\begin{tabular}{|c|c|c|c|c|}
\hline $\begin{array}{c}\text { New Zealand } \\
\text { radiocarbon } \\
\text { No. }\end{array}$ & Loeality & Material & Date & Reliability \\
\hline 1 & Taupo & c & $1820 \pm 150$ & op. \\
\hline 4 & Waiouru & $c$ & $1800 \pm 150$ & Op. \\
\hline 37 & Ngaruawahia & C & $1780 \pm 60$ & Min \\
\hline 38 & Waikato & c & $1800 \pm 70$ & Op. \\
\hline 82 & Waiora & c & $2000 \pm 100$ & $\operatorname{Max}$ \\
\hline 158 & Hastings & $\mathrm{c}$ & $1760 \pm 80$ & Min \\
\hline 159 & Hastings & w & $1750 \pm 80$ & Min \\
\hline 161 & Kinleith & C & $1780 \pm 80$ & $\mathrm{Op}$ \\
\hline 162 & Kinleith & c & $1830 \pm 70$ & $O p$ \\
\hline 163 & Maroa & c & $1840 \pm 50$ & $O p$ \\
\hline 164 & Maroa & c & $1890 \pm 70$ & op \\
\hline 165 & Arapuni & W & $1900 \pm 70$ & $\operatorname{Max}$ \\
\hline 168 & Broadlands & W & $1900 \pm 60$ & $\operatorname{Max}$ \\
\hline 170 & National Park & $\mathrm{C}$ & $1800 \pm 50$ & $o p$ \\
\hline 172 & Rerewhakaaitu & c & $1800 \pm 100$ & op \\
\hline 173 & Atiamuri & C & $1750 \pm 50$ & Min \\
\hline 174 & Atiamuri & c & $1800 \pm 100$ & $o p$ \\
\hline 175 & Wairakei & c & $1850 \pm 100$ & Op \\
\hline 176 & Taupo & c & $1900 \pm 70$ & Max \\
\hline 183 & Tutira & c & $1800 \pm 70$ & op \\
\hline 502 & Gisborne & P & $1770 \pm 70$ & Min \\
\hline 503 & Gisborne & P & $1900 \pm 56$ & $\operatorname{Max}$ \\
\hline 524 & Whakatane & w & $1775 \pm 75$ & Min \\
\hline 1059 & Poukawa & $\mathrm{P}$ & $1870 \pm 60$ & Min \\
\hline 1060 & Poukawa & P & $2090 \pm 60$ & $\operatorname{Max}$ \\
\hline 1548 & & & $1840 \pm 50$ & Op \\
\hline
\end{tabular}

\begin{tabular}{ll}
\hline $\mathrm{O}=$ Optimum & $\mathrm{C}=$ charcoal \\
Min $=$ Minimun & $\mathrm{D}=$ peat \\
Max $=$ Maximum & $\mathrm{W}=$ wood
\end{tabular}

Table 2 Values of a (extrapolated thickness at the source) and $b$ (distance over which thickness halves) used to calculate volumes of plinian phases in formula $V=$ $13 a b^{2}$, assuming circular distribution and exponential relationship of thickness to distance from the source.

\begin{tabular}{|c|c|c|c|}
\hline Member & $\underset{(\mathrm{m})}{a}$ & $\stackrel{b}{b}(\mathrm{~km})$ & $\begin{array}{l}\text { Volume } \\
\left(\mathrm{km}^{3}\right)\end{array}$ \\
\hline Taupo Lapilli & 3.25 & 17 & 12.2 \\
\hline Rotongaio Ash & 5.20 & 7 & 3.3 \\
\hline Hatepe Tephra Laph $_{\text {Lali }}$ & $\begin{array}{l}3.00 \\
3.60\end{array}$ & $\begin{array}{r}9 \\
10\end{array}$ & $\begin{array}{l}3.2 \\
4.7\end{array}$ \\
\hline \multicolumn{4}{|c|}{ Total $=23.4$} \\
\hline
\end{tabular}

Ignimbrite. All relevant radiocarbon dates are listed in Table 1 where the reliability of each date is assessed. Mean of the optimum dates is 1820 years B.P., little different from the mean of Healy (1964). The standard deviation on the dates ranges from 50 to 150 years, with a mean of 77 years. The optimum date is thus best expressed as $1820 \pm 80$ years B.P.
Abundance of charcoal associated with the Taupo Pumice eruptions has made available many radiocarbon dates for the deposit. Healy (1964) evaluated many of these and derived a mean age of $1819 \pm 17$ years B.P. Several dates are for "Taupo Pumice Alluvium" or "lahar deposits", but these deposits are now regarded here as primary Taupo 


\section{ERUPTED VOLUMES}

Volume of each airfall member is calculated here from the formula $V=13 a b^{2}$ (Cole \& Stephenson 1972) where $a$ is the extrapolated thickness at the source and $b$ is the distance over which the thickness is halved. The formula presupposes an exponential thickness distribution with distance from the source. These values and the calculated volumes are listed in Table 2. The total for the airfall phases is $23 \mathrm{~km}^{3}$.

Calculated volume for Taupo Lapilli is about 12 $\mathrm{km}^{3}$ and this is almost half the $25 \mathrm{~km}^{3}$ derived by Walker (1980) from crystal concentration studies. However, the relationship of thickness to distance from the source closely approaches exponential in form, so nearly all the erupted material is on land, within $200 \mathrm{~km}$ of the source. Walker (1980) concluded two-thirds of the volume was beyond 220 $\mathrm{km}$ of the source and was of material finer than 1 $\mathrm{mm}$. These conclusions do not accord with those presented here.

Thickness of Taupo Ignimbrite is highly variable and shows no relationship with distance from the source, so no straightforward method to calculate volume is known. However, an estimate can be made by assuming a near-circular thickness distribution and by calculating volumes of concentric cylinders. If dimensions of radius $15 \mathrm{~km}, 30 \mathrm{~km}$, and $45 \mathrm{~km}$, and thicknesses of $50 \mathrm{~m}, 10 \mathrm{~m}$, and $5 \mathrm{~m}$ respectively, are assumed, the total erupted volume of Taupo Ignimbrite is about $70 \mathrm{~km}^{3}$. Beneath Lake Taupo, seismic reflection (Northey pers. comm. 1980) indicates an uppermost layer of about $100 \mathrm{~m}$ thickness which is almost certainly Taupo Ignimbrite.

Total volume of erupted Taupo Pumice is about $100 \mathrm{~km}^{3}$ of vesicular pumice and ash. Assuming a pumice density of $0.5 \mathrm{Mg} \mathrm{m}^{-3}$ this volume represents $20 \mathrm{~km}^{3}$ of magma. An explanation of the origin of such a large volume of magma is beyond the scope of this paper.

\section{ACKNOWLEDGMENTS}

Mr C. Vucetich and Drs Pullar and Howorth assisted in the field and made valuable comments on drafts of this paper. Their assistance and support is appreciated. New Zealand Forest Service and New Zealand Forest Products Ltd are thanked for providing access to forests, as is the Tuwharetoa Trust Board, owners of Lake Taupo Forest. Fieldwork was financed by Victoria University of Wellington Internal Research Committee.

\section{REFERENCES}

Baumgart, I. L. 1954: Some ash showers of the central North Island. New Zealand journal of science and technology $35 B$ : $456-467$.

Baumgart, I. L.; Healy, J. 1956: Recent volcanicity at Taupo, New Zealand. Proceedings, 8th Pacific Science Congress 2: 113-125.

Bullard, F. M. 1962: Volcanoes: in history, in theory, in eruption. Austin, Texas. University of Texas Press.

Cole, J. W.; Stephenson, T. M. 1972: Calculation of the volume of a tephra deposit. In: Cole, J. W.: Distribution of high alumina basalts in the Taupo Volcanic Zone. Geology Department, Victoria University of Wellington, publication no. 1 : 13-15.

Cotton, C. A. 1922: The geomorphology of New Zealand Pt. 1. New Zealand Board of Science and Art, Wellington, manual no. 3. 462 p.

Dieffenbach, E. 1843: Travels in New Zealand. Vol. 1. London, John Murray. 431 p.

Ewart, A. 1963: Petrology and petrogenesis of the Quaternary pumice ash in the Taupo area, New Zealand. Journal of petrology $4: 392-431$.

Fisher, R. V. 1960: Classification of volcanic breccias. Bulletin of the Geological Society of America 71 : 973-982.

1979: Models for pyroclastic surges and pyroclastic flows. Journal of volcanology and geothermal research $6: 305-318$.

Fleming, C. A. 1972: The contribution of C14 dates to the Quaternary geology of the "Golden Coast", western Wellington. Tuatara 19: 61-69.

Froggatt, P. C. 1980: Lake Taupo-probable source of the Taupo Pumice Formation. New Zealand journal of geology and geophysics 22: 763-764.

Froggatt, P. C.; Howorth, R. 1980: Uniformity of vertical faulting for the last 7000 years at Lake Poukawa, Hawke's Bay, New Zealand. New Zealand journal of geology and geophysics 23: 493-497.

Froggatt, P. C.; Wilson, C. J. N.; Walker, G. P. L. 1981: Orientation of logs in the Taupo Ignimbrite as an indicator of flow direction and vent position. Geology 9(3) : $109-111$.

Gage, M.; Black, R. D..1979: Slope stability and geological investigations at Mangatu State Forest. Forest Research Institute technical paper 66, $37 \mathrm{p}$.

Gibb, J. G. 1977: Late Quaternary sedimentary processes at Ohiwa Spit. Wellington, Water and Soil Division, Ministry of Works. Technical publication no. 5 .

Grange, L. I. 1927: Rotorua Subdivision. New Zealand Geological Survey 21 st annual report (n.s.) : 19-20.

1931: Volcanic ash showers. New Zealand journal of science and technology $12: 219-228$.

1937: The geology of the Rotorua-Taupo subdivision. New Zealand Geological Survey bulletin 37.

Grange, L. I.; Taylor, N. H. 1939: Soils and agriculture of part of Waipa County. New Zealand Department of Scientific and Industrial Research bulletin 76.

Grindley, G. W. 1960: Sheet 8-Taupo. Geological map of New Zealand 1:250 000. Wellington, New Zealand Department of Scientific and Industrial Research. 
Healy, J. 1964: Stratigraphy and chronology of late Quaternary volcanic ash in Taupo, Rotorua and Gisborne Districts. Part 1. New Zealand Geological Survey bulletin 73.88 p.

Hochstetter, F. von 1864: Geologie von Neu-Seeland. Beitrage zur Geologie der Provinzen Auckland und Nelson. Novara-Expedition, geologie theil, 1(1). $274 \mathrm{p}$.

Howorth, R. 1975: New formations of Late Pleistocene tephras from the Okataina Volcanic Centre, New Zealand. New Zealand journal of geology and geophysics $18: 683-712$.

Kennedy, N. M.; Pullar, W. A.; Pain, C. F. 1978: Late Quaternary land surfaces and geomorphic changes in the Rotorua Basin, North Island, New Zealand. New Zealand journal of science 21: 249-264.

Kohn, B. P. 1970: Identification of New Zealand tephra layers by emission spectrographic analysis of their titanomagnetites. Lithos 3(4): $361-368$.

1973: Studies of New Zealand Quaternary pyroclastic rocks. Unpublished $\mathrm{Ph} . \mathrm{D}$. thesis, lodged in the Library, Victoria University of Wellington, New Zealand.

Kohn, B. P.; Topping, W. W. 1978: Time-space relationships between late Quaternary rhyolitic and andesitic volcanism in the southern Taupo volcanic zone, New Zealand. Geological Society of America bulletin 89: 1265-1271.

Lewis, K. B.; Kohn, B. P. 1978: Ashes, turbidites and rates of sedimentation on the continental slope off Hawke's Bay. New Zealand journal of geology and geophysics 16: $439-454$.

Lirer, L.; Pescatore, T.; Booth, B.; Walker, G. P. L. 1972: Two Plinian pumice-fall deposits from Somma-Vesuvius, Italy. Geological Society of America bulletin 84: 759-772.

MacFadgen, B. G. 1978: The antiquity of man at Lake Poukawa, New Zealand. Journal of the Royal Society of New Zealand 9: 375-382.

Marshall, P. 1934: Acid rocks of the Taupo-Rotorua volcanic district. Transactions of the Royal Society of New Zealand 64: 323-366.

Pullar, W. A. 1967: Volcanic ash beds in the Waikato district. Earth science journal 1: 17-30.

1973: Isopachs of tephra, central North Island, New Zealand. Scale 1:1 000000 New Zealand soil survey report 31 .

Pullar, W. A.; Selby, M. J. 1971: Coastal progradation of Rangitaiki Plains, New Zealand. New Zealand journal of science 14: 419-434.

Self, S.; Sparks, R. S. J. 1978: Characteristics of widespread pyroclastic deposits formed by the interaction of silicic magma and water. Bulletin volcanologique 41(3): 1-17.

Smith, S. P. 1877: Sketch of the geology of the northern portion of Hawke Bay. Transactions of the New Zealand Institute 9: 565-576.

Sparks, R. S. J.; Walker, G. P. L. 1973: The ground surge deposit: a third type of pyroclastic rock. Nature physical science 241(107): 62-64.

1977: The significance of vitric-enriched air-fall ashes associated with crystal-enriched ignimbrites. Journal of volcanology and geothermal research 2 : $329-341$.
Sparks, R. S. J.; Wilson, L. 1976: A model for the formation of ignimbrite by gravitational column collapse. Journal of the Geological Society of London $132: 441-451$.

Taylor, R. 1855: Te ika a Maui, or New Zealand and its inhabitants. London, Wertheim and Macintosh. $490 \mathrm{p}$.

Tonkin, P. J. 1967: Note on the occurrence of Taupo Pumice in the Hamilton Basin. Earth science journal $1: 31-32$.

Topping, W. W.; Kohn, B. P. 1973: Rhyolitic tephra marker beds in the Tongariro area, North Island, New Zealand. New Zealand journal of geology and geophysics $16: 375-395$.

Vucetich, C. G.; Pullar, W. A. 1964: Stratigraphy and chronology of Late Quaternary volcanic ash in Taupo Rotorua and Gisborne districts. New Zealand Geological Survey bulletin 73. 88 p.

1973: Holocene tephra formations erupted in the Taupo area, and interbedded tephras from other volcanic sources. New Zealand journal of geology and geophysics $16: 745-780$.

Vucetich, C. G.; Wells, N. 1978: Soils, agriculture and forestry of Waiotapu region, Central North Island, New Zealand. New Zealand Soil Bureau bulletin 31 . $100 \mathrm{p}$.

Wakefield, E. J. 1845: Adventure in New Zealand, from 1839-1844, vol. 2. London, John Murray. 546 p.

Walker, G. P. L. 1973: Explosive volcanic eruptions-a new classification scheme. Geologische Rundschau $62(2): 431-446$

1980: The Taupo plinian pumice: Product of the most powerful known (ultraplinian) eruption? Journal of volcanology and geothermal research 8 : $69-94$.

Walker, G. P. L.; Wilson, C. J. N.; Froggatt, P. C. 1980; Fines-depleted ignimbrite in New Zealand-the product of a turbulent pyroclastic flow. Geology 8 : 245-249.

Walker, G. P. L.; Self, S.; Froggatt, P. C. 1981a: The ground layer of the Taupo Ignimbrite: a striking example of sedimentation from a pyroclastic flow. Journal of volcanology and geothermal research 10 : $1-11$.

Walker, G. P. L.; Wilson, C. J, W.; Froggatt, P. C. 1981b: An ignimbrite veneer deposit: The trail marker of a pyroclastic flow. Journal of volcanology and geothermal research 9: 409-421.

Wellman, H. W. 1962: Holocene of the North Island of New Zealand: a coastal reconnaissance. Transactions of the Royal Society of New Zealand, geology 1(5) : $29-99$.

Wilson, C. J. N. 1980: The role of fluidization in the emplacement of pyroclastic flows: an experimental approach. Journal of volcanology and geothermal research $8: 231-249$.

Wright, J. V.; Smith, A. L.; Self, S. 1980: A working terminology of pyroclastic deposits. Journal of volcanology and geothermal research $8: 315-336$. 


\section{APPENDIX 1}

Section 1

Cliff section Blake Road N103/569230 (See Fig. 2)

1-2 m Bedded white ash and lapilli (Upper unit)

$10 \mathrm{~m}$ White ash lapilli and blocks, unsorted, matrix supported, uniform, massive.

(Middle ignimbrite unit)

- sharp contact-

25-30 m Brown grading down to pink-red pumice ash, lapilli, and few blocks, scattered rhyolite lapilli throughout (Lower ignimbrite unit)

- sharp eroded contact-

$1 \mathrm{~m}+\quad$ Moderately well sorted pumice lapilli and blocks up to $105 \mathrm{~mm}$ and scattered rhyolite lapilli up to $135 \mathrm{~mm}$. Pumice lapilli pink coloured. Two red ash layers near base. $0.05 \mathrm{~m}$ basal layer of well sorted coarse ash, scattered lapilli of pumice and lithics, dark black-brown (Taupo Lapilli)

- sharp contact

$4 \mathrm{~m} \quad$ Medium to coarse ash; rhyolite and obsidian fragments. Upper $1 \mathrm{~m}$ firm brick-red, grading down to soft grey. Well bedded top (Rotongaio Ash)

- sharp undulating contact (erosional)

c. $1 \mathrm{~m} \quad$ White, medium to coarse ash and lapilli, rudimentary bedding (upper Hatepe Tephra)

- sharp contact

c. $4 \mathrm{~m} \quad$ Moderately well sorted pumice lapilli and blocks up to $0.2 \mathrm{~m}$, scattered rhyolitic lithics up to $80 \mathrm{~mm}$. Basal 60 $\mathrm{mm}$ olive brown medium ash (Hatepe Lapilli)

$0.04 \mathrm{~m} \quad$ Black grading down to silver-grey medium ash and lapilli (Mapara Tephra in paleosol) on

c. $0.3 \mathrm{~m}$ shower bedded pale orange-yellow pumice lapilli, abundant (30\%) rhyolite content (Whakaipo Tephra)

c. $4 \mathrm{~m} \quad$ Well bedded medium to coarse ash, pink and grey layers, scattered lapilli, grading to

c. $20 \mathrm{~m}$ uniform massive pink-brown pumice ash and lapilli, matrix supported (Waimihia Ignimbrite)

- sharp contact-

$4 \mathrm{~m}+\quad$ Moderately well sorted rhyolitic pumice lapilli and blocks up to $0.2 \mathrm{~m}$; upper $2 \mathrm{~m}$ abundant grey banded pumice and orange weathered rhyolite lithics (Waimihia Lapilli). Small stream flows out of base of lapilli.

\section{Section 2}

Forestry Road cutting N103/565260 (top of section missing) c. $1 \mathrm{~m}$

Rhyolite blocks up to $1 \mathrm{~m}$

- sharp contact-
$0.64 \mathrm{~m} \quad$ Massive fine to medium pumice lapilli and rhyolite lithics (3\%), light yellow orange (7.5YR 7/2) fine-medium ash matrix

$0.49 \mathrm{~m} \quad$ Reverse graded pumice lapilli with ash matrix, pumice to $90 \mathrm{~mm}$. $2 \%$ lithics gradational contact over $50 \mathrm{~mm}$ to

$0.27 \mathrm{~m} \quad$ Massive fine-medium ash. $10 \%$ pumice lapilli. Dull orange brown (7.5YR 7/3)

- sharp contact

$0.11 \mathrm{~m} \quad$ Moderately sorted pumice lapilli, light-grey (10YR 8/2), no ash matrix, pumice up to $45 \mathrm{~mm}$, lithics to $40 \mathrm{~mm}$. Finer lapilli at base, not obviously graded - sharp contact-

$0.03 \mathrm{~m} \quad$ Fine ash with few lapilli light-brownish grey (7.5YR 7/2)

sharp contact-

$0.03 \mathrm{~m} \quad$ Sorted pumice lapilli, no fine ash matrix (similar to $0.11 \mathrm{~m}$ layer above - sharp contact-

$0.12 \mathrm{~m} \quad$ Massive fine-medium ash with $10 \%$ pumice lapilli and $15 \%$ lithics, dull orange (7.5YR 7/3)

- sharp contact-

$5 \mathrm{~mm}$ Distinctive orange (5YR 6/6) fine ash. Marks textural contrast to

c. $4 \mathrm{~m} \quad$ pumice lapilli with ash matrix non-sorted. Pale orange (5YR 8/3) grading down to orange (5YR 6/6) - sharp contact

$0.23 \mathrm{~m} \quad$ Moderately sorted pumice lapilli, no ash matrix, 5-10\% lithic content. Pumice to $60 \mathrm{~mm}$, lithics to $45 \mathrm{~mm}$. Finer lapilli top but not obviously graded. Pale orange (5YR 8/6)

- sharp contact-

$10 \mathrm{~m}+\quad$ Ash lapilli and blocks, ash-rich matrix. $5 \%$ lithics. Colour grades down from orange (5YR 6/6) to bright brown (2.5YR 5/8)

\section{Section 3}

Straight Line Road, $200 \mathrm{~m}$ south of Crater Road N103/621244 (See Fig. 9)

$0.50 \mathrm{~m} \quad$ Topsoil, disturbed, brown (7.5YR 4/6)

$0.15 \mathrm{~m}$ Partly rounded pumice lapilli and ash, weakly bedded

$0.20 \mathrm{~m} \quad$ Medium ash with occasional lapilli becoming firmer towards base, finely bedded, light grey (10YR 8/1), occasional chalazoidites

- sharp contact-

$0.26 \mathrm{~m} \quad$ Fine to medium ash with scattered lapilli $5 \%$. Becomes firmer towards base. Scattered chalazoidites throughout. Colour grades down from light grey (10YR 8/1) to yellow orange (7.5YR 7/8) 
_ sharp bright orange contact-_

$0.85 \mathrm{~m} \quad$ Pumice lapilli, distinctive yellow-orange (7.5YR 7/8) with abundant lithics (30\%). Grades upwards to coarse ash then to $40 \mathrm{~mm}$ compact white bedded ash

- sharp contact -

$0.24 \mathrm{~m} \quad$ Coarse ash and lapilli with fine ash matrix, abundant lithics

- distinct contact-

$0.15 \mathrm{~m} \quad$ Uniform medium ash, numerous chalazoidites throughout. Colour grades down from light yellow orange (10YR 8/3) to light grey (10YR 8/1)

- distinct contact-

$0.80 \mathrm{~m} \quad$ Pumice lapilli and coarse ash poorly sorted, $10 \%$ lithics. Regularly bedded into 4 graded beds with top $30 \mathrm{~mm}$ coarse ash. Pumice to $260 \mathrm{~mm}$, lithics to $40 \mathrm{~mm}$

- sharp contact-

$0.30 \mathrm{~m} \quad$ Poorly sorted coarse ash and lapilli with abundant lithics (40-50\%).

Frequent vertical lithic rich "pipes"

(fluidisation features)

- gradational contact-

$0.70 \mathrm{~m} \quad$ Poorly sorted medium ash and lapilli. $10 \%$ lithics reverse graded with 100 $\mathrm{mm}$ medium ash base

- distinct contact-

$0.07 \mathrm{~m} \quad$ Moderately well sorted coarse ash. Faint continuous bedding

- sharp contact-

$0.40 \mathrm{~m} \quad$ Uniform medium ash with scattered lapilli through centre. Well bedded with a few cross-beds and filled channels near base

- sharp contact

$0.45 \mathrm{~m}$ Massive uniform fine-medium ash with common chalazoidites, grades down to

$10 \mathrm{~m}+\quad$ ash with lapilli and blocks up to $0.5 \mathrm{~m}$ (Middle ignimbrite unit).

\section{Section 4}

Road cutting on Motukino Road N103/678226

(See Fig. 10)

$2 \mathrm{~m} \pm \quad$ Medium to coarse ash, lapilli and blocks, coarser towards top

5-10 $\mathrm{mm}$ Coarse ash, well sorted, iron stained - sharp regular contact-

$185 \mathrm{~mm}$ Fine to medium ash, firm, uniform pale-grey colour, with a bed of pockets of dark grey coarse ash lithics in upper $30 \mathrm{~mm}$

5-10 mm Coarse ash, well sorted - gradational contact

$40 \mathrm{~mm}$ Fine to medium ash, graded light grey top

- gradational contact-

$10 \mathrm{~mm}$ Dark grey medium ash, abundant lithics
- sharp contact-

$20 \mathrm{~mm} \quad$ Medium to coarse ash, normally graded, friable - distinct contact-_

$20 \mathrm{~mm}$ Medium ash, firm - irregular contact-_

$145 \mathrm{~mm}$ Medium to coarse ash with scattered lapilli especially near base, firm - distinct contact-

$1.5 \mathrm{~m}+\quad$ Ash, lapilli and blocks, unsorted, matrix supported. (Middle ignimbrite unit).

\section{Section 8}

Southern Boundary Road, north bank of Waitahanui River N103/592177

c. $45 \mathrm{~m} \quad$ Unsorted pumice ash lapilli and blocks, uniform with no bedding apparent (Middle unit Taupo Ignimbrite)

0-1 m Lapilli and blocks of rhyolite and mudstone up to $0.6 \mathrm{~m}$ diameter (lithic lag layer)

$650 \mathrm{~mm} \pm$ Cream-white pumice ash and lapilli, top strongly eroded. (Upper Hatepe Tephra)

$2.13 \mathrm{~m}$ Uniform pumice lapilli (Hatepe Lapilli).

\section{Section 9}

State Highway 1, 2 Mile Bay N94/560350

$3 \mathrm{~m} \pm \quad$ Ash and lapilli, uniform, matrix supported (Middle unit Taupo Ignimbrite). Few pumice blocks and lithics to $400 \mathrm{~mm}$ in base

$350 \mathrm{~mm} \quad$ Ash and lapilli, mostly lithics and crystals up to $130 \mathrm{~mm}$ (lithic lag layer) - distinct contact

$100 \mathrm{~mm}$ Sorted pumice lapilli with $10 \%$ lithics, yellow-white - sharp contact-

$500 \mathrm{~mm}$ Uniform fine to medium ash, soft

$1.05 \mathrm{~m}$ Ash with scattered lapilli near top of bed. Lapilli in narrow bands - distinct contact-

$800 \mathrm{~mm} \quad$ Ash, lapilli and blocks, matrix supported, firm, pale pink - distinct contact-

$1.05 \mathrm{~m}$ Medium to coarse ash uniform, firm, pale pink-brown

$350 \mathrm{~mm}$ Medium ash with scattered yellow lapilli

$200 \mathrm{~mm}$ Fine to medium ash, red-pink

$300 \mathrm{~mm}$ Fine to medium ash, yellow-brown - distinct contact-

$100 \mathrm{~mm}+$ Pumice lapilli with $10 \%$ lithics, well sorted, pink-red. 


\section{Late Quaternary volcanic ash stratigraphy of the Poukawa area, Central Hawke's Bay, New Zealand}

3

\section{R. HOWORTH}

P. C. FROGGATT

S. M. ROBERTSON

Geology Department

Victoria University of Wellington

Private Bag

Wellington, New Zealand

Abstract 7 Holocene and 3 Late Pleistocene volcanic ashes (=tephras) are interbedded with peat, lake sediment, loess, and alluvial fan debris in the Poukawa Basin, Central Hawke's Bay. Identification is based on field appearance and stratigraphy, and where possible, is supported by mineralogy.

These tephras are from youngest to oldest: Kaharoa, Taupo, Mapara, Whakaipo, Waimihia, Whakatane, Hinemaiaia, Okareka, Kawakawa, and Tahuna.

5 new radiocarbon dates (new $\frac{1}{2}$ life) were obtained: Waimihia $3380 \pm 110$ years B.P.; Whakatane $4740 \pm 90$ and $4770 \pm 70$ years B.P.; Hinemaiaia $5840 \pm 140$ and $5530 \pm 100$ years B.P. Assuming constant peat accumulation rates, estimated ages for the Mapara and Whakaipo Tephras are $2280 \pm 20$ and 2730 years B.P. respectively.

Keywords Quaternary; tephras; stratigraphy; Hawke's Bay; C-14

\section{INTRODUCTION}

Poukawa Basin (Fig. 1) in Central Hawke's Bay, New Zealand, is a predominantly flat area with Lake Poukawa near its centre. Moderately eroded limestone ranges surround the basin. Kaokaoroa Range to the east and Raukawa Range to the west rise to just over $300 \mathrm{~m}$.

Lake Poukawa is the largest of a few lakes and peat-filled hollows which indicate areas of high water table. The lake is almost circular, being about $1.5 \mathrm{~km}$ in diameter. Surrounding it is a low-lying Holocene peat swamp with an area of approximately $10 \mathrm{~km}^{2}$. The peat progressively thins outwards from a maximum recorded depth of $9.8 \mathrm{~m}$ (hole 10, Fig. 2) to a well-defined margin overlying Late Pleistocene terrestrial sediments of alluvial fan

Received 15 October 1979, revised 9 May 1980 debris and loess which extend beneath the peat. The lake is approximately $20 \mathrm{~m}$ above mean sealevel and is usually less than $1 \mathrm{~m}$ deep. Lake levels fluctuate seasonally, and flooding of the surrounding peat swamp occurs almost annually. For example, in August 1977, the lake extended $4 \mathrm{~km}$ to the west to State Highway 2, and was observed to be at least 3 times its normal area. At present the lake is drained northeast to the Heretaunga Plains via a man-made outlet to Poukawa Stream (Fig. 1). In 1931, water level of the lake, and consequently the water level in the swamp, was artificially lowered by approximately $1 \mathrm{~m}$, and again, in 1961, the outlet was deepened by approximately $1 \mathrm{~m}$.

For this study over 50 holes have been cored to the base of the peat swamp (Fig. 1). These holes cover the entire swamp with the exception of the

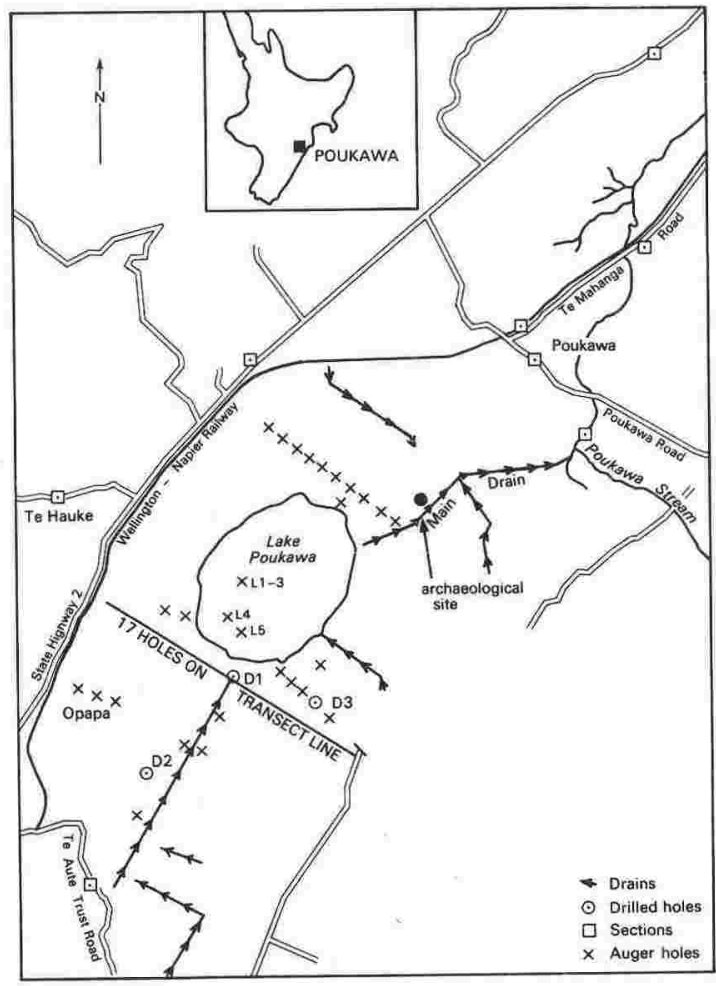

Fig. 1 Map of the Poukawa Basin showing positions of peat auger holes; transect line; lake sediment auger holes (L1-LS); 3 holes cored in sediments beneath peat swamp (D1-D3); and sections where Kawakawa Tephra is exposed and has been described. 


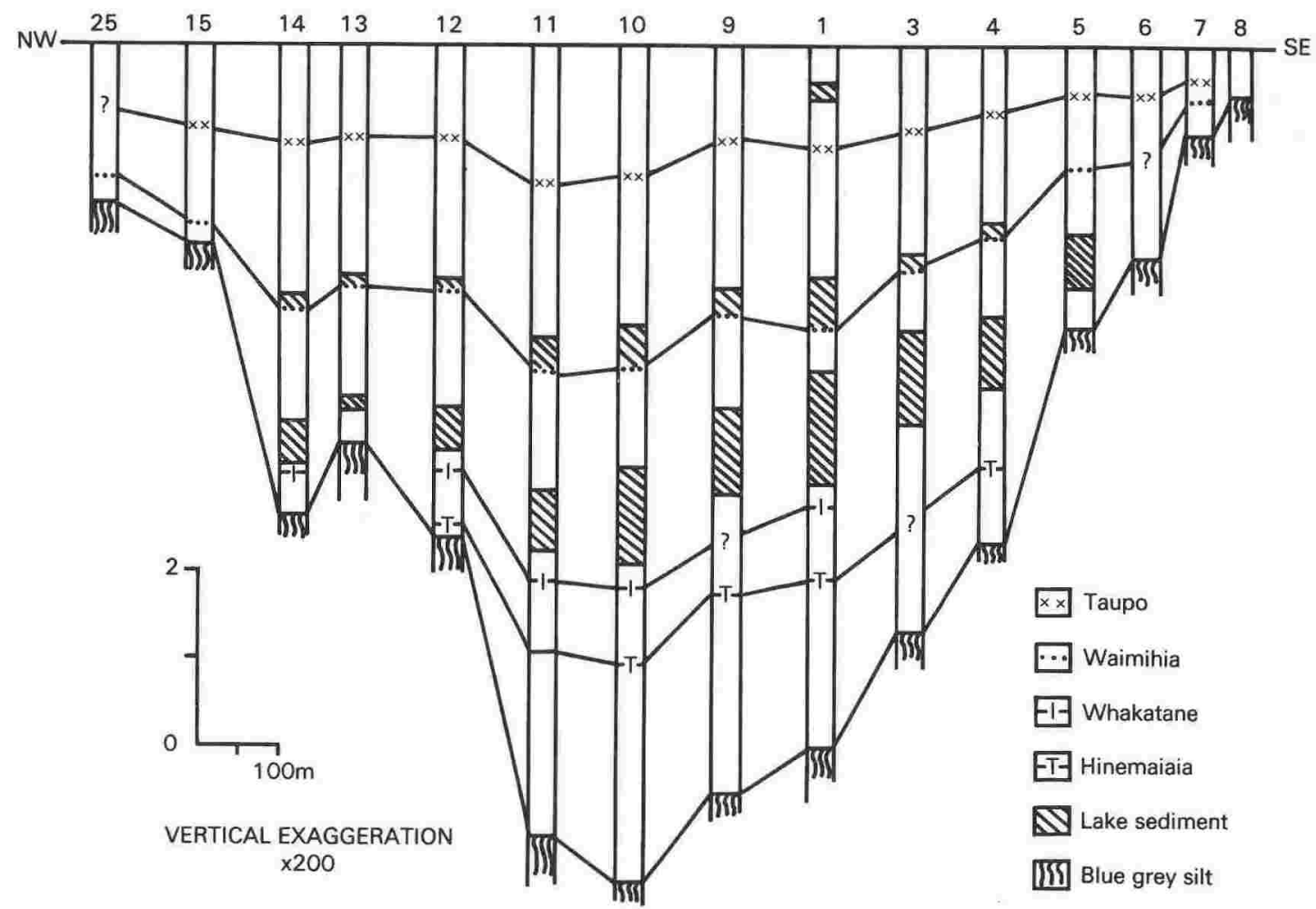

Fig. 2 Peat transect line south of Lake Poukawa showing occurrence of Taupo, Waimihia, Whakatane, and Hinemaiaia Tephras and the 2 extensive lake sediment horizons.

area immediately northeast of the lake. 15 of these holes were located along a northwest-southeast transect line immediately south of Lake Poukawa (Fig. 2).

Around the margin of the lake several layers of lake sediment are interbedded in the peat. These layers pinch out away from the lake and thicken until they all coalesce beneath the present lake. 5 holes (L1-L5, Fig. 1) located near the centre of the lake passed through up to $5.5 \mathrm{~m}$ of lake sediment before reaching peat. The lake sediment is composed of up to $95 \% \mathrm{CaCO}_{3}$. 3 further holes, D1, D2, and D3 (Fig. 1) were drilled in an attempt to core the sediments beneath the swamp. A maximum depth of $35.10 \mathrm{~m}$ was reached in D1. Core descriptions are reported by Robertson (1978).

7 Holocene, and 3 Late Pleistocene tephras are recognised. These are from youngest to oldest: Kaharoa, Taupo, Mapara, Whakaipo, Waimihia, Whakatane, Hinemaiaia, Okareka, Kawakawa, and Tahuna, (Healy et al. 1964; Vucetich \& Pullar 1969, 1973; Howorth 1975; Vucetich \& Howorth 1976). Recognition of the tephras was based principally on field appearance and stratigraphy, supported wherever possible by mineralogy. 5 new radiocarbon dates are reported (Fig. 3).

\section{HOLOCENE TEPHRAS}

Taupo and Waimihia Tephras were first described and identified at an archaeological site northeast of Lake Poukawa (Pullar 1965, 1970; Price 1965). They had been previously recognised as volcanic ashes by Price (1963). These tephras were recorded in nearly every hole cored in the peat, the only exceptions were close to the swamp margin. They occur at progressively increasing depths from the swamp margin to a recorded maximum in hole 11 (Fig. 2), where the base of the Taupo Tephra is at $1.60 \mathrm{~m}$ and Waimihia Tephra at $3.80 \mathrm{~m}$.

Taupo Tephra is typically a discrete white to pale grey, loose, coarse ash and lapilli up to $30 \mathrm{~mm}$ thick. Below water table the loose pumice is stained brown by the peaty water. Waimihia Tephra is typically a discrete bluish-white, firm, coarse ash with scattered lapilli, grading up to a fine ash. Graded bedding is well developed and thickness varies between 70 and $130 \mathrm{~mm}$.

Ferromagnesian mineral assemblage of both Taupo and Waimihia Tephras is hypersthene dominant, with minor calcic hornblende and augite (Table 1). None of the other Holocene tephras are as widespread as either the Taupo or Waimihia 


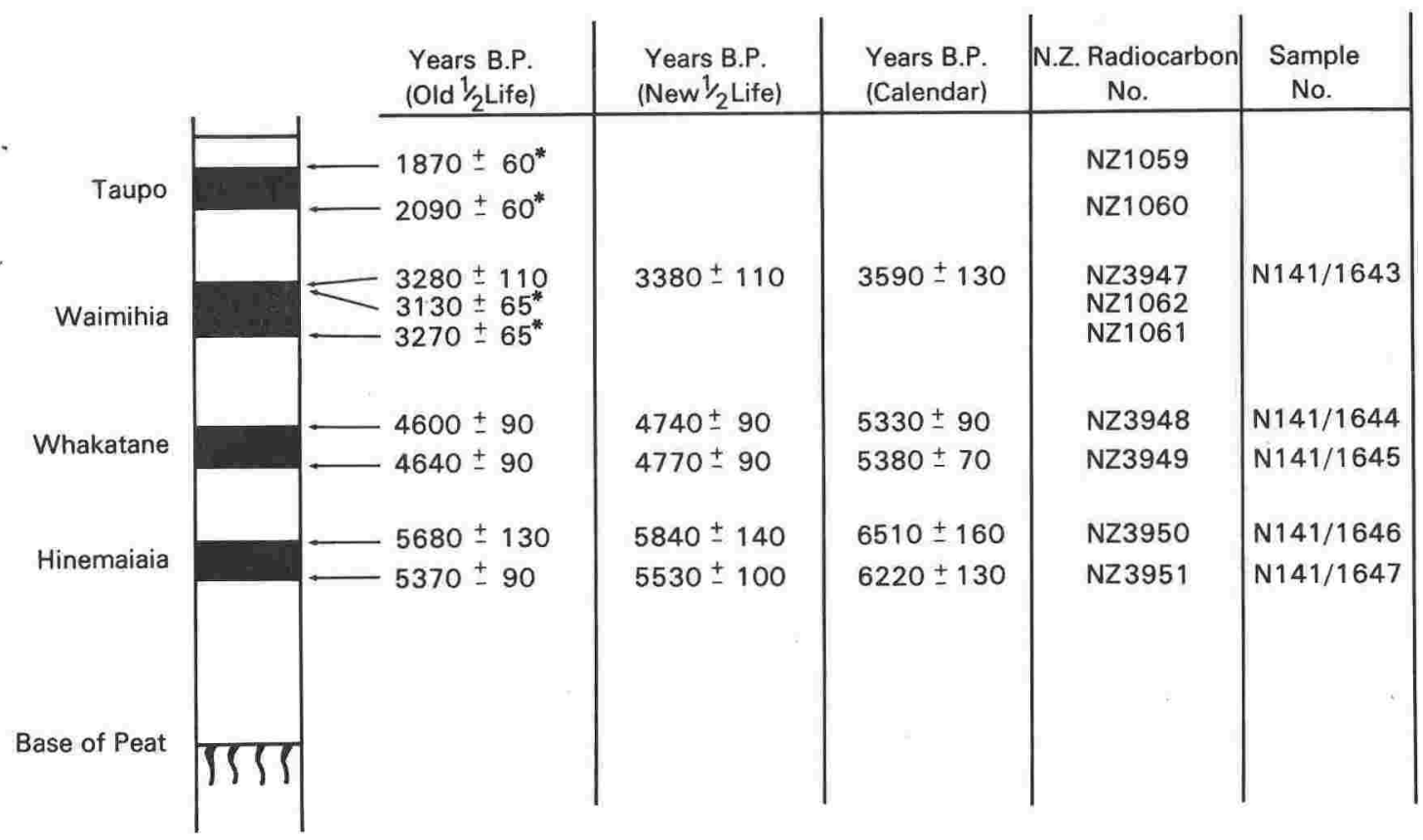

Fig. 3 Radiocarbon dates from peat associated with Taupo, Waimihia, Whakatane, and Hinemaiaia Tephras at Poukawa. Dates shown (*) from Pullar (1970).

Table 1 Representative ferromagnesian mineral abundances of tephras from Poukawa compared with those from near-source localities. Numbers are expressed as percentages of calcic homblende, hypersthene, augite, cummingtonite, and biotite.

\begin{tabular}{|c|c|c|c|c|c|}
\hline TEPHRA & Hypers thene & Augite & Hornblende & Cummingtonite & Biotite \\
\hline \multicolumn{6}{|l|}{ TAUPO } \\
\hline $\begin{array}{l}\text { Poukawa } \\
\text { De Bretts (N94/573353) }\end{array}$ & 74 & 21 & 4 & - & - \\
\hline $\begin{array}{l}\text { De Bretts (N94/573353) } \\
\text { Taupo Ignimbrite }\end{array}$ & 73 & 10 & 15 & - & - \\
\hline $\begin{array}{l}\text { Taupo Ignimbrite } \\
\text { Taupo Lapilli }\end{array}$ & 100 & - & -2 & - & 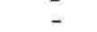 \\
\hline Hatepe Tephra & 98 & 1 & - & - & - \\
\hline \multicolumn{6}{|l|}{ WAIMIHIA } \\
\hline $\begin{array}{r}\text { Poukawa } \\
\text { De Bretts }\end{array}$ & $\begin{array}{l}74 \\
86\end{array}$ & 21 & 3 & - & - \\
\hline De Bretts & 86 & 13 & - & - & - \\
\hline \multicolumn{6}{|l|}{ WHAKATANE } \\
\hline Poukawa & 53 & 13 & 23 & 11 & - \\
\hline Gavin Road (N86/995825) & 2 & - & 7 & 90 & - \\
\hline \multicolumn{6}{|l|}{ HINEMAIAIA } \\
\hline Poukawa & 84 & 11 & 4 & - & - \\
\hline De Bretts & 98 & 2 & - & - & - \\
\hline \multicolumn{6}{|l|}{ OKAREKA } \\
\hline Poukawa & 19 & 9 & 20 & - & 49 \\
\hline Gavin Road & 16 & $i$ & 61 & - & 19 \\
\hline \multicolumn{6}{|l|}{ KAWAKAWA } \\
\hline Poukawa & 60 & 16 & 23 & - & - \\
\hline Whangamata Rd (N93/373458) & $41-62$ & $2-20$ & $25-53$ & & \\
\hline \multicolumn{6}{|l|}{ TAHUNA } \\
\hline Poukawa & 60 & 3. & 26 & - & - \\
\hline Okataina area & $32-46$ & $2-10$ & $48-62$ & - & - \\
\hline
\end{tabular}


Tephras. When recognised in more than 2 or 3 holes, each of these tephras was seen to increase in depth towards the centre of the swamp.

Kaharoa Tephra was recognised in only 1 hole, L3 (Fig. 1). It was seen as very fine white pumice with flakes of biotite in the acid insoluble residues of the lake sediment. It occurred at a depth of $2.50 \mathrm{~m}$, above Taupo Tephra which was at $3.60 \mathrm{~m}$.

Mapara and Whakaipo Tephras occur in hole L3 (Fig. 1). Neither were seen as discrete layers, but were identified as concentrations of rhyolite glass in the acid insoluble residues of the lake sediment between the Taupo and Waimihia TephrasMapara Tephra at a depth of $2.80 \mathrm{~m}$, and Whakaipo Tephra at a depth of $3.50 \mathrm{~m}$. Both were also recognised as a scattered white ash between the Taupo and Waimihia Tephras in the peat north of the lake; Mapara Tephra in 4 holes, and Whakaipo Tephra in only 1 hole. Both have hypersthenedominant ferromagnesian mineral assemblages.

Whakatane and Hinemaiaia Tephras are widespread beneath the Waimihia Tephra where depth of the swamp is greater than $3 \mathrm{~m}$ (Fig. 2). Whakatane Tephra is recognised in the peat as a scattered, fine, white ash in which cummingtonite occurs as a characteristic dominant amphibole (Table 1). Hinemaiaia Tephra occurs below Whakatane Tephra as a discrete layer of pale grey, fine ash up to $10 \mathrm{~mm}$ thick (Fig. 2) and has hypersthene as the dominant ferromagnesian mineral (Table 1).

\section{LATE PLEISTOCENE TEPHRAS}

Kawakawa Tephra is widespread throughout the basin. It is recorded in 2 of the 3 holes cored beneath the swamp (D1 and D3), and has been described in 8 exposures around the basin (Robertson 1978). In hole D3, Kawakawa Tephra occurs at a depth of c. $10 \mathrm{~m}$ as a 12 -cm-thick light grey ash with a fine, white base, resting directly on a thin lens of organic material; it passes up into a 27 -cm-thick light grey, pumiceous, medium to coarse grained sand. In a cutting on Te Aute Trust Road (N141/108011*) Kawakawa Tephra occurs in loess as a $30-\mathrm{cm}$-thick layer of greyish white, firm, medium to fine ash, with a finer basal layer and sharp lower contact. Ferromagnesian mineralogy of Kawakawa Tephra at Poukawa is hypersthene and calcic hornblende dominant (Fig. 4), comparable with data from the type section in the Taupo area and a reference section at Havelock North, $20 \mathrm{~km}$ north of Poukawa (Howorth 1976).

* Grid references here and on Table 1 are based on the national thousand-yard grid of the 1:63 360 topographical map series (NZMS 1); sheets : N141, 2nd ed. 1962; N86, 3rd ed. 1977; N93, 2nd ed. 1968; N94, 1st ed. 1969.

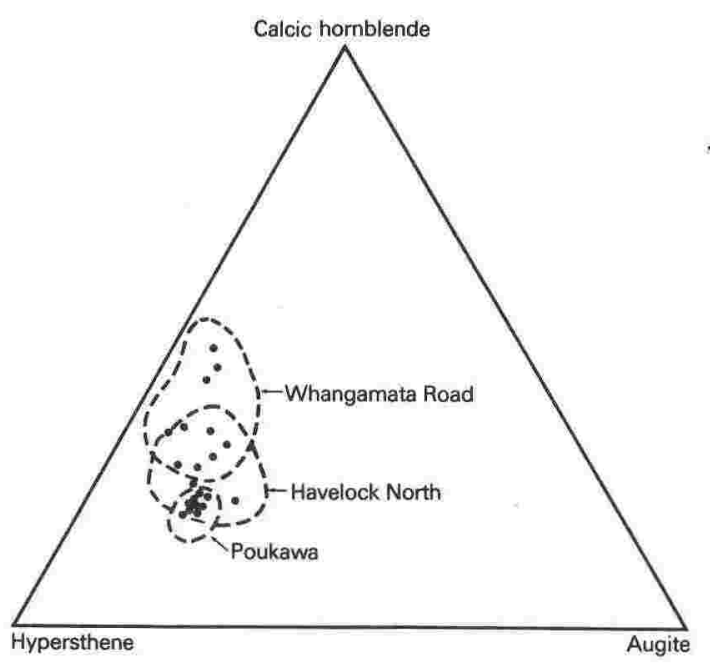

Fig. 4 Ferromagnesian mineralogy of Kawakawa Tephra at Poukawa compared with the type section (Whangamata Road) and reference section at Havelock North (Howorth 1976).

Okareka Tephra occurs as a white fine-grained ash, in irregular pockets up to $0.01 \mathrm{~m}$ thick, approximately $1 \mathrm{~m}$ above Kawakawa Tephra in holes D1 and D3. Mineralogy is dominated by biotite (Table 1).

Tahuna Tephra was recognised only in hole D1 at a depth of $30.18 \mathrm{~m}$ as a well-bedded fine white ash. Hypersthene and calcic hornblende are the dominant ferromagnesian minerals (Table 1).

\section{CHRONOLOGY}

9 radiocarbon dates are associated with tephra layers in the peat at Poukawa (Fig. 3); 4 of these were reported by Pullar (1970), 2 for Taupo, and 2 for Waimihia. An age for Mapara Tephra, estimated by assuming uniform accumulation rates at 4 sites northwest of the lake, and averaged old $\frac{1}{2}$ life dates from Fig. 3, is $2210 \pm 16$ years B.P. Similarly, an age for Whakaipo Tephra is 2730 years B.P. These compare favourably with previously published radiocarbon dates of Vucetich \& Pullar (1973).

\section{ACKNOWLEDGMENTS}

We thank Professor H. W. Wellman who initiated our studies at Poukawa, the geology students who have assisted with the peat boring, and F. Brownrigg for providing accommodation and access. University Grants Committee (Grant 34/75) provided financial support. 


\section{REFERENCES}

Healy, J.; Vucetich, C. G.; Pullar, W. A. 1964. Stratigraphy and chronology of Late Quaternary volcanic ash in Taupo, Rotorua and Gisborne districts. New Zealand Geological Survey bulletin (n.s.) 73 .

- Howorth, R. 1975. New formations of Late Pleistocene tephras from the Okataina Volcanic Centre, New Zealand. New Zealand journal of geology and geophysics $18: 683-712$.

1976. Late Pleistocene tephras of the Taupo and Bay of Plenty regions. Unpublished $\mathrm{PhD}$. thesis, Victoria University of Wellington Library, Wellington.

Price, T. R. 1963. Moa remains at Poukawa, Hawke's Bay. New Zealand Archaeological Association newsletter 6: 169-174.

1965. Excavations at Poukawa, Hawke's Bay, New Zealand. New Zealand Archaeological Association newsletter $8: 8-11$.
Pullar, W. A. 1965. Note on ash beds at Poukawa, Hawke's Bay. New Zealand Archaeological Association newsletter 8 : 11-13.

1970. Pumice ash beds and peaty deposits of archaeological significance near Lake Poukawa, Hawke's Bay. New Zealand journal of science 13 : 687-705

Robertson, S. M. 1978. Study of the late Quaternary history of Poukawa Basin. Unpublished M.Sc. thesis, Victoria University of Wellington Library, Wellington.

Vucetich, C. G.; Howorth, R. 1976. Proposed definition of the Kawakawa Tephra, the c. 20000 years B.P. marker horizon in the New Zealand region. New Zealand joumal of geology and geophysics 19 : 4350.

Vucetich, C. G.; Pullar, W. A. 1969. Stratigraphy and chronology of Late Pleistocene volcanic ash beds in central North Island, New Zealand. New Zealand journal of geology and geophysics 12 : 784-837.

1973. Holocene tephra formations erupted in the Taupo area, and interbedded tephras from other volcanic centres. New Zealand journal of geology and geophysics 16: 745-780. 


\section{Uniformity of vertical faulting for the last 7000 years at Lake Poukawa, Hawke's Bay, New Zealand}

\author{
P. C. FROGGATT \\ R. HOWORTH \\ Geology Department \\ Victoria University of Wellington \\ Private Bag \\ Wellington, New Zealand
}

Abstract Rates of fault movement are commonly assumed to be uniform. Analysis of the progressive increase in offset, by the Wairarapa Fault, of dated tephras within peat at Lake Poukawa, shows this to be true. A uniform vertical faulting rate of $0.2 \mathrm{~mm} / \mathrm{year}$ is determined.

Age of each offset of the fault is estimated giving a recurrence time of $800-900$ years. The constant rate of faulting indicates that the next major earthquake affecting the fault at Poukawa will be in no more than 500 years time. This does not, however, exclude the possibility of other earthquakes in this region.

Keywords faults; Wairarapa Fault; Hawke's Bay; rates; tephras; stratigraphy; earthquakes

\section{INTRODUCTION}

Lake Poukawa (Fig. 1) lies in a broad valley surrounded almost entirely by hills of limestone. Poukawa Stream drains the valley northeast to the Heretaunga Plains through a narrow gorge. The outlet has extremely low gradient, and there is almost no water flowage through the gorge. To the east, Tukituki River flows from south to north draining the Ruahine Ranges which are composed of Mesozoic greywacke. Absence of greywacke gravels in the Poukawa valley (Kingma 1971) shows that Tukituki River has never flowed through it.

Structurally, this area is interpreted as a faulted asymmetrical syncline, with the west flank dipping $30^{\circ}$ east and the east flank dipping $15^{\circ}$ west, which Kingma (1971) referred to as Lake Poukawa Depression. The flanks of the syncline, forming dip slopes within the valley, are composed of Te Aute Limestone, a sandy coquina of Waitotaran age which Kingma (1971, fig. 46) infers to be continuous from east to west beneath the basin.
Surrounding the lake edge are Holocene peat deposits in which tephras (volcanic ashes) are preserved. Pullar $(1965 ; 1970)$ described 2 thin rhyolitic tephras to the northeast of the lake which he identified as Taupo Pumice and Waimihia Lapilli. Their association with archaeological deposits of moa bones and Maori occupation sites has been described elsewhere (Price 1963; McFadgen 1979).

Bisecting the Lake Poukawa Depression is a northeast-southwest-trending fault which was last active during the Hawke's Bay earthquake of 1931. At that time, a fracture, known as the "Poukawa Shear" (Henderson 1933), developed to the north of the lake. It had a maximum displacement of $0.5 \mathrm{~m}$ vertical and $2.0 \mathrm{~m}$ right lateral. In 1931-32, following the earthquake, this fault was traced as far south as the northern edge of the peat swamp, by

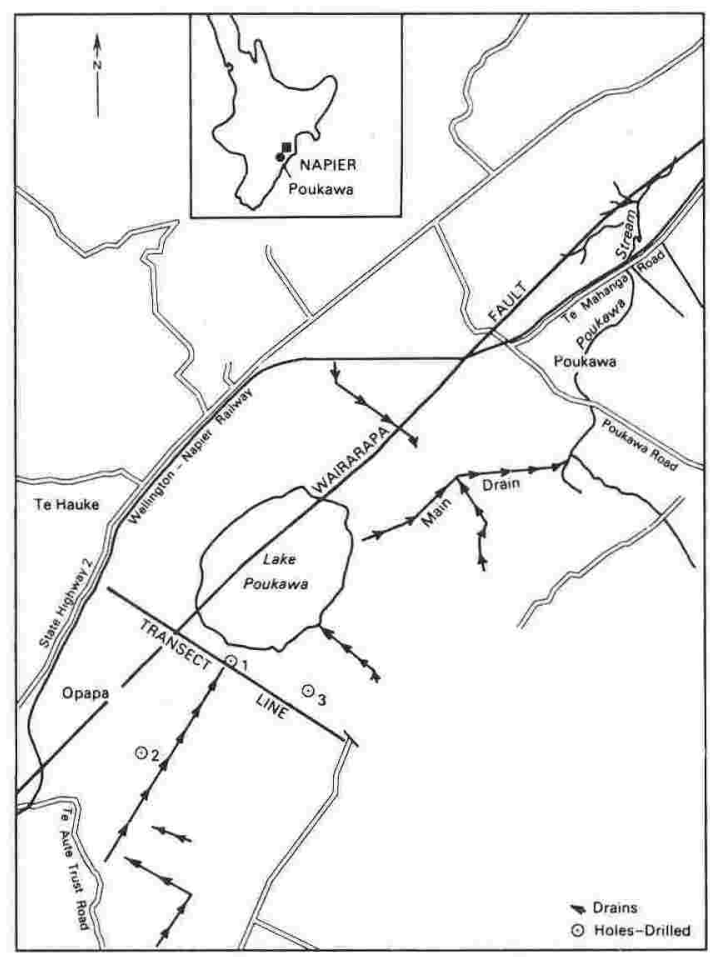

Fig. 1 Map of Poukawa area showing the transect line of Fig. 2 (Howorth et al. 1980, this issue), the Wairarapa Fault, and the position of 3 holes cored in sediments beneath peat swamp. 
Henderson (1933). Subsequent relevelling of the railway line through the Poukawa valley revealed vertical changes extending to the south, beyond the lake (Henderson 1933). Kingma (1971) considered the Poukawa Shear to be the northern extension of Wairarapa Fault.

\section{PEAT STRATIGRAPHY}

Detailed peat stratigraphy and chronology along a northwest-southeast transect line south of the lake has been described by Howorth et al. (1980, this issue). The stratigraphic relationships of the peat, 2 lake sediment layers, and 4 tephras are summarised (see fig. 2 Howorth et al. 1980, this issue).

Present ground surface of the swamp is very close to horizontal, as there is less than $1.0 \mathrm{~m}$ of relief along a transect line across the swamp. Several attempts to drain the peat swamp have lowered the peat surface by a maximum of only $1.6 \mathrm{~m}$. This suggests that the upper part of the peat is effectively held buoyant by groundwater.

Two lake sediment layers within the peat are almost pure calcium carbonate and are considered to be analogous to the carbonate now accumulating beneath the lake. Auger holes drilled in the middle of the lake, when lake level was low, penetrated continuous lake sediment overlying continuous peat, which in turn overlies coarse sandy silt. It is assumed, therefore, that since the lake formed it has precipitated carbonate seasonally, if not continuously. The lake sediment layers in the transect (fig. 2 in Howorth et al. 1980, this issue) are thus attributed to expansions of the lake. These expansions lasted for some years, and whether they were climatically controlled is unknown. An active fault passes through the narrow gorge in which Poukawa Stream flows. Possibly landslides, fault movement, or a combination of these could have blocked Poukawa Stream, but whether the effects would be sufficient to cause a lasting expansion of the lake is uncertain.

Each tephra within the peat has been identified (Howorth et al. 1980, this isssue) by a combination of stratigraphy, field character, and phenocryst assemblage. From youngest to oldest these are Taupo, Waimihia, Whakatane, and Hinemaiaia Tephras. Averaged radiocarbon dates of peat collected from immediately above and below each of the 4 major tephras are given in Table 1. All dates have been corrected to calendar years using the secular variations of Michael \& Ralph (1972).

Assuming constant, but not necessarily equal, accumulation rates between Taupo and Waimihia Tephras, and Waimihia and Whakatane Tephras, we calculated ages for the upper and lower contacts of each of the 2 lake sediment layers (Howorth et al. 1980, fig. 2). Errors shown are the standard error on the mean of 9 determinations. Peat and lake sediment may not accumulate at equal rates, though the average appears to be close to $1 \mathrm{~mm}$ /year.

\section{FAULT MOVEMENT}

As shown on the cross-section (fig. 2 in Howorth et al. 1980 , this issue), a marked step in the base of the peat occurs between holes 11 and 12 . A step at this point is also apparent in each stratigraphic horizon. It lies on the extension of the Poukawa Shear (Wairarapa Fault). If it is assumed that these steps are due to movement of this fault, then the apparent greater offset of older horizons indicates repeated movement.

Some assumptions need to be made before absolute displacement can be determined. (1) Surface topography of a growing peat bog is largely controlled by the water table. This maintains a level

\begin{tabular}{|c|c|c|c|c|c|}
\hline HORIZON & AGE & $\begin{array}{c}\text { (Years } \\
\text { B.P.) }\end{array}$ & Hole 12 & $\begin{array}{l}\text { (m) } \\
\text { Hole } 11\end{array}$ & $\begin{array}{l}\text { OFFSET } \\
\text { (m) }\end{array}$ \\
\hline TAUPO & 2039 & \pm 60 & 1.04 & 1.60 & 0.56 \\
\hline \multicolumn{6}{|c|}{ LAKE SEDIMENT } \\
\hline Top & 3340 & \pm 35 & 2.70 & 3.44 & 0.74 \\
\hline Bottom & 3530 & \pm 35 & 2.80 & 3.82 & 1.02 \\
\hline WAIMIHIA & 3590 & \pm 130 & 2.80 & 3.86 & 1.06 \\
\hline \multicolumn{6}{|c|}{ LAKE SEDIMENT } \\
\hline Top & 4360 & \pm 80 & 4.20 & 5.22 & 1.02 \\
\hline Bottom & 5160 & \pm 35 & 4.70 & 5.90 & 1.22 \\
\hline WHAKATANE & 5355 & \pm 80 & 4.96 & 6.26 & 1.30 \\
\hline HINEMAIAIA & 6365 & \pm 145 & 5.55 & 7.06 & 1.51 \\
\hline
\end{tabular}

Table 1 Age in calendar years, depth, and offset of horizons within the peat cored in holes 11 and 12 along the transect line on Fig. 1. Ages of lake sediment layers are calculated from sedimentation rates; the errors quoted are the standard error on the mean of 9 determinations. Dates are averages from Howorth et al. (1980, this issue). 
ground surface so that tephras and lake sediment are deposited horizontally. Close to the fault the beds are nearly horizontal, so any horizontal component of movement will not create vertical offset; thus, the measured vertical offset is wholly due to vertical fault movement. (2) As it is not possible to precisely determine the effects of peat compaction, it is assumed that this process is horizontally uniform. (3) Artificial drainage has had little effect on subsurface layers. Taupo Tephra, the shallowest layer used in this study, is continuous and still below the permanent water table. Draining of the swamp from 1931 onwards appears to have only affected the near-surface peat, deflating and compacting it so that stumps rose through the surface. Throughout the peat profile below the permanent water table, in situ peat density is constant at $1.04 \mathrm{Mg} / \mathrm{m}^{3}$ and water content is uniform at $85 \%$, supporting the validity of this last assumption.

Age (in calendar years), depth, and offset of each horizon within the peat is given in Table 1. Errors on each date are as quoted, and errors for the offsets are $\pm 0.05 \mathrm{~m}$. All offsets increase with age except for 1 reversal, the top of the lake sediment beneath the Waimihia Tephra. Significance of this apparent reversal is uncertain because the amount $(0.04 \mathrm{~m})$ is within the error limits. However, Lensen (1968a) recorded a reversal and change of upthrown side with time for a flight of river terraces offset by Wairarapa Fault at Waingawa River, Masterton, $200 \mathrm{~km}$ to the southwest of Lake Poukawa, so this reversal may have occurred.

Offset of each horizon is plotted against age in Fig. 2. As a first analysis, a linear function fits closely to these points $(r=0.980)$. This indicates that vertical fault movement is occurring at a uniform rate of $0.2 \mathrm{~mm} /$ year. Dominantly strike-slip faults such as the Wairarapa, Wellington, or Alpine Faults commonly have horizontal to vertical ratios (H/V) of 6 or greater (Lensen 1958; Lensen \& Vella 1971; Wellman 1972), and assuming this figure for the fault at Poukawa gives a horizontal rate of at least $1.2 \mathrm{~mm} /$ year. If this was occurring as "creep" then surface displacements of suitable structures across the fault would be expected. Detailed field examinations of 2 tarsealed roads where they cross the fault (Te Mahanga Road at N141/174096 and Poukawa Road at N141/147068*) shows no sign of displacement. Fault movements must therefore be occurring as discrete events, namely earthquakes, which produce an overall uniform average rate of displacement.

Uniform rates of tectonic events have commonly been assumed (Wellman 1952, 1969, 1971, 1972; Lensen 1968b, 1976; Lensen \& Vella 1971; Suggate

* Grid references are based on the thousand-yard grid of the $1: 63360$ topographical map series NZMS 1 .

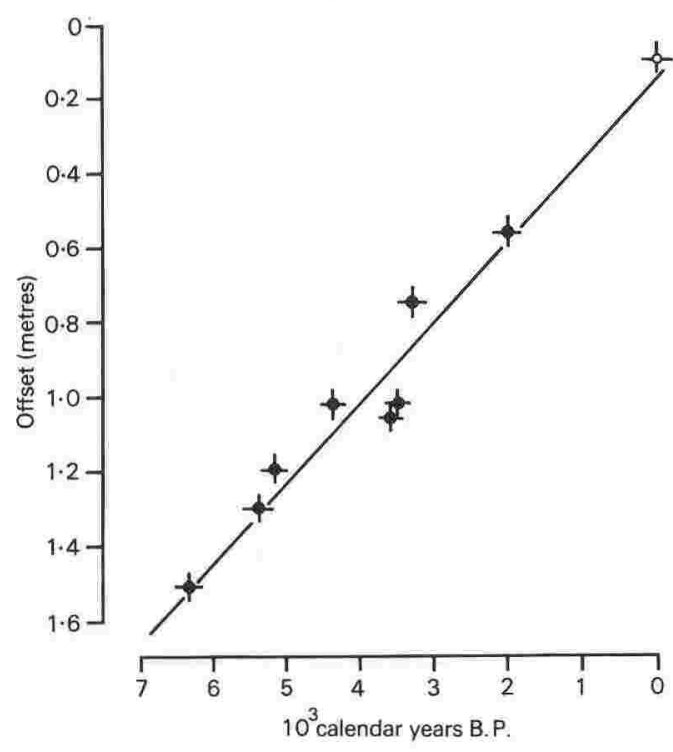

Fig. 2 Plot of offset against age for each of the dated horizons within the peat. Ages are in calendar years with the point near zero the estimated effect of the 1931 earthquake. Regression line fitted is $\mathrm{y}=0.00022 \mathrm{x}+0.125$ with correlation coefficient $r=0.980$.

1960) to allow analysis of fault displacements. Poukawa is the first example where this hypothesis could be tested.

\section{Step function analysis}

To examine in more detail the history of fault movements, a step function can be fitted to the data. A step function used to analyse tectonic events through time is bascially 1 of 3 general forms:

1. Steps of equal tread width centred on, and symmetrical about, the average rate (Fig. 3A);

2. Steps where the next displacement is proportional to the time to the next event (Fig. 3B);

3. Steps where time to the next earthquake is proportional to the displacement of the preceding event (Fig. 3C).

Wellman (1969) used type (1) in determining age of beach ridges at Cape Turakirae; however, the function which best fits the Poukawa data (Fig. 4) appears to be a combination of all three.

As the faulting rate has been constant, steps were inferred between 2000 years and the present where no data are available. Eight steps are required over about 6500 years giving 1 earthquake every $800-900$ years for this section of the fault. A similar recurrence rate has been determined for a sequence of Holocene beach ridges at Cape Turakirae $250 \mathrm{~km}$ southwest of Poukawa (Wellman 1969) and for a 


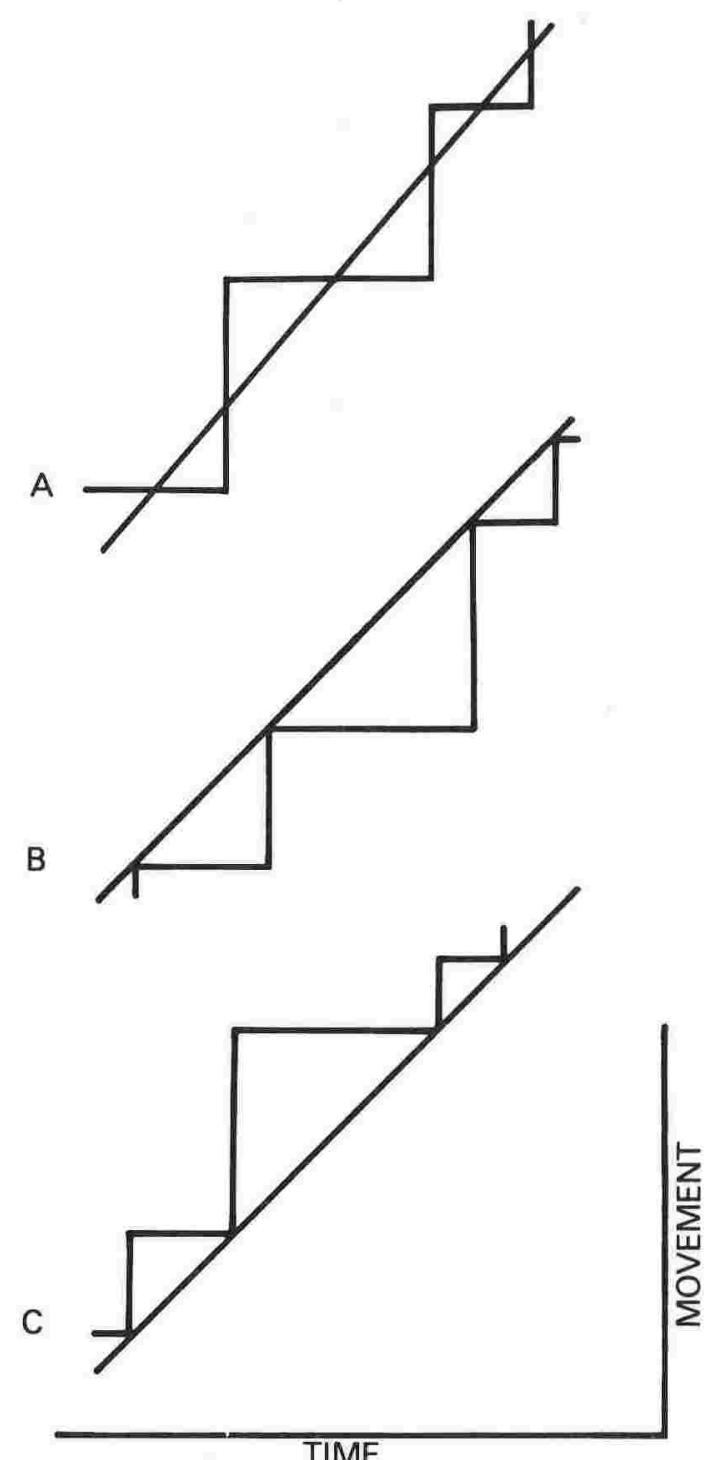

Fig. 3 The 3 general forms of a step function fitted to an assumed constant rate of tectonic movement. A Time between events symmetrical about the average rate. B Displacement is proportional to the time to the next event. C Time to the next event is proportional to the displacement of the preceding event.

flight of faulted river terraces at Waiohine River (Lensen \& Vella 1971; Wellman 1972). Extrapolation of the steps indicates that the next major offset at Poukawa will be in about 500 years time.

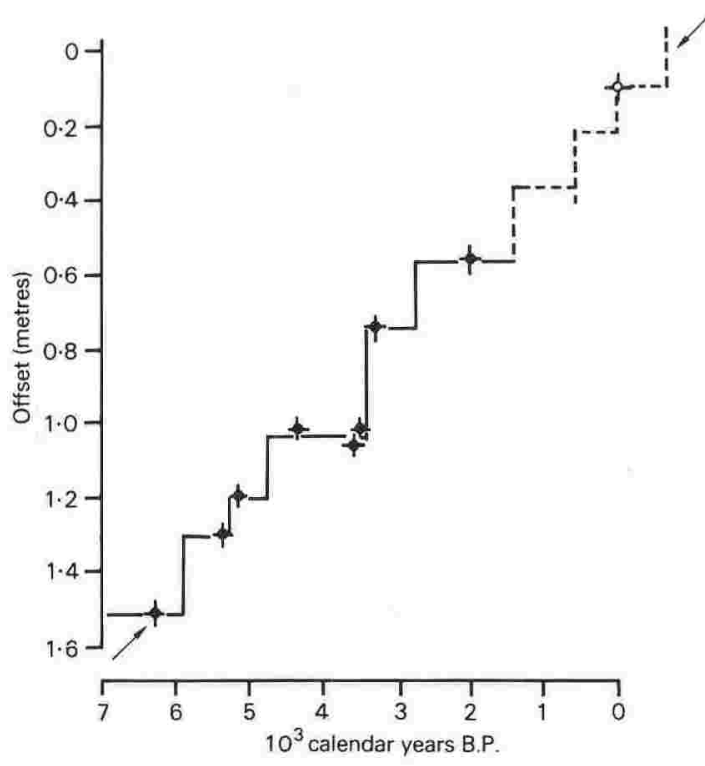

Fig. 4 Step function fitted to the Poukawa data. Dashed line is an extrapolation based on constant faulting rate and estimate for the 1931 earthquake. Arrows indicate position of the regression line from Fig. 2.

\section{CONCLUSIONS}

Pumice layers interbedded with peat provide dated reference planes that clearly indicate vertical movement on Wairarapa Fault at Lake Poukawa. Progressive offset of each plane with time shows vertical fault movement has been occurring for the last 7000 years at a uniform rate of $0.2 \mathrm{~mm} /$ year. Field studies show that this is not occurring as "creep" so it must be as a finite number of earthquakes. The time of each of these events can be estimated from the data and the known uniform rate of movement. Poukawa is the first known example where average rates of fault movement can be shown to be uniform, validating this commonly made assumption.

\section{ACKNOWLEDGMENTS}

We thank Professor H. W. Wellman who initiated our studies at Poukawa and who has provided many comments on this fault analysis; also G. J. Lensen for some stimulating discussions on faulting. To the geology students who have assisted with the peat boring, and F. Brownrigg for providing accommodation and access, we are grateful. University Grants Committee (Grant 34/75) provided financial support. 


\section{REFERENCES}

Henderson, J. 1933. Geological aspects of the Hawke's Bay earthquake. New Zealand journal of science and technology $16: 38-75$.

Howorth, R.; Froggatt, P. C.; Robertson, S. M. 1980. Late Quaternary volcanic ash stratigraphy in the Poukawa area, Central Hawke's Bay, New Zealand. New Zealand journal of geology and geophysics 23 : (this issue).

Kingma, J. T. 1971. Geology of Te Aute subdivision. New Zealand Geological Survey bulletin n.s. 70. Wellington, Department of Scientific and Industrial Research.

Lensen, G. J. 1958. Rationised fault interpretation. New Zealand journal of geology and geophysics. 1 : 307317.

1968a. Sheet N158-Masterton (1st ed.). Late Quaternary tectonic map of New Zealand, 1:63 360. Wellington, Department of Scientific and Industrial Research.

1968b. Analysis of progressive fault displacement during downcutting at the Branch River, South Island, New Zealand. Geological Society of America bulletin 79 : 545-556.

1976. Sheets N28D, O28C, \& N29B-Hilldersden and O28D, P28A, \& P28C-Renwick (1st ed.) Late Quaternary tectonic map of New Zealand, 1:50 000. Wellington, Department of Scientific and Industrial Research.

Lensen, G. J.; Vella, P. 1971. The Waiohine River faulted terrace sequence. In: Collins, B. W.; Fraser, R. ed.Recent crustal movements. Royal Society of New Zealand bulletin 9 : 117-119.
McFadgen, B. G. 1979. The antiquity of man at Lake Poukawa, New Zealand. Journal of the Royal Society of New Zealand 9: 375-382.

Michael, H. N.; Ralph, E. K. 1972. Discussion of radiocarbon dates from precisely dated Sequoia and Bristlecone pine samples. In: Proceedings of 8th International Conference on radiocarbon dating, Lower Hutt, New Zealand. 27-43.

Price, T. R. 1963. Moa remains at Poukawa, Hawke's Bay. New Zealand Archaeological Association newsletter 6 : $169-174$.

Pullar, W. A. 1965. Note on ash beds at Poukawa, Hawke's Bay. New Zealand Archaeological Association newsletter $8: 11-13$.

1970. Pumice ash beds and peaty deposits of archaeological significance near Lake Poukawa, Hawke's Bay. New Zealand journal of science. $13: 687-705$.

Suggate, R. P. 1960 . The interpretation of progressive fault displacement by flights of terraces. New Zealand journal of geology and geophysics $3: 364$ 374.

Wellman, H. W. 1952. The Alpine Fault in detail. River terrace displacement at Maruia River. New Zealand journal of science and technology B33 : 409-415.

1969. Tilted marine beach ridges at Cape Turakirae, New Zealand. Tuatara 17: 82-93.

1971. Holocene tilting and uplift on the White Rocks coast Wairarapa, New Zealand. In: Collins, B. W.; Fraser, R. ed. Recent crustal movements. Royal Society of New Zealand bulletin 9 : 221-223.

1972. Rate of horizontal fault displacement in New Zealand. Nature 237 : 275-277. 


\section{Uniformity of Late Quaternary Tectonic Tilting, Lake Poukawa, New Zealand}

\section{R. HOWORTH* and P. C. FROGGATT*}

Tectonic processes, for example sea floor spreading, subduction, faulting, subsidence and emergence, are continuous processes commonly assumed to be occurring at constant rates. However, proof of uniform rates is rare because of the lack of dated reference features. At Poukawa, New Zealand, tectonic tilting, determined using five dated reference features, is shown to have been uniform for the last 20,000 years.

Lake Poukawa, central Hawke's Bay, New Zealand, (Figure 1 inset) is situated

* Geology Department, Victoria University of Wellington, New Zealand. on a Holocene peat swamp in which four dated rhyolitic tephras (volc ashes) (Howorth et al., 1980). The swamp floors a tectonic depressior growing syncline, one of several in region, and the Wairarapa Fault major active transcurrent fault, cro the depression (Kingma, 1971). fault has been mapped and is recogn: in the area of the peat swamp by vert offset of the base of the peat and tephras (Froggatt \& Howorth, 1980).

Wairarapa Fault is one of sevt subparallel active dextral faults alig! northeast-southwest, in a zone wh crosses the central part of New Zeali and the eastern North Island and is $p$ of the Alpine Fault Zone (Wellman 1969). The Alpine Fault Zone is a transform plate boundary with movement between the Indian and Pacific Plates (McKenzie \& Morgan, 1969).

Lake Poukawa is roughly circular (1.5 $\mathrm{km}$ diameter) and very shallow, the minimum recorded depth in the last 30 years being $0.3 \mathrm{~m}$. The peat is up to $10 \mathrm{~m}$ thick in the axis of the depression (Howorth et al., 1980) and thins to zero $1.5 \mathrm{~km}$ away from the lake. The original swamp was eutrophic with the dominant vegetation being flax (Phormium tenax). Ground surface of the swamp is closely related to water table and is thus nearly horizontal. There is less than $2 \mathrm{~m}$ of relief across the swamp from northwest to southeast (Figure 1) resulting from successive deliberate lowerings of the water table in the last 50 years. The mean annual water table level in the axis of the swamp is now $1.6 \mathrm{~m}$ lower than the original level. Cultivation of the peat has been possible since controlled lowering of the water table commenced.

Below permanent water table moisture contents as measured by us are constant with depth at $95 \%$, as are in situ peat

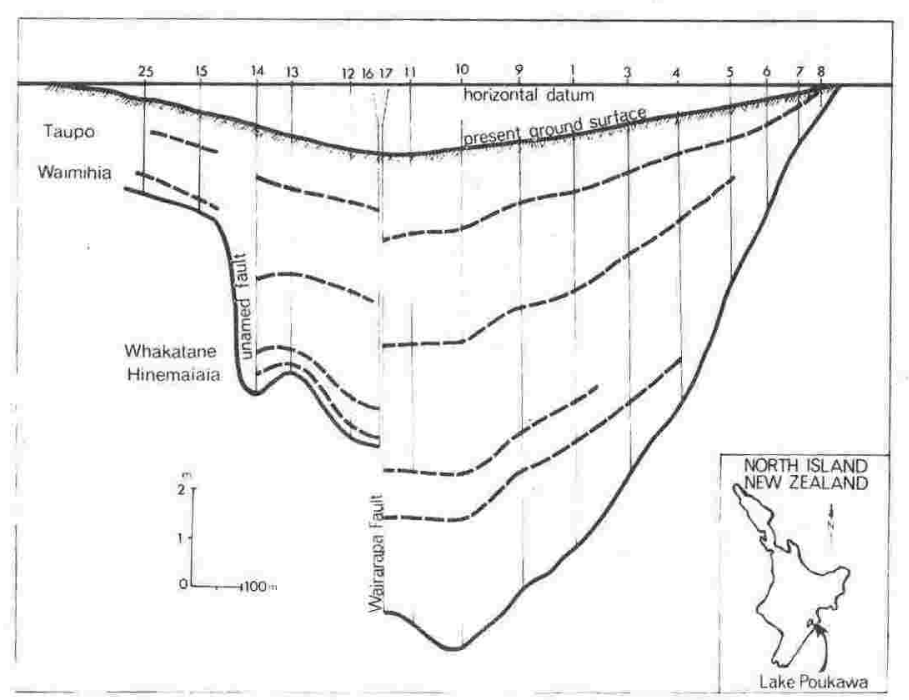

FIGURE 1

Peat transect line south of Lake Poukawa showing positions of Taupo, Waimihia, Whakata. $n e$ and Hinemaiaia tephras. Borehole positions are shown by numbered vertical lines. 
k densities at $1.04 \mathrm{MGM}^{-3}$. The a, together with a uniform structure, licate the peat at Poukawa to be held byant by the water, and therefore e has been no compaction of the below permanent water table. ove the permanent water table the per $1-2 \mathrm{~m}$ undergoes seasonal wetting drying, and oxidation has occurred result of draining and cultivation. wever, in peats where the water table ot confined by a drainage outlet, for mple coastal marshes, autompaction of the peat is observed aye \& Barghoorn, 1964).

png a $3 \mathrm{~km}$ northwest-southeast nsect south of the lake 17 holes have en logged through the peat (Figure 1) ng a Hiler Borer. Altogether a total 50 holes have been drilled in the area ath, west and north of the lake oworth et al., 1980). Along the insect four tephras are easily ognisable and stratigraphically conmable. Tephras were well-sorted fine medium ash and definitely not rorked. Holes occasionally missed a hra, probably due to the boring thod. Radiocarbon dates have been tained from within the peat from and below each tephra in hole 1 ave been corrected to calendar ising the secular correction curves hael \& Ralph (1972). The mean of tes for a tephra has been taken to the age of the timeplane. Each nra is a known event in the Taupo
TABLE 1

Radiocarbon dates calendar years tephras within peat at Poukawa.

\begin{tabular}{|c|c|c|c|}
\hline Tephra & $\begin{array}{l}\text { Laboratory } \\
\text { Number }\end{array}$ & $\begin{array}{l}\text { C14 Date (new } 1 / 2 \cdot \text { life) } \\
\text { (dates in yrs BP) }\end{array}$ & $\begin{array}{l}\text { Average date } \\
\text { (calendar yrs) }\end{array}$ \\
\hline Taupo & $\begin{array}{l}\text { NZ1059 } \\
\text { NZ1060 }\end{array}$ & $\begin{aligned} 1926 & \pm 60 \\
2151 & \pm 60\end{aligned}$ & $2039 \pm 60$ \\
\hline Waimihia & $\begin{array}{l}\text { NZ1062 } \\
\text { NZ3947 } \\
\text { NZ1061 }\end{array}$ & $\begin{array}{l}3244 \pm 65 \\
3380 \pm 110 \\
3368 \pm 65\end{array}$ & $3590 \pm 130$ \\
\hline Whakatane & $\begin{array}{l}\text { NZ3948 } \\
\text { NZ3949 }\end{array}$ & $\begin{array}{l}4740 \pm 90 \\
4770 \pm 90\end{array}$ & $5355 \pm 80$ \\
\hline Hinemaiaia & $\begin{array}{l}\text { NZ3950 } \\
\text { NZ3951 }\end{array}$ & $\begin{array}{l}5840 \pm 140 \\
5530 \pm 100\end{array}$ & $6365 \pm 110$ \\
\hline
\end{tabular}

Volcanic Zone $150 \mathrm{~km}$ to the northwest (Vucetich \& Pullar, 1969, 1973) and the ages of these timeplanes as determined at Poukawa are in Table 1. The Poukawa peat dates agree well with relevant charcoal dates from the central North Island but are considered more reliable and consistent, being from the same environment. Positions of the tephras and the Wairarapa Fault are shown on a cross-section (Figure 1).

Depths to horizons in the peat (Table 2) have been adjusted to allow for up to $1.6 \mathrm{~m}$ of surface deflation at the centre of the swamp, decreasing to zero at the margins. The value of $1.6 \mathrm{~m}$ is taken from level surveys conducted from 1931 to 67 when the swamp was drained. For all holes, the ratio of the corrected depths to any two timeplanes is constant. This is indicated on the relation diagram (Figure 2) where the position of the holes with three or more tephras has been replotted to give a

\begin{tabular}{llllllllll}
\hline $\begin{array}{l}\text { le } \\
\text { mber } \\
\text { phra }\end{array}$ & 10 & 9 & 1 & 12 & 3 & 4 & $\begin{array}{c}\text { Age } \\
(\mathrm{K} y \mathrm{r})\end{array}$ & $\begin{array}{c}\text { Tilt } \\
\mu \mathrm{rad} / \mathrm{yr}\end{array}$ \\
\hline upo & 2.6 & 2.0 & 2.9 & 2.2 & 2.1 & 1.2 & 2.04 & 1.7 \\
limihia & 4.8 & 4.1 & 4.1 & 4.1 & 4.1 & 2.6 & 3.59 & 1.6 \\
lakatane & 7.4 & $(6.8)$ & 5.2 & 6.1 & 6.0 & $(4.2)$ & 5.36 & 1.6 \\
temaiaia & 8.3 & 7.2 & 7.0 & 6.7 & $(7.0)$ & 5.2 & 6.37 & 1.2 \\
& 0.997 & 0.989 & 0.985 & 0.994 & 0.998 & 1.00 & & \\
\hline wakawa & & & & & & & 20.0 & 1.2 \\
\hline
\end{tabular}

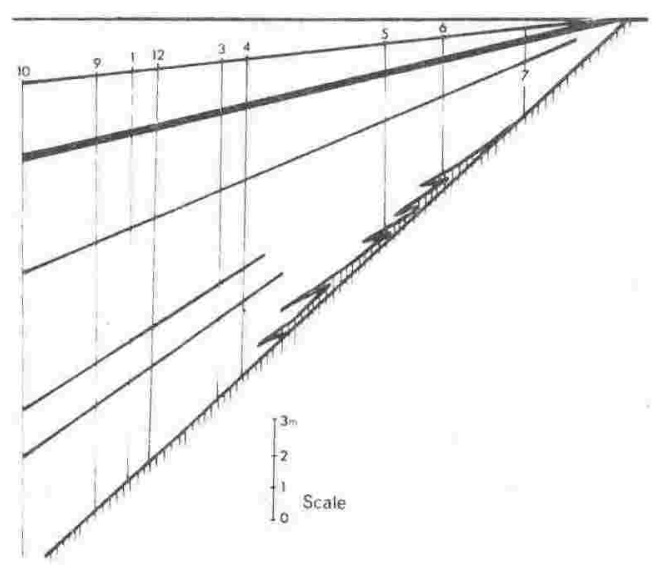

TABLE 2

Depths (in metres) of tephras for holes in which at least three tephras are recognised; depths in brackets are estimated. $R=$ correlation coefficients between depth and age for each hole.

FIGURE 2

Relation diagram of depth against age for tephras preserved at Poukawa. For method of construction see texi. Data for holes where at least three tephras are recognised are given in Table 2. linear best fit for all timeplanes. Lack of scatter of the data is shown by the high correlation coefficients relating depth to age (average of six holes $R=0.994$ ). This further indicates that compaction of the peat below permanent water table is negligible.

On the relation diagram it can be seen that there is a regular increase of slope of the timeplanes with increasing age (Figure 2). Tectonic tilting is the only known process which will explain these data. The tilt rate for each timeplane (Table 2) averages 1.5 microradians per year (ur/yr), indicating uniformity of tectonic tilting over the last 6,000 years. For this time period, the tilt rate is at least three times as high as elsewhere in New Zealand (Wellman, 1971; Singh, 1971). Within alluvial silts underlaying the peat, Kawakawa Tephra with a C14 age of 20,000 \pm 500 years BP (Vucetich \& Howorth, 1976) has been identified by stratigraphy and minerology in three deep boreholes close to the transect line. This timeplane gives a tilt rate of 1.6 ur/yr, substantiating the continuity of the high tilt rate at Poukawa during the late Quaternary.

Assuming a 'no compaction' model as above, the simplest explanation of the data is that tilting is caused by earthquakes recurring at c. 900-year intervals. This recurrence rate has been suggested for the Alpine Fault Zone to explain a sequence of Holocene beach ridges $250 \mathrm{~km}$ southwest of Poukawa (Wellman, 1972) and also to explain a sequence of offset Holocene river terraces (Lensen \& Vella, 1971). In both these examples uniformity of processes was assumed. At Poukawa the Holocene data would be explained by eight such earthquakes each causing a deepening of the axis of the depression, the last possibly being the well-known Napier earthquake in 1931.

It is likely that peat accumulation rates are affected by each such earthquake, and to identify the position in the peat when the events occurred would require many - possibly several hundred peat samples for dating.

Field evidence suggests that creep is not occurring at such a high rate on the 
Wairarapa Fault (Froggatt \& Howorth, 1980). However, a precise level line has been surveyed which will enable us to check this possibility within two to three years.

\section{References}

FROGGATT, P. C. \& HOWORTH, R. (1980) - Uniformity of vertical faulting for the last 7,000 years at Lake Poukawa, Hawke's Bay, New Zealand. New Zealand Journal of Geology and Geophysics 23

"HOWORTH, R. FROGGATT. P. C. \& ROBERTSON, S. M. (1980) Late Quarternary volcanic ash stratigraphy in the Poukawa area, central Hawke's Bay, New Zealand. New Zealand Journal of Geology and Geophysics 23.

KAYE, C. A. \& BARGHOORN, E.S. (1964) Late Quaternary sea level change and crustal rise at Boston, Massachusetts, with notes on the autocompaction of peat. Geological Society of America Bulletin 75 63-80.

KINGMA, J. T. (1971) Geology of Te Aute Subdivision. New Zealand Geological Survey Bulletin n.s. 70.

LENSEN, G. J. \& VELLA, P. P. (1971) The Waiohine River faulted terrace sequence, in 'Recent Crustal Movements', Royal Society of New Zealand Bulletin 9 117-119.

MCKENZIE, D. P. \& MORGAN, W. J. (1969) Evolution of triple junctions. Nature 224125 . 133.

MICHAEL, H. N. \& RALPH, E. K. (1972) Discussion of Radiocarbon dates obtained from precisely dated Sequoia and Bristlecone pine samples. Proceedings 8th international Conference on Radiocarbon Dating, Wellington, New Zealand, 1972 Volume 1: A 11-27.

SINGH, L. J. (1971) Uplight and tilting of the Oterei Coast, Wairarapa, New Zealand, during the last ten thousand years, in 'Recent Crustal Movements', Royal Society of New Zealand Bulletin $9221-223$

VUCETICH, C. G. \& HOWORTH, R. (1976) Proposed definition of the Kawakawa Tephra, the c. 20,000 years BP marker horizon in the New Zealand Region. New Zealand Journal of Geology and Geophysics 19 43-50.

VUCETICH, C. G. \& PULLAR, W. A. (1969) Stratigraphy and chronology of late Pleistocene volcanic ash beds in central North Island, New Zealand. New Zealand Journal of Geology and Geophysics 12 784-837.

VUCETICH, C. G. \& PULLAR, W. A. (1973) Holocene tephra formations erupted in the Taupo area, and interbedded tephras from other volcanic sources. New Zealand Journal. of Geology and Geophysics 16 745-780.

WELLMAN, H. W. (1969) Tilted marine beach ridges at Cape Turakarae, New Zealand. Tuatara 17(2) 82.93.

WELLMAN, H. W. (1971) Holocene tilting and tuplift on the White Rocks Coast, Wairarapa, New Zealand, in Collins, B. W. \& Fraser, R. (Eds.) Recent Crustal Movements, Royal Sociefy of New Zealand Bulletin 9 221-223.

WUELLMAN, H. W. (1972) Rate of Horizontal Fault displacement in New Zealand. Nature 237 275-277. 
APPENDIX A3.

ANALYTICAL DATA. 


\section{$30 ; 3$}

\section{APPENDIX 3}

All analytical data, not presented elsewhere are grouped in this appendix. It is subdivided into three sections:

A3/1 whole rock, major and trace element data;

A3/2 mineral chemistry determined by electron microprobe;

A3/3 glass chemistry determined by electron microprobe.

Techniques of sample preparation and analysis are in Appendix Al.

Sample numbers refer to the 50,000 tephra series of the Geology Department, Victoria University. Relevant sample numbers and locations, not described elsewhere, are listed below. 


\begin{tabular}{|c|c|}
\hline 50030 & Scinde Is. Ash \\
\hline 50031 & Aokautere Ash \\
\hline 50038 & Mt Curl Tephra \\
\hline 50041 & Kawakawa Tephra \\
\hline 50045 & Atiamuri Ignimbrite \\
\hline 50052 & Kaingaroa Ig. \\
\hline 50034 & ?Rocky Hills Ig. \\
\hline 50057 & ?Kaingaroa Ig \\
\hline 50058 & ?Kaingaroa \\
\hline 50060 & Griffin Rd lower tephra \\
\hline 50061 & Griffin Rd upper Tephra \\
\hline 50063 & Mt Curl Tephra \\
\hline 50064 & 3Mt Curl Tephra \\
\hline 50065 & ?Te Piki tephra \\
\hline 50068 & Kaingaroa Ignimbrite \\
\hline 50071 & Kawakawa Tephra \\
\hline 50075 & Mamaku Ignimbrite \\
\hline 50077 & ?Kaingaroa Ig. \\
\hline 50079 & Mamaku Ignimbrite \\
\hline 50080 & Mamaku Ignimbrite \\
\hline 50089 & ?Rocky Hills Ig. \\
\hline 50097 & Rotoehu Ash \\
\hline 50098 & Marshall Ignimbrite \\
\hline 50099 & Marshall plinian \\
\hline 50100 & Matahina Ignimbrite \\
\hline 50103 & Mt Curl Tephra (type) \\
\hline 50105 & Mt Curl Tephra \\
\hline 50110 & Matahina plinian \\
\hline 50111 & Matahina Ignimbrite \\
\hline 50122 & Mt Curl Tephra \\
\hline 50124 & \\
\hline 50125 & \\
\hline 50126 & \\
\hline 50127 & \\
\hline 50128 & r \\
\hline 50129 & Mt Curl \\
\hline 50131 & Mt Cur1 Tephra \\
\hline 50138 & "Omokoroa 9" \\
\hline 50142 & "Omokoroa 13" \\
\hline 50143 & "Omokoroa 14" \\
\hline 50144 & "Omokoroa 15" \\
\hline 50145 & "Omokoroa 16" \\
\hline 50156 & ?Mt Curl Tephra \\
\hline 50157 & Mt Curl Tephra \\
\hline 50160 & ?Kaukatea Ash \\
\hline 50165 & Rangitaiki Ignimbrite \\
\hline 50166 & Te Whaiti Ignimbrite \\
\hline 50167 & Mt Curl Tephra \\
\hline 50168 & Rangitawa pumice \\
\hline 50171 & ?ROCky Hills Ig. \\
\hline 50177 & \\
\hline 50178 & . \\
\hline 50179 & \\
\hline 50182 & Taupo Ignimbrite \\
\hline 50183 & Taupo Ignimbrite \\
\hline 50184 & Oruanui Breccia \\
\hline 50191 & Rangitaiki Ig. \\
\hline
\end{tabular}

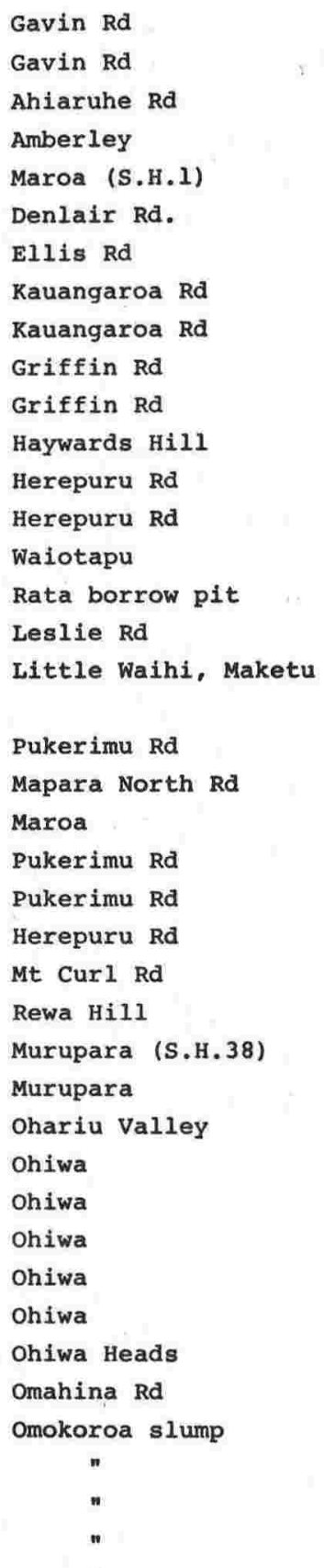

\begin{tabular}{|c|c|}
\hline N86/995825 & V16/196149 \\
\hline N86/995825 & V16/196149 \\
\hline $\mathrm{N} 162 / 081458$ & S27/274095 \\
\hline$S 68 / 154033$ & N34/935851 \\
\hline N85/534687 & $\mathrm{U} 17 / 771035$ \\
\hline N138/762873 & S22/019397 \\
\hline N93/026590 & $\mathrm{T} 17 / 307960$ \\
\hline $\mathrm{N} 138 / 75983$ & $\$ 22 / 015365$ \\
\hline N138/771851 & S22/026376 \\
\hline N143/929781 & $\mathrm{S} 22 / 169308$ \\
\hline $\mathrm{N} 143 / 929781$ & S22/169308 \\
\hline $\mathrm{N} 160 / 511416$ & $\mathrm{R} 27 / 752072$ \\
\hline N68/176352 & v15/375626 \\
\hline N68/176352 & v15/375626 \\
\hline N85/875776 & $\mathrm{U} 16 / 085107$ \\
\hline N144/023781 & S22/255306 \\
\hline
\end{tabular}

N59/942501

V14/165768

N85/535843 U16/776177

N83/725604 $517 / 030980$

N85/495625 U17/734979

N85/531821 U16/722157

N85/531821 U16/722157

N68/175344 V15/374618

$\mathrm{N} 138 / 956822 \quad \mathrm{~S} 22 / 195345$

N144/133779 T22/355301

N86/120657 V17/306992

N86/120657 V17/306992

N160/342330 R27/595998

N69/599211 W15/758486

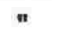

n

"

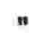

N69/601211

N138/953820

พ15?760486 S22/192343 U14/792926
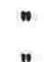

"
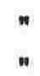

N149/297248

N149/286255

N112/392938

N104/963055

N137/466044

N143/962624

N83/816747

N78/740188

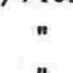

N94/539378

N103/486095

N103/489078

N112/298825
T24/492812

T24/482818

T19/023399

V19/147446

R22/753561

s23/195164

$516 / 117108$

พ15/886461

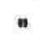

U18/768752

U19/712477

T19/533253
U19/712479 


\begin{tabular}{|c|c|c|}
\hline 50193 & "Torere 1" & \\
\hline 50194 & "Torere $2 "$ & \\
\hline 50195 & "Torere 3" & \\
\hline 50196 & "Torere 4" & \\
\hline 50203 & Tepiki tephra & \\
\hline 50207 & Mt Curl Tephra & \\
\hline 50208 & Whakamaru Ignimbr & rite \\
\hline 50209 & Whitby ash & \\
\hline 50210 & "Cape Kidnappers & $1^{\prime \prime}$ \\
\hline 50211 & & 2 \\
\hline 50212 & & 3 \\
\hline 50213 & & 4 \\
\hline 50214 & & 5 \\
\hline 50215 & & 6 \\
\hline 50216 & & 7 \\
\hline 50217 & & 8 \\
\hline 50218 & & 9 \\
\hline 50219 & & 10 \\
\hline 50220 & & 11 \\
\hline 50221 & & 13 \\
\hline 50222 & Taupo Ignimbrite & \\
\hline 50223 & Taupo Lapilli & \\
\hline 50224 & Rotongaio Ash & \\
\hline 50225 & Hatepe ash & \\
\hline 50226 & Hatepe Lapilli & \\
\hline 50227 & Mapara Tephra & \\
\hline 50228 & Whakaipo Tephra & \\
\hline 50229 & Waimihia Ignimbri & ite \\
\hline 50230 & Waimihia Lapilli & \\
\hline 50234 & Karapiti Tephra ( & (upper) \\
\hline 50235 & Hinemaiaia Tephra & \\
\hline 50237 & Opepe Tephra (upp & per) \\
\hline 50238 & Opepe Lapilli & \\
\hline 50239 & Poronui Tephra & \\
\hline 50240 & Karapiti Tephra ( & (lapilli) \\
\hline 50241 & & \\
\hline 50242 & & \\
\hline 50243 & & \\
\hline 50244 & & \\
\hline 50245 & & \\
\hline 50246 & & \\
\hline 50247 & & \\
\hline 50248 & & \\
\hline 50249 & & \\
\hline 50250 & & \\
\hline 50251 & & \\
\hline 50253 & & \\
\hline 50254 & & \\
\hline 50255 & . & \\
\hline 50256 & & \\
\hline 50257 & & \\
\hline 50258 & & \\
\hline 50515 & Finnis Rd upper $t$ & tephra \\
\hline 50156 & Finnis Rd lower $t$ & tephra \\
\hline 50519 & Kaukatea Ash & \\
\hline 50533 & Whakamaru Ignimbr & orite \\
\hline
\end{tabular}

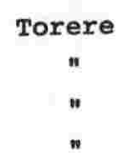

Te Piki tephra walker Rd Te kuiti Waipapa $\mathrm{Rd}$ Whitby

Cape Kidnappers

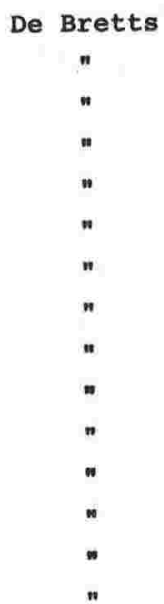

RC9-110 $384-387 \mathrm{~cm}$ RC9-110 555-558cm RC9-110 675-678cm RC9-113 142-153 ' $E$ ' RC9-113 175-185 'D' RC9-113 370-371 'C' RC9-113 404-405 'B' RC9-113 471-479 'A' $\mathrm{RC} 12-215 \quad 0-2 \mathrm{~cm}$ RC12-215 230-232 245-252 290-2.92 552-553 662-666 $750-752$ 920-922 970-972

Finnis Rd, Pohangina Finnis Rd, Pohangina Kaukatea Stream Tongariro Power hole Dll4

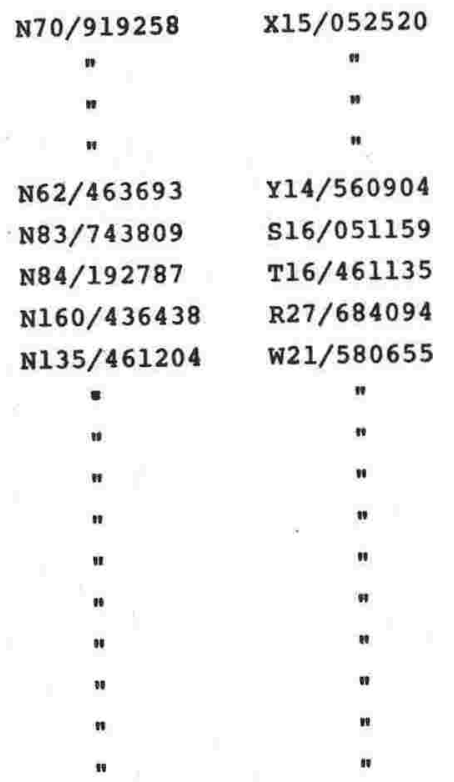

N135/418208 W21/541657 N94/573353 U18/798728

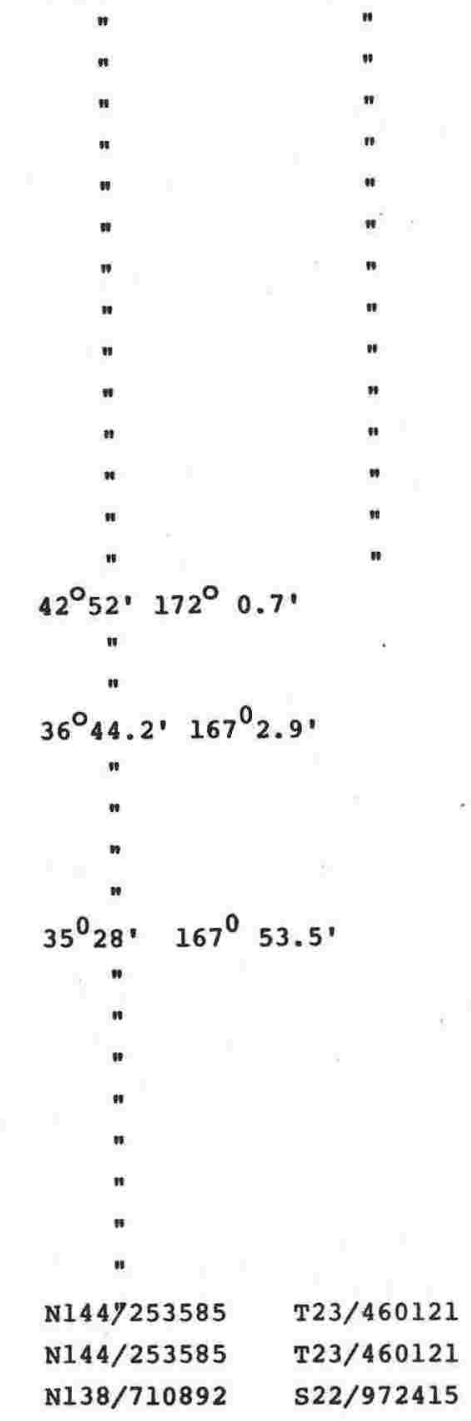




\section{6}

\begin{tabular}{|c|c|c|c|c|c|c|}
\hline 50468 & Taupo & Ignimbrite & & Forestry Rd & $\mathrm{N} 103 / 565260$ & U18/789644 \\
\hline 50469 & Taupo & $I_{\ddot{E}}$ (Iower & ) & $"$ & $"$ & " \\
\hline 50474 & Taupo & Ignimbrite & & Tutukau Rd & N94/561583 & U17/793939 \\
\hline 50477 & Taupo & Ignimbrite & & Werata Rd & N93/359553 & T17/608917 \\
\hline 50583 & & $"$ & & Boat Harbour & N94/539378 & U18/768752 \\
\hline 50584 & & $"$ & & Marotiri & N93/302553 & $\mathrm{T} 17 / 558919$ \\
\hline 50585 & & $"$ & & Waikato Falls & $\mathrm{N} 112 / 308832$ & \\
\hline 50586 & & $"$ & & Maroa & N85/526708 & \\
\hline 50587 & & $"$ & & Crater Rd & $\mathrm{N} 103 / 620248$ & U18/839631 \\
\hline 50588 & & $"$ & & Whanganata Rd & $2 \times 94 / 482465$ & U17//718835 \\
\hline 50589 & & $"$ & & Tarawera & $\mathrm{N} 114 / 012965$ & \\
\hline 50590 & & $"$. & & Iwitahi & N103/761209 & U18/967593 \\
\hline 50592 & & $"$ & & Mangatete $\mathrm{Rd}$ & N85/674714 & \\
\hline 50593 & & $"$ & & Kirikiri Rd & $\mathrm{N} 103 / 667239$ & U18/881623 \\
\hline 50594 & Taupo & Lapilli & & Motukino Rd & $\mathrm{N} 103 / 668252$ & U18/882634 \\
\hline
\end{tabular}



ન

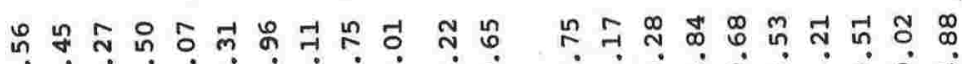

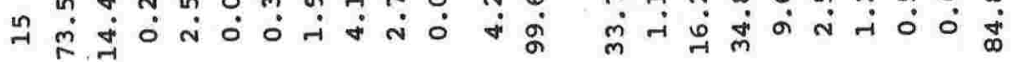

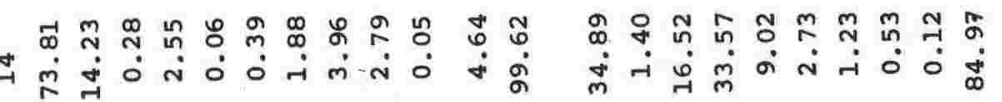
๓ ఐ

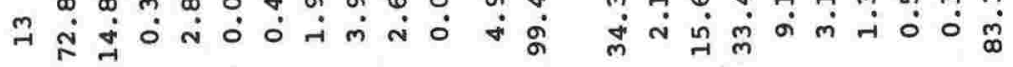

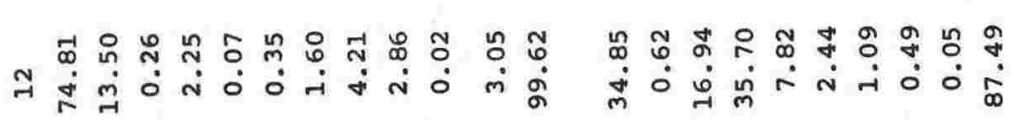

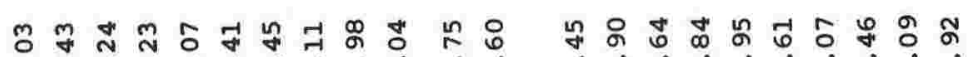

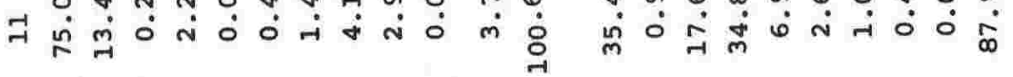

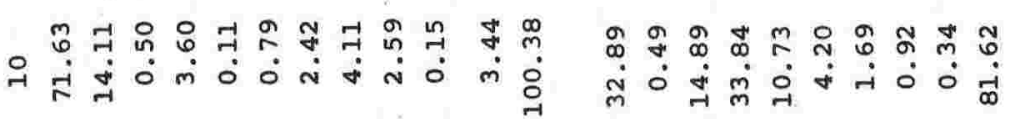

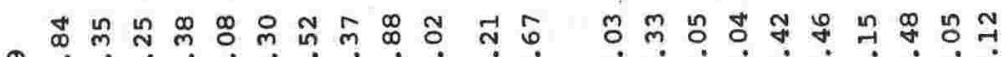

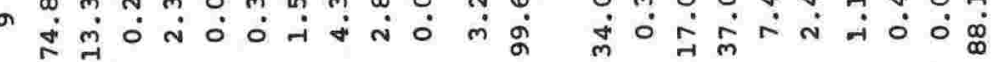

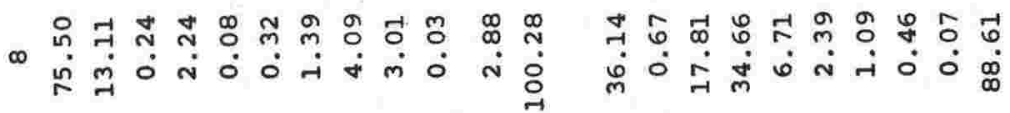

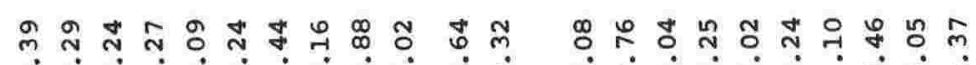
م亦方

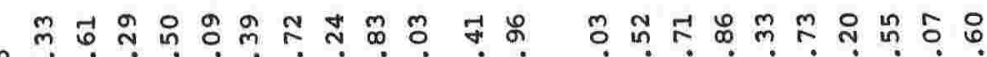
j ๓ 凹 仿の

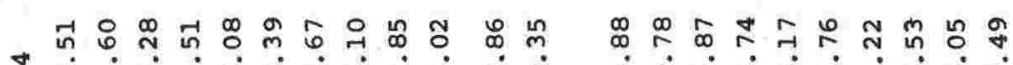

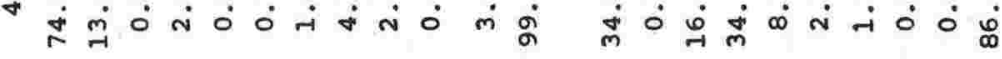
m 유ำ

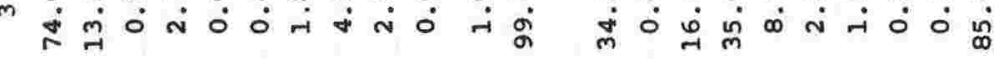

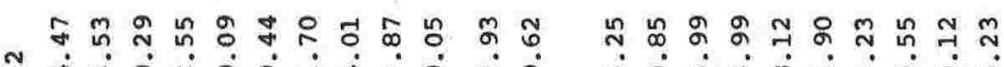
N -

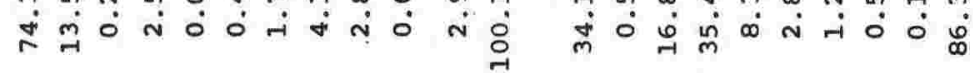

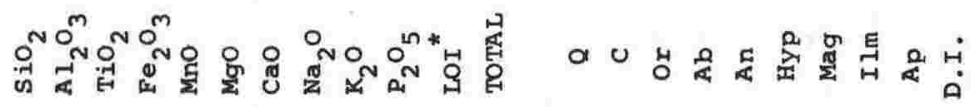

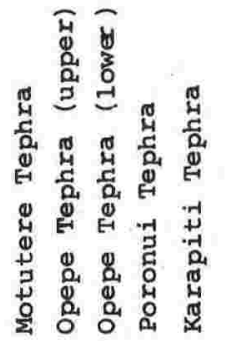

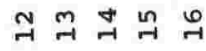<smiles>C1CCC(C2CCCC2)C1</smiles>

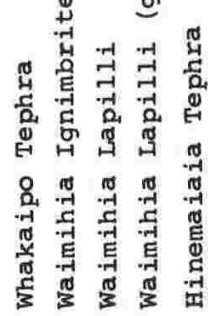

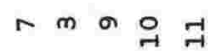

至

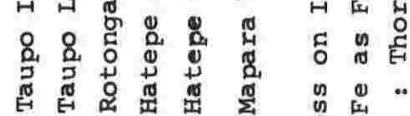

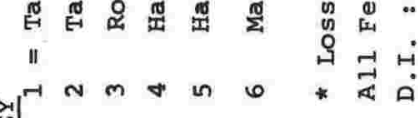




\begin{tabular}{|c|c|c|c|c|c|c|c|c|c|c|c|c|c|}
\hline & \multicolumn{2}{|c|}{50222} & \multicolumn{2}{|c|}{50223} & \multirow{2}{*}{$\begin{array}{c}50224 \\
\text { WR }\end{array}$} & \multicolumn{2}{|c|}{50225} & \multicolumn{2}{|c|}{50226} & \multicolumn{2}{|c|}{50227} & \multicolumn{2}{|c|}{50228} \\
\hline & WR & Glass & WR & Glass & & WR & Glass & WR & Glass & WR & GIass & WR & Glass \\
\hline $\mathrm{Rb}$ & 90 & 84 & 92 & 80 & 96 & 93 & 87 & 97 & 90 & 94 & 95 & 106 & 100 \\
\hline Sr & 152 & 157 & 166 & 174 & 178 & 160 & 151 & 157 & 160 & 163 & 171 & 129 & 132 \\
\hline $\mathrm{Ba}$ & 570 & 585 & 568 & 576 & 577 & 572 & 578 & 581 & 579 & 586 & 589 & 604 & 604 \\
\hline $\mathrm{zr}_{x}$ & 217 & 217 & 225 & 224 & 226 & 226 & 211 & 222 & 218 & 228 & 233 & 225 & 204 \\
\hline $\mathrm{Cu}$ & 7 & 6 & 22 & 15 & 6 & 15 & 4 & 15 & 13 & 6 & 19 & 7 & 8 \\
\hline $\mathrm{Ni}$ & 4 & 8 & 4 & 7 & 3 & 6 & 0 & 8 & 5 & 6 & 4 & 3 & 4 \\
\hline v & 3 & 3 & 4 & 3 & 4 & 2 & 3 & 2 & 3 & 4 & 2 & 1 & 1 \\
\hline $\mathrm{Cr}$ & 36 & 23 & 24 & 17 & 10 & - & 15 & 50 & 24 & 10 & 13 & 14 & 11 \\
\hline $\mathrm{Pb}$ & 14 & 13 & 16 & 16 & 16 & 15 & 16 & 17 & 16 & 16 & 20 & 22 & 16 \\
\hline $\mathrm{zn}$ & 73 & 62 & 75 & 73 & 64 & 69 & 66 & 75 & 72 & 73 & 72 & 67 & 57 \\
\hline Th & 9.9 & 9.2 & 9.7 & 8.7 & 8.9 & 8.3 & 9.4 & 10.6 & 10.2 & 9.3 & 9.3 & 10.6 & 8.4 \\
\hline $\mathrm{U}$ & 2.5 & 0.9 & 2.7 & 2.7 & 3.0 & 2.1 & 1.8 & 1.3 & 2.1 & 2.2 & 1.4 & 2.0 & 2.4 \\
\hline$Y$ & 30 & 27 & 32 & 28 & 28 & 31 & 30 & 33 & 31 & 34 & 34 & 36 & 32 \\
\hline$T i$ & 1625 & 1312 & 1663 & 1498 & 1759 & 1532 & 1390 & 1543 & 1410 & 1560 & 1450 & 1190 & 940 \\
\hline
\end{tabular}

\begin{tabular}{|c|c|c|c|c|c|c|c|c|c|c|c|c|c|}
\hline & \multicolumn{2}{|c|}{50229} & \multicolumn{3}{|c|}{50230} & \multicolumn{2}{|c|}{50235} & \multirow{2}{*}{$\begin{array}{c}50495 \\
\text { WR }\end{array}$} & \multirow{2}{*}{$\begin{array}{c}50237 \\
\text { WR }\end{array}$} & \multicolumn{2}{|c|}{50238} & \multicolumn{2}{|c|}{50239} \\
\hline & WR & Glass & WR & Glass & Grey & WR & Glass & & & WR & Glass & WR & Glass \\
\hline $\mathrm{Rb}$ & 97 & 98 & 91 & 101 & 79 & 79 & 97 & 105 & 84 & 94 & 78 & 100 & 95 \\
\hline sr & 127 & 112 & 128 & 121 & 164 & 124 & 121 & 120 & 150 & 154 & 161 & 136 & 156 \\
\hline $\mathrm{Ba}$ & 593 & 598 & 600 & 583 & 539 & 615 & 580 & 610 & 543 & 577 & 565 & 598 & 564 \\
\hline $\mathrm{Zr}$ & 226 & 223 & 223 & 218 & 215 & 216 & 217 & 220 & 238 & 236 & 237 & 235 & 223 \\
\hline $\mathrm{Cu}$ & 5 & 7 & 6 & 14 & 2 & 10 & 8 & 5 & 13 & 8 & 13 & 6 & 10 \\
\hline $\mathrm{N} i$ & 3 & 3 & 6 & 6 & 4 & 12 & 4 & 3 & 5 & 4 & 4 & 2 & 7 \\
\hline v & - & - & 4 & 2 & 22 & & & & 9 & 8 & 6 & 8 & 6 \\
\hline $\mathrm{Cr}$ & - & - & 10 & 12 & 15 & & & & 7 & 6 & 12 & 12 & 11 \\
\hline $\mathrm{Pb}$ & 15 & 17 & 12 & 21 & 12 & 4 & 17 & 19 & 16 & 13 & 11 & 16 & 18 \\
\hline $\mathrm{Zn}$ & 70 & 70 & 70 & 69 & 77 & 65 & 64 & 62 & 56 & 54 & 51 & 50 & 45 \\
\hline Th & 9.3 & nd & 9.6 & 9.2 & 8.9 & 8.9 & 8.7 & nd & 10.2 & 9.2 & 8.8 & 8.5 & 8.8 \\
\hline U & 2.4 & nd & 1.5 & 2.0 & 2.1 & 1.4 & 2.4 & nd & 1.1 & 2.5 & 1.4 & 0.9 & 1.8 \\
\hline $\mathrm{Y}$ & 33 & 35 & 29 & 36 & 30 & 24 & 32 & 35 & 28 & 28 & 24 & 30 & 29 \\
\hline $\mathrm{T} i$ & 1314 & 1160 & 1400 & 1162 & 2830 & 1244 & 1104 & 1222 & 1717 & 1426 & 1107 & 1305 & 918 \\
\hline
\end{tabular}

\begin{tabular}{|l|r|r|}
\hline \multicolumn{3}{c}{50240} \\
\hline \multicolumn{1}{r}{ WR } & \multicolumn{1}{c|}{ Glass } \\
\hline $\mathrm{Rb}$ & 98 & 84 \\
$\mathrm{Ba}$ & 143 & 179 \\
$\mathrm{Zr}$ & 591 & 579 \\
$\mathrm{Cu}$ & 12 & 222 \\
$\mathrm{Ni}$ & 6 & 6 \\
$\mathrm{~V}$ & 9 & 4 \\
$\mathrm{Cr}$ & 12 & 13 \\
$\mathrm{~Pb}$ & 17 & 13 \\
$\mathrm{Zn}$ & 52 & 46 \\
$\mathrm{Th}$ & 8.9 & 9.9 \\
$\mathrm{U}$ & 1.7 & 2.6 \\
$\mathrm{X}$ & 30 & 26 \\
$\mathrm{Ti}$ & 1361 & 939 \\
\hline
\end{tabular}

Trace elements determined on whole rock (WR) and glass samples by XRF.

$$
\text { - = not detected }
$$

nd $=$ not determined 
Taupo Ignimbrite: De Bretts (50222)

\begin{tabular}{|c|c|c|c|c|c|c|c|c|c|c|}
\hline $\mathrm{SiO}_{2}$ & 54.09 & 53.90 & 51.79 & 52.43 & 53.88 & 51.67 & 53.48 & 51.79 & 53.78 & 52.26 \\
\hline $\mathrm{Al}_{2} \mathrm{O}_{3}$ & 0.92 & 1.28 & 0.33 & 0.46 & 1.44 & 0.75 & 0.91 & 0.60 & 1.28 & 0.58 \\
\hline $\mathrm{TiO}_{2}$ & 0.24 & 0.24 & 0.13 & 0.22 & 0.27 & 0.19 & 0.24 & 0.13 & 0.14 & 0.20 \\
\hline $\mathrm{FeO}$ & 18.57 & 18.98 & 28.36 & 26.90 & 17.75 & 28.73 & 20.40 & 28.16 & 16.34 & 27.52 \\
\hline Mno & 0.51 & 0.46 & 1.68 & 1.47 & 0.39 & 1.32 & 0.65 & 1.47 & 0.40 & 1.45 \\
\hline Mgo & 23.77 & 24.48 & 15.58 & 17.27 & 25.36 & 16.74 & 23.89 & 16.93 & 24.88 & 18.32 \\
\hline $\mathrm{CaO}$ & 1.58 & 1.40 & 1.31 & 1.18 & 1.53 & 1.30 & 1.24 & 1.20 & 1.53 & 1.05 \\
\hline CAL & 99.68 & 100.91 & 99.16 & 99.94 & 100.61 & 100.69 & 100.80 & 100.27 & 98.36 & 101.37 \\
\hline
\end{tabular}

Cations based on $6(0)$

$\begin{array}{lllllllllll}\text { Si } & 1.987 & 1.962 & 2.015 & 2.007 & 1.955 & 1.982 & 1.962 & 1.989 & 1.982 & 1.982 \\ \text { Al } & 0.040 & 0.055 & 0.015 & 0.021 & 0.061 & 0.034 & 0.040 & 0.027 & 0.056 & 0.056 \\ \text { Ti } & 0.007 & 0.007 & 0.004 & 0.006 & 0.007 & 0.006 & 0.007 & 0.004 & 0.004 & 0.004 \\ \text { Fe } & 0.570 & 0.578 & 0.923 & 0.861 & 0.539 & 0.921 & 0.626 & 0.905 & 0.504 & 0.504 \\ \text { Mn } & 0.016 & 0.014 & 0.055 & 0.048 & 0.012 & 0.043 & 0.020 & 0.048 & 0.013 & 0.013 \\ \text { Mg } & 1.301 & 1.329 & 0.904 & 0.985 & 1.372 & 0.957 & 1.307 & 0.970 & 1.367 & 1.367 \\ \text { Ca } & 0.062 & 0.054 & 0.054 & 0.049 & 0.059 & 0.053 & 0.049 & 0.050 & 0.060 & 0.060 \\ \text { SUM } & 3.983 & 3.998 & 3.971 & 3.976 & 4.004 & 3.996 & 4.009 & 3.992 & 3.986 & 3.986\end{array}$

Taupo Lapilli: De Bretts (50223)

\begin{tabular}{|c|c|c|c|c|c|c|c|c|c|c|}
\hline $\mathrm{SiO}_{2}$ & 51.40 & 51.63 & 52.18 & 52.02 & 51.69 & 51.83 & 51.64 & 51.87 & 52.00 & 51.34 \\
\hline $\mathrm{A}{ }_{2} \mathrm{O}_{3}$ & 0.42 & 0.85 & 0.62 & 0.52 & 0.36 & 0.41 & 0.26 & 0.35 & 0.43 & 0.79 \\
\hline $\mathrm{TiO}_{2}$ & 0.14 & 0.19 & 0.10 & 0.15 & 0.09 & 0.14 & 0.09 & 0.10 & 0.12 & 0.22 \\
\hline $\mathrm{FeO}$ & 27.31 & 29.17 & 26.23 & 27.46 & 28.07 & 27.04 & 28.94 & 28.08 & 28.42 & 29.09 \\
\hline MnO & 1.56 & 1.31 & 1.32 & 1.38 & 1.48 & 1.48 & 1.59 & 1.51 & 1.61 & 1.39 \\
\hline $\mathrm{MgO}$ & 17.11 & 16.55 & 19.11 & 17.58 & 16.46 & 17.49 & 16.80 & 17.49 & 16.80 & 16.42 \\
\hline $\mathrm{CaO}$ & 1.13 & 1.31 & 1.05 & 1.07 & 1.14 & 1.18 & 1.13 & 1.17 & 1.18 & 1.32 \\
\hline TOTAL & 99.06 & 101.00 & 100.62 & 100.22 & 99.34 & 99.57 & 100.46 & 100.57 & 100.55 & 100.57 \\
\hline
\end{tabular}

Cations based on 6 (0)

\begin{tabular}{|c|c|c|c|c|c|c|c|c|c|c|}
\hline $\mathrm{Si}$ & 1.993 & 1.997 & 1.976 & 1.991 & 2.003 & 1.996 & 1.989 & 1.987 & 1.993 & 1.977 \\
\hline Al & 0.019 & 0.039 & 0.028 & 0.023 & 0.016 & 0.019 & 0.012 & 0.016 & 0.020 & 0.036 \\
\hline $\mathrm{Ti}$ & 0.004 & 0.005 & 0.003 & 0.004 & 0.003 & 0.004 & 0.003 & 0.003 & 0.003 & 0.006 \\
\hline $\mathrm{Fe}$ & 0.886 & 0.934 & 0.831 & 0.879 & 0.910 & 0.871 & 0.932 & 0.899 & 0.911 & 0.937 \\
\hline $\mathrm{Mn}$ & 0.051 & 0.042 & 0.042 & 0.045 & 0.049 & 0.048 & 0.052 & 0.049 & 0.051 & 0.045 \\
\hline $\mathrm{Mg}$ & 0.989 & 0.945 & 1.079 & 1.003 & 0.951 & 1.004 & 0.964 & 0.999 & 0.960 & 0.943 \\
\hline $\mathrm{Ca}$ & 0.047 & 0.054 & 0.042 & 0.044 & 0.047 & 0.049 & 0.047 & 0.048 & 0.048 & 0.054 \\
\hline SUM & 3.989 & 3.996 & 3.998 & 3.994 & 3.980 & 3.990 & 3.995 & 4.000 & 3.989 & 3.998 \\
\hline
\end{tabular}

Rotongaio Ash: De Bretts (50224)

$\begin{array}{lrrrrrrrr}\mathrm{SiO}_{2} & 52.67 & 51.32 & 50.69 & 50.93 & 52.35 & 51.78 & 50.13 & 51.17 \\ \mathrm{Al}_{2} \mathrm{O}_{3} & 0.48 & 0.41 & 0.47 & 0.71 & 0.49 & 0.62 & 0.46 & 0.51 \\ \mathrm{TiO}_{2} & 0.20 & 0.13 & 0.12 & 0.22 & 0.16 & 0.37 & 0.18 & 0.15 \\ \mathrm{FeO}^{2} & 25.24 & 30.77 & 31.69 & 25.08 & 25.00 & 27.93 & 31.99 & 27.75 \\ \mathrm{MnO} & 1.36 & 1.72 & 1.92 & 0.91 & 1.45 & 1.50 & 1.92 & 1.70 \\ \mathrm{MgO} & 18.45 & 14.96 & 13.76 & 19.47 & 17.48 & 16.34 & 12.10 & 15.35 \\ \text { CaO } & 1.31 & 1.14 & 1.28 & 1.32 & 1.36 & 1.22 & 1.30 & 1.17 \\ \text { TOTAL } & 99.71 & 100.45 & 99.92 & 98.64 & 98.28 & 99.77 & 98.08 & 97.78\end{array}$

Cations based on 6 (0)

$\begin{array}{lllllllll}\mathrm{Si} & 2.003 & 1.996 & 1.996 & 1.961 & 2.020 & 1.997 & 2.015 & 2.015 \\ \mathrm{~A} 1 & 0.021 & 0.019 & 0.022 & 0.032 & 0.022 & 0.028 & 0.022 & 0.024 \\ \mathrm{Ti} & 0.006 & 0.004 & 0.004 & 0.006 & 0.005 & 0.011 & 0.005 & 0.004 \\ \mathrm{Fe} & 0.803 & 1.000 & 1.043 & 0.808 & 0.807 & 0.901 & 1.076 & 0.914 \\ \mathrm{Mn} & 0.044 & 0.056 & 0.064 & 0.030 & 0.047 & 0.049 & 0.065 & 0.057 \\ \mathrm{Mg} & 1.046 & 0.867 & 0.808 & 1.117 & 1.005 & 0.940 & 0.725 & 0.910 \\ \mathrm{Ca} & 0.053 & 0.048 & 0.054 & 0.054 & 0.056 & 0.051 & 0.056 & 0.049 \\ \text { SUM } & 3.978 & 3.989 & 3.990 & 4.014 & 3.966 & 3.977 & 3.968 & 3.965\end{array}$


Hatepe ash; De Bretts (50225)

\begin{tabular}{|c|c|c|c|c|c|c|c|c|c|c|}
\hline $\mathrm{SiO}_{2}$ & 51.50 & 51.59 & 52.11 & 51.84 & 52.09 & 51.29 & 50.87 & 51.71 & 51.47 & 51.89 \\
\hline $\mathrm{Al}_{2} \mathrm{O}_{3}$ & 0.55 & 0.42 & 0.44 & 0.40 & 0.54 & 0.53 & 0.38 & 0.37 & 0.45 & 0.60 \\
\hline $\mathrm{TiO}_{2}$ & 0.14 & 0.12 & 0.17 & 0.09 & 0.10 & 0.15 & 0.12 & 0.13 & 0.12 & 0.15 \\
\hline Feo & 28.21 & 28.30 & 28.06 & 27.15 & 27.51 & 27.41 & 31.04 & 27.38 & 31.06 & 25.63 \\
\hline & 1.73 & 1.59 & 1.64 & 1.55 & 0.86 & 1.54 & 1.60 & 1.49 & 1.61 & 1.43 \\
\hline $\mathrm{MgO}$ & 16.37 & 17.16 & 17.20 & 16.96 & 17.95 & 17.01 & 14.75 & 17.40 & 15.16 & 17.48 \\
\hline $\mathrm{Ca}$ & 1.26 & 1.17 & 1.06 & 1.07 & 1.15 & 1.07 & 1.03 & 1.31 & 1.03 & 0.98 \\
\hline TOTAL & 99.76 & 100.35 & 100.69 & 99.05 & 100.20 & 98.97 & 99.77 & 99.80 & 100.92 & 98.16 \\
\hline & based & on 6 & & & & & & & & \\
\hline Si & 1.993 & 1.985 & 1.992 & 2.006 & 1.989 & 1.991 & 1.994 & 1.991 & 1.992 & 2.009 \\
\hline A. & 0.025 & 0.019 & 0.020 & 0.018 & 0.024 & 0.024 & 0.017 & 0.017 & 0.021 & 0.027 \\
\hline $\mathrm{T} i$ & 0.004 & 0.004 & 0.005 & 0.003 & 0.003 & 0.004 & 0.003 & 0.004 & 0.003 & 0.004 \\
\hline $\mathrm{Fe}$ & 0.913 & 0.911 & 0.897 & 0.879 & 0.879 & 0.890 & 1.018 & 0.882 & 1.006 & 0.830 \\
\hline Mn & 0.057 & 0.052 & 0.053 & 0.051 & 0.028 & 0.050 & 0.053 & 0.049 & 0.053 & 0.047 \\
\hline $\mathrm{Mg}$ & 0.944 & 0.984 & 0.980 & 0.978 & 1.022 & 0.984 & 0.862 & 0.999 & 0.875 & 1.010 \\
\hline $\mathrm{Ca}$ & 0.052 & 0.048 & 0.043 & 0.045 & 0.047 & 0.044 & 0.042 & 0.054 & 0.043 & 0.041 \\
\hline SUM & 3.989 & 4.002 & 3.991 & 3.981 & 3.991 & 3.987 & 3.992 & 3.994 & 3.992 & 3.970 \\
\hline
\end{tabular}

Hatepe Lapilli: De Bretts (50226)

$\begin{array}{lrrrrrrr}\mathrm{SiO}_{2} & 51.14 & 50.35 & 51.55 & 51.96 & 51.68 & 51.66 & 50.75 \\ \mathrm{Al}_{2} \mathrm{O}_{3} & 0.52 & 0.36 & 0.35 & 0.57 & 0.36 & 0.48 & 0.86 \\ \mathrm{TiO}_{2} & 0.18 & 0.14 & 0.16 & 0.14 & 0.18 & 0.16 & 0.22 \\ \mathrm{FeO}^{2} & 27.68 & 27.53 & 30.04 & 27.94 & 28.66 & 28.15 & 29.08 \\ \mathrm{MnO} & 1.71 & 1.60 & 1.79 & 1.72 & 1.61 & 1.65 & 1.67 \\ \mathrm{MgO} & 16.48 & 15.75 & 15.58 & 17.00 & 16.50 & 16.35 & 14.79 \\ \text { CaO } & 1.21 & 1.23 & 1.19 & 1.20 & 1.30 & 1.23 & 1.65 \\ \text { TOTAL } & 8.92 & 96.94 & 100.64 & 100.53 & 100.29 & 99.67 & 99.01\end{array}$

Cations based on 6 (0)

$\begin{array}{llllllll}\text { Si } & 1.992 & 2.004 & 1.994 & 1.990 & 1.992 & 1.997 & 1.991 \\ \mathrm{Al} & 0.024 & 0.017 & 0.016 & 0.026 & 0.016 & 0.022 & 0.040 \\ \mathrm{Ti} & 0.005 & 0.004 & 0.005 & 0.004 & 0.005 & 0.005 & 0.006 \\ \mathrm{Fe} & 0.901 & 0.917 & 0.972 & 0.895 & 0.924 & 0.910 & 0.954 \\ \mathrm{Mn} & 0.056 & 0.054 & 0.059 & 0.056 & 0.053 & 0.054 & 0.055 \\ \mathrm{Mg} & 0.957 & 0.935 & 0.899 & 0.971 & 0.948 & 0.942 & 0.865 \\ \mathrm{Ca} & 0.050 & 0.053 & 0.049 & 0.049 & 0.054 & 0.051 & 0.070 \\ \mathrm{SUM} & 3.986 & 3.983 & 3.994 & 3.990 & 3.992 & 3.981 & 3.981\end{array}$

Mapara Tephra: De Bretts (50227)

$\begin{array}{lrrrrr}\mathrm{SiO}_{2} & 51.47 & 52.04 & 51.31 & 52.34 & 52.11 \\ \mathrm{Al}_{2} \mathrm{O}_{3} & 0.46 & 0.42 & 0.47 & 0.79 & 0.35 \\ \mathrm{TiO}_{2} & 0.14 & 0.11 & 0.17 & 0.17 & 0.16 \\ \mathrm{FeO} & 29.14 & 29.66 & 29.85 & 28.11 & 29.92 \\ \mathrm{MnO} & 1.58 & 1.69 & 1.72 & 1.41 & 1.73 \\ \mathrm{MgO} & 16.44 & 15.72 & 15.06 & 15.93 & 15.46 \\ \mathrm{CaO} & 1.19 & 1.13 & 1.37 & 1.33 & 1.14\end{array}$

TOTAL $100.41 \quad 100.79 \quad 99.94 \quad 100.07 \quad 100.86$ Cations based on 6 (0)

$\begin{array}{llllll}\text { Si } & 1.985 & 2.003 & 1.998 & 2.009 & 2.006 \\ \text { Al } & 0.021 & 0.019 & 0.022 & 0.036 & 0.016 \\ \mathrm{Ti} & 0.004 & 0.003 & 0.005 & 0.005 & 0.005 \\ \mathrm{Fe} & 0.940 & 0.955 & 0.972 & 0.902 & 0.963 \\ \mathrm{Mn} & 0.052 & 0.055 & 0.057 & 0.046 & 0.057 \\ \mathrm{Mg} & 0.945 & 0.902 & 0.874 & 0.911 & 0.887 \\ \mathrm{Ca} & 0.049 & 0.047 & 0.057 & 0.054 & 0.047 \\ \text { SUM } & 3.995 & 3.984 & 3.984 & 3.963 & 3.981\end{array}$


Whakaipo Tephra: De Bretts (50228)

$\begin{array}{lllll}\mathrm{SiO}_{2} & 50.07 \quad 51.04 & 50.10 \quad 51.7\end{array}$

$52.08 \quad 51.93 \quad 51.33$

$\begin{array}{llllllll}\mathrm{Al}_{2} \mathrm{O}_{3} & 0.41 & 0.36 & 0.56 & 0.38 & 0.41 & 0.59 & 0.35\end{array}$

$\begin{array}{llllllll}\mathrm{TiO}_{2} & 0.09 & 0.10 & 0.21 & 0.13 & 0.11 & 0.15 & 0.13\end{array}$

$\begin{array}{llllllll}\mathrm{FeO} & 31.36 & 31.75 & 32.24 & 31.52 & 30.26 & 31.50 & 31.01\end{array}$

$\begin{array}{llllllll}\text { MnO } & 1.71 & 1.79 & 1.82 & 1.60 & 1.59 & 1.71 & 1.69\end{array}$

$\begin{array}{llllllll}\text { MgO } & 14.61 & 13.33 & 13.26 & 14.60 & 15.08 & 14.51 & 14.31\end{array}$

$\begin{array}{llllllll}\mathrm{CaO} & 1.19 & 1.12 & 1.41 & 1.13 & 1.17 & 1.21 & 1.13\end{array}$

$\begin{array}{lllllllll}\text { TOTAL } & 99.45 & 99.49 & 99.57 & 101.07 & 100.68 & 101.60 & 99.92\end{array}$

Cations based on $6(0)$ 


\section{2}

Waimihia Lapilli (grey pumice):

\begin{tabular}{lrrrrrrrrrrrrrr} 
Waimihia Lapilli & \multicolumn{1}{l}{ (grey pumice) } \\
$\mathrm{SiO}_{2}$ & 51.90 & 50.25 & 51.36 & 52.10 & 51.87 & 54.30 & 51.31 & 52.62 & 50.68 & 50.55 & 50.57 & 50.84 & 50.80 \\
$\mathrm{Al}_{2} \mathrm{O}_{3}$ & 0.37 & 0.37 & 0.59 & 0.76 & 0.35 & 1.89 & 0.38 & 0.37 & 0.37 & 0.40 & 0.49 & 0.40 & 0.42 \\
$\mathrm{TiO}_{2}$ & 0.11 & 0.10 & 0.18 & 0.20 & 0.12 & 0.35 & 0.10 & 0.13 & 0.10 & 0.14 & 0.15 & 0.13 & 0.12 \\
$\mathrm{FeO}^{2}$ & 29.82 & 30.63 & 30.79 & 25.14 & 30.19 & 18.84 & 29.96 & 28.48 & 30.01 & 29.92 & 31.22 & 30.80 & 30.73 \\
$\mathrm{MnO}$ & 1.65 & 1.79 & 1.82 & 1.48 & 1.68 & 0.47 & 1.61 & 1.82 & 1.84 & 1.71 & 1.87 & 1.72 & 1.87 \\
$\mathrm{MgO}$ & 15.08 & 14.78 & 14.26 & 18.70 & 15.27 & 23.51 & 15.17 & 15.10 & 15.05 & 15.27 & 15.06 & 15.09 & 14.93 \\
$\mathrm{CaO}$ & 1.12 & 1.13 & 1.59 & 1.34 & 1.10 & 1.45 & 1.25 & 1.13 & 1.20 & 1.18 & 1.27 & 1.19 & 1.13 \\
$\mathrm{TOTAL}$ & 100.05 & 99.04 & 100.59 & 99.73 & 100.57 & 100.82 & 99.78 & 99.66 & 99.25 & 99.17 & 100.63 & 100.17 & 100.00 \\
$\mathrm{Cations}$ & based & $0 \mathrm{n}$ & $6(0)$ & & & & & & & & & & & \\
$\mathrm{Si}$ & 2.012 & 1.987 & 1.997 & 1.985 & 2.004 & 1.970 & 2.001 & 2.033 & 1.992 & 1.988 & 1.973 & 1.986 & 1.988 \\
$\mathrm{Al}$ & 0.017 & 0.017 & 0.027 & 0.034 & 0.016 & 0.081 & 0.017 & 0.017 & 0.017 & 0.019 & 0.023 & 0.018 & 0.019 \\
$\mathrm{Ti}$ & 0.003 & 0.003 & 0.005 & 0.006 & 0.003 & 0.010 & 0.003 & 0.004 & 0.003 & 0.004 & 0.004 & 0.004 & 0.004 \\
$\mathrm{Fe}$ & 0.967 & 1.013 & 1.001 & 0.801 & 0.975 & 0.572 & 0.977 & 0.920 & 0.987 & 0.984 & 1.018 & 1.006 & 1.006 \\
$\mathrm{Mn}$ & 0.054 & 0.060 & 0.060 & 0.048 & 0.055 & 0.015 & 0.053 & 0.059 & 0.061 & 0.057 & 0.062 & 0.057 & 0.062 \\
$\mathrm{Mg}$ & 0.871 & 0.871 & 0.827 & 1.062 & 0.879 & 1.272 & 0.882 & 0.870 & 0.882 & 0.896 & 0.876 & 0.879 & 0.871 \\
$\mathrm{Ca}$ & 0.047 & 0.048 & 0.066 & 0.055 & 0.045 & 0.056 & 0.052 & 0.047 & 0.051 & 0.050 & 0.053 & 0.050 & 0.047 \\
$\mathrm{SUM}$ & 3.972 & 3.998 & 3.982 & 3.990 & 3.979 & 3.976 & 3.986 & 3.950 & 3.991 & 3.997 & 4.009 & 3.999 & 3.997
\end{tabular}

Hinemaiaia Tephra: De Bretts (50235)

\begin{tabular}{|c|c|c|c|c|c|c|c|c|c|}
\hline $\mathrm{SiO}_{2}$ & 51.76 & 54.18 & 51.99 & 54.62 & 53.13 & 53.77 & 52.07 & 52.44 & 53.70 \\
\hline $\mathrm{Al}_{2} \mathrm{O}_{3}$ & 0.41 & 0.81 & 0.42 & 0.74 & 1.37 & 0.99 & 0.46 & 0.51 & 0.20 \\
\hline $\mathrm{TiO}_{2}$ & 0.13 & 0.28 & 0.13 & 0.14 & 0.32 & 0.28 & 0.08 & 0.18 & 0.27 \\
\hline $\mathrm{FeO}$ & 30.43 & 19.97 & 29.80 & 19.97 & 21.11 & 20.33 & 29.11 & 22.72 & 18.52 \\
\hline Mno & 1.54 & 0.79 & 7.64 & 0.78 & 0.57 & 0.72 & 1.65 & 0.77 & 0.38 \\
\hline Mgo & 14.37 & 22.35 & 15.27 & 22.83 & 22.52 & 23.20 & 16.22 & 20.09 & 24.13 \\
\hline $\mathrm{CaO}$ & 1.08 & 1.12 & 1.25 & 1.10 & 1.61 & 1.38 & 1.18 & 1.30 & 1.75 \\
\hline TOTAL & 99.73 & 99.49 & 100.49 & 100.18 & 100.64 & 100.66 & 100.77 & 98.04 & 100.96 \\
\hline Cations & based & on $6(0)$ & & & & & & & \\
\hline $\mathrm{Si}$ & 2.018 & 2.004 & 2.007 & 2.006 & 1.959 & 1.973 & 1.999 & 2.002 & 1.948 \\
\hline Al & 0.019 & 0.035 & 0.019 & 0.032 & 0.060 & 0.043 & 0.021 & 0.025 & 0.094 \\
\hline $\mathrm{Ti}$ & 0.004 & 0.008 & 0.004 & 0.004 & 0.009 & 0.008 & 0.002 & 0.005 & 0.007 \\
\hline $\mathrm{Fe}$ & 0.992 & 0.618 & 0.962 & 0.613 & 0.651 & 0.624 & 0.935 & 0.725 & 0.562 \\
\hline Mn & 0.051 & 0.025 & 0.054 & 0.024 & 0.018 & 0.023 & 0.054 & 0.025 & 0.012 \\
\hline Mg & 0.835 & 1.232 & 0.878 & 1.250 & 1.238 & 1.269 & 0.928 & 1.143 & 1.305 \\
\hline $\mathrm{Ca}$ & 0.045 & 0.044 & 0.052 & 0.043 & 0.064 & 0.054 & 0.049 & 0.053 & 0.068 \\
\hline SUM & 3.964 & 3.967 & 3.975 & 3.973 & 3.999 & 3.992 & 3.987 & 3.978 & 3.997 \\
\hline
\end{tabular}

Motutere Tephra: Opawa Road (50493)

\begin{tabular}{|c|c|c|c|c|c|c|c|c|c|c|c|c|c|}
\hline $\mathrm{iO}_{2}$ & 50.78 & 51.18 & 53.27 & 49.51 & 52.31 & 50.00 & 51.03 & 49.72 & 51.77 & 50.17 & 50.47 & 51.31 & 50.78 \\
\hline $\mathrm{I}_{2} \mathrm{O}_{3}$ & 0.41 & 0.41 & 0.96 & 0.38 & 0.45 & 0.36 & 0.43 & 0.52 & 0.10 & 0.42 & 0.37 & 0.43 & 0.49 \\
\hline $\mathrm{iO}_{2}$ & 0.18 & 0.14 & 0.23 & 0.13 & 0.13 & 0.22 & 0.12 & 0.14 & 0.22 & 0.13 & 0.11 & 0.12 & 0.09 \\
\hline & 31.19 & 30.98 & 20.09 & 30.70 & 29.52 & 30.57 & 29.85 & 30.12 & 24.73 & 30.13 & 30.26 & 29.26 & 30.32 \\
\hline & 1.72 & 1.68 & 0.72 & 1.74 & 1.66 & 1.36 & 1.71 & 1.54 & 1.39 & 1.60 & 1.74 & 1.52 & 1.53 \\
\hline & 15.53 & 15.06 & 23.63 & 15.13 & 15.90 & 15.51 & 15.11 & 15.96 & 19.57 & 15.59 & 15.85 & 15.30 & 15.41 \\
\hline & 1.19 & 1.19 & 1.36 & 1.14 & 1.17 & 1.10 & 1.24 & 1.16 & 1.36 & 1.16 & 1.11 & 1.13 & 1.17 \\
\hline & 100.99 & 100.64 & 100.25 & 98.73 & 101.14 & 99.12 & 99.49 & 99.15 & 99.94 & 99.20 & 99.90 & 99.70 & 99.79 \\
\hline
\end{tabular}

Cations based on $6(0)$

$\begin{array}{llllllllllllll}\text { Si } & 1.971 & 1.988 & 1.964 & 1.969 & 2.001 & 1.974 & 1.997 & 1.961 & 1.961 & 1.976 & 1.973 & 2.006 & 1.984 \\ \text { Al } & 0.019 & 0.019 & 0.042 & 0.018 & 0.020 & 0.017 & 0.020 & 0.024 & 0.049 & 0.019 & 0.017 & 0.020 & 0.023 \\ \text { Ti } & 0.005 & 0.004 & 0.006 & 0.004 & 0.004 & 0.007 & 0.004 & 0.004 & 0.006 & 0.004 & 0.003 & 0.004 & 0.003 \\ \mathrm{Fe} & 1.013 & 1.006 & 0.620 & 1.021 & 0.944 & 1.009 & 0.977 & 0.993 & 0.784 & 0.992 & 0.990 & 0.957 & 0.991 \\ \mathrm{Mn} & 0.057 & 0.055 & 0.022 & 0.059 & 0.054 & 0.045 & 0.057 & 0.051 & 0.044 & 0.053 & 0.058 & 0.050 & 0.051 \\ \mathrm{Mg} & 0.899 & 0.872 & 1.299 & 0.897 & 0.906 & 0.913 & 0.881 & 0.938 & 1.105 & 0.915 & 0.924 & 0.892 & 0.898 \\ \mathrm{Ca} & 0.049 & 0.050 & 0.054 & 0.049 & 0.048 & 0.047 & 0.052 & 0.049 & 0.055 & 0.019 & 0.046 & 0.047 & 0.049 \\ \text { SuM } & 4.013 & 3.994 & 4.006 & 4.017 & 3.977 & 4.011 & 3.991 & 4.019 & 4.006 & 4.008 & 4.010 & 3.975 & 3.997\end{array}$


Opepe Upper: De Bretts (50237)

\begin{tabular}{|c|c|c|c|c|c|c|c|c|c|c|}
\hline $\mathrm{SiO}_{2}$ & 52.58 & 50.95 & 51.02 & 51.67 & 51.56 & 51.78 & 51.81 & 51.92 & 51.35 & 51.97 \\
\hline $\mathrm{Al}_{2} \mathrm{O}_{3}$ & 1.03 & 0.43 & 0.41 & 0.57 & 0.95 & 0.51 & 0.48 & 0.39 & 0.63 & 0.42 \\
\hline $\mathrm{iO}_{2}$ & 0.21 & 0.07 & 0.14 & 0.14 & 0.31 & 0.15 & 0.14 & 0.13 & 0.20 & 0.12 \\
\hline $0^{\circ}$ & 22.58 & 28.04 & 28.87 & 28.40 & 25.94 & 28.63 & 27.98 & 29.47 & 29.23 & 27.45 \\
\hline Mno & .37 & 1.52 & 1.77 & 1.62 & 1.52 & 1.66 & 1.73 & 1.71 & 1.80 & 1.72 \\
\hline Mgo & 20.99 & 17.21 & 15.49 & 16.86 & 17.63 & 16.89 & 17.34 & 16.10 & 16.18 & 17.22 \\
\hline $\mathrm{CaO}$ & 1.35 & 1.16 & 1.27 & 1.20 & 1.21 & 1.23 & 1.22 & 1.16 & 1.20 & 1.22 \\
\hline TOTAL & 100.00 & 99.38 & 98.97 & 100.46 & 99.12 & 100.85 & 100.70 & 100.90 & 100.60 & 100.12 \\
\hline \multicolumn{3}{|c|}{ Cations based on } & $6(0)$ & & & & & & & \\
\hline Si & 1.97 .1 & 1.977 & 1.999 & 1.984 & 1.984 & 1.984 & 1.983 & 1.994 & 1.980 & 1.994 \\
\hline Al & 0.045 & 0.019 & 0.019 & 0.026 & 0.043 & 0.023 & 0.022 & 0.018 & 0.029 & 0.019 \\
\hline $\mathrm{Ti}$ & 0.006 & 0.002 & 0.004 & 0.004 & 0.009 & 0.004 & 0.004 & 0.004 & 0.006 & 0.003 \\
\hline $\mathrm{Fe}$ & 0.706 & 0.910 & 0.946 & 0.912 & 0.835 & 0.917 & 0.896 & 0.947 & 0.943 & 0.881 \\
\hline $\mathrm{Mn}$ & 0.043 & 0.050 & 0.059 & 0.053 & 0.049 & 0.054 & 0.056 & 0.056 & 0.059 & 0.056 \\
\hline 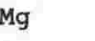 & 170 & 0.996 & 0.905 & 0.965 & 1.011 & 0.965 & 0.989 & 0.922 & 0.930 & 0.985 \\
\hline $\mathrm{Ca}$ & 0.054 & 0.048 & 0.053 & 0.049 & 0.050 & 0.050 & 0.050 & 0.048 & 0.049 & 0.050 \\
\hline SUM & 3.997 & 4.004 & 3.985 & 3.995 & 3.982 & 3.997 & 3.999 & 3.988 & 3.996 & 3.989 \\
\hline
\end{tabular}

Opepe Lapilli: De Bretts (50238)

$\begin{array}{lrrrrrrrrrrr}\mathrm{SiO}_{2} & 51.92 & 52.79 & 52.46 & 55.25 & 52.95 & 52.00 & 51.05 & 51.86 & 51.14 & 52.18 & 51.26 \\ \mathrm{Al}_{2} \mathrm{O}_{3} & 0.31 & 0.73 & 0.34 & 0.80 & 0.35 & 0.54 & 0.36 & 0.86 & 0.47 & 0.14 & 0.13 \\ \mathrm{TiO}_{2} & 0.09 & 0.14 & 0.09 & 0.15 & 0.12 & 0.12 & 0.12 & 0.18 & 0.08 & 0.26 & 0.10 \\ \mathrm{FeO}^{2} & 30.60 & 28.07 & 29.79 & 19.89 & 29.02 & 29.43 & 31.46 & 27.70 & 29.51 & 24.16 & 30.33 \\ \mathrm{MnO} & 1.18 & 1.27 & 1.23 & 0.45 & 1.25 & 1.16 & 1.32 & 1.38 & 1.12 & 0.76 & 1.10 \\ \mathrm{MgO} & 14.88 & 17.44 & 16.35 & 24.03 & 15.69 & 15.27 & 14.23 & 17.27 & 14.81 & 19.67 & 14.50 \\ \mathrm{CaO} & 1.15 & 1.35 & 1.14 & 0.50 & 1.25 & 1.24 & 1.28 & 1.64 & 1.20 & 1.60 & 1.15 \\ \mathrm{TOTAL} & 100.13 & 101.78 & 101.38 & 101.06 & 100.63 & 99.74 & 99.82 & 100.89 & 98.32 & 99.77 & 98.57 \\ \mathrm{Si} & \text { Cations based on } & 6(0) & & & & & & & & \\ \mathrm{Al} & 2.015 & 1.990 & 2.002 & 2.002 & 2.025 & 2.014 & 2.002 & 1.976 & 2.015 & 1.973 & 2.021 \\ \mathrm{Ti} & 0.014 & 0.033 & 0.015 & 0.034 & 0.016 & 0.025 & 0.017 & 0.039 & 0.022 & 0.071 & 0.006 \\ \mathrm{Fe} & 0.003 & 0.004 & 0.002 & 0.004 & 0.004 & 0.003 & 0.003 & 0.005 & 0.002 & 0.007 & 0.003 \\ \mathrm{Mn} & 0.993 & 0.885 & 0.951 & 0.603 & 0.928 & 0.953 & 1.032 & 0.882 & 0.972 & 0.764 & 1.000 \\ \mathrm{Mg} & 0.861 & 0.040 & 0.040 & 0.014 & 0.040 & 0.038 & 0.044 & 0.045 & 0.037 & 0.024 & 0.037 \\ \mathrm{Ca} & 0.048 & 0.054 & 0.046 & 0.019 & 0.051 & 0.051 & 0.054 & 0.067 & 0.051 & 0.065 & 0.049 \\ \mathrm{SUM} & 3.973 & 3.987 & 3.986 & 3.974 & 3.979 & 3.967 & 3.984 & 3.996 & 3.970 & 3.993 & 3.967\end{array}$

Poronui Tephra: De Bretts (50239)

$\begin{array}{lrrrrrrrrrrrr}\mathrm{SiO}_{2} & 51.19 & 50.32 & 51.54 & 51.02 & 52.13 & 51.10 & 51.90 & 51.31 & 51.01 & 51.97 & 50.95 & 51.53 \\ \mathrm{Al}_{2} \mathrm{O}_{3} & 0.69 & 0.46 & 0.54 & 0.39 & 0.66 & 0.47 & 0.70 & 0.40 & 0.35 & 0.51 & 0.48 & 0.32 \\ \mathrm{TiO}_{2} & 0.19 & 0.11 & 0.10 & 0.14 & 0.23 & 0.14 & 0.20 & 0.14 & 0.13 & 0.16 & 0.13 & 0.11 \\ \mathrm{FeO}^{2} & 30.35 & 30.39 & 30.84 & 29.68 & 27.08 & 31.12 & 27.27 & 30.55 & 30.88 & 27.97 & 32.22 & 30.97 \\ \mathrm{MnO} & 1.03 & 1.16 & 1.16 & 1.23 & 0.85 & 1.11 & 0.79 & 1.07 & 1.12 & 0.87 & 1.22 & 1.69 \\ \mathrm{MgO} & 15.02 & 15.14 & 15.50 & 15.17 & 18.22 & 15.23 & 17.75 & 15.43 & 14.59 & 17.80 & 14.19 & 15.02 \\ \mathrm{CaO} & 1.48 & 1.25 & 1.32 & 1.25 & 1.37 & 1.18 & 1.34 & 1.15 & 1.31 & 1.12 & 1.10 & 1.27 \\ \mathrm{TOTAL} & 99.95 & 98.82 & 101.01 & 98.89 & 100.55 & 100.34 & 99.96 & 100.04 & 99.38 & 100.39 & 100.31 & 100.90 \\ & \mathrm{Cations} & \text { based } & \text { on } 6(0) & & & & & & & & & \\ \mathrm{Si} & 1.992 & 1.985 & 1.987 & 2.002 & 1.981 & 1.987 & 1.986 & 1.995 & 2.003 & 1.984 & 1.993 & 1.995 \\ \mathrm{Al} & 0.032 & 0.022 & 0.024 & 0.018 & 0.030 & 0.022 & 0.032 & 0.018 & 0.016 & 0.023 & 0.022 & 0.014 \\ \mathrm{Ti} & 0.006 & 0.003 & 0.003 & 0.004 & 0.007 & 0.004 & 0.006 & 0.004 & 0.004 & 0.004 & 0.004 & 0.003 \\ \mathrm{Fe} & 0.988 & 1.003 & 0.995 & 0.974 & 0.861 & 1.012 & 0.873 & 0.994 & 1.014 & 0.893 & 1.054 & 1.003 \\ \mathrm{Mn} & 0.034 & 0.039 & 0.038 & 0.041 & 0.027 & 0.037 & 0.026 & 0.035 & 0.037 & 0.028 & 0.040 & 0.055 \\ \mathrm{Mg} & 0.872 & 0.891 & 0.891 & 0.888 & 1.033 & 0.883 & 1.012 & 0.894 & 0.854 & 1.013 & 0.827 & 0.867 \\ \mathrm{Ca} & 0.062 & 0.053 & 0.054 & 0.053 & 0.056 & 0.049 & 0.055 & 0.048 & 0.055 & 0.046 & 0.046 & 0.053 \\ \mathrm{SUM} & 3.985 & 3.995 & 3.993 & 3.980 & 3.995 & 3.993 & 3.988 & 3.989 & 3.983 & 3.992 & 3.987 & 3.992\end{array}$


Karapiti Tephra (upper bed): De Bretts (50240)

$\begin{array}{lrrrrrrrr}\mathrm{SiO}_{2} & 51.59 & 51.57 & 52.16 & 50.90 & 52.32 & 51.24 & 51.43 & 51.67 \\ \mathrm{Al}_{2} \mathrm{O}_{3} & 0.44 & 2.94 & 0.57 & 0.44 & 0.54 & 0.28 & 0.43 & 0.28 \\ \mathrm{TiO}_{2} & 0.10 & 0.10 & 0.13 & 0.14 & 0.17 & 0.11 & 0.16 & 0.10 \\ \mathrm{FeO} & 31.57 & 29.19 & 27.82 & 31.06 & 27.25 & 29.84 & 31.29 & 29.05 \\ \mathrm{MnO} & 1.13 & 0.83 & 0.91 & 1.13 & 0.91 & 1.21 & 1.18 & 1.07 \\ \mathrm{MgO} & 15.16 & 16.50 & 18.38 & 15.07 & 18.45 & 15.11 & 14.66 & 16.83 \\ \text { CaO } & 1.22 & 1.20 & 1.18 & 1.22 & 1.24 & 1.22 & 1.20 & 1.18 \\ \text { TOTAL } & 101.21 & 102.32 & 101.15 & 100.06 & 100.88 & 99.01 & 100.35 & 100.18\end{array}$

\begin{tabular}{lllllllll}
\multicolumn{8}{l}{ Cations based on $6(0)$} \\
Si & 1.991 & 1.939 & 1.976 & 1.988 & 1.983 & 2.008 & 2.001 & 1.993 \\
Al & 0.020 & 0.130 & 0.026 & 0.020 & 0.024 & 0.013 & 0.020 & 0.013 \\
Ti & 0.003 & 0.003 & 0.004 & 0.004 & 0.005 & 0.003 & 0.005 & 0.003 \\
Fe & 1.019 & 0.918 & 0.881 & 1.015 & 0.863 & 0.978 & 1.018 & 0.937 \\
Mn & 0.037 & 0.026 & 0.029 & 0.037 & 0.029 & 0.040 & 0.039 & 0.035 \\
Mg & 0.872 & 0.925 & 1.038 & 0.877 & 1.042 & 0.882 & 0.850 & 0.968 \\
Ca & 0.050 & 0.049 & 0.048 & 0.051 & 0.050 & 0.051 & 0.050 & 0.049 \\
SUM & 3.994 & 3.989 & 4.000 & 3.993 & 3.997 & 3.976 & 3.981 & 3.996
\end{tabular}

Karapiti Tephra (basal lapilli): De Bretts (50240)

\begin{tabular}{|c|c|c|c|c|c|c|c|c|c|c|}
\hline $\mathrm{SiO}_{2}$ & 51.18 & 51.06 & 51.25 & 52.13 & 50.79 & 51.29 & 51.37 & 51.17 & 50.64 & 51.33 \\
\hline $\mathrm{Al}_{2} \mathrm{O}_{3}$ & 0.35 & 0.39 & 0.83 & 0.96 & 0.49 & 0.46 & 0.44 & 0.41 & 0.44 & 0.45 \\
\hline $\mathrm{TiO}_{2}$ & 0.15 & 0.14 & 0.17 & 0.20 & 0.11 & 0.16 & 0.14 & 0.11 & 0.13 & 0.14 \\
\hline FeO & 30.15 & 31.45 & 26.57 & 25.05 & 30.56 & 31.00 & 28.93 & 29.56 & 32.97 & 31.15 \\
\hline MnO & 1.15 & 1.22 & 1.09 & 0.87 & 1.13 & 1.23 & 1.06 & 1.17 & 1.24 & 1.10 \\
\hline Mgo & 15.03 & 14.69 & 17.59 & 19.70 & 14.66 & 15.02 & 16.21 & 14.84 & 13.32 & 15.49 \\
\hline $\mathrm{CaO}$ & 1.20 & 1.29 & 1.44 & 1.33 & 1.26 & 1.24 & 1.29 & 1.28 & 1.15 & 1.16 \\
\hline \multirow[t]{2}{*}{ TOTAL } & 99.19 & 100.24 & 98.92 & 100.22 & 99.00 & 100.40 & 99.44 & 98.54 & 99.92 & 100.81 \\
\hline & \multicolumn{2}{|c|}{ Cations based } & on 610 & & & & & & & \\
\hline Si & 2.005 & 1.994 & 1.982 & 1.970 & 1.999 & 1.993 & 1.995 & 2.013 & 1.998 & 1.986 \\
\hline Al & 0.016 & 0.018 & 0.038 & 0.043 & 0.023 & 0.021 & 0.020 & 0.019 & 0.020 & 0.021 \\
\hline 14 & 0.004 & 0.004 & 0.005 & 0.006 & 0.003 & 0.005 & 0.004 & 0.003 & 0.004 & 0.004 \\
\hline $\mathrm{Fe}$ & 0.988 & 1.027 & 0.859 & 0.792 & 1.006 & 1.007 & 0.940 & 0.973 & 1.088 & 1.008 \\
\hline $\mathrm{Mn}$ & 0.038 & 0.040 & 0.036 & 0.028 & 0.038 & 0.041 & 0.035 & 0.039 & 0.041 & 0.036 \\
\hline $\mathrm{Mg}$ & 0.878 & 0.855 & 1.014 & 1.110 & 0.860 & 0.870 & 0.939 & 0.870 & 0.784 & 0.893 \\
\hline $\mathrm{Ca}$ & 0.050 & 0.054 & 0.060 & 0.054 & 0.053 & 0.051 & 0.054 & 0.054 & 0.049 & 0.048 \\
\hline SUM & 3.980 & 3.992 & 3.993 & 4.001 & 3.981 & 3.987 & 3.986 & 3.972 & 3.984 & 3.997 \\
\hline
\end{tabular}




\begin{tabular}{|c|c|c|c|}
\hline \multicolumn{4}{|c|}{ Hatepe Ash (50225) } \\
\hline $\mathrm{SiO}_{2}$ & 52.84 & 51.71 & 52.86 \\
\hline $\mathrm{Al}_{2} \mathrm{O}_{3}$ & 1.38 & 1.63 & 1.60 \\
\hline $\mathrm{TiO}_{2}$ & 0.38 & 0.37 & 0.40 \\
\hline FeO & 10.14 & 9.62 & 9.64 \\
\hline Mno & 0.39 & 0.44 & 0.51 \\
\hline MgO & 14.58 & 14.21 & 14.33 \\
\hline $\mathrm{CaO}$ & 20.19 & 20.22 & 19.42 \\
\hline $\mathrm{Na}_{2} \mathrm{O}$ & 0.34 & 0.29 & 0.27 \\
\hline \multirow[t]{2}{*}{ TOTAL } & 100.25 & 98.49 & 99.01 \\
\hline & Cation & 5 based & on $6(0)$ \\
\hline Si & 1.966 & 1.958 & 1.980 \\
\hline Al & 0.061 & 0.073 & 0.071 \\
\hline Ti & 0.010 & 0.011 & 0.011 \\
\hline $\mathrm{Fe}$ & 0.316 & 0.305 & 0.302 \\
\hline Mn & 0.012 & 0.014 & 0.016 \\
\hline Mg & 0.809 & 0.802 & 0.800 \\
\hline $\mathrm{Ca}$ & 0.805 & 0.820 & 0.779 \\
\hline $\mathrm{Na}$ & 0.024 & 0.021 & 0.019 \\
\hline UM & 4.004 & 4.003 & 3.978 \\
\hline
\end{tabular}

\section{CLINOPYROXENE ANALYSES.}

$\begin{array}{crcc}\text { Hatepe Lapilli } & \text { (50226) } & \text { Karapiti Tephra } & \text { (50240) } \\ 50.48 & 50.26 & 52.43 \\ 4.56 & 4.44 & 1.09 \\ 0.42 & 0.44 & 0.20 \\ 7.82 & 7.76 & 12.93 \\ 0.16 & 0.18 & 0.57 \\ 14.33 & 14.42 & 12.57 \\ 19.91 & 19.91 & 20.38 \\ 0.13 & 0.14 & 0.24 \\ 97.81 & 97.55 & 100.41 \\ & & \\ 1.900 & 1.898 & 1.976 \\ 0.202 & 0.198 & 0.048 \\ 0.012 & 0.012 & 0.006 \\ 0.246 & 0.245 & 0.407 \\ 0.005 & 0.006 & 0.018 \\ 0.804 & 0.812 & 0.706 \\ 0.803 & 0.805 & 0.823 \\ 0.010 & 0.010 & 0.018 \\ 3.982 & 3.986 & 4.002\end{array}$


Taupo Ignimbrite (50222)

$\begin{array}{lrrrrrrr}\mathrm{SiO}_{2} & 47.36 & 46.88 & 41.41 & 45.64 & 47.29 & 47.31 & 45.12 \\ \mathrm{Al}_{2} \mathrm{O}_{3} & 6.91 & 6.72 & 13.73 & 8.10 & 6.67 & 6.76 & 8.26 \\ \mathrm{TiO}_{2} & 1.32 & 1.33 & 2.17 & 1.57 & 1.20 & 1.21 & 1.91 \\ \mathrm{FeO} & 18.10 & 17.15 & 10.98 & 17.81 & 16.62 & 15.22 & 17.13 \\ \mathrm{MnO} & 0.43 & 0.32 & 0.04 & 0.38 & 0.34 & 0.38 & 0.38 \\ \mathrm{MgO} & 12.16 & 12.17 & 13.85 & 11.24 & 13.36 & 13.17 & 11.97 \\ \mathrm{CaO} & 10.38 & 10.57 & 12.15 & 10.34 & 10.62 & 10.28 & 10.49 \\ \mathrm{Na}_{2} \mathrm{O} & 1.48 & 1.52 & 2.46 & 1.73 & 1.44 & 1.39 & 1.94 \\ \mathrm{~K}_{2} \mathrm{O} & 0.30 & 0.27 & 0.74 & 0.28 & 0.36 & 0.31 & 0.36 \\ \mathrm{TOTAL}^{2} & 98.43 & 96.92 & 97.56 & 97.09 & 97.89 & 96.02 & 97.56\end{array}$

Cations based on $23(0)$

$\begin{array}{lrrrrrrr}\text { Si } & 7.014 & 7.029 & 6.098 & 6.865 & 7.005 & 7.084 & 6.758 \\ \text { Al(iv) } & 0.986 & 0.971 & 1.902 & 1.135 & 0.995 & 0.916 & 1.242 \\ \text { Al(vi) } & 0.220 & 0.217 & 0.485 & 0.300 & 0.170 & 0.276 & 0.216 \\ \text { Ti } & 0.147 & 0.150 & 0.241 & 0.178 & 0.133 & 0.136 & 0.215 \\ \text { Fe } & 2.242 & 2.150 & 1.352 & 2.240 & 2.058 & 1.906 & 2.146 \\ \text { Mn } & 0.054 & 0.041 & 0.005 & 0.049 & 0.042 & 0.047 & 0.048 \\ \text { Mg } & 2.685 & 2.720 & 3.041 & 2.250 & 2.949 & 2.938 & 2.672 \\ \text { Ca } & 1.647 & 1.698 & 1.917 & 1.666 & 1.685 & 1.648 & 1.684 \\ \text { Na } & 0.424 & 0.441 & 0.702 & 0.506 & 0.414 & 0.404 & 0.562 \\ \text { K } & 0.056 & 0.052 & 0.139 & 0.053 & 0.067 & 0.058 & 0.068 \\ \text { SuM } & 15.475 & 15.469 & 15.882 & 15.242 & 15.518 & 15.413 & 15.611\end{array}$

Hatepe Ash (50225)

$\begin{array}{rrrr}47.41 & 48.05 & 47.11 & 46.73 \\ 6.41 & 6.55 & 6.77 & 9.41 \\ 1.03 & 1.31 & 1.00 & 1.27 \\ 18.05 & 13.49 & 18.08 & 13.01 \\ 0.68 & 0.45 & 0.57 & 0.29 \\ 11.95 & 13.97 & 11.64 & 14.81 \\ 9.56 & 10.61 & 9.76 & 11.03 \\ 1.36 & 1.37 & 1.25 & 1.87 \\ 0.36 & 0.30 & 0.33 & 0.16 \\ 96.80 & 96.10 & 96.52 & 98.57\end{array}$

$\begin{array}{rrrr}7.125 & 7.127 & 7.103 & 6.758 \\ 0.875 & 0.873 & 0.887 & 1.242 \\ 0.261 & 0.273 & 0.317 & 0.360 \\ 0.116 & 0.146 & 0.115 & 0.138 \\ 2.268 & 1.674 & 2.281 & 1.572 \\ 0.087 & 0.056 & 0.073 & 0.035 \\ 2.677 & 3.090 & 2.614 & 3.193 \\ 1.540 & 1.686 & 1.576 & 1.710 \\ 0.395 & 0.394 & 0.368 & 0.521 \\ 0.069 & 0.057 & 0.065 & 0.031 \\ 15.413 & 15.376 & 15.409 & 15.560\end{array}$

\begin{tabular}{lrrrr} 
Wm Ig. $(50229)$ & \multicolumn{3}{c}{ Karapiti Tephra $(50240$} \\
$\mathrm{SiO}_{2}$ & 54.22 & 45.75 & 46.23 & 45.55 \\
$\mathrm{Al}_{2} \mathrm{O}_{3}$ & 2.40 & 7.42 & 7.35 & 7.89 \\
$\mathrm{TiO}_{2}$ & 0.42 & 1.29 & 1.19 & 1.81 \\
$\mathrm{FeO}$ & 11.66 & 21.09 & 21.14 & 17.75 \\
$\mathrm{MnO}$ & 0.68 & 0.39 & 0.35 & 0.33 \\
$\mathrm{MgO}$ & 13.38 & 9.79 & 8.64 & 10.77 \\
$\mathrm{CaO}$ & 17.43 & 10.17 & 9.88 & 10.84 \\
$\mathrm{Na}_{2} \mathrm{O}$ & 0.58 & 1.66 & 1.65 & 1.67 \\
$\mathrm{~K}_{2} \mathrm{O}^{\mathrm{O}}$ & 0.12 & 0.41 & 0.39 & 0.41 \\
$\mathrm{TOTAL}$ & 100.89 & 97.96 & 96.82 & 97.00
\end{tabular}

Cations based on $23(0)$

$\begin{array}{lrrrr}\mathrm{Si} & 7.655 & 6.928 & 7.061 & 6.873 \\ \mathrm{Al} \text { (iv) } & 0.345 & 1.072 & 0.939 & 1.127 \\ \mathrm{Al} \text { (vi) } & 0.045 & 0.253 & 0.384 & 0.214 \\ \mathrm{Ti} & 0.045 & 0.147 & 0.137 & 0.205 \\ \mathrm{Fe} & 1.377 & 2.671 & 2.700 & 2.240 \\ \mathrm{Mn} & 0.081 & 0.050 & 0.045 & 0.042 \\ \mathrm{Mg} & 2.815 & 2.209 & 1.968 & 2.423 \\ \mathrm{Ca} & 2.637 & 1.650 & 1.617 & 1.752 \\ \mathrm{Na} & 0.159 & 0.487 & 0.488 & 0.487 \\ \mathrm{~K} & 0.022 & 0.079 & 0.076 & 0.078 \\ \mathrm{SuM} & 15.190 & 15.546 & 15.415 & 15.441\end{array}$


Fe - Ti Oxides

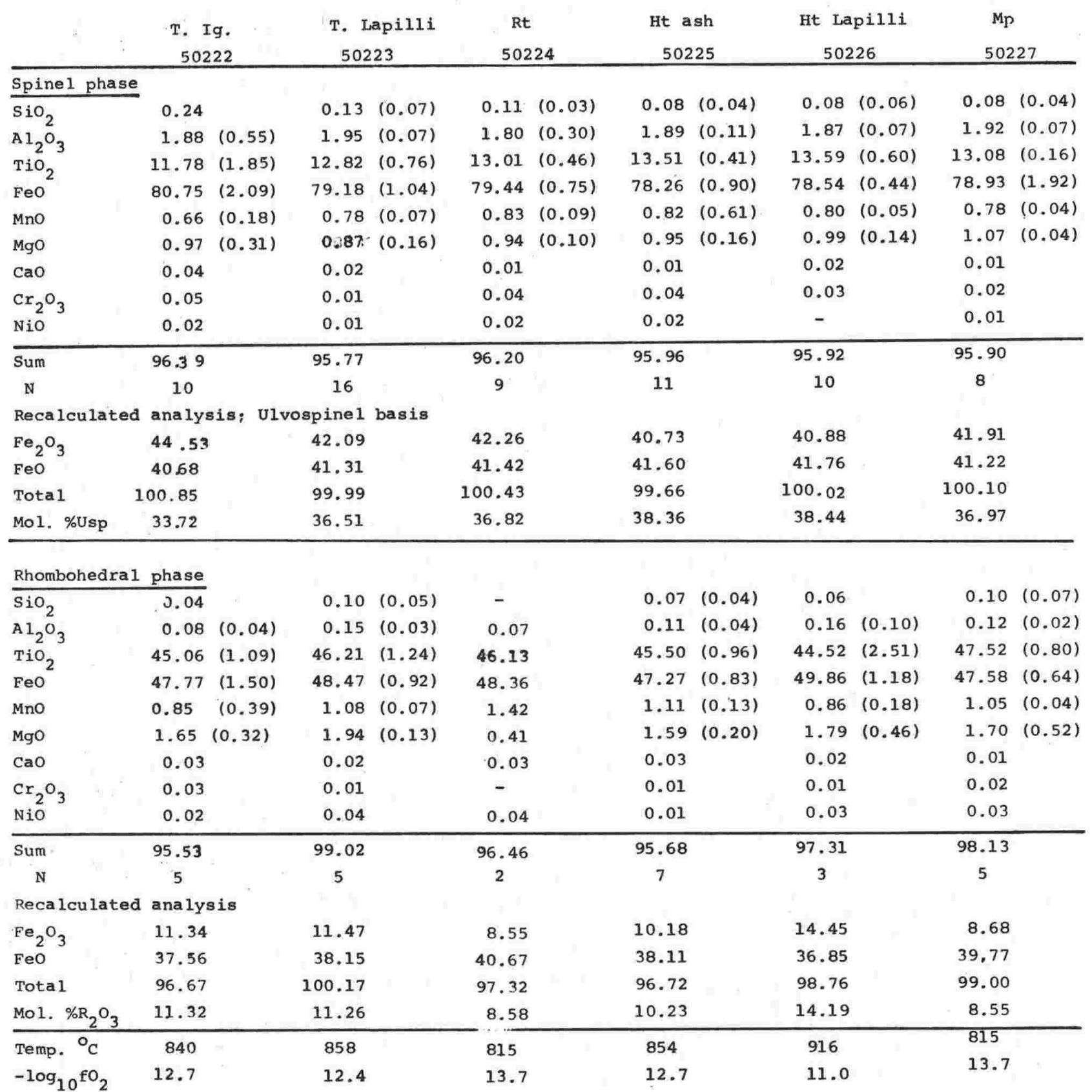




\section{8}

\begin{tabular}{|c|c|c|c|c|c|c|c|c|c|c|}
\hline \multirow[b]{2}{*}{ Spinel phas } & $\begin{array}{c}\text { Wo } \\
50228 \\
\end{array}$ & \multicolumn{2}{|c|}{$\begin{array}{r}\text { Wm Ig. } \\
50229 \\
\end{array}$} & \multicolumn{2}{|c|}{$\begin{array}{l}\text { Wm Lapilli } \\
50230\end{array}$} & \multicolumn{2}{|c|}{$\begin{array}{c}\text { Wm (grey) } \\
50507\end{array}$} & $\begin{array}{c}\mathrm{Hm} \\
50235 \\
\end{array}$ & \multicolumn{2}{|c|}{$\begin{array}{c}\text { Mt (upper) } \\
50493\end{array}$} \\
\hline & & & & & & & & & & \\
\hline $\mathrm{SiO}_{2}$ & $0.11(0.04)$ & 0.07 & $(0.05)$ & 00.10 & $(0.05)$ & 0.10 & $(0.05)$ & $0.09(0.02)$ & 0.09 & $(0.05)$ \\
\hline $\mathrm{Al}_{2} \mathrm{O}_{3}$ & $1.52(0.13)$ & 1.72 & $(0.06)$ & 1.75 & $(0.07)$ & 1.74 & $(0.11)$ & $1.73(0.30)$ & 1.70 & $(0.06)$ \\
\hline $\mathrm{TiO}_{2}$ & $14.87 \quad(0.25)$ & 14.35 & $(0.28)$ & 13.50 & $(0.22)$ & 14.24 & $(0.27)$ & $13.60(0.71)$ & 13.28 & $(0.32)$ \\
\hline $\mathrm{FeO}^{2}$ & $77.72 \quad(0.89)$ & 78.22 & $(0.67)$ & 77.48 & $(0.44)$ & 78.22 & $(1.28)$ & $78.37 \quad(0.95)$ & 78.98 & $(0.90)$ \\
\hline Mno & $0.88 \quad(0.16)$ & 0.76 & $(0.03)$ & 0.79 & $(0.06)$ & 0.81 & $(0.09)$ & $0.73(0.10)$ & 0.77 & $(0.05)$ \\
\hline Mgo & $0.65 \quad(0.17)$ & 0.80 & $(0.06)$ & 0.71 & $(0.05)$ & 0.70 & $(0.07)$ & $0.88 \quad(0.47)$ & 0.71 & $(0.06)$ \\
\hline $\mathrm{CaO}$ & 0.01 & 0.03 & & 0.04 & & 0.02 & & 0.01 & 0.01 & \\
\hline $\mathrm{Cr}_{2} \mathrm{O}_{3}$ & 0.02 & 0.03 & & 0.02 & & - & & 0.02 & 0.02 & \\
\hline $\mathrm{NiO}$ & 0.02 & 0.01 & & 0.02 & & 0.03 & & 0.02 & 0.02 & \\
\hline Sum & 95.80 & 95.99 & & 94.41 & & 95.86 & & 95.45 & 95.58 & \\
\hline $\mathrm{N}$ & 10 & 5 & & 9 & & 7 & & 12 & .11 & \\
\hline \multicolumn{11}{|c|}{ Recalculated analysis; Ulvospinel basis } \\
\hline $\mathrm{Fe}_{2} \mathrm{O}_{3}$ & 38.31 & 39.46 & & 39.90 & & 39.46 & & 40.60 & 41.30 & \\
\hline $\mathrm{FeO}$ & 43.25 & 42.71 & & 41.58 & & 42.71 & & 41.83 & 41.82 & \\
\hline Total & 99.64 & 99.94 & & 98.41 & & 99.81 & & 99.52 & 99.72 & \\
\hline Mol. \%Usp & 42.43 & 40.63 & & 38.98 & & 40.51 & & 38.75 & 37.84 & \\
\hline \multicolumn{11}{|c|}{ Rhombohedral phase } \\
\hline $\mathrm{SiO}_{2}$ & 0.07 & 0.04 & & 0.02 & & 0.06 & & 0.04 & - & \\
\hline $\mathrm{Al}_{2} \mathrm{O}_{3}$ & 0.09 & 0.09 & $(0.06)$ & 0.13 & $(0.08)$ & 0.20 & $(0.12)$ & 0.09 & 0.07 & \\
\hline $\mathrm{TiO}_{2}$ & $49.64(1.46)$ & 48.39 & $(0.72)$ & 44.74 & $(1.25)$ & 46.48 & $(2.09)$ & 50.96 & 47.31 & \\
\hline FeO & $47.15(1.07)$ & 47.72 & $(0.41)$ & 46.82 & $(0.55)$ & 47.17 & $(1.89)$ & 48.13 & 48.22 & \\
\hline MnO & $1.20(0.16)$ & 1.17 & $(0.07)$ & 1.16 & $(0.08)$ & 1.00 & $(0.19)$ & 1.12 & 1.19 & \\
\hline MgO & $1.27(0.13)$ & 1.21 & $(0.39)$ & 1.38 & $(0.04)$ & 2.37 & $(1.03)$ & 1.42 & 1.43 & \\
\hline $\mathrm{CaO}$ & 0.02 & 0.04 & & 0.05 & & 0.04 & & 0.02 & 0.01 & \\
\hline $\mathrm{Cr}_{2} \mathrm{O}_{3}$ & 0.02 & 0.01 & & - & & - & & - & - & \\
\hline NiO & 0.02 & 0.02 & & - & & 0.02 & & 0.01 & - & \\
\hline Sum & 99.48 & 98.69 & & 94.30 & & 97.34 & & 101.79 & 98.23 & \\
\hline $\mathrm{N}$ & 4 & 8 & & 3 & & 7 & & 2 & 2 & \\
\hline \multicolumn{11}{|c|}{ Recalculated analysis } \\
\hline $\mathrm{Fe}_{2} \mathrm{O}_{3}$ & 5.27 & 7.10 & & 10.11 & & 10.67 & & 5.37 & 9.16 & \\
\hline $\mathrm{FeO}$ & 42.41 & 41.33 & & 37.73 & & 37.57 & & 43.30 & 39.98 & \\
\hline Tota 1 & 100.01 & 99.40 & & 95.31 & & 98.41 & & 102.33 & 99.15 & \\
\hline Mol. $\%_{2} \mathrm{R}_{3}$ & 5.19 & 6.98 & & 10.34 & & 10.57 & & 5.13 & 8.93 & \\
\hline Temp ${ }^{\circ} \mathrm{C}$ & 773 & 806 & & 860 & & 874 & 8 & 751 & 828 & \\
\hline$-\log _{10} \mathrm{fO}_{2}$ & 15.5 & 14.2 & & 12.5 & & 12.2 & & 15.9 & 13.4 & \\
\hline
\end{tabular}




\begin{tabular}{|c|c|c|c|c|c|c|c|c|c|c|c|c|}
\hline \multirow[b]{2}{*}{ Spinel phase } & \multicolumn{2}{|c|}{$\begin{array}{c}\text { Mt (basal) } \\
50495 \\
\end{array}$} & \multicolumn{2}{|c|}{$\begin{array}{c}\text { Op (upper) } \\
50237 \\
\end{array}$} & \multicolumn{2}{|c|}{$\begin{array}{l}\text { Op Lapilli } \\
50238\end{array}$} & \multicolumn{2}{|c|}{$\begin{array}{c}\text { Po } \\
50239\end{array}$} & \multicolumn{2}{|c|}{$\begin{array}{c}\text { Kp (upper) } \\
50234\end{array}$} & \multicolumn{2}{|c|}{$\begin{array}{c}\text { Kp (lower) } \\
50240\end{array}$} \\
\hline & & & & & & & & & & & & \\
\hline $\mathrm{SiO}_{2}$ & 0.10 & $(0.07)$ & 0.07 & $(0.03)$ & 0.08 & $(0.04)$ & 0.10 & $(0.05)$ & 0.11 & $(0.08)$ & 0.08 & $(0.04)$ \\
\hline $\mathrm{Al}_{2} \mathrm{O}_{3}$ & 1.73 & $(0.06)$ & 1.79 & $(0.02)$ & 1.72 & $(0.09)$ & 1.63 & $(0.08)$ & 1.75 & $(0.30)$ & 1.65 & $(0.16)$ \\
\hline $\mathrm{TiO}_{2}$ & 12.90 & $(0.37)$ & 13.52 & $(0.33)$ & 12.99 & $(0.52)$ & 13.99 & $(0.15)$ & 12.75 & $(0.35)$ & 13.78 & $(0.38)$ \\
\hline $\mathrm{FeO}$ & 78.66 & $(1.77)$ & 78.60 & $(0.60)$ & 78.73 & $(0.92)$ & 78.21 & $(0.44)$ & 80.08 & $(0.61)$ & 78.41. & $(0.52)$ \\
\hline Mno & 0.72 & $(0.06)$ & 0.56 & $(0.04)$ & 0.59 & $(0.07)$ & 0.52 & $(0.06)$ & 0.53 & $(0.05)$ & 0.50 & $(0.04)$ \\
\hline MgO & 0.77 & $(0.05)$ & 0.85 & $(0.08)$ & 0.77 & $(0.08)$ & 0.66 & $(0.10)$ & 0.81 & $(0.25)$ & 0.69 & $(0.07)$ \\
\hline $\mathrm{CaO}$ & 0.02 & & 0.01 & & 0.02 & & 0.01 & & 0.02 & & 0.02 & \\
\hline $\mathrm{Cr}_{2} \mathrm{O}_{3}$ & - & & 0.04 & & 0.09 & & 0.03 & & 0.04 & & 0.04 & \\
\hline $\mathrm{NiO}$ & - & & 0.04 & & 0.02 & & -- & & - & & 0.02 & \\
\hline Sum & 94.90 & & 95.48 & & 95.01 & & 95.15 & & 96.09 & & 95.19 & \\
\hline $\mathbb{N}$ & 9 & & 4 & & 11 & & 8 & & 5 & & 9 & \\
\hline \multicolumn{5}{|c|}{ Recalculated analysis; Ulvospinel basis } & & & & & & & & \\
\hline $\mathrm{Fe}_{2} \mathrm{O}_{3}$ & 41.58 & & 40.73 & & 41.44 & & 39.53 & & 42.70 & & 40.03 & \\
\hline $\mathrm{FeO}$ & 41.24 & & 41.96 & & 41.44 & & 42.64 & & 41.66 & & 42.39 & \\
\hline Total & 9.07 & & 99.56 & & 99.16 & & 99.11 & & 100.37 & & 99.20 & \\
\hline Mol \%Usp & 37.03 & & 38.44 & & 37.18 & & 40.13 & & 36.17 & & 39.42 & \\
\hline \multicolumn{13}{|c|}{ Rhombohedral phase } \\
\hline $\mathrm{SiO}_{2}$ & 0.06 & $(0.02)$ & 0.05 & & 0.04 & & 0.04 & & 0.05 & & 0.05 & \\
\hline $\mathrm{Al}_{2} \mathrm{O}_{3}$ & 0.08 & $(0.04)$ & 0.17 & $(0.05)$ & 0.08 & & 0.11 & $(0.05)$ & 0.08 & $(0.06)$ & 0.10 & $(0.06)$ \\
\hline $\mathrm{TiO}_{2}$ & 46.59 & $(0.22)$ & 47.23 & $(0.82)$ & 48,43 & $(1.63)$ & 48.97 & $(0.18)$ & 46.15 & $(0.36)$ & 49.62 & $(0.83)$ \\
\hline $\mathrm{FeO}$ & 47.48 & $(1.62)$ & 48.26 & $(0.26)$ & 47.96 & $(0.49)$ & 47.87 & $(0.56)$ & 48.33 & $(0.63)$ & 47.17 & $(1.49)$ \\
\hline $\mathrm{MnO}$ & 1.09 & $(0.05)$ & 1.12 & $(0.03)$ & 0.82 & $(0.05)$ & 0.82 & $(0.05)$ & 0.80 & $(0.04)$ & 0.80 & $(0.03)$ \\
\hline Mgo & 1.54 & $(0.01)$ & 1.95 & $(0.03)$ & 1.48 & $(0.05)$ & 1.39 & $(0.16)$ & 1.45 & $(0.32)$ & 1.61 & $(0.29)$ \\
\hline $\mathrm{CaO}$ & 0.03 & & 0.02 & & 0.02 & & 0.04 & & 0.03 & & 0.01 & \\
\hline $\mathrm{Cr}_{2} \mathrm{O}_{3}$ & - & & 0.02 & & 0.03 & & - & & 0.02 & & 0.02 & \\
\hline $\mathrm{NiO}$ & - & & 0.01 & & 0.01 & $\because$ & 0.01 & & 0.02 & & 0.02 & \\
\hline Sum & 96.87 & & 98.83 & & 98.87 & & 99.25 & & 96.93 & & 99.40 & \\
\hline $\mathrm{N}$ & 3 & & 3 & & 2 & & 4 & & 5 & & 7 & \\
\hline \multicolumn{13}{|c|}{ Recalculated analysis } \\
\hline $\mathrm{Fe}_{2} \mathrm{O}_{3}$ & 9.23 & & 10.28 & & 7.83 & & 7.04 & & 10.47 & & 6.00 & \\
\hline $\mathrm{FeO}$ & 39.18 & & 39.01 & & 40.92 & & 41.54 & & 38.91 & & 41.77 & \\
\hline Total & 97.79 & & 99,86 & & 99.65 & & 99.95 & & 97.98 & & 100.00 & \\
\hline Mol. $\% \mathrm{R}_{2} \mathrm{O}_{3}$ & 9.13 & & 10.06 & & 7.62 & & 6.86 & & 10.32 & & 5.86 & \\
\hline Temp ${ }^{\circ} \mathrm{C}$ & 826 & & 852 & & 799 & & 800 & & 841 & & 773 & \\
\hline$-\log _{10} \mathrm{fo}_{2}$ & 13.4 & & 12.7 & ' & 14.2 & & 14.4 & & 12.9 & & 15.2 & \\
\hline
\end{tabular}




\section{GLASS ANALYSES}

\begin{tabular}{|c|c|c|c|c|c|c|c|c|c|c|c|c|}
\hline \multirow{3}{*}{$\begin{array}{l}\mathrm{SiO}_{2} \\
\mathrm{Al}_{2} \mathrm{O}_{3}\end{array}$} & \multicolumn{2}{|c|}{$\begin{array}{c}\mathrm{T} . \mathrm{Ig} . \\
50222\end{array}$} & \multicolumn{2}{|c|}{$\begin{array}{l}\text { T. Lapilli } \\
50223\end{array}$} & \multicolumn{2}{|c|}{$\begin{array}{c}\text { Rt } \\
50224\end{array}$} & \multicolumn{2}{|c|}{$\begin{array}{c}\text { Ht (ash) } \\
50225\end{array}$} & \multicolumn{2}{|c|}{$\begin{array}{l}\text { Ht Lapilli } \\
\quad 50226\end{array}$} & \multicolumn{2}{|l|}{$\begin{array}{c}\text { Mp } \\
50227\end{array}$} \\
\hline & 75.84 & $(0.70)$ & 77.27 & $(0.38)$ & 76.82 & $(1,00)$ & 76.13 & $(0.55)$ & 75.63 & $(0.13)$ & 76.181 & $(0.54)$ \\
\hline & 13.38 & $(0.33)$ & 13.25 ( & $(0,12)$ & 12.72 & $(0.70)$ & 13.62 & $(0.20)$ & 13.04 & $(0.11)$ & 13.07 & $(0.19)$ \\
\hline $\mathrm{TiO}_{2}$ & 0.241 & $(0.05)$ & 0.26 & $(0,02)$ & 0.21 & $(0.04)$ & 0.21 & $(0.06)$ & 0.25 & $(0.02)$ & 0.23 & $(0.03)$ \\
\hline $\mathrm{FeO}$ & 1.86 & $(0.24)$ & 1.911 & $(0.11)$ & 1.92 & $(0.22)$ & 1.85 & $(0.14)$ & 1.78 & $(0.06)$ & 1.81 & $(0.11)$ \\
\hline Mno & 0.101 & $(0.06)$ & $0.06 \quad($ & $(0.04)$ & 0.09 & $(0.01)$ & 0.07 & $(0.05)$ & 0.10 & $(0.04)$ & 0.081 & $(0.04)$ \\
\hline $\mathrm{MgO}$ & 0.25 & $(0.08)$ & 0.251 & $(0.02)$ & 0.26 & $(0.10)$ & 0.24 & $(0.05)$ & 0.25 & $(0.03)$ & 0.251 & $(0.02)$ \\
\hline $\mathrm{CaO}$ & 1.47 & $(0.12)$ & 1.201 & $(0.04)$ & 1.27 & $(0.23)$ & 1.24 & $(0.11)$ & 1.44 & $(0.05)$ & 1.37( & $(0.08)$ \\
\hline $\mathrm{Na}_{2} \mathrm{O}$ & 4.03 & $(0.41)$ & 3.361 & $(0.21)$ & 3.93 & $(0.15)$ & 4.16 & $(0.33)$ & 4.60 & $(0.12)$ & 4.201 & $(0.40)$ \\
\hline $\mathrm{K}_{2} \mathrm{O}$ & 2.82 & $(0.24)$ & $2.54 \quad 1$ & $(0.09)$ & 2.87 & $(0.14)$ & 2.48 & $(0.08)$ & 2.90 & $(0.10)$ & 2.811 & $(0.19)$ \\
\hline WATER & 2.23 & & 2.101 & $(0.86)$ & 0.42 & & 2.53 & $(0.83)$ & 1.13 & $(0.54)$ & 0.501 & $(0.62)$ \\
\hline $\mathrm{N}$ & 48 & & 10 & & 5 & & 12 & & 10 & & 15 & \\
\hline Q & 36.63 & & 4356 & & 38.44 & & 37.98 & & 33.10 & & 36.28 & \\
\hline C & 1.03 & & 2,79 & & 0.84 & & 1.84 & & - & & 0.63 & \\
\hline or & 16.67 & & 1500 & & 1696 & & 14.66 & & 17.14 & & 16.61 & \\
\hline $\mathrm{Ab}$ & 34.11 & & 28.10 & & 3325 & & 35.20 & & 38.93 & & 35.54 & \\
\hline An & 7.29 & & 5.95 & & 630 & & 6.15 & & 6.37 & & 6.80 & \\
\hline $\mathrm{Di}$ & - & & - & & - & & - & & 0.67 & & - & \\
\hline Hy & 3.13 & & 3.81 & & 3.82 & & 3.78 & & 3.32 & & 3.72 & \\
\hline II & 0.46 & & 0.49 & & 0.40 & & 0.40 & & 0.47 & & 0.44 & \\
\hline \multirow[t]{3}{*}{ D.I. } & 87.40 & & 86.96 & & 88.65 & & 87.83 & & 89.17 & & 88.42 & \\
\hline & \multicolumn{2}{|c|}{ พo } & \multicolumn{2}{|c|}{ Wm Ig. } & \multicolumn{2}{|c|}{ Wm Lapilli } & \multicolumn{2}{|c|}{$\mathrm{Hm}$} & \multicolumn{2}{|c|}{ Mt (upper) } & \multirow{2}{*}{\multicolumn{2}{|c|}{$\begin{array}{c}\text { Mt (lower) } \\
50495\end{array}$}} \\
\hline & \multicolumn{2}{|c|}{50228} & \multicolumn{2}{|c|}{50229} & \multicolumn{2}{|c|}{50230} & \multicolumn{2}{|c|}{50235} & \multicolumn{2}{|c|}{50493} & & \\
\hline $\mathrm{SiO}_{2}$ & 77.30 & $(0.48)$ & 76.55 & $(0.60)$ & 76.43 & $(0.41)$ & 75.66 & $(0.95)$ & 76.09 & $(0.30)$ & 77.01 & $(0.22)$ \\
\hline $\mathrm{Al}_{2} \mathrm{O}_{3}$ & 12.37 & $(0.34)$ & 12.81 & $(0.22)$ & 13.06 & $(0.13)$ & 13.76 & $(0.51)$ & 13.40 & $(0.20)$ & 13.18 & $(0.11)$ \\
\hline $\mathrm{TiO}_{2}$ & 0.15 & $(0.04)$ & 0.19 & $(0.03)$ & 0.20 & $(0.03)$ & 0.21 & $(0.03)$ & 0.18 & $(0.05)$ & 0.16 & $(0.01)$ \\
\hline $\mathrm{FeO}$. & 1.47 & $(0.18)$ & 1.69 & $(0.07)$ & 1.73 & $(0.11)$ & 1.51 & $(0.29)$ & 1.76 & $(0.13)$ & 1.62 & $(0.08)$ \\
\hline Mno & 007 & $(0.04)$ & 0.07 & $(0.04)$ & 0.10 & $(0.03)$ & 0.10 & $(0.05)$ & 0.07 & $(0.05)$ & 0.08 & $(0.04)$ \\
\hline MgO & 0.11 & $(0.04)$ & 0.17 & $(0.03)$ & 0.18 & $(0.04)$ & 0.20 & $(0.08)$ & 0.18 & $(0.04)$ & 0.19 & $(0.03)$ \\
\hline $\mathrm{CaO}$ & 0.99 & $(0.04)$ & 1.23 & $(0.06)$ & 1. 34 & $(0.10)$ & 1.31 & $(0.34)$ & 1.26 & $(0.05)$ & 1.30 & $(0.04)$ \\
\hline $\mathrm{Na}_{2} \mathrm{O}$ & 4.40 & $(0.27)$ & 4.28 & $(0.52)$ & 4.13 & $(0.22)$ & 4.56 & $(0.33)$ & 4.15 & $(0.19)$ & 3.59 & $(0.08)$ \\
\hline $\mathrm{K}_{2} \mathrm{O}$ & 3.13 & $(0.14)$ & 2.96 & $(0.25)$ & 2.84 & $(0.05)$ & 2.67 & $(0.38)$ & 2.91 & $(0.11)$ & 2.88 & $(0.08)$ \\
\hline WATER & 213 & $(0.29)$ & 1.55 & (1.16) & 3.27 & $(1.00)$ & 0.54 & $(0.62)$ & 2.07 & $(1.38)$ & 1.79 & $(1.66)$ \\
\hline $\mathrm{N}$ & 11 & & 14 & & 10 & & 10 & & 9 & & 9 & \\
\hline$Q$ & 3630 & & $36 \quad 12$ & & 3701 & & 34.63 & & 36.45 & & 40.73 & \\
\hline c & - & & 0.33 & & 0.76 & & 0.99 & & 1.13 & & 1.79 & \\
\hline or & 1850 & & 17.50 & & 1678 & & 15.78 & & 17.20 & & 17.02 & \\
\hline $\mathrm{Ab}$ & 37.24 & & 36.24 & & 34.95 & & 38.59 & & 35.12 & & 30.38 & \\
\hline An & 4.76 & & 611 & & 6.65 & & 6.50 & & 6.25 & & 6.45 & \\
\hline $\mathrm{Di}$ & 013 & & - & & - & & - & & - & & - & \\
\hline Hy & 2.79 & & 3.34 & & 3. 48 & & 3.11 & & 3.51 & & 3.33 & \\
\hline I 1 & 028 & & 0.36 & & 0.38 & & 0.40 & & 0.34 & & 0.30 & \\
\hline D.I. & 92.04 & & 89.86 & & 88.74 & & 89.00 & & 88.76 & & 88.12 & \\
\hline
\end{tabular}




\section{1}

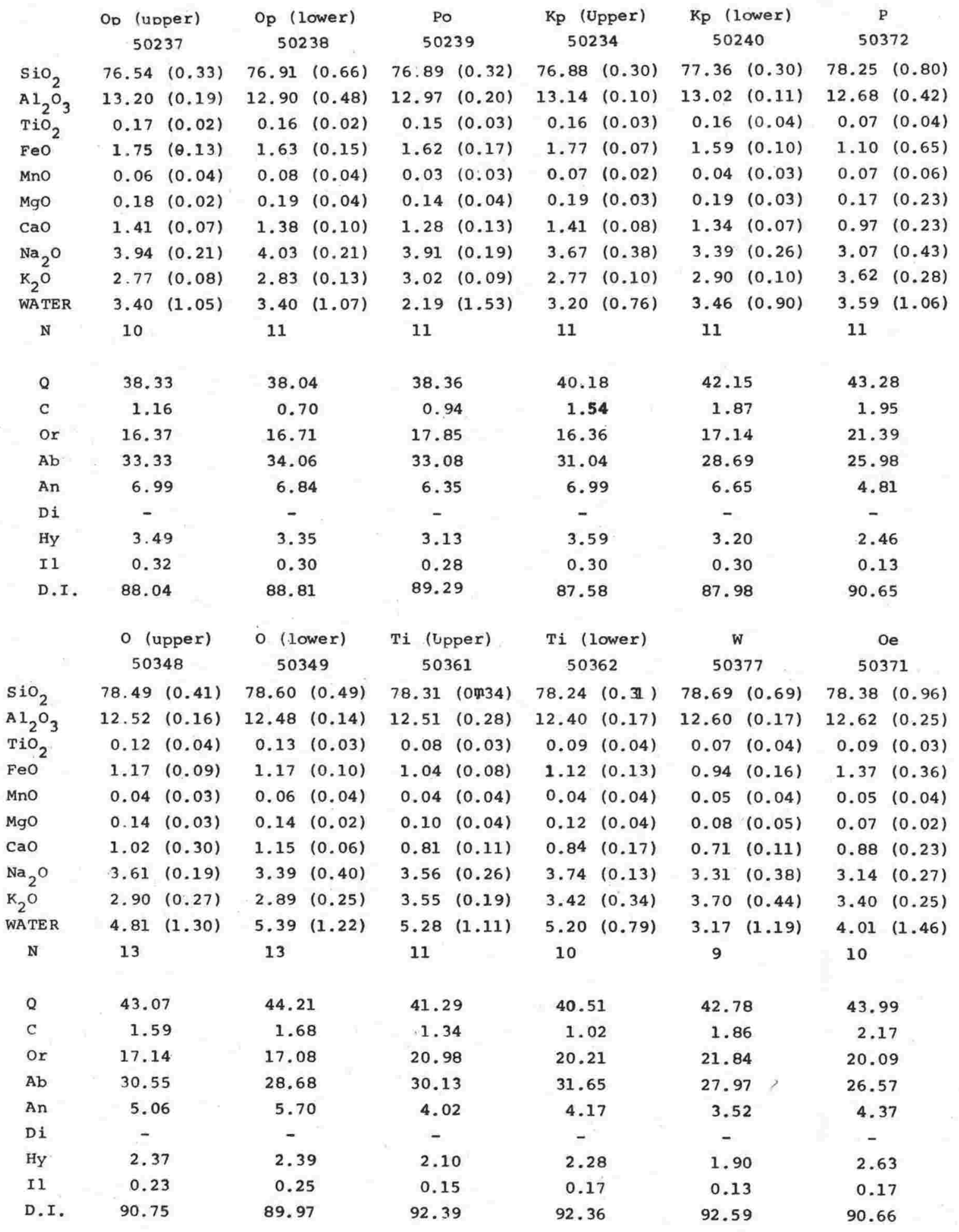




\section{2}

KAWAKAWA TEPHRA FORMATION

\begin{tabular}{|c|c|c|c|c|c|c|c|c|c|c|c|c|c|}
\hline \multirow[b]{2}{*}{$\mathrm{SiO}_{2}$} & $\begin{array}{l}\text { Ou B. } \\
50334\end{array}$ & \multicolumn{2}{|c|}{$\begin{array}{l}\text { Ou B. } \\
50335\end{array}$} & \multicolumn{2}{|c|}{$\begin{array}{l}\text { Sc Is. } \\
50336\end{array}$} & \multicolumn{2}{|c|}{$\begin{array}{l}\text { Sc Is. } \\
50337\end{array}$} & \multicolumn{2}{|c|}{$\begin{array}{l}\text { Sc Is. } \\
50338\end{array}$} & \multicolumn{2}{|c|}{$\begin{array}{l}\text { Sc Is. } \\
50339\end{array}$} & \multicolumn{2}{|c|}{$\begin{array}{l}\text { Aok. Ash } \\
50340\end{array}$} \\
\hline & $79.14(0.20)$ & 78.82 & $(0.45)$ & 79.23 & $(0.38)$ & 78.97 & $(0.46)$ & 78.92 & $(0.39)$ & 79.14 & $(0.71)$ & 78.39 & $(0.54)$ \\
\hline $\mathrm{A}_{2} \mathrm{O}_{3}$ & $12.10(0.07)$ & 12.14 & $(0.38)$ & 11.95 & $(0.31)$ & 12.30 & $(0.46)$ & 12.17 & $(0.12)$ & 12.10 & $(0.20)$ & 12.38 & $(0.24)$ \\
\hline $\mathrm{TiO}_{2}$ & $0.12(0.03)$ & 0.12 & $(0.04)$ & 0.11 & $(0.03)$ & 0.14 & $(0.03)$ & 0.13 & $(0.03)$ & 0.12 & $(0.02)$ & 0.15 & $(0.04)$ \\
\hline $\mathrm{FeO}$ & $1.23(0.07)$ & 1.15 & $(0.05)$ & 1.09 & $(0.07)$ & 1.12 & $(0.06)$ & 1.20 & $(0.16)$ & 1.04 & $(0.30)$ & 1.20 & $(0.17)$ \\
\hline Mno & $0.06 \quad(0.09)$ & 0.06 & $(0.03)$ & 0.06 & $(0.04)$ & 0.06 & $(0.04)$ & 0.05 & $(0.04)$ & 0.05 & $(0.05)$ & 0.08 & $(0.10)$ \\
\hline MgO & $0.13(0.02)$ & 0.13 & $(0.02)$ & 0.12 & $(0.01)$ & 0.12 & $(0.02)$ & 0.13 & $(0.03)$ & 0.12 & $(0.02)$ & 0.13 & $(0.06)$ \\
\hline $\mathrm{CaO}$ & $1.09(0.03)$ & 1.10 & $(0.12)$ & 1.00 & $(0.07)$ & 1.02 & $(0.07)$ & 1.06 & $(0.12)$ & 0.99 & $(0.09)$ & 1.10 & $(0.16)$ \\
\hline $\mathrm{Na}_{2} \mathrm{O}$ & $3.20(0.18)$ & 3.40 & $(0.36)$ & 3.39 & $(0.19)$ & 3.21 & $(0.14)$ & 3.16 & $(0.25)$ & 3.35 & $(0.20)$ & 3.40 & $(0.15)$ \\
\hline $\mathrm{K}_{2} \mathrm{O}$ & $2.93(0.10)$ & 3.07 & $(0.64)$ & 3.05 & $(0.31)$ & 3.06 & $(0.19)$ & 3.18 & $(0.24)$ & 2.95 & $(0.70)$ & 3.16 & $(0.30)$ \\
\hline WATER & $5.57 \quad(1.33)$ & 4.80 & $(1.45)$ & 4.38 & $(0.60)$ & 6.19 & $(2.07)$ & 5.49 & $(1.24)$ & 7.15 & $(1.30)$ & 5.79 & (1.75) \\
\hline $\mathrm{N}$ & 9 & 13 & & 10 & & 10 & & 10 & & 9 & & 12 & \\
\hline$Q$ & 45.79 & 43.8 & & 44.6 & & 45.3 & & 44.9 & & 45.1 & & 43.0 & \\
\hline c & 1.68 & 1.2 & & 1.2 & & 1.8 & & 1.6 & & 1.6 & & 1.3 & \\
\hline Or & 17.32 & 18.1 & & 18.0 & & 18.0 & & 18.7 & & 17.4 & & 18.6 & \\
\hline $\mathrm{Ab}$ & 27.08 & 28.7 & & 28.6 & & 27,1 & & 26.7 & & 28.3 & & 28.7 & \\
\hline An & 5.41 & 5.4 & & 4.9 & & 5.0 & & 5.2 & & 4.9 & & 5.4 & \\
\hline $\mathrm{Di}$ & - & - & & - & & - & & - & & - & & - & \\
\hline Hy & 2.50 & 2.3 & & 2.2 & & 2.2 & & 2.4 & & 2.3 & & 2.4 & \\
\hline I1 & 0.23 & 0.2 & & 0.2 & & 0.2 & & 0.2 & & 0.2 & & 0.2 & \\
\hline D.I. & 90.19 & 90.7 & & 91.3 & & 90.5 & & 90.4 & & 90.9 & & 90.4 & \\
\hline
\end{tabular}




\section{3}

\section{0}

$78.68(0.34)$

50031

$78.45 \quad(0.32)$

$12.38 \quad(0.15)$

$0.09(0.03)$

$1.25(0.09)$

$0.07(0.05)$

$0.14(0.02)$

$1.08(0.05)$

$2.88 \quad(0.22)$

8
$3.65(0.19)$

$3.55(2.18)$

\section{8}

$77.45(0.30)$

$12.58 \quad(0.18)$

$0.14(0.03)$

$1.13(0.06)$

0.03

$0.11(0.07)$

$0.79(0.02)$

$3.55(0.19)$

$4.13(0.16)$

$4.95(0.92)$ 10

50065

$77.87(0.47)$

$12.51(0.15)$

$0.18(0.03)$

$1.32(0.19)$

0.07

$0.21(0.06)$

$1.33(0.16)$

$3.23(0.15)$

$3.37(0.17)$

$3.11(0.80)$

$$
7
$$

\section{8}

$\begin{array}{lllll}\mathrm{SiO}_{2} & 79.13 & (0.20) & 78.33 & (0.43)\end{array}$

$$
50079
$$

50080

$\begin{array}{lrrrr}\mathrm{Al}_{2} \mathrm{O}_{3} & 12.12 & (0.12) & 12.48 & (0.22) \\ \mathrm{TiO}_{2} & 0.08 & (0.04) & 0.13 & (0.03)\end{array}$

$\mathrm{FeO}$

Mno

Mgo

$\mathrm{CaO}$

$\mathrm{Na}_{2} \mathrm{O}$

$\mathrm{K}_{2} \mathrm{O}$

WATER

N

$0.96(0.09) \quad 1.30 \quad(0.12)$

$$
0.04
$$

0.04

$0.07(0.03)$

$0.05(0.02)$

$0.46(0.04)$

$0.74(0.07)$

$3.46(0.21)$

$3.38 \quad(0.18)$

$3.67(0.24)$

$3.54(0.14)$

$4.94(0.76) \quad 2.07 \quad(0.63)$ 10

\section{1}

$78.76(0.43)$

$12.43(0.15)$

$0.11(0.03)$

$1.18(0.09)$

$0.05 \quad(0.04)$

$0.12(0.02)$

$1.02(0.09)$

$3.36 \quad(0.22)$

$2.96(0.37)$

$3.41(1.40)$

10

50068

$77.97(0.27)$

$12.42(0.16)$

$0.11(0.03)$

$1.26(0.04)$

$-$

$0.12 \quad(0.02$

$0.88 \quad(0.05)$

$3.81(0.08)$

$3.40(0.23)$

$3.18(0.54)$

10

\subsection{9}

$77.86(0.23)$

$12.49(0.19)$

$0.13(0.03)$

$1.36(0.07)$

$0.07(0.03)$

$0.11 \quad(0.03)$

$0.87(0.03)$

$3.58(0.17)$

$3.53(0.14)$

$5.38 \quad(1.25)$

$$
10
$$

\section{6}

$78.45(0.24)$

$12.62(0.19)$

$0.10(0.03)$

$0.97(0.14)$

$0.08(0.02)$

$0.15(0.04)$

$0.97(0.04)$

$3.23(0.32)$

$3.43(0.12)$

$5.29(0.89)$

3

\section{5}

$78.49(0.38)$

$12.19(0.24)$

$0.10(0.04)$

$1.16(0.05)$

$0.06(0.05)$

$0.08 \quad(0.02)$

$0.63(0.02)$

$3.40(0.17)$

$4.40(1.59)$
$3.90(0.11)$

50060

$\begin{array}{llll}77.16 & (0.48) & 78.10 & (0.37)\end{array}$

$13.07 \quad(0.37) \quad 12.46 \quad(0.20)$

$\begin{array}{lllll}0.21 & (0.05) & 0.12 & (0.03)\end{array}$

$1.23(0.11) \quad 1.35 \quad(0.19)$

0.04

$0.24(0.09)$

$1.32(0.18)$

$3.62(0.29)$

$3.11-0.28)$

5.75 (1.14)

11

\section{1}

$78.26(0.19)$

$12.54(0.13)$

$0.12(0.03)$

$1.31(0.13)$

0.04

$0.13(0.03)$

$1.07(0.05)$

$3.97(0.20)$

$2.57(0.14)$

$5.98(0.15)$

5

\section{0}

$78.22(0.27)$

$12.36(0.22)$

$0.09(0.04)$

$1.08(0.14)$

$0.07(0.03)$

$0.09(0.01)$

$0.76 \quad(0.09)$

$3.71(0.25)$

$3.61(0.17)$

$5.50(1.35)$

$$
11
$$

\section{7}

$77.74(0.14)$

$12.55(0.12)$

$0.08 \quad(0.05)$

$0.90(0.09)$

0.04

$0.07 \quad(0.03)$

$0.59(0.13)$

$3.43(0.10)$

$4.59(0.21)$

$4.87 \quad(0.87)$

\section{5}

$78.13(0.31)$

$12.32(0.12)$

$0.10 \quad(0.02)$

$1.05(0.05)$

0.03

$0.08 \quad(0.03)$

$0.63(0.10)$

$3.90 \quad(0.26)$

$3.76(0.08)$

$2.70(0.77)$

10

50110

$\begin{array}{lllll}78.18 & (0.39) & 78.71 & (0.18)\end{array}$

$12.59 \quad(0.31) \quad 12.69 \quad(0.09)$

$0.09(0.03) \quad 0.05 \quad(0.04)$

$1.02(0.08) \quad 0.97 \quad(0.12)$

0.05

$0.09(0.03)$

$0.86(0.11)$

$3.72(0.12)$

$3.40(0.28)$

$3.84(0.65)$

11

\section{8}

$78.46(0.29)$

$12.27(0.15)$

$0.09(0.03)$

$0.94(0.08)$

0.05

$0.08(0.02)$

$0.74(0.06)$

$3.51(0.13)$

$3.86(0.21)$

$1.97(0.84)$

11
$07(0.04)$

$11(0.02$

$3.62(0.32)$

$3.30(0.34)$

$6.45(0.96)$

11

\section{7}

$78.31(0.42)$

$2.57(0.33)$

$1(0.03)$

$0.98 \quad(0.07)$

$3.15(0.26)$

$3.60(0.14)$

$5.22(1.93)$ 8

0.03

$0.09(0.03)$

$0.86(0.06)$

$3.25(0.16)$

$3.35(0.21)$

$2.85(0.69)$

10

\section{9}

$78.62(0.33)$

$11.96(0.26)$

$0.11(0.02)$

$0.94(0.08)$

0.04

$0.11(0.03)$

$0.74(0.10)$

$3.22(0.12)$

$4.25 \quad(0.18)$

$2.43(0.91)$

10 


\begin{tabular}{|c|c|c|c|c|c|c|c|c|c|c|c|c|c|c|}
\hline \multirow[b]{2}{*}{$\mathrm{SiO}_{2}$} & \multicolumn{2}{|c|}{50131} & \multicolumn{2}{|c|}{50138} & \multicolumn{2}{|c|}{50142} & \multicolumn{2}{|c|}{50143} & \multicolumn{2}{|c|}{50144} & \multicolumn{2}{|c|}{50145} & \multicolumn{2}{|c|}{50156} \\
\hline & 78.44 & $(0.41)$ & 78.45 & $(0.28)$ & 78.27 & $(0.04)$ & 78.59 & $(0.14)$ & 78.20 & $(0.60)$ & 78.34 & $(0.45)$ & 78.17 & 10.32 \\
\hline $\mathrm{Al}_{2} \mathrm{O}_{3}$ & 12.22 & $(0.12)$ & 12.27 & $(0.11)$ & 12.39 & $(0.10)$ & 12.41 & $(0.11)$ & 12.45 & $(0.09)$ & 12.19 & $(0.12)$ & 12.29 & $(0.18$ \\
\hline $\mathrm{TiO}_{2}$ & 0.14 & $(0.03)$ & 0.12 & $(0.03)$ & 0.13 & $(0.03)$ & 0.13 & $(0.03)$ & 0.14 & $(0.02)$ & 0.12 & $(0.04)$ & 0.14 & $(0.14$ \\
\hline Feo ${ }^{2}$ & 1.06 & $(0.08)$ & 0.97 & $(0.25)$ & 1.01 & $(0.04)$ & 0.87 & $(0.08)$ & 1.05 & $(0.20)$ & 1.10 & $(0.15)$ & 1.02 & 10.08 \\
\hline Mno & 0.08 & & 0.06 & & 0.03 & & 0.07 & & 0.04 & & 0.06 & & 0.06 & \\
\hline MgO & 0.11 & $(0.01)$ & 0.10 & $(0.04)$ & 0.12 & $(0.01)$ & 0.14 & $(0.02)$ & 0.14 & $(0.03)$ & 0.11 & $(0.02)$ & 0.11 & 10.04 \\
\hline $\mathrm{CaO}$ & 0.73 & $(0.02)$ & 0.73 & $(0.11)$ & 0.77 & $(0.04)$ & 0.80 & $(0.01)$ & 0.88 & $(0.13)$ & 0.82 & $(0.05)$ & 0.75 & 10.04 \\
\hline $\mathrm{Na}_{2} \mathrm{O}$ & 3.18 & $(0.20)$ & 3.61 & $(0.15)$ & 3.25 & $(0.07)$ & 3.79 & $(0.13)$ & 3.68 & $(0.14)$ & 3.53 & $(0.22)$ & 3.24 & 10.13 \\
\hline $\mathrm{K}_{2} \mathrm{O}$ & 4.05 & $(0.15)$ & 3.69 & $(0.30)$ & 4.02 & $(0.10)$ & 3.21 & $(0.11)$ & 3.41 & $(0.45)$ & 3.72 & $(0.39)$ & 4.21 & 10.18 \\
\hline WATER & 6.07 & $(0.53)$ & 2.17 & $(1.94)$ & 4.63 & $(0.67)$ & 1.89 & $(1.65)$ & 4.31 & $(0.93)$ & 2.38 & $(1.27)$ & 5.35 & $(0.67$ \\
\hline \multirow[t]{2}{*}{$\mathrm{N}$} & \multicolumn{2}{|c|}{10} & \multicolumn{2}{|c|}{6} & \multicolumn{2}{|l|}{3} & \multicolumn{2}{|l|}{8} & \multicolumn{2}{|c|}{6} & \multicolumn{2}{|c|}{9} & \multicolumn{2}{|l|}{13} \\
\hline & \multicolumn{2}{|c|}{50157} & \multicolumn{2}{|c|}{50160} & 501 & 165 & 501 & 166 & 501 & 67 & 501 & 168 & 501 & 177 \\
\hline $\mathrm{SiO}_{2}$ & 77.65 & $(0.34)$ & 77.06 & $(0.77)$ & 78.24 & $(0.15)$ & 77.66 & $(0.26)$ & 78.19 & $(0.54)$ & 78.17 & $(0.32)$ & 78.55 & $(0.14)$ \\
\hline $\mathrm{Al}_{2} \mathrm{O}_{3}$ & 12.63 & $(0.32)$ & 13.09 & $(0.34)$ & 12.26 & $(0.14)$ & 12.42 & $(0.09)$ & 12.30 & $(0.33)$ & 12.41 & $(0.13)$ & 12.27 & 10.23 \\
\hline $\mathrm{TiO}_{2}$ & 0.13 & $(0.03)$ & 0.17 & $(0.03)$ & 0.16 & $(0.03)$ & 0.13 & $(0.03)$ & 0.13 & $(0.04)$ & 0.13 & $(0.05)$ & 0.06 & $(0.02)$ \\
\hline $\mathrm{FeO}$ & 1.13 & $(0.09)$ & 1.54 & $(0.10)$ & 1.10 & $(0.07)$ & 1.05 & $(0.06)$ & 1.02 & $(0.13)$ & 1.02 & $(0.10)$ & 0.71 & $(0.24)$ \\
\hline Mno & 0.05 & & 0.04 & & 0.03 & & - & & 0.04 & & 0.04 & & 0.05 & \\
\hline MgO & 0.11 & $(0.03)$ & 0.12 & $(0.07)$ & 0.14 & $(0.03)$ & 0.12 & $(0.01)$ & 0.11 & $(0.03)$ & 0.12 & $(0.03)$ & 0.06 & 10.03 \\
\hline $\mathrm{CaO}$ & 0.80 & $(0.04)$ & 1.11 & $(0.05)$ & 0.75 & $(0.04)$ & 0.79 & $(0.05)$ & 0.73 & $(0.11)$ & 0.77 & $(0.09)$ & 0.61 & 10.02 \\
\hline $\mathrm{Na}_{2} \mathrm{O}$ & 3.53 & $(0.16)$ & 3.54 & $(0.59)$ & 2.96 & $(0.13)$ & 3.73 & $(0.10)$ & 3.29 & $(0.20)$ & 3.23 & $(0.25)$ & 3.32 & 10.06 \\
\hline $\mathrm{K}_{2} \mathrm{O}$ & 3.98 & $(0.16)$ & 3.34 & $(0.22)$ & 4.36 & $(0.13)$ & 4.10 & $(0.18)$ & 4.20 & $(0.22)$ & 4.11 & $(0.18)$ & 4.38 & 10.15 \\
\hline WATER & 6.02 & $(1.18)$ & 6.29 & $(1.14)$ & 2.88 & $(0.46)$ & 3.20 & $(0.59)$ & 5.81 & $(1.94)$ & 5.20 & $(0.90)$ & 1.60 & 10.58 \\
\hline $\mathrm{N}$ & 10 & & 9 & & 10 & & 13 & & 11 & & 16 & & 7 & \\
\hline & 501 & & 501 & 179 & 501 & 82 & 501 & 183 & 501 & $184 \leq$ & 501 & 191 & 501 & 193 \\
\hline $\mathrm{SiO}_{2}$ & 78.63 & $(0.20)$ & 78.94 & $(0.22)$ & 76.26 & $(0.48)$ & 75.91 & $(0.21)$ & 78.67 & $(0.23)$ & 78.01 & $(0.33)$ & 78.56 & 10.33 \\
\hline $\mathrm{Al}_{2} \mathrm{O}_{3}$ & 12.56 & $(0.14)$ & 12.12 & $(0.22)$ & 13.67 & $(0.18)$ & 13.65 & $(0.18)$ & 12.18 & $(0.17)$ & 12.35 & $(0.15)$ & 12.48 & 10.12 \\
\hline $\mathrm{TiO}_{2}$ & 0.13 & $(0.03)$ & 0.09 & $(0.03)$ & 0.22 & $(0.02)$ & 0.25 & $(0.04)$ & 0.12 & $(0.03)$ & 0.15 & $(0.04)$ & 0.13 & 10.05 \\
\hline Feo & 0.94 & $(0.03)$ & 0.98 & $(0.06)$ & 1.94 & $(0.08)$ & 1.92 & $(0.09)$ & 1.13 & $(0.06)$ & 1.03 & $(0.09)$ & 1.18 & 10.07 \\
\hline Mno & 0.04 & & 0.05 & & 0.07 & $(0.05)$ & 0.11 & $(0.05)$ & 0.05 & $(0.03)$ & 0.04 & & 0.06 & \\
\hline Mgo & 0.15 & $(0.20)$ & 0.09 & $(0.01)$ & 0.27 & $(0.02)$ & 0.28 & $(0.02)$ & 0.12 & $(0.04)$ & 0.11 & $(0.05)$ & 0.16 & 10.0 \\
\hline $\mathrm{CaO}$ & 0.98 & $(0.02)$ & 0.81 & $(0.03)$ & 1.46 & $(0.06)$ & 1.49 & $(0.06)$ & 0.98 & $(0.04)$ & 0.78 & $(0.04)$ & 0.75 & \\
\hline $\mathrm{Na}_{2} \mathrm{O}$ & 3.24 & $(0.22)$ & 3.50 & $(0.09)$ & 3.27 & $(0.53)$ & 3.59 & $(0.21)$ & 3.46 & $(0.16)$ & 3.06 & $(0.16)$ & 2.90 & $(0.13)$ \\
\hline $\mathrm{K}_{2} \mathrm{O}$ & 3.34 & $(0.08)$ & 3.42 & $(0.15)$ & 2.82 & $(0.21)$ & 2.80 & $(0.08)$ & 3.28 & $(0.07)$ & 4.47 & $(0.10)$ & 3.23 & 10.17 \\
\hline WATER & 1.31 & & 3.57 & $(1.43)$ & 3.01 & $(1.80)$ & 3.55 & $(2.92)$ & 1.88 & $(0.47)$ & 2.36 & $(0.88)$ & 5.72 & (1.26 \\
\hline $\mathrm{N}$ & 4 & & 9 & & 6 & & 8 & & 10 & & 10 & & 10 & \\
\hline & 501 & & 501 & & 501 & & 502 & & 502 & 207 & 502 & 208 & 502 & 209 \\
\hline $\mathrm{SiO}_{2}$ & 77.25 & $(0.20)$ & 78.16 & $(0.20)$ & 79.19 & $(0.29)$ & 77.16 & $(0.55)$ & 77.87 & $(0.22)$ & 77.99 & $(0.20)$ & 76.24 & $(0.64)$ \\
\hline $\mathrm{Al}_{2} \mathrm{O}_{3}$ & 13.32 & $(0.11)$ & 12.74 & $(0.15)$ & 12.12 & $(0.25)$ & 12.77 & $(0.16)$ & 12.30 & $(0.10)$ & 12.17 & $(0.11)$ & 13.16 & $(0.38)$ \\
\hline $\mathrm{TiO}_{2}$ & 1.27 & $(0.09)$ & 0.16 & $(0.03)$ & 0.11 & $(0.02)$ & 0.16 & $(0.04)$ & 0.15 & $(0.03)$ & 0.15 & $(0.02)$ & 0.21 & 10.02 \\
\hline Feo & 1.27 & $(0.09)$ & 1.16 & $(0.10)$ & 0.86 & $(0.07)$ & 1.39 & $(0.13)$ & 1.06 & $(0.07)$ & 1.07 & $(0.07)$ & 1.75 & $(0.04)$ \\
\hline Mno & 0.06 & $(0.04)$ & 0.09 & $(0.03)$ & 0.05 & & 0.03 & & 0.02 & & 0.03 & & 0.14 & $(0.08)$ \\
\hline Mgo & 0.20 & $(0.03)$ & 0.18 & $(0.23)$ & 0.13 & $(0.02)$ & 0.23 & $(0.04)$ & 0.12 & $(0.02)$ & 0.11 & $(0.03)$ & 1.02 & $(0.06)$ \\
\hline $\mathrm{CaO}$ & 1.18 & $(0.07)$ & 0.98 & $(0,03)$ & 0.81 & $(0.04)$ & 1.31 & $(0.13)$ & 0.80 & $(0.04)$ & 0.78 & $(0.02)$ & 4.44 & $(0.20)$ \\
\hline $\mathrm{Na}_{2} \mathrm{O}$ & 4.01 & $(0.17)$ & 3.75 & $(0.20)$ & 3.71 & $(0.09)$ & 3.70 & $(0.09)$ & 3.35 & $(0.26)$ & 3.28 & $(0.15)$ & 2.97 & $(0.22)$ \\
\hline $\mathrm{K}_{2} \mathrm{O}$ & 2.50 & $(0.22)$ & 2.78 & $(0.10)$ & 3.02 & $(0.11)$ & 3.26 & $(0.08)$ & 4.30 & $(0.19)$ & 4.43 & $(0.17)$ & 4.96 & (1.58) \\
\hline WATER & 3.62 & $(0.32)$ & 3.25 & $(0.62)$ & 1.97 & $(1.38)$ & 5.93 & $(0.78)$ & 4.66 & $(0.65)$ & 3.23 & $(0.50)$ & 6 & \\
\hline $\mathrm{N}$ & 5 & & 11 & & 11 & & 5 & & 20 & & 10 & & & \\
\hline
\end{tabular}




\begin{tabular}{|c|c|c|c|c|c|c|c|c|c|c|c|c|c|c|}
\hline \multirow[b]{2}{*}{$\mathrm{SiO}_{2}$} & \multicolumn{2}{|c|}{50210} & \multicolumn{2}{|c|}{50211} & \multicolumn{2}{|c|}{50212} & \multicolumn{2}{|c|}{50213} & \multicolumn{2}{|c|}{50214} & \multicolumn{2}{|c|}{$502 I 5 A$} & \multicolumn{2}{|c|}{$50215 B$} \\
\hline & 78.38 & $(0.32)$ & 76.93 & $(0.23)$ & 78.14 & $(0.53)$ & 77.42 & $(0.54)$ & 76.68 & $(0.38)$ & 78.16 & $(0.33)$ & 76.93 & $(0.21)$ \\
\hline $\mathrm{Al}_{2} \mathrm{O}_{3}$ & 12.31 & $(0.17)$ & 13.03 & $(0.11)$ & 12.46 & $(0.22)$ & 12.78 & $(0.23)$ & 13.09 & $(0.19)$ & 12.43 & $(0.31)$ & 12.91 & $(0.10)$ \\
\hline $\mathrm{TiO}_{2}$ & 0.12 & $(0.03)$ & 0.19 & $(0.02)$ & 0.13 & $(0.04)$ & 0.16 & $(0.04)$ & 0.17 & $(0.03)$ & 0.10 & $(0.04)$ & 0.21 & $(0.03)$ \\
\hline $\mathrm{FeO}$ & 1.16 & $(0.07)$ & 1.62 & $(0.07)$ & 1.35 & $(0.33)$ & 1.49 & $(0.32)$ & 1.70 & $(0.08)$ & 1.06 & $(0.21)$ & 1.61 & 10.07 \\
\hline Mno & 0.04 & & 0.04 & & 0.04 & & 0.05 & & 0.07 & & 0.04 & & 0.06 & \\
\hline Mgo & 0.10 & $(0.02)$ & 0.17 & $(0.03)$ & 0.10 & $(0.03)$ & 0.14 & $(0.03)$ & 0.12 & $(0.04)$ & 0.09 & $(0.04)$ & 0.17 & 10.03 \\
\hline $\mathrm{CaO}$ & 0.92 & $(0.06)$ & 1.04 & $(0.05)$ & 0.86 & $(0.12)$ & 0.94 & $(0.10)$ & 1.00 & $(0.06)$ & 0.78 & $(0.09)$ & 0.97 & 10.05 \\
\hline $\mathrm{Na}_{2} \mathrm{O}$ & 3.37 & $(0.18)$ & 3.64 & $(0.21)$ & 3.39 & $(0.25)$ & 3.63 & $(0.65)$ & 3.86 & $(0.25)$ & 3.45 & $(0.14)$ & 3.94 & 10.19 \\
\hline $\mathrm{K}_{2} \mathrm{O}$ & 3.61 & $(0.21)$ & 3.35 & $(0.09)$ & 3.53 & $(0.28)$ & 3.34 & $(0.32)$ & 3.31 & $(0.12)$ & 3.89 & $(0.22)$ & 3.21 & $(0.06)$ \\
\hline WATER & 3.45 & $(0.99)$ & 4.74 & $(1.27)$ & 4.63 & $(1.54)$ & 2.78 & $(0.76)$ & 3.81 & $(0.60)$ & 2.25 & (1.58) & 2.87 & 10.82 \\
\hline \multirow[t]{2}{*}{$\mathrm{N}$} & \multicolumn{2}{|l|}{17} & \multicolumn{2}{|l|}{10} & \multicolumn{2}{|l|}{10} & \multicolumn{2}{|l|}{11} & \multicolumn{2}{|l|}{10} & & & \multicolumn{2}{|c|}{8} \\
\hline & \multicolumn{2}{|c|}{50216} & \multicolumn{2}{|c|}{50217} & 502 & $218 \mathrm{~A}$ & 50 & $218 \mathrm{~B}$ & 502 & 219 & 502 & 220 & & 221 \\
\hline $\mathrm{SiO}_{2}$ & 78.76 & $(0.24)$ & 78.50 & $(0.29)$ & 76.35 & $(0.85)$ & 78.28 & $(0.34)$ & 78.94 & $(0.33)$ & 78.60 & $(0.32)$ & 78.23 & $(0.32)$ \\
\hline $\mathrm{Al}_{2} \mathrm{O}_{3}$ & 12.18 & $(0.17)$ & 12.24 & $(0.23)$ & 13.06 & $(0.54)$ & 12.34 & $(0.31)$ & 12.28 & $(0.25)$ & 12.14 & $(0.17)$ & 12.30 & 10.39 \\
\hline $\mathrm{TiO}_{2}$ & 0.12 & $(0.03)$ & 0.13 & $(0.01)$ & 0.22 & $(0.13)$ & 0.09 & $(0.06)$ & 0.11 & $(0.02)$ & 0.12 & $(0.03)$ & 0.12 & 10.03 \\
\hline $\mathrm{FeO}$ & 0.94 & $(0.10)$ & 1.07 & $(0.05)$ & 1.81 & $(0.19)$ & 1.03 & $(0.17)$ & 1.23 & $(0.08)$ & 1.08 & $(0.06)$ & 1.03 & 10.08 \\
\hline MnO & 0.06 & & 0.04 & & 0.05 & & 0.03 & & 0.05 & & 0.05 & & 0.06 & \\
\hline Mgo & 0.10 & $(0.05)$ & 0.14 & $(0.02)$ & 0.20 & $(0.14)$ & 0.09 & $(0.05)$ & 0.13 & $(0.04)$ & 0.11 & $(0.02)$ & 0.12 & $(0.01)$ \\
\hline $\mathrm{CaO}$ & 0.77 & $(0.08)$ & 0.95 & $(0.03)$ & 1. 35 & $(0.22)$ & 0.86 & $(0.11)$ & 1.07 & $(0.10)$ & 0.88 & $(0.08)$ & 0.85 & 10.23 \\
\hline $\mathrm{Na}_{2} \mathrm{O}$ & 3.29 & $(0.19)$ & 3.30 & $(0.10)$ & 3.64 & $(0.16)$ & 3.44 & $(0.14)$ & 3.40 & $(0.11)$ & 3.23 & $(0.21)$ & 3.20 & $(0.15)$ \\
\hline $\mathrm{K}_{2} \mathrm{O}$ & 3.77 & $(0.25)$ & .62 & $(0.19)$ & 3.31 & $(0.26)$ & 3.83 & $(0.32)$ & 2.88 & $(0.13)$ & 3.79 & $(0.13)$ & 4.08 & $(0.11)$ \\
\hline WATER & 3.02 & $(1.05)$ & 3.65 & $(0.88)$ & 3.06 & $(0.61)$ & - & & 4.27 & $(1.09)$ & 1.91 & $(1.92)$ & 3.39 & $(1.17)$ \\
\hline N & 14 & & 8 & & 10 & & 8 & & 9 & & 9 & & 10 & \\
\hline & & & & & & & & & & & & & & \\
\hline & 502 & & 502 & 242 & 502 & 243 & 502 & 244 & 502 & 245 & 502 & 246 & 502 & 247 \\
\hline $\mathrm{SiO}_{2}$ & 78.30 & $(0.21)$ & 77.94 & $(0.32)$ & 77.99 & $(0.42)$ & 78.27 & $(0.56)$ & 77.70 & $(0.16)$ & 77.21 & $(1.88)$ & 78.17 & 10.33 \\
\hline $\mathrm{Al}_{2} \mathrm{O}_{3}$ & 12.23 & $(0.22)$ & 12.49 & $(0.22)$ & 12.40 & $(0.26)$ & 12.33 & $(0.26)$ & 12.58 & $(0.19)$ & 12,60 & $(0.72)$ & 12.50 & $(0.18)$ \\
\hline $\mathrm{TiO}_{2}$ & 0.10 & $(0.02)$ & 0.12 & $(0.03)$ & 0.14 & $(0.05)$ & 0.12 & $(0.02)$ & 0.13 & $(0.05)$ & 0.12 & $(0.04)$ & 0.09 & $(0.03)$ \\
\hline $\mathrm{FeO}$ & 1.10 & $(0.17)$ & 1.16 & $(0.15)$ & 0.94 & $(0.18)$ & 1.11 & $(0.16)$ & 1.06 & $(0.11)$ & 1.09 & $(0.23)$ & 0.90 & $(0.28)$ \\
\hline Mno & 0.05 & & 0.04 & & 0.05 & & 0.04 & & 0.04 & & 0.06 & & 0.06 & \\
\hline Mgo & 0.09 & $(0.03)$ & 0.12 & $(0.03)$ & 0.12 & $(0.04)$ & 0.10 & $(0.02)$ & 0.11 & $(0.06)$ & 0.12 & $(0.04)$ & 0.13 & $(0.08)$ \\
\hline $\mathrm{CaO}$ & 0.66 & $(0.03)$ & 0.96 & $(0.12)$ & 0.79 & $(0.07)$ & 0.87 & $(0.07)$ & 0.74 & $(0.09)$ & 0.86 & $(0.12)$ & 0.83 & $(0.10)$ \\
\hline $\mathrm{Na}_{2} \mathrm{O}$ & 4.09 & $(0.15)$ & 3.94 & $(0.16)$ & 3.48 & $(0.24)$ & 3.61 & $(0.44)$ & 3.49 & $(0.11)$ & 3.90 & $(0.44)$ & 3.66 & $(0.17)$ \\
\hline $\mathrm{K}_{2} \mathrm{O}$ & 3.38 & $(0.30)$ & 3.23 & $(0.17)$ & 4.11 & $(0.32)$ & 3.55 & $(0.22)$ & 4.15 & $(0.22)$ & 3.50 & $(0.26)$ & 3.68 & $(0.28)$ \\
\hline WATER & 3.94 & $(0.64)$ & 4.59 & $(0.98)$ & 4.68 & $(0.86)$ & 4.61 & $(0.99)$ & 4.60 & $(0.92)$ & 4.27 & $(1.57)$ & 1.33 & - \\
\hline $\mathrm{N}$ & 17 & & 21 & & 18 & & 20 & & 11 & & 19 & & 19 & \\
\hline & 502 & & 502 & 249 & 502 & $250 \mathrm{~A}$ & 502 & $250 B$ & 502 & 51 & 5025 & 53 & 502 & 254 \\
\hline $\mathrm{SiO}_{2}$ & 78.26 & $(0.36)$ & 75.95 & $(0.55)$ & 77.80 & $(0.56)$ & 76.04 & $(0.51)$ & 78.11 & $(0.33)$ & 77.901 & $(0.25)$ & 77.74 & $(0.28)$ \\
\hline $\mathrm{Al}_{2} \mathrm{O}_{3}$ & 12.36 & $(0.16)$ & 13.49 & $(0.33)$ & 12.65 & $(0.43)$ & 13.48 & $(0.31)$ & 12.46 & $(0.24)$ & 12.26 & $(0.14)$ & 12.49 & $(0.17)$ \\
\hline $\mathrm{TiO}_{2}$ & 0.091 & $(0.02)$ & 0.22 & $(0.03)$ & 0.11 & $(0.04)$ & 0.20 & $(0.05)$ & 0.13 & $(0.03)$ & 0.12 & $(0.03)$ & 0.13 & $(0.03)$ \\
\hline $\mathrm{FeO}$ & 0.93 & $(0.09)$ & 1.81 & $(0.16)$ & 1.06 & $(0.12)$ & 1.60 & $(0.15)$ & 1.13 & $(0.12)$ & 0.87 & $(0.09)$ & 1.16 & $(0.11)$ \\
\hline uno & 0.07 & & 0.10 & $(0.05)$ & 0.05 & & 0.04 & & 0.05 & & 0.04 & & 0.05 & \\
\hline Mgo & 0.11 & $(0.02)$ & 0.27 & $(0.04)$ & 0.11 & $(0.04)$ & 0.22 & $(0.04)$ & 0.11 & $(0.03)$ & 0.12 & $(0.02)$ & 0.12 & $(0.02)$ \\
\hline $\mathrm{CaO}$ & 0.85 & $(0.10)$ & 1.45 & $(0.06)$ & 0.92 & $(0.15)$ & 1.33 & $(0.15)$ & 0.89 & $(0.07)$ & 0.78 & $(0.06)$ & 0.87 & $(0.05)$ \\
\hline $\mathrm{Na}_{2} \mathrm{O}$ & 3.70 & $(0.23)$ & 4.18 & $(0.52)$ & 3.89 & $(0.17)$ & 3.93 & $(0.17)$ & 3.76 & $(0.17)$ & 3.53 & $(0.11)$ & 4.05 & $(0.14)$ \\
\hline $\mathrm{K}_{2} \mathrm{O}$ & 3.63 & $(0.32)$ & 2.51 & $(0.15)$ & 3.41 & $(0.25)$ & 3.16 & $(0.1 i)$ & 3.37 & $(0.18)$ & 4.38 & $(0.21)$ & 3.39 & $(0.18)$ \\
\hline WATER & 3.69 & $(0.89)$ & 1.16 & $(1.22)$ & 4.59 & $(0.95)$ & 4.71 & $(1.02)$ & 4.35 & $(0.69)$ & 4.34 & $(1.03)$ & 4.77 & $(0.85)$ \\
\hline $\mathrm{N}$ & 16 & & 19 & & 15 & & 6 & & 21 & & 18 & & 18 & \\
\hline
\end{tabular}




\section{6}

\begin{tabular}{lrrrrrrrrrrrrrr} 
& \multicolumn{2}{c}{50255} & \multicolumn{2}{c}{50256} & \multicolumn{2}{c}{50257} & \multicolumn{2}{c}{50258} & \multicolumn{2}{c}{50528} & \multicolumn{2}{c}{50529} & 50533 \\
$\mathrm{SiO}_{2}$ & 78.13 & $(0.32)$ & 78.33 & $(0.25)$ & 75.79 & $(0.23)$ & 78.11 & $(0.37)$ & 76.50 & $(0.58)$ & 77.98 & $(0.32)$ & 78.27 & $(0.25)$ \\
$\mathrm{Al}_{2} \mathrm{O}_{3}$ & 12.35 & $(0.20$ & 12.33 & $(0.17)$ & 13.39 & $(0.22)$ & 12.27 & $(0.15)$ & 13.12 & $(0.28)$ & 12.55 & $(0.23)$ & 12.20 & $(0.12)$ \\
$\mathrm{TiO}_{2}$ & 0.12 & $(0.04)$ & 0.09 & $(0.03)$ & 0.16 & $(0.03)$ & 0.13 & $(0.02)$ & 0.17 & $(0.03)$ & 0.10 & $(0.02)$ & 0.12 & $(0.03)$ \\
$\mathrm{FeO}$ & 1.02 & $(0.11)$ & 0.90 & $(0.13)$ & 1.89 & $(0.11)$ & 1.02 & $(0.11)$ & 1.95 & $(0.14)$ & 1.08 & $(0.13)$ & 1.03 & $(0.06)$ \\
$\mathrm{MnO}$ & 0.06 & & 0.05 & & 0.07 & & 0.05 & & 0.09 & $(0.04)$ & - & & 0.05 & \\
$\mathrm{MgO}$ & 0.12 & $(0.02)$ & 0.10 & $(0.02)$ & 0.15 & $(0.02)$ & 0.11 & $(0.02)$ & 0.14 & $(0.05)$ & 0.11 & $(0.04)$ & 0.12 & $(0.03)$ \\
$\mathrm{CaO}$ & 0.79 & $(0.05)$ & 0.82 & $(0.12)$ & 1.30 & $(0.05)$ & 0.86 & $(0.04)$ & 1.26 & $(0.12)$ & 0.87 & $(0.15)$ & 0.72 & $(0.04)$ \\
$\mathrm{Na}_{2} \mathrm{O}$ & 3.95 & $(0.11)$ & 3.73 & $(0.14)$ & 4.39 & $(0.14)$ & 3.57 & $(0.34)$ & 3.62 & $(0.25)$ & 3.81 & $(0.14)$ & 3.15 & $(0.14)$ \\
$\mathrm{K}_{2} \mathrm{O}$ & 3.46 & $(0.16)$ & 3.65 & $(0.28)$ & 3.06 & $(0.15)$ & 3.88 & $(0.18)$ & 3.16 & $(0.28)$ & 3.46 & $(0.16)$ & 4.32 & $(0.25)$ \\
$\mathrm{WATER}$ & 4.97 & $(1.11)$ & 5.50 & $(0.80)$ & 6.00 & $(0.72)$ & 6.19 & $(0.65)$ & 3.94 & $(1.67)$ & 5.22 & $(0.83)$ & 4.52 & $(0.63)$ \\
$\mathrm{N}$ & 19 & & 18 & & 17 & & 19 & & 10 & & 9 & & 12 &
\end{tabular}




\section{REFERENCES}

ADAMS, J.E. 1977: Sieve size statistics from grain measurement. Journal of Geology 85: 209-227.

ADAMS, J.E. 1978: Data for New Zealand pebble abrasion studies. N.Z. Journal of Science 21: 607-610.

ARAMAKE, S.; YAMASAKI, M. 1963: Pyroclastic flows in Japan. Bulletin Volcanologique 26: 89-99.

BAUMGART, I.L. 1954: Some Ash Showers of the Central North Island. N.Z. Journal of Science and Technology B35: 456-467.

BAUMGART, I.L.; HEALY, J. 1956: Recent volcanicity at Taupo, New Zealand, Proceedings, 8th Pacific Science Congress 2: 113-25.

BENCE, A.E.; ALBEE, A.L. 1968: Empirical correction factors for the electron microanalysis of silicates and oxides. Journal of Geology 76: $382-403$.

BECK, A.C.; ROBERTSON, E.I. 1955: Geology and Geophysics. In: Geothermal Steam for Power in New Zealand. N.Z. DSIR Bulletin 117: $15-19$.

BERRY, J.A. 1928: The volcanic deposits of Scinde Island, with special reference to the pumice bodies called chalazoidites. Transactions of the New Zealand Institute 59: 571-608.

BIRRELL, K.S. 1978: More about sources of Taupo Pumice. N.Z. Soil NewS $\underline{26(1)}: \quad 32-3$.

BIRRELL, K.S.; PULLAR, W.A. 1973: Weathering of paleosols in Holocene and late Pleistocene tephras in central New Zealand. N.Z. Journal of Geology and Geophysics 16: 687-702.

BLANK, H.R. 1965: Ash-flow deposits of the central King Country, New Zealand. N.Z. Journal of Geology and Geophysics 8: 588-607. 
BOOTH, B.; CROASDALE, R.; WALKER, G.P.L. 1978: A quantitative study of five thousand years of volcanism on Sao Miguel, Azores. Philosophical Transactions of Royal Society A 288: 271-319.

BOELLSTORFF, J.D.; TE PUNGA, M.T. 1977: Fission-track ages and correlation of middle and lower Pleistocene sequences from Nebraska and New Zealand. N.Z. Journal of Geology and Geophysics 20: 47-58.

BORCHARDT, G.A.; HARVARD, M.E.; SCHMITT, R.A. 1971: Correlation of volcanic ash deposits by activation analysis of glass separates. Quaternary Research 1: 247-260.

BRIGGS, N.D. 1973: Investigations of New Zealand pyroclastic-flow deposits. Unpublished Thesis in Library, Victoria University of Wellington. $438 \mathrm{p}$.

BRIGGS, N.D. 1976: Recognition and correlation of subdivisions within The Whakamaru Ignimbrite, Central North Island, New Zealand. N.Z. Journal of Geology and Geophysics 19: 463-501.

BUDDINGTON, A.F.; LINDSLEY, D.H. 1964: Iron-Titanium Oxide minerals and Synthetic Equivalents. Journal of Petrology 5: 310-357.

BULLARD, F.M. 1962: Volcanoes: in history, in theory, in eruption. Austin, Texas. University of Texas Press.

CAREY, S.N.; SIGURDSSON, H. 1980: The Roseau Ash: Deep-sea tephra deposits from a major eruption on Dominica, Lesser Antilles arc. Journal of Volcanology and Geothermal Research 7: 67-86.

CARMICHAEL, I.S.E. 1967: The iron-titanium oxides of salic volcanic rocks and their associated ferro-magnesian silicates. Contributions to Mineralogy and Petrology 14: 36-64.

CERLING, T.F.; CERLING, B.W. 1978: Correlation of reworked ash deposits; the KBS Tuff, Northern Kenya. In: Short papers on the 4 th international conference, geochronology, cosmochronology, isotope geology, 1978, R.E. Zartman, ed. U.S. Geological Survey Openfile report $78-701$. 
CHALLIS, G.A. 1971: Chemical analyses of New Zealand rocks and minerals with C.I.P.W. norms and petrographic descriptions. 1917-1957. Part I: Igneous and pyroclastic rocks. N.Z. Geological Survey Bulletin 84: 178 p.

CHAPMAN-SMITH, M.; GRANT-MACKIE, J.A. 1971: Geology of the Whangaparoa area, eastern Bay of Plenty, New Zealand. N.Z. Journal of Geology and Geophysics 14: 3-38.

CHRISTOFFEL, D.A.; CALHAEM, I.M. 1979: Geothermal measurements over a hot spot in Lake Taupo (Abstract). 49th ANZAAS Congress, Auckland, January 1979, Abstracts Vol. 1 Section 3, p.158.

CLARK, R.H. 1960: Andesite lavas of the North Island, New Zealand. International Geological Congress, Norden, part 13: 123-131.

CLARK, S.P. 1960: Handbook of physical constants (Revised). Geological Society of America Memoir 97.

COLE, J.W. 1970: Description and correlation of Holocene volcanic formations in the Tarawera-Rerewhakaaitu region. Transactions of the Royal Society of New Zealand 8: 3-4l.

COLE, J.W. 1979: Chemical analyses of lavas and ignimbrites of the Taupo Volcanic Zone. Geology Department, Victoria University of Wellington publication 13: 31 p.

COLE, J.W.; LEWIS, K.B. 1981: Evolution of the Taupo-Hikurangi subduction system. Tecton ophysics 72 : 1-21.

COLE, J.W.; NAIRN, I.A. 1975: Catalogue of the active volcanoes of the World including solfatara fields. Part XXII New Zealand, International Association of Volcanology and Chemistry of the Earth's Interior. Rome. 156p.

COLE, J.W.; STEPHENSON, T.M. 1972: Calculation of the volume of a tephra deposit. pp.13-15 in Cole, J.W. 'Distribution of High-Alumina Basalts in the Taupo Volcanic Zone'. Victoria University of Wellington Geology Department Publication 1. 


\section{0}

COTTON, C.A. 1922: The Geomorphology of New Zealand, Pt. 1. New Zealand Board of Science and Art, Wellington, Manual No. 3. 462p.

COX, A. 1969: A paleomagnetic study of secular variations in New Zealand. Earth and Planetary Science Letters, 6: 257-267.

COX, A. 1971: Remnant magnetization and susceptibility of late Cenozoic rocks from New Zealand. N.Z. Journal of Geology and Geophysics 14: $\quad 192-207$.

CROWE, B.M.; FISHER, R.V. 1973: Sedimentary structures in base-surge deposits with special reference to cross-bedding, Ubehebe Craters, Death Valley, California. Geological Society of America Bulletin 84: 663-682.

DIEFFENBACH, E. 1843: Travels in New Zealand. Vol. 1. London, John Murray. 431p.

EWART, A. 1963: Petrology and Petrogenesis of the Quaternary Pumice Ash in the Taupo Area, New Zealand. Journal of Petrology 4: 392-431.

EWART, A. 1965: Mineralogy and petrogenesis of the Whakamaru Ignimbrite in the Maraetai area of the Taupo Volcanic Zone, New Zealand. N.z. Journal of Geology and Geophysics 8: 611-677.

EWART, A. 1966: Review of mineralogy and chemistry of the acidic rocks of Taupo Volcanic Zone, New Zealand. Bulletin Volcanologique 29: $\quad 147-171$.

EWART, A. 1967a: The petrography of the Central North Island rhyolite lavas. Part I - Correlations between the phenocryst assemblages. N.z. Journal of Geology and Geophysics 10: 182-197.

EWART, A. 1967b: Pyroxene and magnetite phenocrysts from the Taupo Quaternary rhyolite deposits, New Zealand. Mineralogical Magazine 36: 180-194. 


\section{1}

EWART, A. 1968: The petrography of the central North Island rhyolitic lavas. Part 2 - regional petrography including notes on assoc-. iated ash-flow pumice deposits. N.Z. Journal of Geology and Geophysics 11: $478-545$.

EWART, A. 1971: Notes on the chemistry of ferromagnesian phenocrysts from selected volcanic rocks, Central Volcanic Region. N.Z. Journal of Geology and Geophysics 14: 323-340.

EWART, A.; CARMICHAEL, I.S.E.; BROWN, F.H. 1971: Voluminous low temperature rhyolite magmas in New Zealand. Contributions to Mineralogy and Petrology 33: 128-144.

EWART, A.; FIELDES, M. 1962: Low temperature thermal effects in natural volcanic glasses due to strain. Mineralogical Magazine 33: 237-246.

EWART, A.; HILDRETH, W.; CARMICHAEL, I.S.E. 1975: Quaternary acid magma in New Zealand. Contributions to Mineralogy and Petrology 51: $1-27$.

EWART, A.; STIPP, J.J. 1968: Petrogenesis of the volcanic rocks of the Central North Island, New Zealand, as indicated by a study of $\mathrm{Sr}^{87} / \mathrm{Sr}^{86}$ ratios, and $\mathrm{Sr}, \mathrm{Rb}, \mathrm{K}, \mathrm{U}$ and $\mathrm{Th}$ abundances. Geochimica et Cosmochimica Acta 32: 699-736.

EWART, A.; TAYLOR, S.R.; CAPP, A.C. 1968: Trace and Minor Element Geochemistry. of the Rhyolitic Volcanic Rocks, Central North Island, New zealand. Total Rock and Residual Liquid Data. Contributions to Mineralogy and Petrology 18: 76-104.

FEDERMAN, A.N.; CAREY, S.N. 1980: Electron microprobe correlation of tephra layers from eastern Mediterranean abyssal sediments and the island of Santorini. Quaternary Research 13: 160-171.

FIELDES, M. 1955: Clay mineralogy of New Zealand soils. N.z. Journal of Science and Technology B37: 336-350. 
FISHER, R:V. 1960: Classification of volcanic breccias. Bulletin of the Geological Society of America 71: 973-982.

FISHER, R.V. 1979: Models for pyroclastic surges and pyroclastic flows. Journal of Volcanology and Geothermal Research 6: 305-318.

FLEMING, C.A. 1953: The Geology of Wanganui Subdivision. N.Z. Geological Survey Bulletin 52: $362 \mathrm{p}$.

FLEMING, C.A. 1972: The contribution of C14 dates to the Quaternary geology of the "Golden Coast", western Wellington. Tuatara 19: 61-69.

FLEMING, C.A. 1975: The Quaternary Record of New Zealand and Australia. In: R.P. Suggate \& M.M. Cresswell (Eds.) Quaternary Studies, Royal Society of N.Z., Wellington. pp.1-20.

FRIEDMAN, I.; SMITH, R.L.; LONG, W.D. 1966: Hydration of natural glass and formation of perlite. Geological Society of America Bulletin 77: $323-328$.

FROGGATT, P.C. 1979: Lake Taupo - Probable source of Taupo Pumice Formation (Note). N.Z. Journal of Geology and Geophysics 22 : 763-4.

FROGGATT, P.C. 1981a: Karapiti Tephra Formation - a 10,000 years B.P. rhyolitic tephra from Taupo, New Zealand. N.Z. Journal of Geology and Geophysics 24: 95-98.

FROGGATT, P.C. 1981b: Motutere Tephra Formation and Redefinition of Hinemaiaia Tephra Formation, Taupo Volcanic Centre, New Zealand. N.Z. Journal of Geology and Geophysics 24: 99-105.

FROGGATT, P.C. 1981c: Stratigraphy and nature of Taupo Pumice Formation. N.Z. Journal of Geology and Geophysics 24: 231-248.

FROGGATT, P.C. (in press): Towards a comprehensive tephra and Ignimbrite stratigraphy in New Zealand using electron microprobe analysis of glass shards. Quaternary Research. 
FROGGATT, P.C.; WILSON, C.N.J.; WALKER, G.P.L. 1981: Orientation of logs in The Taupo Ignimbrite as an indicator of flow direction and vent position. Geology 9: 109-111.

GAGE, M.; BLACK, R.D. 1979: Slope stability and geological investigations at Mangatu state Forest. Forest Research Institute technical paper $66.37 \mathrm{p}$.

GIBB, J.G. 1977: Late Quaternary sedimentary processes at Ohiwa Spit. Wellington, Water and Soil Division, Ministry of Works, Technical Publication No. 5.

GOODHEW, P.J. 1975: Electron probe microanalysis of glasses containing alkali metals. Microstructural Science 3: 631-641.

GOODHEW, P.J.; GULIEY, J.E.C. 1974: The determination of alkali metals in glasses by electron probe microanalysis. Glass Technology 15: $\quad 123-126$.

GRANGE, L.I. 1927: Rotorua Subdivision. New Zealand Geological Survey 2lst Annual Report (n.s.): 19-20.

GRANGE, L.I. 1929: A classification of soils of Rotorua County. N.Z. Journal of Science and Technology 11: 219-228.

GRANGE, L.I. 1931: Volcanic ash showers. A geological reconnaisance of volcanic-ash showers of the central part of the North Island. N.Z. Journal of Science and Technology 12: 228-240.

GRANGE, L.I. 1932: Taupo Earthquakes, 1922. Rents and faults formed during earthquake of 1922 in Taupo District. N.Z. Journal of Science and Technology 14: 139-141.

GRANGE, L.I. 1937: The Geology of the Rotorua-Taupo Subdivision, Rotorua and Kaimanawa Divisions. N.Z. Geological Survey Bulletin n.s. 37: $138 \mathrm{pp}$.

GRANGE, L.I.; TAYLOR, N.H. 1939: Soils and agriculture of Waipa County. N.Z. Department of Scientific and Industrial Research, bulletin 76. 
GRINDLEY, G.W. 1959: Sheet N85, Waiotapu. "Geological map of New Zealand 1 : 63,360". N.z. Department of Scientific and Industrial Research, Wellington.

GRINDLEY, G.W. 1960: Sheet 8 - Taupo. "Geological map of New Zealand 1 : 250,000. N.z. Department of Scientific and Industrial Research, Wellington.

HACKETT, W.H. 1982: The Waimarino Basalt: a new basalt locality from the Taupo Volcanic Zone, New Zealand. Manuscript submitted to N.Z. Journal of Geology and Geophysics.

HATHERTON, T. 1954: The magnetic properties of the Whakamaru Ignimbrites. N.z. Journal of Science and Technology B35: 421-452.

HATHERTON, T.; LEOPARD, A.E. 1964: The densities of New Zealand rocks. N.Z. Journal of Geology and Geophysics 7: 605-625.

HAYS, J.D.; IMBRIE, J.; SHACKLETON, N.J. 1976: Variations in the earth's orbit: pacemakers of the ice ages. Science 194: 1121-1132.

HEALY, J. 1959: "Whakamaru Ignimbrites". In: Fleming, C.A. ed. New zealand. Lexique Stratigraphique International 6: $527 \mathrm{p}$.

HEALY, J. 1964: Volcanic mechanisms in the Taupo Volcanic Zone, New Zealand. N.Z. Journal of Geology and Geophysics 7: 6-23.

HEALY, J.; VUCETICH, C.G.; PULLAR, W.A. 1964: Stratigraphy and chronology of Late Quaternary volcanic ash in Taupo, Rotorua and Gisborne districts. New Zealand Geological Survey Bulletin, N.S. 73: 81 p.

HEIKEN, G. 1978: Plinian-type eruptions in the Medicine Lake Highland, California, and the nature of the underlying magma. Journal of Volcanology and Geothermal Research 4: 375-402.

HENSON, F.A. 1952: Volcanic ash from the Hekla eruption of 1947. Geological Magazine 89: 293-298. 


\section{5}

HILDRETH, W. 1979: The Bishop Tuff; evidence for the origin of compositional zonation in silicic magma chambers. Geological Society of America Special Paper 180: 43-75.

HOCHSTETTER, F. von 1864: Geologie von Neu-Seeland. Beitrage zur Geologie der Provinzen Auckland und Nelson. Novara-Expedition, geologie theil 1(1): $274 \mathrm{p}$.

HODDER, A.P.W. 1974: The use of physical and chemical techniques in the identification of Tephra (volcanic ash) in the North Island, New Zealand. Unpublished D.Phil. thesis, University of Waikato library.

HODDER, A.P.W. 1978: Refractive index and hydration of rhyolitic glass from Holocene tephras, North Island, New Zealand. N.Z. Journal of Geology and Geophysics 21: 155-66.

HOWORTH, R. 1975: New formations of Late Pleistocene tephras from the Okataina Volcanic Centre, New Zealand. New Zealand Journal of Geology and Geophysics 18: 683-712.

HOWORTH, R. 1976: Late Pleistocene tephras of the Taupo and Bay of Plenty Regions. Unpublished Ph.D. Thesis in Library, Victoria University of Wellington, New Zealand.

HOWORTH, R.; FROGGATT, P.C.; ROBERTSON, S.M. 1980: Late Quaternary volcanic ash stratigraphy in the Poukawa area, Central Hawke's Bay, New Zealand. N.z. Journal of Geology and Geophysics 23: 486-492.

HOWORTH, R.; FROGGATT, P.C.; VUCETICH, C.G.; COLLEN, J.D. 1981: Proceedings of tephra workshop, June 30th - July lst 1980, Victoria University of Wellington. Publication of Geology Department, V.U.W. No. 20.

HOWORTH, R; RANKIN, P.C. 1975: Multi-element characterisation of glass shards from stratigraphically correlated rhyolitic tephra units. Chemical Geology 15: 239-250. 


\section{6}

HOWORTH, R.; ROSS, A. 1981: Holocene tephra stratigraphy and chronology at Tiniroto, Cook County. IN: Howorth et al. ed. Proceedings of Tephra Workshop held at Geology Department, Victoria University of Wellington, June 30-July 1, 1980. Wellington, Geology Department, Victoria University of Wellington, New Zealand.

IRWIN, J. 1972: Lake Taupo, provisional bathymetry, 1:50,000, New Zealand Oceanographic Institute chart, lake series.

JAKOBSSON, A. 1976: The deposition, preservation and weathering of the upper Quaternary sediments exposed in a road cutting near Judgeford. Unpublished B.Sc. (Hons) project in Geology Library, Victoria University.

KAEWYANA, W. 1980: Late Quaternary alluvial terraces and their cover bed stratigraphy, Ekatahuna and Pahiatua districts, New Zealand. M.Sc. thesis, Victoria University.

KATSUI, Y,; Oba, K.; Unuma, K. et al. 1978: Preliminary report of the 1977 eruption of Usu volcano (E). Journal of Faculty of Science of Hokkaido University, Series IV, 18: 385-408.

KEAR, D. 1960: Sheet 4, Hamilton. "Geological Map of New Zealand $1: 250,000 "$. N.z. DSIR, Wellington.

KENNEDY, N.M.; PULLAR, W.A.; PAIN, C.F. 1978: Late Quaternary land surfaces and geomorphic changes in the Rotorua Basin, North Island, New Zealand. N.Z. Journal of Science 2l: 249-264.

KENNEDY, P.; PALMER, K.; ROSER, B.P. 1981: Chemical analyses of the 8 USGS rock standards. Geology Department, Victoria University of Wellington Publication 21.

KINGMA, J.T. 1971: Geology of the Te Aute Subdivision. New Zealand Geological Survey Bulletin 70: $173 \mathrm{p}$.

KIRKMAN, J.H. 1975: Clay mineralogy of some tephra beds of Rotorua area, North Is land, New Zealand. Clay Minerals 10: 437-449. 


\section{7}

KIRKMAN, J.H. 1976: Clay mineralogy of thirteen palesols developed in Holocene and late Pleistocene tephras of Central North Island, New Zealand. N.z. Journal of Geology and Geophysics 19: 179-187.

KITTLEMAN, L.R. 1973: Mineralogy, correlations and grainsize distributions of Mazama tephra and other post-glacial pyroclastic layers, Pacific Northwest. Geological Society of America Bulletin 84: 2957-2980.

KOHN, B.P. 1970: Identification of New Zealand tephra layers by emission spectrographic analysis of their titanomagnetite. Lithos 3 : $361-368$.

KOHN, B.P. 1973: Some studies of New Zealand Quaternary pyroclastic rocks. Unpublished Ph.D. thesis lodged in Victoria University, Wellington, New Zealand.

KOHN, B.P. 1979: Identification and significance of a late Pleistocene tephra in Canterbury District, South Island, New Zealand. Quaternary Research 11: 78-92.

KOHN, B.P.; NEALL, V.E. 1973: Identification of late Quaternary tephras for dating Taranaki lahar deposits. N.z. Journal of Geology and Geophysics 16: 781-792.

KOHN, B.P.; NEALL, V.; STEWART, R.B. 1981: Holocene tephra-stratigraphy revisited at Tiniroto, North Island, New Zealand. In: Howorth et al. ed. Proceedings of Tephra Workshop held at Geology Department, Victoria University of Wellington, June 30-July 1, 1980. Wellington, Geology Department, Victoria University of Wellington, New Zealand.

KOHN, B.P.; TOPPING, W.W. 1978: Time-space relationships between late Quaternary rhyolitic and andesitic volcanism in the southern Taupo Volcanic zone, New Zealand. Geological Society of America Bulletin 89: 1265-1271. 


\section{8}

KUNO, H.; ISHIKAWA, T. 1964: Sorting of pumice and lithic fragments as a key to eruptive and emplacement mechanisms. Japanese Journal of Geology and Geography 35: 223-238.

KUSHIRO, I.; NAKAMURA, Y. 1970: Petrology of some lunar crystalline rocks. Proceedings of Apollo II Lunar Science Conference, 1. $607 \mathrm{p}$.

KYLE, P. 1978: Mineralogy and glass chemistry of recent volcanic ejecta from Mt. Erebus, Ross Island, Antarctica. N.Z. Journal of Geology and Geophysics 20(6): 1123-46.

LEWIS, K.B.; KOHN, B.P. 1973: Ashes, turbidites, and rates of sedimentation on the continental slope off Hawkes Bay. N.Z. Journal of Geology and Geophysics 16: 439-454.

LINEWEAVER, J.L. 1962: Oxygen outgassing caused by electron bombardment of glass. Journal of Applied Physics 34: 1786-1791.

LLOYD, E.F. 1972: Geology and Hot Springs of Orakei Korako. New Zealand Geological Survey Bulletin 85.

LIPMAN, P.W.; CHRISTIANSEN, R.L.; O'CONNOR, J.T. 1966: A compositionally zoned ash-flow sheet in southern Nevada. U.S. Geological Survey Professional paper 524-F: $47 \mathrm{p}$.

LIRER, L.; PESCATORE, T.; BOOTH, B.; WALKER, G.P.L. 1972: Two plinian pumice-fall deposits from Somma-Vesuvius, Italy. Geological Society of America Bulletin 84: 750-772.

LOWE, D.J.; HOGG, A.G.; GREEN, J.D.; BOUBÉE, J.A.T. 1980: Stratigraphy and chronology of late Quaternary tephras in Lake Maratoto, Hamilton, New Zealand. N.Z. Journal of Geology and Geophysics 23: $\quad 481-485$.

MacFADGEN, B.G. 1978: The antiquity of man at Lake Poukawa, New Zealand. Journal of the Royal Society of New Zealand 9: 375-382. 
MARSHALL, P. 1934: Acid rocks of the Taupo-Rotorua Volcanic district. Transactions of Royal Society of N.Z. 64: 323-66.

MARTIN, R.C. 1961: Stratigraphy and structural outline of the Taupo Volcanic Zone. N.z. Journal of Geology and Geophysics 4: 449-478.

MCBIRNEY, A.R.; MURASE, T. 1970: Factors governing the formation of pyroclastic rocks. Bulletin Volcanologique 34: 372-384.

MCGETCHIN, R.R.; ULLRICH, G.W. 1973: Xenoliths in Maars and diatremes with inferences for the Moon, Mars and Venus. Journal of Geophysical Research 78: 1833-1853.

MCGLONE, M. 1981: Forest fire following Holocene tephra fall. In: Howorth et al. ed. Proceedings of Tephra Workshop held at Geology Department, Victoria University of Wellington, June 30July 1, 1980, Wellington, Geology Department, Victoria University of Wellington, New Zealand.

McINTOSH, P.D. 1979: Halloysite in a New Zealand tephra and paleosol less than 2500 years old. N.Z. Journal of Science 22: 49-54.

MCINTOSH, P.D. 1980a: Soil changes under Radiata pine in Kaingaroa Forest, Central North Island, New Zealand. N.Z. Journal of Science 23: 83-92.

MCINTOSH, P.D. 1980b: Weathering products in vitrandept profiles under pine and manuka, New Zealand. Geoderma 24: 225-239.

MILDENHALL, D.C.; WILLIAMS, D.N.; SEWARD, D. 1977: Ohariu Tephra and associated pollen bearing sediments near Wellington, New Zealand. N.Z. Journal of Geology and Geophysics 20: 157-165.

MIINE, J.D.G. 1973: Mount Curl Tephra, a 230,000-year-old marker bed in New Zealand, and its implications for quaternary chronology. N.Z. Journal of Geology and Geophysics 16: 519-532. 


\section{0}

MURAI, I. 1961: A study of the textural characteristics of pyroclastic flow deposits in Japan. Bulletin of the Earthquake Research Institute 39: 133-248.

NAESER, C.W.; NISHIMURA, S.; TE PUNGA, M.T. 1980: Fission-track age of the Mangaroa Ash and tectonic implications at Wellington, New Zealand. N.z. Journal of Geology and Geophysics 23: 615-620.

NAIRN, I.A. 1971: Studies of Earthquake Flat Breccia Formation and other unwelded pyroclastic flow deposits of the Central Volcanic Region. Unpublished M.Sc. thesis lodged in Victoria University of Wellington Library.

NAIRN, I.A. 1972: Rotoehu Ash and the Rotoiti Breccia Formation, Taupo Volcanic Zone, New Zealand. N.z. Journal of Geology and Geophysics 15: 251-261.

NAIRN, I. 1980: Source, age, and eruptive mechanisms of the Rotorua Ash, N.z. Journal of Geology and Geophysics 23: 193-207.

NAIRN, I.; KOHN, B.P. 1973: Relation of the Earthquake Flat Breccia to the Rotoiti Breccia, Central North Island, New Zealand. N.Z. Journal of Geology and Geophysics 16: 269-279.

NASEDKIN, V.V.; SANINA, E.A.; YAVITS, I.N. 1967: Porosity of natural and distended varieties of volcanic glass. In: Zalesskii, B.V. editor, Physical and mechanical properties of rocks. Academy of Sciences of the USSR. Translated from Russian by Israel Program for Scientific Translations, Jerusalem.

NICOL, E.R. 1972: Aspects of late Quaternary geology of the Wellington region. Unpublished B.SC. (Hons) project in Geology Library, Victoria University.

NIELSEN, C.H.; SIGURDSSON, H. 1981: Quantitative methods for electron microprobe analysis of sodium in natural and synthetic glasses. American Mineralogist 66: 547-552. 


\section{1}

NINKOVICH, D. 1968: Pleistocene volcanic eruptions in New Zealand recorded in deep-sea sediments. Earth and Planetary Science Letters 4: 89-102.

NORRISH, K.; HUTTON, J.T. 1969: An accurate X-ray spectrographic method for analysis of a wide range of geological samples. Geochemica et Cosmochemica Acta 33: 431-53.

O'BRIEN, C.M. 1980: The stratigraphy, petrography and glass chemistry of some mid to late Pleistocene tephras eastern Wairarapa. Unpublished B.Sc.(Hons) project in Geology Library, Victoria University.

PAIN, C.F.; PULLAR, W.A. 1968: Chronology of fans and terraces in the Galatea Basin. Earth Science Journal 2: 1-14.

PILLANS, B.; KOHN, B.P. 1981: Rangitawa Pumice: A widespread (?) Quaternary marker bed in Taranaki-Wanganui. In Howorth et al. (eds.) Proceedings of tephra workshop June 30. Victoria University of Wellington. Geology Department, Victoria University Publication 20: $142 \mathrm{p}$.

POWELL, R.; POWELL, M. 1977: Geothermometry and oxygen barometry using coexisting iron-titanium oxides: a reappraisal. Mineralogical Magazine 41: 257-263.

PULLAR, W.A. 1967: Volcanic ash beds in the Waikato district. Earth Science Journal 1: 17-30.

PULLAR, W.A. 1973: Isopachs of tephra, central North Island, New Zealand. Scale 1:1,000,000, New Zealand soil survey report 31 .

PULLAR, W.A. 1978: Sources of Taupo Pumice - a discussion, N.Z. Soil News $26(1): 33-4$.

PULLAR, W.A.; HEINE, J.C. 1971: Ages, inferred from ${ }^{14}$ C dates, of some tephra and other deposits from Rotorua, Taupo, Bay of Plenty, Gisborne, and Hawke's Bay districts. Proceedings of Radiocarbon Users Conference, Wellington: 119-138. 


\section{4}

PULLAR, W.A.; PATEL, RANJI N. 1972: Identification of tree stumps and driftwood associated with tephra layers in alluvium, peat and dune sands. N.Z. Journal of Botany 10: 605-14.

PULLAR, W.A.; PENHALE, H.R. 1970: Period of recent infilling of the Gisborne Plains basin: associated marker beds and changes in shoreline. N.Z. Journal of Science 13: 410-34.

PULLAR, W.A.; SELBY, M.J. 1971: Coastal progradation of Rangitaiki Plains, New Zealand. N.Z. Journal of Science 14: 419-434.

RANKIN, P.C.; HOWORTH, R.; WHITTEN, J.; BURKE, A.S. 1975: Comparison of two extraction techniques for volcanic glass. N.Z. Journal of Science 18: 103-107.

RIJKSE, W.C. 1977: Additional sources of Taupo Pumice, N.Z. Soil NewS 25(6): $219-21$.

ROBERTS, N.L.; WILLIAMS, R.B. 1966: Magnetic survey of Lake Taupo. Geophysics Division report 39. Wellington, Department of Scientific and Industrial Research. $2 \mathrm{p}$.

ROBERTSON, S.M. 1976: The Pahiatua tephra - a Pleistocene marker bed at Pahiatua. Unpublished B.Sc. (Hons) project in Geology Library, Victoria University.

ROSS, C.S.; SMITH, R.L. 1955: Water and other volatiles in volcanic glasses. American Mineralogist 40: 1071-1089.

ROXBURGH, H.J. I976: Lake Taupo Pleistocene tephras - a petrochemical study. Unpublished M.Sc. Thesis lodged in Library, Victoria University of Wellington.

RUTHERFORD, N.F.; HEMING, R.F. 1978: The volatile component of Quaternary ignimbrite magmas from the North Island, New Zealand. Contributions to Mineralogy and Petrology 65: 401-411. 
SCOTT, R.B. 1966a: Origin of chemical variations within ignimbrite cooling units. American Journal of Science 264: 273-288.

SCOTT, R.B. 1966b: Alkali exchange during devitrification and hydration of glasses in ignimbrite cooling units. Journal of Geology 79 : $100-110$.

SELF, S.; SPARKS, R.S.J. 1978: Characteristics of widespread pyroclastic deposits formed by the interaction of silicic magma and water. Bulletin Vocanologique 41: 196-212.

SEWARD, D. 1974a: Age of New Zealand Pleistocene substages by fissiontrack dating of glass shards from tephra horizons. Earth and Planetary Science Letters 24: 242-248.

SEWARD, D. 1974b: Some aspects of the sedimentology of the Wanganui Basin, North Island, New Zealand. Unpublished Ph.D. Thesis in Library, Victoria University of Wellington, New Zealand.

SEWARD, D. 1975: Fission-track ages of some tephras from Cape Kidnappers, Hawke's Bay, New Zealand. N.Z. Journal of Geology and Geophysics 18: $\quad 507-510$.

SEWARD, D. 1976: Tephrostratigraphy of the marine sediments in the Wanganui Basin, New Zealand. N.z. Journal of Geology and Geophysics 19: 9-20.

SEWARD, D. 1979: Comparison of zircon and glass fission-track ages from tephra horizons. Geology 7: 479p.

SINCLAIR, M.W. 1973: A Quaternary fossil gully containing a rhyolitic tephra bed at Whitby, Wellington. Unpublished B.Sc.(Hons) project in Geology Library, Victoria University.

SMITH, D.W.G.; WESTGATE, J.A. 1969: Electron probe technique for characterising pyroclastic deposits. Earth and Planetary Science Letters 5: 313-319. 
SMITH, R.L. 1960: Ash Flows. Geological Society of America Bulletin 71: $795-842$.

SMITH, S.P. 1877: Sketch of the geology of the northern portion of Hawke Bay. Transactions of the New Zealand Institute 9: 565-576.

SPARKS, R.S.J. 1976: Grain size variations in ignimbrites and implications for the transport of pyroclastic flows. Sedimentology 23: 147-188.

SPARKS, R.S.J. 1978: The dynamics of bubble formation and growth in Magmas: a review and analysis. Journal of Volcanology and Geothermal Research 3: 1-37.

SPARKS, R.S.J.; WALKER, G.P.L. 1973: The ground surge deposit: a third type of pyroclastic rock. Nature physical science 241(107): $62-64$.

SPARKS, R.S.J.; SELF, S.; WALKER, G.P.L. 1973: The products of ignimbrite eruptions. Geology 1: 115-118.

SPARKS, R.S.J.; WALKER, G.P.L. 1977: The significance of vitric-enriched airfall ashes associated with crystal-enriched ignimbrites. Journal of Volcanology and Geothermal Research 2: 329-341.

SPARKS, R.S.J.; WILSON, L. 1976: A model for the formation of ignimbrite by gravitational column collapse. Journal of Geological Society of London 132: 441-451.

SPARKS, R.S.J.; WIISON, L.; HUME, G. 1978: Theoretical modelling of the generation, movement and emplacement of pyroclastic flows by column collapse. Journal of Geophysical Research 83: 1727-1739.

STEEN MCINTYRE, V. 1973: Hydration and Superhydration of pumiceous volcanic glass - a potential tool for estimating age of Holocene and Pleistocene tephra. Ninth Congress INQUA Abstracts, Christchurch, New Zealand: 242-243.

TAYLOR, N.H. 1933 : Soil processes in volcanic ash beds. N.Z. Journal of Science and Technology (B) 14: 388-52. 


\section{5}

TAYLOR, R. 1855: Te ika a Maui, or New Zealand and its inhabitants. London, Wertheim and Macintosh. 490p.

TE PUNGA, M.T. 1952: The geology of the Rangitikei Valley. N.Z. Geological Survey Memoir 8: $46 \mathrm{pp}$.

TE PUNGA, M.T. 1963: An ash bed near Upper Hutt, Wellington. N.Z. Journal of Geology and Geophysics 6: 155-159.

TE PUNGA, M.T. 1973: In: Te Punga, M.T.; Mildenhal1, D.C. ed. Guidebook for excursion A13 - western North Island of New Zealand. Ninth INQUA congress: 263 p.

THORARINSSON, S. 1974: The terms tephra and tephrochronology. in Westgate, J.A. \& Gold, C.M. (eds): World bibliography and index of Quaternary tephrochronology. University of Alberta. $528 \mathrm{p}$.

THORNTON, C.P.; TUTTLE, O.F. 1960: Chemistry of igneous rocks I. Differentiation Index. American Journal of Science 258: 664-684.

TONKIN, P.J. 1967: Note on the occurrence of Taupo Pumice in the Hamilton Basin. Earth Science Journal 1: 31-2.

TOPPING, W.W. 1973: Tephrostratigraphy and chronology of late Quaternary eruptives from the Tongariro Volcanic Centre, New Zealand. N.Z. Journal of Geology and Geophysics 16: 397-424.

TOPPING, W.W. 1974: Some aspects of Quaternary history of Tongariro volcanic centre. Unpublished Ph.D. Thesis lodged in Victoria University of wellington library.

TOPPING, W.W.; KOHN, B.P. 1973: Rhyolitic tephra marker beds in the Tongariro area, North Island, New Zealand. N.Z. Journal of Geology and Geophysics 16(3): 375-95.

VARSHNEYA, A.K.; COOPER, A.R.; CABLE, M. 1966: Changes in composition during electron microprobe analysis of $\mathrm{K}_{2} \mathrm{O}-\mathrm{SrO}-\mathrm{SiO}_{2} \mathrm{glass}$. Journal of Applied Physics 37: 2199-2202. 


\section{6}

VUCETICH, C.G.; BIRRELL, K.S.; PULIAR, W.A. 1978: Ohinewai Tephra Formation; a c. 150,000-year-old tephra marker in New Zealand. N.z. Journal of Geology and Geophysics 21: 71-73.

VUCETICH, C.G.; HOWORTH, R. 1976a: Proposed definition of the Kawakawa Tephra, the c. 20,000-years-B.P. marker horizon in the New Zealand region. N.z. Journal of Geology and Geophysics 19: 43-50.

VUCETICH, C.G.; HOWORTH, R. 1976b: Late Pleistocene tephrostratigraphy in the Taupo district, New Zealand. N.z. Journal of Geology and Geophysics 19: $51-70$.

VUCETICH, C.G.; KOHN, B.P.; PULLAR, W.A. 1981: Correlation of Aratora Tephra, Ahuroa cover bed type section, Te Kuiti. In: Howorth et al. (eds). Proceedings of Tephra Workshop held at Victoria University June 30, 1980. Geology Department, Victoria University of Wellington Publication 20: 142 p.

VUCETICH, C.G.; PULLAR, W.A. 1969: Stratigraphy and chronology of late Pleistocene volcanic ash beds in central North Island, New Zealand. N.Z. Journal of Geology and Geophysics 12: 784-837.

VUCETICH, C.G.; PULLAR, W.A. 1973: Holocene tephra formations erupted in the Taupo area, and interbedded tephras from other volcanic sources. N.Z. Journal of Geology and Geophysics 16(3): 745-780.

VUCETICH, C.G.; WELLS, N. 1978: Soils, agriculture, and forestry of Waiotapu region, Central North Island, New Zealand. N.z. Soil Bureau Bulletin 31: 100p.

WAKEFIELD, E.J. 1845: Adventure in New Zealand, from 1839-1844, vol. 2. London, John Murray, 546p.

WALKER, G.P.L. 1971: Grainsize characteristics of pyroclastic deposits. Journal of Geology 79: 696-714.

WALKER, G.P.L. 1972: Crystal concentration in ignimbrites. Contributions to Mineralogy and petrology 36: 135-146. 


\section{$34 y$}

WALKER, G.P.L. 1973: Explosive volcanic eruptions - a new classification scheme. Geologische Rundschau 62(2): 431-446.

WALKER, G.P.L. 1980: The Taupo Pumice: product of the most powerful known (ultraplinian) eruption? Journal of Volcanology and Geothermal Research 8: 69-94.

WALKER, G.P.L. 1981: The Waimihia and Hatepe plinian deposits from the rhyolitic Taupo Volcanic Centre. N.z. Journal of Geology and Geophysics 24: $305-324$.

WALKER, G.P.L.; CROASDALE, R. 1971: Two Plinian-type eruptions in the Azores. Journal of the Geological Society of London 127: 17-55.

WALKER, G.P.L.; SELF, S.; FROGGATT, P.C. 198la: The ground layer of the Taupo Ignimbrite: a striking example of sedimentation from a pyroclastic flow. Journal of volcanology and geothermal research 10: 1-11.

WALKER, G.P.L.; WILSON, L.; BOWELL, E.L.G. 1971: Explosive volcanic eruptions - I. The rate of fall of pyroclasts. Geophysical Journal of the Royal Astronomical Society 22: 377-383.

WALKER, G.P.L.; WILSON, C.N.J.; FROGGATT, P.C. 1980: Fines-depleted ignimbrite in New Zealand - the product of a turbulent pyroclastic flow. Geology 8: 245-249.

WARD, W.T. 1967: Volcanic ash beds of the lower Waikato Basin, North Island, New Zealand. N.z. Journal of Geology and Geophysics 10: 1109-1135.

WATKINS, N.D.; HUANG, T.C. 1977: Tephras in abyssal sediments east of North Island, New Zealand: Chronology, paleowind velocity, and paleo-explosivity. N.Z. Journal of Geology and Geophysics 20: 179-199.

WELLMAN, H.W. 1962: Holocene of the North Island of New Zealand: A coastal Reconnaissance. Transactions of the Royal society of N.z., Geology 1: 29-99. 


\section{8}

WESTGATE, J.A. 1977: Identification and significance of late Holocene tephra from Otter Creek, southern British Columbia, and localities in west-central Alberta. Canadian Journal of Earth Sciences 14: 2593-2600.

WESTGATE, J.A.; EVANS, M.E. 1978: Compositional variability of Glacier Peak tephra and its stratigraphic significance. Canadian Journal of Earth Sciences 15: 1554-1567.

WESTGATE, J.A.; FULTON, R.J. 1975: Tephrostratigraphy of Olympia interglacial sediments in south-central British Columbia, Canada. Canadian Journal of Earth Science 12: 489-502.

WESTGATE, J.A.; GORTON, M.P. 1981: Correlation techniques in tephra studies. in: Self, S. \& Sparks, R.S.J. (eds) Tephra studies. Dr. Reidel: 73-94.

WHITEFORD, C.M.; LUMB, J.T. 1975: A catalogue of physical properties of rocks. Volume 3: Listing by rock type. Geophysics Division, DSIR. Report No. 107, Wellington, New Zealand.

WILCOX, R.E. 1965: Volcanic ash chronology, pp.807-816 in "The Quaternary of the United States. 7th INQUA Conference", Princeton Press.

WILDE, R.H. 1979: Stratigraphy and soils of late Quaternary terrace cover beds in the Wanganui and South Taranaki District, North Island, New Zealand. M.Sc. Thesis, Victoria University of Wellington Library.

WILSON, C.J.N. 1980: The role of fluidization in the emplacement of pyroclastic flows: an experimental approach. Journal of volcanology and geothermal research 8: 231-249.

WILSON, G.J. 1973: Palynology of the middle Pleistocene Te Piki bed, Cape Runaway, New Zealand. N.z. Journal of Geology and Geophysics 16: 345-354. 


\section{9}

WILSON, L. 1976: Explosive Volcanic Eruptions - III. Plinian eruption columns. Geophysical Journal of Royal Astronomical Society 45: 543-556.

WRIGHT, J.V.; SMITH, A.L.; SELF, S. 1980: A working terminology of pyroclastic deposits. Journal of volcanology and geothermal research 8: 315-336. 